
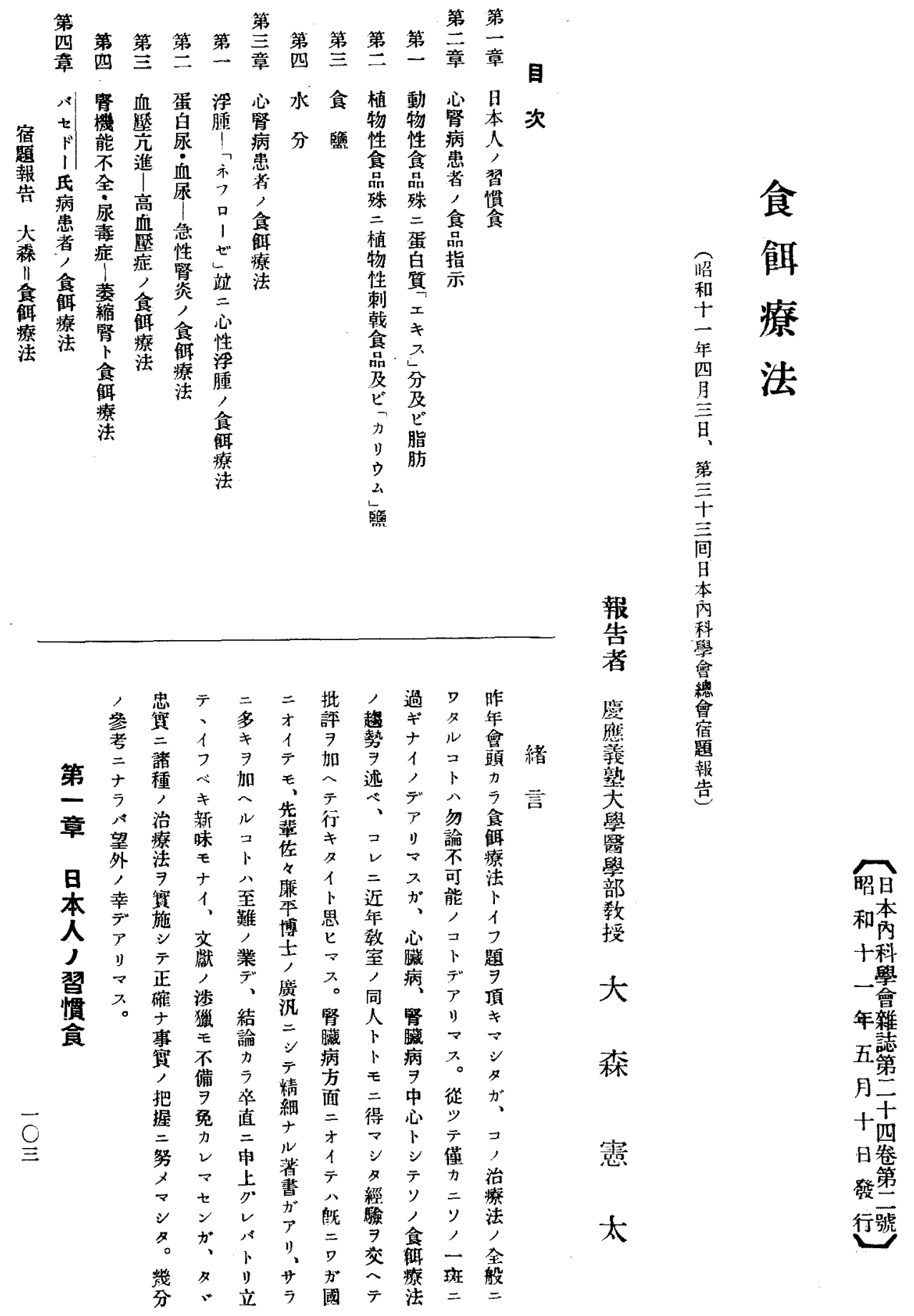


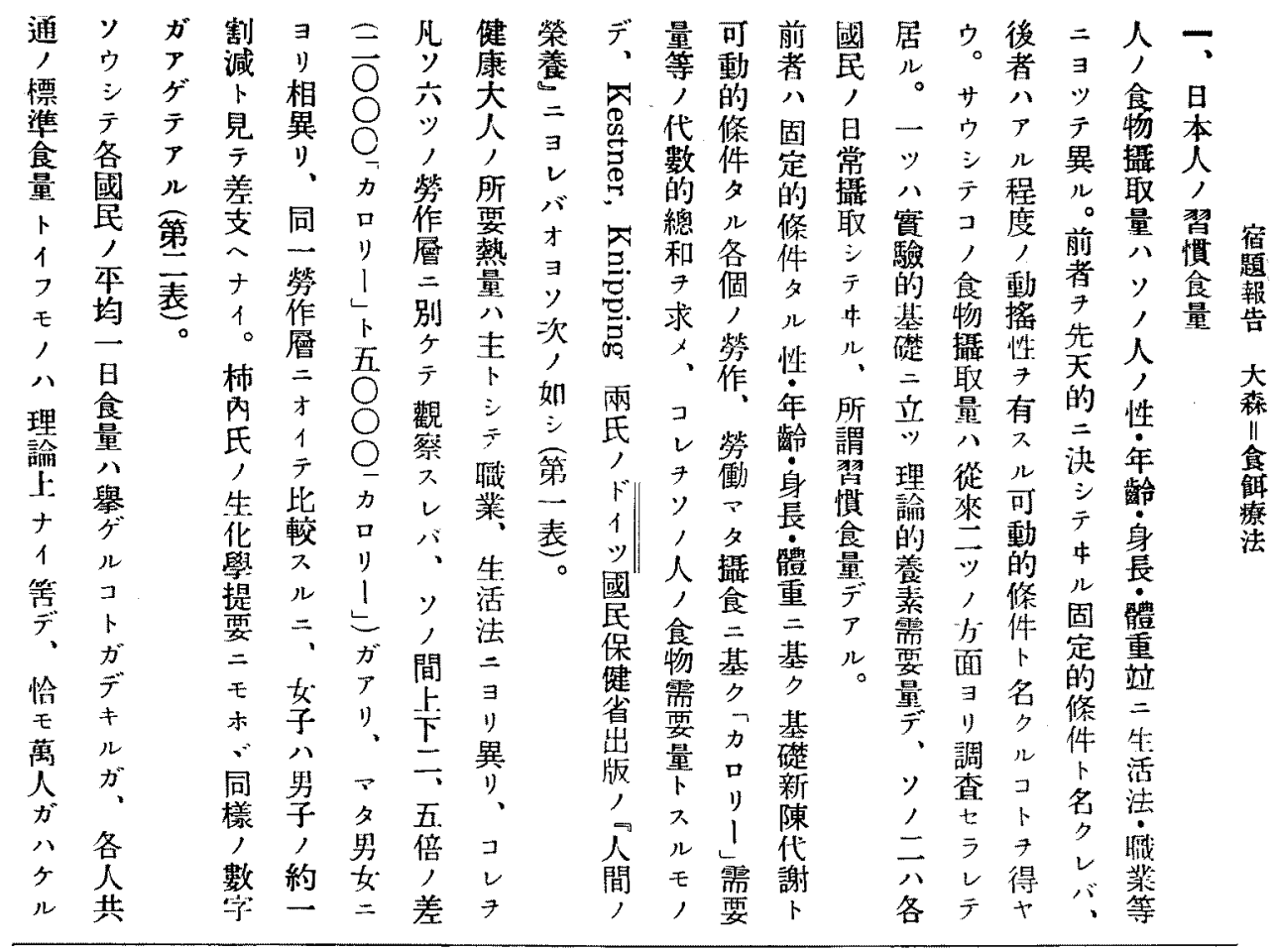

第二表 健康大人所姴熱量表 第一表 健康大人所要熱量表 (Kestner und Knipping氏) （柿丙三郎氏）

A. 男子所姴熱歯

體重 $70 \mathrm{~kg}$ ，男于

\begin{tabular}{|c|c|c|}
\hline 狀 & \multirow{2}{*}{\multicolumn{2}{|c|}{ 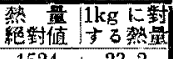 }} \\
\hline 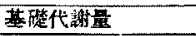 & & \\
\hline 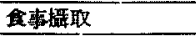 & 1800 & 25.7 \\
\hline 又，狇上休息 & 2000 & 28.6 \\
\hline 食事船 & 2230 & 31.9 \\
\hline 食事搔取，坐業 & 2400 & 34.3 \\
\hline 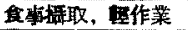 & 2600 & 37.1 \\
\hline 全事檘取，中等作業 & 3000 & 42.6 \\
\hline 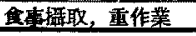 & & \\
\hline
\end{tabular}

\begin{tabular}{|c|c|c|c|c|c|}
\hline \multicolumn{2}{|c|}{ 労作啳 } & 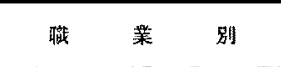 & 「カロリー」 & 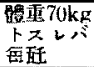 & 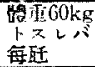 \\
\hline 1 & 坐 業 & 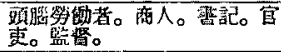 & $2200-2400$ & $32-34$ & $37-40$ \\
\hline 2 & 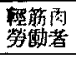 & 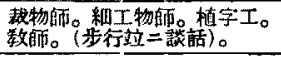 & $2600-2800$ & $37-40$ & $43-47$ \\
\hline 3 & $\begin{array}{l}\text { 中解商 } \\
\text { 勞搉者 } \\
\end{array}$ & 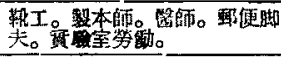 & 3000 & 44 & 50 \\
\hline 4 & 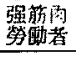 & 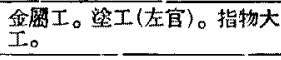 & $3400-3600$ & $49-51$ & $57-60$ \\
\hline 5 & 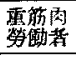 & & 4000 & 57 & 67 \\
\hline 6 & 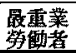 & & 5000 & 71 & 83 \\
\hline
\end{tabular}

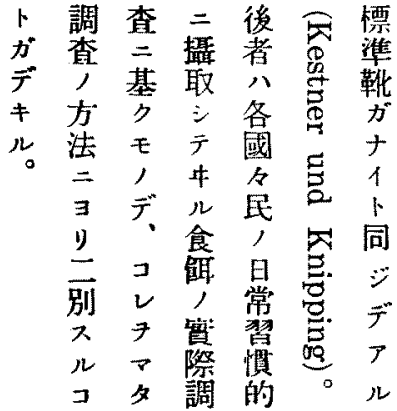

B. 奴子所要熱量

\begin{tabular}{|c|c|c|c|c|c|c|}
\hline \multicolumn{2}{|c|}{ 勞 作 露 } & 鞿 & 例 & 「カロリー1 & 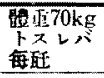 & 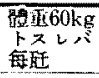 \\
\hline 1 & 坐 業 & \multicolumn{2}{|c|}{ 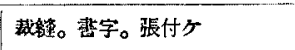 } & 2200 & 32 & 37 \\
\hline 2 & 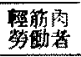 & \multicolumn{2}{|c|}{ 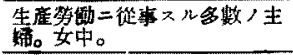 } & 2600 & 37 & 43 \\
\hline 3 & 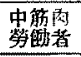 & \multicolumn{2}{|c|}{ 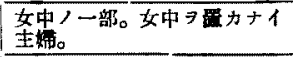 } & 3000 & 44 & 50 \\
\hline 4 & 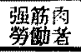 & \multicolumn{2}{|c|}{ 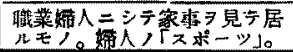 } & 3400 & 49 & 57 \\
\hline
\end{tabular}




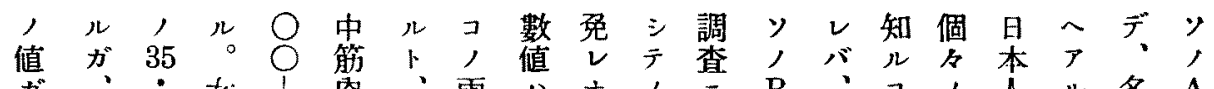

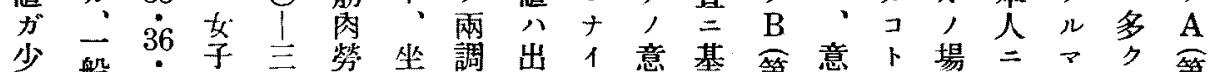

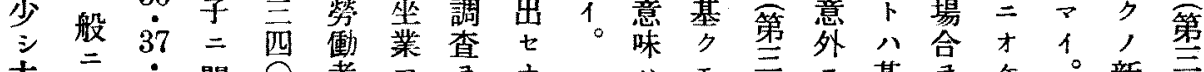

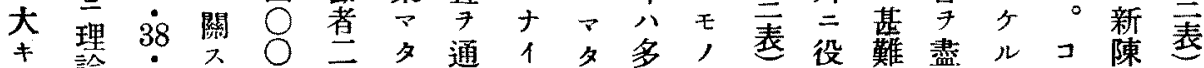

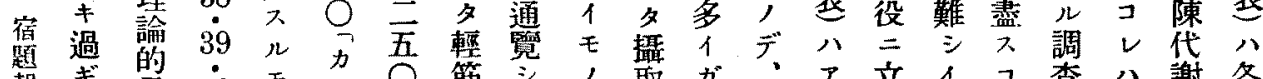

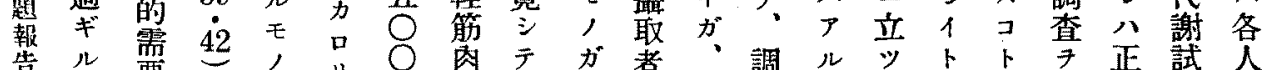

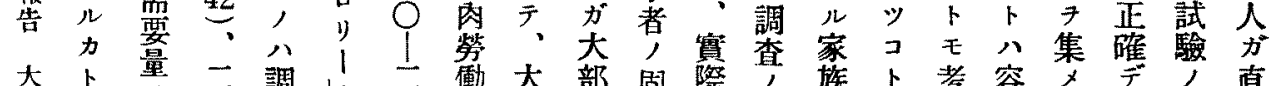

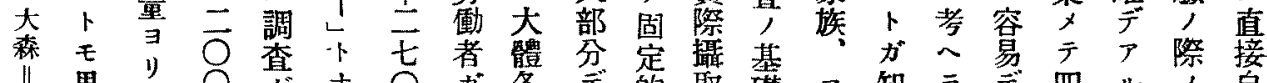

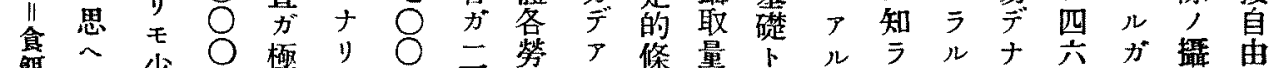

$$
\begin{aligned}
& \text { 簝 }
\end{aligned}
$$

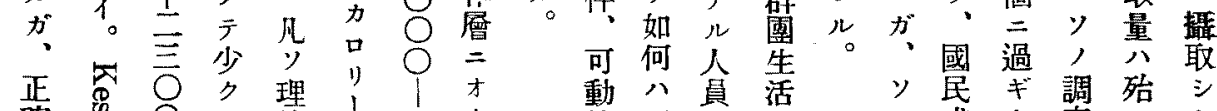

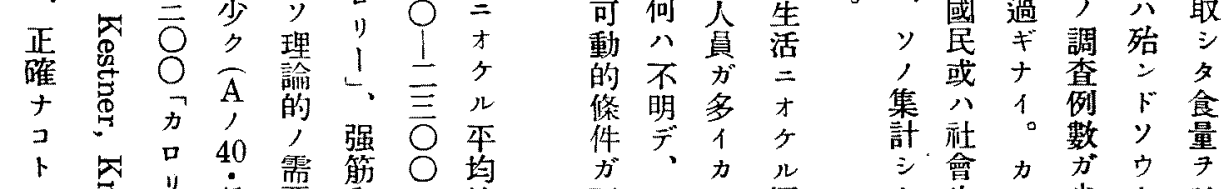

$$
\begin{aligned}
& \text { 八 }
\end{aligned}
$$

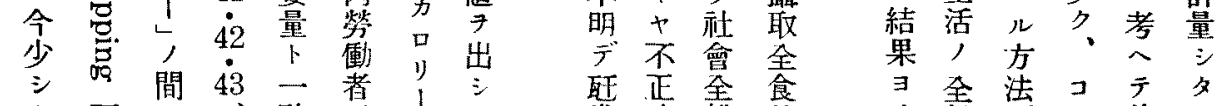

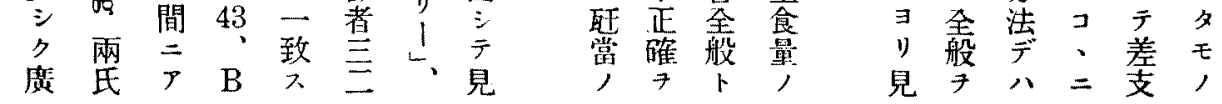


第三表 日本人習慣食鲜調查表 (1)

(A) 自由嘼食( 新陳代謝陚驗) $=ヨ ル モ$,

\begin{tabular}{|c|c|c|c|c|c|c|c|c|c|c|c|c|c|c|c|}
\hline & & 䤋 & 澲 & $\begin{array}{l}\text { 試的人員 } \\
\text { 及日 數 }\end{array}$ & $\begin{array}{l}\text { 年鹳 } \\
(\text { (年) }\end{array}$ & 髅平 & 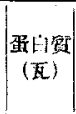 & $\begin{array}{l}\text { 脂肪 } \\
(\text { 五 }\end{array}$ & 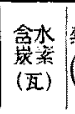 & $\left(\begin{array}{cc}\text { ch } & \text { 量 } \\
\left(\begin{array}{cc}\text { 力 } & 0 \\
1 & -\end{array}\right)\end{array}\right.$ & 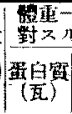 & 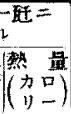 & $\begin{array}{l}\text { 㕵素 } \\
\text { 出倆 }\end{array}$ & 籍 & \\
\hline \multirow{10}{*}{ 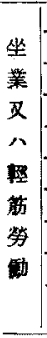 } & 1 & 器 & 王 & 1人 13日 & & 48 & 90 & 6 & 472 & 2456 & 1.88 & 51.2 & $1+1$ & 䏂川 & \\
\hline & 2 & 學 & 亘 & $1 \wedge \quad 10$ 日 & 20 & 43 & 83 & 24 & 442 & 2375 & 1.93 & 55.2 & $(+)$ & 天谷，桐涼 & \\
\hline & 3 & 虽 & 促 & 2 人 7 国 & $21-\overline{25}$ & 53 & 70 & 15 & 529 & 2595 & 1.32 & 48.9 & $(+)$ & 湯川 & \\
\hline & 4 & 老 & $\Lambda$ & $5 \AA \quad 7$ 日 & $67-87$ & 45 & 62 & 10 & 385 & 1917 & 1.40 & 43.0 & $(+1)$ & 服部 & \\
\hline & 5 & 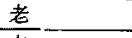 & 人 & 1 人 28 百 & 76 & 45 & 49 & 10 & 417 & 2023 & 1.09 & 45.0 & it) & 级本 & \\
\hline & 6 & 老 & $\Lambda$ & 1人 9 日 & 74. & 42 & 54 & 6 & 405 & 1816 & 1.24 & 43.2 & $(+)$ & $"$ & \\
\hline & 7 & 是 & 夫 & 1今 7日 & 34 & 54 & 60 & 13 & 417 & 2090 & 1.11 & 38.6 & & 稳蓗 & \\
\hline & 8 & $\Delta$ & 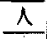 & & & 55 & 74 & 18 & 548 & 2717 & 1.34 & 49.4 & & 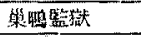 & \\
\hline & 9 & 䩶 & I & 1 人 7日 & 23 & 57 & 57 & 10 & 545 & 2596 & 1.05 & 45.8 & $(+)$ & 余田, 寺同 & \\
\hline & & & & 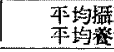 & 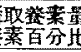 & & $\begin{array}{r}66 \text { 形 } \\
11.9 \% \\
\end{array}$ & $\begin{array}{r}13 \bar{\kappa} \\
5.6 \% \\
\end{array}$ & $\begin{array}{l}462 \pi \\
82.5 \%\end{array}$ & $\begin{array}{l}2287 \\
103 \% \\
\end{array}$ & 1.37 & 46.7 & & & \\
\hline \multirow{7}{*}{ 中 } & 10 & 小 & 倮 & 1 人 30 日 & & & 65 & 5 & 601 & 2779 & & & & 致口 & \\
\hline & 11 & 小: & 捚 & 116 日 & 23 & 63 & 64 & 4 & 569 & 2627 & 1.02 & 41.6 & $(t)$ & 正升 & \\
\hline & 12 & 噇 & 兵 & $6 \wedge \quad 8$ 日 & & 58 & 85 & 15 & 534 & 2672 & 1.46 & 46.0 & & 森 & \\
\hline & 13 & 陵 & 兵 & 5 人 14 日 & & 58 & 88 & 21 & 566 & 2870 & 1.51 & 49.2 & & 较山! & \\
\hline & 14 & 陻 & 兵 & 5人 12 日 & & 56 & 123 & 34 & 503 & 2801 & 2.18 & 49.8 & & $"$ & \\
\hline & 15 & 酸 & 太 & 1 人 7日 & 21 & 52 & 104 & 26 & 540 & 2882 & 1.98 & 55.2 & & 稻葉 & \\
\hline & 16 & $B$ & 规 & $5 \wedge 7$ 日 & 20 & 53 & 83 & 18 & 553 & 2805 & 1.57 & 53.0 & & 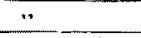 & \\
\hline \multirow{3}{*}{ 施 } & 17 & 防 & 夫 & 2 人 7日 & $28-30$ & 52 & 102 & 9 & 568 & 2828 & 1.96 & 54.4 & & 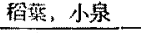 & \\
\hline & 18 & 盤 & $I$ & $1 \wedge \quad 21 日$ & 23 & 58 & 74 & 12 & 673 & 3061 & 1.28 & 53.2 & $1+1$ & 坂本 & \\
\hline & 19 & 粒 & $I$ & $1 \wedge 21 日$ & 23 & 51 & 63 & 12 & 576 & 2670 & 1.24 & 52.4 & $(+1)$ & " & \\
\hline \multirow{4}{*}{ 纳 } & 20 & 酸 金洗。 & $I$ & $1 \wedge \quad 21$ 旦 & 22 & 63 & 74 & 12 & 648 & 2988 & 1.18 & 47.5 & $(+)$ & "י & \\
\hline & 21 & 電車亚霜 & 手 & $1 \wedge \quad 49 日$ & 22 & 54 & 66 & 7 & 589 & 2654 & 1.22 & 49.3 & $(+)$ & $\because$ & \\
\hline & 22 & 篓 坧 & $I$ & 1人 21 日 & 21 & 56 & 60 & 8 & 614 & 2756 & 1.07 & 49.3 & $(+1)$ & $\because$ & \\
\hline & 23 & 役 & $I$ & 1А 21日 & 27 & 57 & 76 & 12 & 706 & 3215 & 1.35 & 56.4 & $(+)$ & $\because$ & \\
\hline \multirow[t]{3}{*}{ 勞 } & 24 & 役 & 丠 & $1 \wedge$ & 41 & 55 & 48 & 2 & 476 & 2072 & 0.89 & 37.3 & & $"$. & \\
\hline & 25 & 役 & E & 11 & 46 & 50 & 43 & 1 & 371 & 1642 & 0.86 & 32.8 & & $\because$. & \\
\hline & 26 & 雔 & 夫 & $1 \wedge \quad 148$ & 52 & 49 & 73 & 8 & 719 & 3330 & 1.49 & 68.0 & $(+)$ & 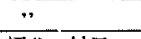 & \\
\hline \multirow[t]{4}{*}{ 酬 } & 27 & 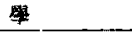 & 生 & & & 46 & 56 & 21 & 468 & 2330 & 1.20 & 50.4 & & 址井，村目 & \\
\hline & 28 & 㘣 & 1 & 7人 7日 & $23-28$ & 61 & 108 & 35 & 557 & 3050 & 1.76 & 49.7 & $\begin{array}{l}5(+) \\
2(-)\end{array}$ & 槄荬, 上野 & \\
\hline & 29 & 凹 & $\Lambda$ & 4A 7日 & $25-45$ & 50 & 99 & 42 & 333 & 2162 & 1.93 & 43.3 & $(+)$ & 锤 111 & \\
\hline & & & & 本均环 & 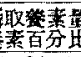 & & $\begin{array}{r}78 \mathrm{i} \\
11.6 \%\end{array}$ & $\begin{array}{r}14 \mathrm{E} \\
5.1 \% \\
\end{array}$ & $\begin{array}{r}58 \mathrm{E} \\
83.3 \% \\
\end{array}$ & $\begin{array}{l}2749 \\
107^{\circ}\end{array}$ & 1.43 & 49.4 & & & \\
\hline \multirow{4}{*}{ 强 } & 30 & 伸 & 仕 & $1 \wedge \quad 34 \mathrm{~B}$ & 34 & 68 & 112 & 20 & 732 & 3618 & 1.66 & 53.2 & $(t)$ & 䛀本 & \\
\hline & 31 & 伸 & 佳 & 1人 33日 & 25 & 66 & 116 & 21 & 788 & 3844 & 1.76 & 58.0 & $(+)$ & $"$ & \\
\hline & 32 & 伸 & 仕 & I $\wedge 28 \mathrm{~B}$ & 24 & 64 & 99 & 14 & 944. & 4270 & 1.54 & 66.8 & $(t)$ & , & \\
\hline & 33 & 偊 & 仕 & 1 人 34日 & 20 & 58 & 84 & 11 & 827 & 3741 & 1.45 & 64.4 & $(t)$ & $\cdot \cdot$ & \\
\hline \multirow[t]{2}{*}{ 䈤 } & 34 & 伸 & 仕 & $11 \quad 28$ 日 & 17 & 50 & 85 & 12 & 819 & 3735 & 1.70 & 74.7 & $(+)$ & ". & \\
\hline & 35 & 伸 & $1 \pm$ & $1 \wedge \quad 281$ & 20 & 56 & 92 & 16 & 606 & 2925 & 1.64 & 52.2 & (t) & ". & \\
\hline 均 & 36 & 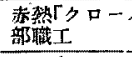 & $n j$ & 1人 21日 & 33 & 53 & 83 & 12 & 783 & 3530 & 1.56 & 66.8 & $(t)$ & , & \\
\hline \multirow[t]{2}{*}{ 勞 } & 37 & 68 & $I$ & 2人 7日 & $20-24$ & 53 & 73 & 6 & 570 & 2694 & 1.38 & 51.0 & $(+)$ & 䆄雚，小泉 & \\
\hline & 38 & 㱐 & 夫 & 6 人 $7 \mathrm{~g}$ & $18-32$ & 54 & 73 & 15 & 338 & 2646 & 1.35 & 49.0 & $(+)$ & 㩁㜪 & \\
\hline \multirow[t]{3}{*}{ 動 } & 39 & 海 & 兵 & 9 人 7 日 & $20-23$ & 62 & 131 & 18 & 647 & 2944 & 2.10 & 47.0 & $1+1$ & 里田 & \\
\hline & & & & $\begin{array}{l}\text { 本均括 } \\
\text { 年均策 }\end{array}$ & 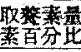 & & $\begin{array}{r}95 \mathrm{E} \\
11.4 \% \\
\end{array}$ & $\begin{array}{r}15 \mathrm{n} \\
4.0 \% \\
\end{array}$ & $\begin{array}{r}705 \mathrm{E} \\
84.6 \%\end{array}$ & $\begin{array}{l}3416 \\
100 \%\end{array}$ & 1.61 & 58.3 & & & \\
\hline & 40 & $x y+x \leq$ & 女xI & $1 \Lambda \quad 36 日$ & 18 & 44 & 153 & 8 & 502 & 2350 & 1.20 & 53.2 & $(+)$ & 扳本 & \\
\hline \multirow{4}{*}{ 子 } & 41 & $x y+2$ & $4 I$ & 1 人 36 日 & 17 & 52 & 51 & 7 & 465 & 2113 & 0.98 & 40.7 & $(+)$ & $" \cdot$ & \\
\hline & 42 & 家 政 & 蟖 & $1 \wedge \quad 36$ 日 & 27 & 47 & 59 & 9 & 510 & 2360 & 1.26 & 50.2 & $(+)$ & $\because$ & \\
\hline & 43 & 北敎 圆 & (女) & 11 & 30 & 59 & 47 & 10 & 417 & 2005 & 0.80 & 34.0 & & $\because$. & \\
\hline & & & & 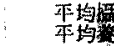 & 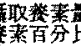 & & $\begin{array}{r}53 \pi \\
9.706\end{array}$ & $\begin{array}{r}9 \mathrm{TI} \\
3.5 \%\end{array}$ & $\begin{array}{r}475 \pi \\
86.8 \%\end{array}$ & $\begin{array}{l}2239 \\
100 \%\end{array}$ & 1.04 & 44.5 & & & \\
\hline
\end{tabular}




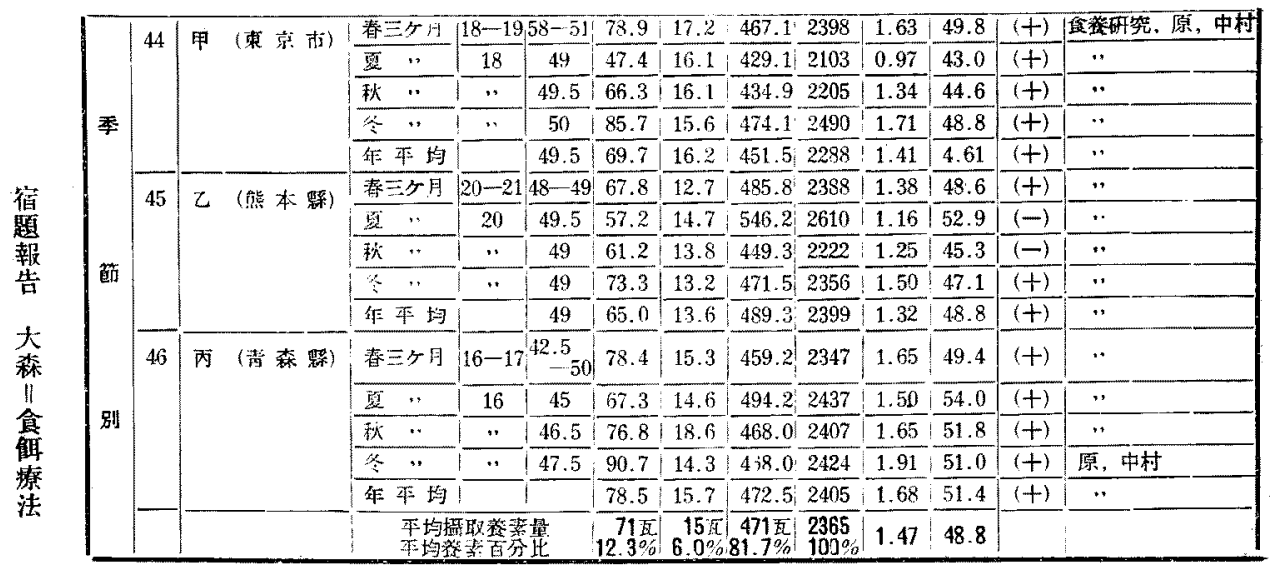

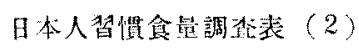

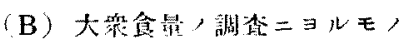

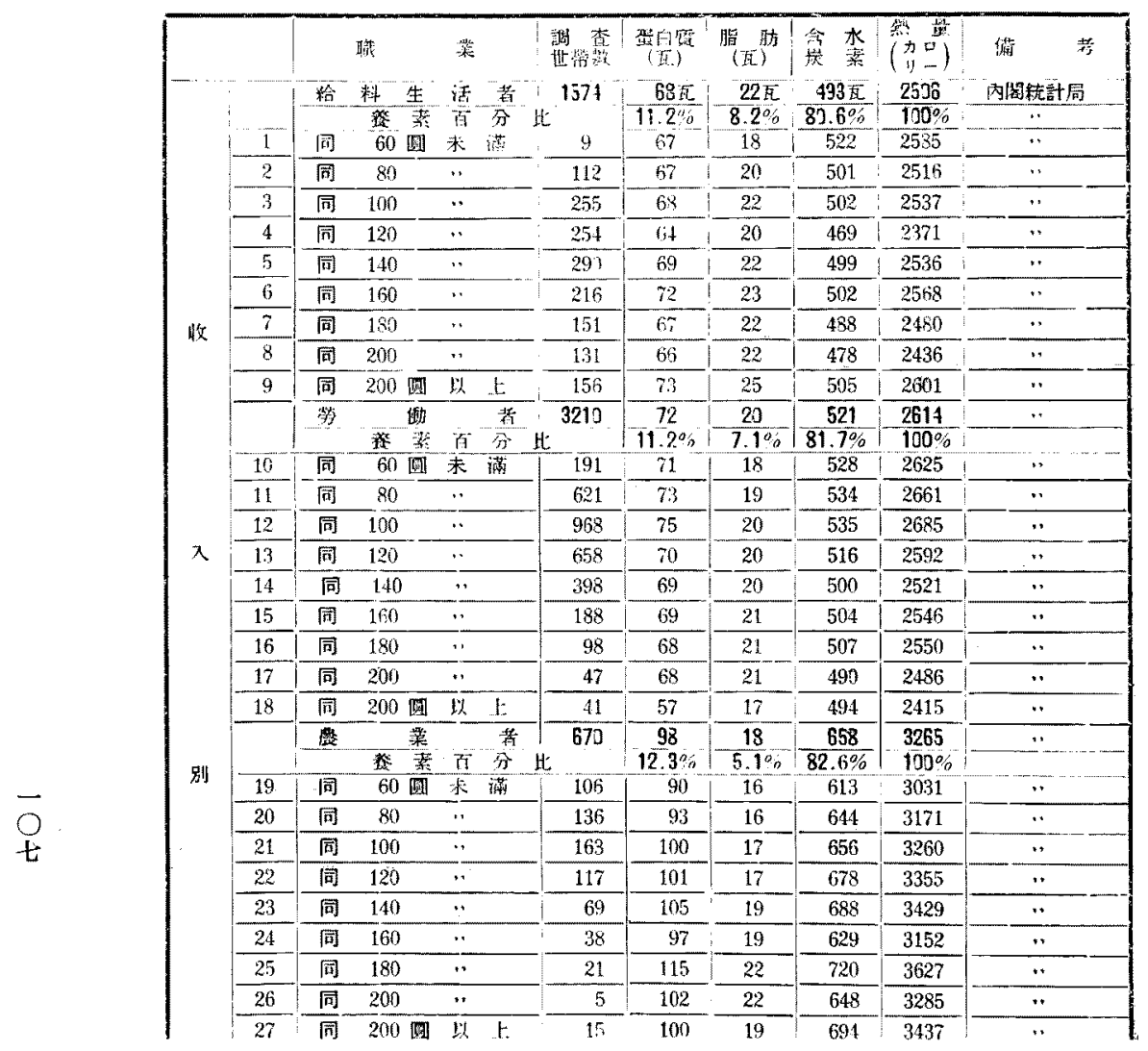




\begin{tabular}{|c|c|c|c|c|c|c|c|c|c|}
\hline \multirow{4}{*}{ 季 } & & 給料生 & 活营平均 & 1574 & 68 & 22 & 493 & 2506 & 內閧㧤的十局 \\
\hline & 28 & 同 & (十月) & " & 68 & 22 & 504 & 2550 & " \\
\hline & 29 & 同 & (五 月) & " & 68 & 22 & 482 & 2460 & .. \\
\hline & & 勞 喓 & 者 平 均 & 3210 & 72 & 20 & 521 & 2614 & ." \\
\hline \multirow[t]{2}{*}{ 鵕 } & 30 & 同 & $(十$ 月) & $"$ & 72 & 20 & 529 & 2551 & $"$ \\
\hline & 31 & 同 & (五月) & $"$ & 71 & 19 & 514 & 2578 & ". \\
\hline \multirow{3}{*}{ 别 } & & 策 & 奢平均 & 670 & 98 & 18 & 658 & 3265 & . \\
\hline & 32 & 阅 & $(+F)$ & " & 101 & 18 & 695 & 3430 & $"$ \\
\hline & 33 & 同 & (和 & 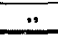 & 96 & 17 & 622 & 3101 & $\therefore$ \\
\hline
\end{tabular}

\begin{tabular}{|c|c|c|c|c|c|c|c|c|c|c|}
\hline & 職鄴又心公踝 & 媩查人員及日數 & 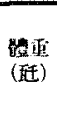 & $\begin{array}{l}\text { 蛋白算 } \\
\text { (五) }\end{array}$ & $\begin{array}{l}\text { 指肪 } \\
(\text { 瓦) }\end{array}$ & 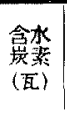 & $\left(\begin{array}{c}\text { 热量 } \\
\left(\begin{array}{l}7 \\
y\end{array}\right)\end{array}\right.$ & 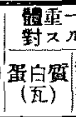 & 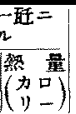 & 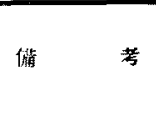 \\
\hline 34 & 管院 & 839 人 2 日 & 44 & 50 & 13 & 321 & 1637 & 1.10 & 36.1 & 山原,所田、吾高 \\
\hline 35 & 女 (絸 綵) & 163003人 100日 & - & 59 & 12 & 407 & 2019 & - & - & 井上 \\
\hline 36 & 女 (祊 箱) & 7052 人 $\quad 30$ 日 & 43 & 72 & 13 & 468 & 2336 & 1.68 & 54.2 & 清水 \\
\hline 37 & 女 (紡 锴) & 13 人 & - & 65 & 11 & 464 & 1859 & - & - & 松昆，田中 \\
\hline 38 & 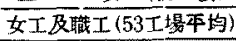 & 95463 人 180 日 & - & 65 & 14 & 456 & 2268 & - & - & 助川，茶业 \\
\hline 39 & 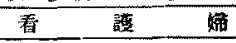 & 360 人 180 日 & 50 & 51 & 14 & 349 & 1772 & 1.01 & 35.4 & 原.中村 \\
\hline 40 & 某病院三等会解 & 180日 & $\cdots$ & 60 & 13 & 397 & 1991 & - & $+\cdots$ & 原，烃岡 \\
\hline 41 & 某病院（別) 三等领解 & 365 日 & - & 73 & 19 & $\overline{386}$ & 2055 & - & - & 原，川口，石川 \\
\hline & & 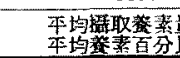 & & $\begin{array}{r}62 \pi \\
12.8 \%\end{array}$ & $\begin{array}{l}14 \mathrm{E} \\
6.4 \% \\
\end{array}$ & $\begin{array}{l}393 \mathrm{E} \\
89.8 \% \\
\end{array}$ & $\begin{array}{l}1994 \\
100 \%\end{array}$ & $\overline{1.26}$ & 41.9 & \\
\hline
\end{tabular}

\begin{tabular}{|c|c|c|c|c|c|c|c|c|c|c|c|}
\hline & & 人名又八芜族名 & 搠筑人買又日數 & 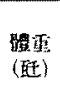 & $\begin{array}{c}\text { 蛋白望 } \\
\text { (而) }\end{array}$ & $\begin{array}{l}\text { 脂肪 } \\
(\bar{E})\end{array}$ & 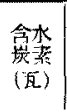 & 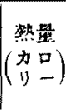 & 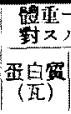 & 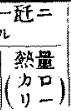 & 嘴 \\
\hline \multirow{10}{*}{ 季 } & \multirow{5}{*}{42} & \multirow{5}{*}{ 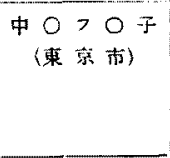 } & 1人 7 日名12间 & 45 & 54 & 23 & 228 & 1367 & 1.20 & 30.4 & 中村，吉田，白井，川口 \\
\hline & & & 䅈 $三$ 月 & $\therefore$ & 49 & 22 & 179 & 1177 & 1.08 & 26.1 & 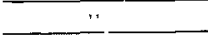 \\
\hline & & & 夏 & $\because$ & 54 & 29 & 257 & 1566 & 1.19 & 34.8 & $\because$ \\
\hline & & & 秋 & " & 59 & 16 & 247 & 1426 & 1.21 & 28.8 & $\stackrel{-}{\sim}$ \\
\hline & & & 冬 & $\ddot{*}$ & 55 & 25 & 229 & 1297 & 1.21 & 28.8 & $\because$ \\
\hline & \multirow[t]{5}{*}{43} & \multirow{5}{*}{$\begin{array}{l}\text { 中 } \mathrm{O} \text { - 家 } \\
(\text { (成 } 11 \text { 酻) }\end{array}$} & $6 \wedge 7$ 日宛12匣 & 50 & 68 & 13 & 395 & 2019 & 1.35 & 40.4 & $\ddot{*}$ \\
\hline & & & 春 三名 月 & "n & 71 & 8 & 386 & 1942 & 1.42 & 38.8 & 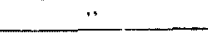 \\
\hline & & & 豆 & ". & 70 & 10 & 362 & 1866 & 1.40 & 37.3 & $\ddot{-}$ \\
\hline & & & 秋 & $\therefore$ & 62 & 15 & 380 & 1947 & 1.24 & 38.9 & 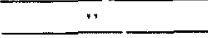 \\
\hline & & & x & $" *$ & 83 & 19 & 455 & 2319 & 1.66 & 46.4 & 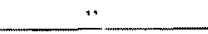 \\
\hline \multirow[t]{5}{*}{ 简 } & \multirow{5}{*}{44} & \multirow{5}{*}{$\begin{array}{c}\text { 奥 } 0 \text { - 家 } \\
\text { (名古屋市) }\end{array}$} & 3 人 7日宛12局 & 46 & 73 & 16 & 372 & 1977 & 1.58 & 43.0 & $\because$ \\
\hline & & & 眷三百 & 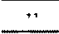 & 66 & 15 & 343 & 1816 & 1.43 & 39.4 & $\ldots$ \\
\hline & & & 夏 & ". & 70 & 14 & 370 & 1931 & 1.52 & 42.0 & $\cdots$ \\
\hline & & & 秋 & 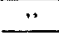 & 77 & 17 & 427 & 2216 & 1.66 & 48.2 & 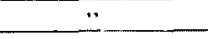 \\
\hline & & & 尔 & 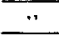 & 79 & 20 & 350 & 1943 & 1.72 & 42.2 & " \\
\hline \multirow{6}{*}{ 別 } & \multirow[t]{6}{*}{45} & \multirow{6}{*}{$\begin{array}{c}\text { ○时一家 } \\
(\text { 東索术) }\end{array}$} & 3 人 7日宛12间 & 60 & 102 & 17 & 466 & 2480 & 1.71 & 41.7 & $\ddot{-}$ \\
\hline & & & 春 $三 っ \quad$ 月 & $\because$ & 105 & 18 & 420 & 2310 & 1.76 & 39.0 & 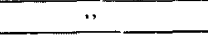 \\
\hline & & & $\mathrm{E}$ & $"$ & 96 & 15 & 506 & 2604 & 1.60 & 43.8 & $\ddot{\ddot{ }}$ \\
\hline & & & 秋 & 1 & 103 & 14 & 465 & 2463 & 1.73 & 41.5 & 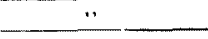 \\
\hline & & & 冬 & $"$ & 104 & 19 & 472 & 2539 & 1.75 & 42.6 & 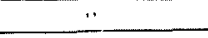 \\
\hline & & & 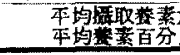 & & $\begin{array}{r}715 \\
15.6 \% \\
\end{array}$ & $\begin{array}{l}171 \\
8.1 \% \\
\end{array}$ & $\begin{array}{r}363 \pi \\
76.3 \% \\
\end{array}$ & $\begin{array}{l}1950 \\
100 \% \\
\end{array}$ & 1.46 & 39.1 & \\
\hline
\end{tabular}




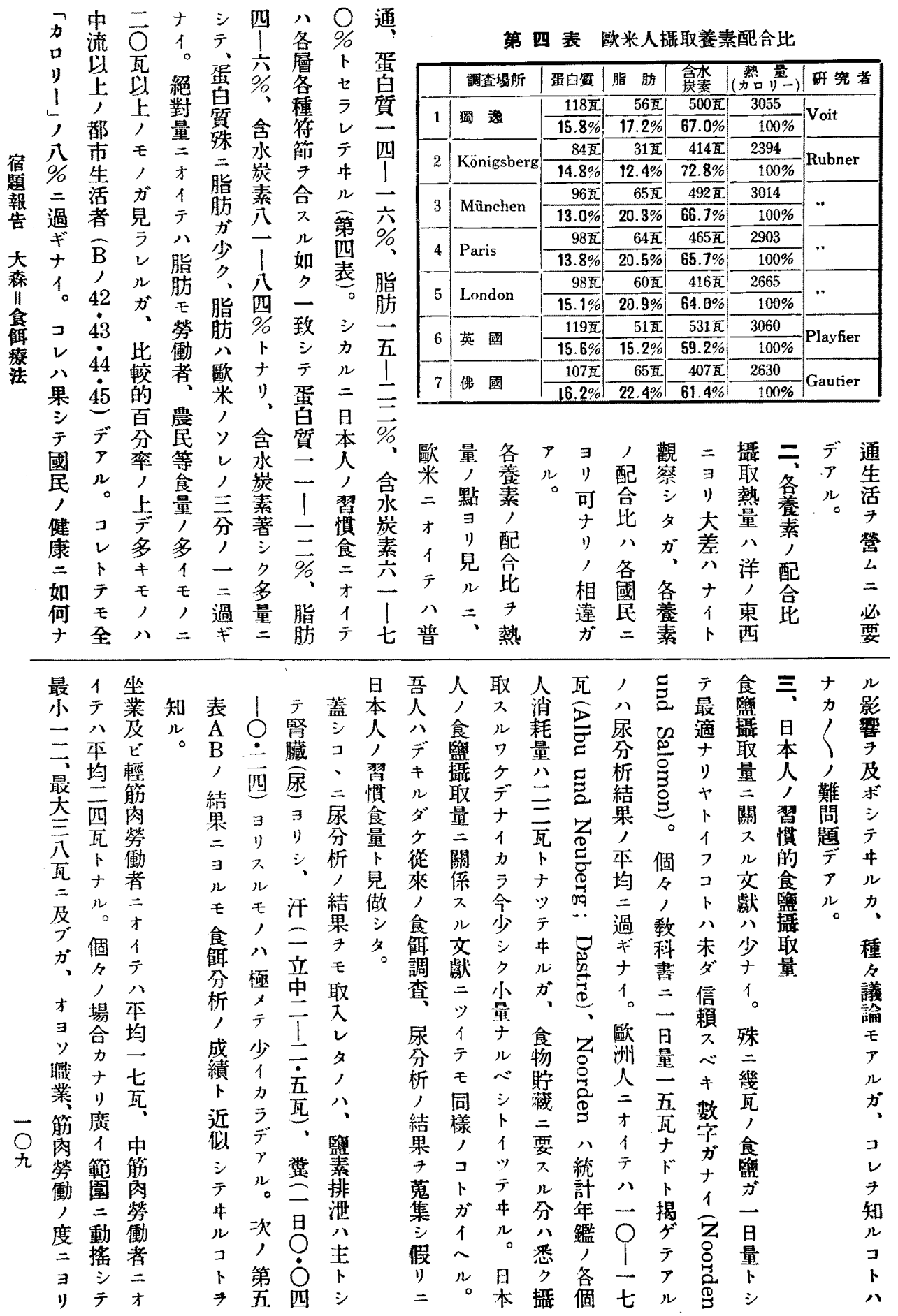


第五表 日本人一日食签攝取量

A）食籃一日攝取量

\begin{tabular}{|c|c|c|c|c|c|c|c|c|c|c|}
\hline & 番制 & 坦 & 業 & 年 月 日 & 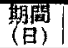 & 八員 & 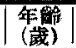 & 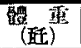 & 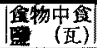 & 㑤 \\
\hline \multirow{10}{*}{ 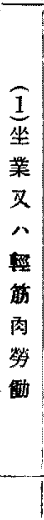 } & 1 & 東京 & 老䬧 & $\begin{array}{l}\text { 大亚11年 } 5 \text { 月 } \\
23 \text { 日 } 29 \text { 日 }\end{array}$ & 7 & 5 & 74 & 43.3 & 16.7 & 服部呀二\& \\
\hline & 2 & 果 腺 & 坐 業 & 大正13年 & & & & & 16.8 & 中西·原 \\
\hline & 3 & 東京苦 & 研垁航助手 & $\begin{array}{l}\text { 炤和 } 3 \text { 年5月 } \\
-4 \text { 年 } 4 \text { 月 }\end{array}$ & 365 & 1 & 18 & 49.5 & 16.3 & 愿筧 \\
\hline & 4 & 熊本䲝村 & 研究所助手 & $\cdot$. & 365 & 1 & 20 & 49.1 & 12.2 & 原宣 \\
\hline & 5 & 望森辰村 & 研究所助手 & $\cdot$ & 365 & 1 & 16 & 46.4 & 17.4 & 原箕 \\
\hline & 6 & 京 城 & 需成病㛡 & 明治44年 6 月 & & & & & 24.9 & 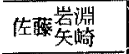 \\
\hline & 7 & 東事桑 & 某病 医 & $\begin{array}{l}\text { 昭租 8年11月 } \\
-9 \text { 知10月月 }\end{array}$ & 365 & & & & 16.1 & 源・川几，石川 \\
\hline & 8 & 東京市 & 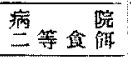 & $\begin{array}{l}\text { 昭租 10年7月 } \\
-12 \text { 月 }\end{array}$ & 13 & & & & 15.7 & 中野七子 \\
\hline & 9 & 東京市 & 病等食㙁 & $\begin{array}{l}\text { 照租104 } 12 \text { 月 } \\
24 \mathrm{G}-28 \mathrm{~B}\end{array}$ & $4 !$ & & & & 16.2 & 中野七子 \\
\hline & 乐 & 均 & & & & & & & 16.9 & 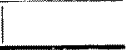 \\
\hline \multirow{7}{*}{ 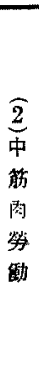 } & 10 & 京 城 & \pm & 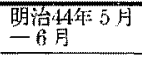 & & & & & 22.3 & 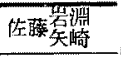 \\
\hline & 11 & 中菲 & 酷軍兵才 & 大正13知= & & & & & 16.5 & 中陆·原 \\
\hline & 12 & 朝 缩 & 夫 & 明治42年 & & & & & 19.5 & \multirow{4}{*}{ 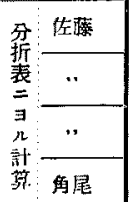 } \\
\hline & 13 & 永登甫 & 要 利 者 & $\begin{array}{l}\text { 明治 } 43 \text { 华 } 3 \text { 月 } \\
-44 \text { 年 } 6 \text { 月 }\end{array}$ & & & & & 23.0 & \\
\hline & 14 & 域 & 受 利 搕 & $\begin{array}{c}\text { 明治 } 44 \text { 年 } \\
3 \text { 月 }\end{array}$ & & & & & 22.7 & \\
\hline & 15 & 毁多篓 & 受 刑 省 & 大正 9 年 3 月 & & & & & 38 & \\
\hline & 16 & 㓠 & 受刑者 & 大正13年 & & & $20-40$ & & 30.7 & 中西·滰 \\
\hline & 平 & 均 & & & & & & & 24.9 & \\
\hline
\end{tabular}

B）食監一日代謝量(尿分析) 1

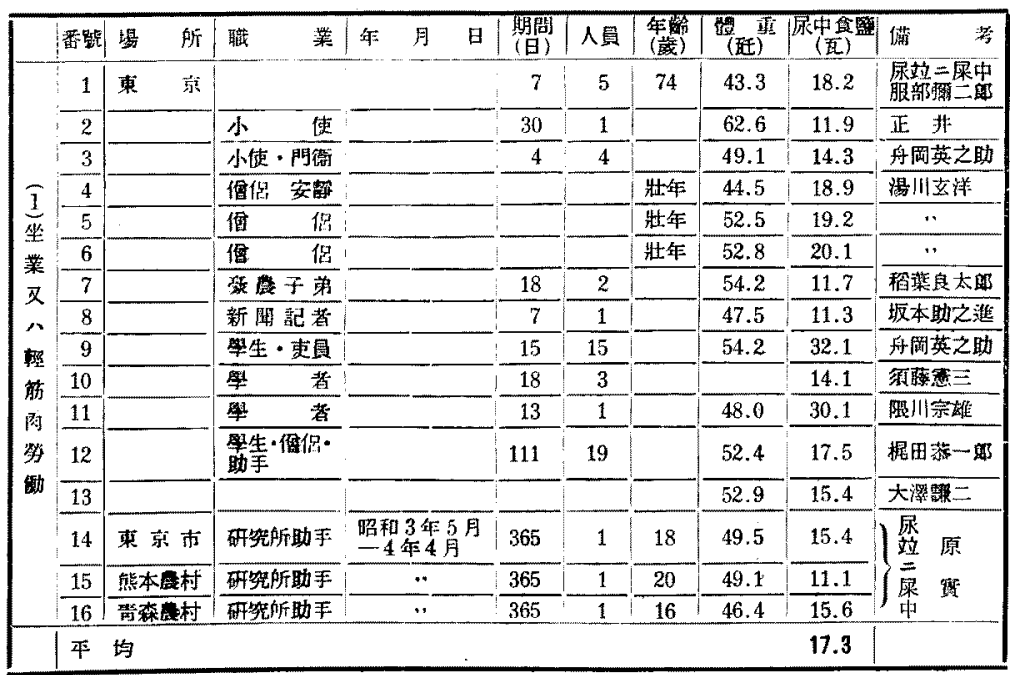

-

空

瓦

$+$

$+$

ッ

$\overline{7}$

年 


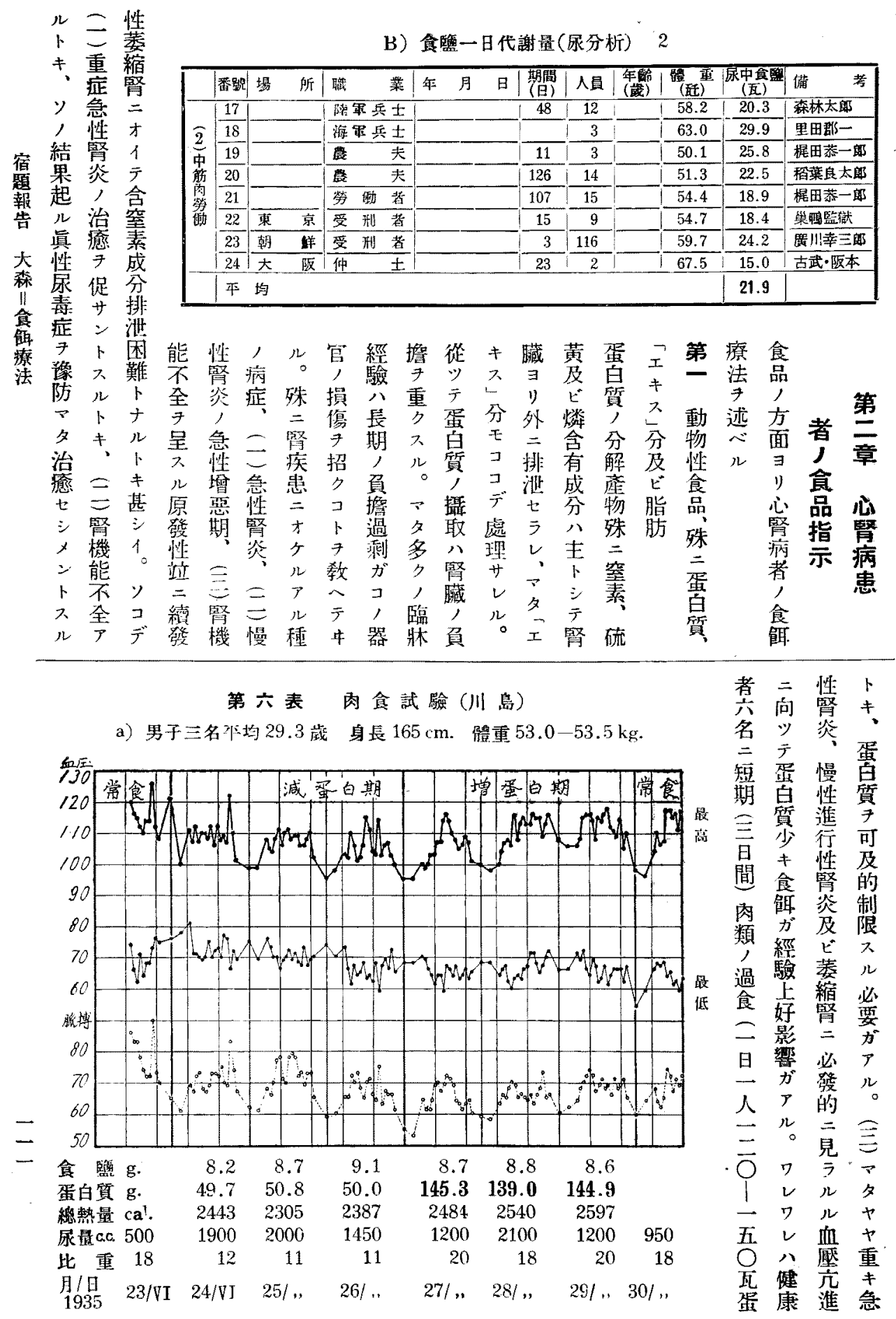


肉食試驗 b) 女子三名本均 27.6 戴 身長 $147.8 \mathrm{~cm}$, 體重 $49.1-50.9 \mathrm{~kg}$.
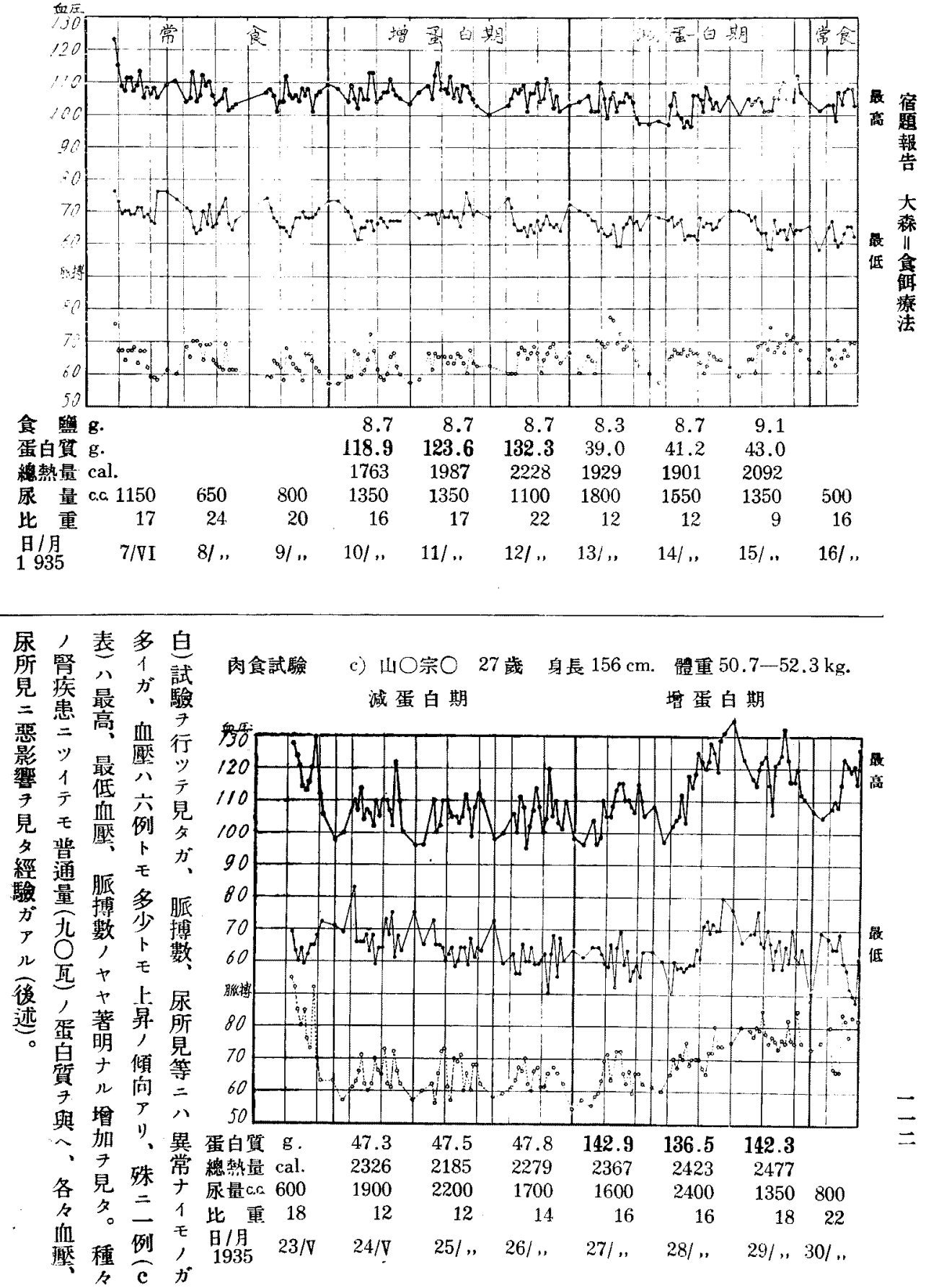


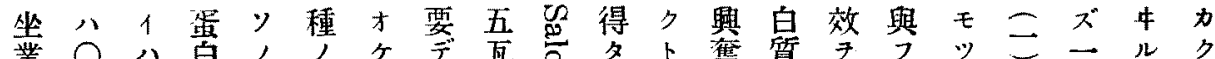

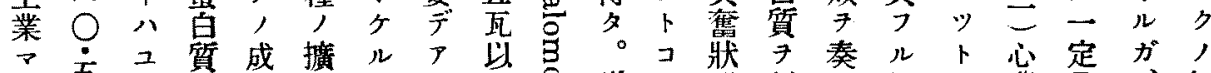

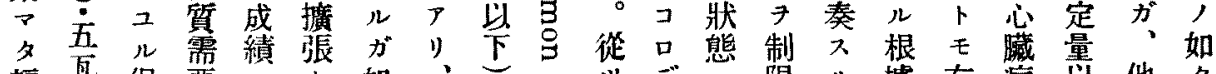

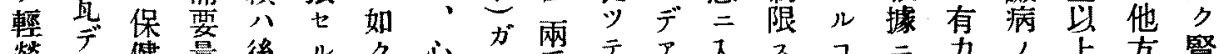

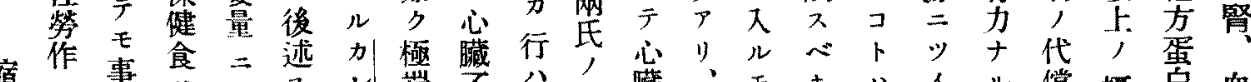
題則足

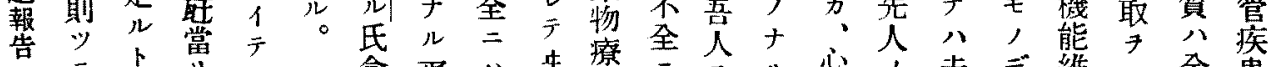

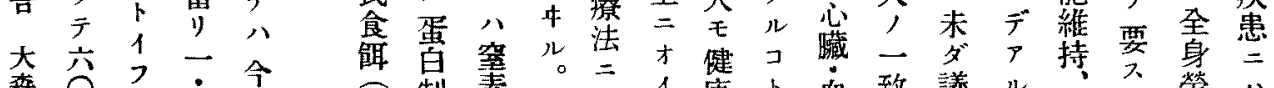

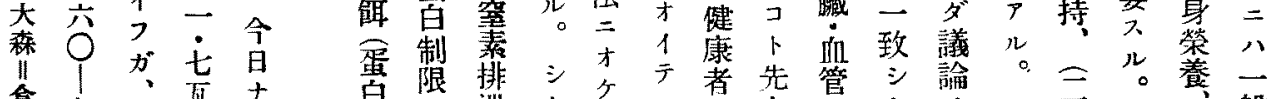

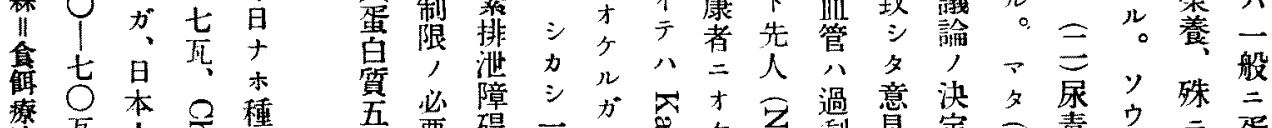

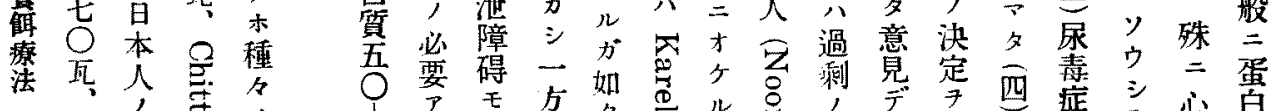

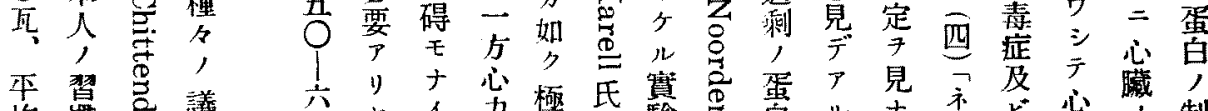

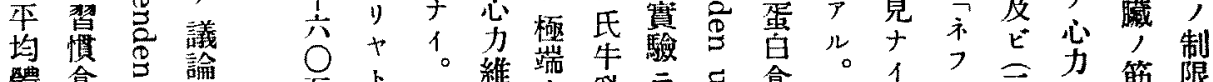

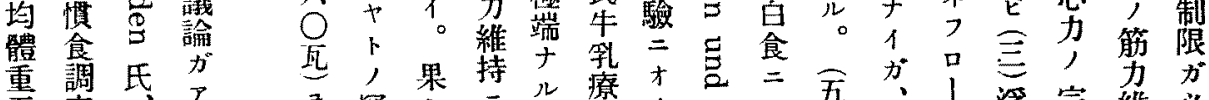

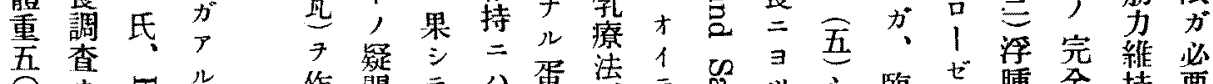
○罗么 作問

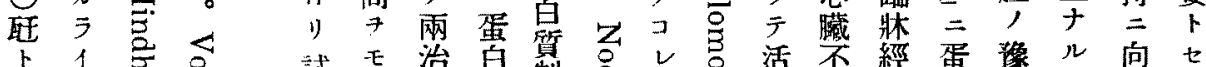

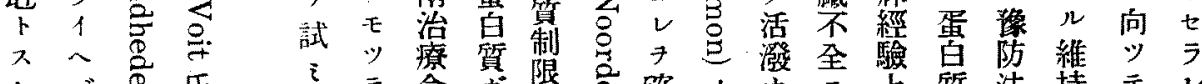

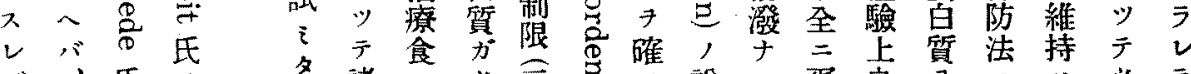

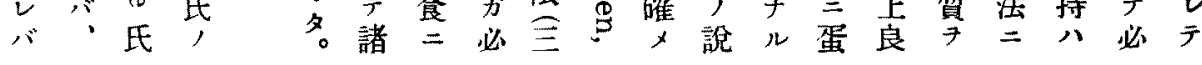

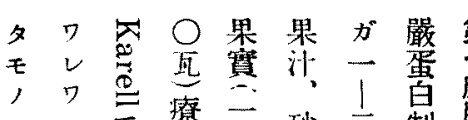

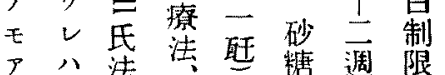

ア少法法造糖遇限

几。少, 承療米使無

$コ$ 马力 $\overrightarrow{0}=$

期荣鮽氏 8 汾儿, 減

$=$ 1牛畱 $i$ 水

八葉單学马拔 デデ

少藮純分心

量荣二

四管ギ

辇等蜜療氏原妾量

, モ使等果料 有蛋

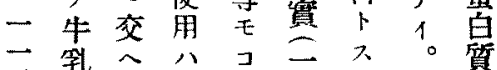

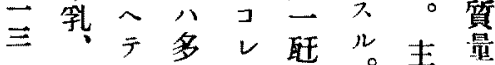

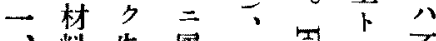

三料失

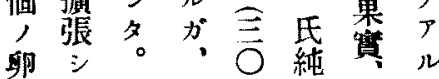

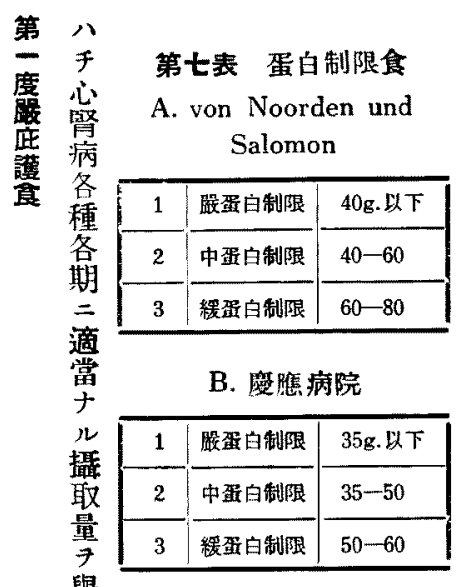

三才牛舩

度 1 算名 賞

于 際意》

分八胃一

分難完玄

次望1。至!

如泉染无

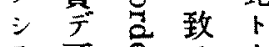

テ不要年ナ

中利見儿

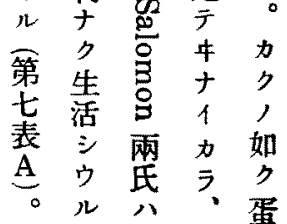

レト, 三少, 合吾卜熱蛋白

バソ蛋タシ體デ人シ量白貿

人白第卜重ア八哲最

適制第見八儿コ蛋分制適

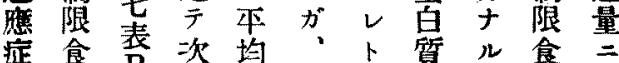

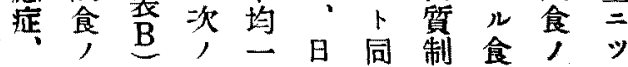

入丙。如 $\bigcirc$ 本 $三$ 限解定1

$ナ$ 容コク䑶人制 $\ni=$ 義 


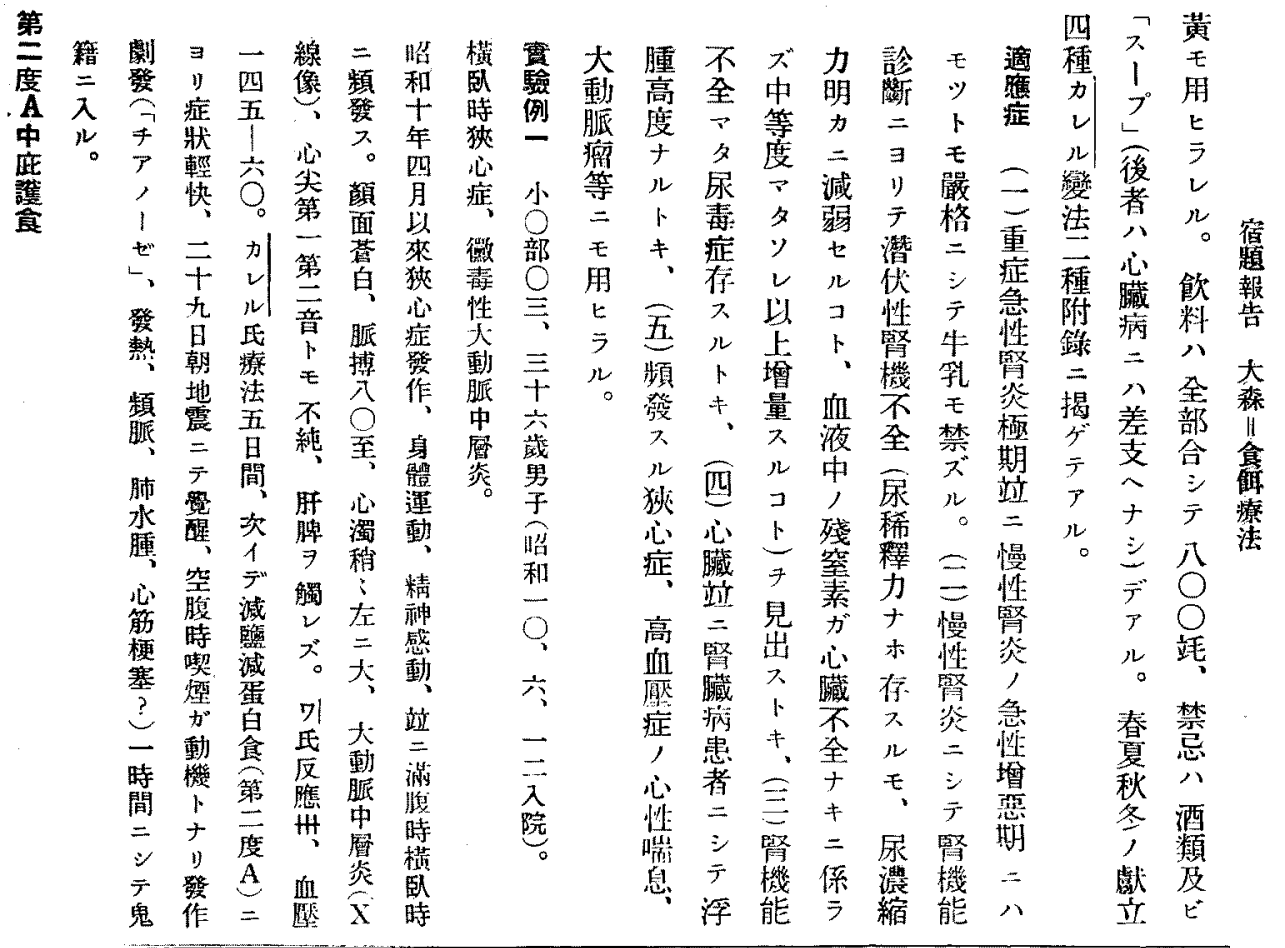

\begin{tabular}{|c|c|c|c|c|c|c|c|c|c|c|c|c|c|c|c|c|c|c|c|c|}
\hline 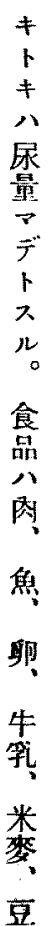 & 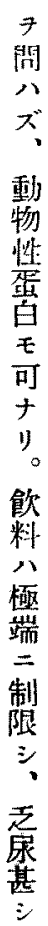 & 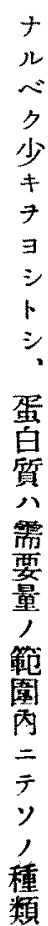 & 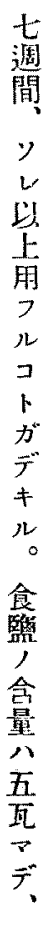 & 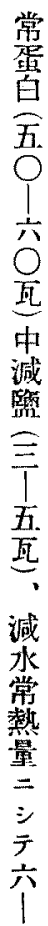 & 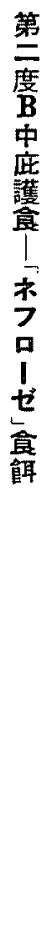 & 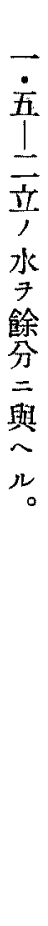 & 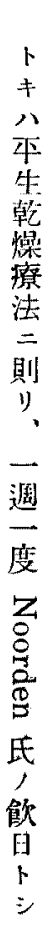 & 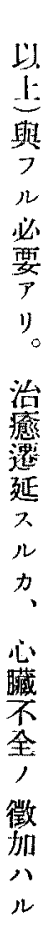 & 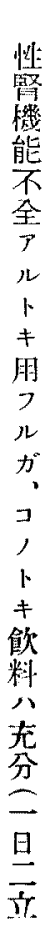 & 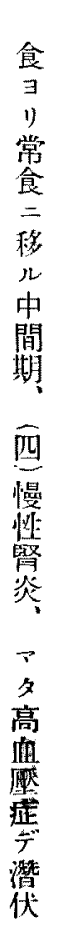 & $\begin{array}{c}\text { カ } \\
\text { U } \\
\text { ル } \\
\text { 氏 } \\
\text { 瘦 } \\
\text { 浩 } \\
\vec{\nabla} \\
\text { タ } \\
\text { 第 } \\
\text { 度 } \\
\text { 店 } \\
\text { 護 }\end{array}$ & 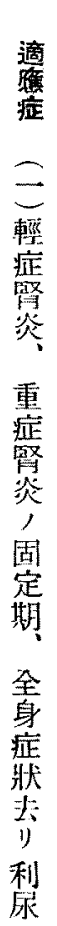 & 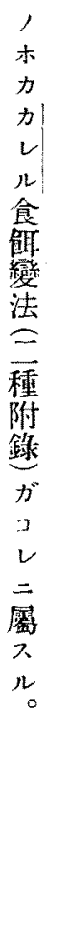 & 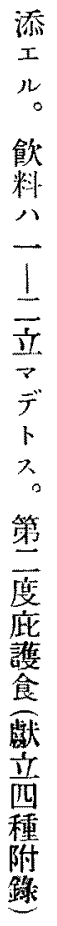 & 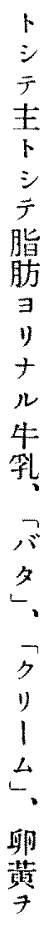 & 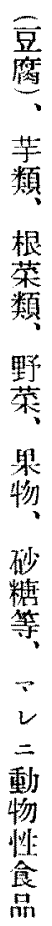 & 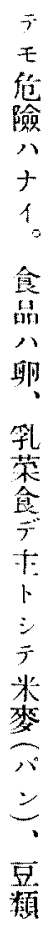 & 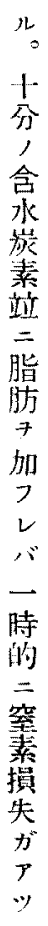 & 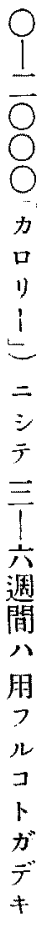 & 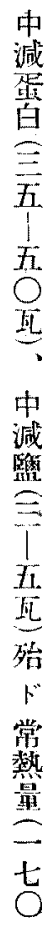 \\
\hline
\end{tabular}



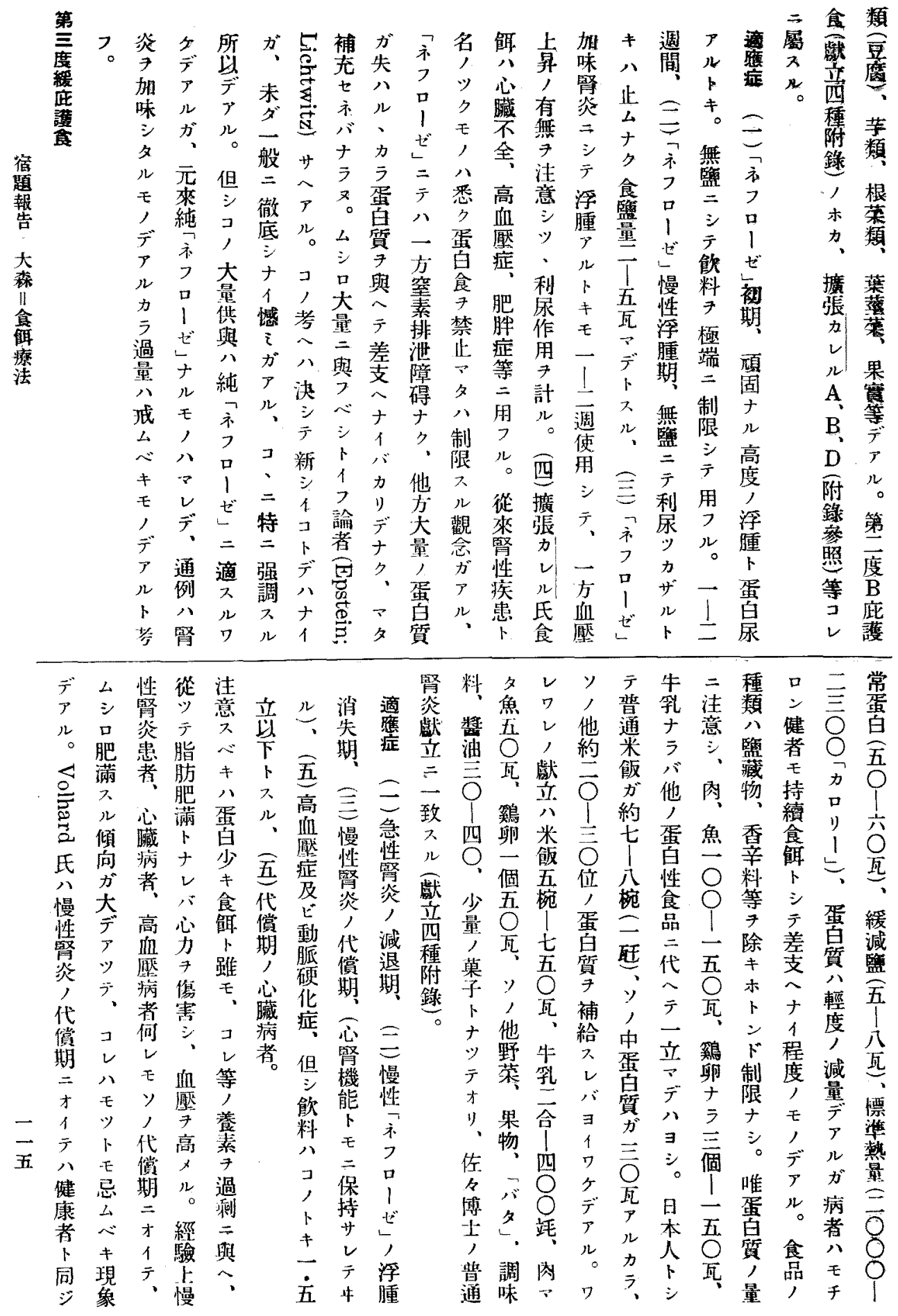


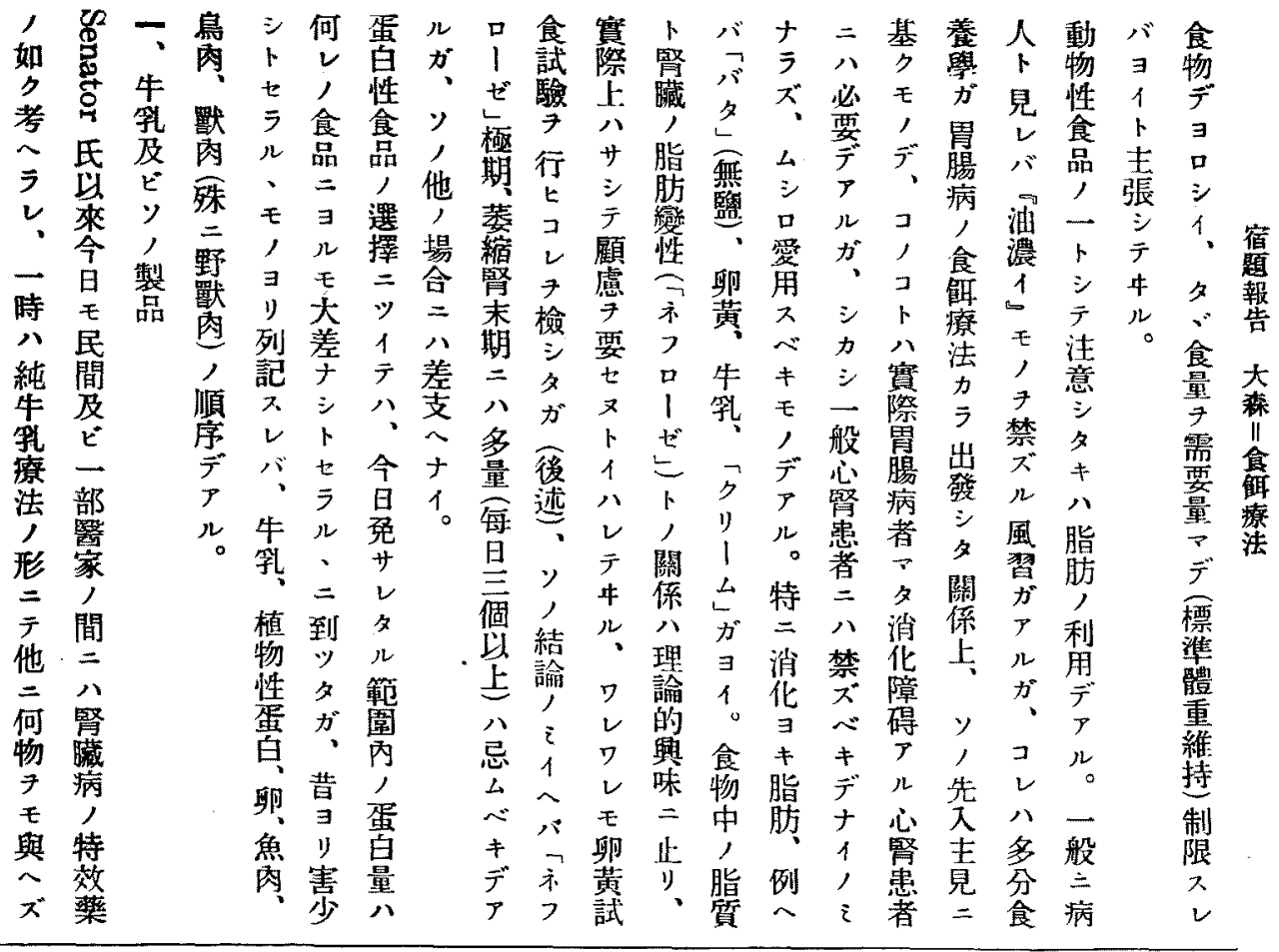

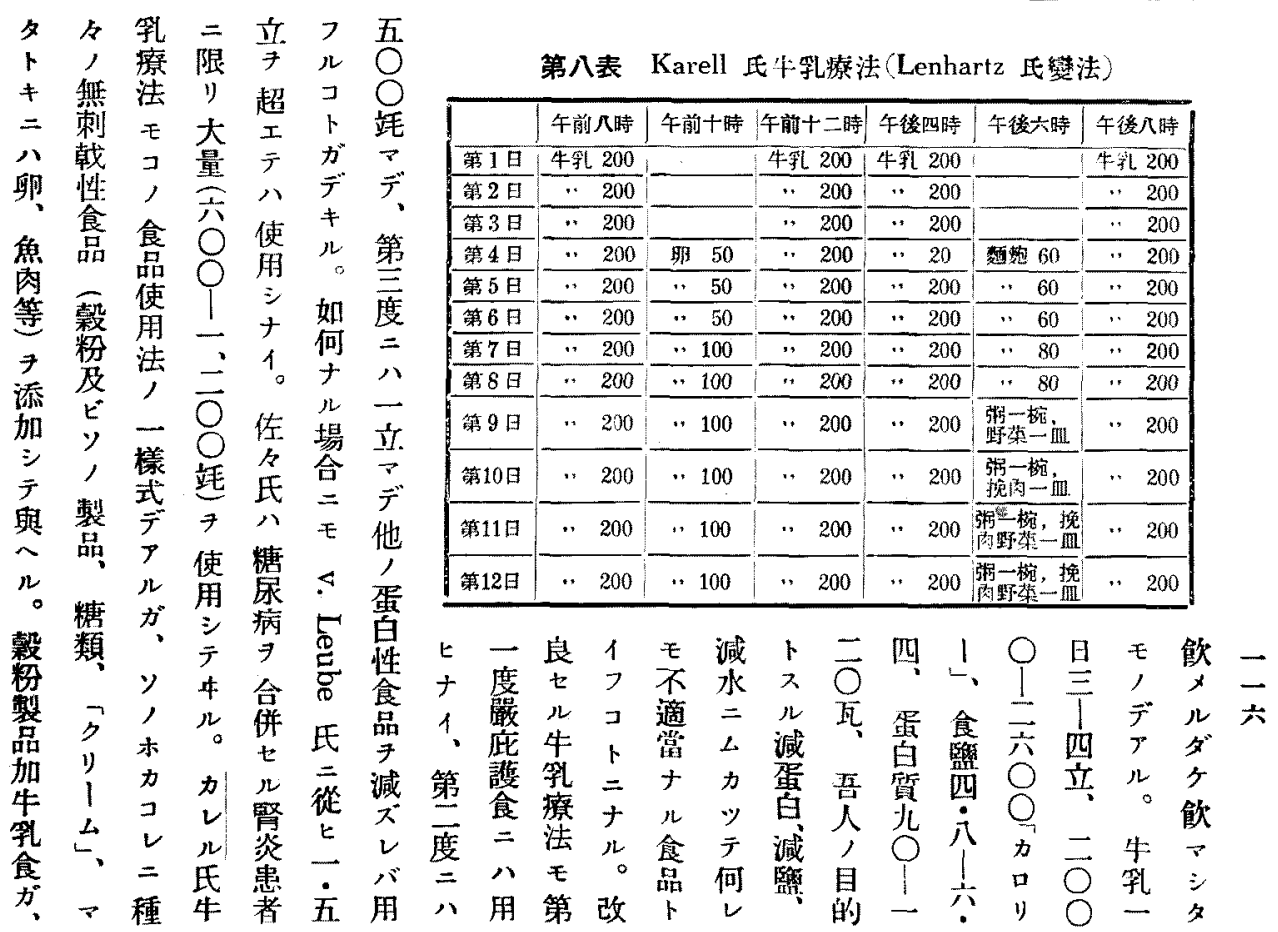




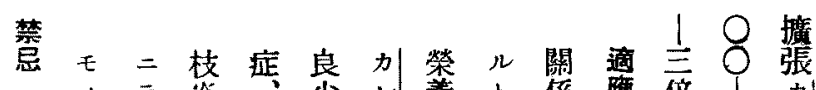

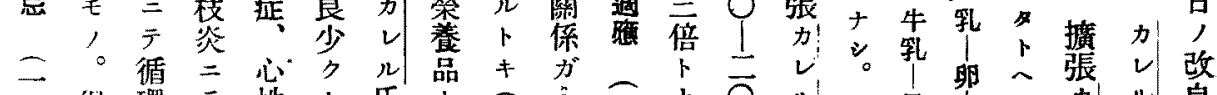

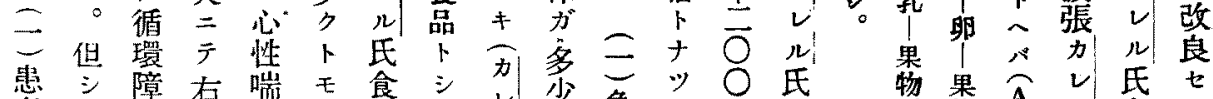
墨

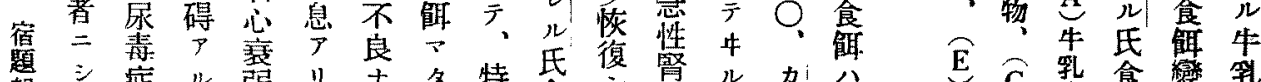

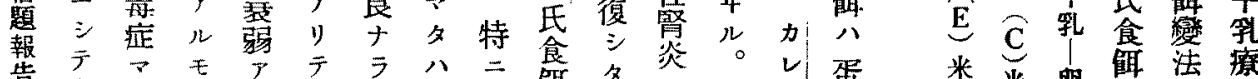

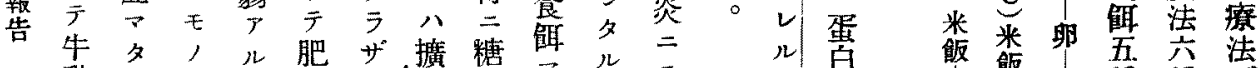

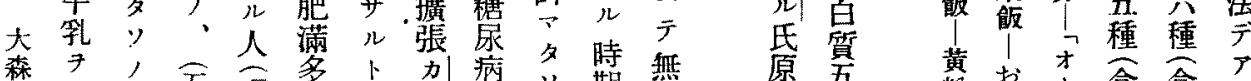
川 好傾五

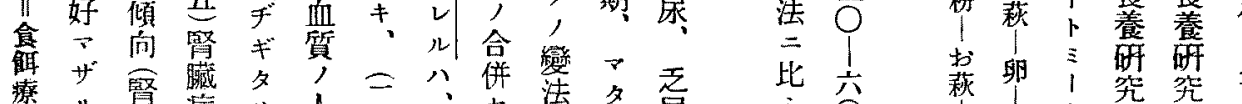

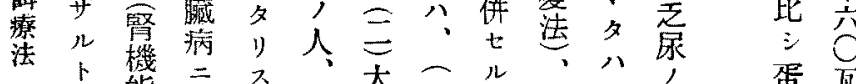

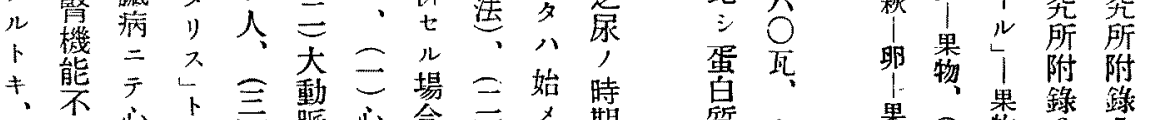

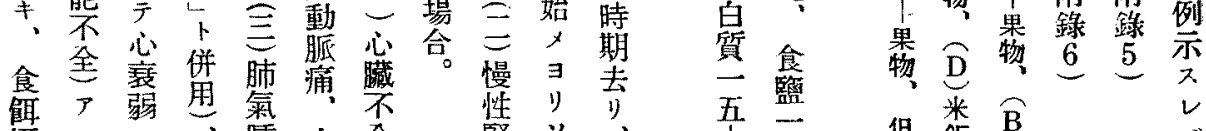

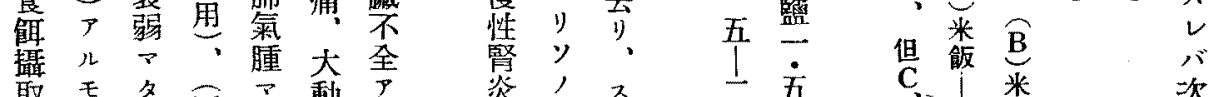

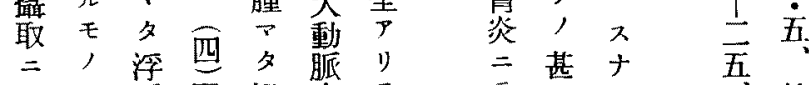

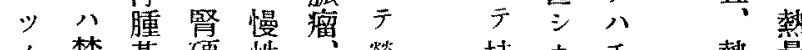

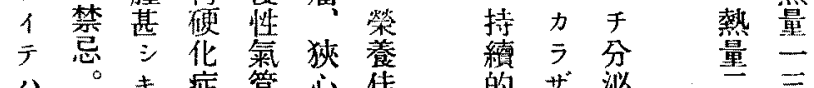

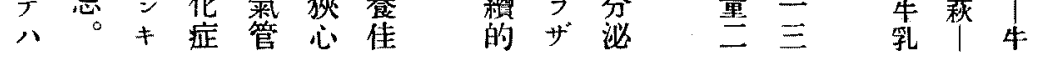

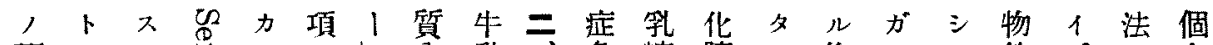

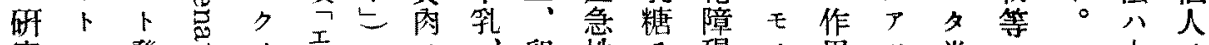

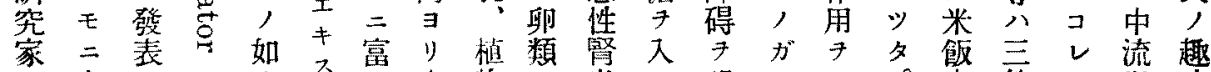

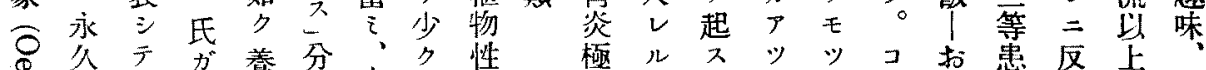

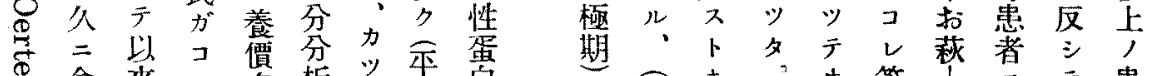

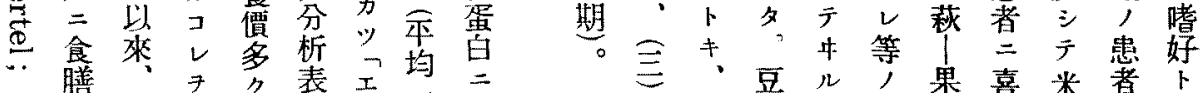

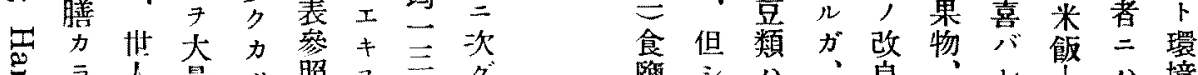

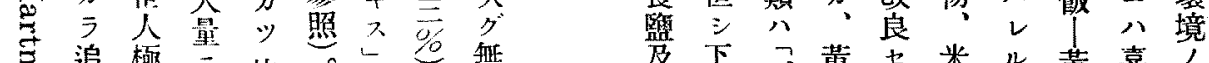

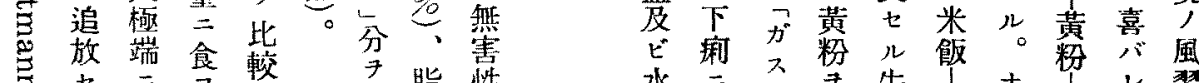

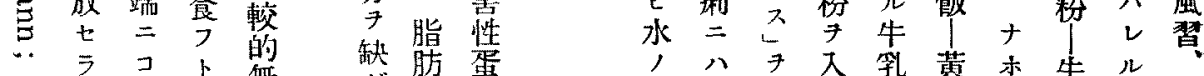

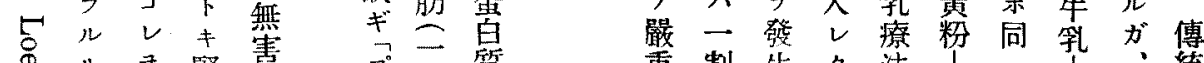

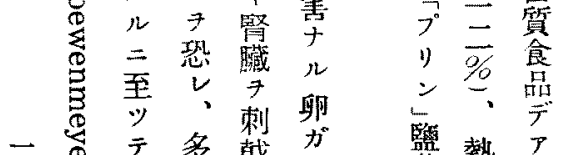
一息 七二ルハシ 昔基量尘 ヨ。掔蛋二痕三卵

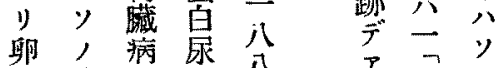
, 卯, 病尿公水方,

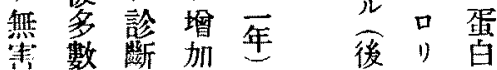
重割纵夕法|一䖻

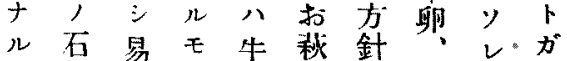
制灰 1 , 学! ! 米以了 限水嫝八, 果下飯永几。 要便唯部，異全黄人力 入秘厂膨健特然粉 こ $ル=ル$ 霂䟤二牛! ハ $卜 八$ 感 $尹$ 喜乳牛喜氏

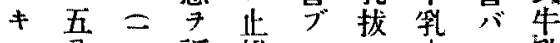
重, 分活訴掦モ, 
第九表 腎・血管病患省二オケル卵黄卵白武驗(淺野)

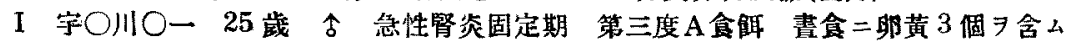

\begin{tabular}{|c|c|c|c|c|c|c|c|c|c|c|c|c|}
\hline 尿排泄時 & 尿量 & 性 & 比重 & $\begin{array}{l}\frac{3}{\text { 蛋白 }} \\
\text { \% }\end{array}$ & 赤血球 & 自血球 & 肢上皮 & 国柱 & 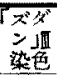 & 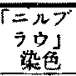 & 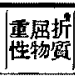 & 㑲 \\
\hline 朝食前 & 400 & 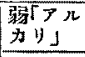 & 17 & 8.0 & 青 & H & \pm & + & \pm & \pm & - & \\
\hline 朝食後 2 時閐 & 200 & ". & 18 & 9.0 & 世 & $H$ & $t$ & + & - & \pm & - & \\
\hline 害亚前 & 0 & $y$ & $y$ & 5 & $y$ & 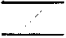 & ' & & & & $Y$ & \\
\hline 变食後 2 時間 & 200 & $\begin{array}{l}\text { 弱アル } \\
\text { カy」 }\end{array}$ & 18 & 9.0 & 世 & $H$ & + & + & + & + & - & \\
\hline 夕食前 & 200 & $"$ & 18 & 8.5 & $\#$ & $H$ & + & + & + & + & - & 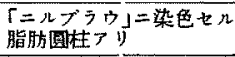 \\
\hline 多定後2 時間 & 200 & $"$ & 16 & 8.0 & 曲 & $H$ & + & + & \pm & \pm & - & \\
\hline 萻 层 & 1780 & " & 20 & 8.0 & 世 & H & $t$ & + & + & + & - & \\
\hline
\end{tabular}

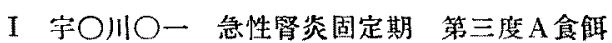

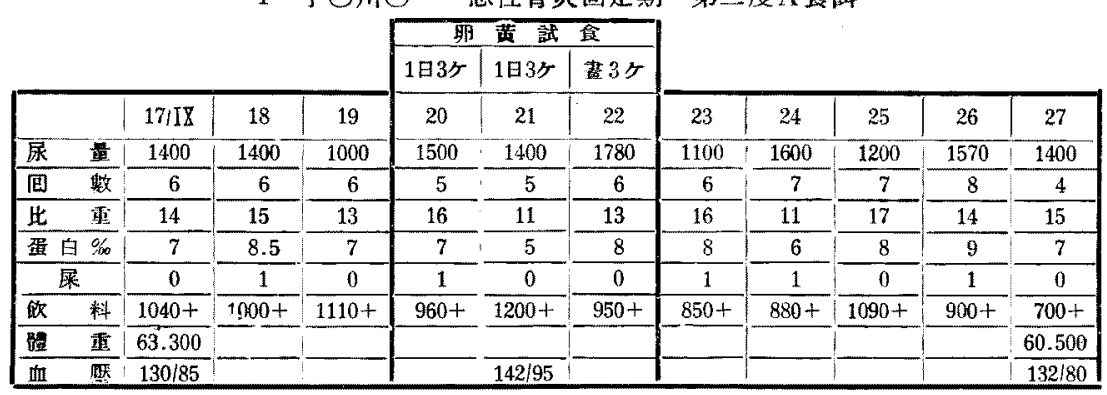

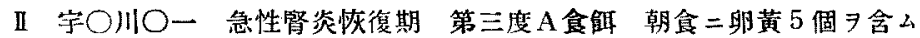

\begin{tabular}{|c|c|c|c|c|c|c|c|c|c|c|c|c|}
\hline 䐂排汁時 & 尿量 & 性 & 此重 & 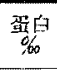 & 赤血球 & 白监球 & 孟上皮 & 国柱. & 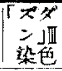 & 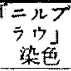 & 值䙓折 & 满 \\
\hline 朝食前 & 380 & 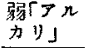 & 15 & 8.0 & \# & H & + & + & + & \pm & - & \\
\hline 朝全徭] 時間 & 0 & 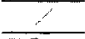 & 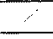 & 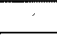 & & & 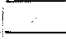 & $y$ & 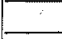 & $\therefore$ & $\therefore$ & \\
\hline " 2 時閣 & 120 & 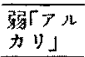 & 15 & 12.0 & H & $\#$ & + & + & + & + & - & \\
\hline$" 3 \bar{B} 4$ 時䦓 & 0 & 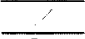 & & & & & $\because$ & & & F & $y$ & \\
\hline “. 5 時問 & 200 & 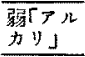 & 12 & 11.0 & $H$ & H & + & + & + & $H$ & - & 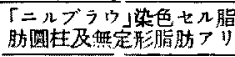 \\
\hline$\because 6$ 時問 & 80 &.$\cdot$ & 13 & 11.0 & H & H & $t$ & + & $t$ & + & - & \\
\hline . 7 時閣 & 0 & 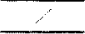 & 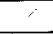 & $\therefore$ & 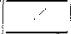 & & 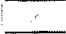 & & $\angle$ & $\zeta$ & $\therefore$ & \\
\hline “ 8 時䦓 & 120 & 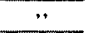 & 14 & 11.0 & $H$ & $H$ & + & + & + & + & - & \\
\hline . 9 時閻 & 100 & $\because$ & 14 & 10.0 & $H$ & $H$ & \pm & + & + & + & - & \\
\hline " 10 時䦓 & 70 & $"$ & 14 & 10.0 & H & $H$ & + & + & $t$ & + & - & \\
\hline 憲 尿 & $170 n$ & ", & 12 & 10.0 & H & $H$ & + & + & + & + & - & \\
\hline
\end{tabular}

II 宇 $\mathrm{O} 川 \mathrm{O}$ - 急性腎炎恢復期 第三度 $\mathrm{A}$ 食聑

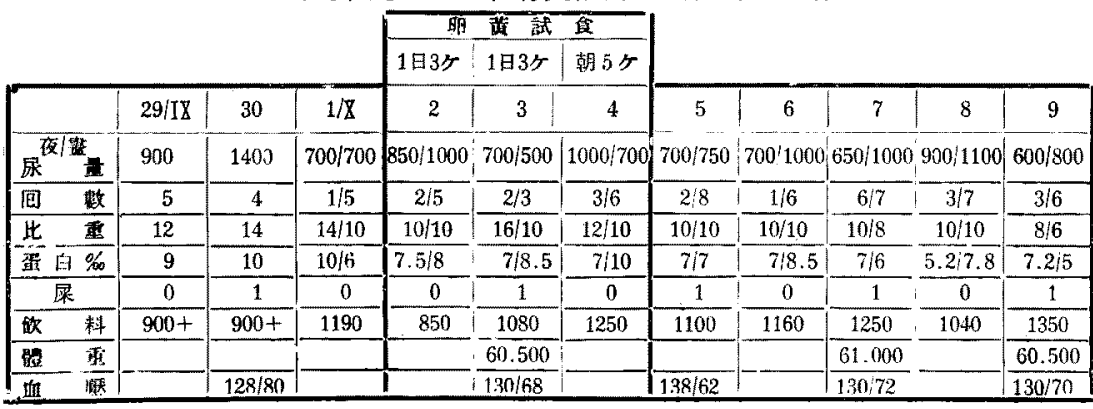


12/IX 1935 朝食二贸黄 5 ケヨ含ム

II 中○直○25 歲 今 慢性腎炎

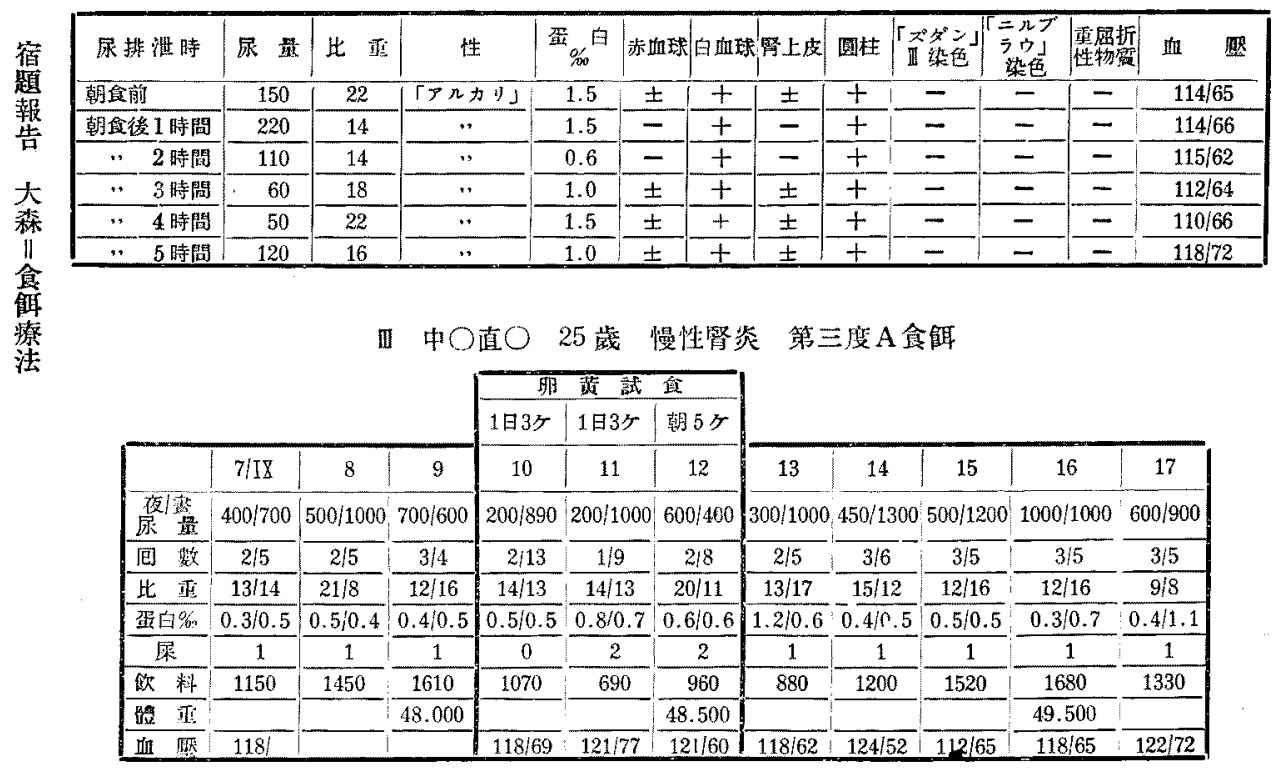

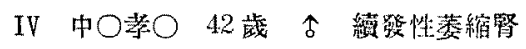

\begin{tabular}{|c|c|c|c|c|c|c|c|c|c|c|c|c|}
\hline 尿排淮時 & 尿 望 & 比 项 & 跣 & 虽自 & 赤血形 & 白血球 & 唡上皮 & 回柱 & 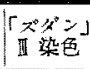 & $\begin{array}{l}=ル フ ゙ \\
\text { 兄 } \\
\text { 染色 }\end{array}$ & 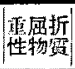 & 血 \\
\hline 朝㿽前 & 70 & 15 & 弱「アルカり」 & 2.8 & \pm & $t$ & + & \pm & - & - & - & $214 / 146$ \\
\hline 朝食後 1 眰䦓 & 90 & 14 & , & 3.2 & - & + & \pm & \pm & - & - & - & $202 / 138$ \\
\hline “ 2 時閣 & 40 & 16 & ," & 3.0 & \pm & + & + & \pm & - & - & - & $202 / 144$ \\
\hline "3時閣 & 60 & 16 & , & 2.7 & - & + & + & \pm & - & - & - & $214 / 142$ \\
\hline$" 4$ 時問 & 90 & 16 & $"$ & 2.0 & - & + & + & \pm & - & - & - & $210 / 138$ \\
\hline 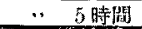 & 80 & 15 & 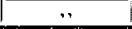 & 2.0 & - & + & + & \pm & - & - & - & $208 / 142$ \\
\hline
\end{tabular}

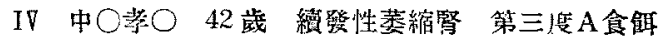

\begin{tabular}{|c|c|c|c|c|c|c|c|c|c|c|c|}
\hline & & & & 姵 & 䊖陚 & & & & & & \\
\hline & & & & 1日37r & 1日3r & 朝 5 & & & & & \\
\hline & $7 / 18$ & 8 & 9 & 10 & 11 & 12 & 13 & 14 & 15 & 16 & 17 \\
\hline 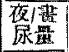 & $1200 / 1000$ & $1000 / 1800$ & $1000 / 1000$ & $1000 / 1485$ & $1200 ; 900$ & 800,500 & $1100 / 1000$ & $900 / 1100$ & $600 / 1300$ & $1300 / 1300$ & $1100 / 2200$ \\
\hline 四薮 & $5 / 8$ & $5 / 8$ & $4 ! 8$ & $4 / 10$ & $5 / 10$ & $4 / 9$ & $4 / 7$ & $3 / 6$ & $4 / 8$ & $4 / 8$ & $5 / 7$ \\
\hline 比韮 & $10 / 12$ & $13 / 11$ & $14 / 18$ & $10 / 13$ & $14 / 13$ & $15 / 14$ & $21 / 9$ & $1 3 \longdiv { 8 }$ & $10 / 10$ & $13 / 12$ & $11 / 10$ \\
\hline 蝳血\% & $1.3 / 1.5$ & $1.5 / 1.2$ & $1.4 / 1.5$ & $1.3 / 1.2$ & $0.6 / 1.2$ & $1.5 / 1.8$ & $1.6 / 1.0$ & $0.8 / 1.0$ & $0.7 / 0.8$ & $0.8 / 0.8$ & $1.0 / 1.1$ \\
\hline 屡 & 1 & 1 & 2 & 1 & 1 & 1 & 1 & 1 & 2 & 2 & 2 \\
\hline 做料 & 1950 & 1450 & 1460 & 1170 & 1120 & 1060 & 980 & 1280 & 870 & 1590 & 1330 \\
\hline 體重 & & & 49.000 & & & $\overline{49.500}$ & & & & 49.000 & \\
\hline 血聮 & $210 / 168$ & & & $\begin{array}{l}190 / 140 \\
213 / 140\end{array}$ & & & $208 / 156$ & $204 / 148$ & $214 / 146$ & $220 / 154$ & $246 / 158$ \\
\hline
\end{tabular}




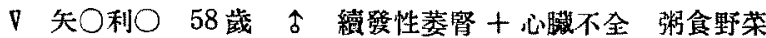

\begin{tabular}{|c|c|c|c|c|c|c|c|c|c|c|c|}
\hline & \multirow[b]{2}{*}{$3 / 1$} & \multirow[b]{2}{*}{4} & \multirow[b]{2}{*}{5} & \multicolumn{3}{|c|}{ 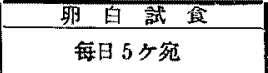 } & \multirow[b]{2}{*}{9} & \multirow[b]{2}{*}{10} & \multirow[b]{2}{*}{11} & \multirow[b]{2}{*}{12} & \multirow[b]{2}{*}{13} \\
\hline & & & & 6 & 7 & 8 & & & & & \\
\hline 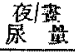 & $340 / 530$ & $450 / 400$ & $500 / 400$ & $500 / 300$ & $400 / 400$ & $550 / 360$ & $450 / 650$ & $350 / 850$ & $300 / 1000$ & $1400 / 1000$ & 1100 \\
\hline [E] 数 & $1 / 1$ & $1 / 1$ & $1 / 1$ & $2 / 2$ & $2 / 2$ & $3 / 4$ & $4 / 4$ & $3 / 5$ & $3 ! 2$ & $3 / 2$ & $2 / 4$ \\
\hline 比重 & $20 / 20$ & $22 / 26$ & $21 / 20$ & $22 / 22$ & $16 / 14$ & $10 / 12$ & $22 / 18$ & 99 & $12 / 14$ & $14 / 14$ & $12 / 14$ \\
\hline 㻎白的 & $10.5 / 11$ & $12 / 13$ & $6 / 11.6$ & $12 / 10$ & $11.5 / 10.6$ & $7.8 / 7$ & $6 / 6$ & $5.6 / 4$ & $4 \sqrt{4}$ & $2.5 / 1.8$ & $2.1 / 2.5$ \\
\hline 金監\% & $0.15 / 0.15$ & $\overline{0.14 ; 0.13}$ & $0.14 / 0.12$ & $0.14 / 0.13$ & $0.13 / 0.14$ & $0.13 / 0.19$ & $0.19 / 0.24$ & $0.25 / 0.25$ & $0.3 / 0.32$ & $0.36 / 0.39$ & $0.39 / 0.45$ \\
\hline 澘 & $\begin{array}{l}0 \\
\end{array}$ & 0 & 1 & 0 & 0 & 0 & 0 & 0 & 0 & 0 & 0 \\
\hline 饮 粦 & 930 & 940 & 440 & 470 & 870 & 790 & 850 & 1020 & 610 & 820 & 680 \\
\hline 值 盟 & $222 / 100$ & & $212 / 105$ & $240 / 110$ & $235 / 105$ & $210 / 110$ & $222 / 100$ & & $200 / 90$ & & \\
\hline 萠 & 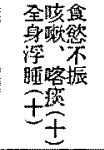 & & & & & 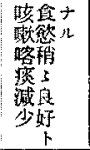 & & 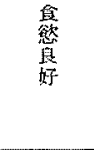 & 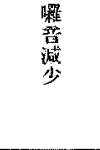 & & 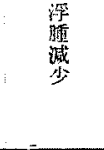 \\
\hline
\end{tabular}

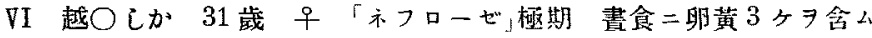

\begin{tabular}{|c|c|c|c|c|c|c|c|c|c|c|c|c|c|}
\hline 尿渄泄時 & 尿量 & 性 & 比重 & 攽白 & 亦血球 & 白血球 & 䧄上皮 & 国柱 & 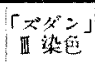 & $\begin{array}{l}=\text { = } \\
5 \text { 少 } \\
\text { 染色 }\end{array}$ & 性物復 & 偰有 & 䌸 \\
\hline 朝食前 & 30 & 「アルカリ」性 & 43 & 21 & - & + & \pm & + & \pm & \pm & -1 & & \\
\hline 朝食徣 2 時間 & 15 & , & 38 & 22 & - & + & \pm & + & + & \pm & - & & \\
\hline 范富前 & 25 & ". & 36 & 13 & - & + & \pm & \pm & \pm & \pm & - & & \\
\hline 䡬豈後 2 時間 & 15 & ". & 38 & 14 & - & + & \pm & $t$ & + & + & - & & \\
\hline 夕会前 & 20 & $*$ & 36 & 15 & - & + & \pm & + & + & + & - & & \\
\hline 夕食媵 2 時問 & 15 & $"$ & 35 & 13 & $=$ & $t$ & \pm & + & \pm & + & - & & \\
\hline 湢果 & 270 & 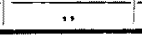 & 44 & 16 & $=$ & + & \pm & \pm & \pm & \pm & $=$ & & \\
\hline
\end{tabular}

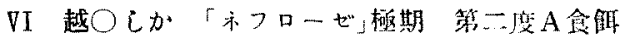

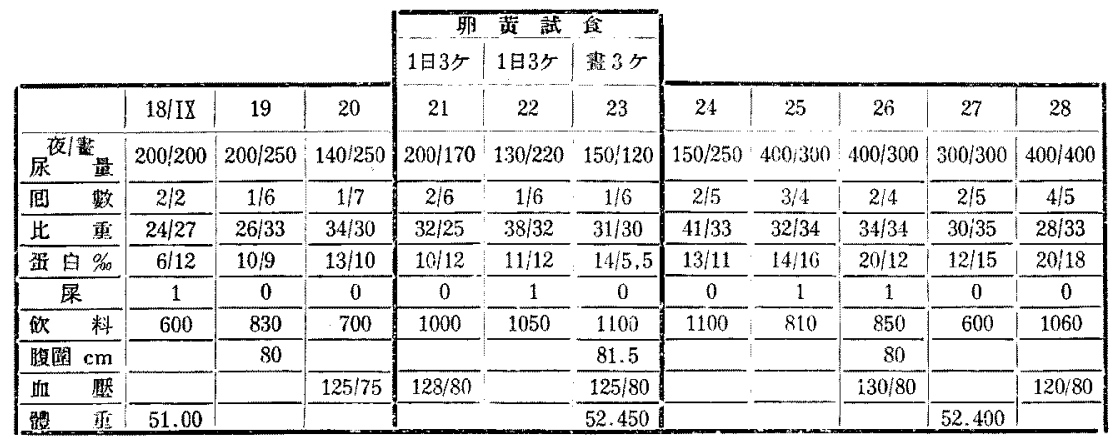

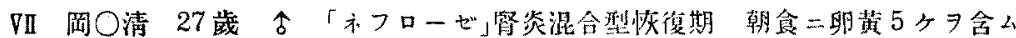

\begin{tabular}{|c|c|c|c|c|c|c|c|c|c|c|c|c|}
\hline 尿排淮時 & 尿宣 & 性 & 比王 & $\begin{array}{l}\text { 蛋白 } \\
\%\end{array}$ & 赤血球 & 白进利 & 紫上皮 & 回杜 & 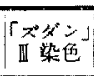 & 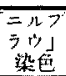 & 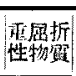 & 俑 \\
\hline 朝食前 & 150 & 辟「アルカリ」 & 16 & 3.0 & H & \# & \pm & + & \pm & + & - & 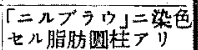 \\
\hline 朝全嵝 2 時問 & 170 & " & 20 & 3.5 & $H$ & \# & \pm & \pm & \pm & - & - & \\
\hline 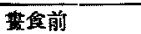 & 150 & $"$ & 18 & 3.5 & $H$ & $\#$ & \pm & \pm & \pm & \pm & - & \\
\hline 整全得2 時間 & 300 & $\ddot{*}$ & 18 & 3.0 & $H$ & H & + & + & + & \pm & - & \\
\hline 多食诵 & 100 & " & 18 & 2.5 & $H$ & $\mathrm{H}$ & + & + & - & \pm & $\rightarrow$ & \\
\hline 多偻 2 時間 & 150 & $"$ & 18 & 2.5 & $H$ & \# & \pm & $t$ & \pm & - & - & \\
\hline 簿 展 & 2400 & $\because$ & 20 & 3.0 & $H$ & 柤 & \pm & \pm & \pm & \pm & - & \\
\hline
\end{tabular}


VII 阙つ清「ネフローゼ」腎炎混合型恢復期 第二度B食印

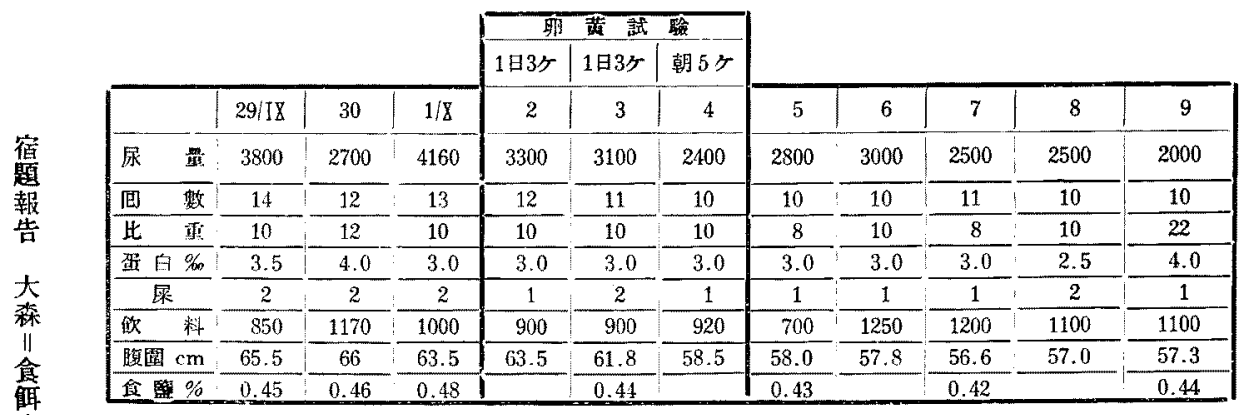

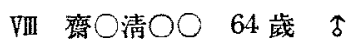

續發性萎縮婜十尿毒症前期 棵食野荣

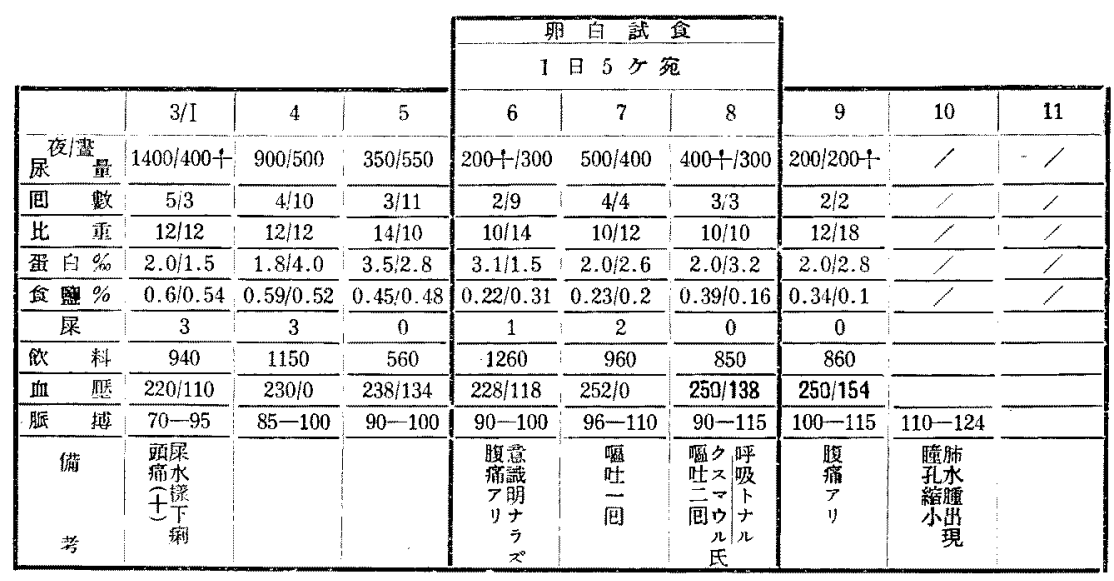

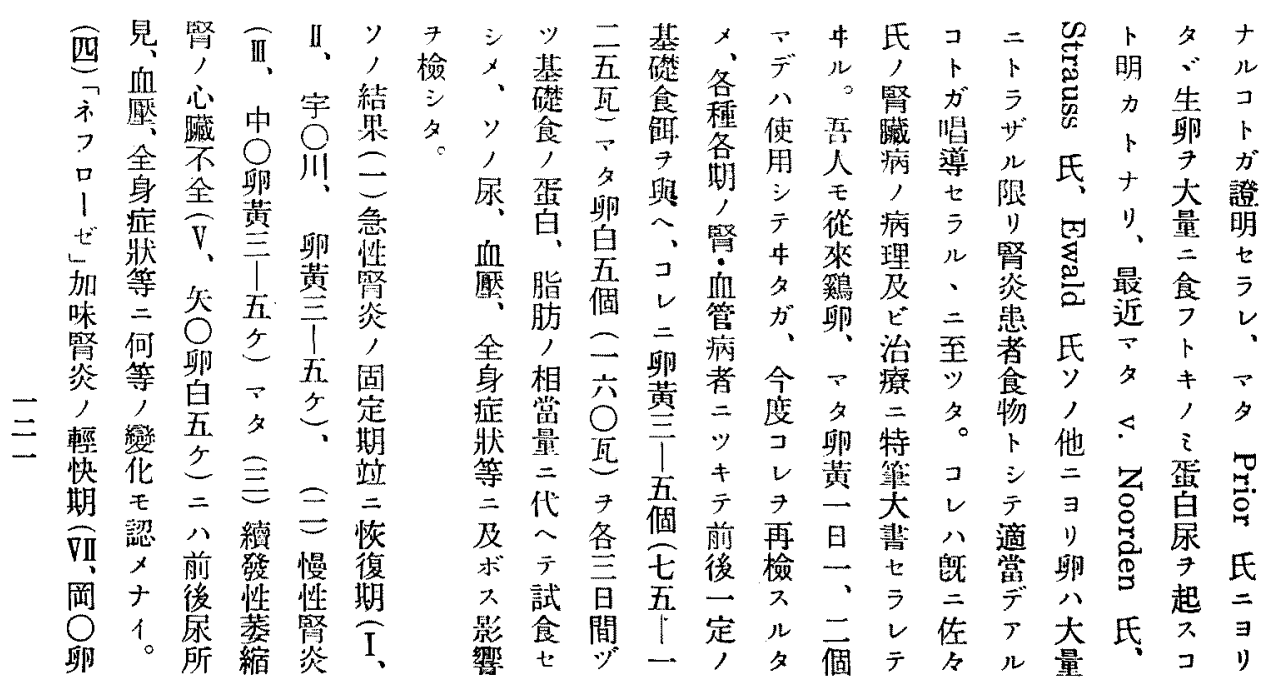




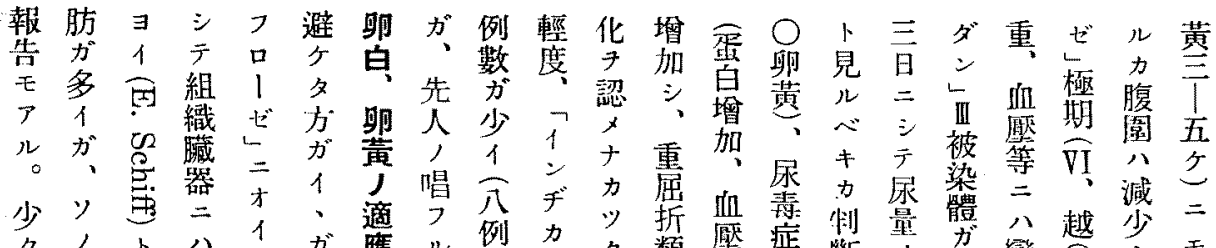

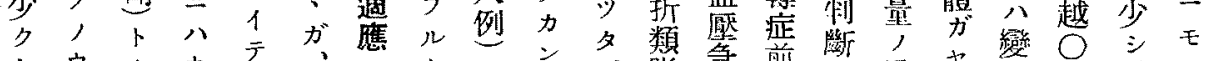

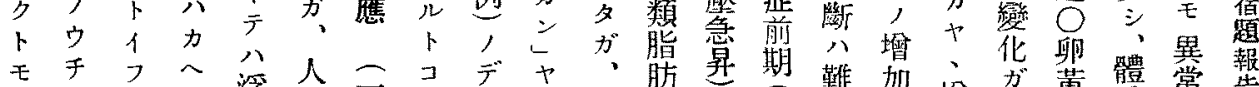

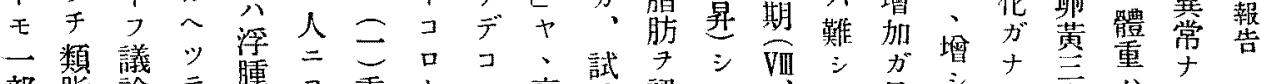

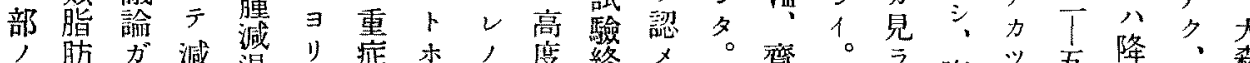
人體ア少退卵症木,

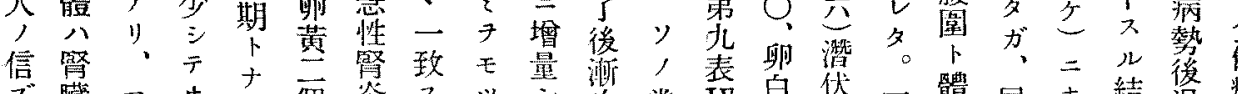
ズ藏、中

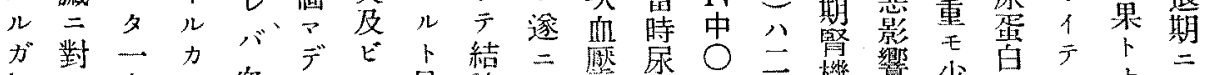

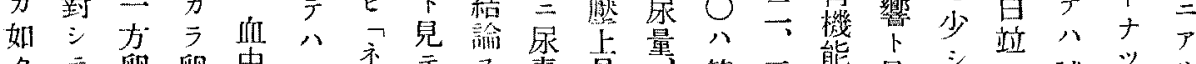

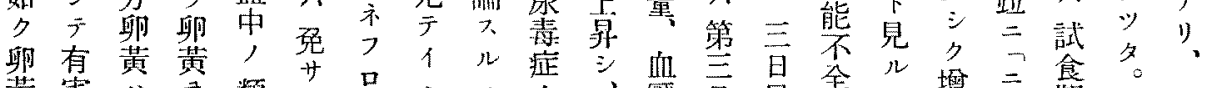
黄害分学

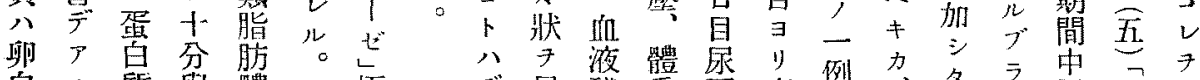

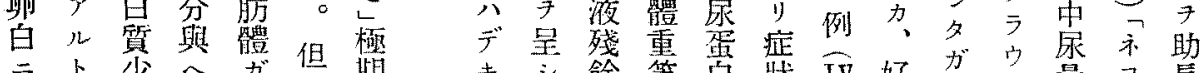

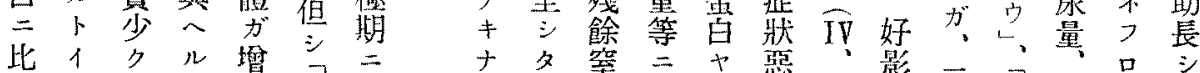

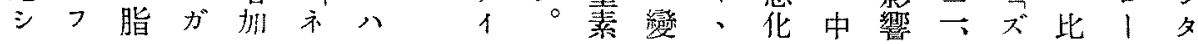

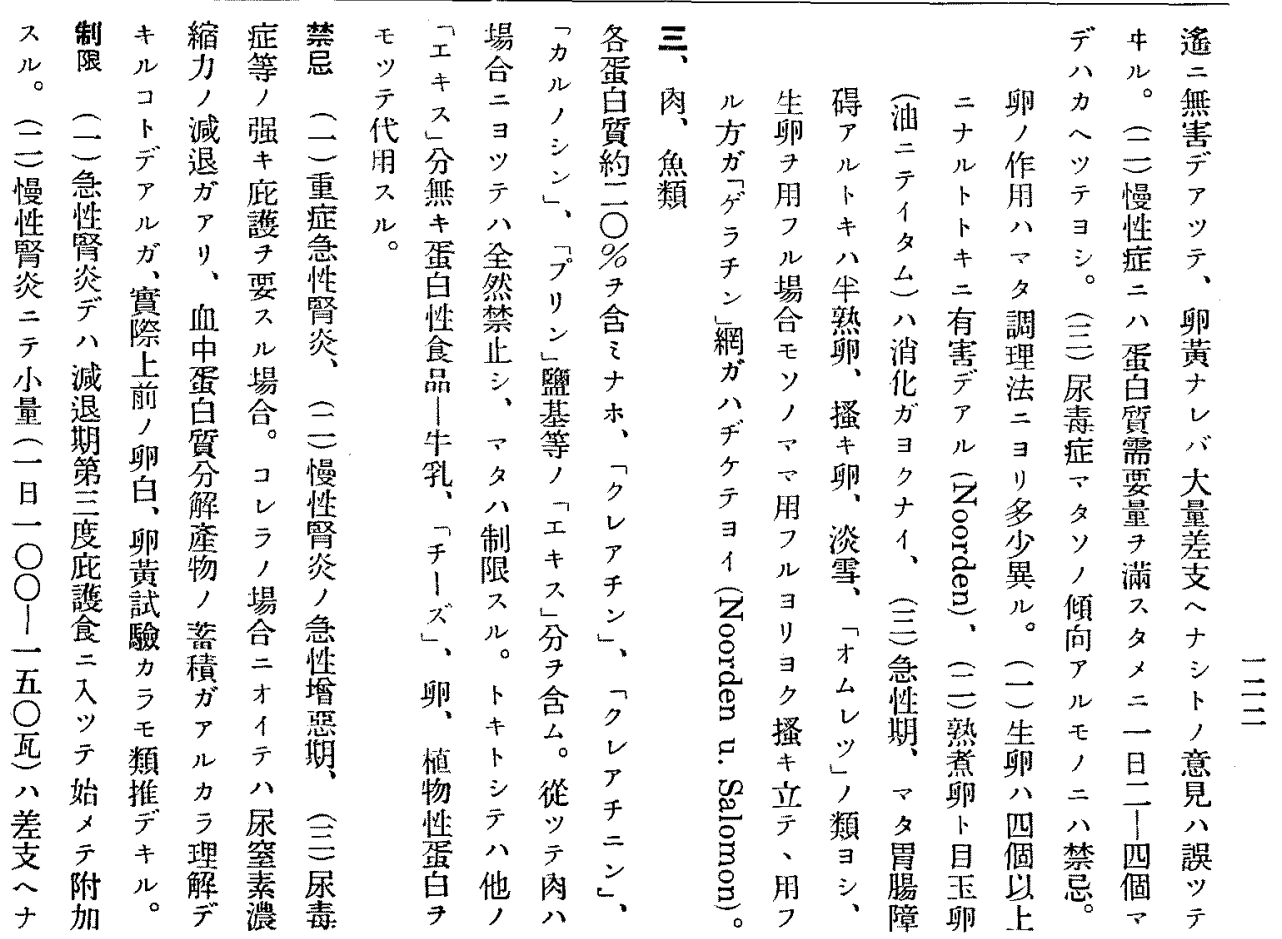


苐十表 動物性蛋白食触

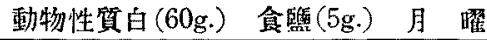

\begin{tabular}{|c|c|c|c|c|c|c|c|}
\hline 時 & 沝 & 材 & 正 量 & 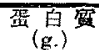 & 脂 ${ }_{(\mathrm{g} .)}$ 肪 & $\begin{array}{c}\text { 含办烷雮 } \\
\text { (g.) }\end{array}$ & (Cal. $)^{\text {亱 }}$ \\
\hline & 主食 & 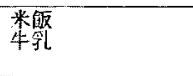 & $\begin{array}{l}750 \\
200 \\
\text { 就 }\end{array}$ & $\begin{array}{r}24.00 \\
7.00 \\
31.00\end{array}$ & $\begin{array}{l}0.38 \\
7.60 \\
7.98\end{array}$ & $\begin{array}{r}242.25 \\
9.80 \\
252.05\end{array}$ & $\begin{array}{r}1095 \\
140 \\
1235\end{array}$ \\
\hline 朝 & 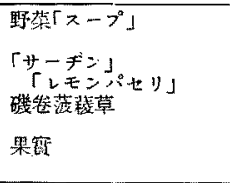 & 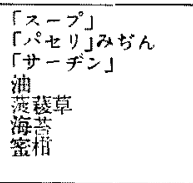 & $\begin{array}{r}150 \\
\text { 少 } \\
80 \\
5 \\
50 \\
1 \\
150 \\
\text { 浬 }\end{array}$ & $\begin{array}{l}\overline{-} \\
\overline{17.12} \\
\overline{1.15} \\
0.30 \\
1.65 \\
20.22\end{array}$ & $\begin{array}{c}\overline{-} \\
\overline{5.36} \\
4.75 \\
0.15 \\
0.13 \\
10.39\end{array}$ & $\begin{array}{l}= \\
= \\
= \\
0.85 \\
0.40 \\
8.40 \\
9.65\end{array}$ & $\begin{array}{r}- \\
120 \\
47 \\
9 \\
3 \\
41 \\
220\end{array}$ \\
\hline 婊 & 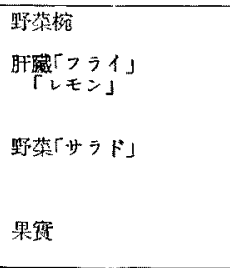 & 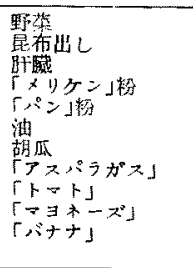 & $\begin{array}{r}150 \\
60 \\
3 \\
3 \\
10 \\
30 \\
20 \\
30 \\
25 \\
100 \\
\text { 棓 }\end{array}$ & $\begin{array}{l}\overline{-} \\
12.07 \\
0.33 \\
0.36 \\
0.27 \\
0.40 \\
0.30 \\
0.35 \\
1.40 \\
15.48\end{array}$ & $\begin{array}{r}\overline{-} \\
\overline{3} .31 \\
0.03 \\
0.04 \\
9.50 \\
0.03 \\
0.02 \\
0.06 \\
21.75 \\
0.40 \\
35.14\end{array}$ & $\begin{array}{l}\overline{-} \\
\overline{1} .01 \\
2.13 \\
2.16 \\
\overline{0.06} \\
0.48 \\
0.12 \\
21.60 \\
27.56\end{array}$ & $\begin{array}{r}- \\
78 \\
10 \\
9 \\
93 \\
4 \\
4 \\
7 \\
207 \\
98 \\
510\end{array}$ \\
\hline 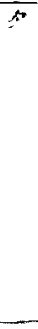 & 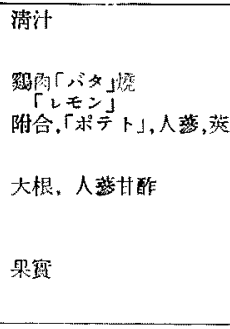 & 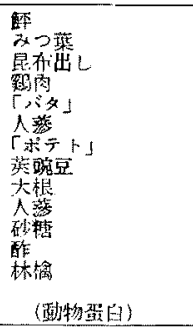 & $\begin{array}{r}30 \\
\text { 少 } \\
150 \\
80 \\
10 \\
30 \\
30 \\
10 \\
30 \\
5 \\
3 \\
150 \\
150 \\
\text { it }\end{array}$ & $\begin{array}{c}5.76 \\
- \\
16.80 \\
0.08 \\
0.39 \\
0.45 \\
0.23 \\
0.21 \\
0.07 \\
- \\
0.45 \\
0.44 \\
(59.18)\end{array}$ & $\begin{array}{l}0.15 \\
= \\
= \\
8.37 \\
0.12 \\
0.03 \\
0.02 \\
\overline{0.02} \\
= \\
= \\
8.71\end{array}$ & $\begin{array}{l}\overline{-} \\
\bar{E} \\
\overline{0} \\
0.05 \\
2.22 \\
5.76 \\
0.24 \\
1.11 \\
0.37 \\
2.82 \\
13.35 \\
25.92\end{array}$ & $\begin{array}{r}25 \\
\frac{1}{69} \\
78 \\
12 \\
26 \\
2 \\
5 \\
2 \\
12 \\
57 \\
288\end{array}$ \\
\hline & 計 & & & 91.14 & 62.22 & 315.18 & 2253 \\
\hline
\end{tabular}

尹三シ

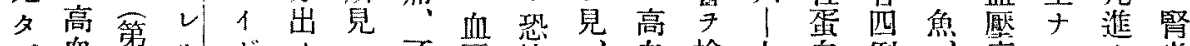

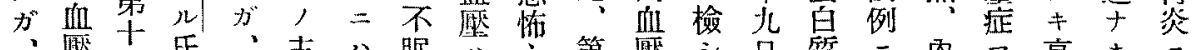

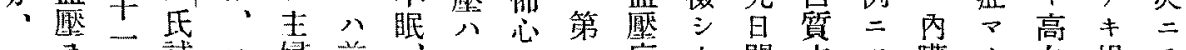

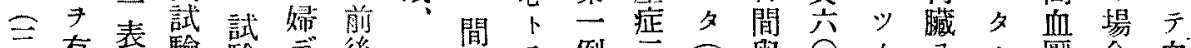

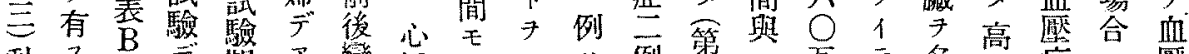

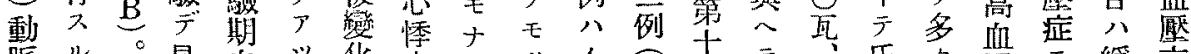

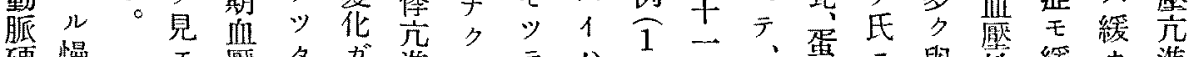

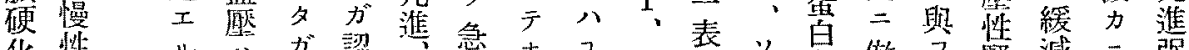

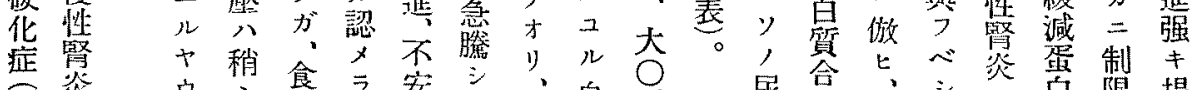

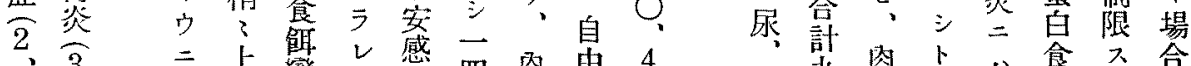

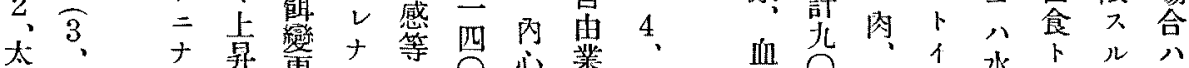

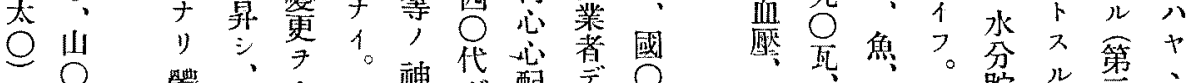

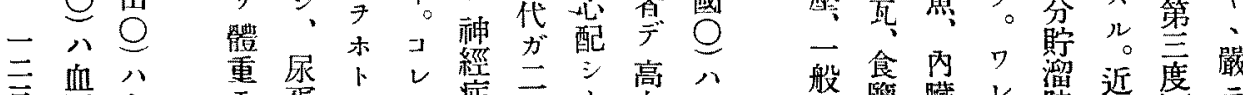

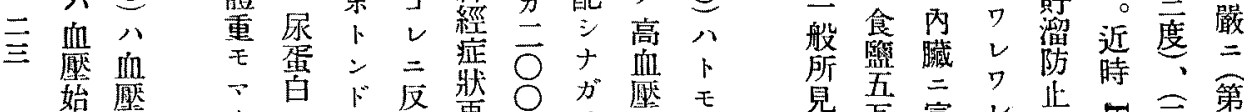

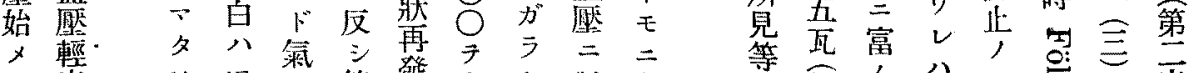
灵度 稍增二第發突食對血第食留貝离腎度

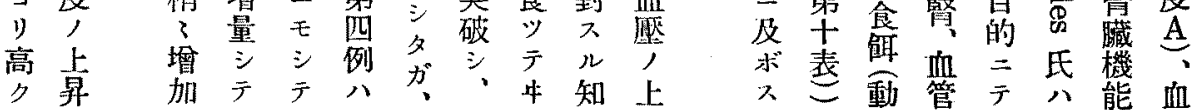


(3)山○キ○1 32歳 우 高血嶎性慢性腎炎

(妊娠 2ケ月)
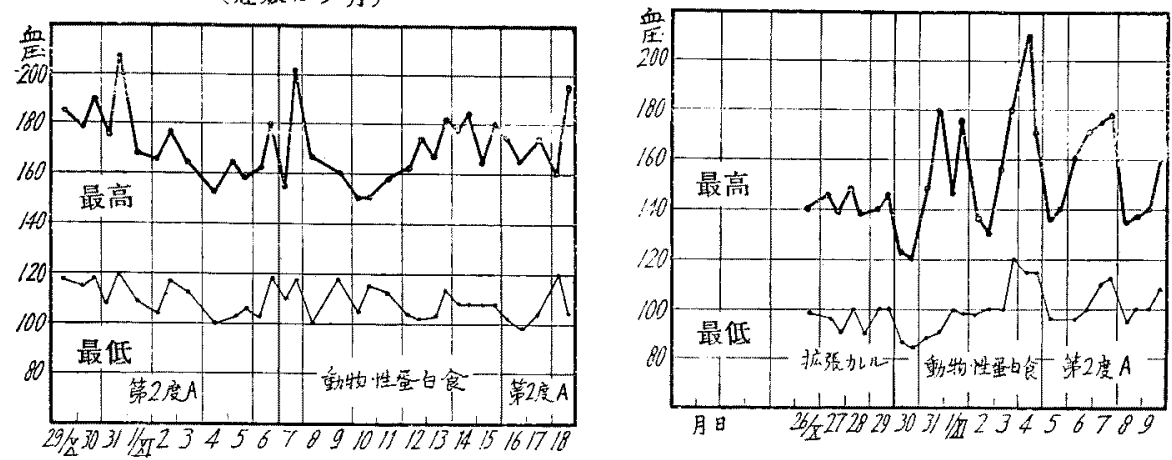

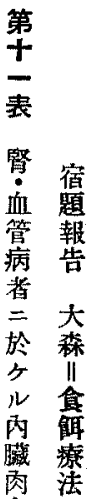

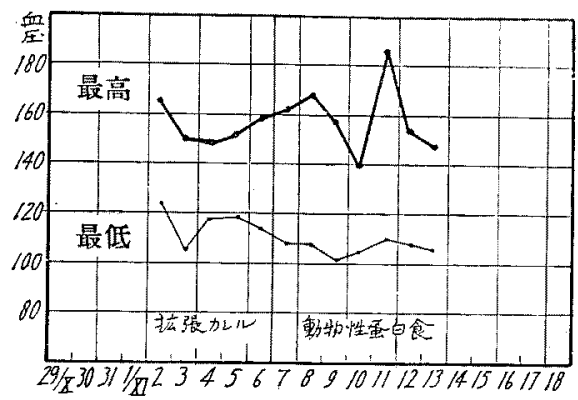

(2) 太○定 $\bigcirc 53$ 歳 占 動脈硬化症

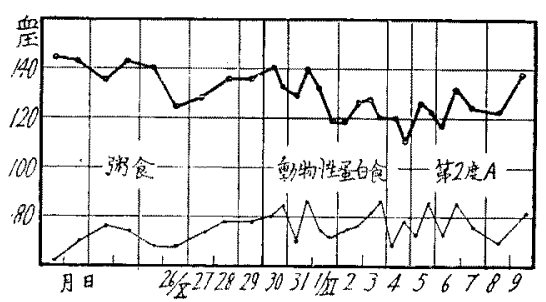

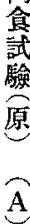

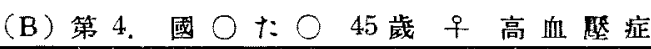

\begin{tabular}{|c|c|c|c|c|c|c|c|c|c|c|}
\hline \multirow{4}{*}{$\begin{array}{c}6 / \mathrm{XI} \\
\text { 食 } \\
\text { 飭 }\end{array}$} & & 㬈 & 此 $\mathrm{T}$ & 绝 & 反 & ズルフォ & $\approx ル レ ル$ & 沈 泚 & 饮 籍 & 锣重 \\
\hline & 朝真首前 & 60 & 19 & 蓝裾色 & 弱 酸 性 & $\pm($ 瘵躈 $)$ & - & - & & \\
\hline & 後一時問 & 60 & 17 & " & 弱 酸 性 & $\pm \cdots$ & - & - & & \\
\hline & 姼二時䦓 & 47 & 20 & $\cdots$ & 中 性 & $\pm \quad \cdots$ & - & - & & \\
\hline \multirow{7}{*}{ 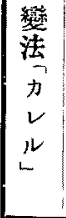 } & 量且前 & 50 & 23 & 䏆色 & 弱 䣹 性 & $\pm \quad$. & - & - & & \\
\hline & 啳一獍間 & 70 & 11 & , & 弱酸 性 & $\pm "$ & - & - & & \\
\hline & 骁二時留 & 110 & 9 & 品䰹色 & 弱 酸 性 & - & - & - & & \\
\hline & 夕苼前 & 100 & 18 & ," & 憧 & $\pm \quad$. & - & - & & \\
\hline & 一缕一睟閣 & 60 & 18 & $\because$ & 弱 酸 诰 & $\pm \quad \cdot$ & - & - & & \\
\hline & 後二時閐 & 45 & 11 & $\because$ & 疆西性 & $\pm \quad "$ & - & - & & \\
\hline & 筑 沓 & 832 & 12 & $\because$ & 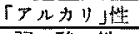 & $\pm \quad$, & - & - & 1200 & $48.50 \mathrm{~kg}$ \\
\hline \multirow{10}{*}{$\begin{array}{c}7 / \mathrm{XI} \\
\text { 動 } \\
\text { 物 } \\
\text { 性 } \\
\text { 蛋 } \\
\text { 皇 } \\
\text { 食 }\end{array}$} & 胡食前 & 70 & 19 & 淡喵色 & 弱 酸 性 & + & + & - & & \\
\hline & 挠一時閻 & 50 & 9 & " & . & + & - & - & & \\
\hline & 啳二時間 & 45 & 9 & $\therefore$ & $\because$ & + & - & - & & \\
\hline & 案会首 & 43 & 20 & $"$ & $\because$ & $t$ & + & - & & \\
\hline & 後一時䦔 & 61 & 15 & $"+$ & 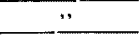 & + & + & - & & \\
\hline & 後二時間 & 37 & 19 & ". & $"$ & + & + & - & & \\
\hline & 多看前 & 30 & 19 & $\because$ & $\because$ & + & - & - & & \\
\hline & 挠一時䦩 & 40 & 21 & $"$ & 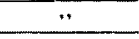 & + & - & - & & \\
\hline & 後二時問 & 40 & 21 & $\because$ & " & + & - & - & & \\
\hline & 䇺 尿 & 916 & 21 & " & {$[7 n \rightarrow 1]$} & + & - & - & 800 & $48.65 \mathrm{~kg}$ \\
\hline \multirow{9}{*}{$\begin{array}{c}8 / \mathrm{XI} \\
\text { 動 } \\
\text { 物 } \\
\text { 性 } \\
\text { 蛋 } \\
\text { 白 } \\
\text { 食 }\end{array}$} & 朝 但献 & 50 & 27 & 谈䓵色 & 弱酸 性 & $t$ & - & - & & \\
\hline & 一 時 問 & 50 & 25 & , & .. & + & - & - & & \\
\hline & 三 時 闆 & 38 & 30 & $\because$ & ". & + & - & - & & \\
\hline & 藍量前 & 50 & 30 & $\because$ & $\because$ & H & + & - & & \\
\hline & 二一時 閵 & 60 & 27 & ". & $\ddot{*}$ & $H$ & $t$ & - & & \\
\hline & 三 時 閻 & 50 & 23 & $\cdots$ & $\because$ & + & - & - & & \\
\hline & 夕食前 & 50 & 27 & $\because$ & $\therefore$ & + & $=$ & - & & \\
\hline & 一 時 問 & 102 & 29 & $\because$ & $\therefore$ & $t$ & - & - & & \\
\hline & 二 時 䦓 & 46 & 20 & 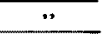 & $\because$ & + & - & - & & \\
\hline
\end{tabular}


第十二表食品中「エ夫入分析表

(A) 從來检査サレッルモ，(1)

\begin{tabular}{|c|c|c|c|c|c|c|c|c|}
\hline & 食品名 & 原 & 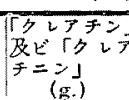 & 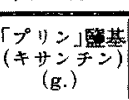 & 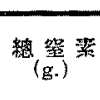 & 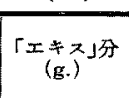 & ${ }_{(\mathrm{g} .)}{ }^{\text {分 }}$ & 氏 名 \\
\hline & 4 & 100 & 0.122 & 0.035 & 3.55 & \multirow{3}{*}{$4.74-5.25$} & \multirow{3}{*}{$1.15-1.27$} & König \\
\hline \multirow{4}{*}{$\begin{array}{l}\text { 㑑 } \\
\text { 䟎 } \\
\text { 啙 }\end{array}$} & 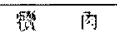 & ", & 0.185 & 0.065 & 3.24 & & & $"$ \\
\hline & 胸 & $\because$ & 0.096 & 0.057 & 3.49 & & & $\because$ \\
\hline & 喓 & $\because$ & 0.255 & 0.108 & & & & Riesser \\
\hline & 鬼而 & $\because$ & 0.241 & 0.103 & & & & $"$ \\
\hline \multirow{3}{*}{ 菻 } & 䖨 & $\because *$ & 0.300 & & & & & 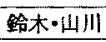 \\
\hline & 鳀 & $\because$ & 0.320 & 0.028 & & & & $"$ \\
\hline & $4 \quad \frac{9}{7}$ & $\because$ & 0.003 & 0.003 & & & & 里・村田 \\
\hline
\end{tabular}

\begin{tabular}{|c|c|c|c|}
\hline & 食 品 名 & 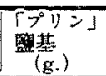 & 氏 \\
\hline \multirow{10}{*}{$\begin{array}{l}\text { (2) } \\
\text { 動 } \\
\text { 物 } \\
\text { 性 } \\
\text { 宏 } \\
\text { 品 } \\
\text { 類 }\end{array}$} & 陔闪 & 0.137 & \multirow{2}{*}{ Hermann } \\
\hline & 「ハム」 & 0.064 & \\
\hline & 羊商 & 0.124 & $\ddot{*}$ \\
\hline & 淡水皕 & 0.103 & 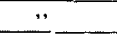 \\
\hline & 盟水䲘 & 0.127 & $\because \cdot$ \\
\hline & 雨南 & 0.100 & Hall \\
\hline & 矬 & 0.108 & Hermann \\
\hline & 僬 & 0.146 & 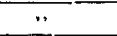 \\
\hline & 舆 & 0.186 & $\cdots$ \\
\hline & 明险 & 0.005 & 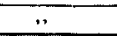 \\
\hline \multirow{10}{*}{ 㩲 } & 太豆 & 0.119 & Hermann \\
\hline & 颢琶 & 0.122 & . \\
\hline & 䖪 & 0.063 & Hall \\
\hline & 馬鈴茗 & 0.016 & Hermann \\
\hline & 人 荍 & 0.022 & ." \\
\hline & 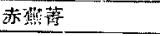 & 0.014 &. \\
\hline & 日籍蒜 & 0.008 & $\because$ \\
\hline & 大 根 & 0.016 & $\ddot{*}$ \\
\hline & 照 & 0.0103 & 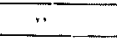 \\
\hline & 玉 蕾 & 0.009 & Hall \\
\hline \multirow[t]{3}{*}{ 荣 } & 「ォンンダ」三䧳 & 0.027 & Hermann \\
\hline & 「キャベッ」 & 0.014 & . \\
\hline & 野蓠草 & 0.027 & $\because$ \\
\hline \multirow{8}{*}{ 類 } & 「アス・゙ラがス & 0.038 & 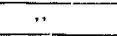 \\
\hline & 薄整草 & 0.062 & $\because$ \\
\hline & 白 㭉 & 0.016 & $\because$. \\
\hline & 胡 瓜 & 0.008 & $\because$ \\
\hline & 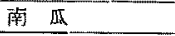 & 0.008 & $\ddot{*}$ \\
\hline & {$[+-1$} & 0.011 & $\because$ \\
\hline & 椎 㩰 & 0.038 & 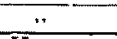 \\
\hline & * & 0.018 & Hermann \\
\hline (4) & 小瑟 & 0.030 & $\therefore$ \\
\hline & 大裂 & 0.055 & Noorden \\
\hline 穀 & 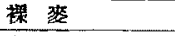 & 0.073 & Hermann \\
\hline 類 & 菲瑟 & 0.081 & $"$ \\
\hline & 王蹝霜 & 0.060 & Noorden \\
\hline 其 & 日「゚゚ン & 0.022 & Hermann \\
\hline 他 & {$[z-t-1$} & 0.176 & Hall \\
\hline & 「ココテ」 & 0.100 & $"$ \\
\hline & Pチヨコレーb & 0.038 & Hermann \\
\hline
\end{tabular}

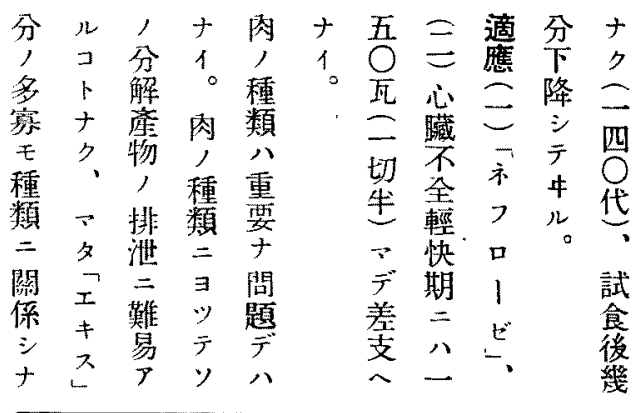

獸 食ンワナ門信肉少化

肉1量度し1弟ゼ, 人。

, テ $=$ 及甲。广注

厥 1 用

別へフプ无肉析テキ方

八バルリ六, 二

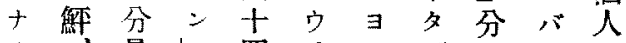

1、量し四千レガニヨ,

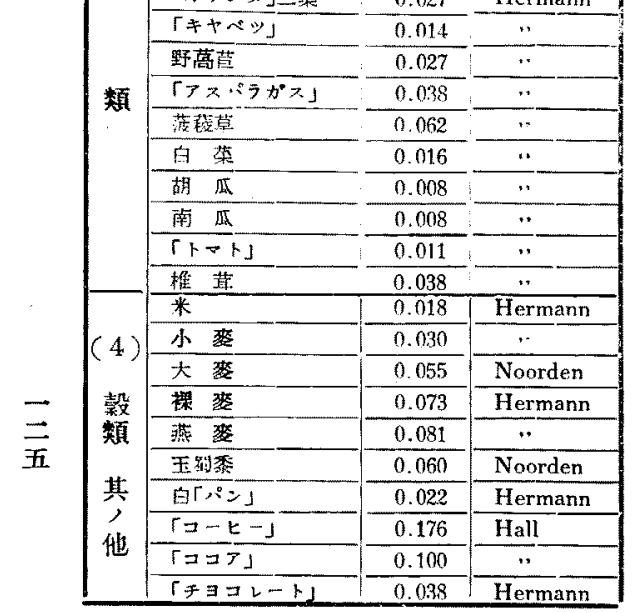

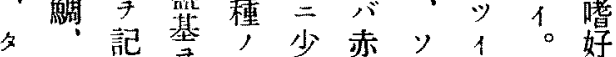

鯆藏分食丰肉, 方, 羿

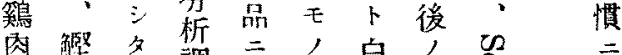

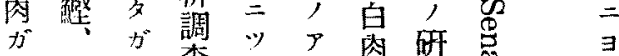

少牛:查 1 リ卜究辛

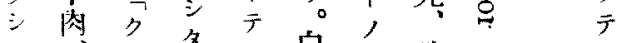

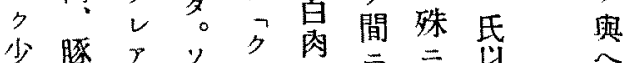

1 肉方

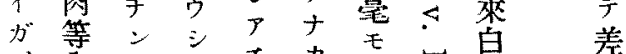

、肉亡、テ

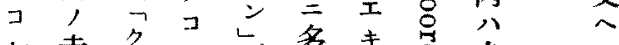

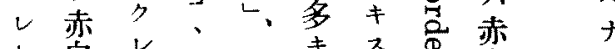

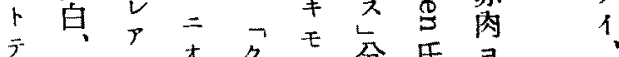

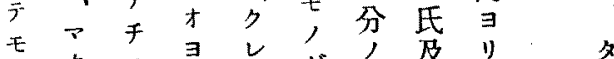

大条

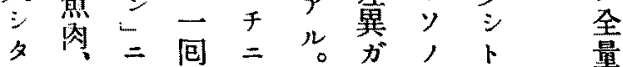


B）新二檢查シタルモ（食養研究所奥田）

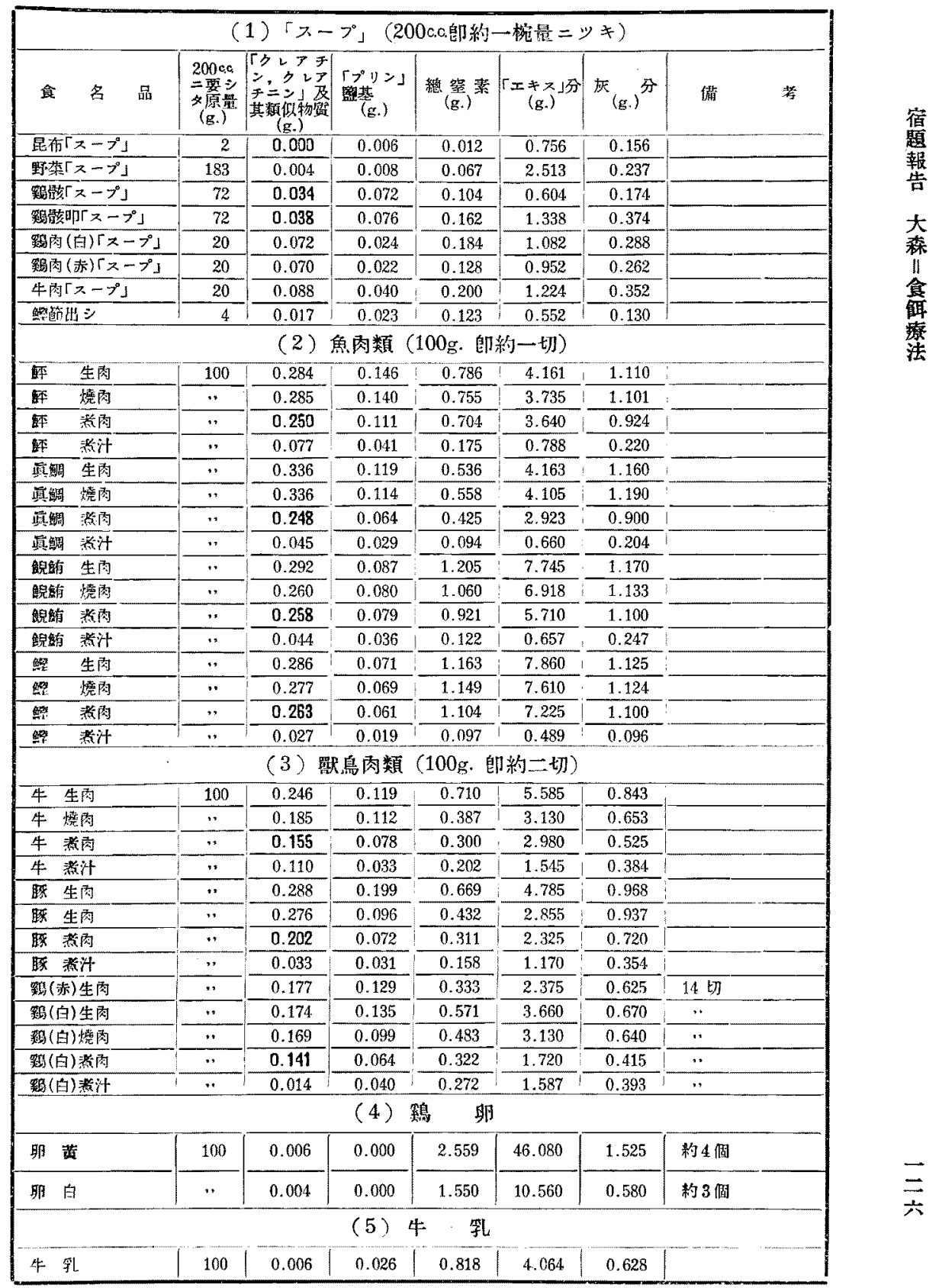




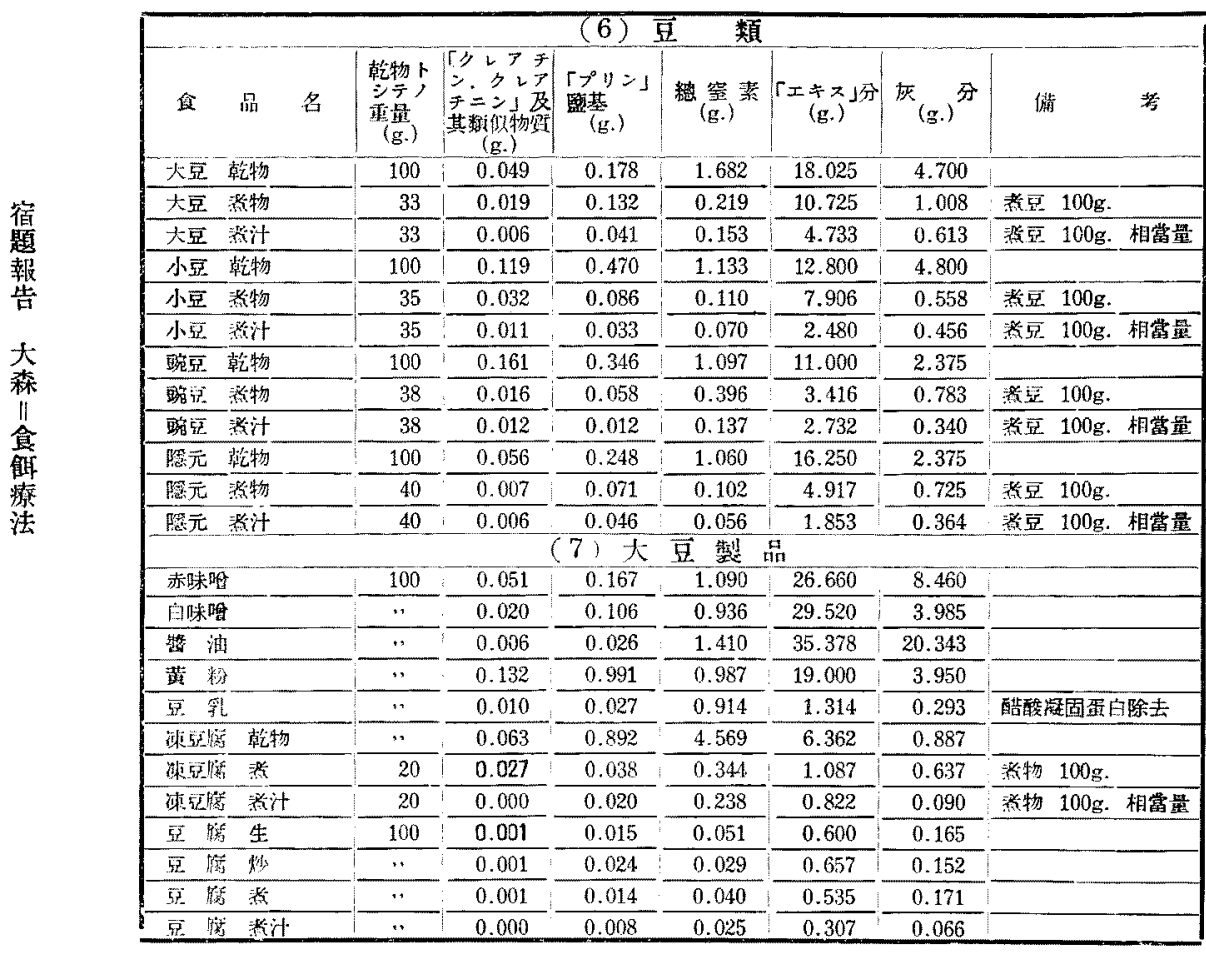

\begin{tabular}{|c|c|c|c|c|c|c|c|c|c|c|c|c|c|c|c|c|c|c|c|}
\hline 苫 & 㳒 & U & 詰 & $\frac{x}{2}$ & $\begin{array}{l}\text { 及 } \\
匕^{*}\end{array}$ & ? & $\begin{array}{l}\text { 特 } \\
\text { 別 }\end{array}$ & $\begin{array}{l}\text { 害 } \\
\text { †. }\end{array}$ & $\begin{array}{l}\mu \\
\epsilon\end{array}$ & ベ & 䧄 & $\begin{array}{c}\text { 沸 } \\
\vdots\end{array}$ & $\begin{array}{l}\text { 今े } \\
\text { 日 }\end{array}$ & $\begin{array}{c}t \\
i\end{array}$ & '固 & 多 & 鯆 & $\underline{-}$ & 暞 \\
\hline र & $y$ & & 罐 & 分 & 具 & 1 & 1 & u & 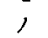 & 獸 & 赤 & $\bar{\xi}$ & 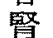 & $r$ & 形 & , & 触 & $\exists$ & 造 \\
\hline v & , & & 站 & 岁 & 㹣 & \} & 㧯 & 分 & $\ddot{y}$ & 䎊 & 肉 & $\neg$ & 藏 & 1 & 成 & 人 & & & $f$ \\
\hline バ & 調 & & , & $t$ & $\therefore$ & ; & 好 & 解 & $T$ & $P$ & 3 & $I$ & 病 & 八 & 分 & $j$ & 兩 & 少 & \\
\hline$\neg$ & 理 & & $y$ & 然 & 特 & 弱 & t & 童 & $u$ & 殊 & 別 & $\neq$ & 者 & $v$ & , & 比 & 者 & ? & \\
\hline$\neq$ & 法 & & , & $\frac{1}{40}$ & $=$ & 立 & $\neq$ & 物 & 力 & $=$ & 八 & 잔 & $=$ & ル & 分 & 較 & ガ & 大 & 9 \\
\hline T & $=$ & & 木 & $\begin{array}{l}\text { III } \\
=\end{array}$ & 食 & モ & 限 & 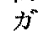 & F & 默 & 全 & 分 & 八 & 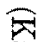 & 量 & 試 & 少 & 體 & \\
\hline 5 & $\exists$ & & $t$ & 闪 & 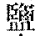 & 多 & リ & 多 & & 数 & 然 & 3 & 洪 & ڤ & $€$ & 驗 & 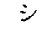 & $=$ & \\
\hline 分 & y & & 直 & y & 含 & b & 獸 & 1 & 新 & 舟 & 石 & - & $\Xi$ & 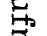 & 蛋 & $=$ & , & 才 & \\
\hline 1 & $\bar{\tau}$ & & 䐴 & 八 & 量 & 八 & 肉 & J & 鮮 & 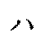 & & 部 & $\overline{5}$ & 8 & 白 & $\exists$ & 含 & 1 & \\
\hline & $I$ & & & 澼 & 及 & 魚 & $\exists$ & p & ナ & 長 & & 7 & 大 & $\mathrm{E}$ & 貿 & $\mu$ & 量 & 5 & \\
\hline 昌 & $\neq$ & & 跣 & $\frac{1}{r}$ & $E^{\circ}$ & 闪 & リ) & 八 & ル & 3 & & 除 & 量 & $F$ & モ & $=$ & ガ & 㸗 & \\
\hline- & $\lambda$ & & 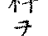 & 3 & $\neg$ & 7 & 魚 & 容 & 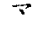 & 吊 & 見 & 1 & , & & 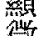 & 付 & 小 & 棰 & \\
\hline 割 & 永 & & 多 & 光 & $I$ & 擇 & 肉 & 易 & 由 & シ & $\frac{\pi}{\bar{\gamma}}$ & $\tilde{r}$ & 闵 & 岁 & 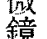 & V & $\begin{array}{l}7 \\
7\end{array}$ & 肉 & \\
\hline . & $=$ & & 量 & ガ & $\neq$ & $\therefore$ & 7 & & A & $\bar{F}$ & 差 & 用 & 八 & క & 的 & , & & & \\
\hline 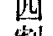 & 相 & & $=$ & $\exists$ & 근 & デ & 擇 & 考 & u & 死 & 䇢 & 7 & 用 & $\therefore$ & 所 & 肉 & & 魚 & \\
\hline 割 & 韑 & & 含 & 1. & 分 & $\bar{テ}$ & ブ & 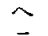 & & 㖟 & $\lambda$ & $\mu$ & t & $\mathrm{g}$ & 兒 & $\Rightarrow$ & & $=$ & \\
\hline ガ & ガ & & 有 & & ガ & $\neq$ & ベ & $\overline{5}$ & 思 & 强 & + & $\therefore$ & $t$ & $\sum$ & 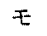 & 用 & & ") & \\
\hline 前 & 來 & & : & 肉 & 多 & $T$ & キ & $\mu$ & 用 & 面 & 1 & ガ & 1 & $\tilde{2}$ & 全 & 7 & & $\stackrel{1}{=}$ & \\
\hline 汁 & ル & & 5 & ' & 3 & sp & デ & & & , & & 例 & & & 身 & $n$ & & & \\
\hline 中 & $0^{\circ}$ & & nt & 留留 & 。 & U。 & $\gamma$ & & 易 & 至 & タ & デ & $\vec{\nabla}$ & $\tau$ & 症 & 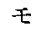 & & 辛 & \\
\hline$=$ & 戍 & & $\pi$ & 品 & & & $\Omega$ & & 肉 & ツ & 、" & $\gamma$ & & 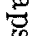 & 狀 & & & 紊 & \\
\hline 移 & 八 & & $t$ & デ & & タ & 卜 & & $=$ & 3 & 强 & ル & 多 & $\doteq$ & $モ$ & 特 & & 3 & \\
\hline 行 & J & & $\overrightarrow{7}$ & $\gamma$ & -1 & $\therefore$ & 思 & 點 & 比 & 後 & 1 & 力 & ク & 0 & 差 & $=$ & & & \\
\hline ᄌ & $v$ & & 构 & $u$ & $I$ & 沚 & 7 & $\exists$ & シ & 用 & $\bar{r}$ & $\overrightarrow{7}$ & 八 & 殊 & 異 & 尿 & & 1 & \\
\hline ル & 7 & & 天 & 腸 & $\neq$ & 軦， & & 1) & 有 & 7 & 1 & 白 & 㐗 & $=$ & カ & 中 & & 73 & \\
\hline
\end{tabular}




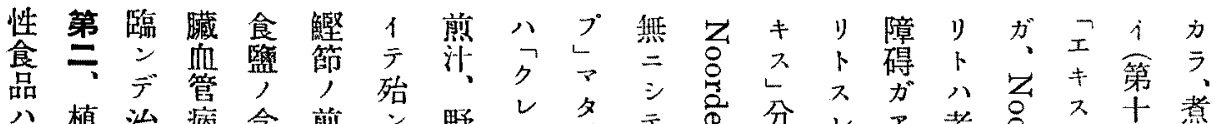

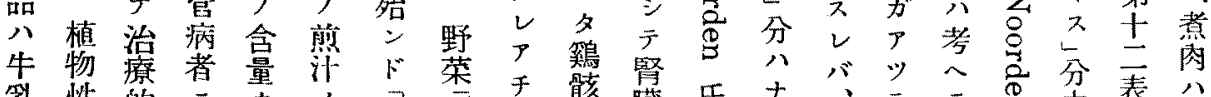

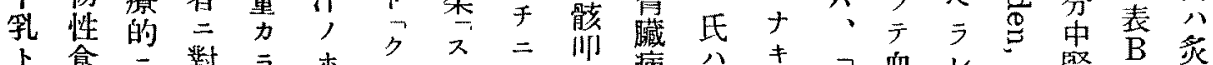

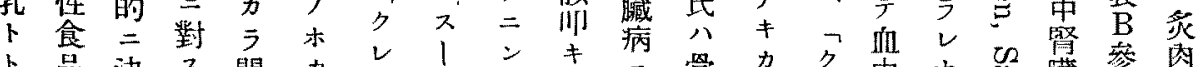

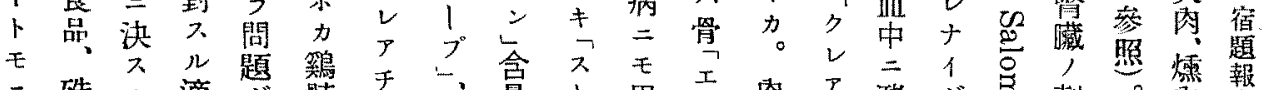

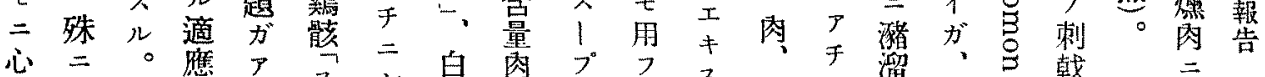

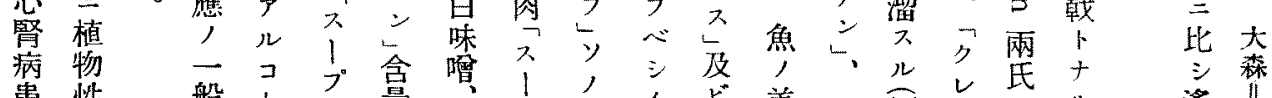

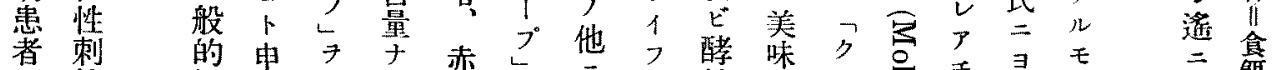
符 替

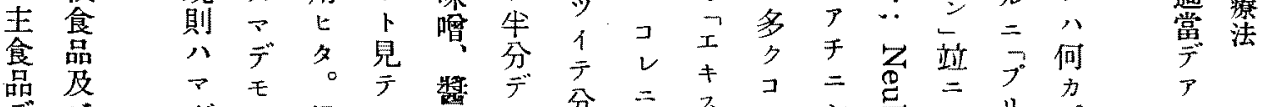

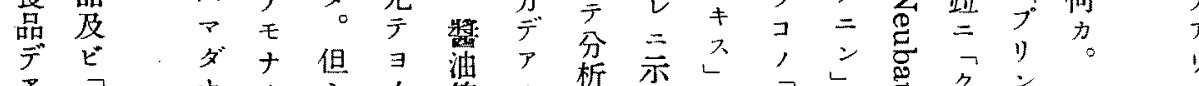
ア ツリ1

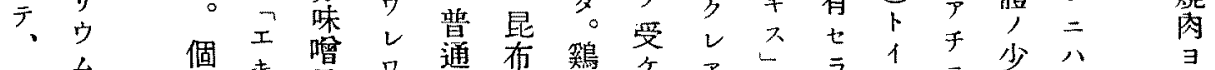

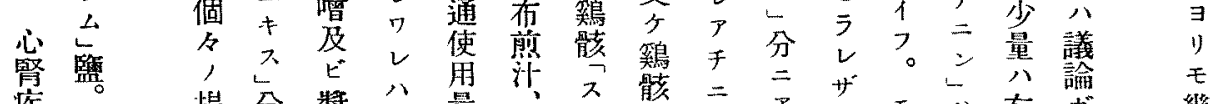

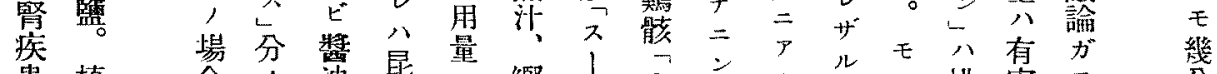

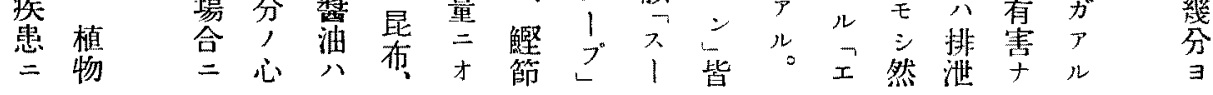

決點へ才日モとル殊心症二八腫症影心゙卜生才 ショルリ、本アテ他二症方他減过㯈テス食 1

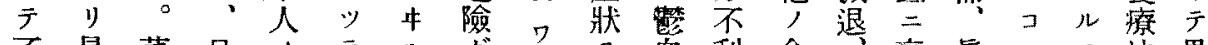

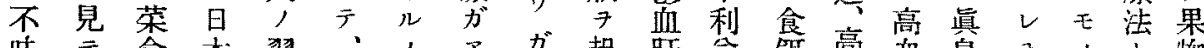

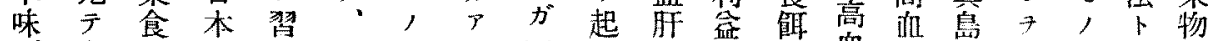
デ肉八人惯必八n國入, , 療血盟藷生デ八療

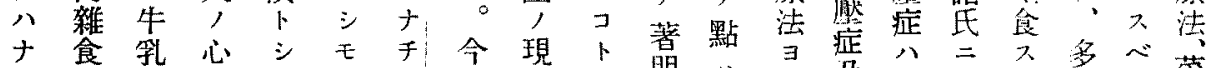

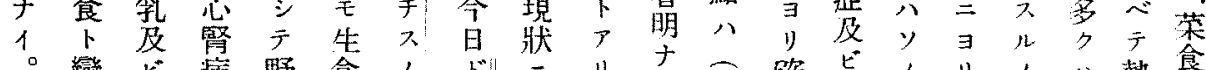
日卛 ビ 病 野食幕

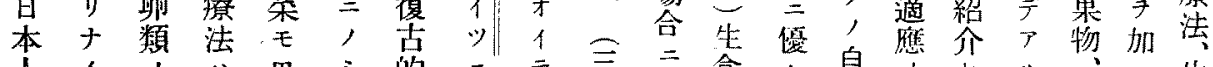

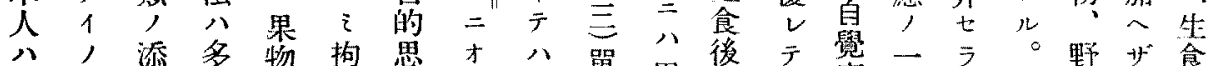
殊 ～添多物拘思才想

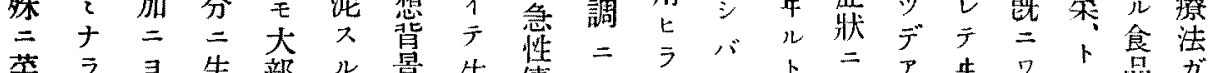

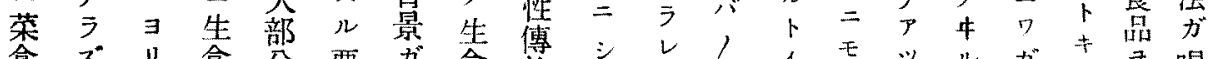
食ズ、食分要方食染 シ

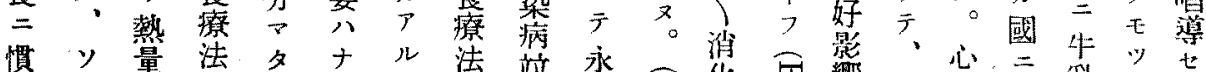

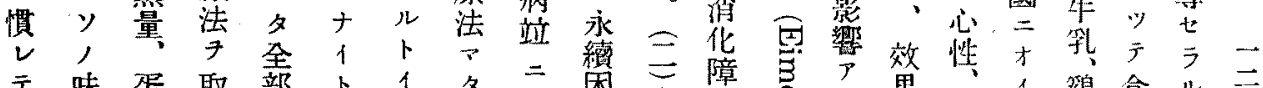

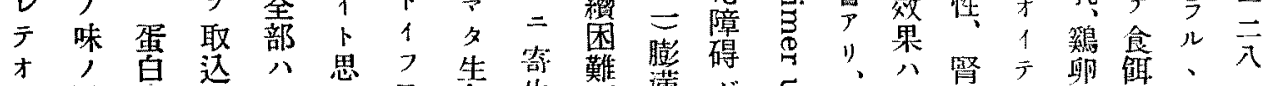

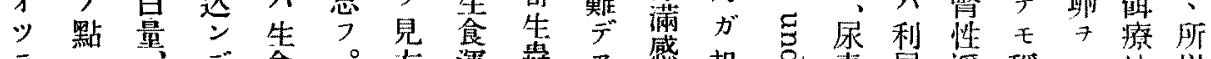

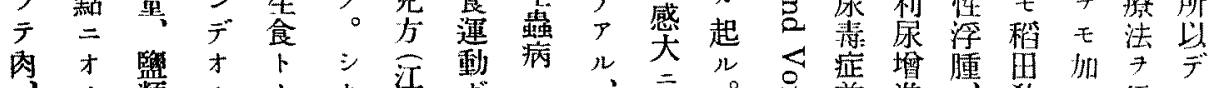
1 蘱ルナカ界出

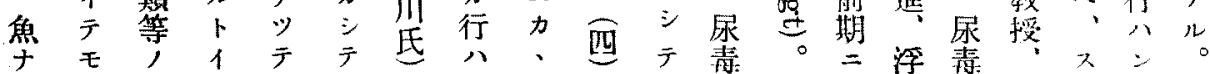


第十三表 植物性蛋白食佴

總蛋白質 $90 \mathrm{~g}$. 豆類蛋白筫 $40-50 \mathrm{~g}$. 食㰓 $5 \mathrm{~g}$.

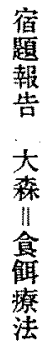

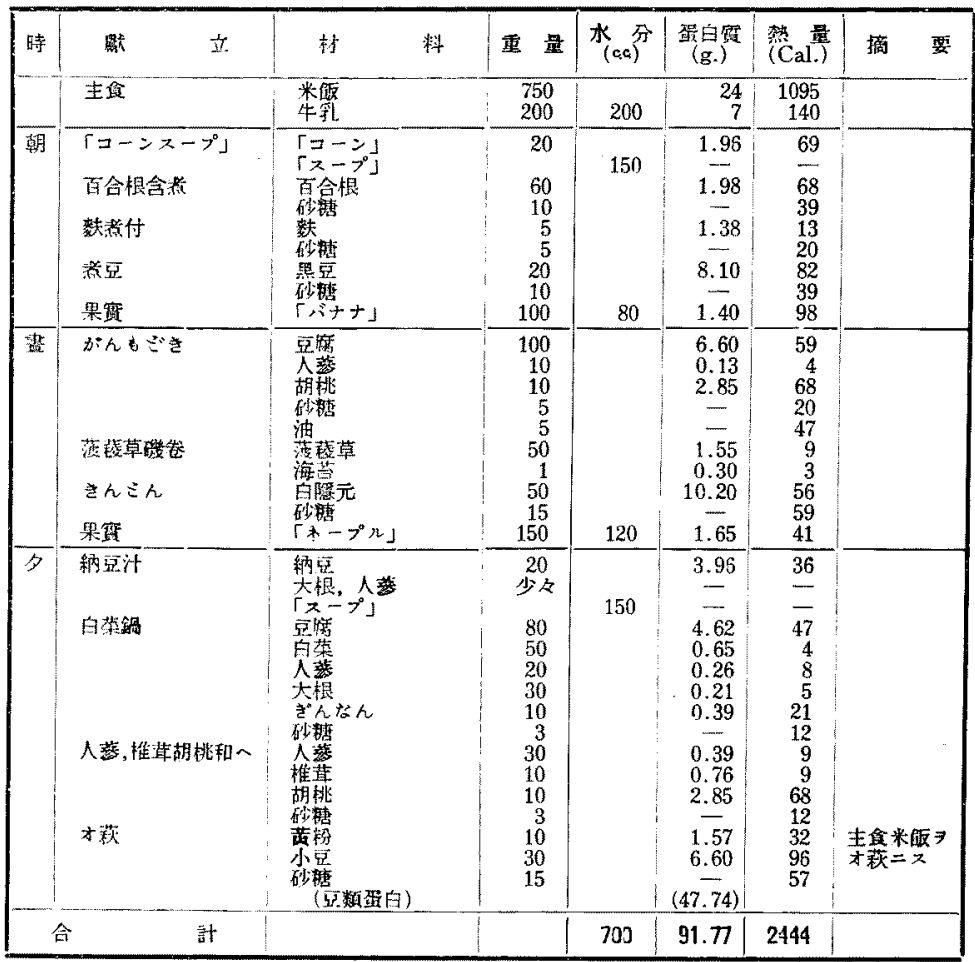

ラ゙噟ツ 乳が ト フ 體

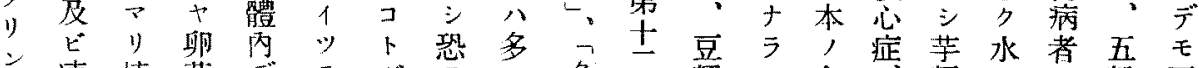

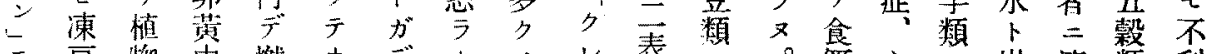

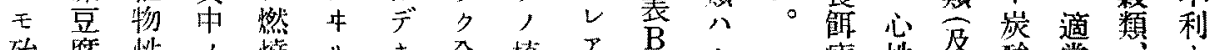

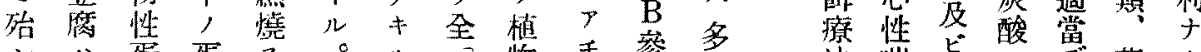

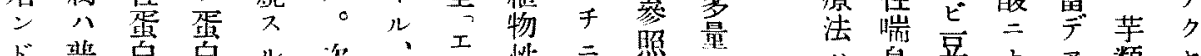
ド晢百白ル次、音性二照量息豆ナア類ヤ

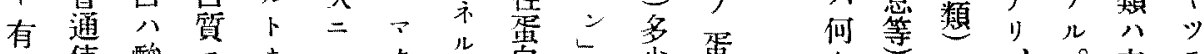

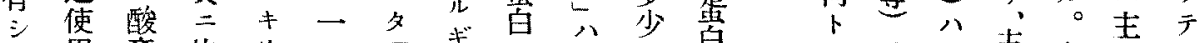
テ用產比生 ッ ブ

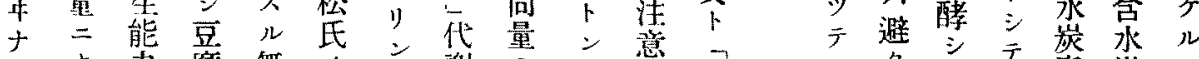

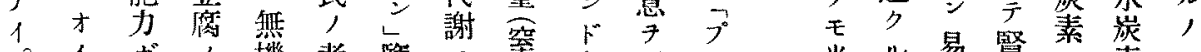

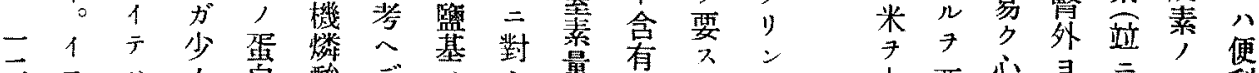

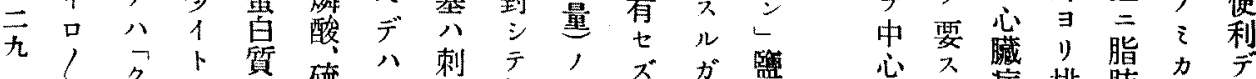

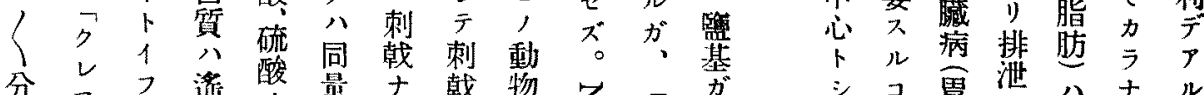

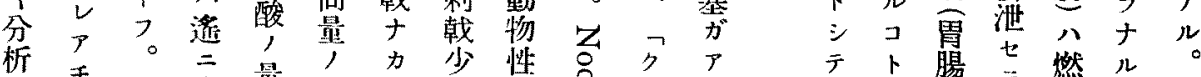

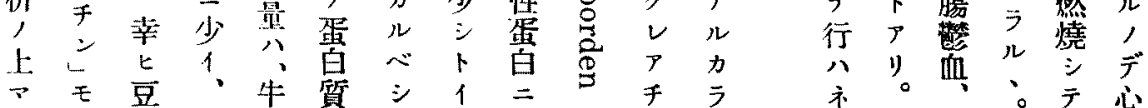


第十四表 豆、豆腐会試驗(原)

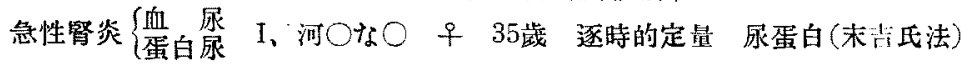
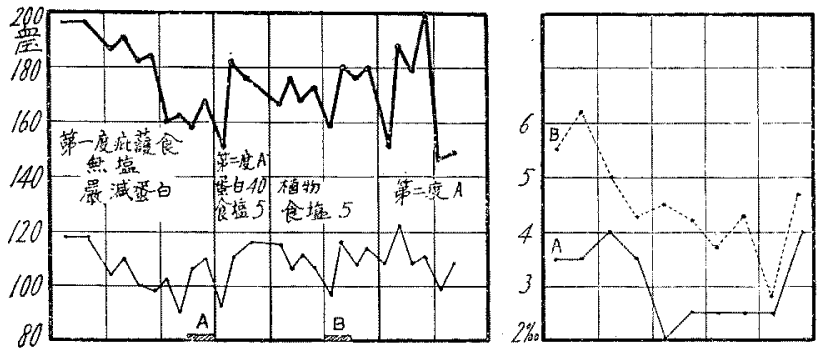

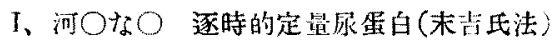

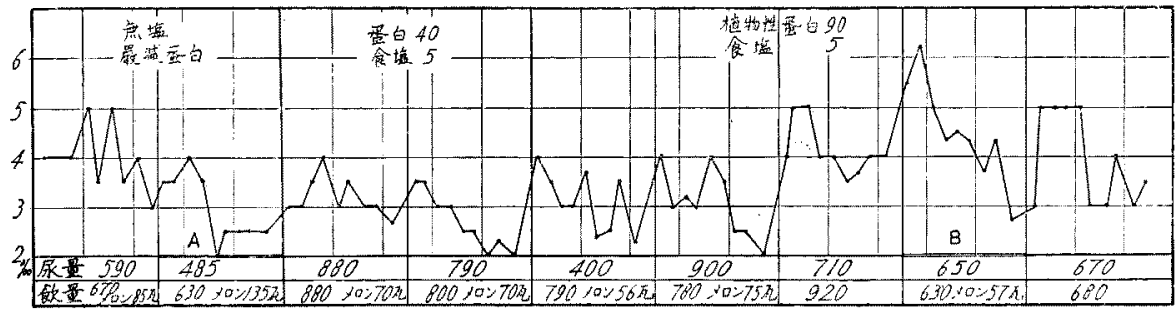

高血暨症

四、小○䙲 令 43 歲。

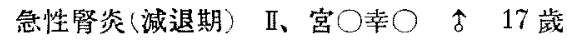
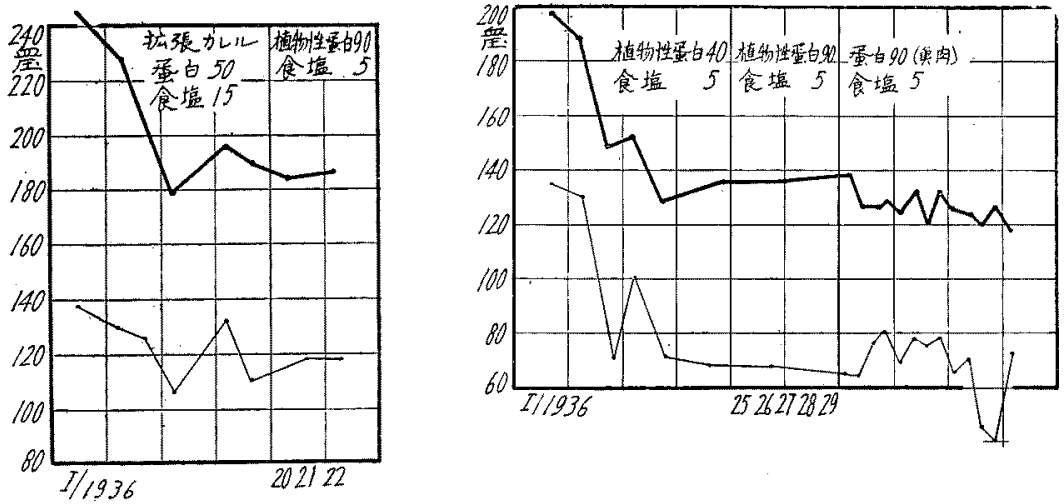

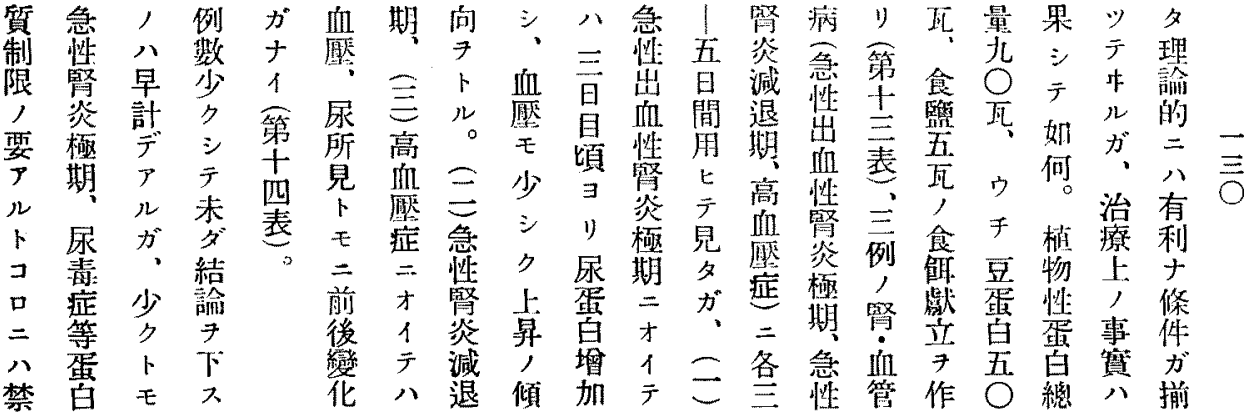


第十五表 各種食品中ノ「カリウム及ビ

$$
\text { 「ナトリウ2、含有置 }
$$

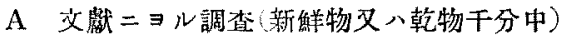

\begin{tabular}{|c|c|c|c|c|c|c|c|}
\hline \multirow{2}{*}{ 食品稙数 } & \multirow{2}{*}{ 食品数 } & \multicolumn{3}{|c|}{$\mathrm{K}_{2} \mathrm{O}$} & \multicolumn{3}{|c|}{$\mathrm{Na}_{2} \mathrm{O}$} \\
\hline & & 平均罪 & 最小量 & 圆大量 & 平均量 & 歇小暗 & 最大是 \\
\hline 数 & 四程(乾 物) & 12.0 & 11.5 & 12.6 & 0.4 & 0.1 & 0.7 \\
\hline 根架類 & 八㮌(新解物) & 4.5 & 1.7 & 8.9 & 0.8 & 0.1 & 1.7 \\
\hline 葚萮 数 & 四䅜( & 3.2 & 1.2 & 4.5 & 0.6 & 0.2 & 0.9 \\
\hline 果茶類 & 四政( & 1.5 & 0.9 & 2.4 & 0.5 & 0.1 & 0.9 \\
\hline 果资 類 & 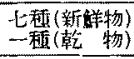 & $\begin{array}{r}3.9 \\
3.6 \\
\end{array}$ & 0.8 & 13.0 & $\begin{array}{l}0.6 \\
0.3 \\
\end{array}$ & 0.1 & 2.7 \\
\hline 菌 菲 類 & 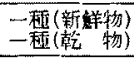 & $\begin{array}{r}3.0 \\
17.4 \\
\end{array}$ & 三 & $\bar{E}$ & $\begin{array}{l}0.2 \\
2.3\end{array}$ & $\overline{-}$ & $=$ \\
\hline 䣦物性但照 & 二程 新鲜物 & 1.8 & 二 & - & 1.5 & 0.6 & 2.3 \\
\hline
\end{tabular}

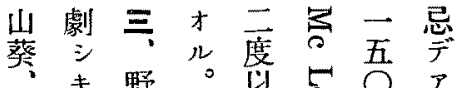

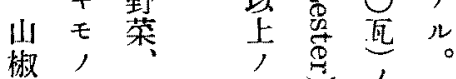

生1物咅势蛋最

姜、向

辛州

䄓厅

生辛，

根! 擇

燕 シ 一

分用定

何 $t$,

限レー䋶八上儿惡アコ二香, 時ラ注

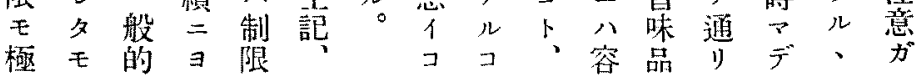

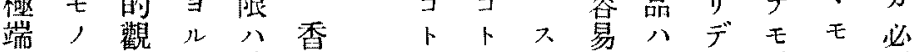

こデ察 ヨ精噪索

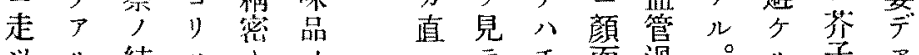

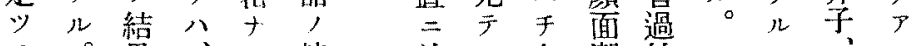

テ○果、儿禁

八コ定 々 試歨

今制

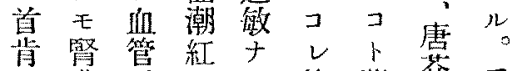

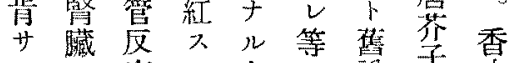

ル

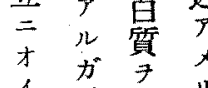

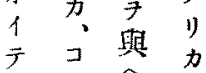

初レ气二

八 $\bar{y}$

于考房

豆慮入テ

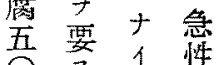

○云年出

○思

桼?、㙰婜

$\rightarrow \square=$

デレ令多

用 $\{0$ 量

第至

馬二ツ野支モ酸ナコ忌等醋ナ味制ナ必後シモモヌ

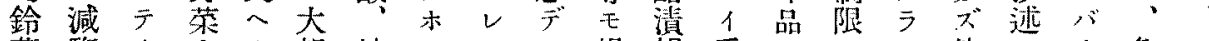

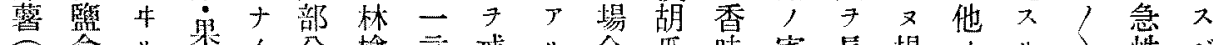

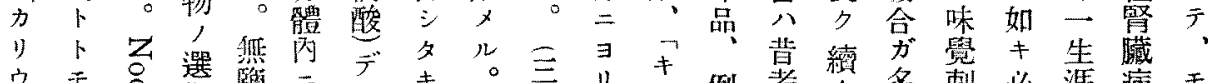

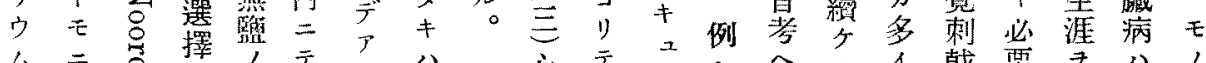

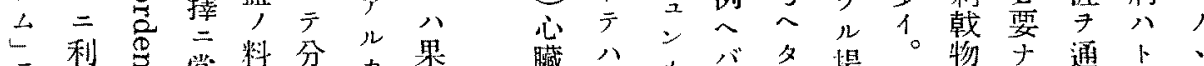

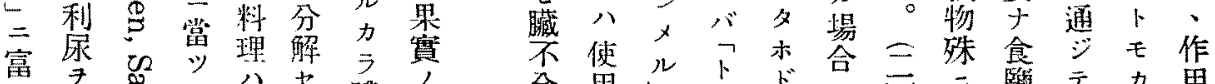

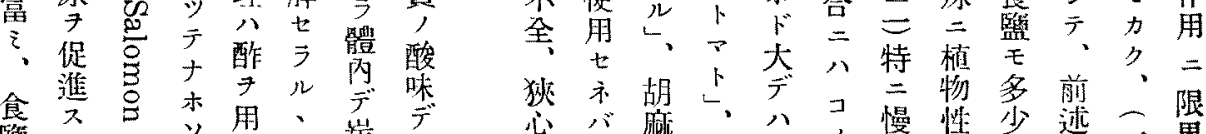

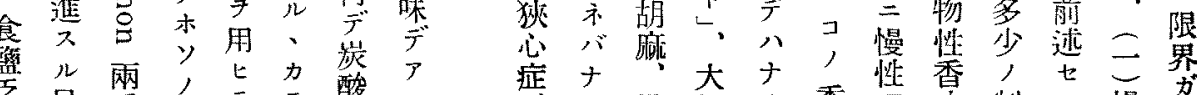

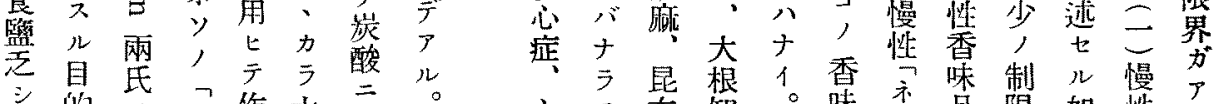

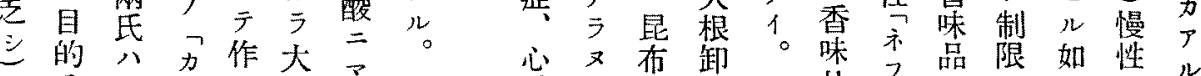

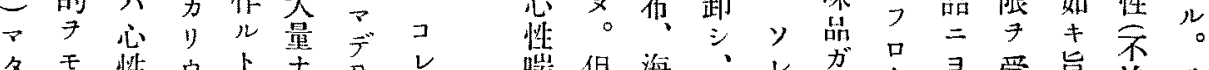

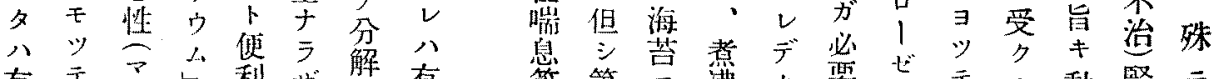

三有

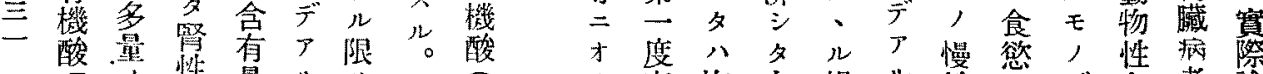

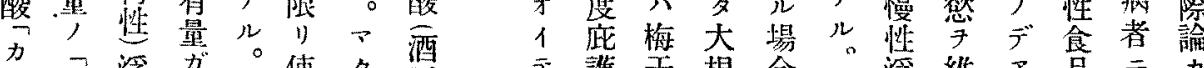

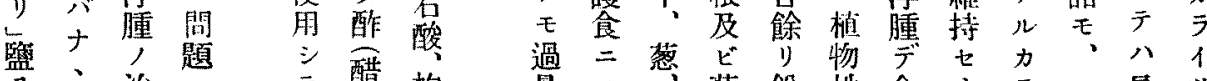

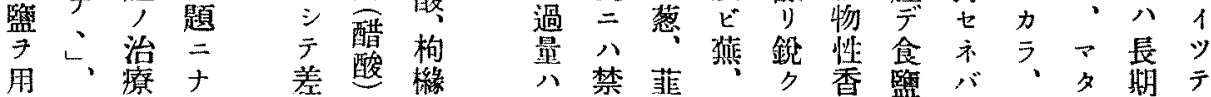


第十五表 各種食品中「カリウム」及ビ「ナトリウム」含有量(新鲜物千分中)

B）金養研究所 (遠䕓)分析

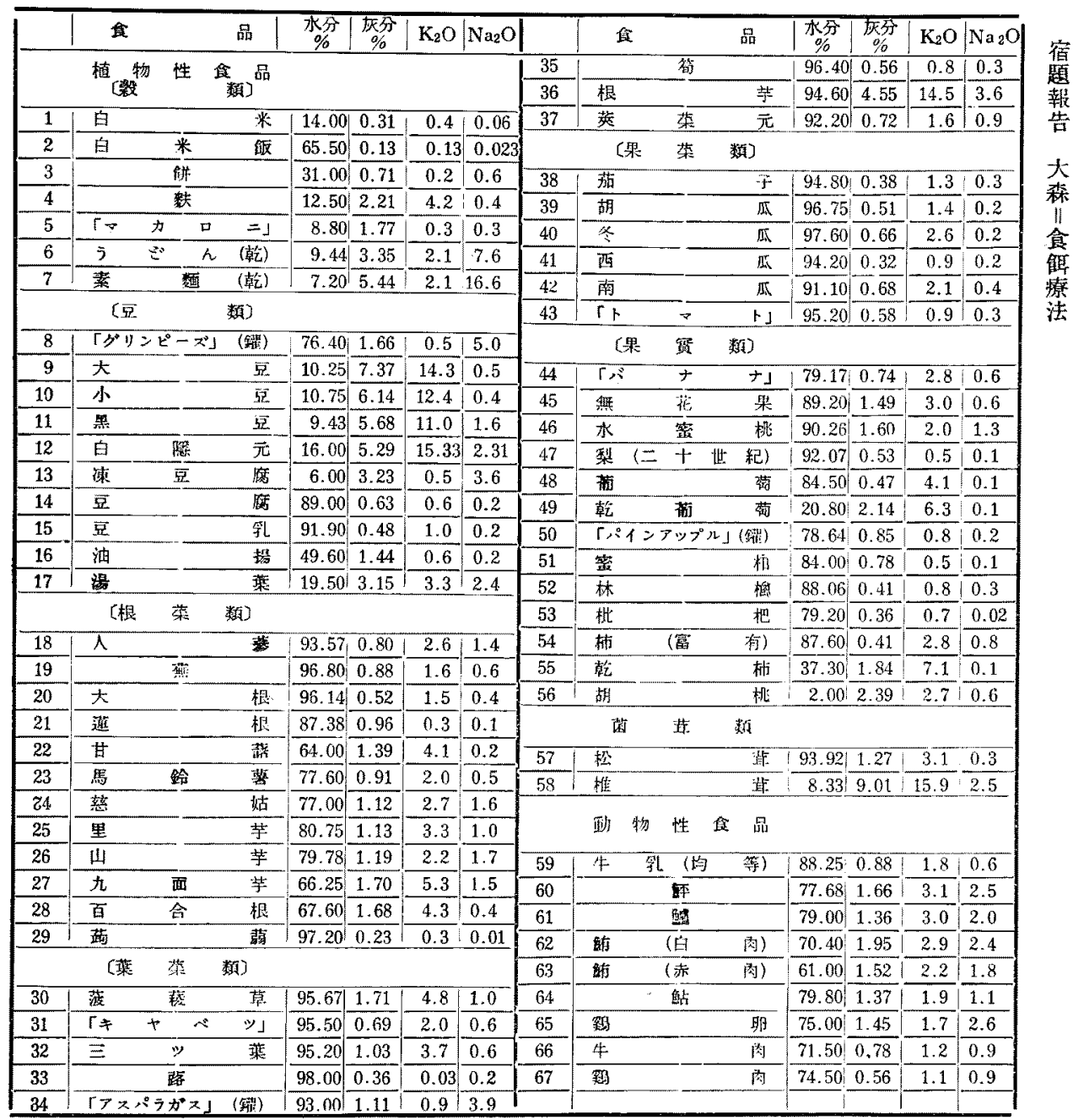

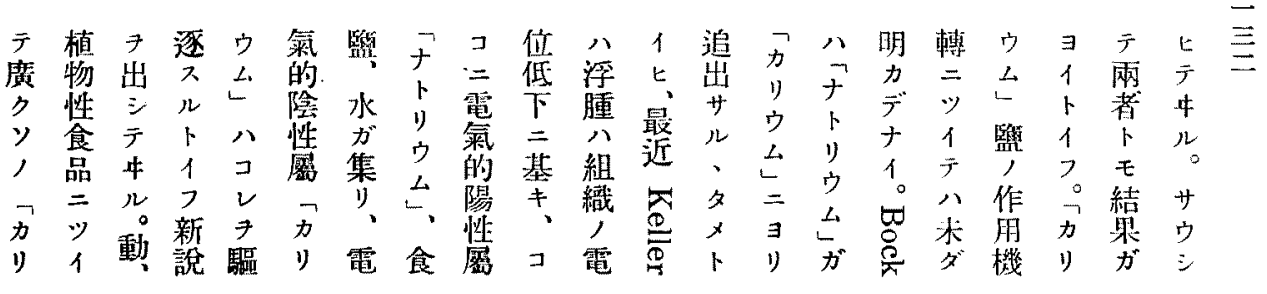




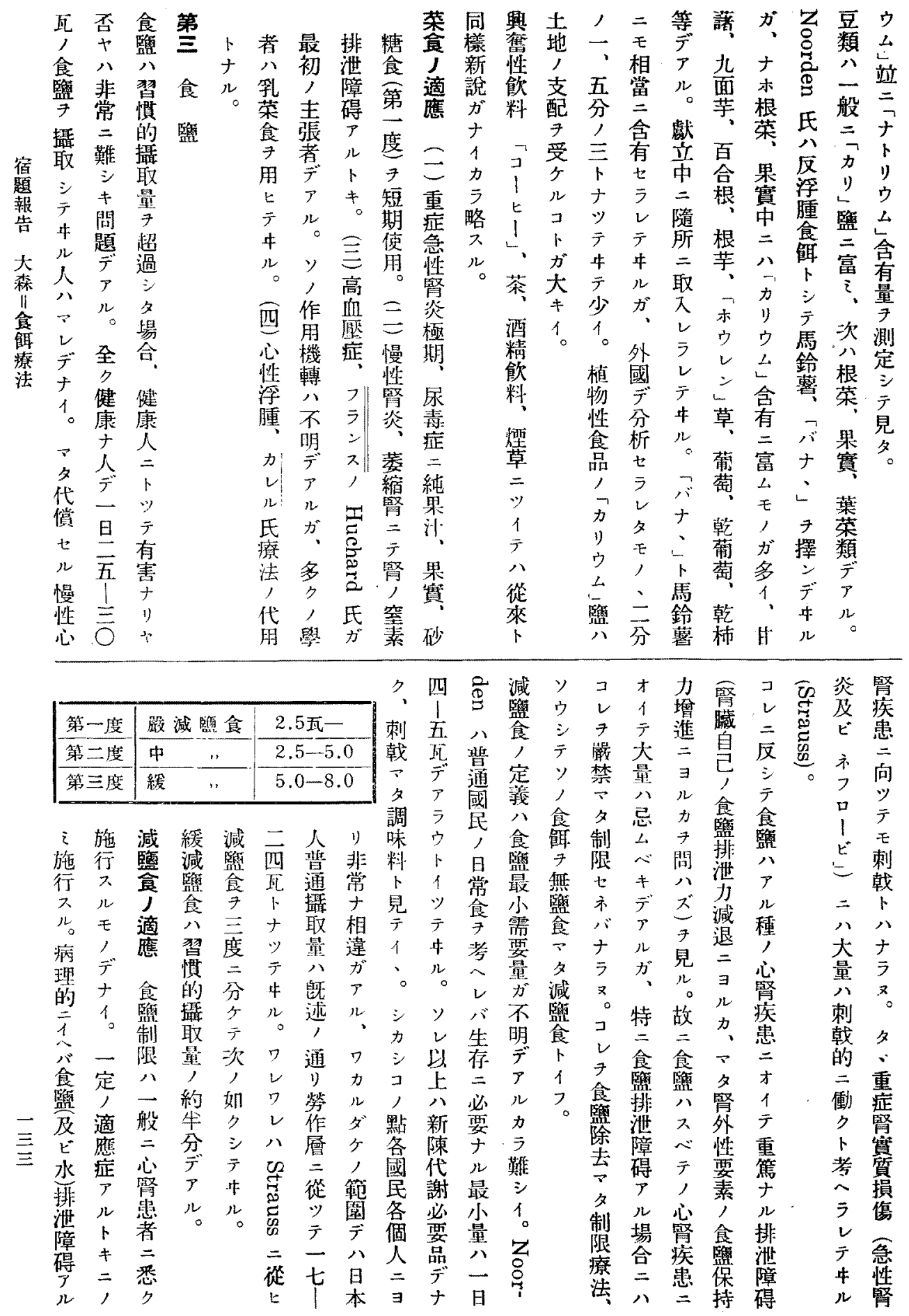




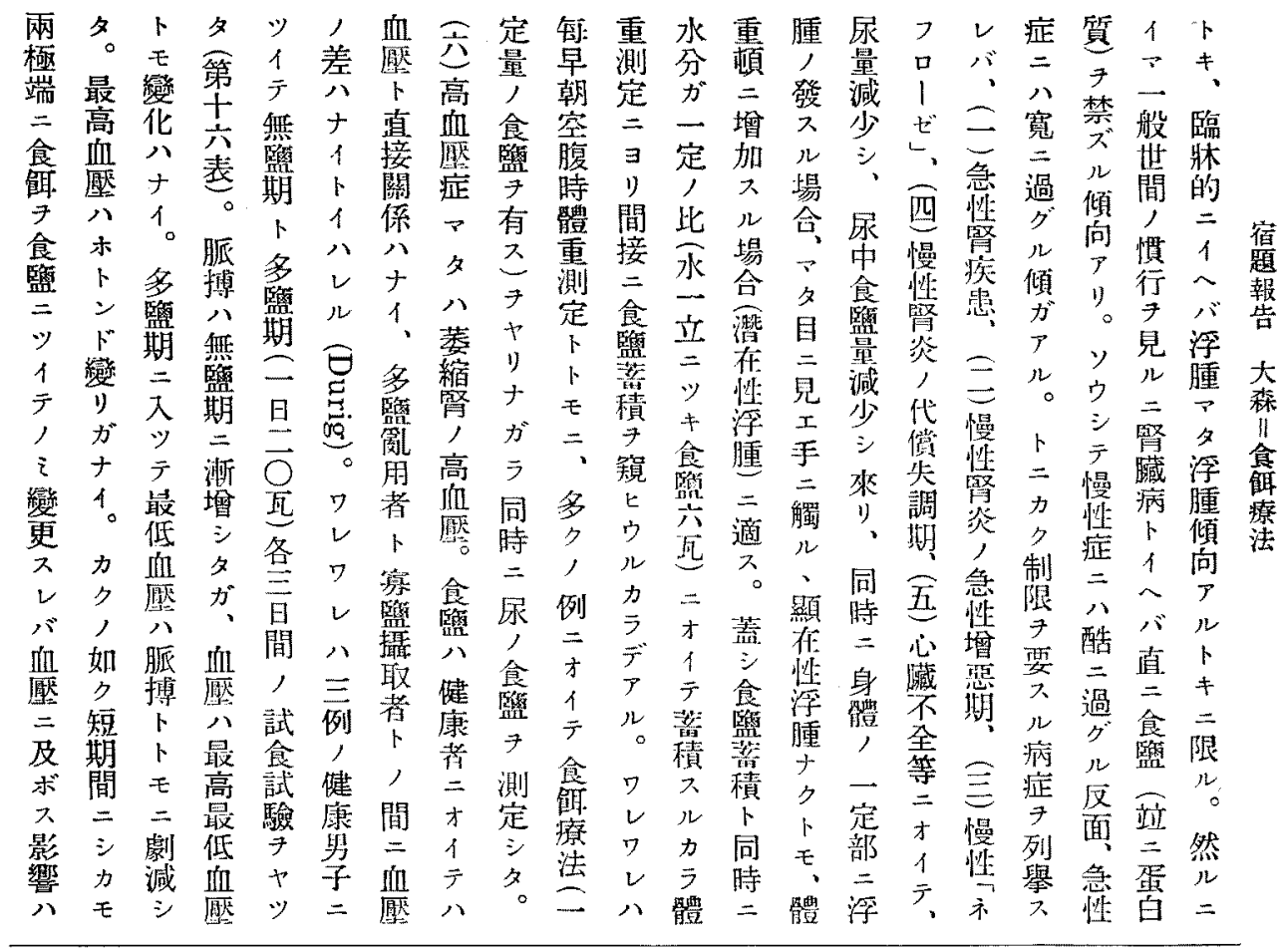

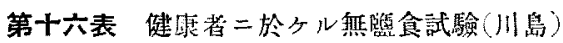

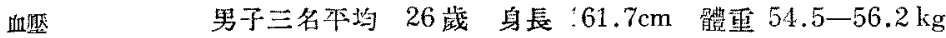

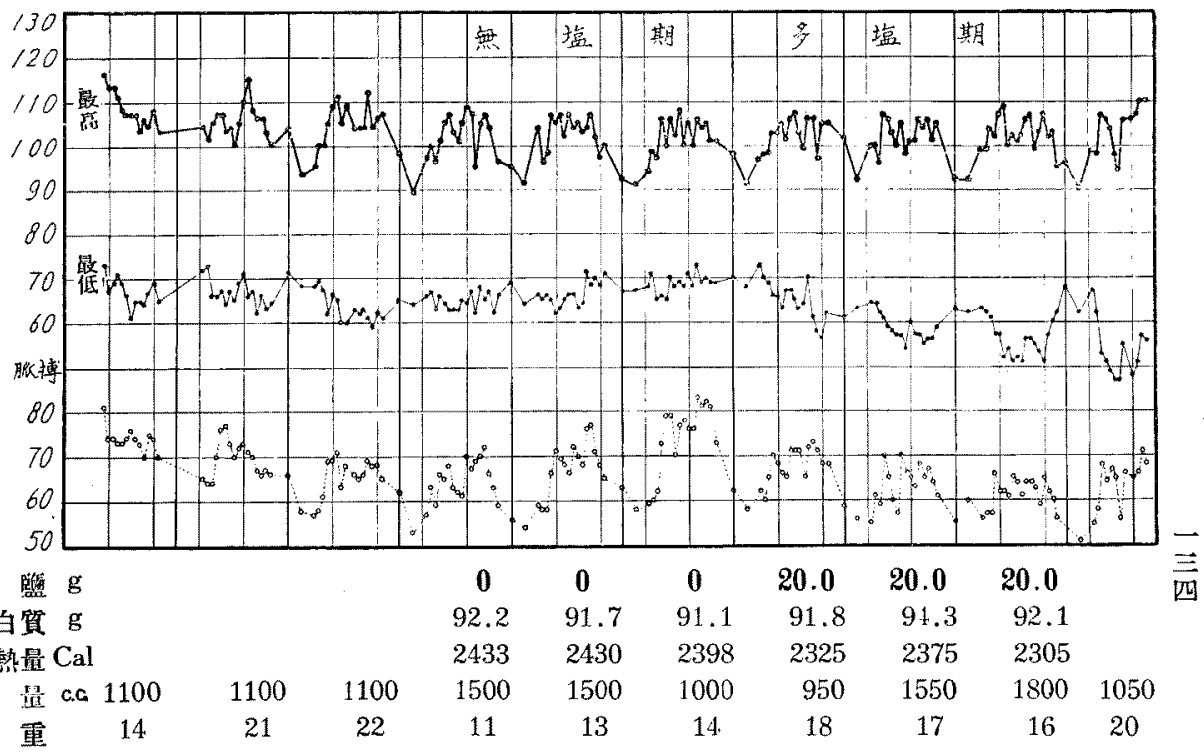

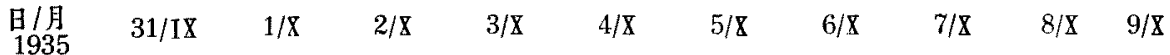




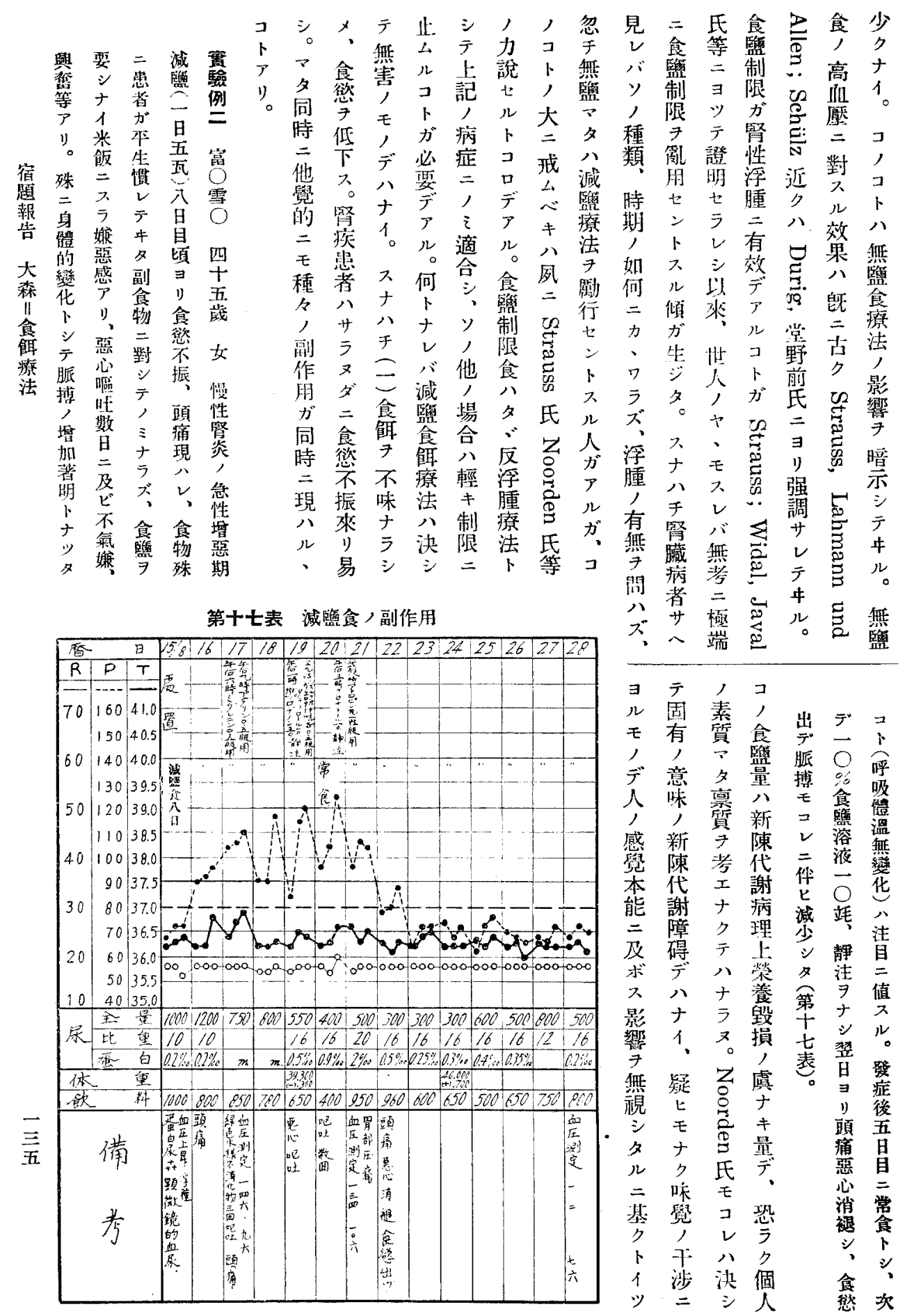




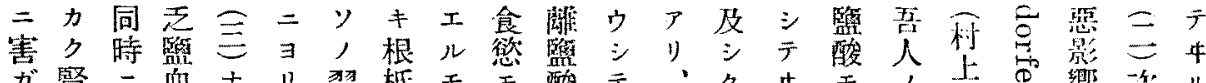

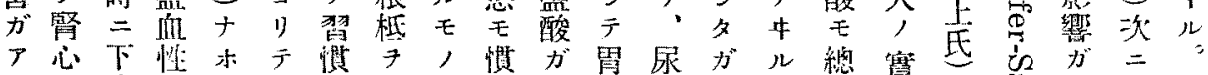

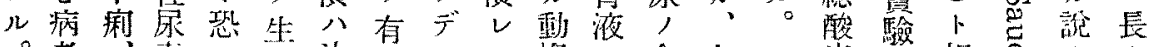

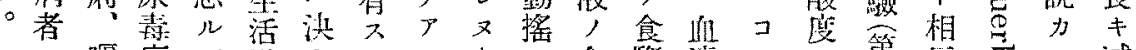

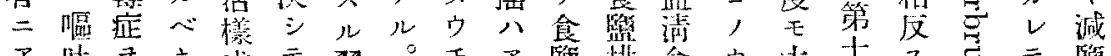

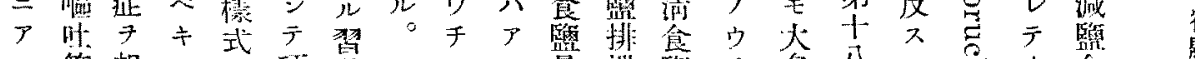

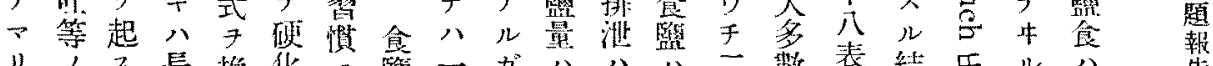

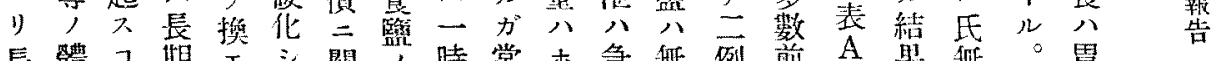

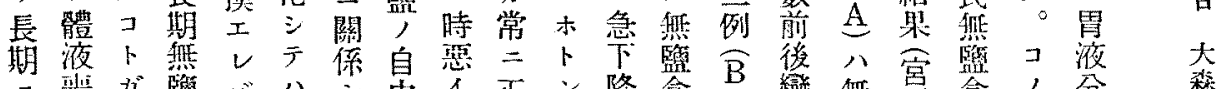

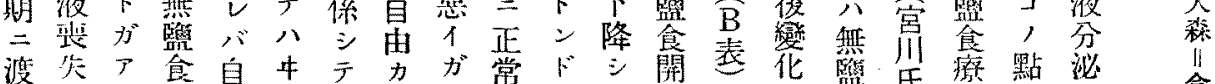
渡先

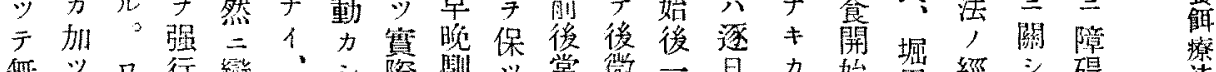

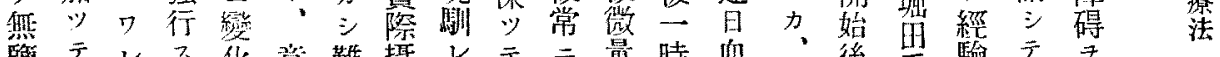

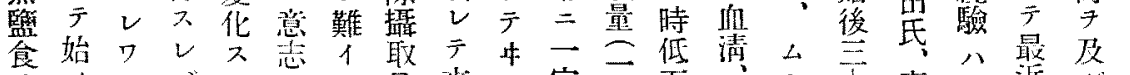

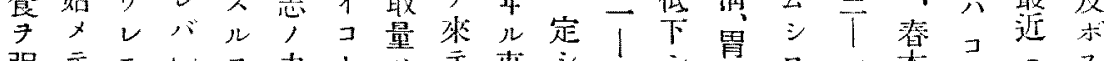

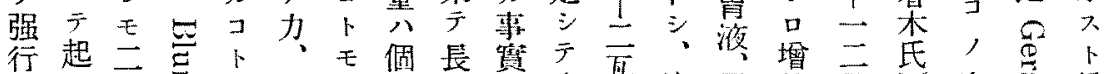

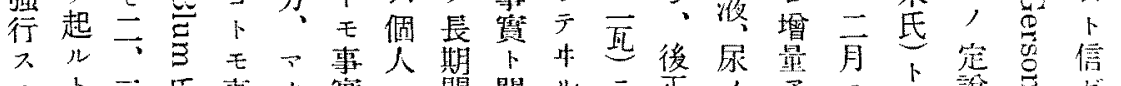
ルト三民事夕筫 $、$ 間關 $=$ 正, $\bar{T}$

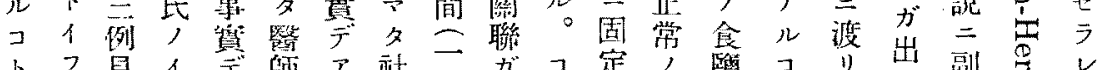

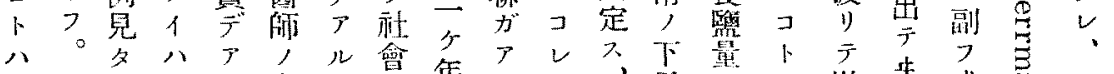

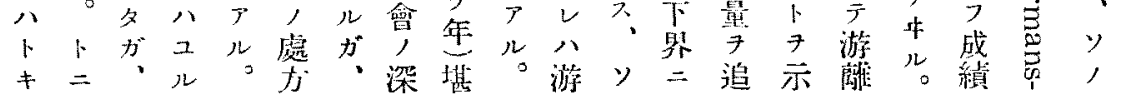

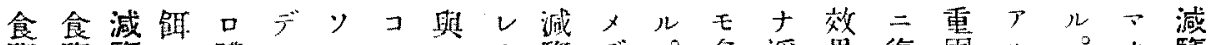

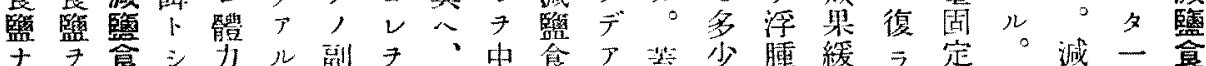

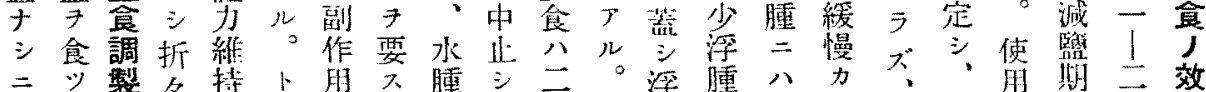

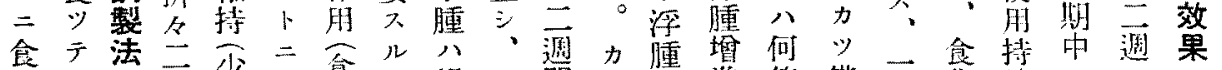

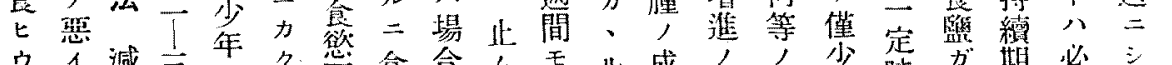

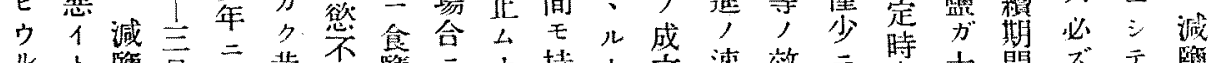

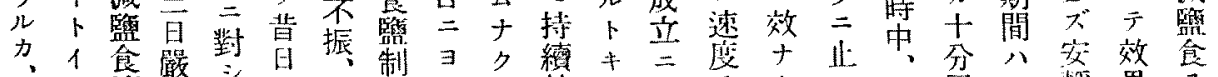

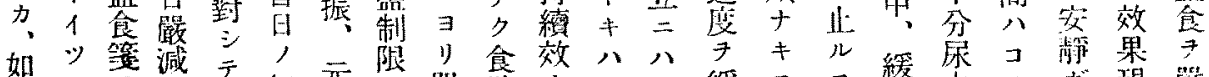

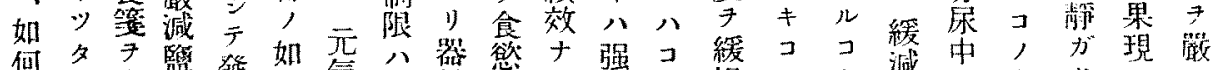

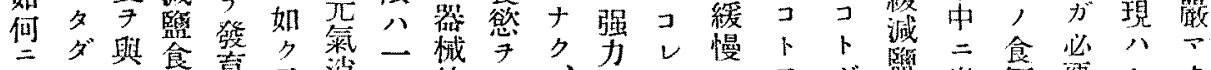

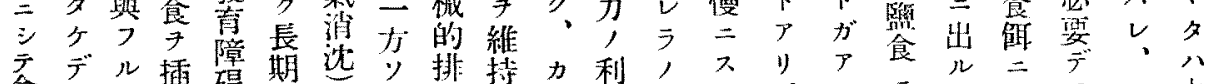

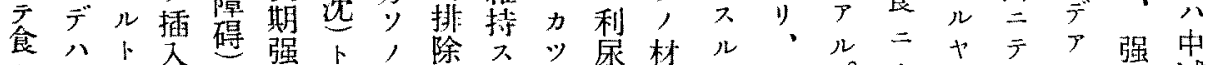
䭾 バ目八几顧入比朋第二省壬, ケ、コメ二重。監

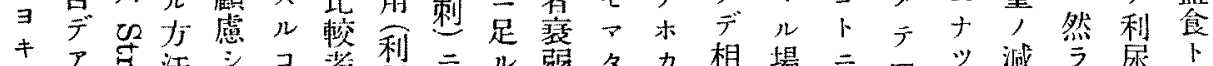
† 可法

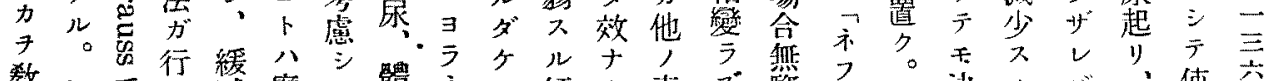

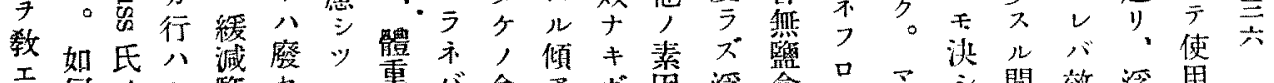

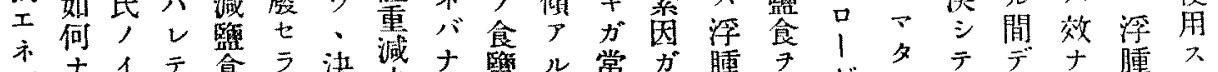

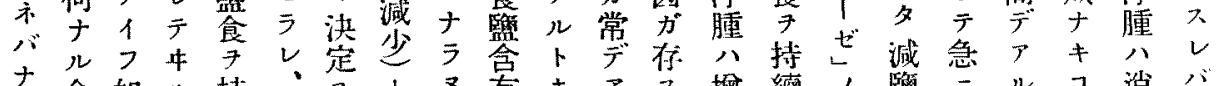

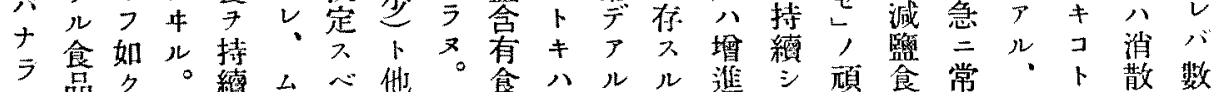

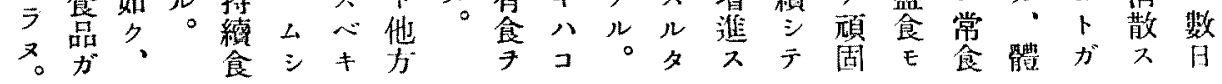




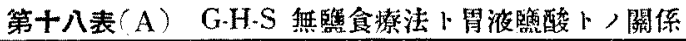

\begin{tabular}{|c|c|c|c|c|c|c|c|c|c|c|c|}
\hline \multirow{2}{*}{ 姓 } & \multirow{2}{*}{$\begin{array}{l}\text { 年 } \\
\text { 踩 }\end{array}$} & \multirow{2}{*}{ 性 } & & \multirow{2}{*}{ 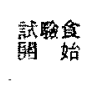 } & \multicolumn{2}{|c|}{ 前期 周 液 } & \multicolumn{2}{|c|}{ 後期霄液 } & \multirow{2}{*}{ 剔作用 } & \multirow{2}{*}{ 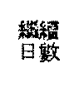 } & \multirow{2}{*}{ 路 } \\
\hline & & & & & 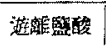 & 總酸度 & 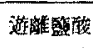 & 榴酸度 & & & \\
\hline 唃 & 17 & $\hat{\delta}$ & 眑䈟結核 & 7 月 2 日 & 201120 & 46 & $28 / 6 \quad 47$ & 67 & 視加陪碛 & 1 ケ年 & 輕 快 \\
\hline 太D正O & 19 & I & 上 & 9月25日 & $27 / 164$ & 98 & $10 / 6$ & 61 & & 9ケ月 & 同 \\
\hline 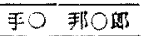 & 2 & 5 & 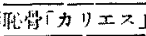 & & 1146 & 8 & $18 / 7$ & & 言語障碍 & 9ケ月 & 同 \\
\hline 两 0 新 0 & 18 & 客 & 同 上 & & $28 ! 111$ & 54 & $31 / 7 \quad 23$ & & & 7ケ月 & 同 上 \\
\hline 雷 0 3i 0 & 20 & + & 祭笞結柆 & 12月23日 & $26 / 1 \quad 18$ & 28 & $6 / 7 \quad 0$ & 1 & 暗 & ケ5月 & 同 上 \\
\hline 牛 0 八 & 26 & + & 智常性狠籍 & 9 月 8 日 & $12 / 931$ & 73 & $\begin{array}{rrr}26 / 10 & 15 \\
5 / 11 & 70 \\
\end{array}$ & $\begin{array}{r}52 \\
132 \\
\end{array}$ & 軥 & 3ケ月 & 全 治 \\
\hline 荒○信。 & 19 & $\hat{\sigma}$ & 同 & & $6: 838$ & 74 & $23 / 12 \quad 34$ & 78 & & 6ク月 & 轻 快 \\
\hline 發 0 繁 & 16 & $\hat{\jmath}$ & E & & & & $27 / 1 \quad 38$ & 82 & 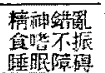 & 9ケ月 & 全 治 \\
\hline
\end{tabular}

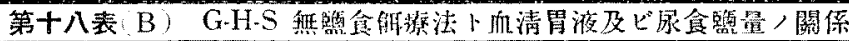

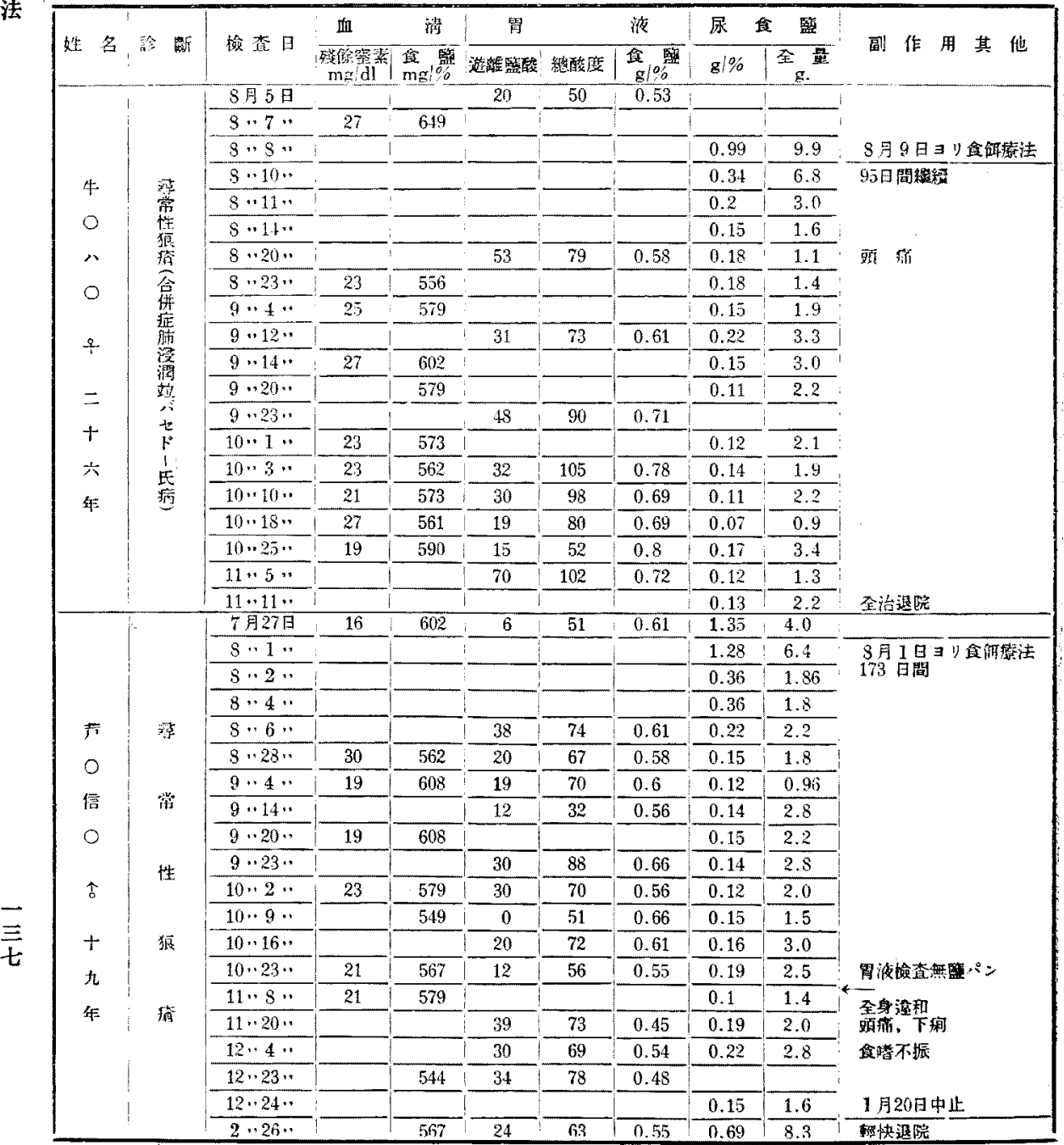


第十九表 各喠食品食監含有量 甲、(佳々廉平氏編)

\begin{tabular}{|c|c|c|c|c|c|}
\hline 品 & $\%$ & 品 & $\%$ & 品 & $\%$ \\
\hline 㽞 & $0.09-0.17$ & 取 & 0.31 & 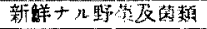 & $0.016-0.188$ \\
\hline 粼 & $0.14-0.17$ & 乳. & $0.15-0.16$ & 北「キサベッ」 & 0.15 \\
\hline 水 保 & $0.06-0.12$ & 41 & 0.012 & 蒜草 & 0.21 \\
\hline 氷 魚 & $0.16-0.41$ & 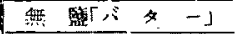 & $0.02-0.21$ & 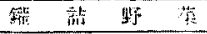 & $(1.67-1.27$ \\
\hline 特 & $0.52-1.14$ & 念 監「バ タ & $1.0-3.0$ & 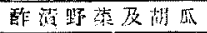 & $0.73-1.45$ \\
\hline 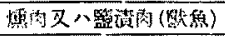 & $1.85-20.59$ & AIT & 2.19 & 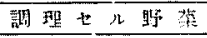 & $0.49-0.91$ \\
\hline 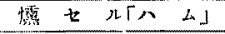 & $1.85=7.5$ & 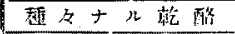 & $1.59-10.57$ & 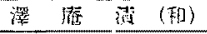 & 8.0 \\
\hline 温 & $2.2-8.1$ & 稚々ナル歇類 & $0.002 \cdot 0.35$ & 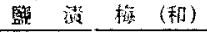 & $2.0 \mathrm{WL}$ \\
\hline 調型七儿敬穭雨 & $0.39-1.92$ 以上 & 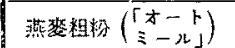 & $0.26-0.29$ & 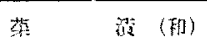 & $0.5 \mathrm{WL}$ \\
\hline 「口レンタインミート & $1.4-1.40$ & 触 & $0.5-0.6$ & 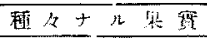 & $0.001-0.07$ \\
\hline$F 2-x J$ & 0.08 & Гピスケット」(「ケーク」) & $0.47=0.87$ & {$[y+\therefore]$} & $0.7-1.5$ 以上 \\
\hline 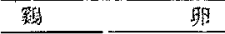 & $0.13-0.21$ & 教 & $0.16-0.078$ & 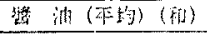 & 16.2 \\
\hline 那 & 0.039 & 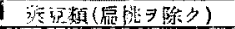 & $0.058-0.09$ & 踘 嘴 (沟) (和) & 9.2 \\
\hline
\end{tabular}

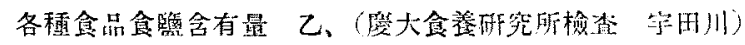

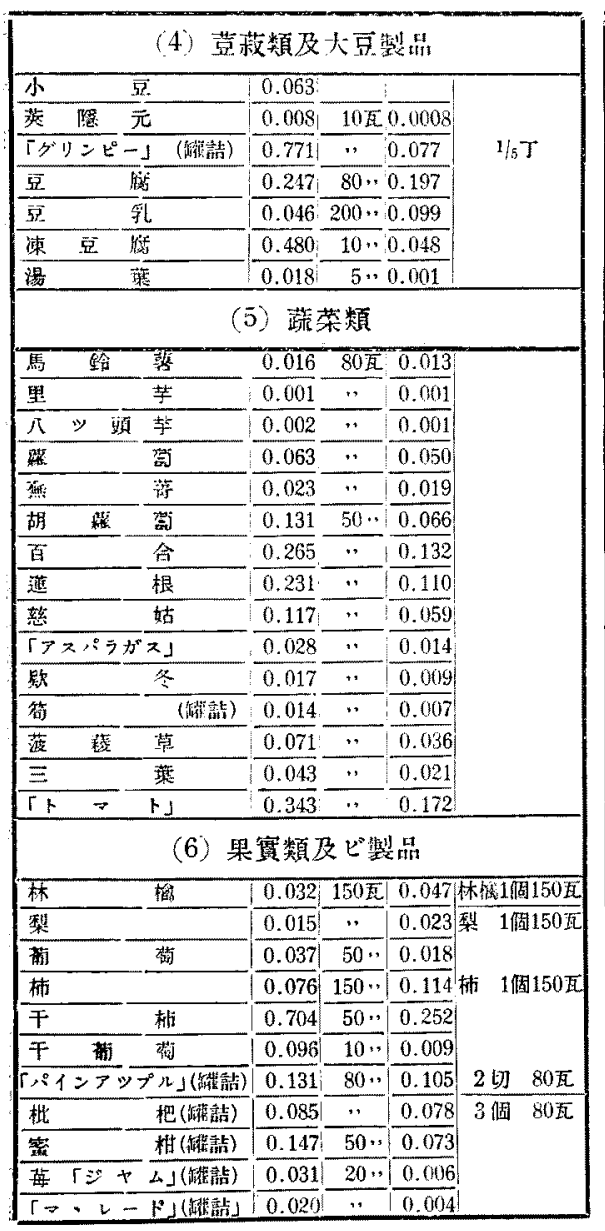

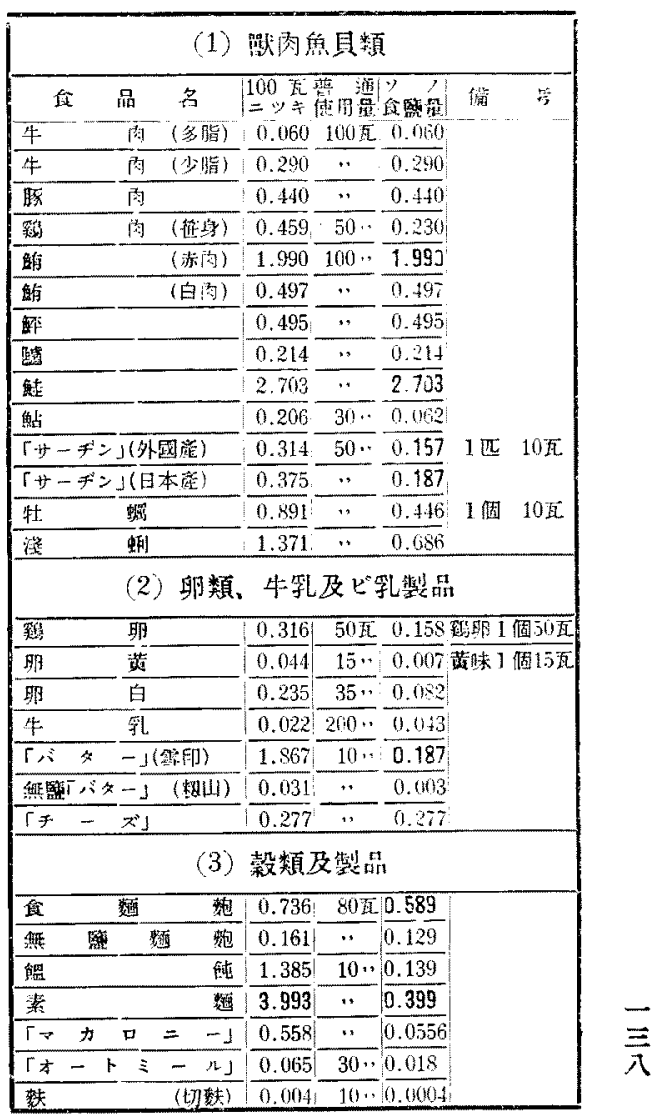




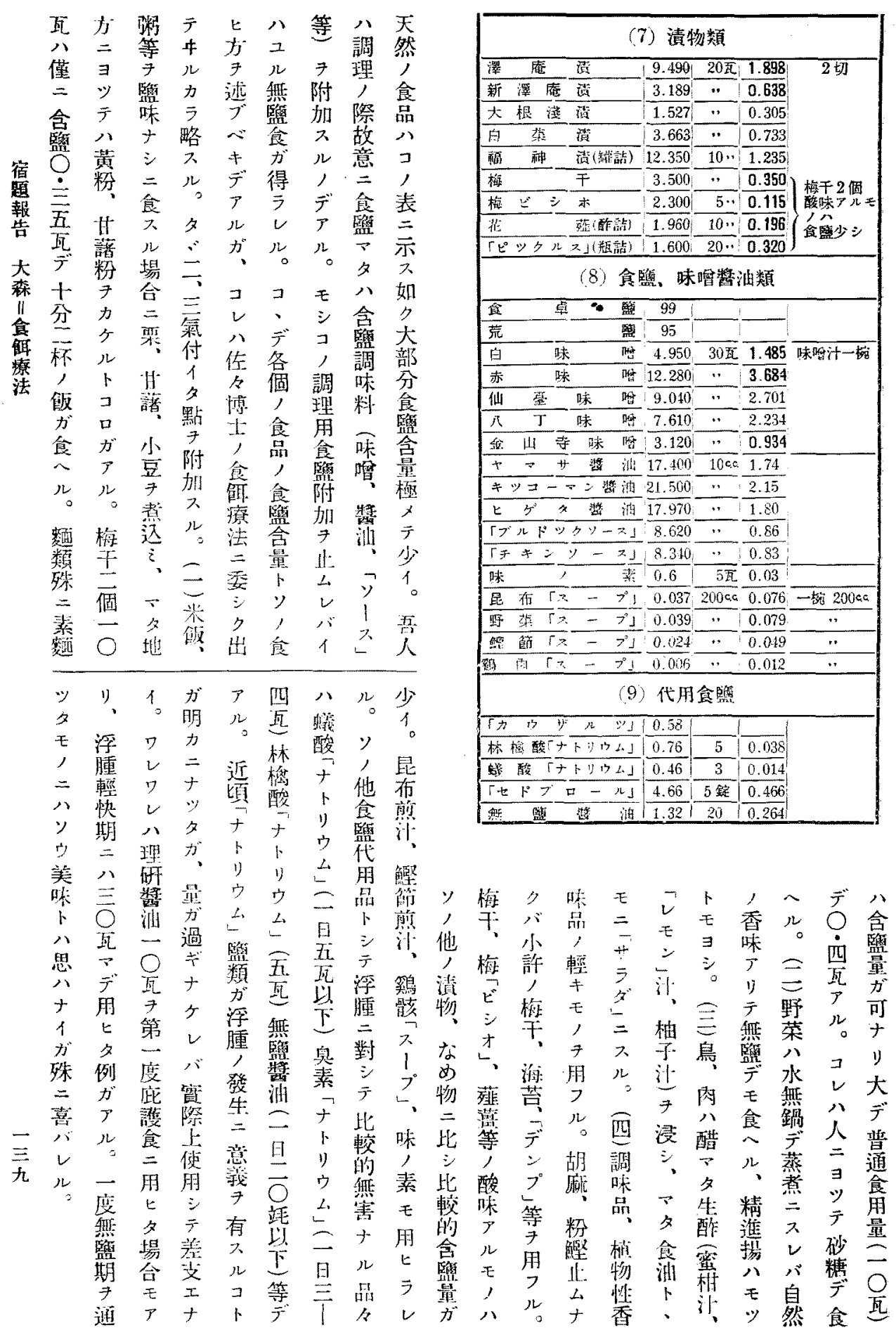




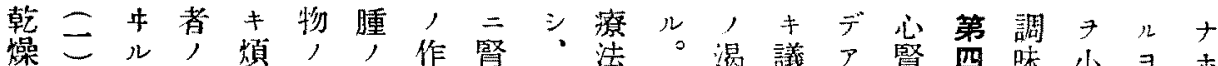

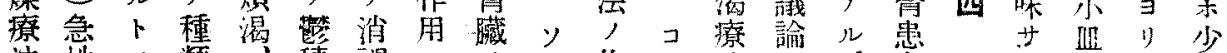

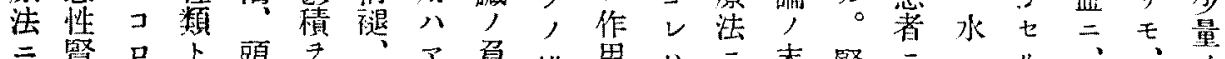

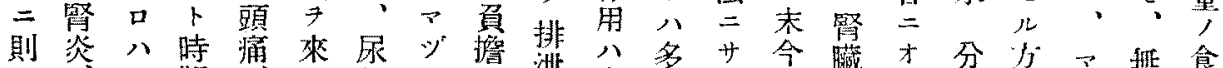

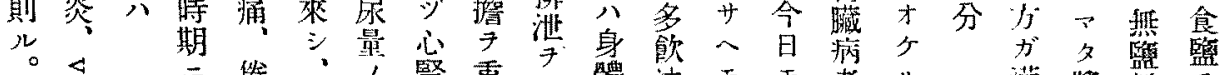

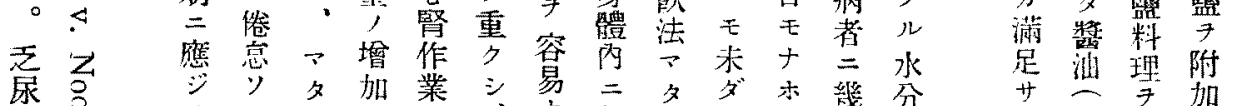

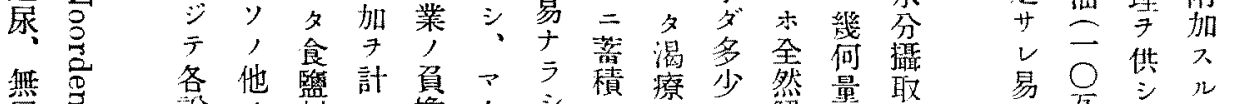

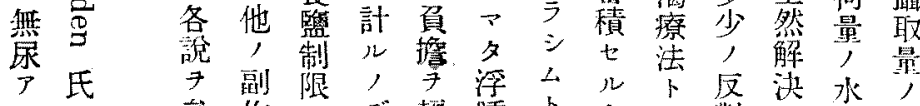

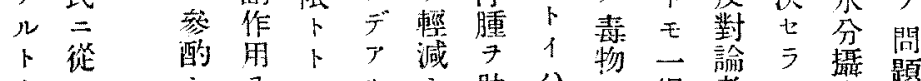

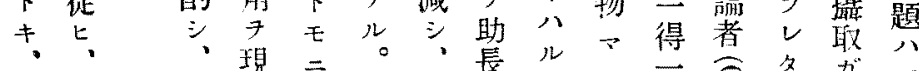

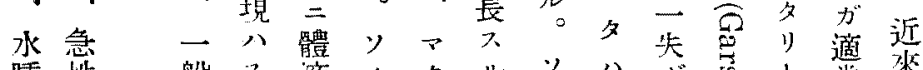

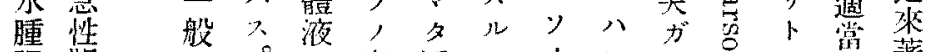

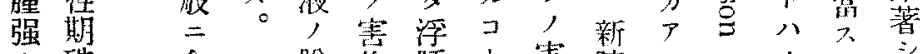

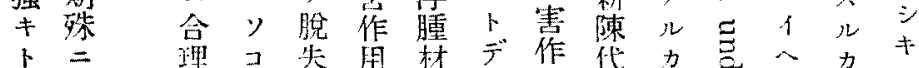

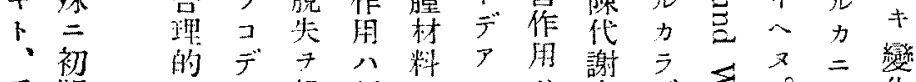

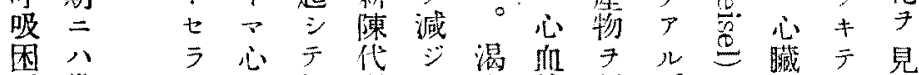

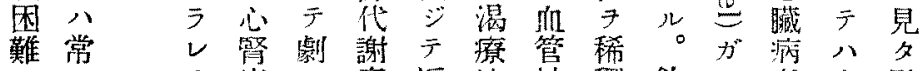

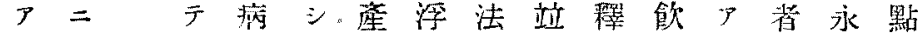

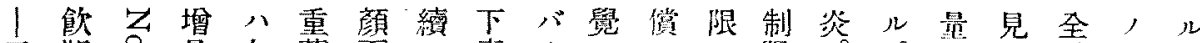

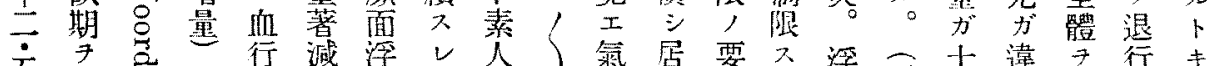

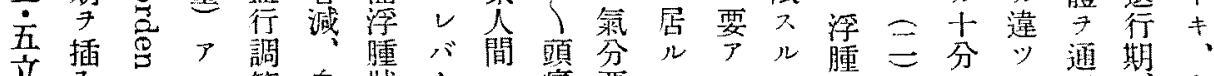

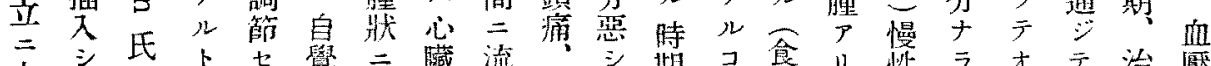
此 シ E

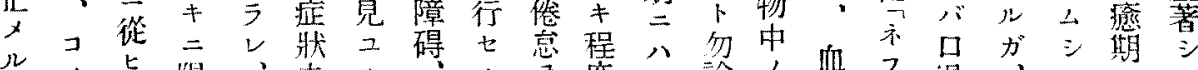

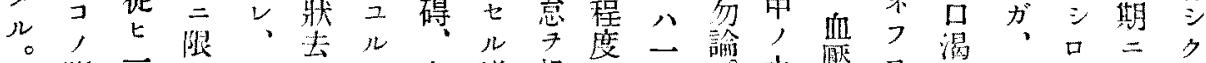

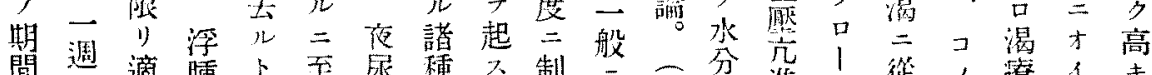

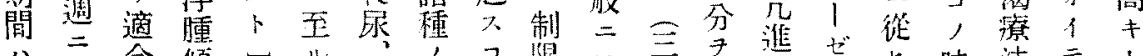

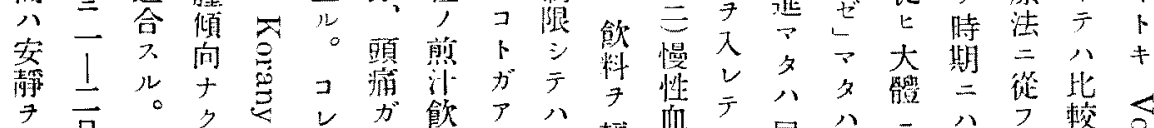

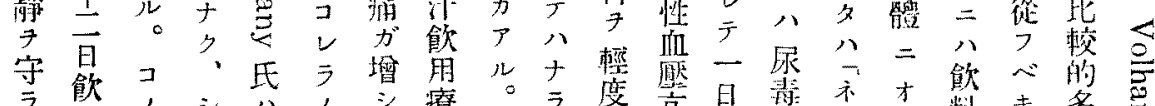

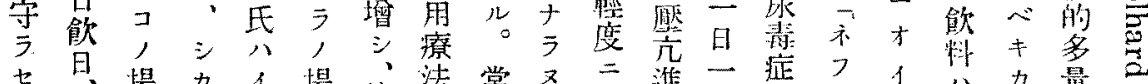

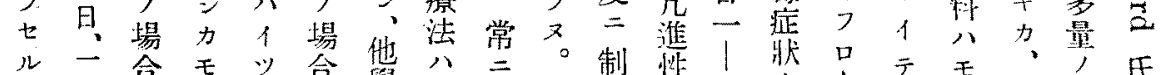

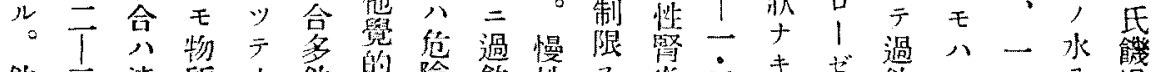

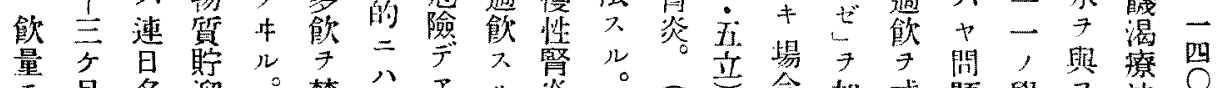

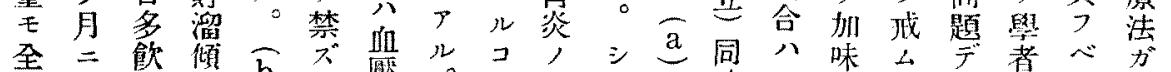

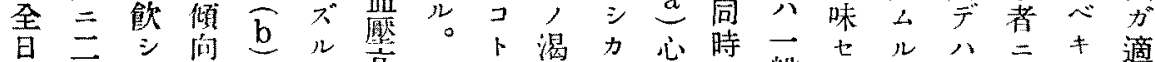
中国

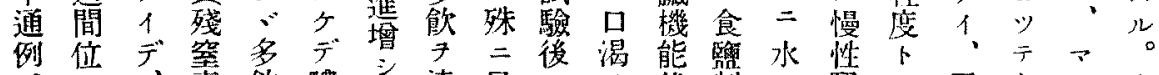

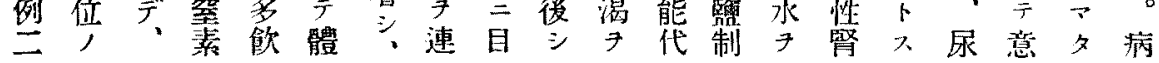



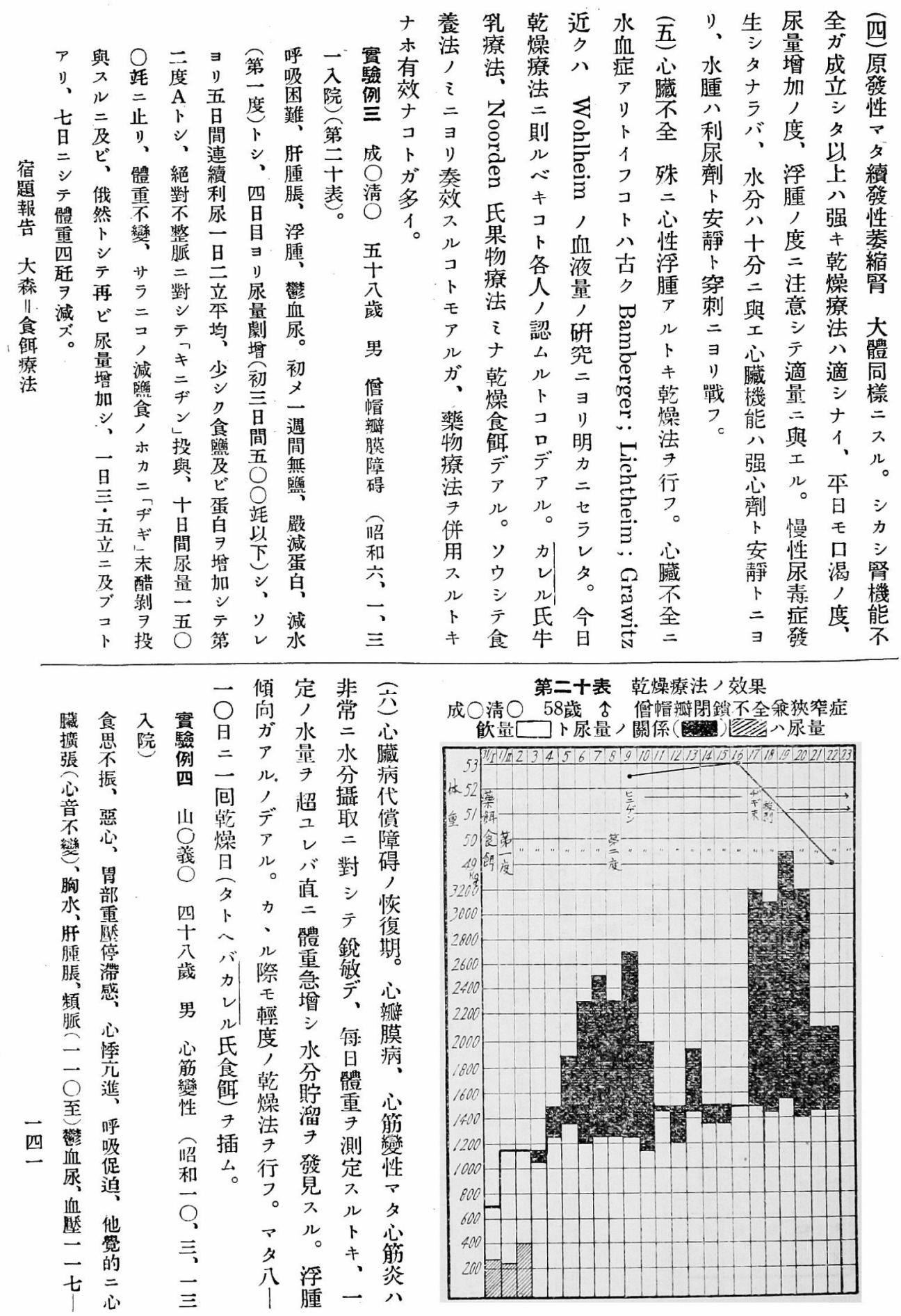

第二十表 乾燥療法, 效果

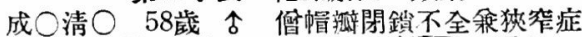

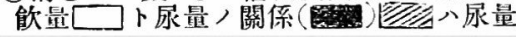

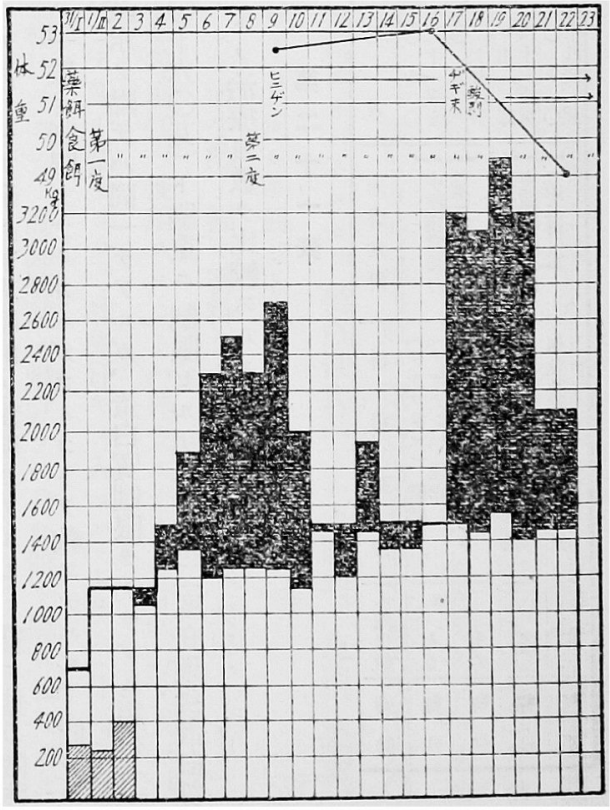




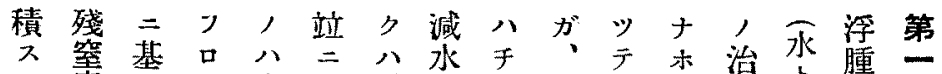

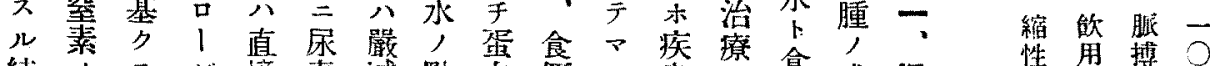

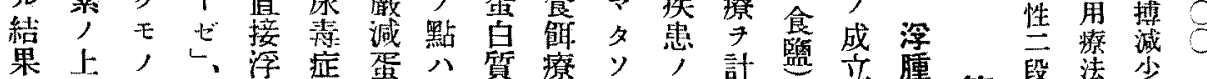

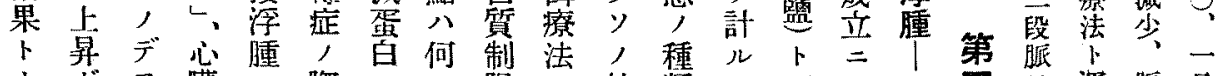

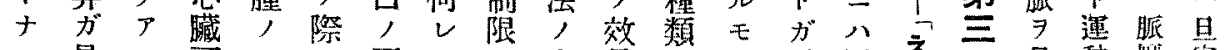

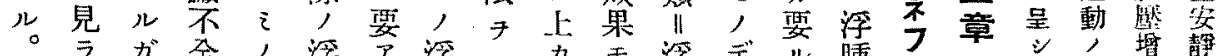

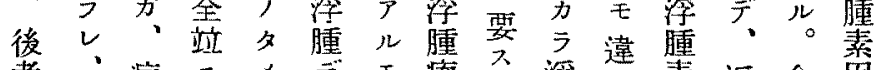

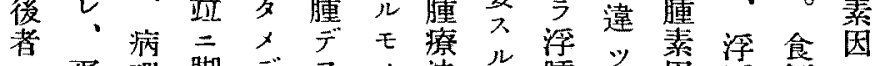

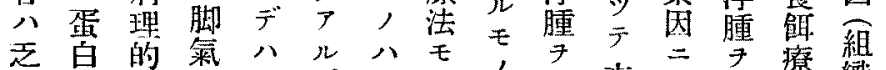

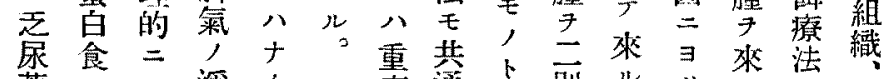

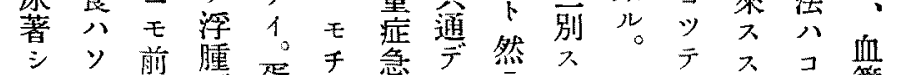

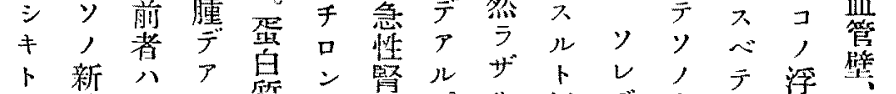

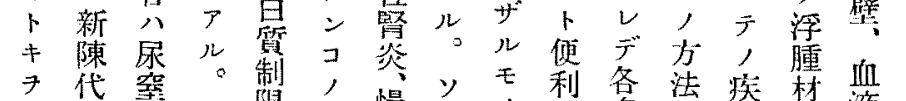

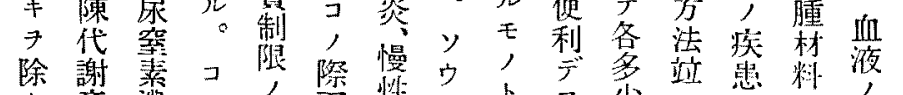

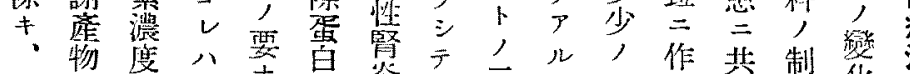

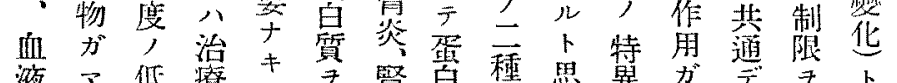

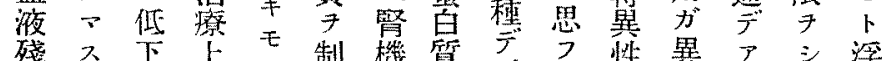

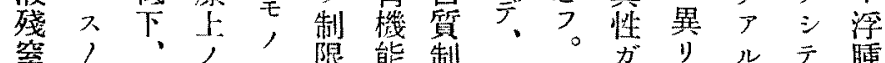

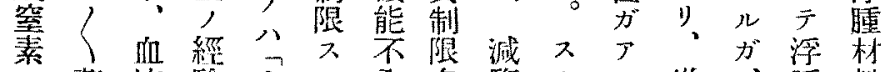
, 滀液驗齐儿全多暨ナル䍀、腫料

疅

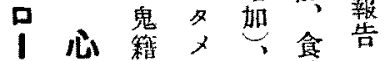
セ腎云三養 涉病公再命强森

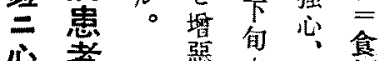
怘韮突利鲫

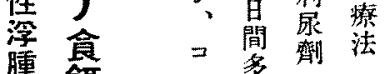

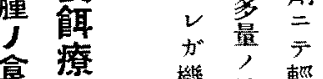
餙法籍輕 法 永证 + 尿

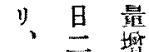
遂 I 加 期主體 收妾重

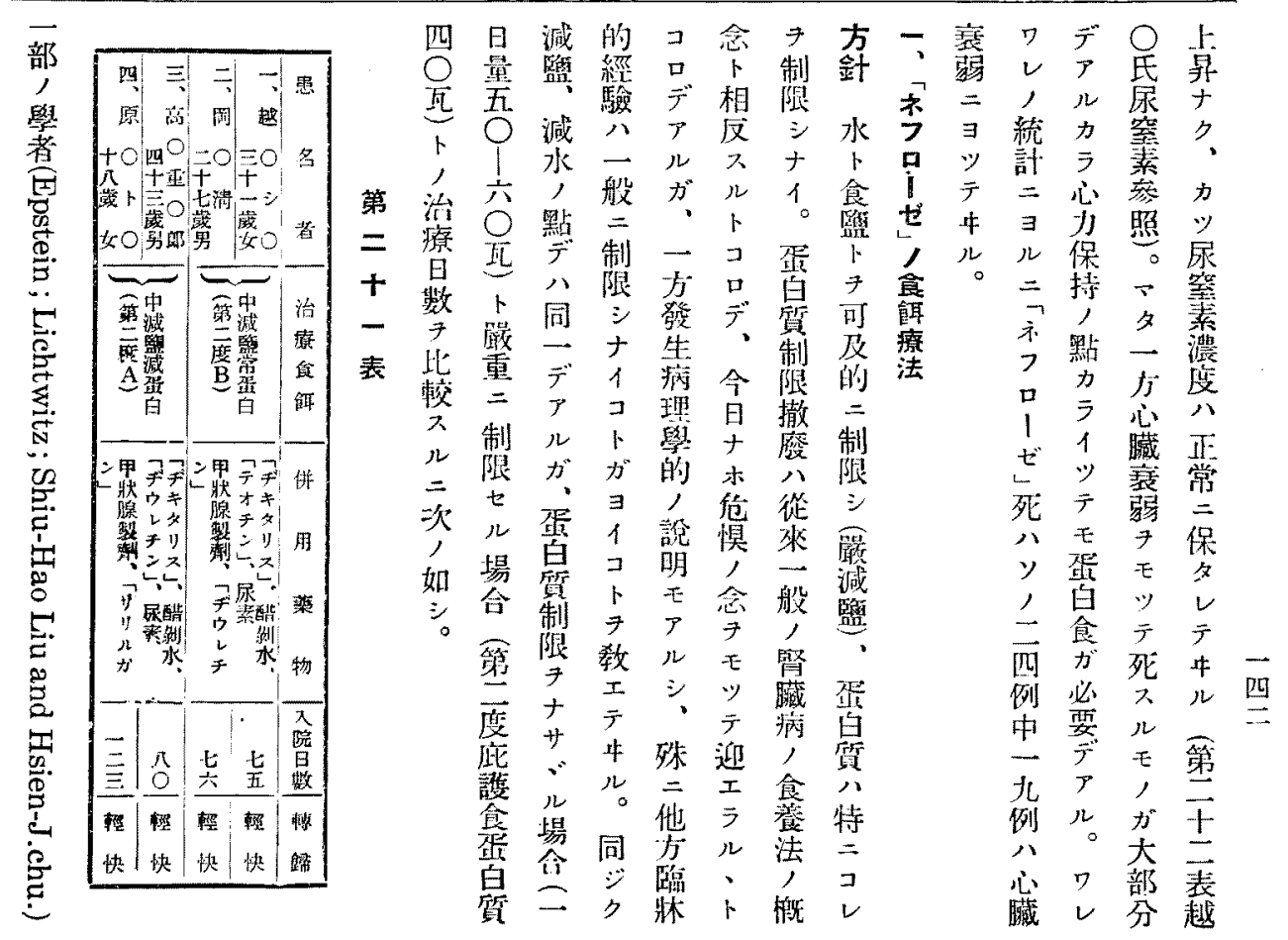




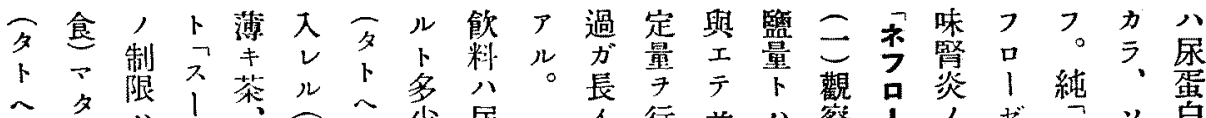

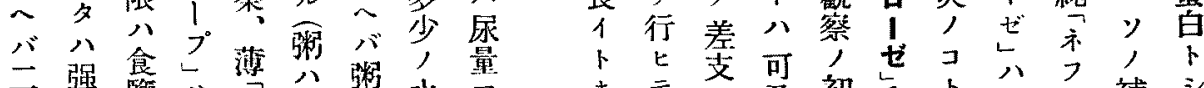

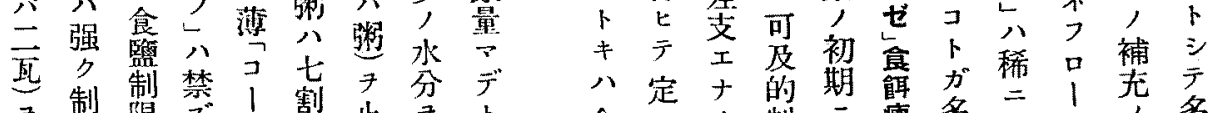

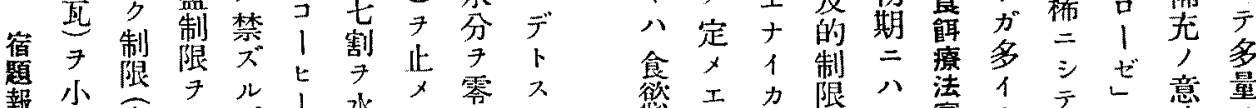

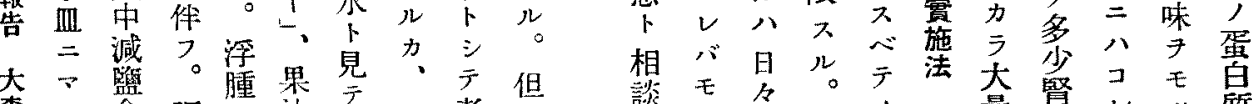

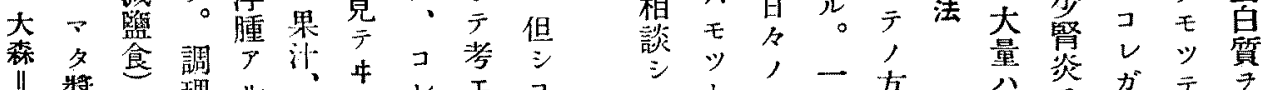

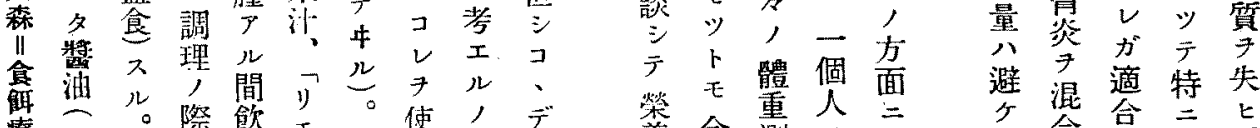

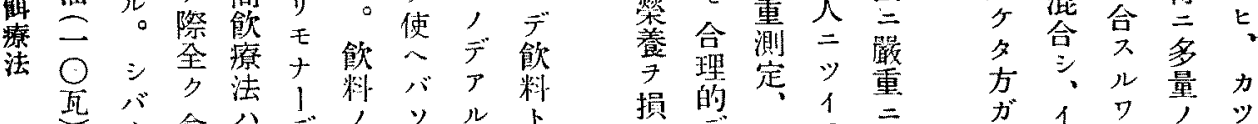

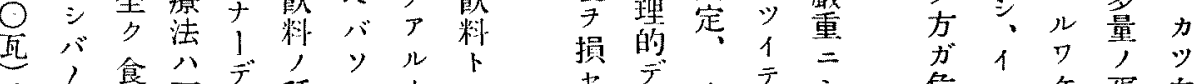

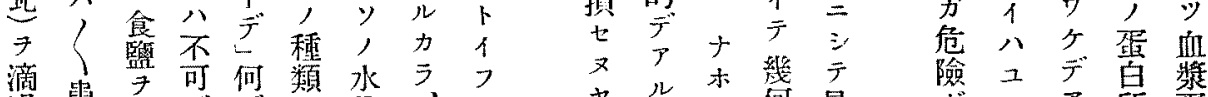

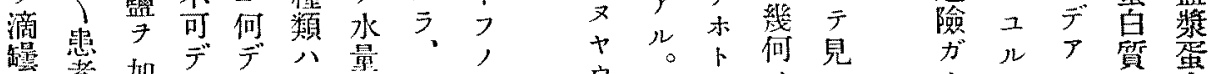

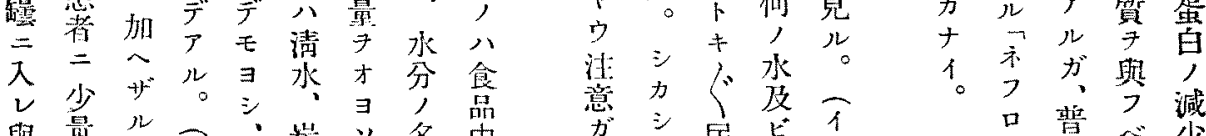

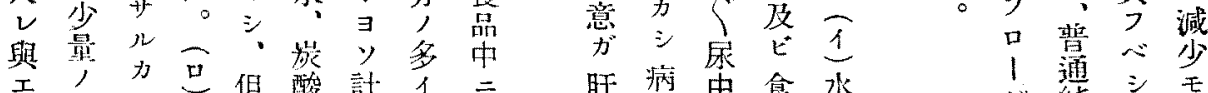

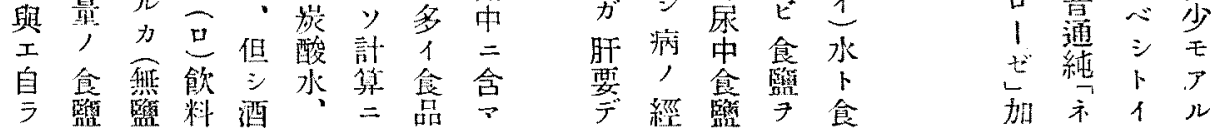

录行

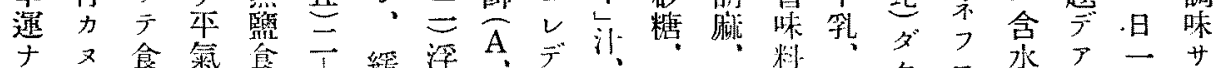

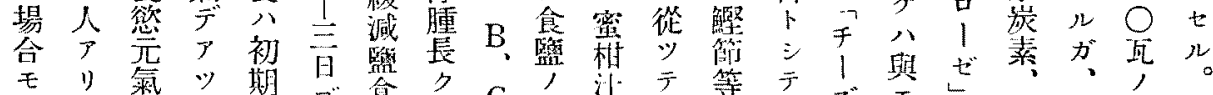

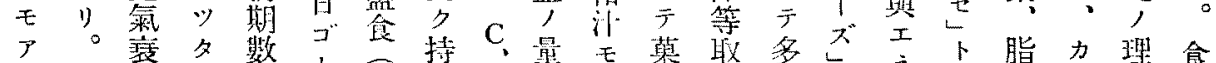

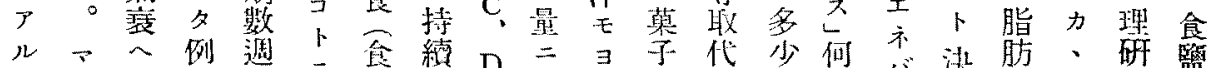

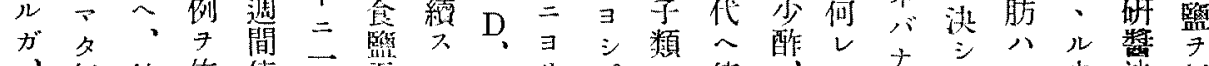

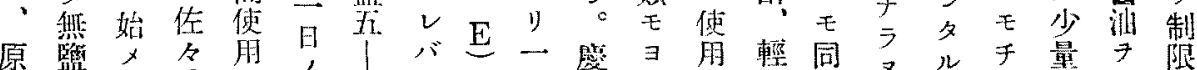

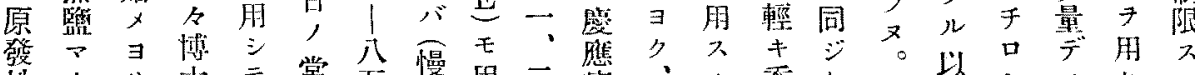

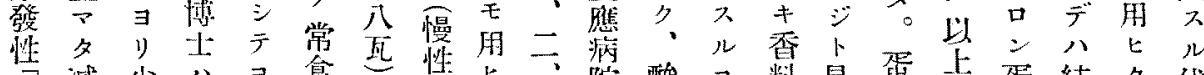

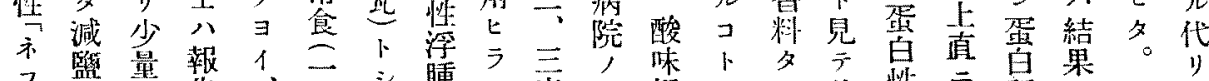

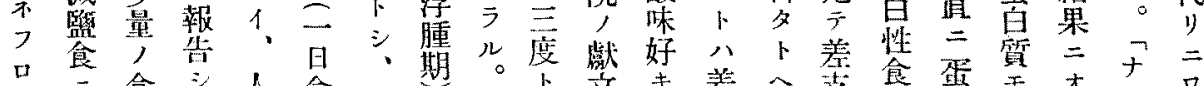

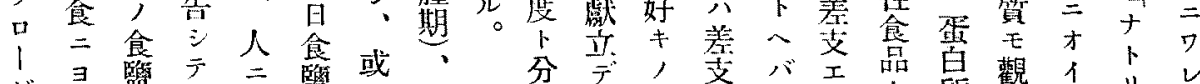

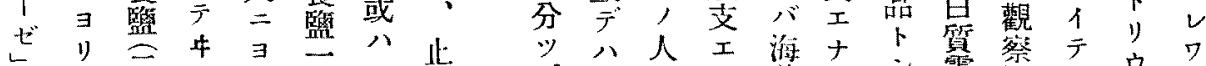
一光直

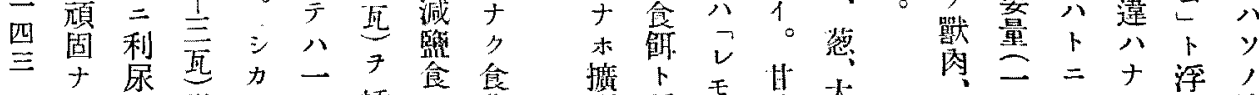

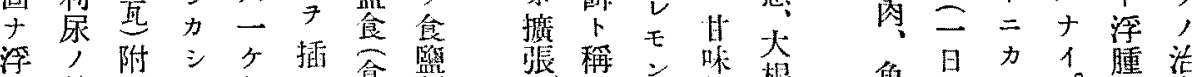

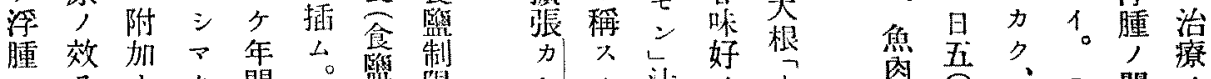

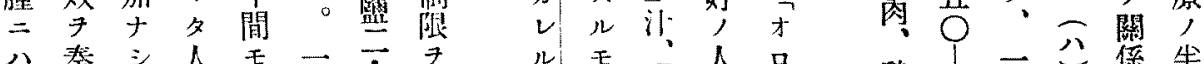

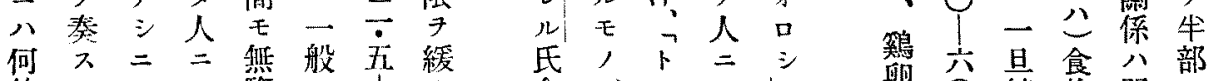

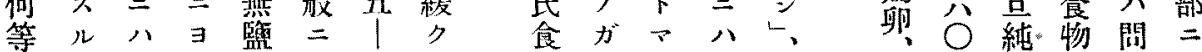




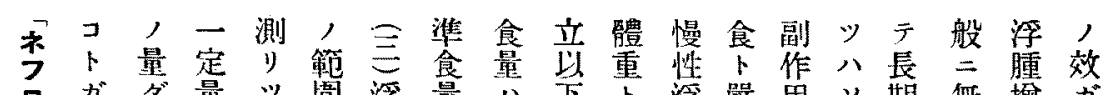

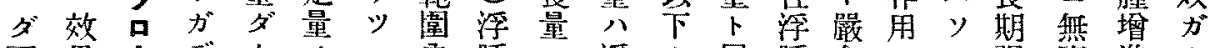

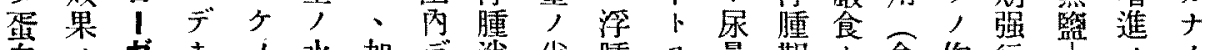

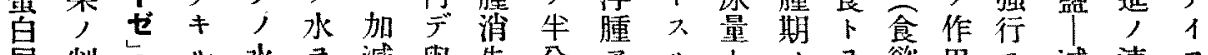

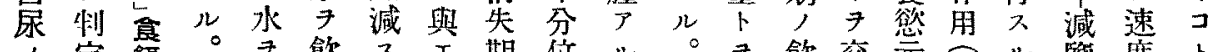

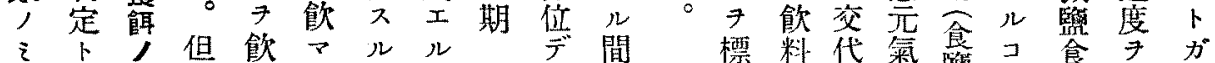

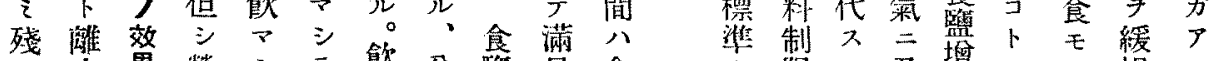

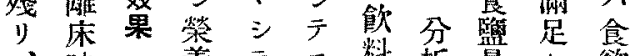

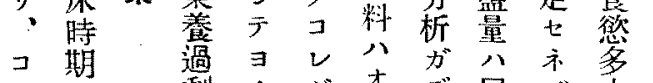

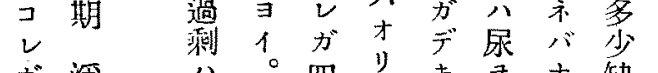

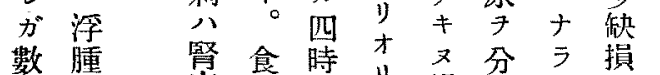

魀去疾量間水場析 叉文

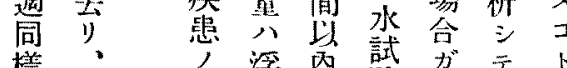

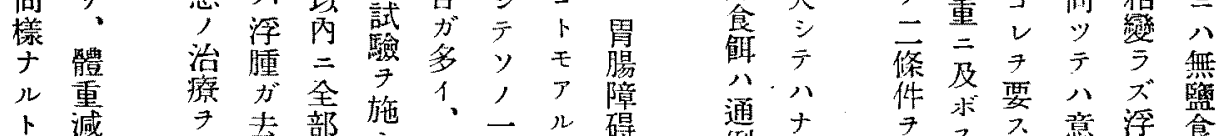

減 7 去部施

八ヤ輕、 ゲバ泄 定公排 起

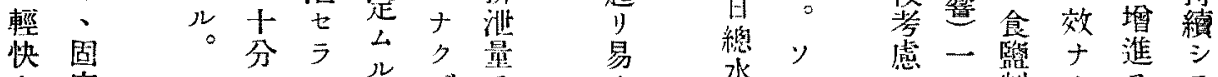

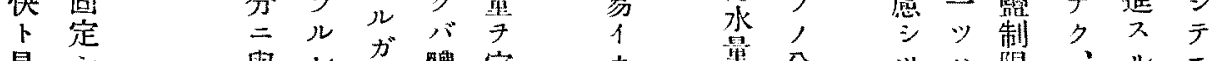

見シ 期レ カ

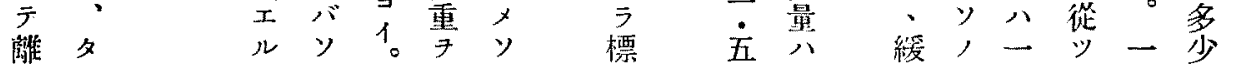

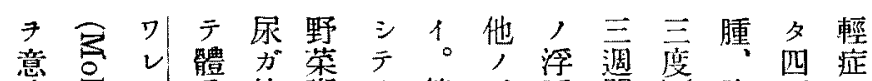

味

シ滎係下 テ

體要數降中使第二十

丙导厡

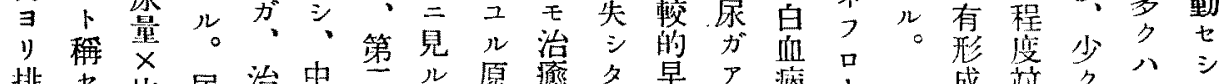

排

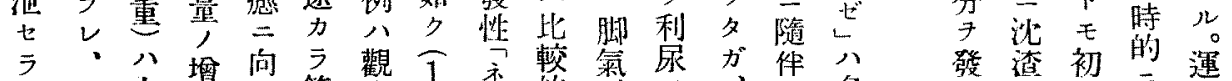

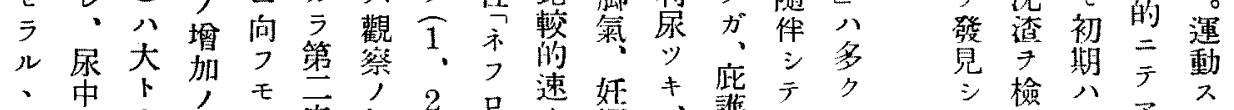

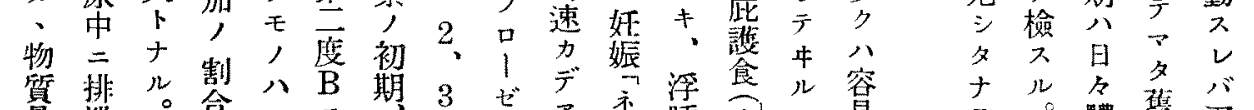

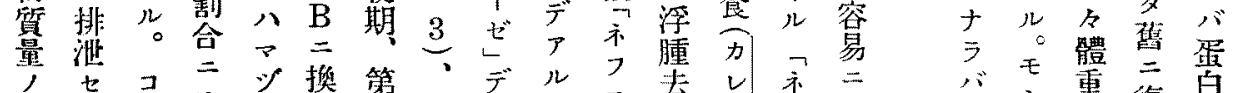

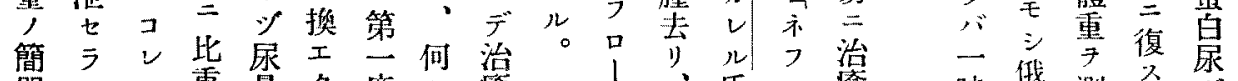

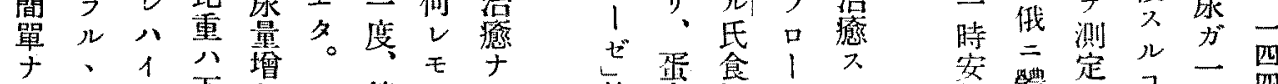

指子分

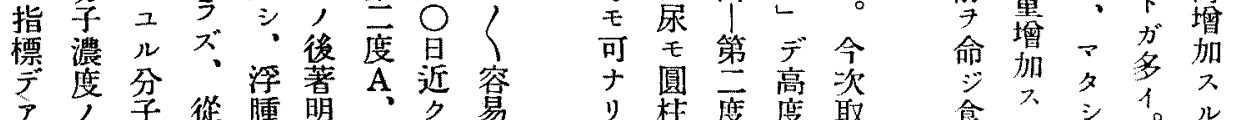

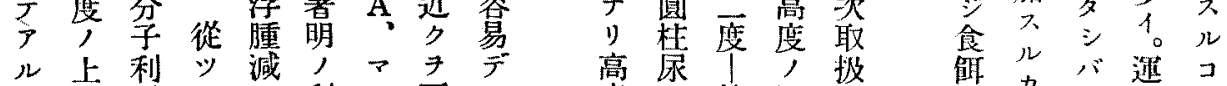

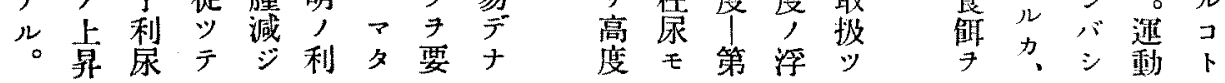

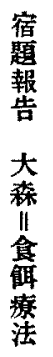

$$
\begin{aligned}
& \text { 大 } \\
& \text { 森 } \\
& \text { 食 } \\
& \text { 䕩 } \\
& \text { 法 }
\end{aligned}
$$




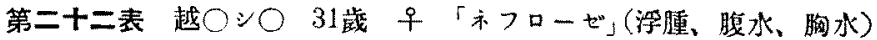

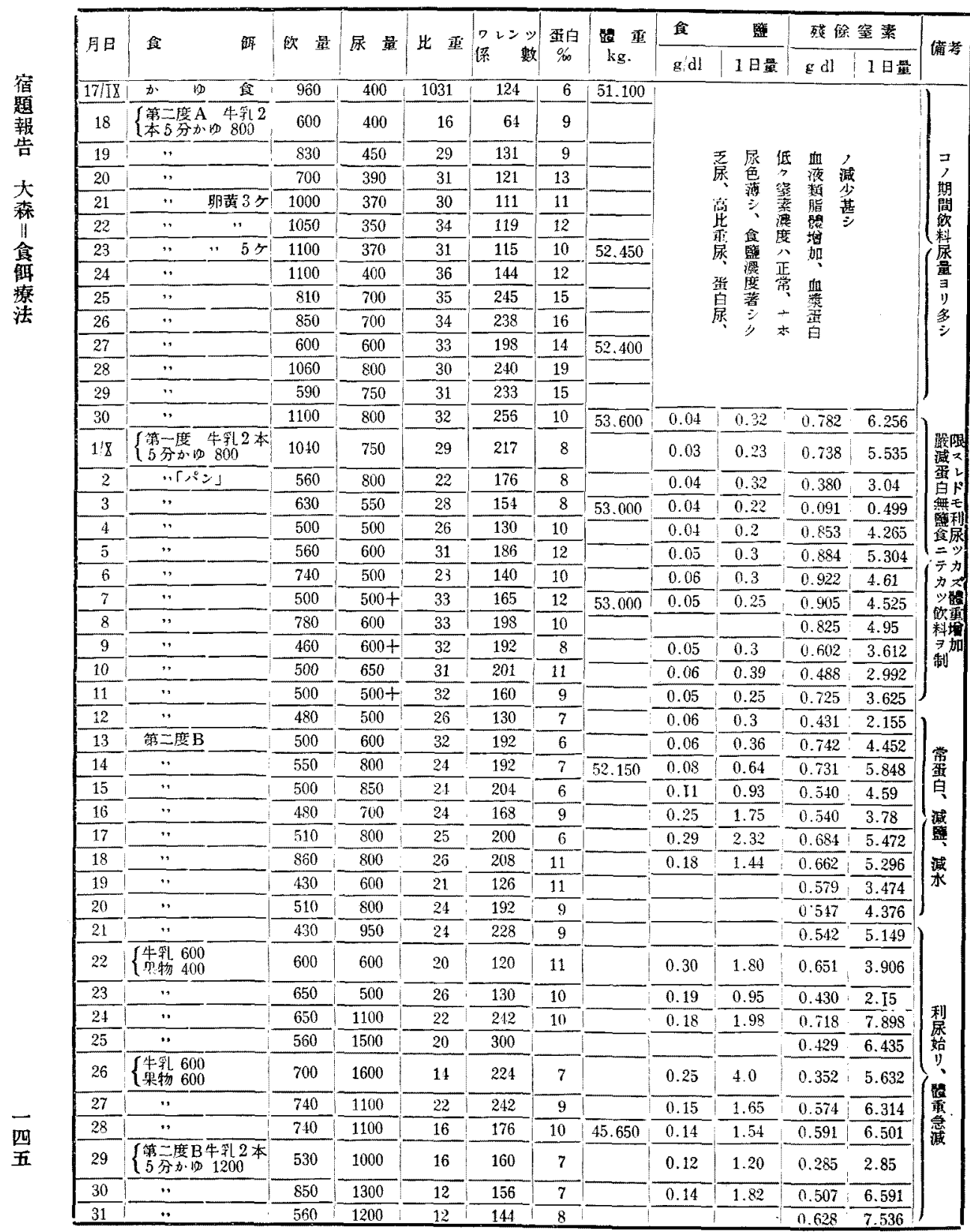




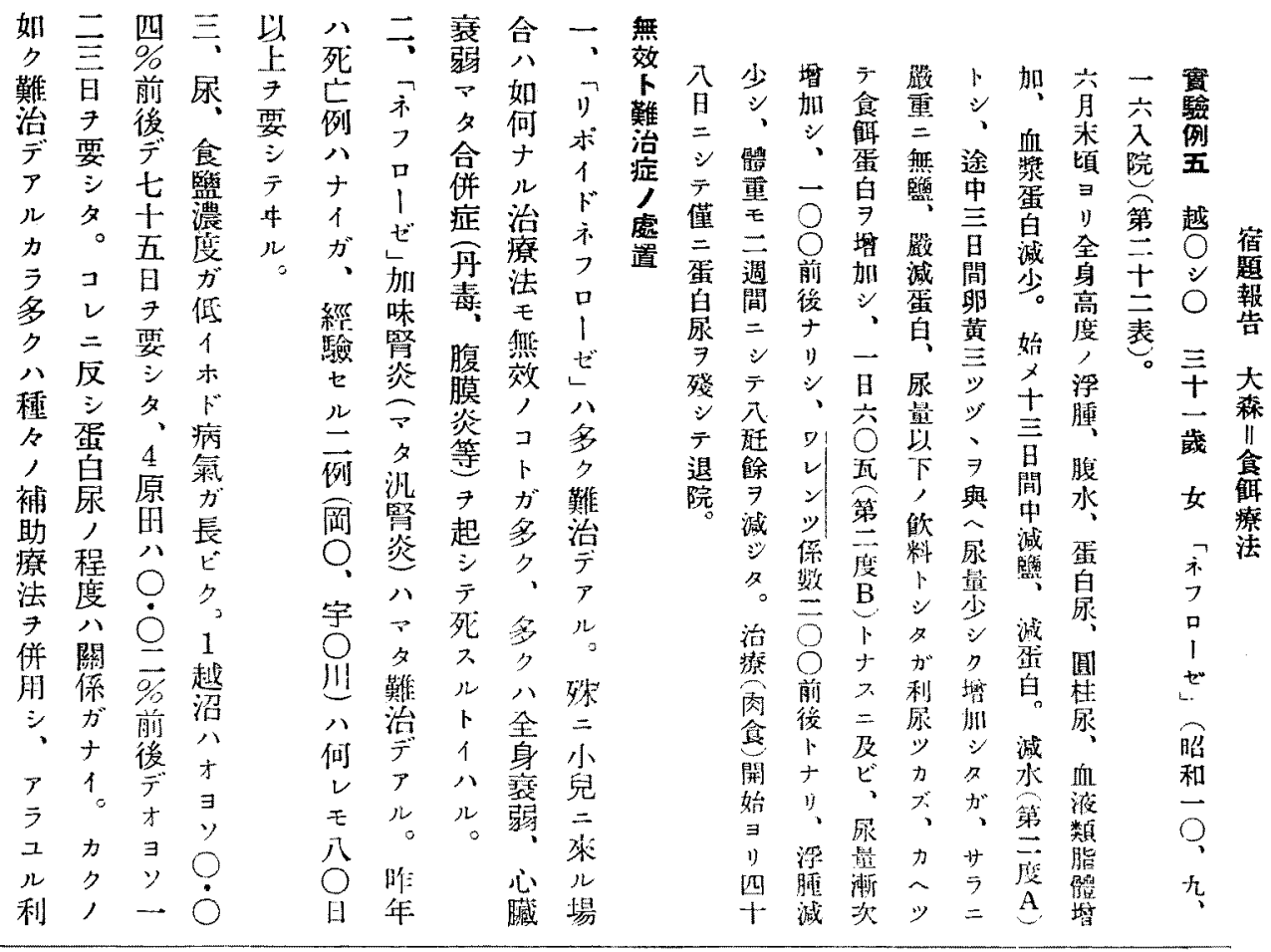

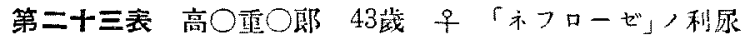

原

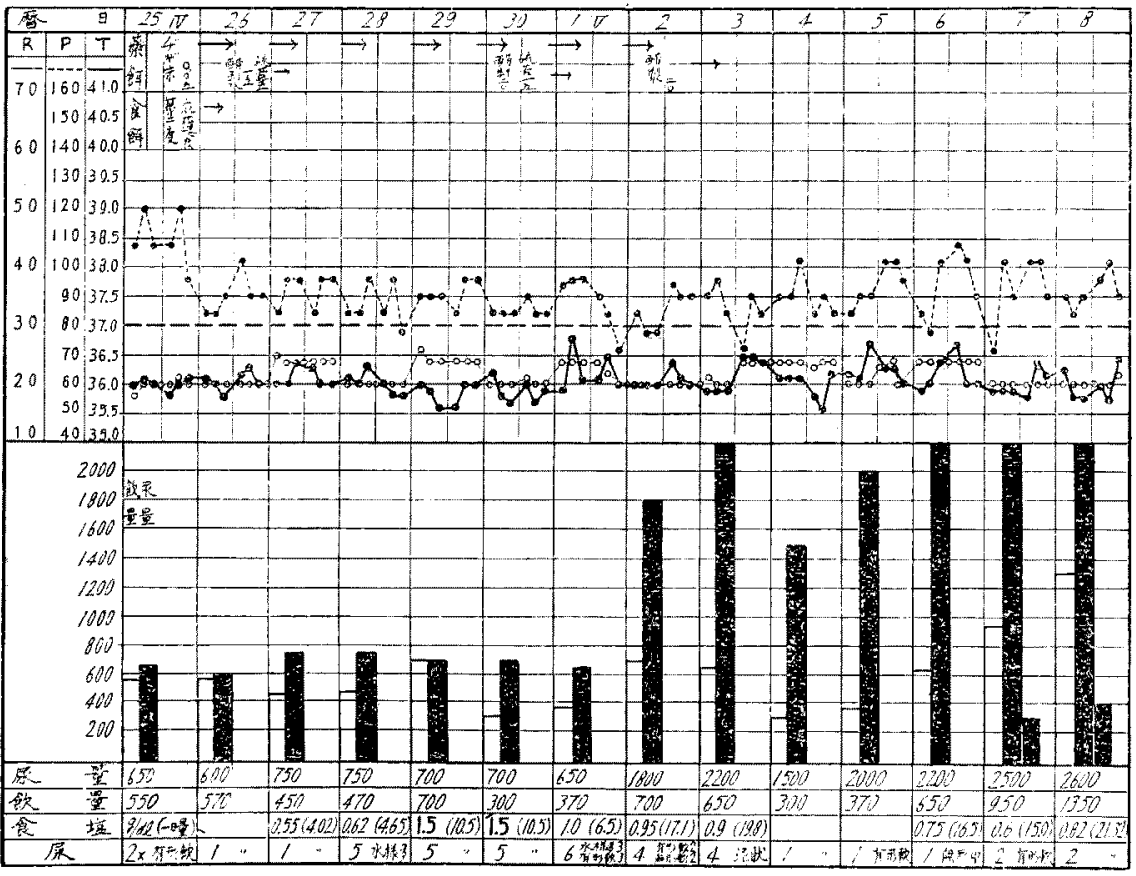

强

剠

夕

八

铻

的

排

等

手

$f x$

紫

†゙ 四

儿公

ス

ベ

テ 


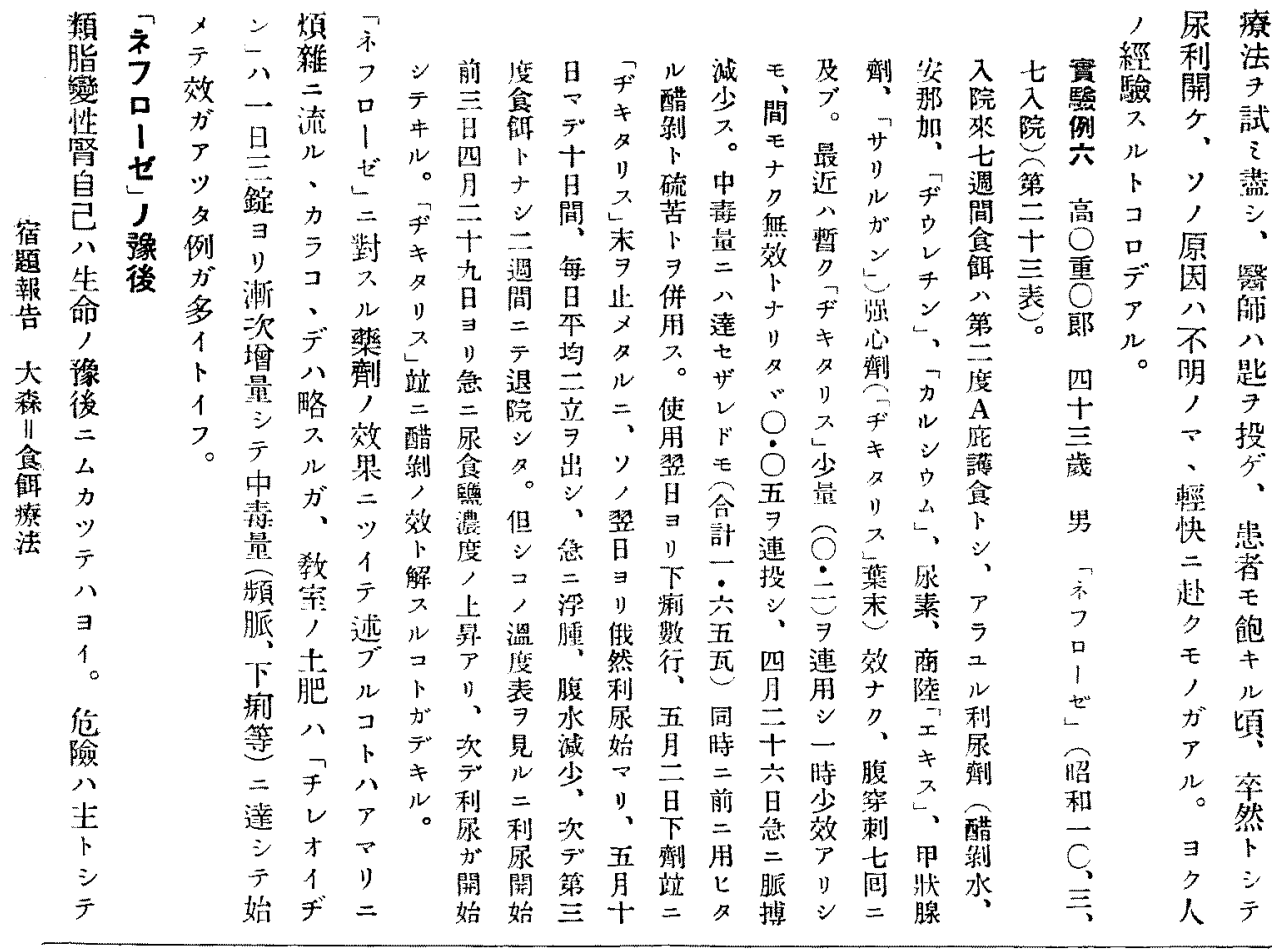

監療心二炎例輕 粵二日八思 $、$ 樣上

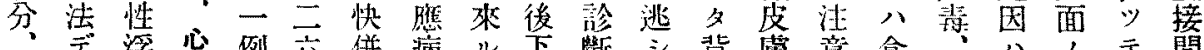

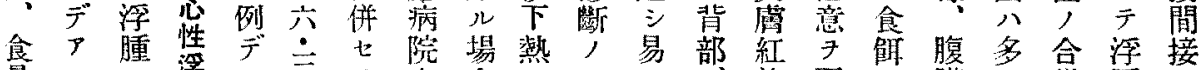
量

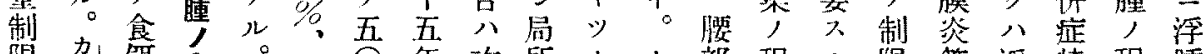
限办菆食。死 $\bigcirc$ 年次所力及部程 $⿻$ 限等浮特程腫 法 2 療鲉死例閒二症兵“度。餘, 腫二度二

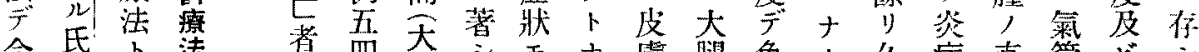

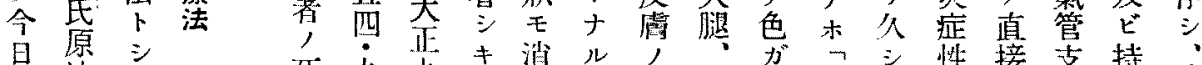

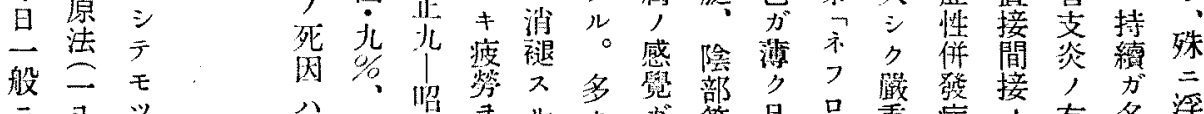

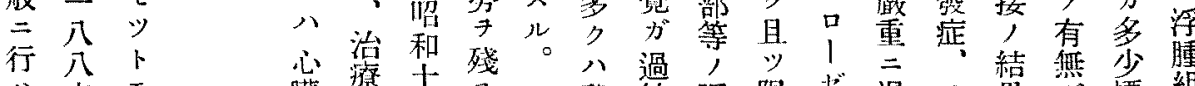

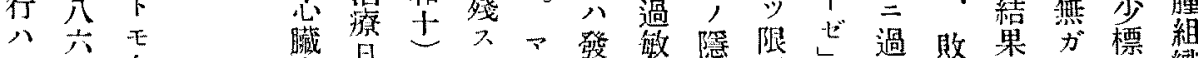

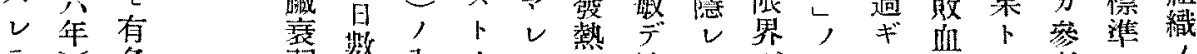

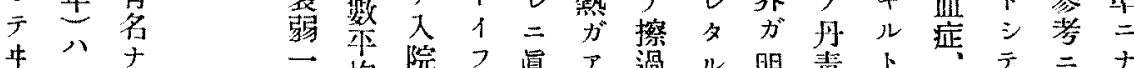

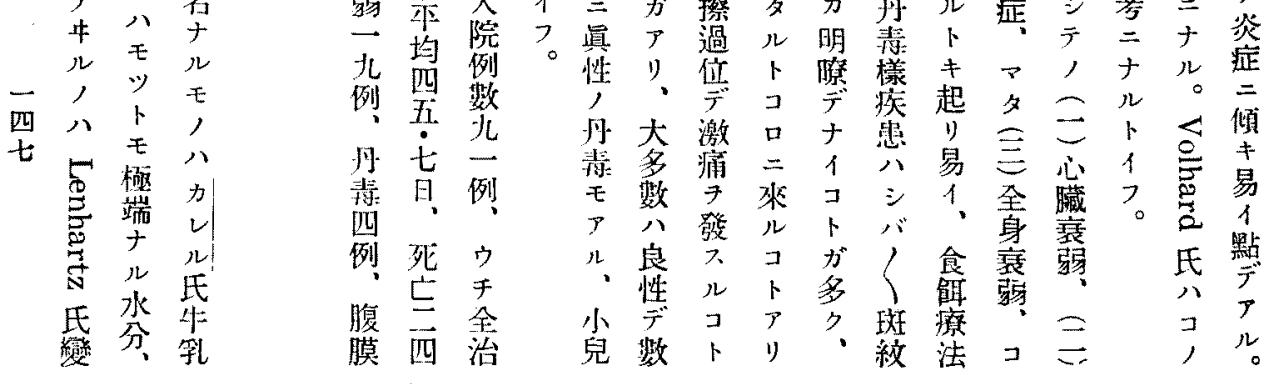




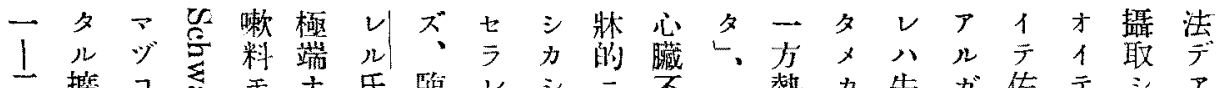

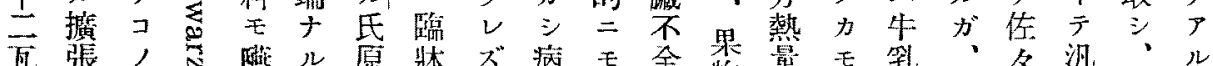

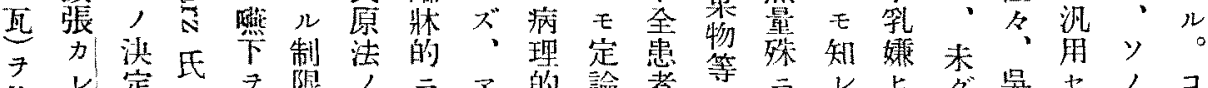
作 $儿$ 定

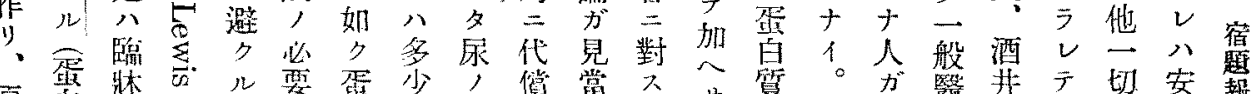

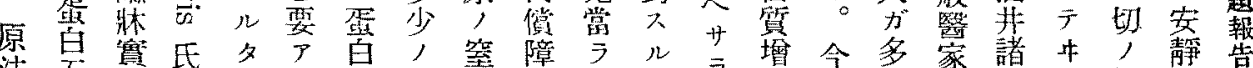

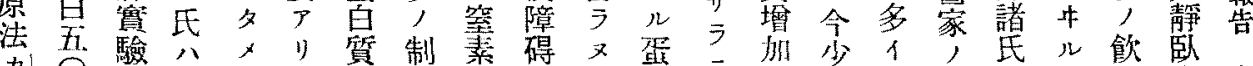

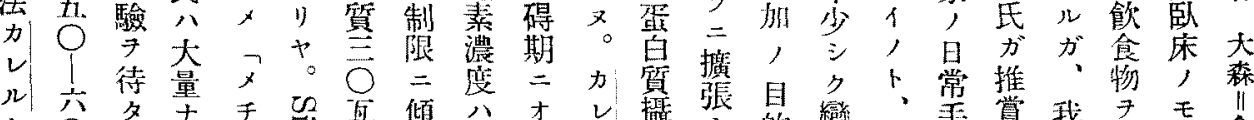
卜 比、㙑 試量力限毒氏五上三八療梨臂 驗二ラ、限青氏

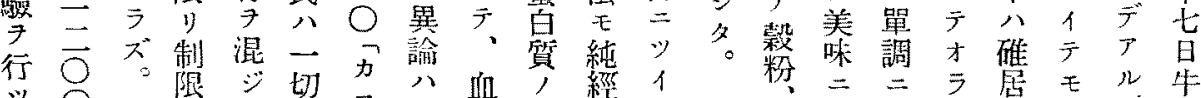

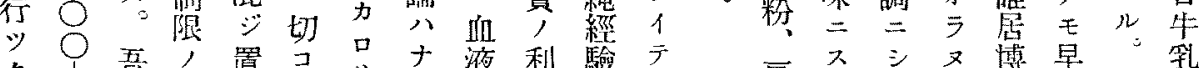

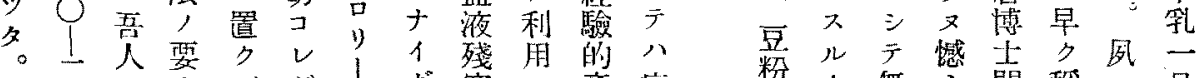

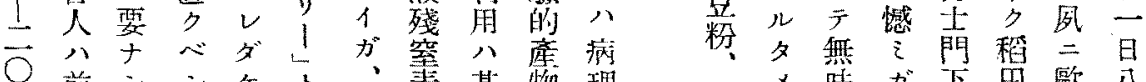

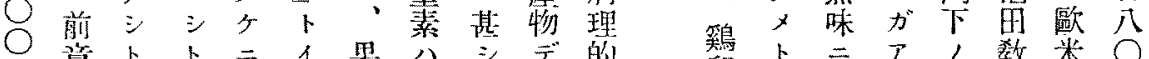

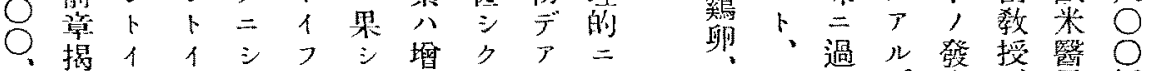

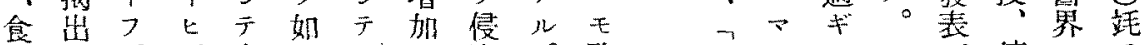

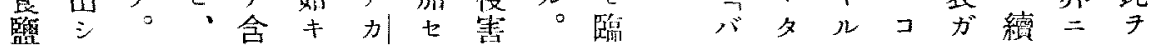

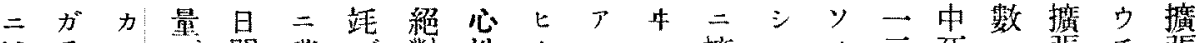

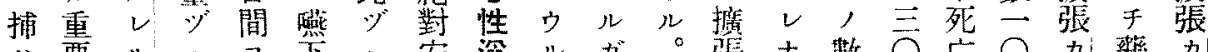

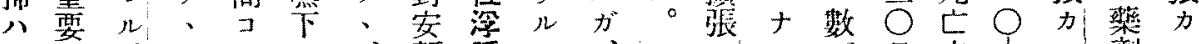

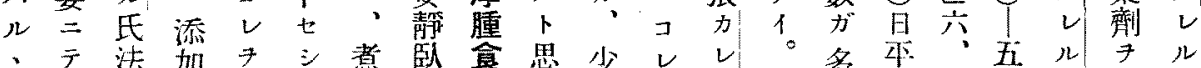

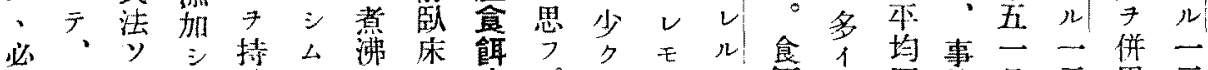

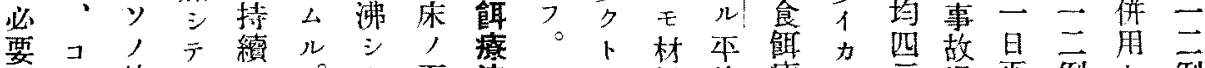

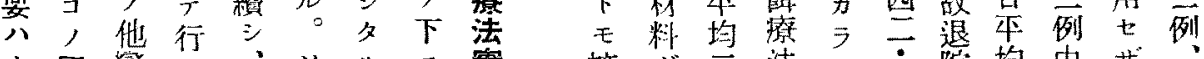

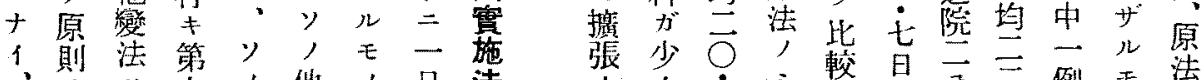
ソ示

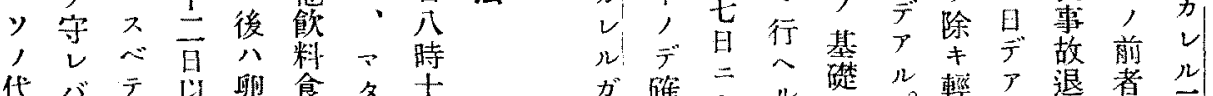

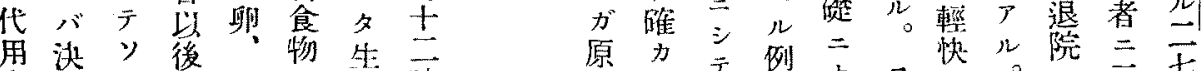

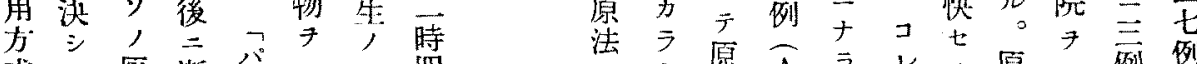
式テ原濑

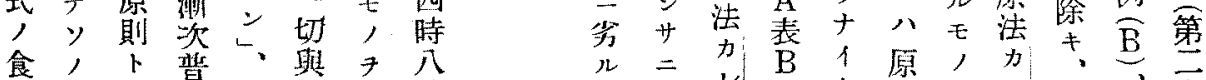

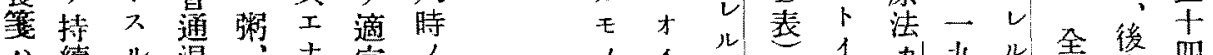
八續儿混守宜,

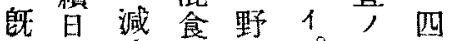
二數水三㭉。溫司 述壬、移原度二 心食娍摡法三牛

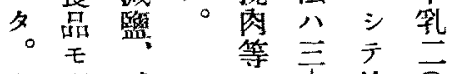
牛形诚觉向徐 筑式食少七务

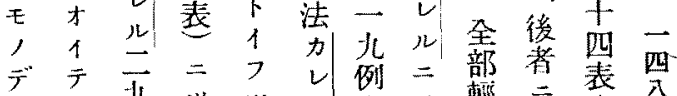

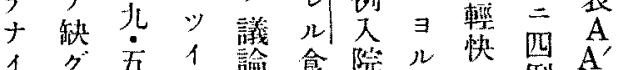

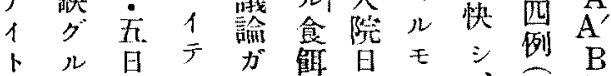
名 $r$ 比 $r=$ 數, $\overparen{A} B^{\prime}$

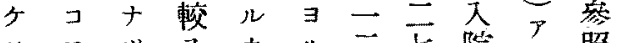

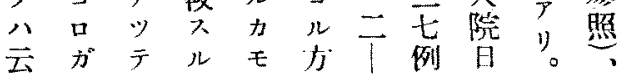


第二十四表 心淢不全二於ヶルカレル氏潦法，效粭

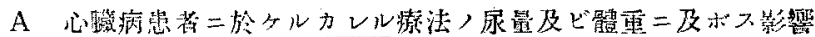

(筴法施行>際强心劑及

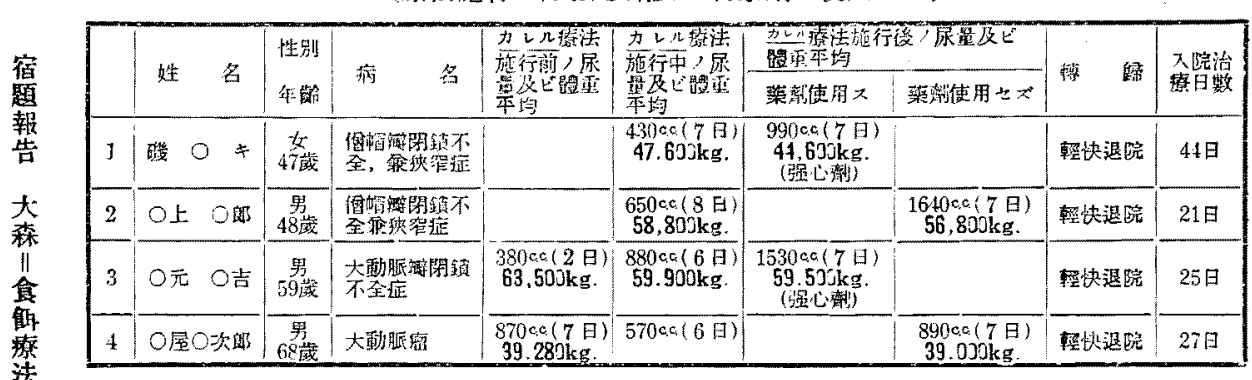

第二十四表 $\mathrm{A}$ 附 楒

\begin{tabular}{|c|c|c|c|c|}
\hline 林重 & 豕星 & 施行前 & 施行中 & 施行症 \\
\hline 55 & 1,0 & & & \\
\hline 50 & 1200 & & & \\
\hline 45 & 1000 & & & \\
\hline 40 & 800 & & & \\
\hline 35 & 600 & & & \\
\hline 30 & 400 & & & \\
\hline 25 & 200 & & & 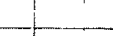 \\
\hline$-\sqrt{3 y}$ & $C \mathrm{C}$ & & & 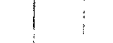 \\
\hline
\end{tabular}

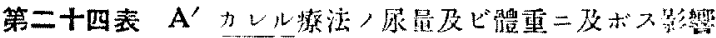

(㙩法施行二際甧二强心刺及

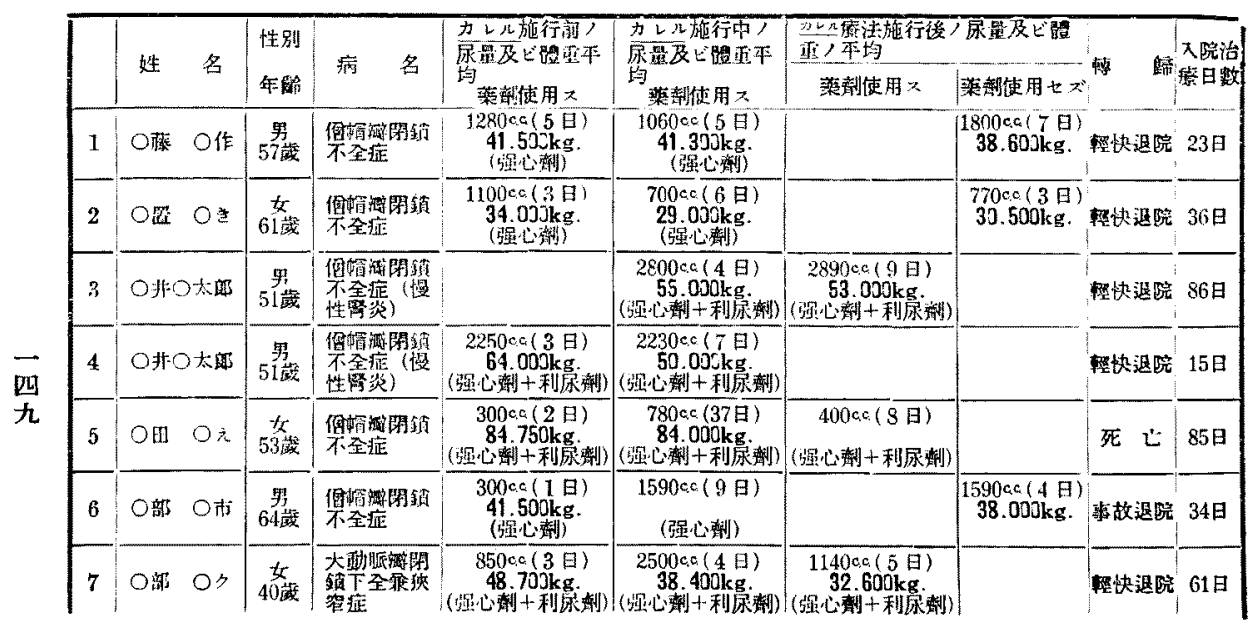




\begin{tabular}{|c|c|c|c|c|c|c|c|c|c|}
\hline$s$ & Oll $O=$ & 㚣 & 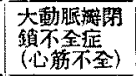 & 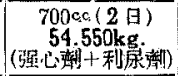 & 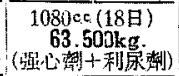 & & & 死亡 & $26 日$ \\
\hline 9 & O撟 $O x$ & 女0歲 & 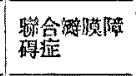 & & $\begin{array}{c}1430 \mathrm{cc}(3 \text { 日) } \\
65.00 \mathrm{~kg} . \\
(\text { 强心缡+利就) }\end{array}$ & 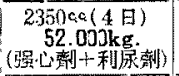 & & 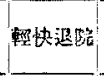 & 199 \\
\hline 10 & ○綗○五郎 & $\begin{array}{l}\text { 男 } \\
40 \% \text {. }\end{array}$ & 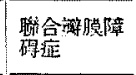 & $\begin{array}{c}200 \mathrm{cc}(2 \mathrm{~g}) \\
53,72 \mathrm{~kg} . \\
\text { (5强心姆) }\end{array}$ & 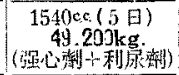 & 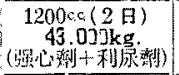 & & 瑟沚退卧 & 12 口 \\
\hline 11 & O解O次部 & $\begin{array}{l}\text { 男 } \\
50 \text { 歲 }\end{array}$ & 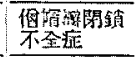 & 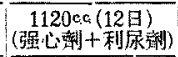 & 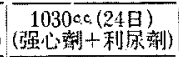 & & & 死亡 & 40 日 \\
\hline 12 & O元 O吉 & 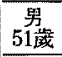 & 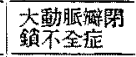 & 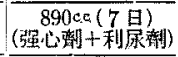 & $\begin{array}{c}1150 \mathrm{ccc}(11 \text { 日) } \\
(\text { 强心刘+ 利展剖) }\end{array}$ & 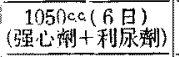 & & 事数退棕 & 64 日 \\
\hline 13 & ○田 ○造 & 50 思 & 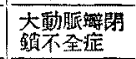 & 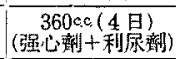 & 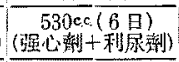 & & & 死 し & 16 日 \\
\hline 14 & O本O次的 & 畕 & 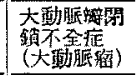 & 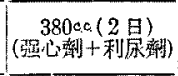 & 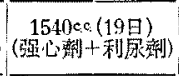 & 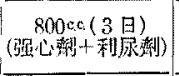 & & 軖玞退聐 & $57 \mathrm{~B}$ \\
\hline 15 & O口 OL & 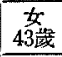 & 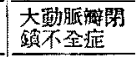 & 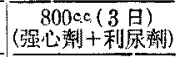 & $\begin{array}{c}550 \mathrm{ec}(10 \text { 日) } \\
\text { (利泳㓡) }\end{array}$ & & $450 \mathrm{ccc}$ (4日) & 整快望院 & 1309 \\
\hline 16 & OH & $\begin{array}{l}\text { 穷 } \\
45 \text { 蛓 }\end{array}$ & 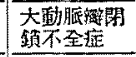 & 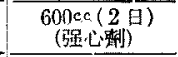 & 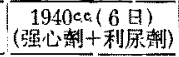 & 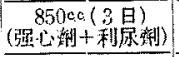 & & 颙快退院 & $28 日$ \\
\hline 17 & O臊 & 32 & 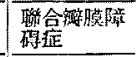 & $\begin{array}{c}600 \mathrm{ec}(2 \text { 日) } \\
\text { (强心䘞) }\end{array}$ & $\begin{array}{c}150000 \text { (7日) } \\
\text { (强心剂) }\end{array}$ & $\begin{array}{c}1220 \mathrm{cc} \text { (5日) } \\
\text { (强心則) }\end{array}$ & & 慗块退陆 & $30 \theta$ \\
\hline 18 & ○々木○太脕 & 男 & 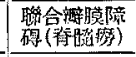 & 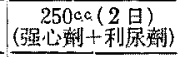 & 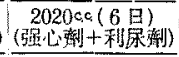 & 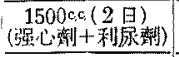 & & 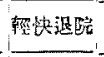 & $29 \mathrm{~B}$ \\
\hline 19 & ○村 0 三暗 & $\begin{array}{l}\text { 男 } \\
36 \text { 或 }\end{array}$ & 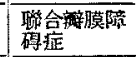 & 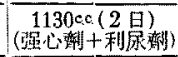 & 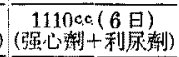 & & & 死亡 & 49 \\
\hline 20 & O期O五郎 & $\begin{array}{l}\text { 男 } \\
399 \text { 歲 }\end{array}$ & 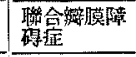 & $\begin{array}{c}1100 \mathrm{ca}(2 \boxminus) \\
\text { (强心鞦) }\end{array}$ & $\begin{array}{c}1590 \mathrm{cc} \text { (7是) } \\
\text { (强心赥+利) }\end{array}$ & 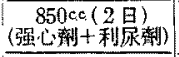 & & 軖错退院 & 12 日 \\
\hline 21 & O\&木O太師 & $\begin{array}{r}\text { 男 } \\
61 \text { 蔵 }\end{array}$ & 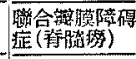 & 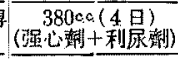 & 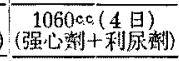 & $\begin{array}{c}800 \mathrm{cc} \text { (4)最) } \\
(\text { 强心制十利) }\end{array}$ & & 慗佉退院 & 498 \\
\hline 22 & ○井 ○っ & $\begin{array}{c}\text { 女 } \\
48 \text { 藏 }\end{array}$ & 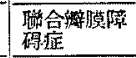 & 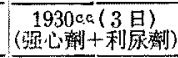 & 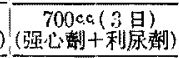 & 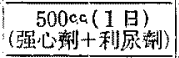 & & 死 已 & 29 日 \\
\hline 23 & $0 \mu$ & 男荿 & 心解端性 & 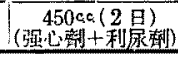 & 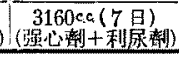 & & & 整执没院 & $14 \mathrm{~B}$ \\
\hline
\end{tabular}

\section{第二十四表 $\mathrm{A}^{\prime}$ 附 圆}

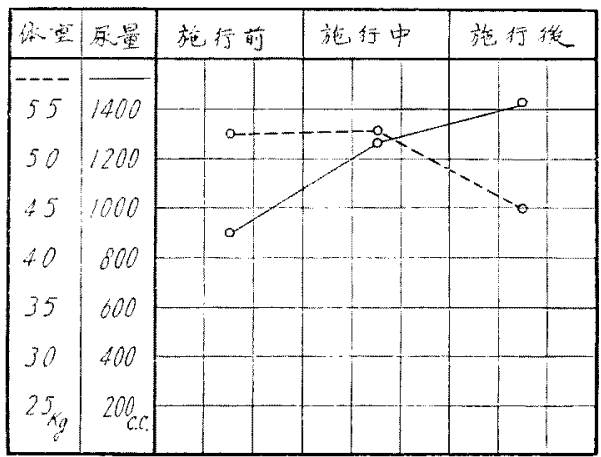


第二十四表 $\mathrm{B}$ 攄張カレル療法，尿量及ビ體重二及ボス影響

（㙩法施行前八强心劑及ビ利尿劑》使用七ズ）

\begin{tabular}{|c|c|c|c|c|c|c|c|c|c|c|}
\hline & 姓 & \multirow{2}{*}{$\begin{array}{l}\text { 性别 } \\
\text { 年囉 }\end{array}$} & \multirow{2}{*}{ 病 } & \multicolumn{5}{|c|}{ 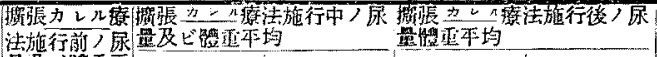 } & \multirow{2}{*}{ 称 } & \multirow{2}{*}{ 入辟治 } \\
\hline & $x$ & & & 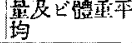 & 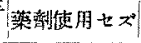 & 莱就使用 & 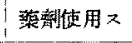 & 菜端伎用七ズ & & \\
\hline 1 & 大O 串O & $\begin{array}{l}\text { 翼 } \\
\text { 51载 }\end{array}$ & 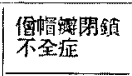 & $750 \mathrm{cc}(4$ 日) & & $\begin{array}{c}1240 \mathrm{cc}(9 \text { 日) } \\
49.039 \mathrm{~kg} . \\
\text { (强心別) }\end{array}$ & $\begin{array}{c}1320 \mathrm{cc}(6 \mathrm{~B}) \\
46.52 \mathrm{~kg} . \\
\text { (强心利) }\end{array}$ & & 辛故退院 & $20 日$ \\
\hline 2 & 太○ 完O & 男荿 & 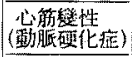 & $\begin{array}{l}2490 \mathrm{cec}(7 \mathrm{G}) \\
60.900 \mathrm{~kg} . \\
\end{array}$ & $\begin{array}{c}2410 \mathrm{ec}(11 \text { 日) } \\
58.00 \mathrm{~kg}\end{array}$ & & & & 琶快退院 & 22 日 \\
\hline 3 & 石O仡口畹 & 57思 & 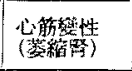 & $\begin{array}{l}1750 \mathrm{cc}(2 \mathrm{~g}) \\
61.900 \mathrm{~kg}\end{array}$ & $\begin{array}{l}2260 \mathrm{cc}(6 \text { 日) } \\
58.400 \mathrm{~kg}\end{array}$ & 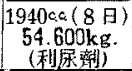 & & $\mid \begin{array}{c}2850 \mathrm{co}(4 \mathrm{a}) \\
5 \mathrm{f} .550 \mathrm{~kg} .\end{array}$ & 型快泿 & 20 日 \\
\hline
\end{tabular}

第二十四表 B 附 阔

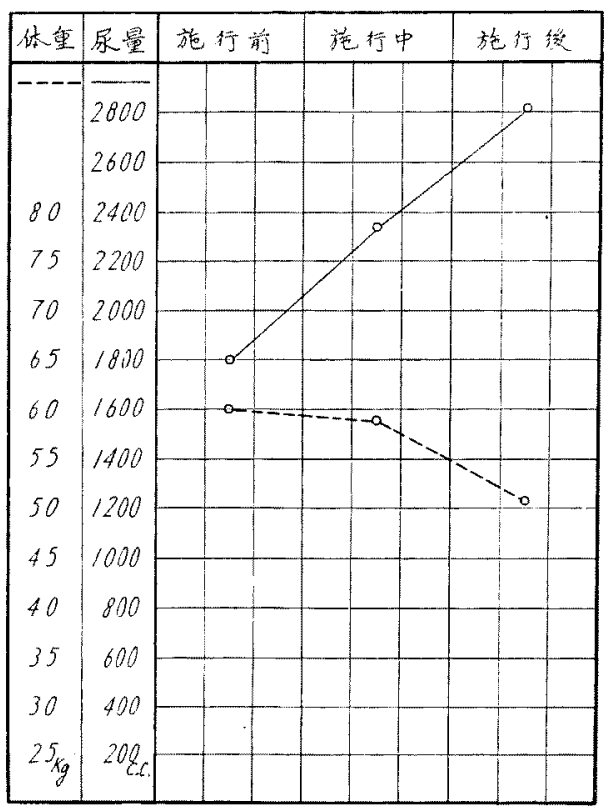

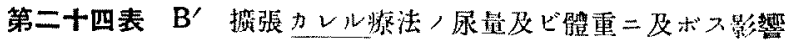

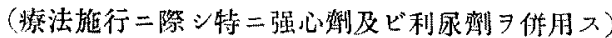

\begin{tabular}{|c|c|c|c|c|c|c|c|c|c|}
\hline & \multirow{2}{*}{ 姓 } & \multirow{2}{*}{$\begin{array}{l}\text { 性别 } \\
\text { 年路 }\end{array}$} & \multirow{2}{*}{ 病 } & \multirow{2}{*}{ 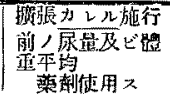 } & \multirow{2}{*}{ 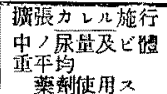 } & \multicolumn{2}{|c|}{ 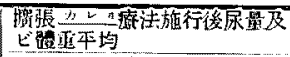 } & \multirow{2}{*}{ 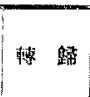 } & \multirow{2}{*}{ 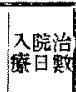 } \\
\hline & & & & & & 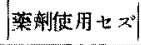 & 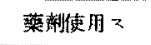 & & \\
\hline 1 & 㸉 $\mathrm{O}$ ソ & 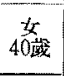 & 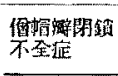 & $\begin{array}{c}620 \mathrm{cc}(3 \mathrm{G}) \\
51.650 \mathrm{~kg} . \\
(\text { (张心猜) }\end{array}$ & 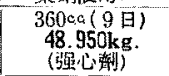 & $\begin{array}{c}1300 \mathrm{ccc}(2 \mathrm{~g}) \\
49.600 \mathrm{~kg} .\end{array}$ & & 故块退睆 & 16 日 \\
\hline 2 & 紐O 10 & 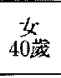 & 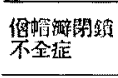 & 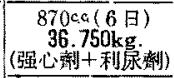 & $\begin{array}{c}770 \mathrm{ca}(15 \mathrm{~B}) \\
34.500 \mathrm{~kg} . \\
\text { (强心剂) }\end{array}$ & & $\begin{array}{c}1360 \mathrm{cc}(5 \mathrm{~B}) \\
35.20 \mathrm{~kg} . \\
\text { (强心赫) }\end{array}$ & 理抰退院 & 348 \\
\hline 3 & 加O部O助 & 䔬蔵 & 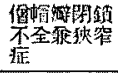 & & $\begin{array}{c}1210 \mathrm{cc} \text { (8日) } \\
47.900 \mathrm{~kg} . \\
\text { (㴽心 }\end{array}$ & $\begin{array}{l}1690 \mathrm{ccc}(7 \mathrm{~g}) \\
48.520 \mathrm{~kg} .\end{array}$ & $\begin{array}{c}1970 \mathrm{ac}(8 \mathrm{\theta}) \\
\text { 43.230kg. } \\
\text { (强心擞) }\end{array}$ & 㥅执退院 & 24 日 \\
\hline 4 & 大O 发O & $\begin{array}{l}\text { 㽞 } \\
49 \text { 藏 }\end{array}$ & 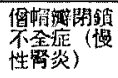 & 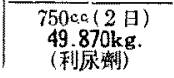 & 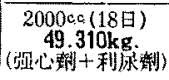 & & & 唔快泿院 & $24 \mathrm{\theta}$ \\
\hline
\end{tabular}




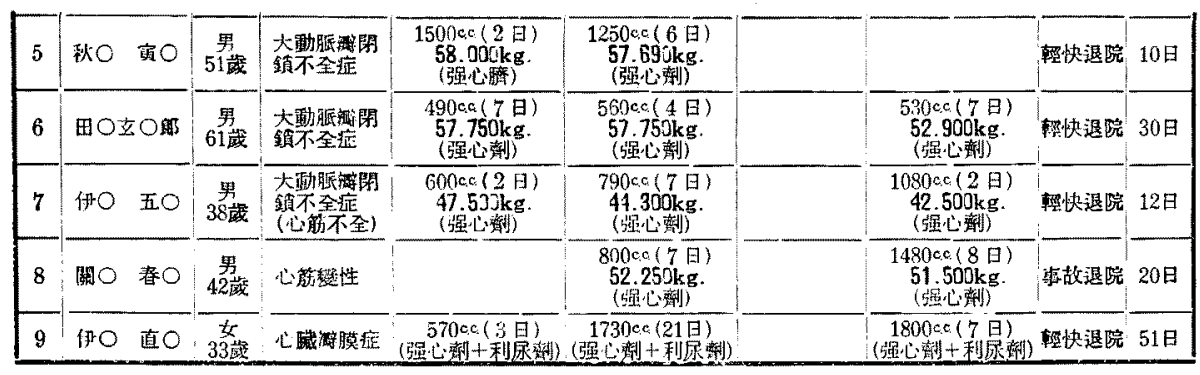

第二十四表 $\mathrm{B}^{\prime}$ 附 圆

\begin{tabular}{|c|c|c|c|c|}
\hline 体重 & 尾量 & 施打前 & 施行中 & 施行後 \\
\hline$-\infty$ & 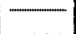 & & & \\
\hline & & & & \\
\hline 50 & 1200 & & & \\
\hline 45 & 1000 & & 8 & \\
\hline 40 & 800 & & & \\
\hline & & or & & \\
\hline 33 & 600 & & & \\
\hline 30 & 400 & & & \\
\hline 25 & 2000 & & & \\
\hline & 2006 & & & \\
\hline
\end{tabular}

宿
題
報
告
大

森
॥
蔇
燎
法

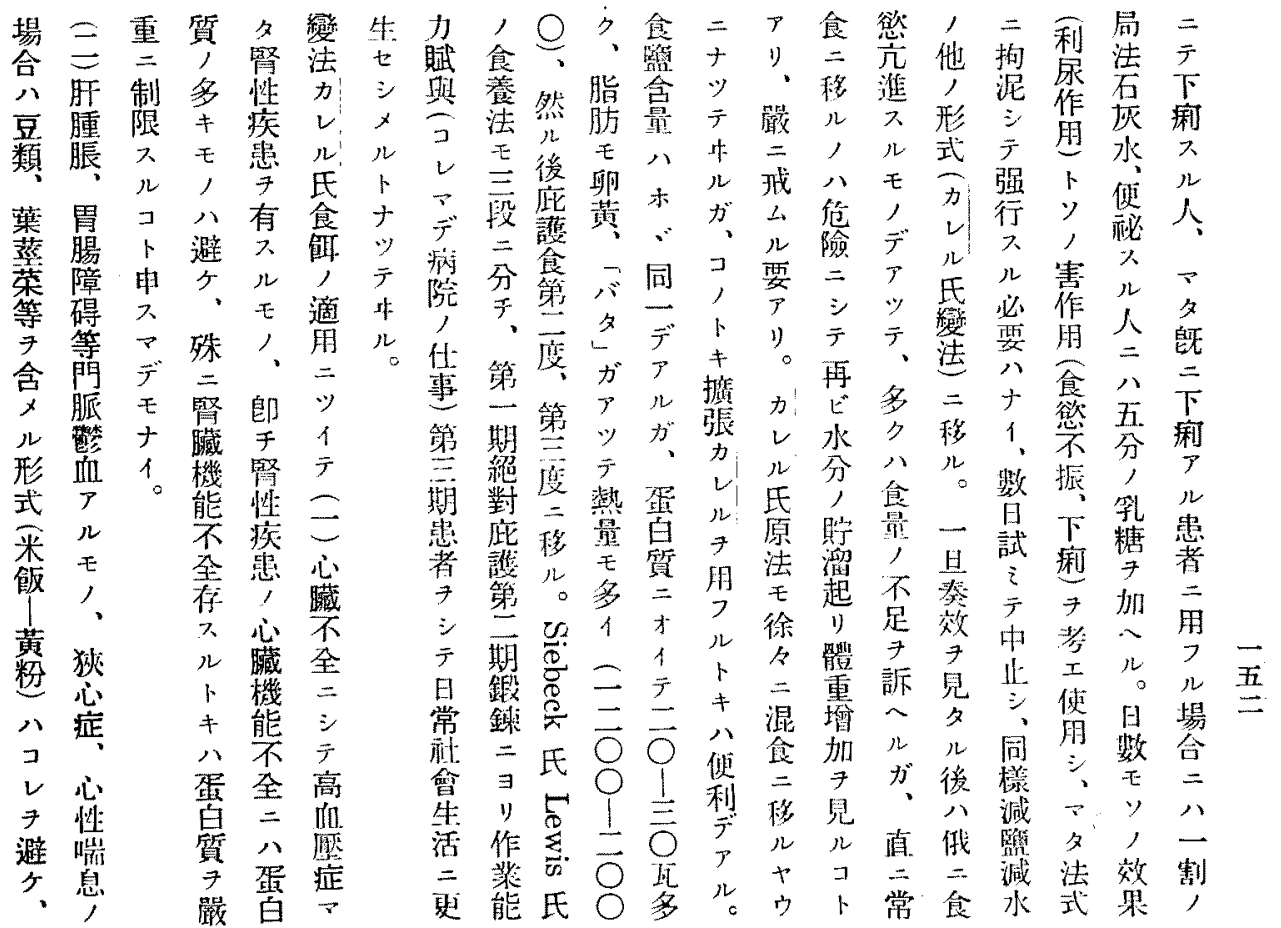




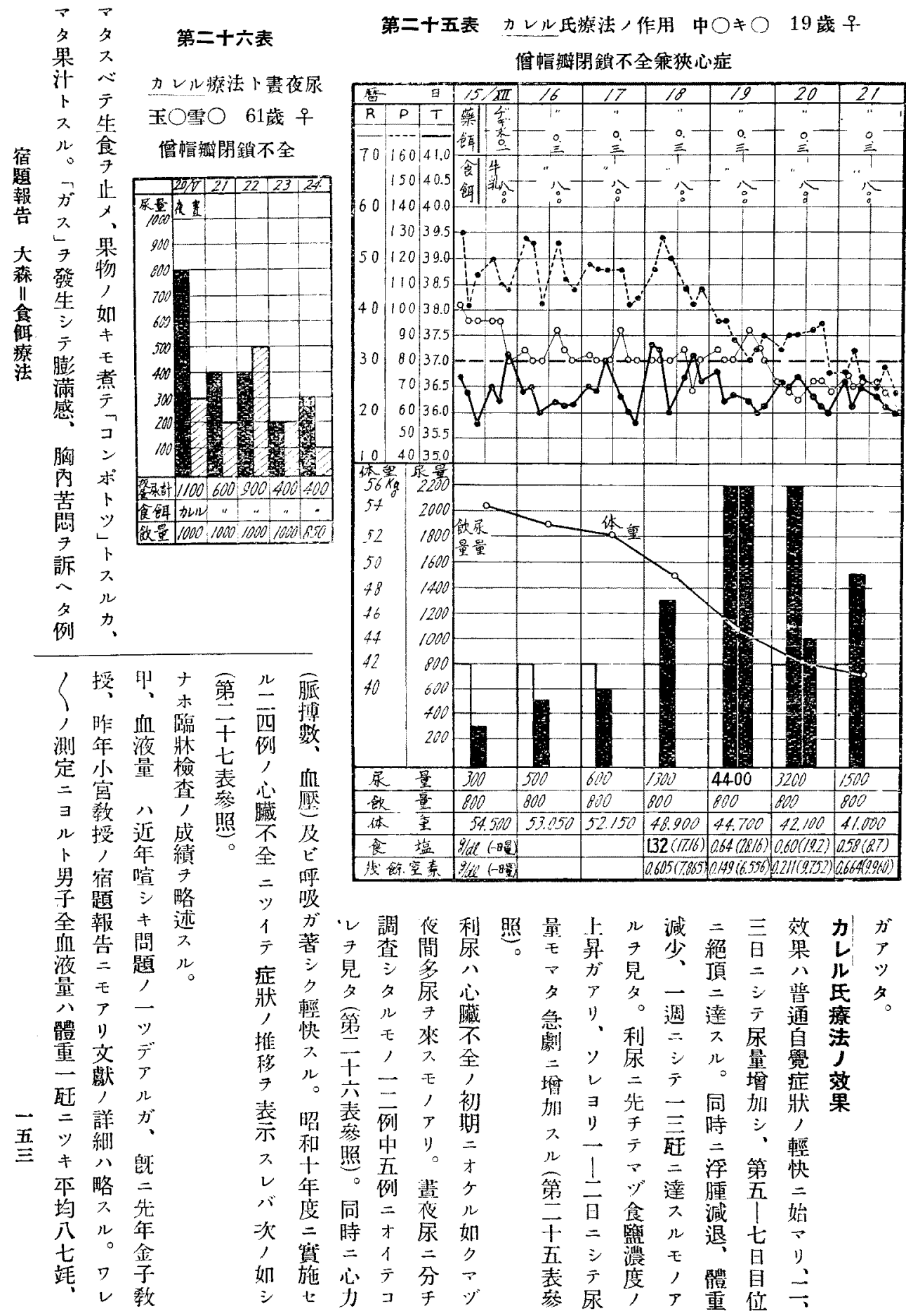




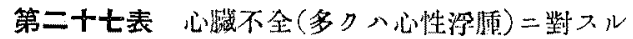

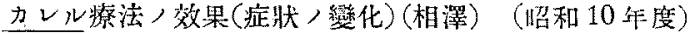

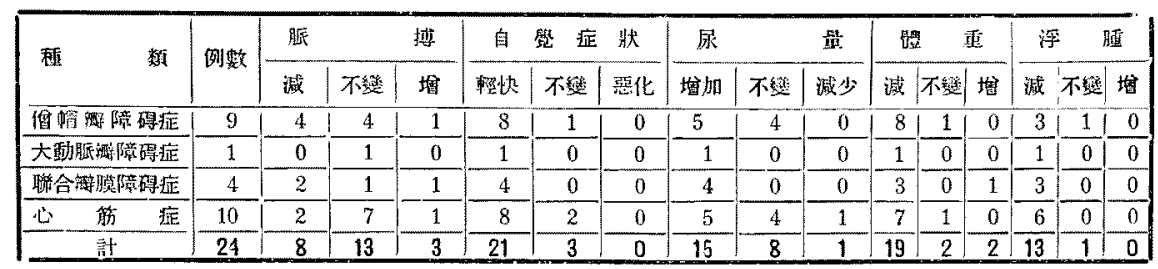

宿
報
告

亡液, 浮 $€$ 少廿少

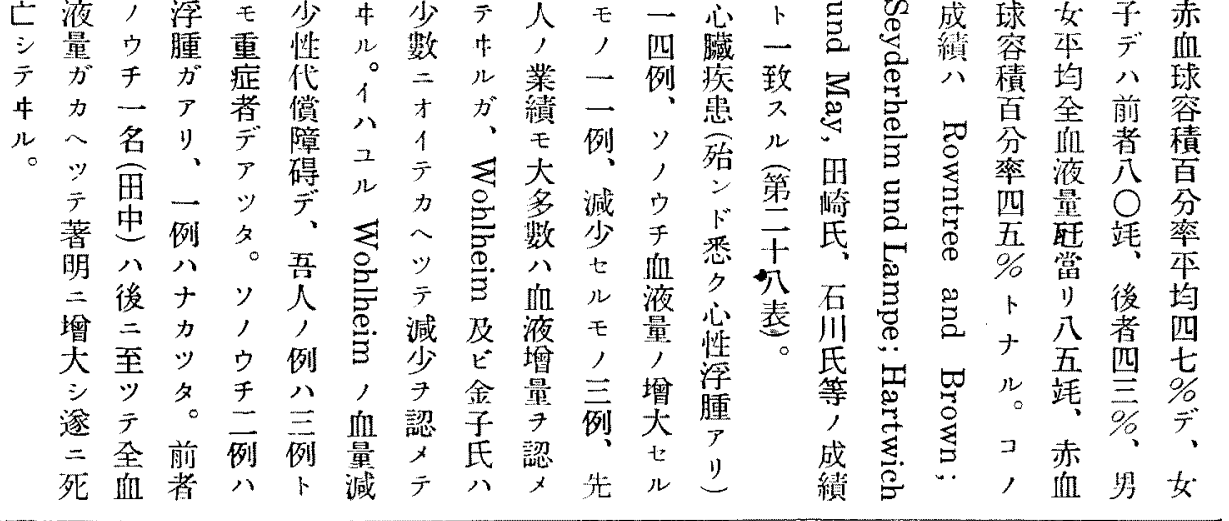

第二十八表 健康者全血液量(大谷周)

\begin{tabular}{|c|c|c|c|c|c|c|c|c|c|c|}
\hline 子 & 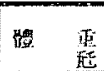 & 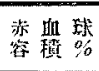 & 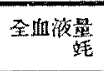 & 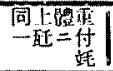 & 于 & 蹱 & 跸 & 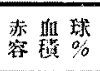 & 爻血旅量 & 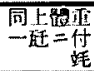 \\
\hline No. & 51 & 45 & 4250 & 83 & No. 19 & 46 & & 50 & 3940 & 85 \\
\hline No. 2 & 45 & 49 & 4530 & 99 & No. 20 & 59 & & 40 & 4650 & 78 \\
\hline No. & 47 & 45 & 4250 & 90 & No. 21 & 46 & & 43 & 3530 & 77 \\
\hline No. 4 & 45 & 44 & 4500 & 100 & No. 22 & 46 & & 44 & 3600 & 77 \\
\hline No. 5 & 51 & 51 & 4030 & 79 & No. 23 & 50 & & 38 & 4100 & 82 \\
\hline No. 6 & 53 & 50 & 3940 & 74 & No. 24 & 52 & & 42 & 4350 & 84 \\
\hline No. 7 & 51 & 45 & 4560 & 89 & No. 25 & 56 & & 45 & 4160 & 74 \\
\hline No. 8 & 53 & 47 & 4400 & 83 & No. 26 & 44 & & 37 & 3270 & 74 \\
\hline No. 9 & 55 & 40 & 4230 & 79 & No. 27 & 56 & & 43 & 4850 & 87 \\
\hline No. 10 & 52 & 43 & 4400 & 85 & No. 28 & 48 & & 46 & 4060 & 84 \\
\hline No. 11 & 53 & 50 & 4580 & 86 & 本 & 均 & & $43 \%$ & & 80 蚝 \\
\hline No. 12 & 45 & 48 & 3800 & 86 & 男 女 & & & $45 \%$ & & 85 竓 \\
\hline No. 13 & 46 & 51 & 4750 & 102 & 男 女 & 皮 & & $40 \%$ & & 85 娌 \\
\hline No. 14 & 50 & 46 & 4160 & 83 & & & & & & \\
\hline No. 15 & 62 & $\cdot 51$ & 5010 & 80 & & & & & & \\
\hline No. 16 & 45 & 45 & 4560 & 100 & & & & & & \\
\hline No. 17 & 48 & 44 & 4950 & 102 & & & & & & \\
\hline No. 18 & 55 & 49 & 4450 & 81 & & & & & & \\
\hline 平 & 均 & $47 \%$ & & 87站 & & & & & & \\
\hline
\end{tabular}




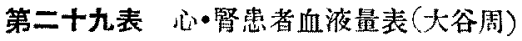

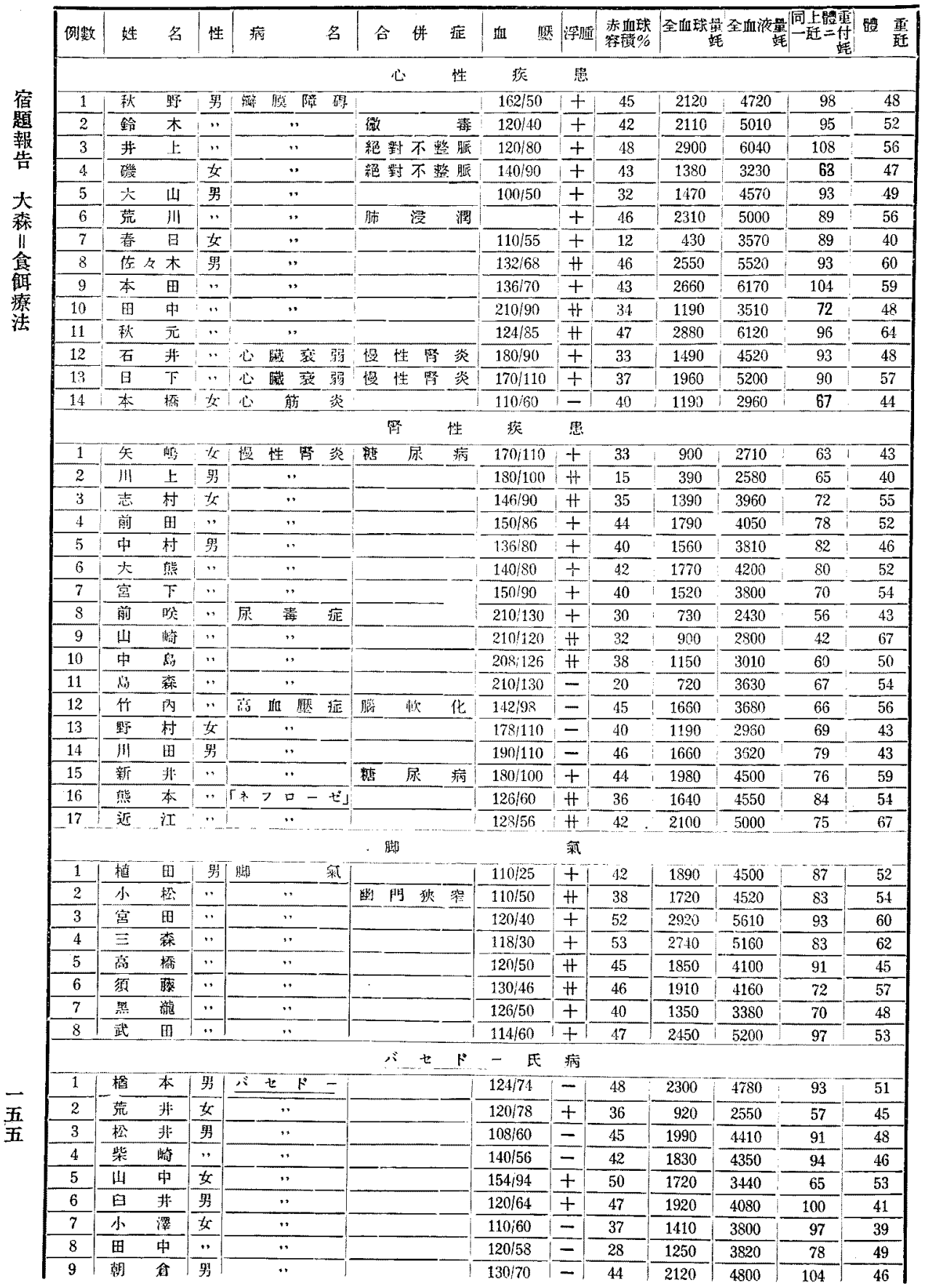




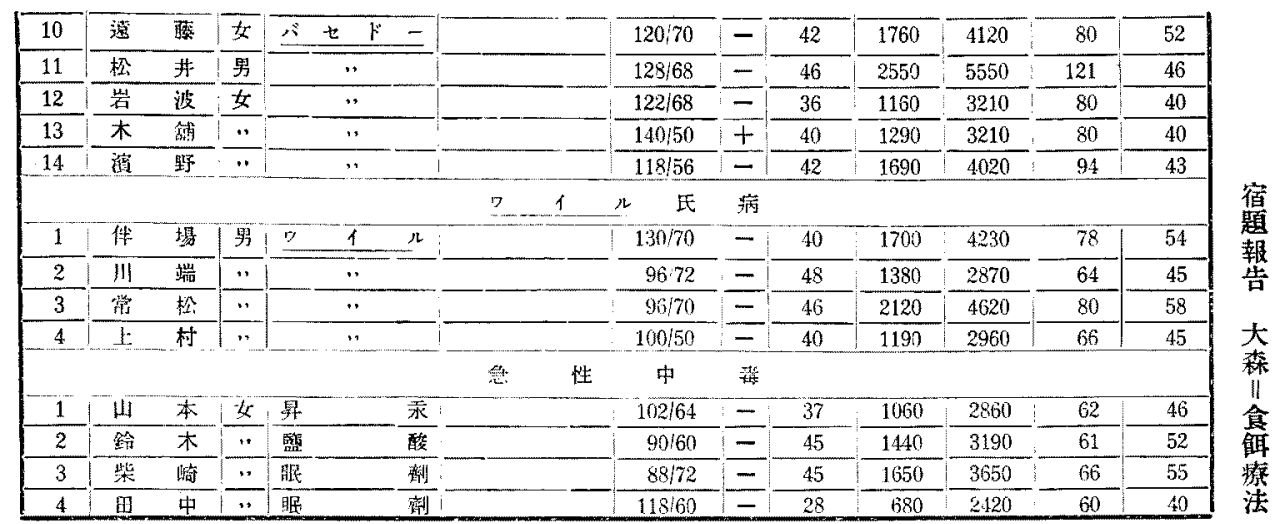

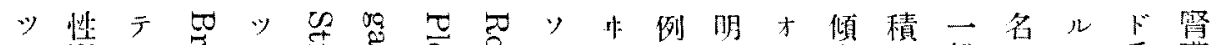

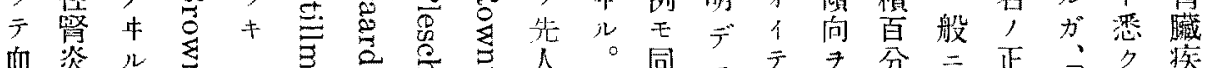

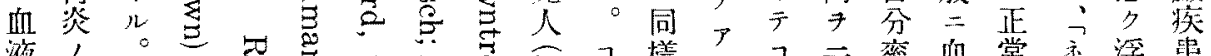

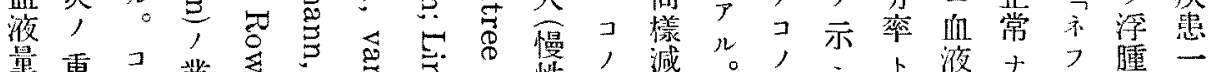

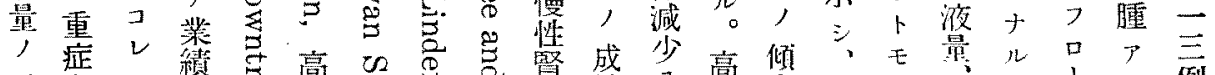

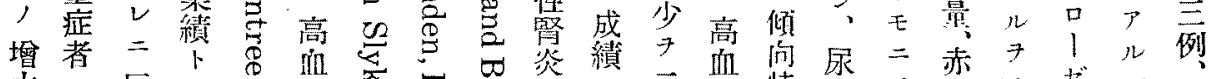

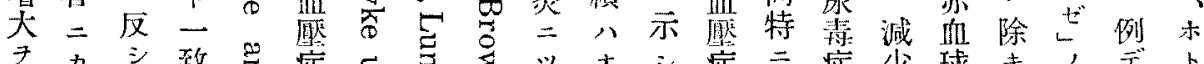

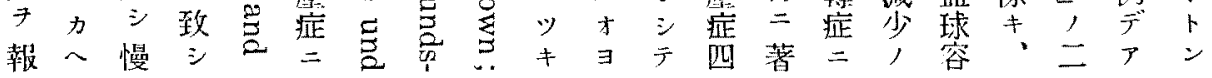

臟枚脚岸四乙表八二例食合下儿上刦卜, 小, ワシ

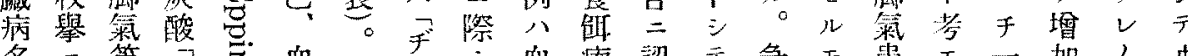
多二等

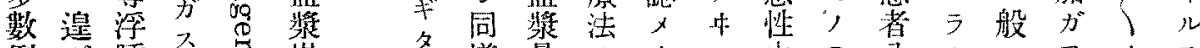

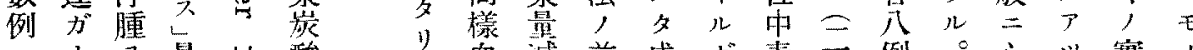

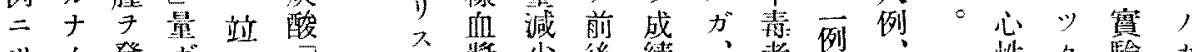

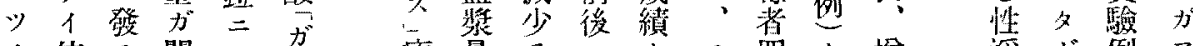

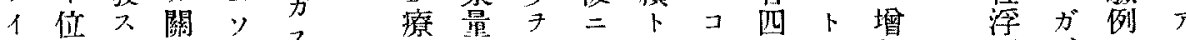

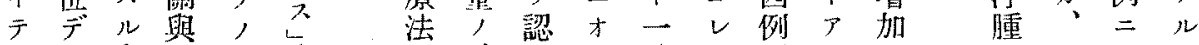

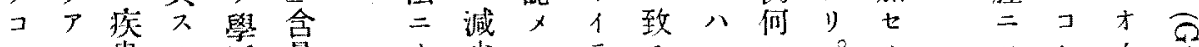

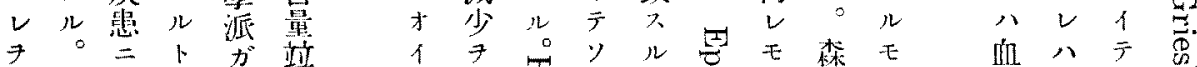

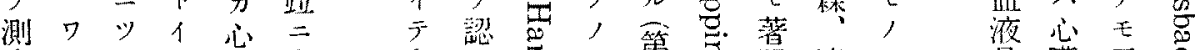

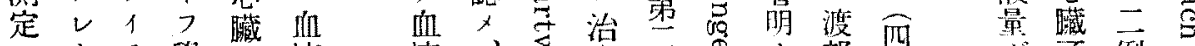

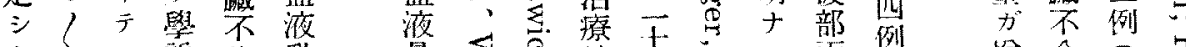

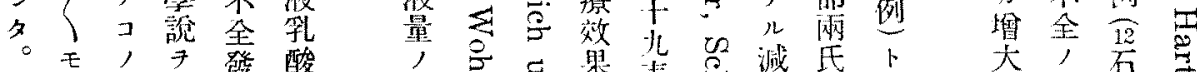

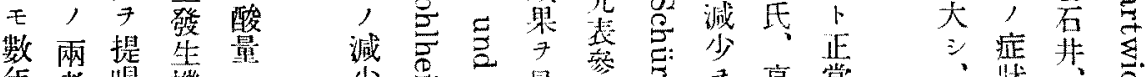
年者唱 機

承, 三序 心测 千 二 藏定以血 病子来液 脚試心酸 氣出心酸 站 $几$ 腎 二 堅

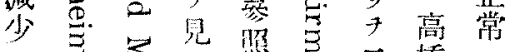

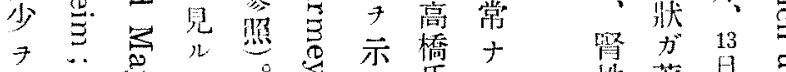

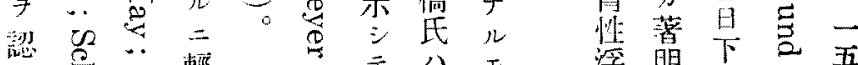

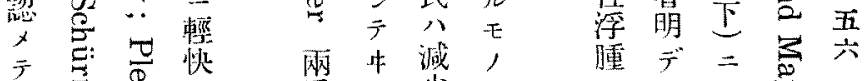

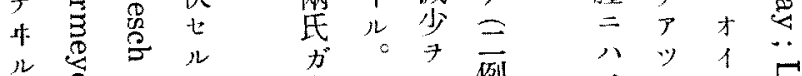

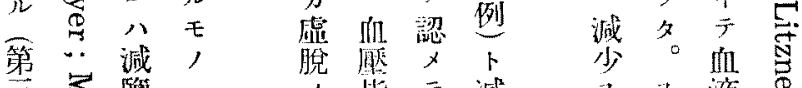

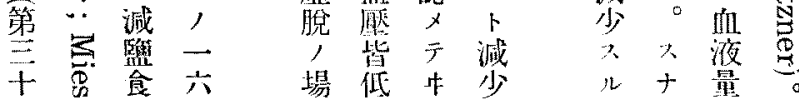




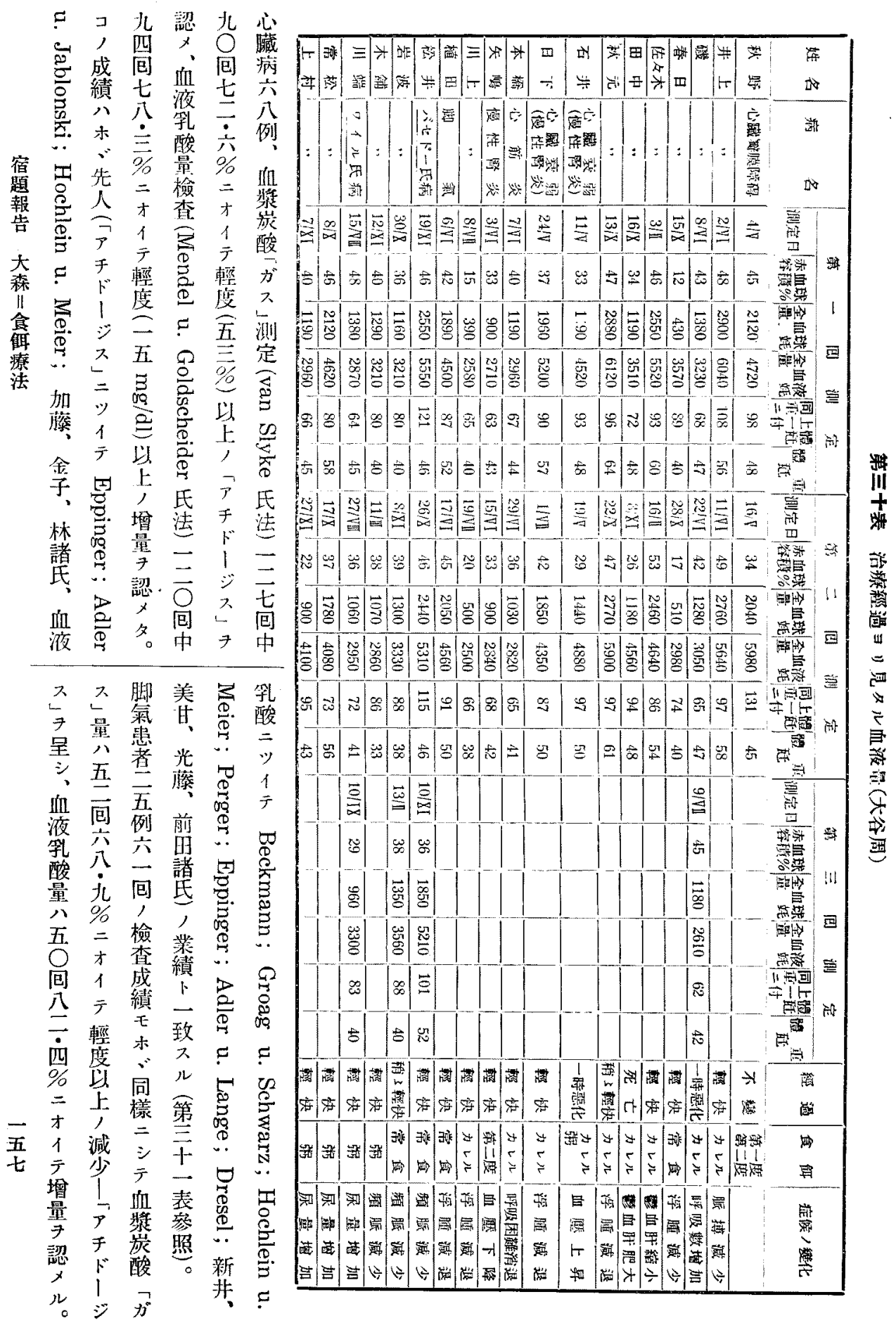


第三ナー表 心疾虫者ニオケル血䈨炭酸「がス」減少及ビ 血液乳酸㩐加，頻度（小西）

\begin{tabular}{|c|c|c|c|c|c|c|c|c|c|c|c|c|c|}
\hline \multirow[b]{2}{*}{$\begin{array}{l}\text { 檢 } \\
\text { 督 } \\
\text { 影 }\end{array}$} & \multirow[b]{2}{*}{ 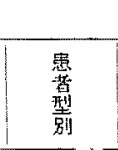 } & \multicolumn{3}{|c|}{ 例 } & \multicolumn{3}{|c|}{ 數 } & \multicolumn{6}{|c|}{$\%$} \\
\hline & & 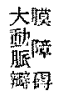 & 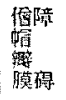 & 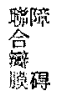 & 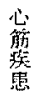 & $\begin{array}{l}\text { 其心 } \\
\text { 他整 } \\
\text { 虫 }\end{array}$ & $\begin{array}{l}\text { 合 } \\
\text { 部 }\end{array}$ & 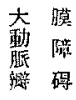 & 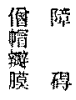 & 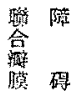 & 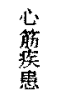 & $\begin{array}{l}\text { 其 } \\
\text { 他 } \\
\text { 慗 }\end{array}$ & $\begin{array}{l}\text { 合 } \\
\text { 計 }\end{array}$ \\
\hline & 频 & 27 & 44 & 16 & 27 & 13 & 127 & 27 & 44 & 16 & 27 & 13 & 127 \\
\hline \multirow{5}{*}{ 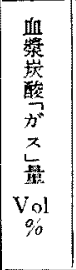 } & $\begin{array}{c}70.0 \text { Volo } \\
\text { 以上 }\end{array}$ & 0 & 0 & 1 & 0 & 1 & 2 & 0 & 0 & 6.2 & 0 & 7.0 & 1.6 \\
\hline & $53.0-70.0$ & 5 & 9 & 4 & 9 & 5 & 32 & 22.7 & 20.4 & 25.0 & 33.7 & 36.0 & 25.8 \\
\hline & $40 . \ddot{0}-53.0$ & 10 & 20 & 7 & 16 & 6 & 59 & 45.5 & 45.4 & 43.8 & 58.7 & 43.0 & 47.6 \\
\hline & $39.0-40.0$ & 5 & 13 & 4 & 2 & 2 & 27 & 22.7 & 30.0 & 25.0 & 7.6 & 14.0 & 21.8 \\
\hline & 30.0 - $\ddot{\mu}$ & 2 & 2 & 0 & 0 & 0 & 4 & 9.1 & 4.2 & 0 & 0 & 0 & 3.2 \\
\hline \multirow{4}{*}{ 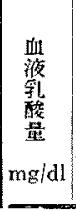 } & $15.0 \mathrm{mg} / \mathrm{dl}$ & 2 & 16 & 0 & 4 & 4 & 26 & 11.1 & 36.4 & 0 & 11.8 & 28.5 & 21.7 \\
\hline & $20 . \ddot{0}-15.0$ & 6 & 11 & 5 & 5 & 5 & 29 & 16.7 & 25.0 & 31.2 & 18.5 & 35.7 & 24.2 \\
\hline & $30.0-20.0$ & 10 & 15 & 10 & 14 & 4 & 53 & 55.5 & 34.1 & 62.5 & 52.7 & 28.5 & 44.1 \\
\hline & 30.0 -以上 & 3 & 2 & 1 & 4 & 1 & 12 & 16.7 & 4.5 & 6.3 & 17.0 & 7.3 & 10.0 \\
\hline
\end{tabular}

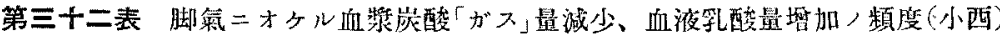

\begin{tabular}{|c|c|c|c|c|c|c|c|c|c|}
\hline \begin{tabular}{l|l} 
检 & 程 \\
查 & \\
别 & 国
\end{tabular} & 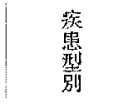 & $\begin{array}{l}\text { 浮 } \\
\text { 碩 } \\
\text { 型 }\end{array}$ & $\begin{array}{l}\text { 知 } \\
\text { 烈 } \\
\text { 型 }\end{array}$ & 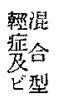 & 苦 & $\begin{array}{l}\text { 浮 } \\
\text { 䒅 } \\
\text { 型 }\end{array}$ & $\begin{array}{l}\text { 知 } \\
\text { 琶 } \\
\text { 型 }\end{array}$ & $\begin{array}{ll}\text { 整 } & \text { 混 } \\
\text { 焉 } & \text { 合 } \\
\text { 型 }\end{array}$ & 合 \\
\hline \multirow{3}{*}{ 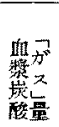 } & & 19 & 29 & 13 & 61 & 19 & 29 & 13 & 61 \\
\hline & $70.0 \mathrm{Vol} \%$ & 1 & 4 & 0 & 5 & 5.3 & 13.8 & 0 & 8.1 \\
\hline & $53.0-70.0$ & 5 & 7 & 2 & 14 & 26.3 & 24.1 & 15.4 & 23.0 \\
\hline \multirow{3}{*}{ Vol } & $40.0-53.0$ & 9 & 14 & 8 & 31 & 47.4 & 48.3 & 61.5 & 50.8 \\
\hline & $30.0-40.0$ & 4 & 4 & 3 & 11 & 21.0 & 13.8 & 23.1 & 18.0 \\
\hline & $30.0-以 \mathrm{~T}$ & 0 & 0 & 0 & 0 & 0 & 0 & 0 & 0 \\
\hline \multirow{4}{*}{ 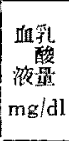 } & $15.0_{\text {以下 }}^{\mathrm{mg} / \mathrm{dl}}$ & 4 & 4 & 3 & 11 & 21.1 & 12.5 & 23.0 & 17.6 \\
\hline & $20.0-15.0$ & 4 & 12 & 5 & 21 & 21.1 & 42.9 & 38.5 & 35.0 \\
\hline & $30.0-20.0$ & 6 & 9 & 4 & 19 & 31.5 & 32.1 & 30.8 & 31.6 \\
\hline & $30.0-015$ & 5 & 4 & 1 & 10 & 26,3 & 12.5 & 7.7 & 15.8 \\
\hline
\end{tabular}

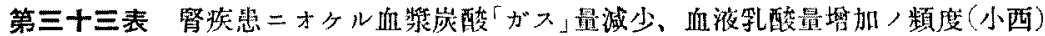

\begin{tabular}{|c|c|c|c|c|c|c|c|c|c|c|c|c|c|c|}
\hline \multirow[b]{2}{*}{$\begin{array}{l}\text { 检 } \\
\text { 㚗 } \\
\text { 别 }\end{array}$} & \multirow[b]{2}{*}{ 程 } & \multirow[b]{2}{*}{ 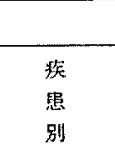 } & \multicolumn{3}{|c|}{ 例 } & \multicolumn{3}{|c|}{ 数 } & \multicolumn{6}{|c|}{$\%$} \\
\hline & & & 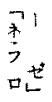 & 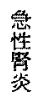 & 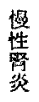 & $\begin{array}{l}\text { 尿 } \\
\text { 粱 } \\
\text { 症 }\end{array}$ & 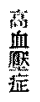 & $\begin{array}{l}\text { 合 } \\
\text { 部 }\end{array}$ & 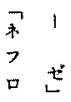 & $\begin{array}{l}\text { 急 } \\
\text { 情 } \\
\text { 叒 }\end{array}$ & 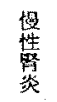 & 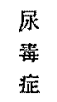 & 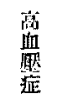 & 合 \\
\hline & 例 & 数 & 26 & 18 & 27 & 29 & 34 & 134 & 26 & 18 & 27 & 29 & 34 & 134 \\
\hline \multirow{5}{*}{ 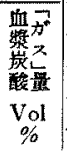 } & & $.0 \mathrm{Vol} \% \mathrm{WL}$ & 3 & 0 & 2 & 1 & 1 & 7 & 11.5 & 0 & 7.4 & 3.4 & 2.9 & 5.8 \\
\hline & & $3.0-70.0 * \cdots$ & 10 & 6 & 5 & 4 & 20 & 45 & 38.5 & 33.3 & 18.5 & 13.8 & 59.0 & 33.5 \\
\hline & & $0-53.0 \cdots$ & 9 & 10 & 14 & 13 & 10 & 56 & 34.6 & 55.6 & 51.8 & 44.8 & 29.5 & 41.7 \\
\hline & & $.0-40.0 \cdot$ & 4 & 2 & 4 & 8 & 3 & 21 & 15.4 & 11.1 & 14.8 & 27.6 & 8.6 & 16.5 \\
\hline & & .0以下 & 0 & 0 & 2 & 3 & 0 & 5 & 0 & 0 & 7.5 & 10.4 & 0 & 3.5 \\
\hline \multirow{4}{*}{ 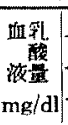 } & & $0 \mathrm{mg} / \mathrm{dl} \mathrm{WT}$ & 6 & 8 & 7 & 3 & 13 & 36 & 23.0 & 44.4 & 25.9 & 10.3 & 38.2 & 27.3 \\
\hline & & $0.0-15.0 \cdot$ & 11 & 7 & 8 & 5 & 15 & 46 & 42.4 & 38.9 & 29.6 & 17.2 & 44.1 & 34.9 \\
\hline & & $0.0-20.0 \cdot$ & 7 & 3 & 11 & 11 & 4 & 35 & 26.9 & 16.7 & 40.7 & 37.9 & 11.8 & 26.5 \\
\hline & & $0.0 "$ 以上 & 2 & 0 & 1 & 10 & 2 & 15 & 7.7 & 0 & 3.8 & 34.6 & 5.9 & 11.2 \\
\hline
\end{tabular}


第三十五表

肚氮浮腫卜血筤炭酸「がス。

量及ビ血液乳酸量卜，關係

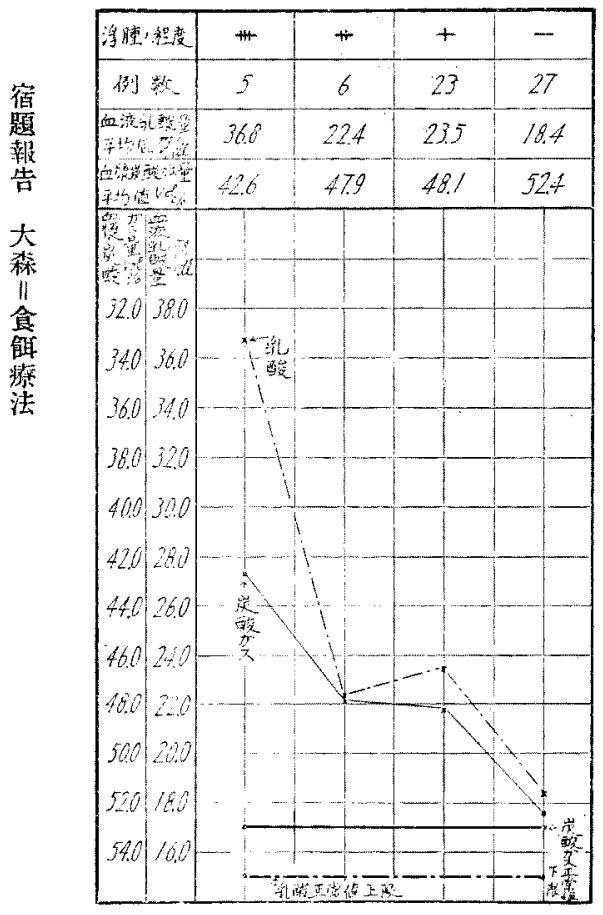

第三十六表

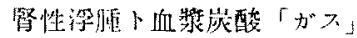
语及ビ血涯乳酸旨卜，關係

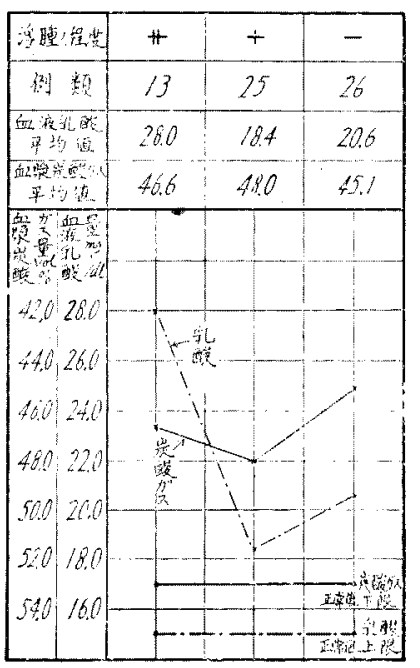

\section{第三十四表}

心性浮腫卜血展炭酸「がス」量及 ビ血液乳酸量卜，閶係（小西）

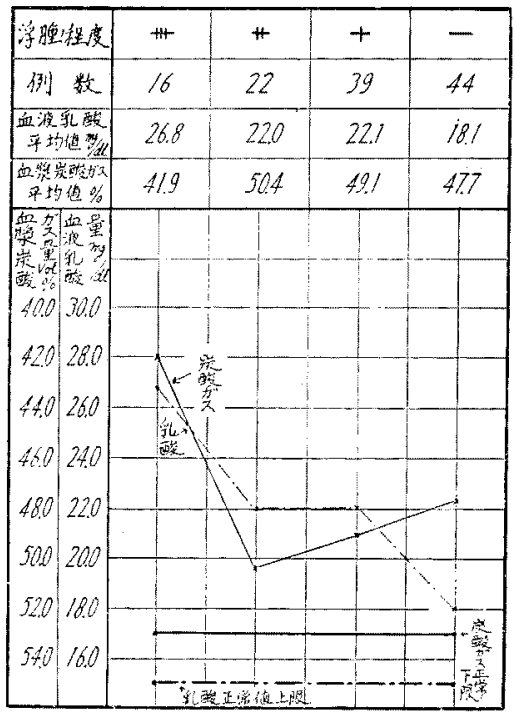

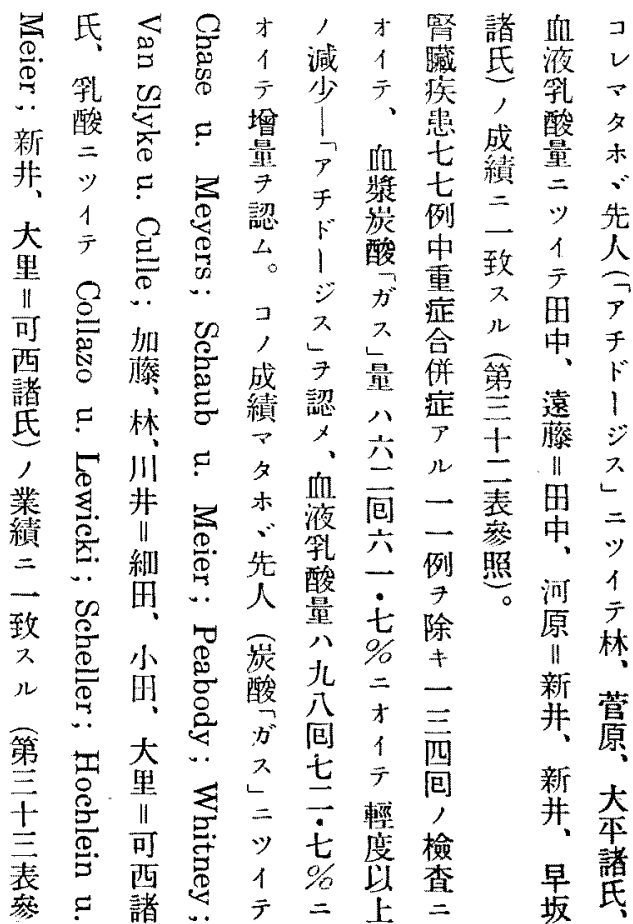




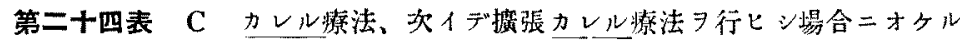

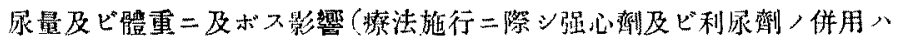

止ムヨ得ザル埸合之ヨ選ブ)

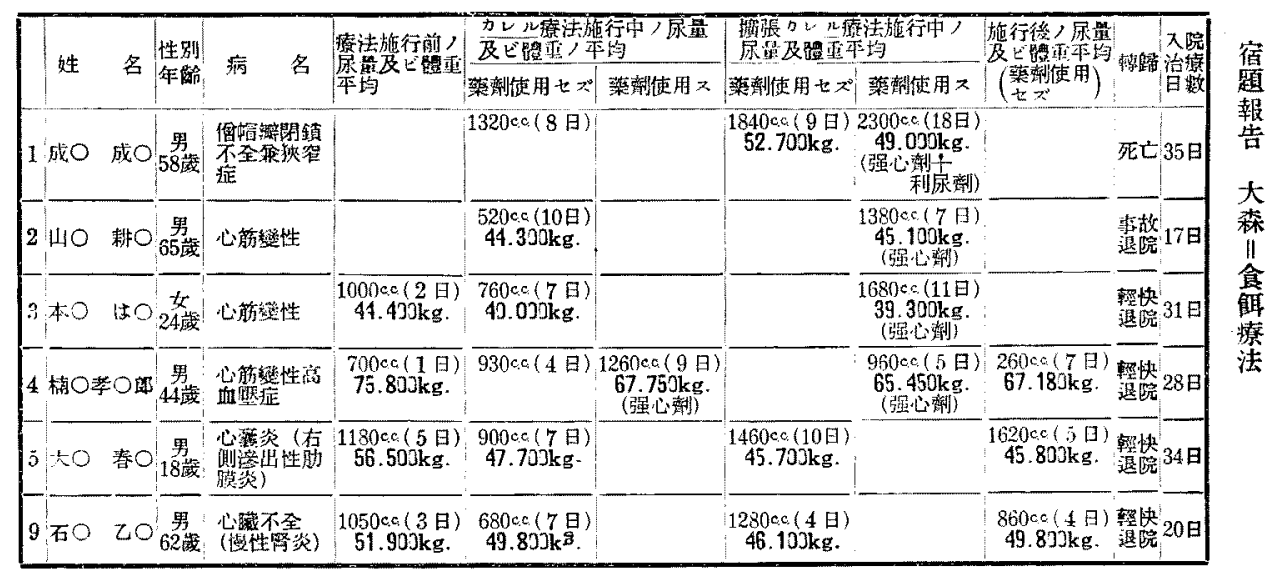

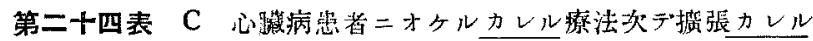

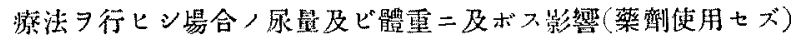

\begin{tabular}{|c|c|c|c|c|c|}
\hline 就宝 & 量 & 施行前 & 施行中 & 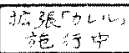 & 施何称 \\
\hline--- & - & & & & \\
\hline 3 & $1 \% 00$ & & & & \\
\hline 50 & 1200 & & & & \\
\hline 45 & 1000 & & & & \\
\hline 40 & 800 & & & & \\
\hline 35 & 600 & & & & \\
\hline 70 & 400 & & & & \\
\hline 30 & & & & & \\
\hline $25 \mathrm{~kg}$ & $200 c$ & & & & \\
\hline
\end{tabular}

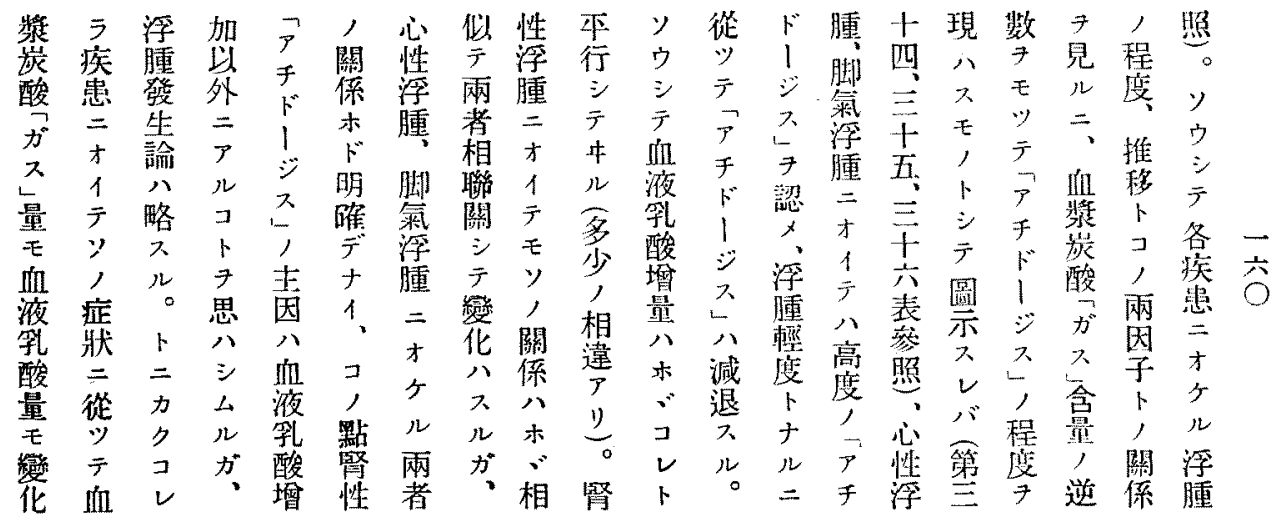




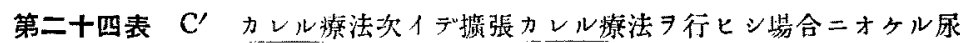

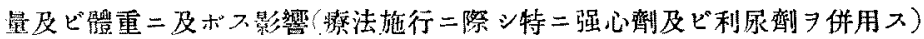

\begin{tabular}{|c|c|c|c|c|c|c|c|c|c|c|}
\hline \multirow{2}{*}{\multicolumn{2}{|c|}{ 姓 名 }} & \multirow{2}{*}{ 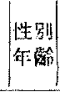 } & \multirow{2}{*}{ 病名 } & \multirow{2}{*}{ 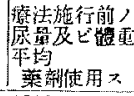 } & \multirow{2}{*}{ 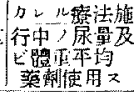 } & \multicolumn{2}{|c|}{ 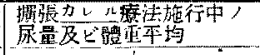 } & \multicolumn{2}{|c|}{ 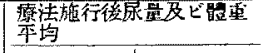 } & \multirow{2}{*}{ 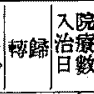 } \\
\hline & & & & & & 萎新使用七代 & 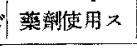 & 倠流渎用 又 & 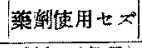 & \\
\hline 1 & 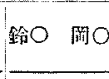 & 4 嫼 & 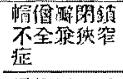 & $\begin{array}{c}1200 \mathrm{cc}(3 \mathrm{~g}) \\
47.250 \mathrm{~kg} . \\
\text { (强心缡) } \\
\end{array}$ & 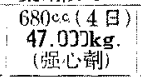 & & 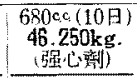 & & $\begin{array}{l}1000 \mathrm{cc}(7 \mathrm{\theta}) \\
46.250 \mathrm{~kg}\end{array}$ & 盐院 \\
\hline 2 & \$O & - tx & 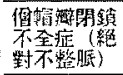 & & $\begin{array}{c}1030 c \mathrm{c}(14 \mathrm{)}) \\
40.60 \mathrm{~kg} \\
\text { (强心赫) }\end{array}$ & $\begin{array}{l}530 \mathrm{ccc}(6 \text { 日) } \\
41.670 \mathrm{~kg} .\end{array}$ & 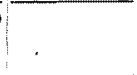 & & & 整快。 \\
\hline 3 & 猍了 & 68男 & 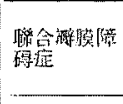 & $\begin{array}{c}900 \mathrm{ec}(2 \text { 日) } \\
53.003 \mathrm{~kg} . \\
\text { (强心剖) }\end{array}$ & 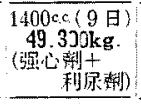 & & 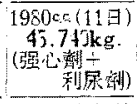 & & & 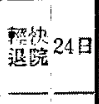 \\
\hline 4 & 传○杰口的 & Q 59 思荗 & 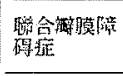 & & 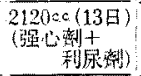 & & 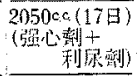 & 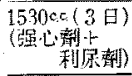 & & 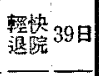 \\
\hline & 江O桃O助 & 20 & 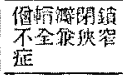 & 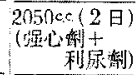 & 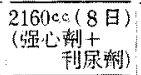 & & 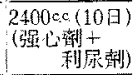 & 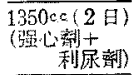 & & 暂稳 55 日 \\
\hline & 加O 310 & 2 男 & 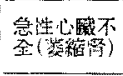 & & 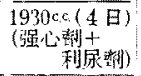 & & 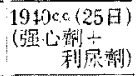 & & & 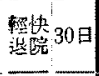 \\
\hline & 热O & 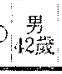 & 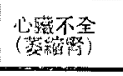 & 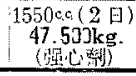 & 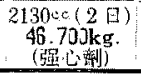 & & 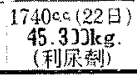 & & 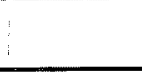 & 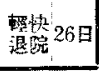 \\
\hline
\end{tabular}

第二十四表 $\mathrm{C}^{\prime}$ ：心贜病患者ニオタルカレル噄法次イデ摭張カレル療法ヨ

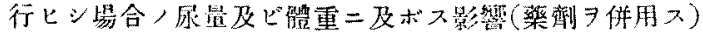

\begin{tabular}{|c|c|c|c|c|c|}
\hline 㑈整 & 焣堅 & 施打朔 & 吅以 & 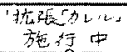 & 施行㣪 \\
\hline$m--$ & - & & & & \\
\hline 53 & $1+100$ & & & & \\
\hline 50 & 1200 & 0 & & & \\
\hline 45 & $1 / 100$ & & & & \\
\hline 40 & 900 & & & & 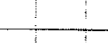 \\
\hline 35 & 600 & & & & \\
\hline & & & & & 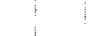 \\
\hline $3 \pi$ & 400 & & & & \\
\hline 25 & 200 & & & & \\
\hline
\end{tabular}

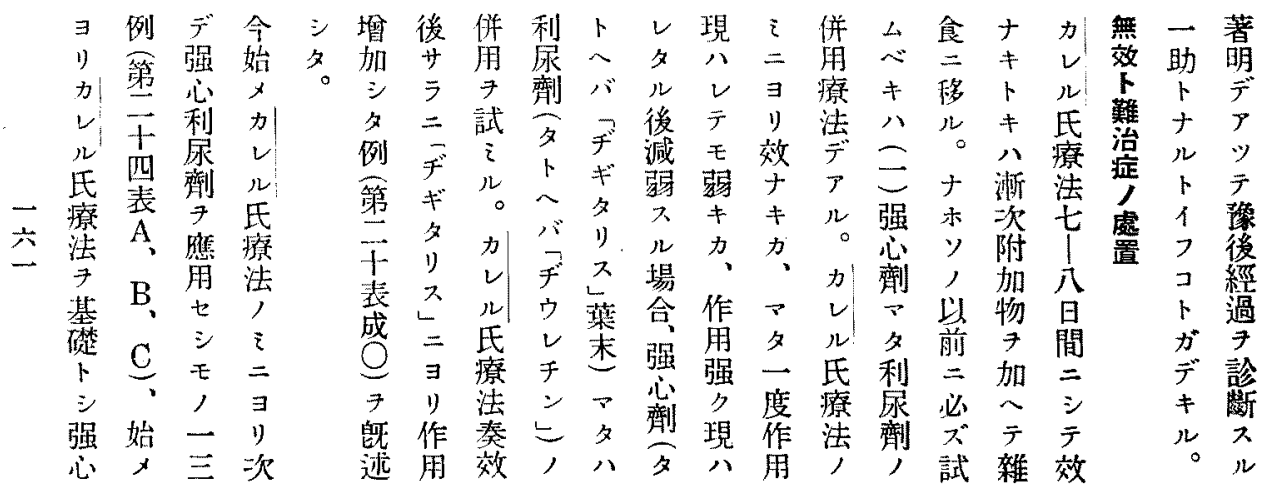


第三十七表 皆O正O57蔵心性圌息+慢性管炎

\begin{tabular}{|c|c|c|c|c|c|c|c|c|c|c|c|}
\hline & . & 饮 款 & 尿 量 & 比亚 & 蛋 & 渡 搏 & 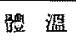 & 呼 吸 & 浮嗹 & 全 浒 & 倩 \\
\hline 4) I & & 600 & $900+$ & 8 & $0.2 \%$ & $84 \cdots 108$ & 洴 & $25-30$ & $\mathrm{Ht}$ & 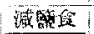 & 蹈坐呼吸 \\
\hline 5 & 「ギギ」末 0.2 & 350 & 1300 & 10 & 0.2 & $90-96$ & . & 30 & 世 & .. &. \\
\hline 6 & 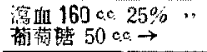 & 400 & 950 & 14 & 0.4 & $78-102$ & $"$ & $26-30$ & W & 「カレル」 & ". \\
\hline 7 & " & 1020 & 2000 & 10 & 0.25 & $78-96$ & ." & 30 & H & ", & 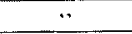 \\
\hline 8 & $"$ & 1100 & 2200 & 10 & 0.1 & $72-90$ & " & $27-30$ & H & ". & 浮隀減少 \\
\hline 9 & 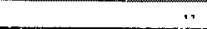 & 1090 & 2553 & 10 & 0.1 & $78-90$ & $"$ & $27-30$ & H & .". & 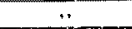 \\
\hline
\end{tabular}

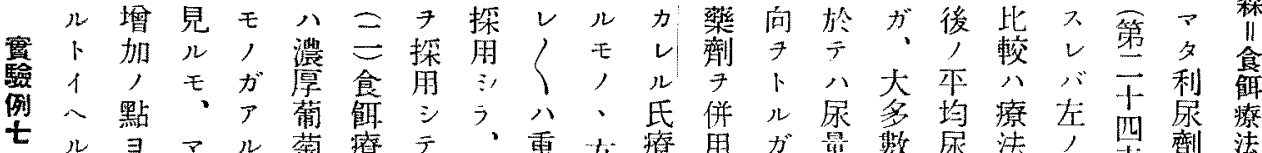

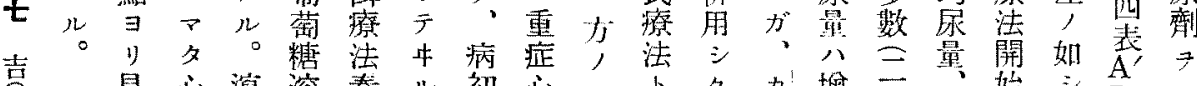

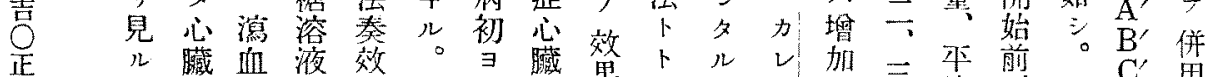

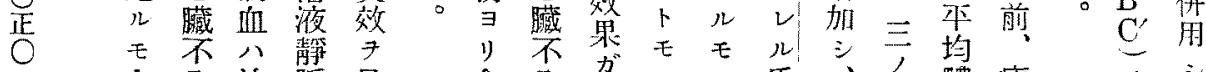

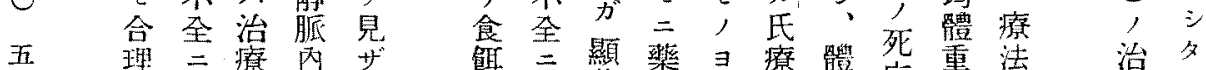

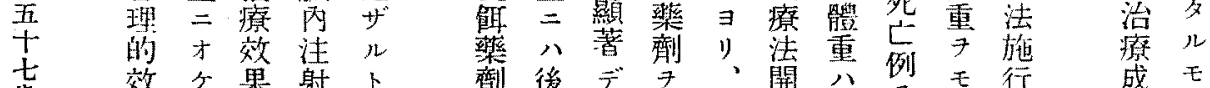

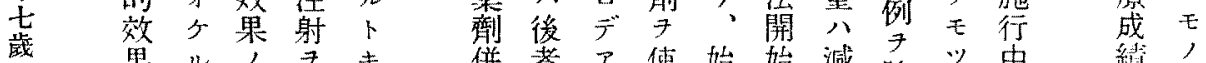
男的血上行瀉角者

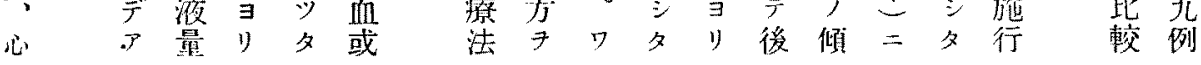

～例者テか, かがザ五が心濃

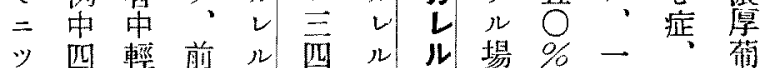

丮四快者療八氏 合溶昨心萄 比例七中法例療療吕液年筋糖 較六儿輕子丹法法厂二宿疾溶 入三モ快施材多了儿包題忽液

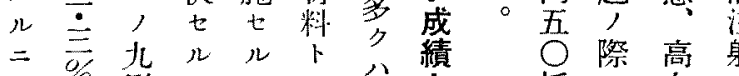

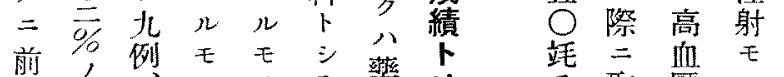

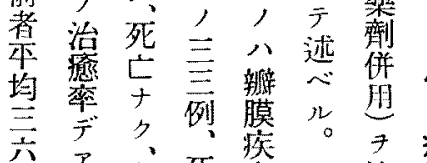

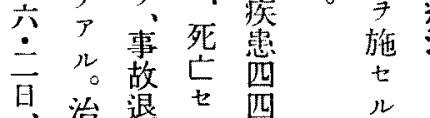

後療院儿例モ比

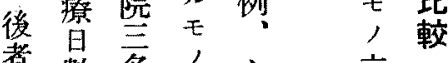

著數名公学交

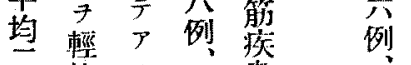

西快少不忠然

六儿合 盟三 然

日枩計 例例拿

$=$, 兵例 $=$ ル

シ, 六後
取 焦

用扱症,

七八等 際

テ $\nu=$ 併

中夕效 朋

ル,

カj デリル

“略卜心

奏入七治

效儿弓療

7 ᄂ 法

見》多多

儿 $<\frac{1}{-}$

場〈交 デ

合

然五勇。

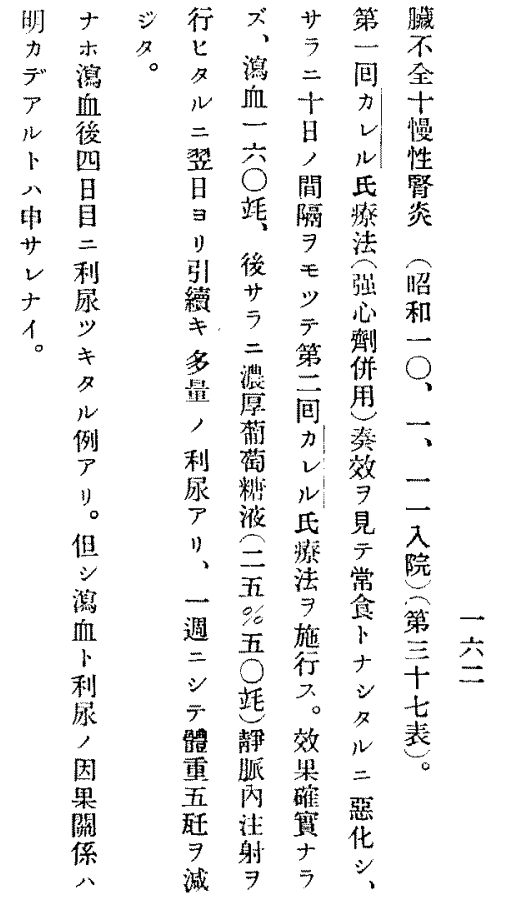




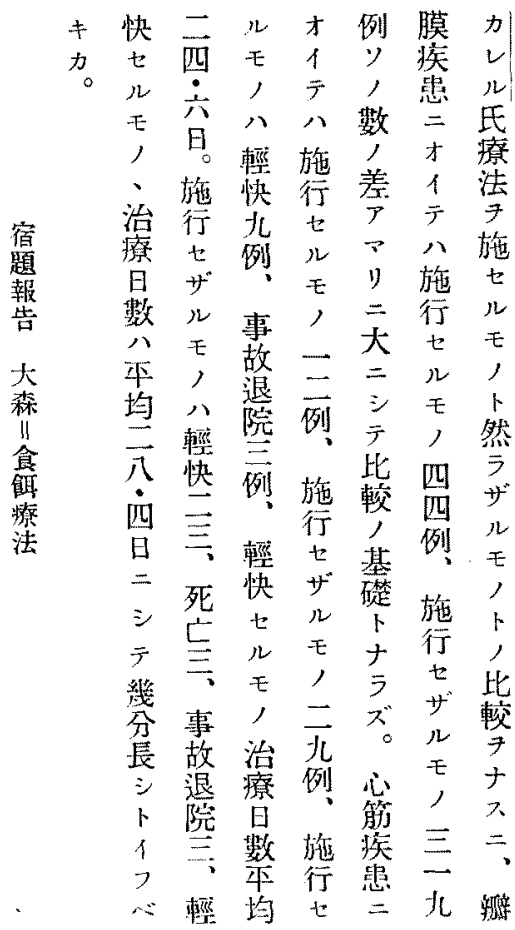

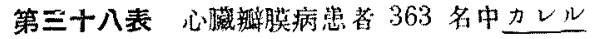

5

痖法 $\exists$ 施行セబモ，44例，治療日數

(大正 10 年 $\exists$ リ绍和 10 年二至儿)(相濢）

\begin{tabular}{|c|c|c|c|c|}
\hline \multicolumn{2}{|c|}{ 䑨脱病，植数 } & \multicolumn{3}{|c|}{ 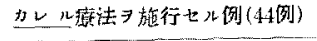 } \\
\hline \multirow{4}{*}{ 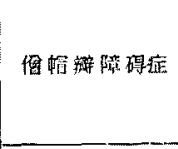 } & 箪 蹼 & 数 & 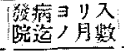 & 治灌日数 \\
\hline & 整 性 & 14 & 52.4 & 34.9 \\
\hline & 薄 故 & 2 & 260.0 & 27.0 \\
\hline & 死 亡 & 3 & 158.3 & 53.3 \\
\hline \multirow{3}{*}{ 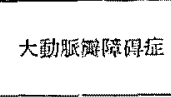 } & 僌 性 & 7 & 35.0 & 45.8 \\
\hline & 慗 故 & 1 & 11.0 & 64.0 \\
\hline & 死 & 3 & 28.3 & 24.0 \\
\hline \multirow{3}{*}{ 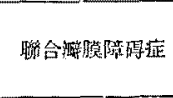 } & 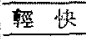 & 12 & 21.1 & 32.1 \\
\hline & 放 故 & 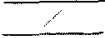 & $\zeta$ & 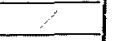 \\
\hline & 死 L & 2 & 171.1 & 18.5 \\
\hline \multirow{3}{*}{ (合 計) } & 整 怢 & 33 & 39.7 & 36.2 \\
\hline & 梆 故 & 3 & 177.0 & 39.3 \\
\hline & 死 $\sqsubset$ & 8 & 112.5 & 33.6 \\
\hline \multicolumn{5}{|c|}{ 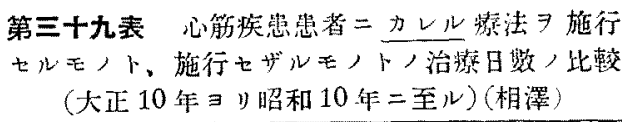 } \\
\hline
\end{tabular}

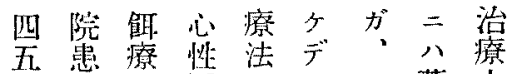

亦者法浮二

七虫 7 腫 $コ$ 1 2 物

快用强匹下芯法秼

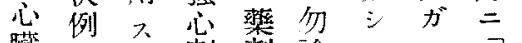

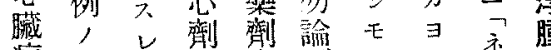

病治, 心呼癔

中療 ソ

膜

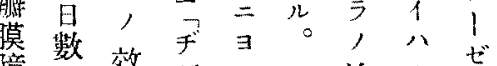

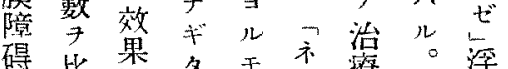

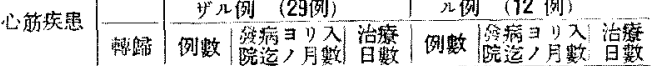

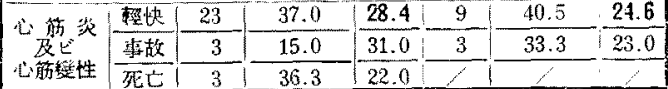

筋

疾

急

方

短

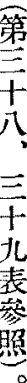

U 照

一較顯りナナフ法コ腫治

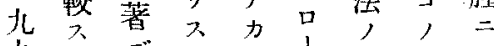

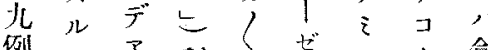

年

均齐乵治腄亏間湶

一三フ鿬留方衣違法

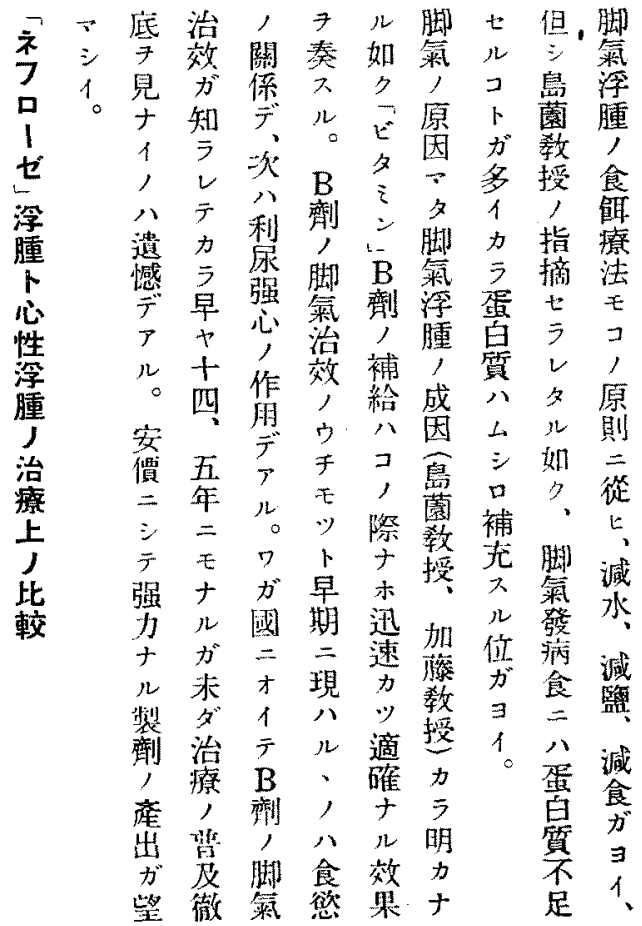

$\equiv$

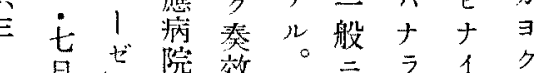

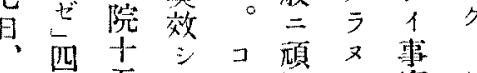

心五、上固卜害心

筋例年殊二元 1 亏゙性

疾本, 三反食子浮

熙均入食 シ喵口儿腫 


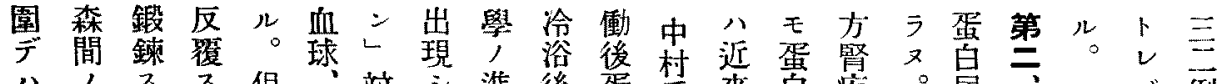

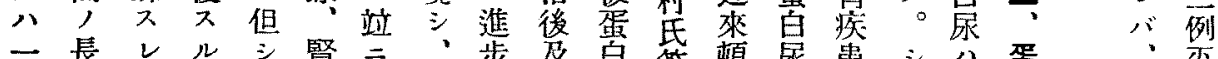

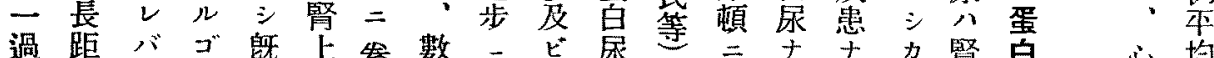

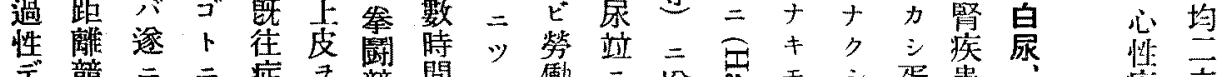

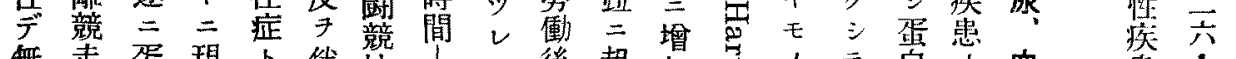
舞走蛋現經

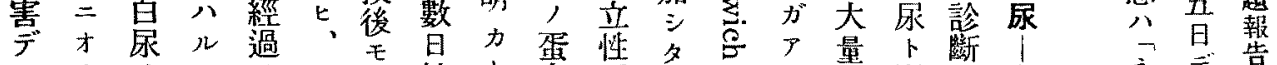

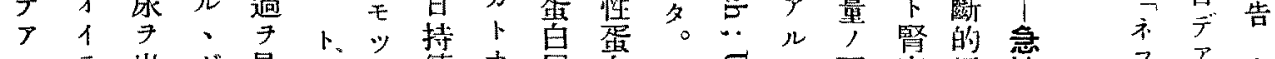

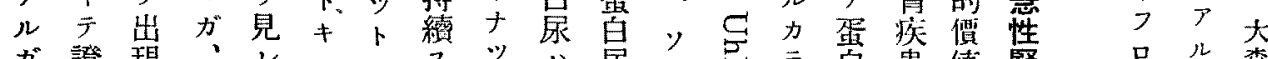
ガ證現、 $、=$ モ 急七 明 せ

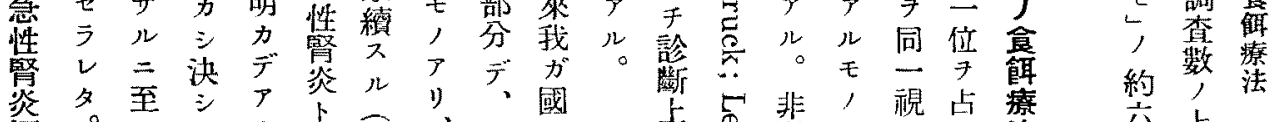

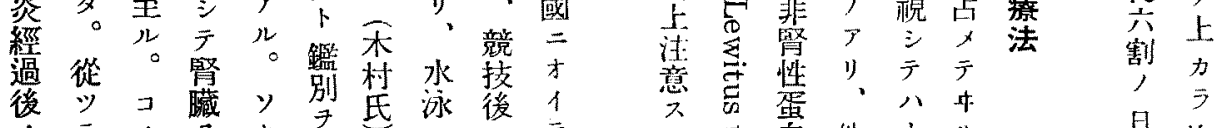

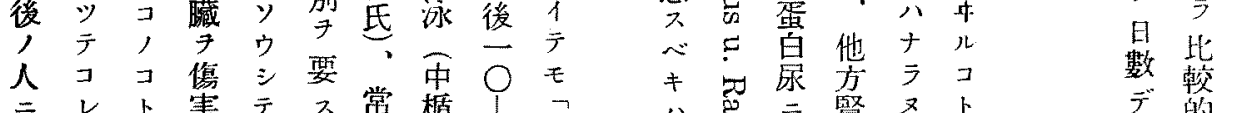

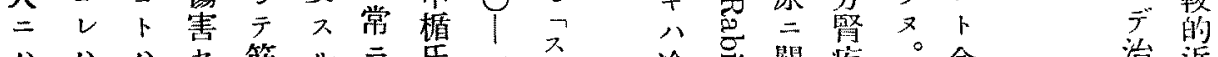

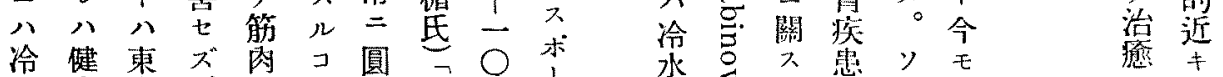
水康亲 長㤦

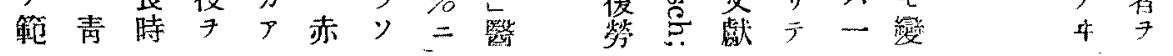

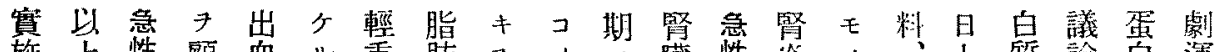

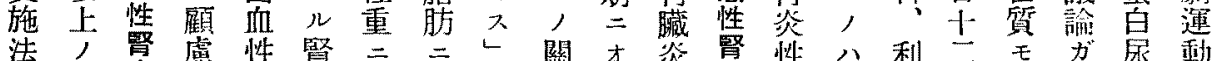

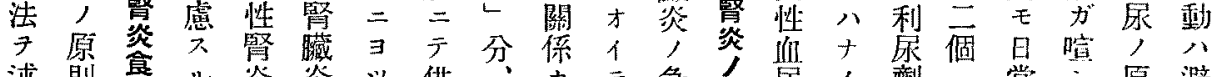

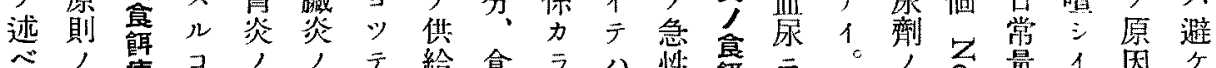

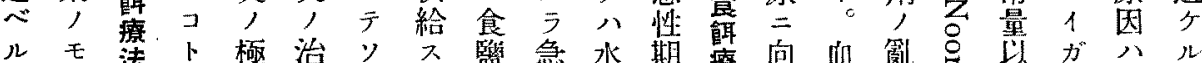

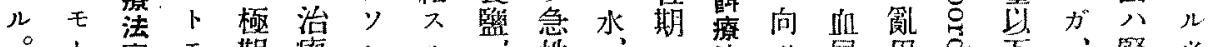
卜惯モ期療しル性”二法ッ尿用吕下、”管必

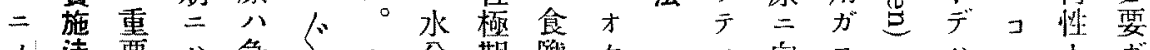

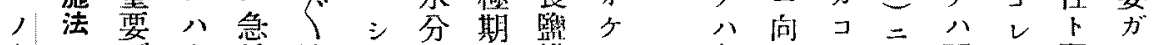
1 方性適力 ル゙不分期應三極才泄食性テチレ白對外ル

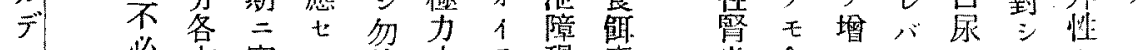

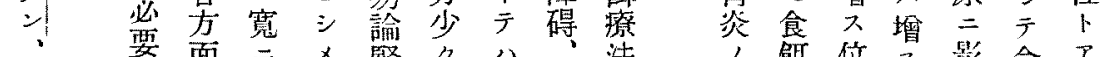

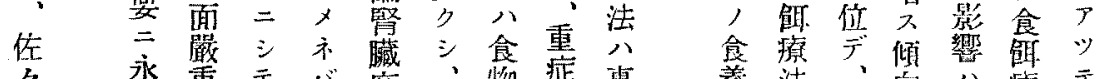

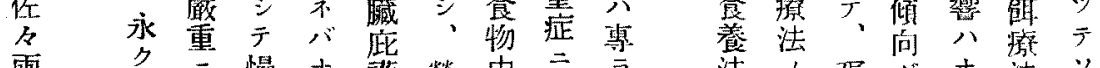

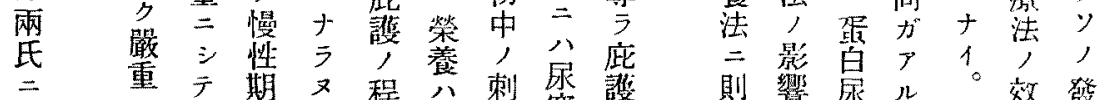

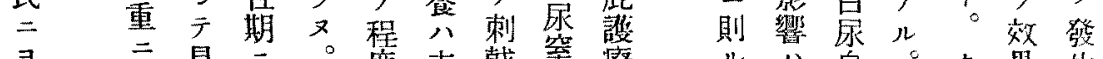

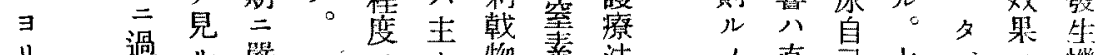

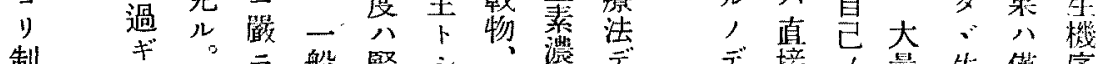

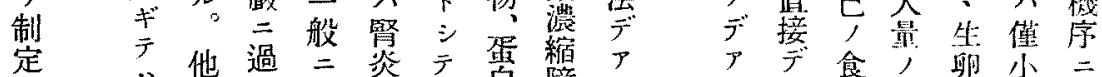

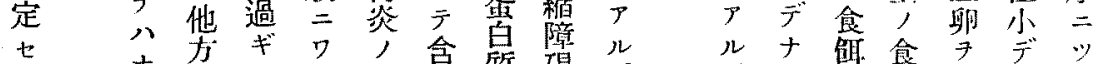

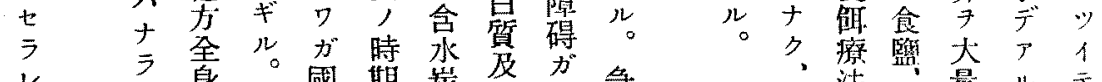

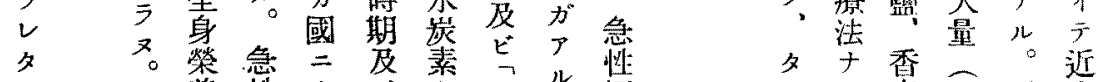

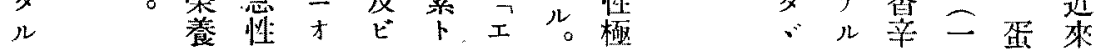




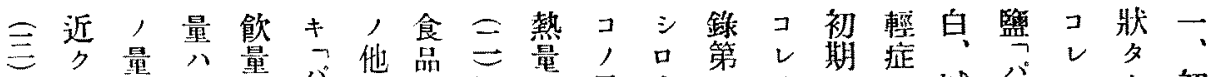
減不食古平

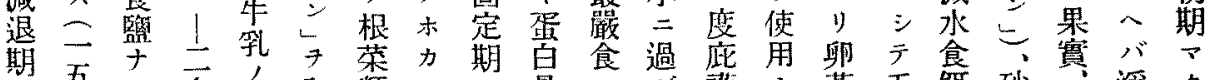

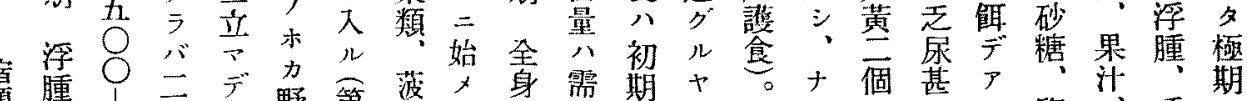

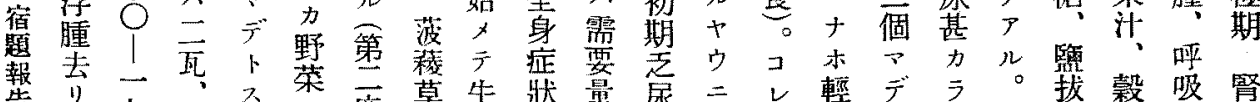

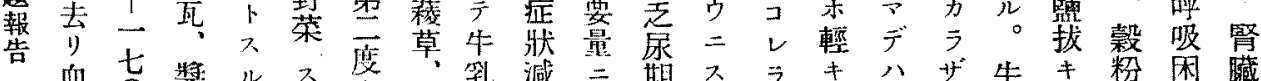

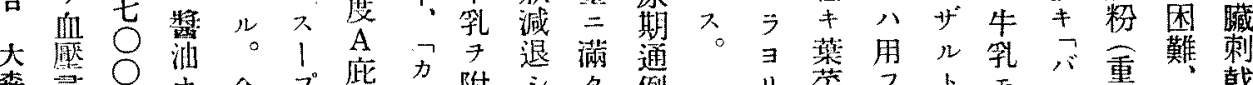
森㴔 食常か ラ 箘復り

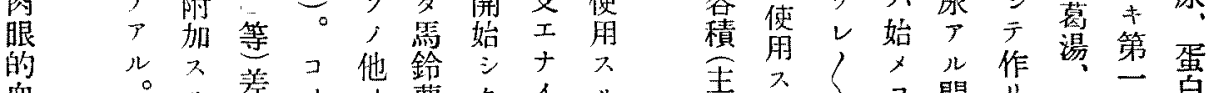

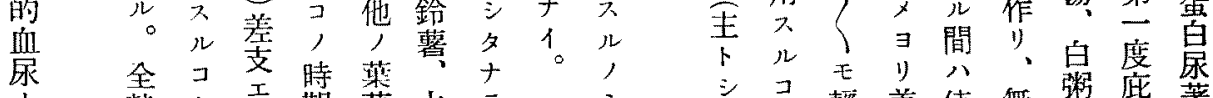
ナ 熱 ト エ

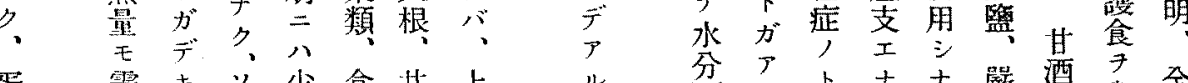

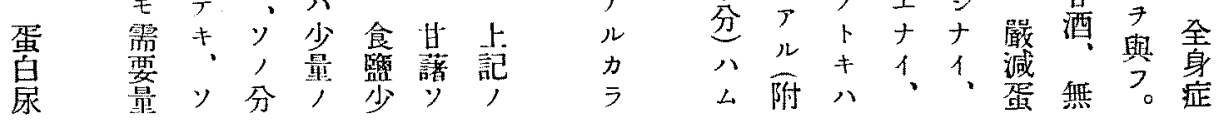

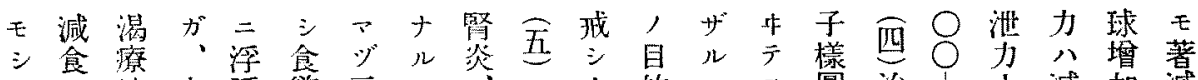

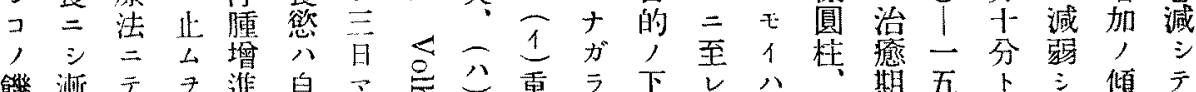

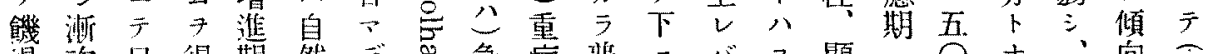

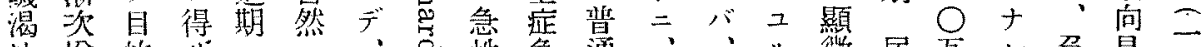

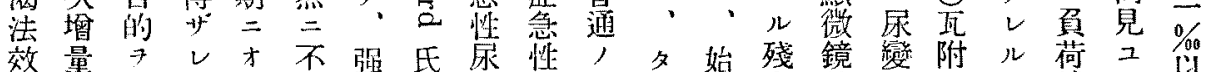

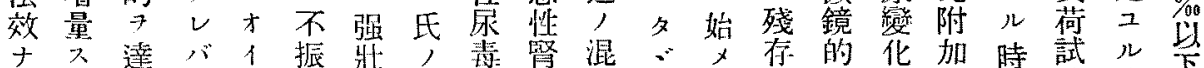

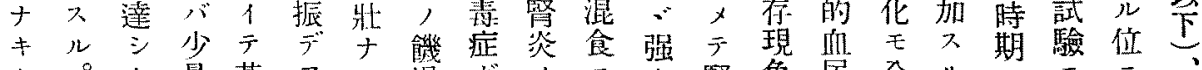

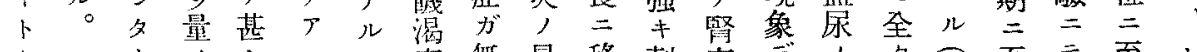

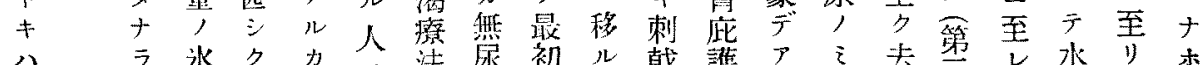

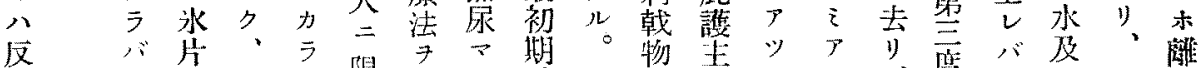

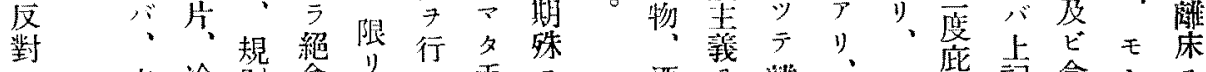

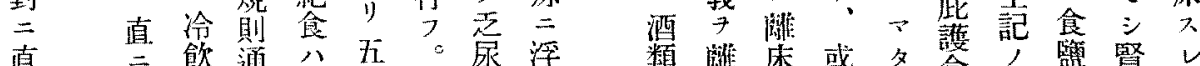

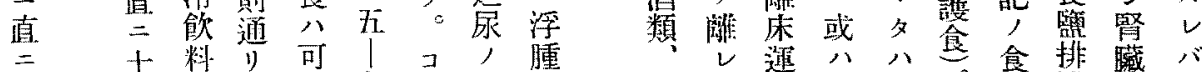

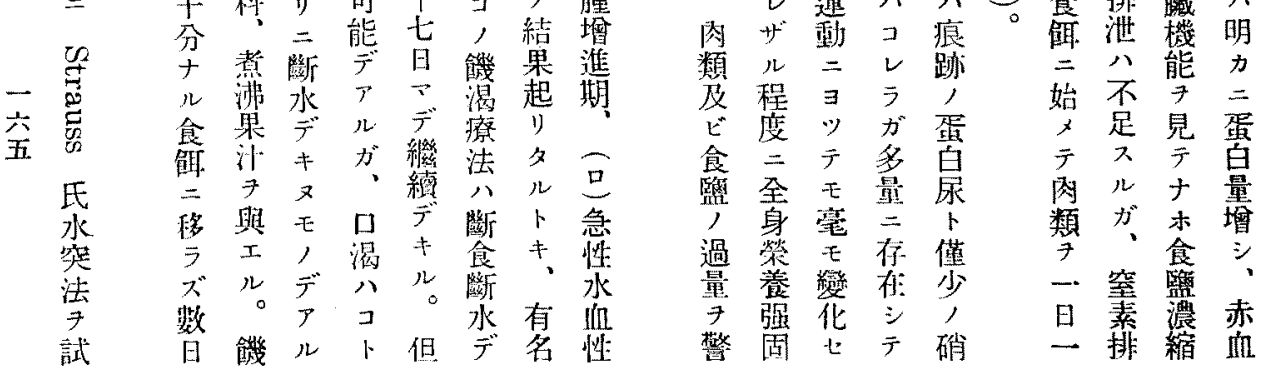


全旦院急

治平均二紧

院十峛炎續症固見

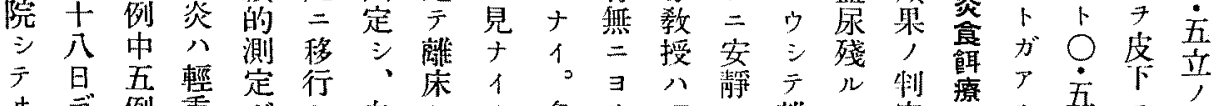

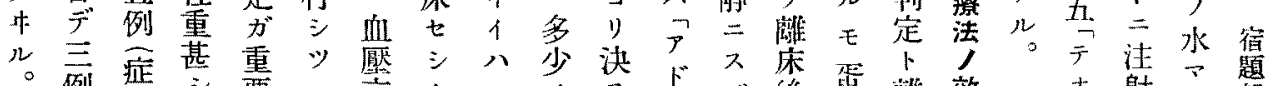

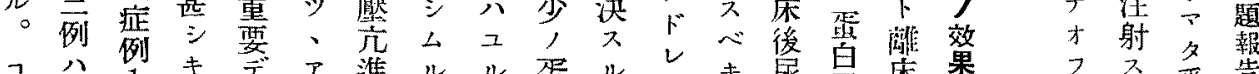

際快 2 兾 ル

始 シ

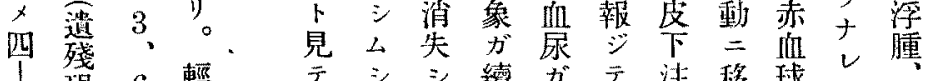

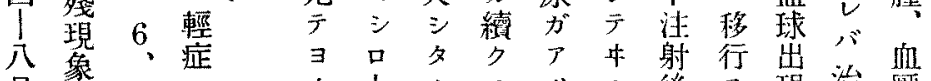

日象 9 分上卡ルコッル後

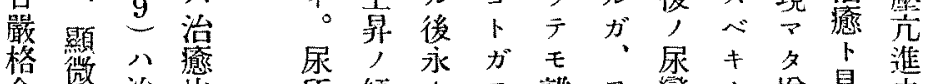

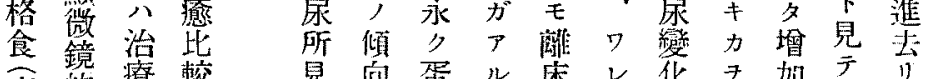

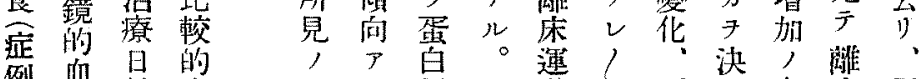

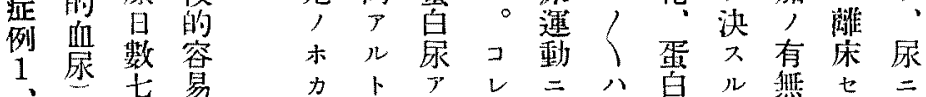

$9=1$ 血

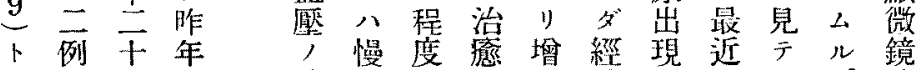

三八七入連性二卜加喓, 饭少。的

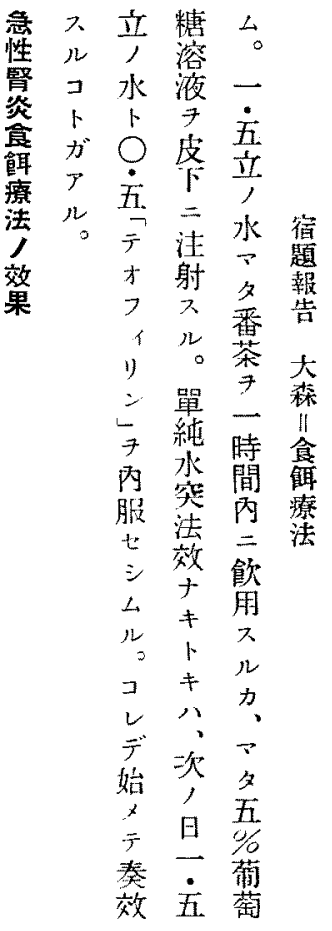

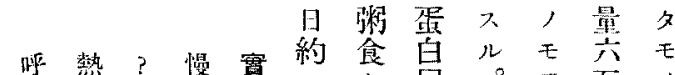

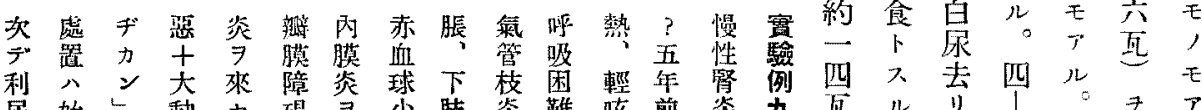

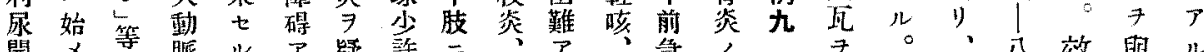

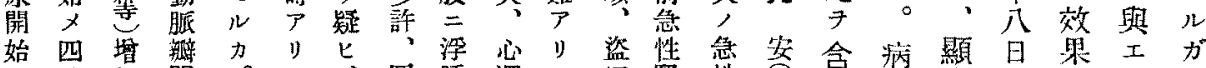

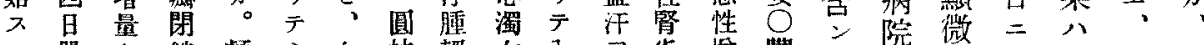

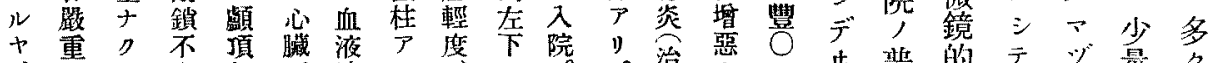
、重 制 $テ$ 卜

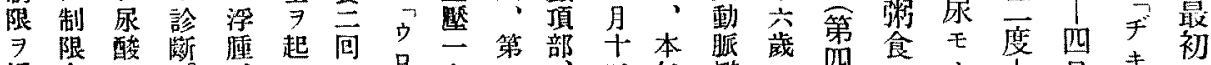

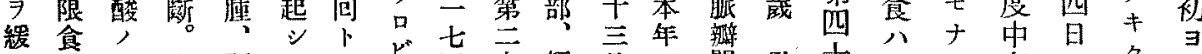

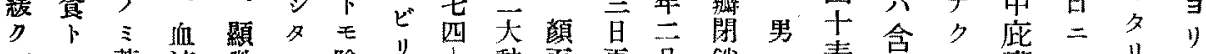

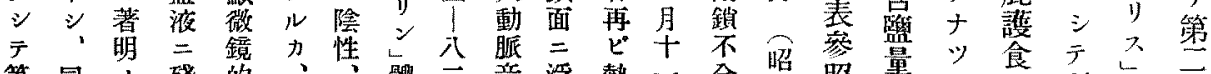

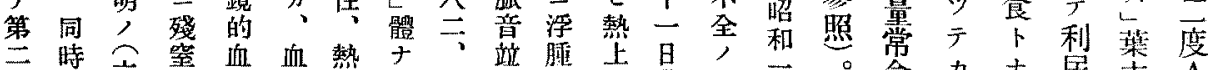

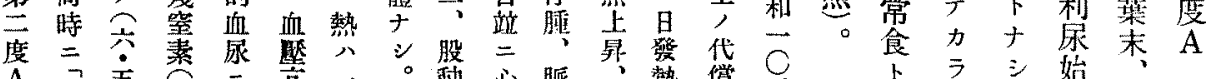

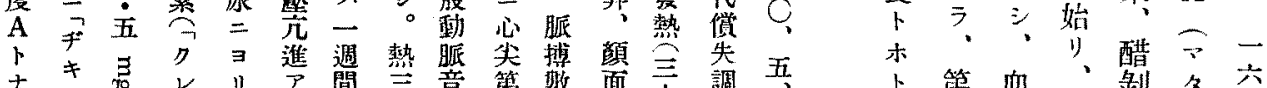

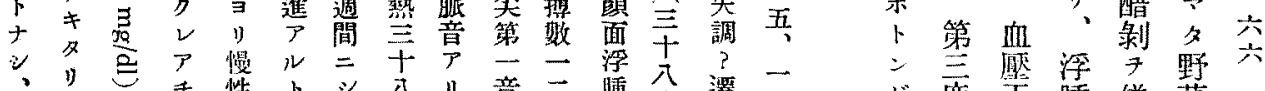

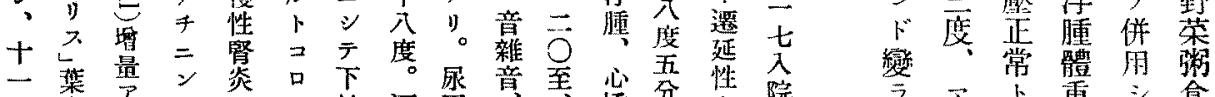

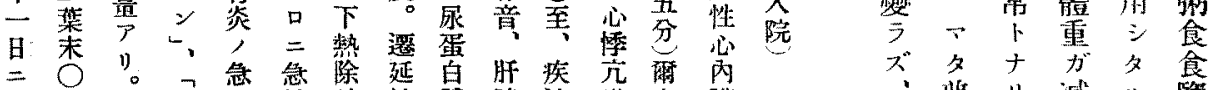

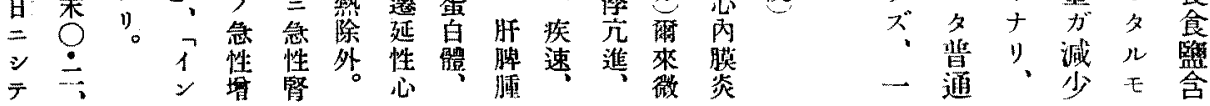




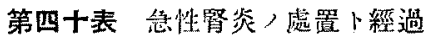

\begin{tabular}{|c|c|c|c|c|c|c|c|c|c|c|c|c|}
\hline & \multirow{3}{*}{ 患 } & \multirow{3}{*}{ 战 } & \multirow{3}{*}{ 合併证 } & \multirow{3}{*}{ 趋 } & \multicolumn{3}{|c|}{ 症 } & \multicolumn{3}{|c|}{ 狀 } & \multirow{3}{*}{$\begin{array}{l}\text { 竞 } \\
\text { 院 } \\
\text { 數 }\end{array}$} & \multirow{3}{*}{ 藏嗳 } \\
\hline & & & & & \multirow{2}{*}{ 浫㭗 } & \multicolumn{3}{|c|}{ 尿 } & \multirow{2}{*}{ 莇整 } & \multirow[b]{2}{*}{ 跓䓝 } & & \\
\hline & & & & & & 蛋 $\theta$ & 血践 & $\begin{array}{l}\text { 國㧼 } \\
\text { 上茫 }\end{array}$ & & & & \\
\hline 1 & 作O & 27 & 扁挑腺炎 & 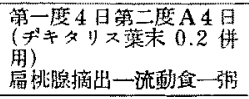 & $\begin{array}{l}H \\
-\end{array}$ & $\begin{array}{l}+ \\
- \\
\end{array}$ & $\begin{array}{l} \pm \\
- \\
\end{array}$ & $\begin{array}{l}H \\
- \\
\end{array}$ & $\begin{array}{l}130 / 58 \\
100 / 65\end{array}$ & $\begin{array}{r}55.5 \\
17.8 \\
\end{array}$ & 15 & 整快 \\
\hline 2 & 村O思口郎 & 20 & アンギナ & 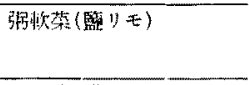 & - & $\begin{array}{l}2 \% \\
\pm \\
\end{array}$ & $\begin{array}{l}+ \\
- \\
\end{array}$ & $\begin{array}{l}+ \\
- \\
\end{array}$ & $\begin{array}{l}18 / 74 \\
101 / 60\end{array}$ & & 27 & 全治 \\
\hline 3 & 岩 $0 \times 0 x$ & 26 & アンギナ & 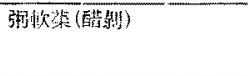 & $\begin{array}{l}+ \\
-\end{array}$ & $\begin{array}{l}+ \\
-\end{array}$ & $\begin{array}{l}+ \\
-\end{array}$ & + & $\begin{array}{l}99 / 50 \\
101 / 68\end{array}$ & $\begin{array}{l}56.0 \\
58.6\end{array}$ & 14 & 全治 \\
\hline 4 & 五 & 36 & $+\quad *$ & 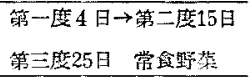 & $\begin{array}{l}+1 \\
-\end{array}$ & $\begin{array}{r}H+16 \\
1.8 \% \\
\end{array}$ & $\begin{array}{l}\text { H } \\
+ \\
\end{array}$ & $\begin{array}{l}+ \\
-\end{array}$ & $\begin{array}{l}150 / 100 \\
175: 105 \\
165 / 105 \\
\end{array}$ & $\begin{array}{l}60.0 \\
62.0 \\
\end{array}$ & 51 & 轻快 \\
\hline 5 & 安○ 瑟O & 16 & 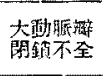 & 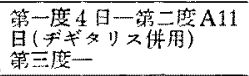 & $\begin{array}{l}+ \\
-\end{array}$ & $\begin{array}{l} \pm \\
-\end{array}$ & $\begin{array}{l}+ \\
-\end{array}$ & $\begin{array}{l}+1 \\
-\end{array}$ & $\begin{array}{l}\operatorname{lit}_{182} \\
130 / 72 \\
\end{array}$ & $\begin{array}{l}40.0 \\
37.0\end{array}$ & 55 & 轻快 \\
\hline 6 & 犬○丵○子 & 39 & 脚埭 & 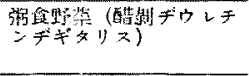 & - & $\begin{array}{l}+ \\
\pm\end{array}$ & + & $\begin{array}{l}+ \\
- \\
\end{array}$ & $\begin{array}{l}98 / 56 \\
101 / 66\end{array}$ & $\begin{array}{l}56.0 \\
58.3 \\
\end{array}$ & 7 & 阷快 \\
\hline 7 & 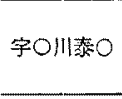 & 25 & 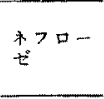 & 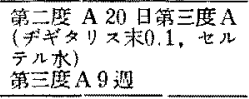 & H & $\begin{array}{l}\text { H } \\
+ \\
\end{array}$ & $\begin{array}{l}\text { H } \\
\pm\end{array}$ & $\begin{array}{l}+ \\
-\end{array}$ & $\begin{array}{l}146 / 45 \\
113 / 70\end{array}$ & $\begin{array}{l}72.7 \\
59.5 \\
\end{array}$ & 88 & 輕块 \\
\hline 8 & 小○原隺○ & 13 & 助募栄 & 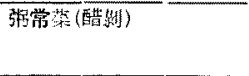 & $\begin{array}{l}+4 \\
-\end{array}$ & $\begin{array}{l}m \\
\pm\end{array}$ & + & $\begin{array}{l}+ \\
-\end{array}$ & & $\begin{array}{l}22.0 \\
\vdots \\
24.8\end{array}$ & 38 & 姃快 \\
\hline 9 & 贸O & 59 & 心瑟弱 & 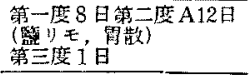 & $\begin{array}{l}\# \\
- \\
\end{array}$ & $\begin{array}{r}4 \\
+ \\
\end{array}$ & $\begin{array}{l}+ \\
-\end{array}$ & $\begin{array}{l}\text { Ht } \\
\pm\end{array}$ & $\begin{array}{l}145 / \mathrm{si} \\
120 / 98 \\
\end{array}$ & $\begin{array}{r}56.5 \\
1 \\
53.5 \\
\end{array}$ & 27 & 㱐快 \\
\hline 10 & 小O 八O & 59 & 皮病病 & 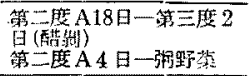 & $\begin{array}{l}+ \\
+\end{array}$ & $\begin{array}{l}0.4 \% \\
0.9 \%\end{array}$ & $\begin{array}{l}H \\
H\end{array}$ & $\begin{array}{l}+ \\
+\end{array}$ & $\begin{array}{l}140 / 70 \\
114 / 12\end{array}$ & & 106 & 军块 \\
\hline 11 & 本○石○助 & 29 & 脚井 & 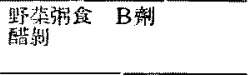 & $\begin{array}{l}H \\
-\end{array}$ & $\begin{array}{l}+11 \\
+ \\
\end{array}$ & $\begin{array}{l}H \\
\pm\end{array}$ & $\begin{array}{l}H \\
-\end{array}$ & $\begin{array}{l}150 / 118 \\
110 / 6 \pi\end{array}$ & $\begin{array}{r}61.3 \\
50.7 \\
\end{array}$ & 18 & 轻快 \\
\hline 12 & 罊O 熋O & 45 & 惨性管炎 & 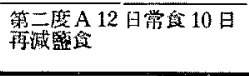 & $\begin{array}{l}+ \\
-\end{array}$ & $\begin{array}{l}+1 \\
+\end{array}$ & $\begin{array}{l}+ \\
-\end{array}$ & $\begin{array}{l}+ \\
-\end{array}$ & $\begin{array}{l}116 / 104 \\
140 / 1100\end{array}$ & $\begin{array}{r}39.0 \\
40.3\end{array}$ & 50 & 中退 \\
\hline
\end{tabular}

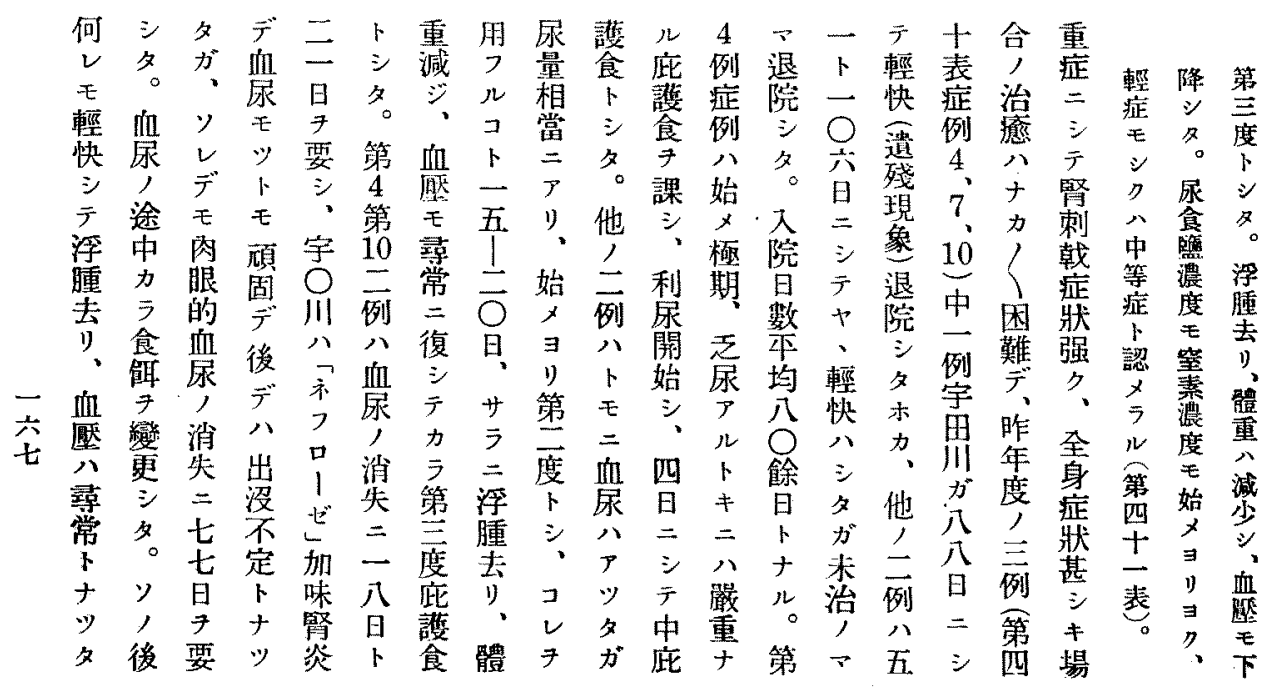




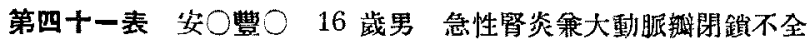

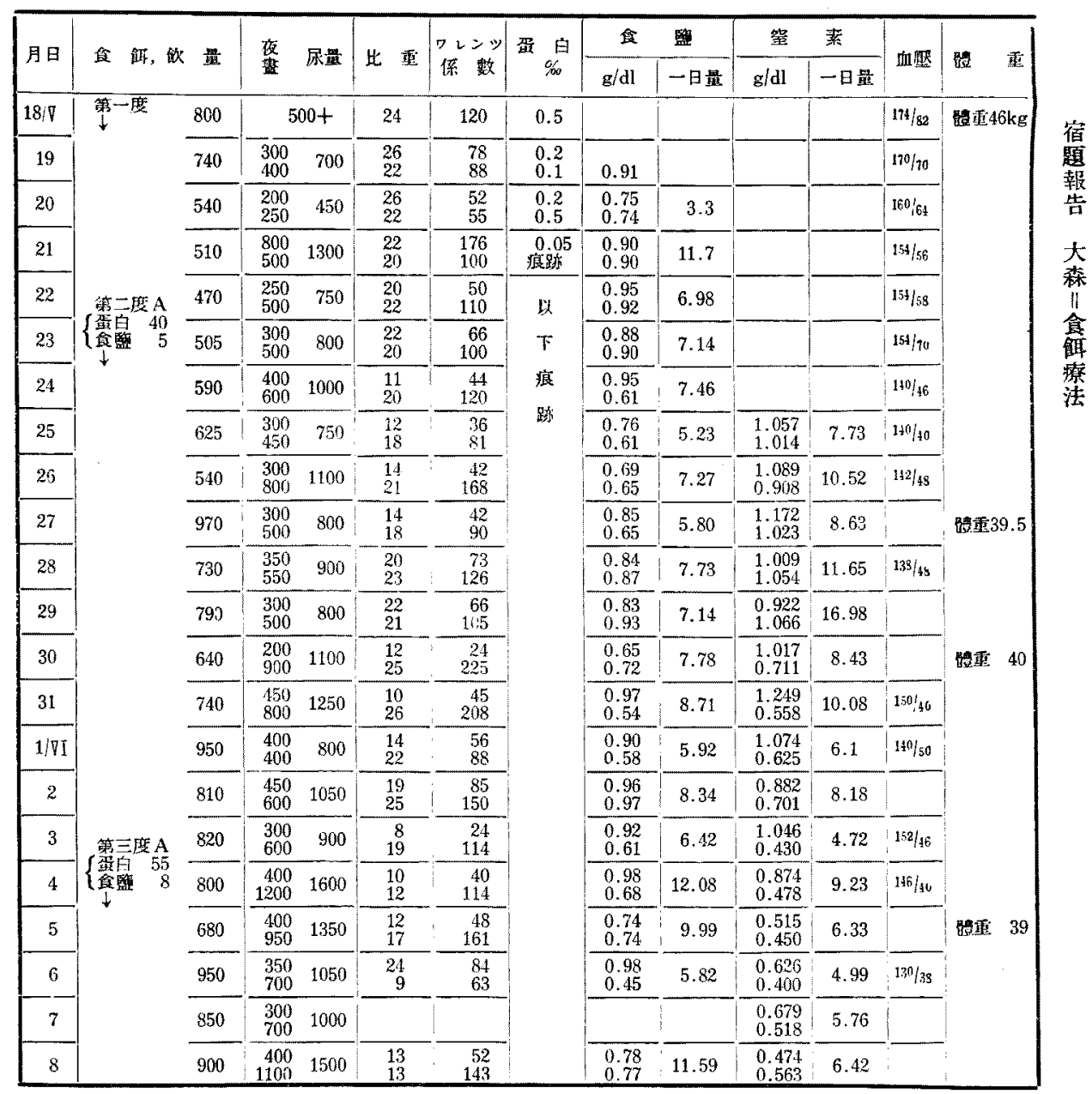

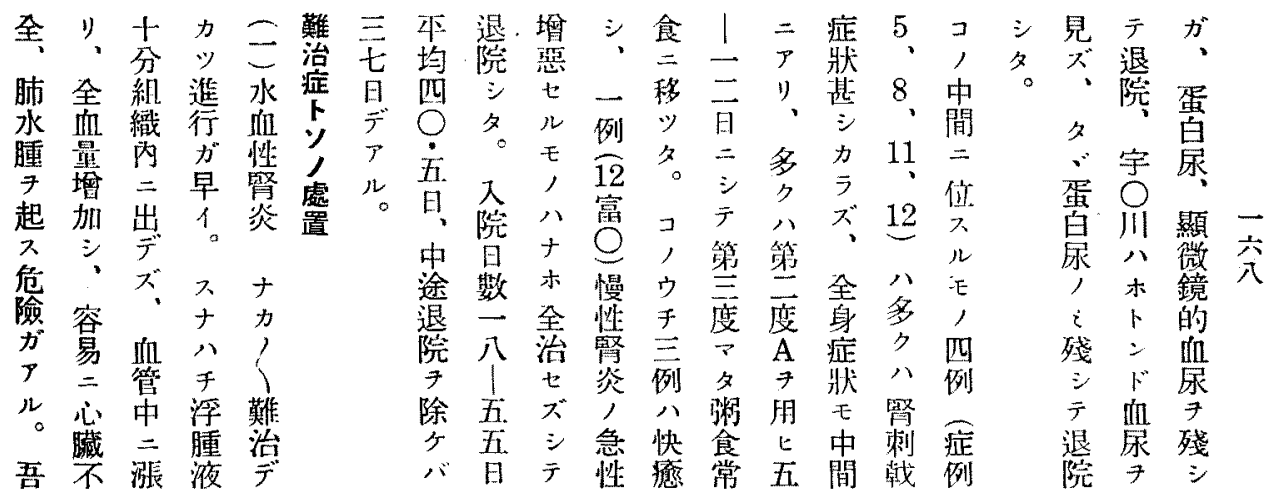


第四十二表 宇つ川つ一 25 歲男 急性腎炎(「ネフローゼ加味)

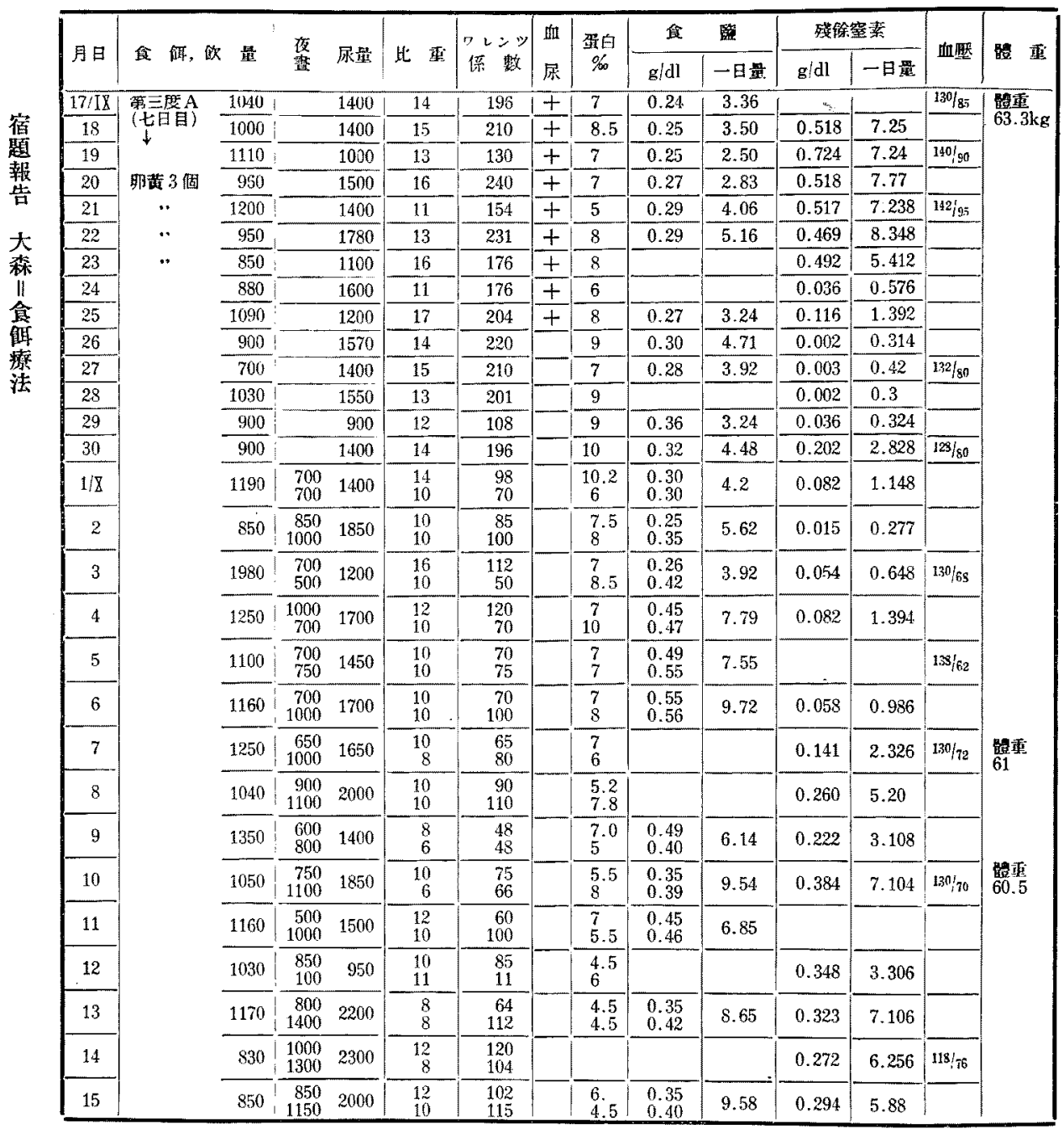

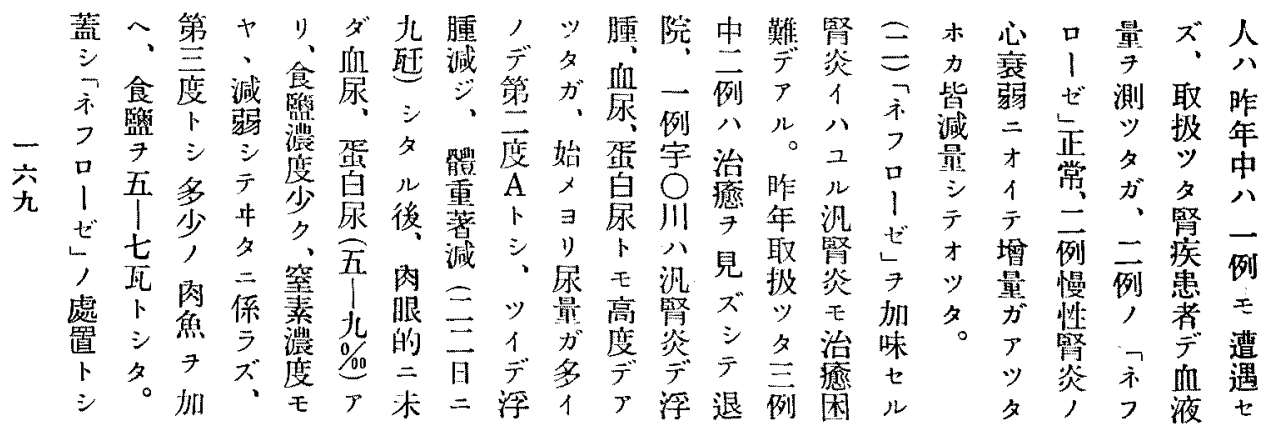




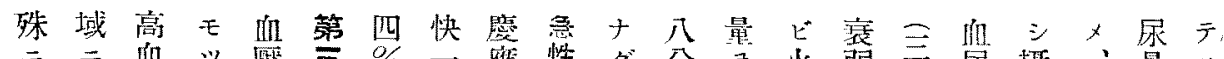

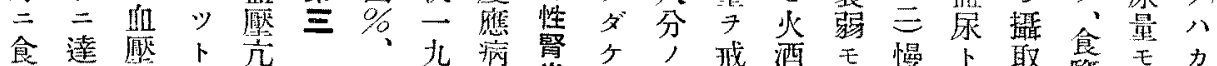

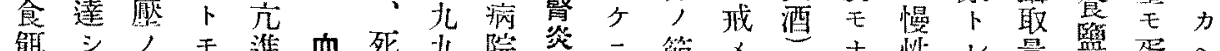

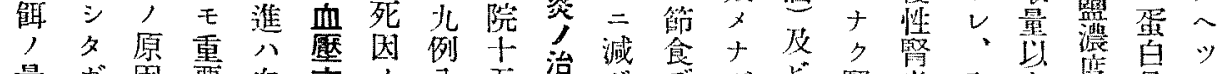

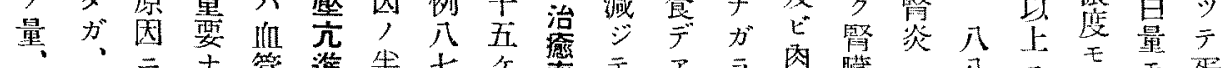

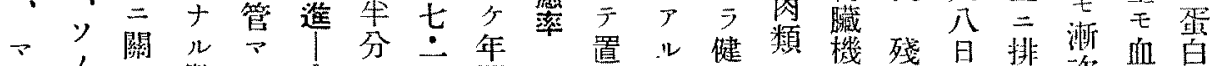

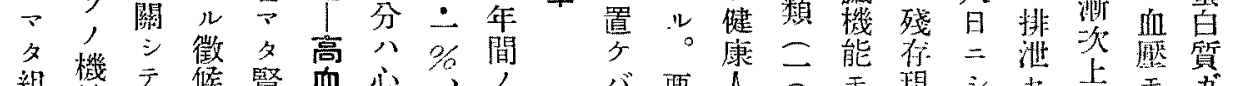

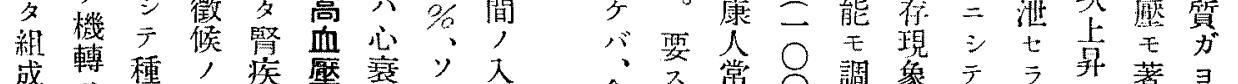

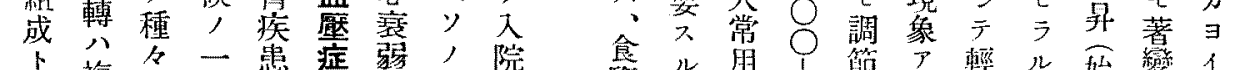
高複活

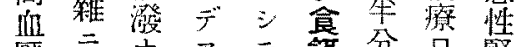

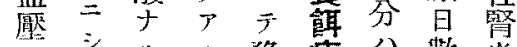

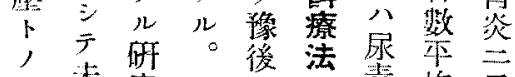

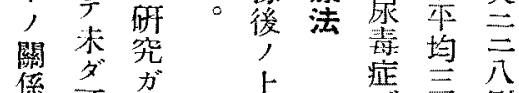

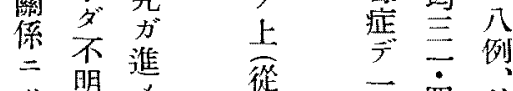

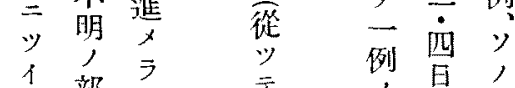

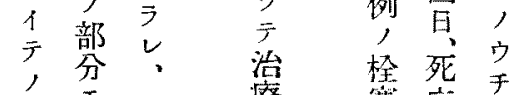

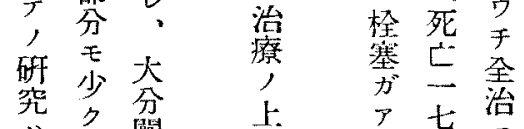

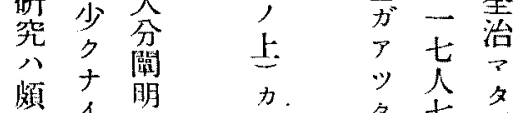

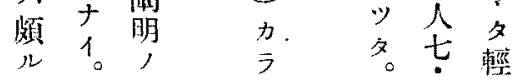

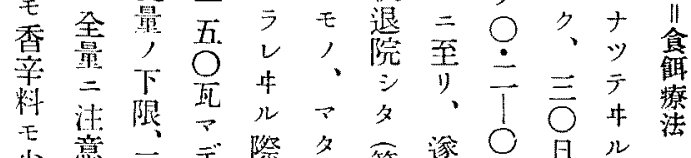

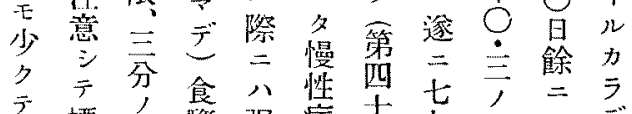

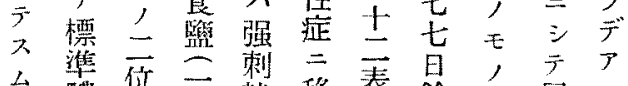

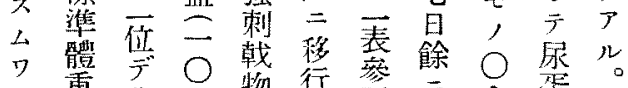

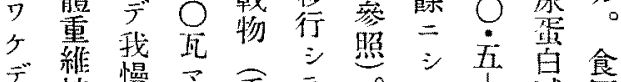

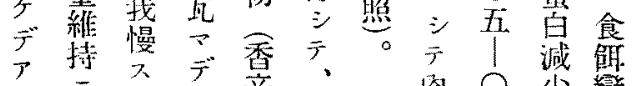

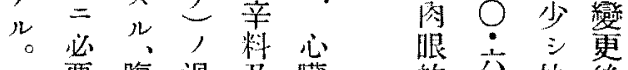
要腹過及臟的六始後

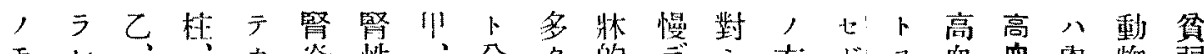

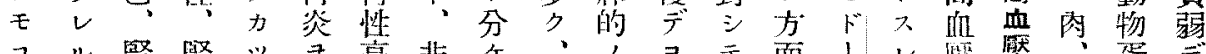

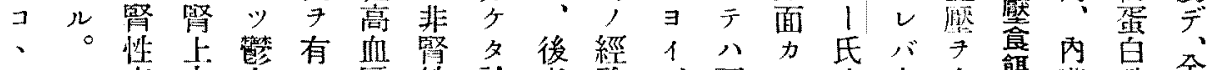

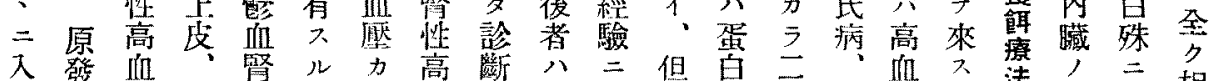

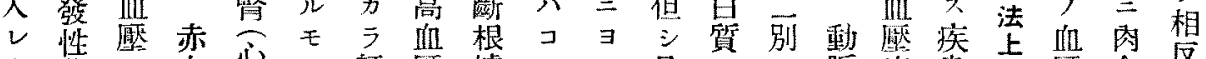

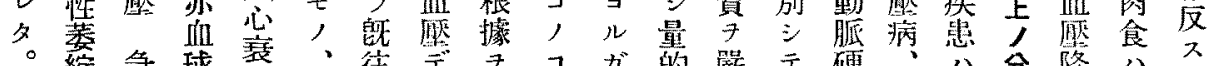

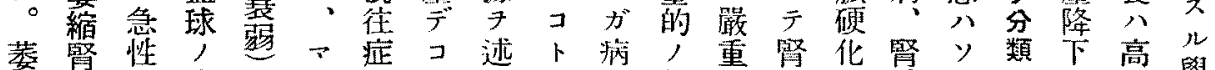

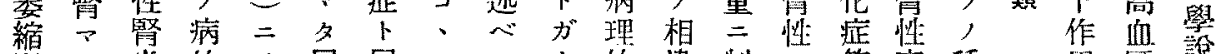

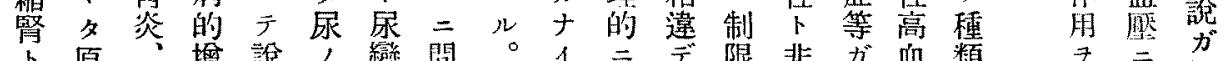

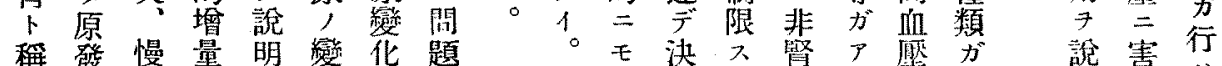

入 $、$ 性 $ア$, 化,

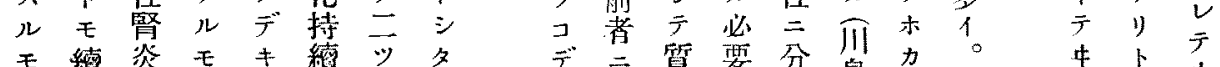

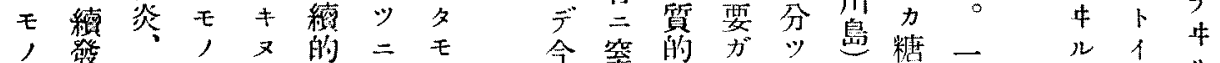

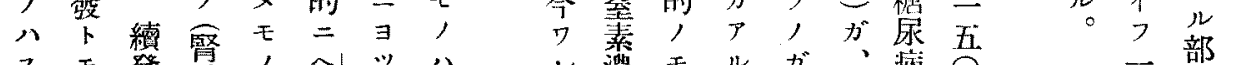

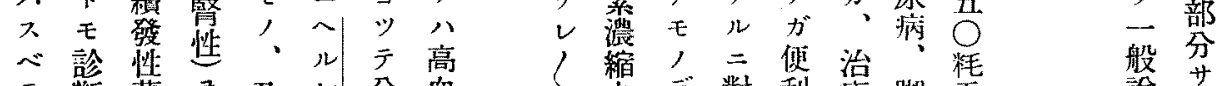

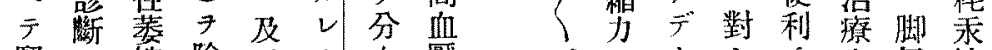

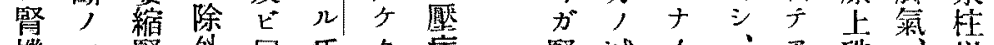

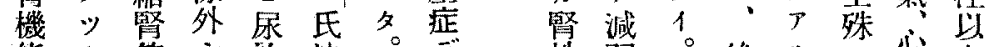

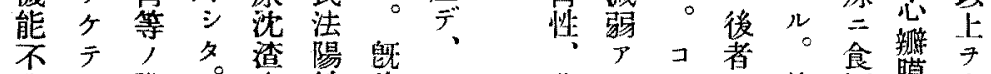

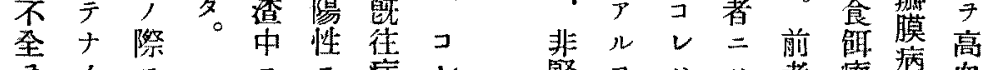

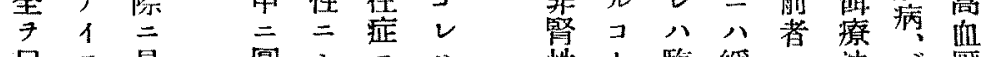

呈モ見圓シ三八性卜臨紱三法心厴 


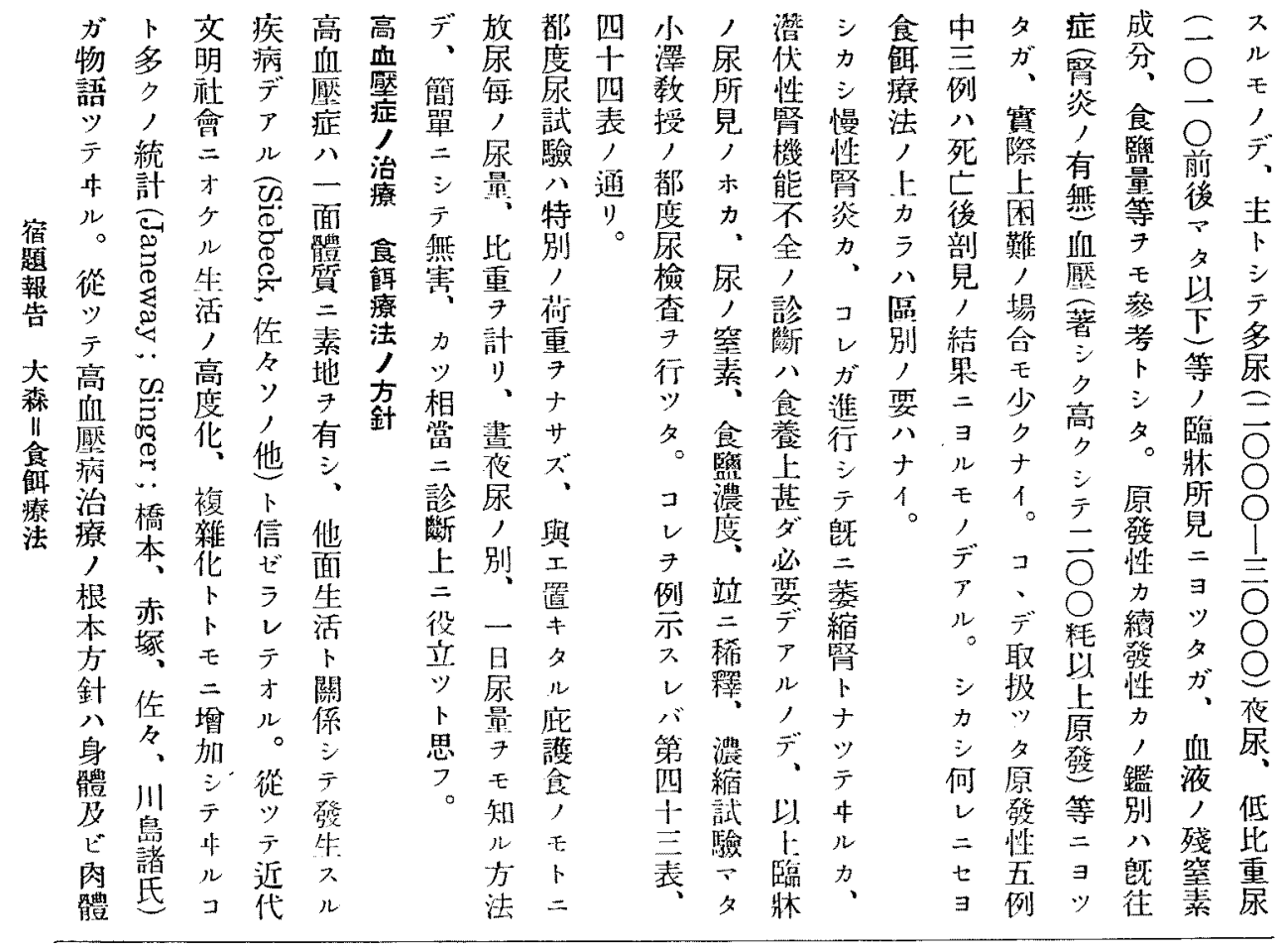

作，售食一低一テデ.1 維蛋等，二素人人高法，

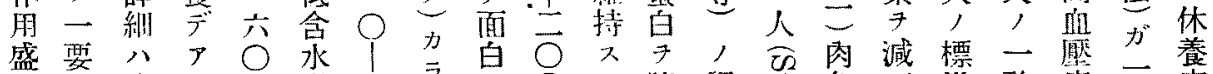
盛要

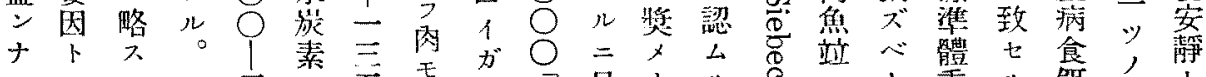

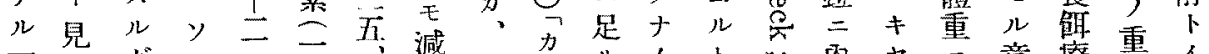
蛋 $\vec{\jmath}$ 只

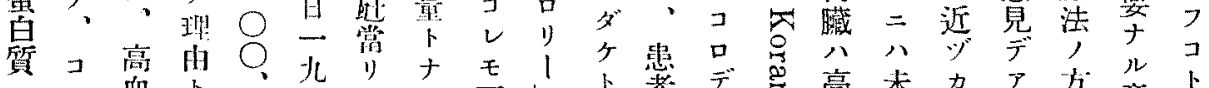

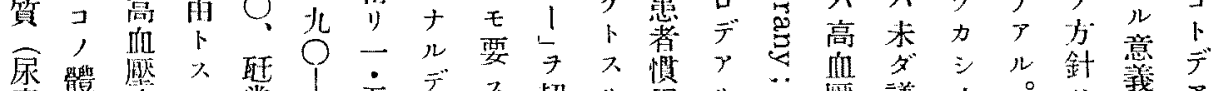

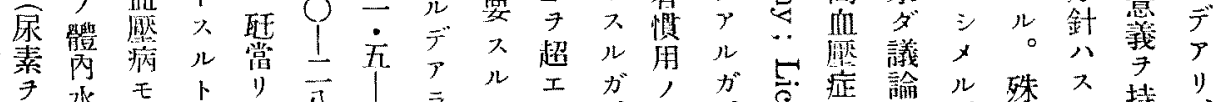
形分篮コ

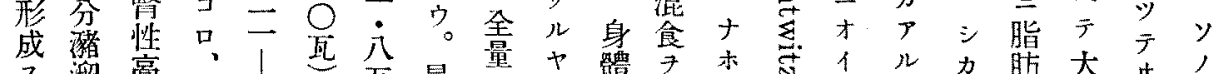

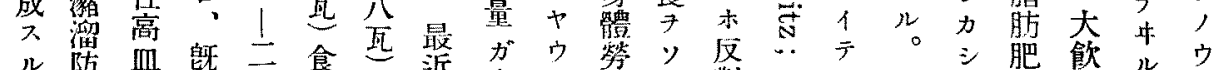

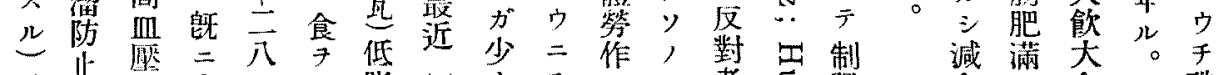

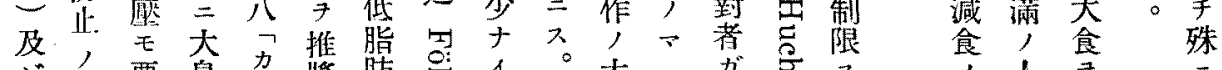

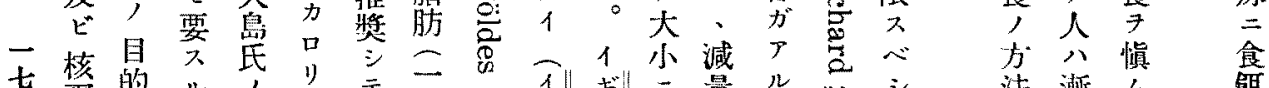
七核的公

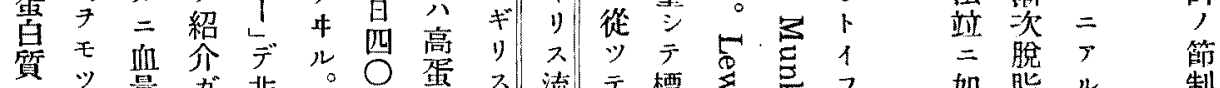

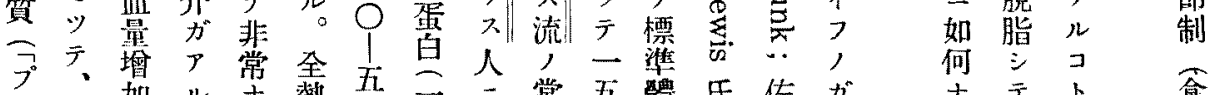

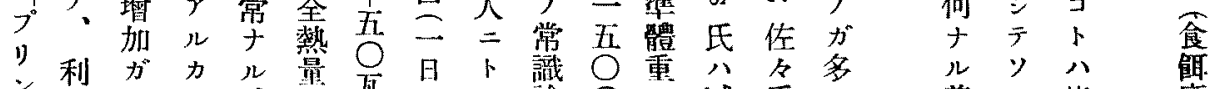
ン犁 
第四十三表＼cjkstart稀釋濃縮試驗 （山

口)

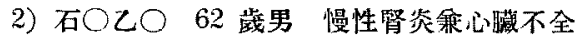

1) 中○直○ 25 歲男 慢性腎炎

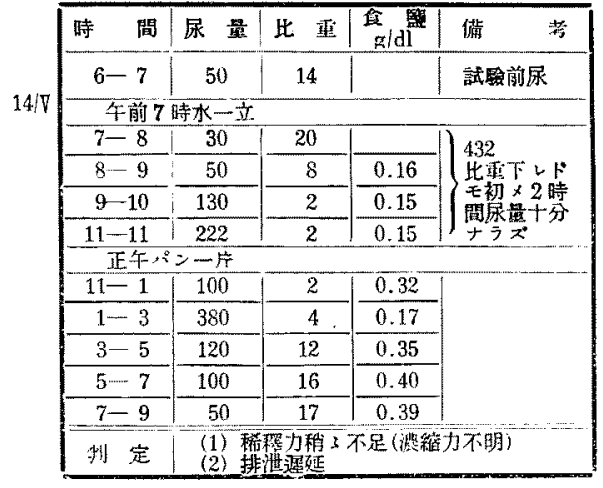

\begin{tabular}{|c|c|c|c|c|}
\hline 時問 & 尿 量 & 比重 & 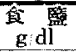 & 㒄 \\
\hline $6-7$ & 50 & 26 & 0.47 & 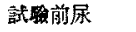 \\
\hline \multicolumn{5}{|c|}{ 竹前7時水一立 } \\
\hline $7 \div-8$ & 30 & 18 & 0.42 & \multirow{4}{*}{$\begin{array}{l}640 \\
\text { 此正下ラ }\end{array}$} \\
\hline $8-9$ & 300 & 8 & 0.07 & \\
\hline $9-10$ & 250 & 8 & 0.08 & \\
\hline $10-11$ & 60 & 11 & 0.21 & \\
\hline \multicolumn{5}{|c|}{ 正午バンー芹 } \\
\hline $11-1$ & 40 & 19 & 0.40 & \multirow{5}{*}{ 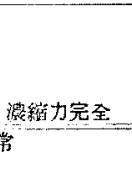 } \\
\hline $1-3$ & 20 & 25 & 0.25 & \\
\hline $3-5$ & 20 & 22 & 0.28 & \\
\hline $5-7$ & 15 & 32 & 0.34 & \\
\hline 判 定 & (2) \pm & 通征 & 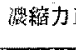 & \\
\hline
\end{tabular}

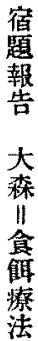

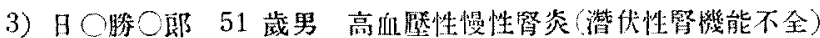

\begin{tabular}{|c|c|c|c|c|}
\hline 䦔 & 杘琵 & 比王: & 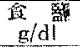 & 䔩 \\
\hline & & & & \\
\hline \multicolumn{5}{|c|}{ 午能 7 時水一立 } \\
\hline $7-8$ & 30 & 19 & 0.19 & \multirow{4}{*}{$\begin{array}{l}129 \\
\text { 比堽下ラス0 }\end{array}$} \\
\hline $8=9$ & 30 & 13 & 0.175 & \\
\hline $9-10$ & 35 & 17 & 0.15 & \\
\hline $11-11$ & 34 & 17 & 0.175 & \\
\hline \multicolumn{5}{|c|}{ 正午ベン一片 } \\
\hline $11-1$ & 70 & 20 & 0.19 & \multirow{6}{*}{ 源繀力不足 } \\
\hline $1-3$ & 75 & 18 & 0.185 & \\
\hline $3-5$ & 105 & 21 & 0.19 & \\
\hline $5-7$ & 100 & 19 & 0.13 & \\
\hline 7一㤠朝7 & 400 & 9 & 0.15 & \\
\hline 全排淤量 & 879 & & & \\
\hline 歫 定 & \multicolumn{4}{|c|}{ 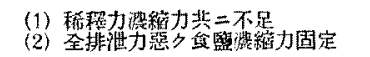 } \\
\hline
\end{tabular}

\begin{tabular}{|c|c|c|c|}
\hline 時間 & 展 量 & 比 正 & 蔽 \\
\hline $6-7$ & 80 & 16.3 & 試谽前尿 \\
\hline \multicolumn{4}{|c|}{ 午謿 7 時水一站 } \\
\hline $7-8$ & 30 & 17.6 & \multirow{4}{*}{$\begin{array}{l}295 \\
\text { 比开下ラ } 20\end{array}$} \\
\hline $8-9$ & 70 & 12.3 & \\
\hline $9-10$ & 70 & 8.5 & \\
\hline $10-11$ & 25 & 6.16 & \\
\hline \multicolumn{4}{|c|}{ 正称パン一片 } \\
\hline $11-1$ & 230 & 10.0 & \multirow{6}{*}{ 比杰上”成 } \\
\hline $1--3$ & 200 & 12.8 & \\
\hline $3-5$ & 230 & 14.5 & \\
\hline $5-7$ & 70 & 20 & \\
\hline 7 - & 450 & 14. & \\
\hline 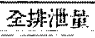 & 1475 & & \\
\hline 夘 定 & \multicolumn{3}{|c|}{ 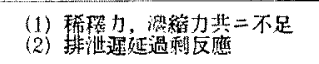 } \\
\hline
\end{tabular}

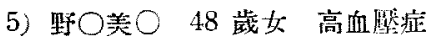

4) 10 重 0 郎 51 歳男 高血筷性慢性列炎

\begin{tabular}{|c|c|c|c|c|c|}
\hline 䦚 & 屡望 & 比开 & $\begin{array}{l}\text { 垔 } \\
\mathrm{g} / \mathrm{d} /\end{array}$ & 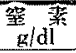 & 箖 \\
\hline $6-7$ & 30 & & 0.33 & 0.401 & 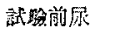 \\
\hline \multicolumn{6}{|c|}{ 年前 7 時本一立 } \\
\hline $7-7$ & 230 & 10 & 0.12 & 0.157 & \multirow{4}{*}{ 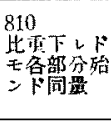 } \\
\hline $8-9$ & 230 & 0 & 0.10 & 0.072 & \\
\hline $9-10$ & 200 & 0 & 0.13 & 0.057 & \\
\hline $10-11$ & 180 & 0 & 0.21 & 0.101 & \\
\hline \multicolumn{6}{|c|}{ 正午ベン一垶 } \\
\hline $11-1$ & 290 & 11 & 0.55 & 0.143 & \multirow{6}{*}{ 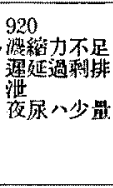 } \\
\hline $1-3$ & 100 & 14 & 0.59 & 0.286 & \\
\hline $3-5$ & 130 & 16 & 0.685 & 0.343 & \\
\hline $5-7$ & 120 & 20 & 0.70 & 0.501 & \\
\hline 7一翌朝7 & 280 & 26 & & 0.309 & \\
\hline 全排知量 & 1630 & & & & \\
\hline 刵 定 & $\begin{array}{l}(1) \\
(2)\end{array}$ & & & & \\
\hline
\end{tabular}

$13 / 7$ II

\begin{tabular}{|c|c|c|c|c|}
\hline 時闃 & 展量 & 比开 & 到 & 熘 \\
\hline $6-7$ & 53 & 17.8 & 0.96 & 却政前展 \\
\hline \multicolumn{5}{|c|}{ 午前神時水一主。 } \\
\hline $7-8$ & 15 & 7.1 & 0.80 & \multirow{4}{*}{$\begin{array}{l}510 \\
\text { 比西下うス }\end{array}$} \\
\hline $8-9$ & 120 & 7.6 & 0.00 & \\
\hline $9-10$ & 255 & 7.6 & 0.51 & \\
\hline $10-11$ & 120 & 12.3 & 0.52 & \\
\hline \multicolumn{5}{|c|}{ 正午ハン一年 } \\
\hline $11-1$ & 55 & & 0.80 & \multirow{6}{*}{ 此代上ラズ } \\
\hline $1-3$ & 53 & 13.6 & 0.70 & \\
\hline $3-5$ & 50 & & 0.90 & \\
\hline $5-7$ & 28 & & & \\
\hline 7 - $19 x$ & 350 & 21 & & \\
\hline 金排泄趾 & 1046 & & & \\
\hline 判 定 & \multicolumn{4}{|c|}{ 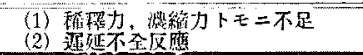 } \\
\hline
\end{tabular}


第四十四表 都度原試驗（山口）

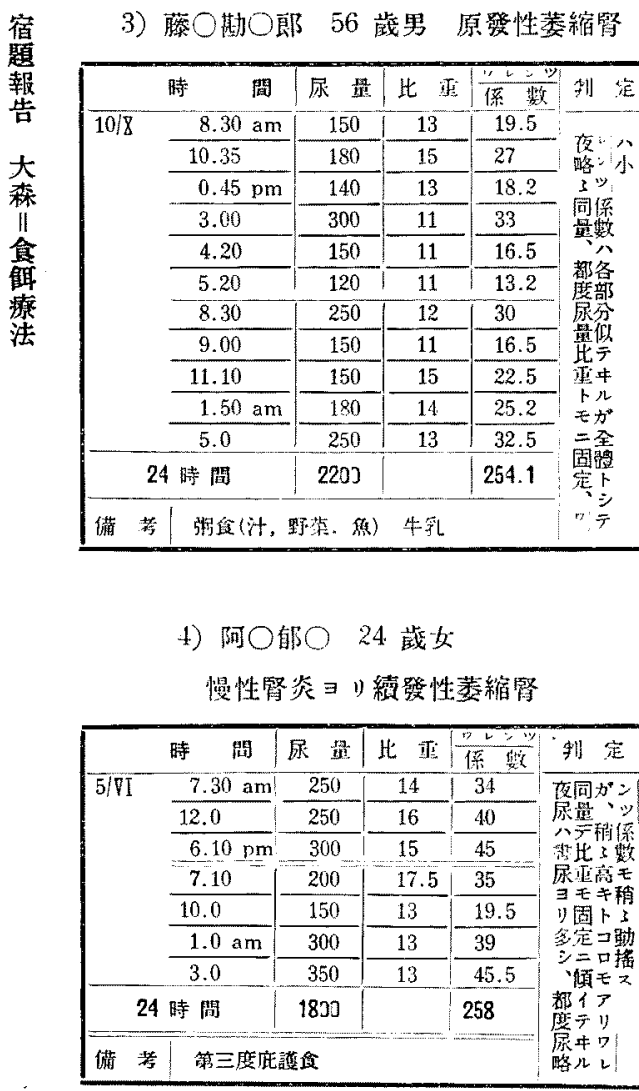

5）川○重○郎 51 歳男 慢性腎炎

\begin{tabular}{|c|c|c|c|c|c|}
\hline & 時成 & 层 畕 & 比 面 & 倿船 & 列) 定 \\
\hline \multirow[t]{7}{*}{$11 / 81$} & $7.20 \mathrm{am}$ & 95 & 14.7 & 14 & \multirow{8}{*}{ 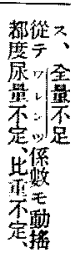 } \\
\hline & 11.10 & 200 & 18.3 & 36.6 & \\
\hline & $3.25 \mathrm{pm}$ & 130 & 18 & 23.4 & \\
\hline & 7.40 & 70 & 14.5 & 10.1 & \\
\hline & 12.0 & 50 & - & & \\
\hline & $4.0 \mathrm{am}$ & 50 & - & & \\
\hline & 7.0 & 100 & 14.3 & 14.3 & \\
\hline \multicolumn{2}{|c|}{24 時問 } & 695 & & $98.4(+)$ & \\
\hline
\end{tabular}

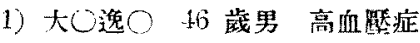

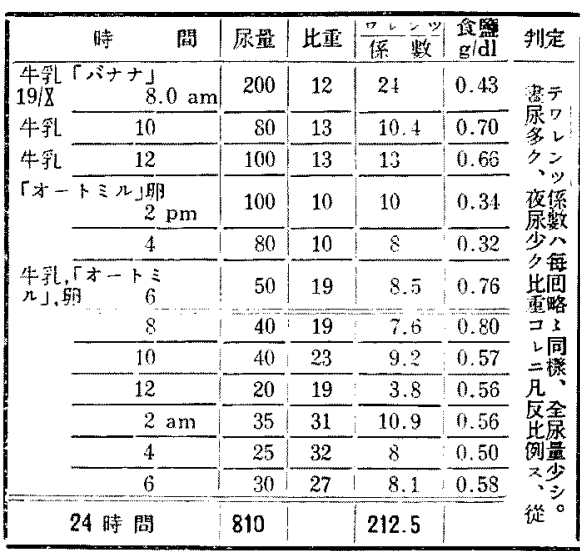

?）三○長○47藏男 高血磨症

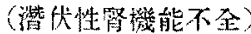

\begin{tabular}{|c|c|c|c|c|c|}
\hline & 閴 & 展 量 & 比 善 & 侄 数 & 舟 定 \\
\hline \multirow[t]{9}{*}{$20 / \mathrm{NI}$} & $7.10 \mathrm{am}$ & 260 & 13 & 33.8 & \multirow{11}{*}{ 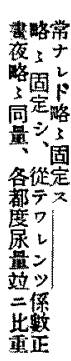 } \\
\hline & 8.50 & 250 & 13 & 32.5 & \\
\hline & 11.15 & 300 & 14 & 42 & \\
\hline & $2.0 \mathrm{pm}$ & 450 & 16 & 72 & \\
\hline & 3.40 & 250 & 13 & 32.5 & \\
\hline & 7.10 & 350 & 14 & 49 & \\
\hline & 8.40 & 250 & 14 & 35 & \\
\hline & $0.30 \mathrm{am}$ & 350 & 13 & 45.5 & \\
\hline & 6.25 & 350 & 15 & 52.5 & \\
\hline \multicolumn{2}{|c|}{24 時問 } & 2810 & & 394.8 & \\
\hline 维 苏 & \multicolumn{4}{|c|}{ 第三度庇護食 } & \\
\hline
\end{tabular}




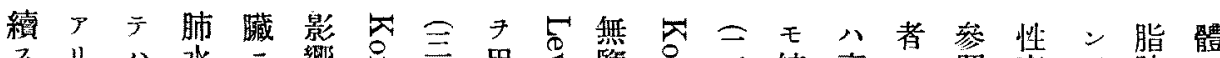

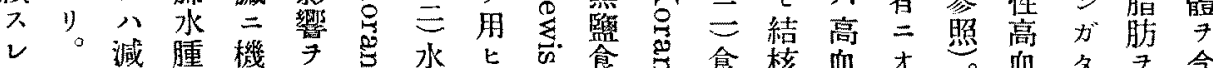

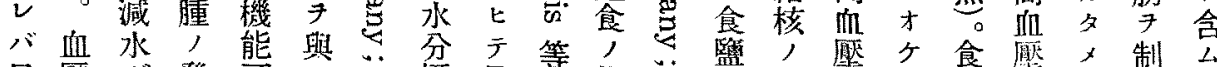

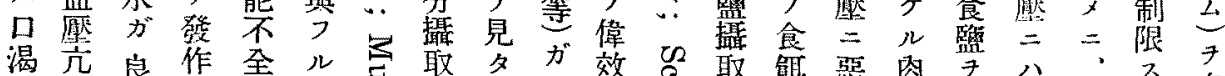
甚進量影

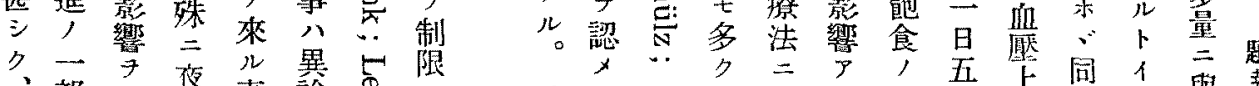

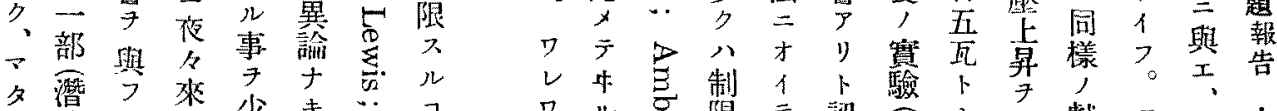
倦茯儿 莣悓 頭機 食示卜 ウ 延

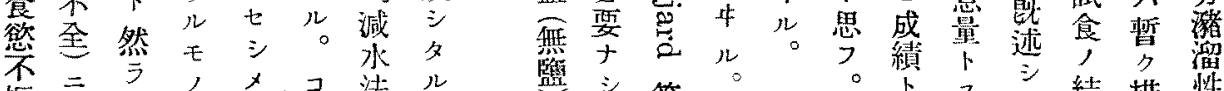
振

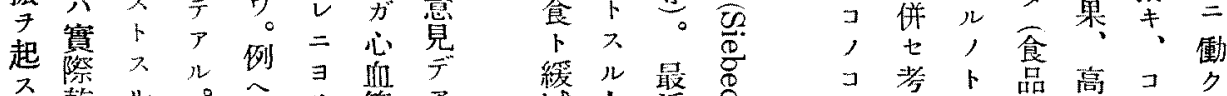

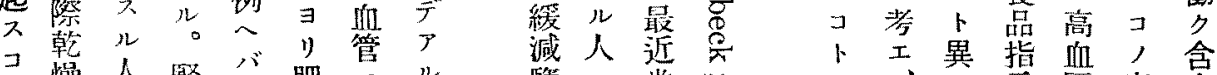

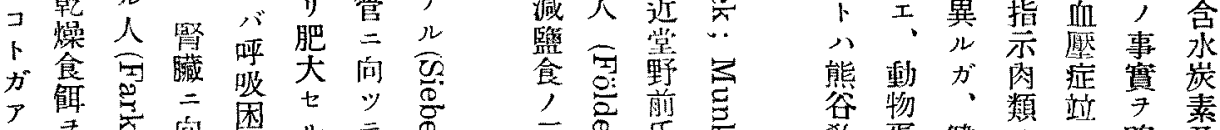

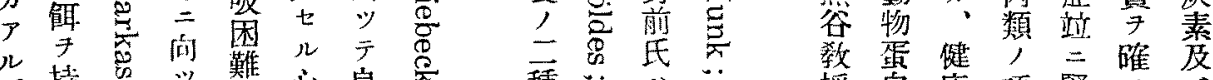

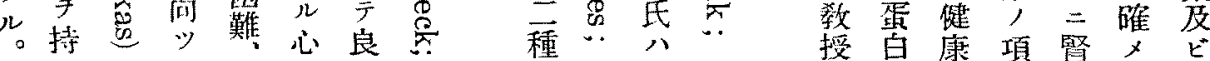

シ次二\%ルコ通場り賽氏一モ八胜全高二, デカ

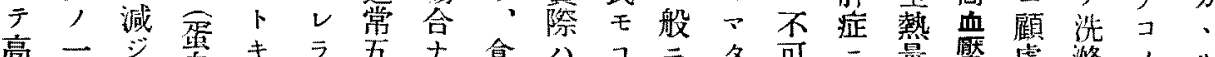

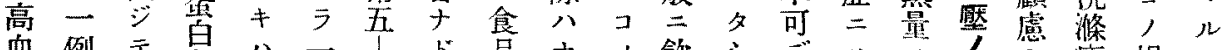
血例 テ蓆八-

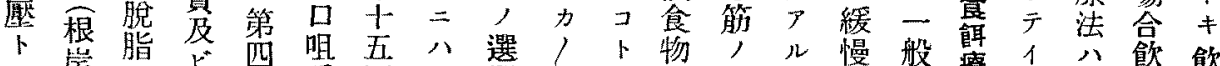

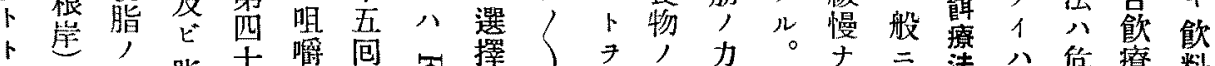

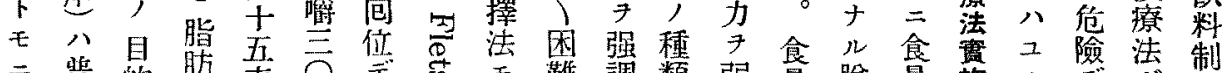

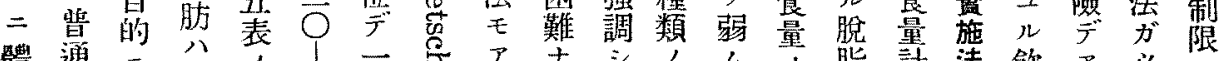

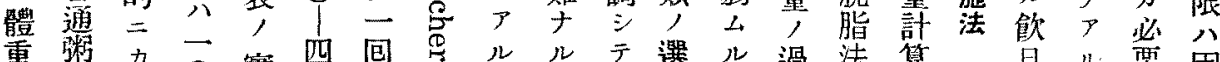

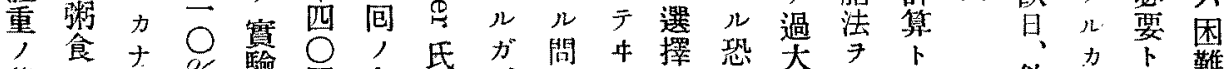
著々 フ。

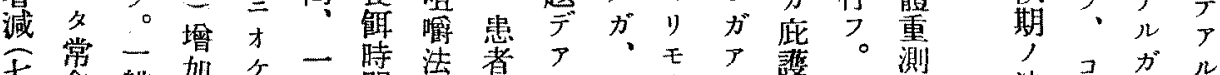
壬常一般前方

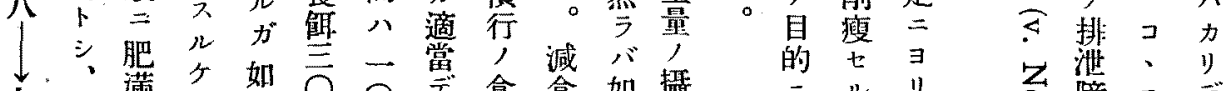
七咀著 レ゙ 如

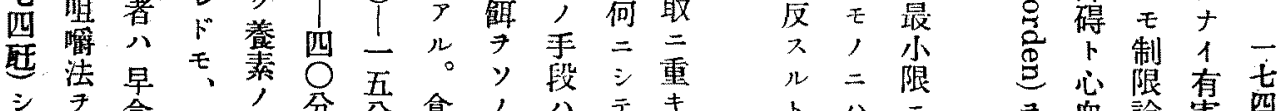

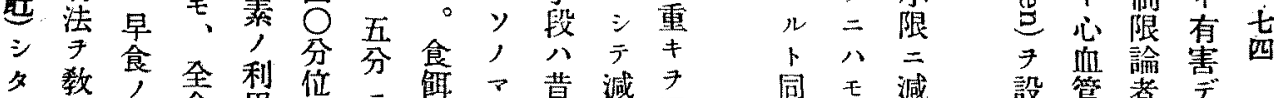

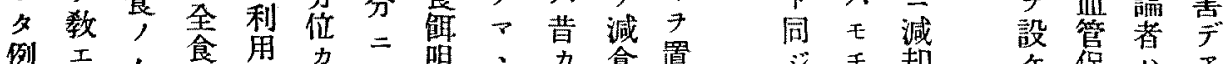

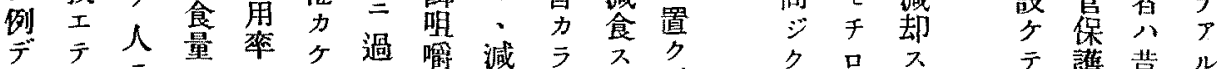

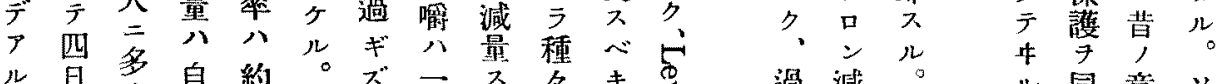

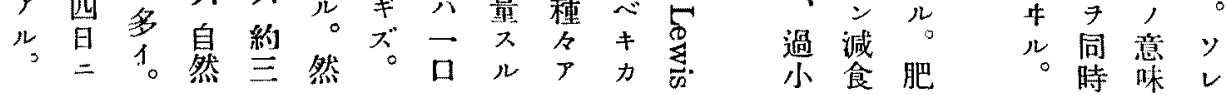




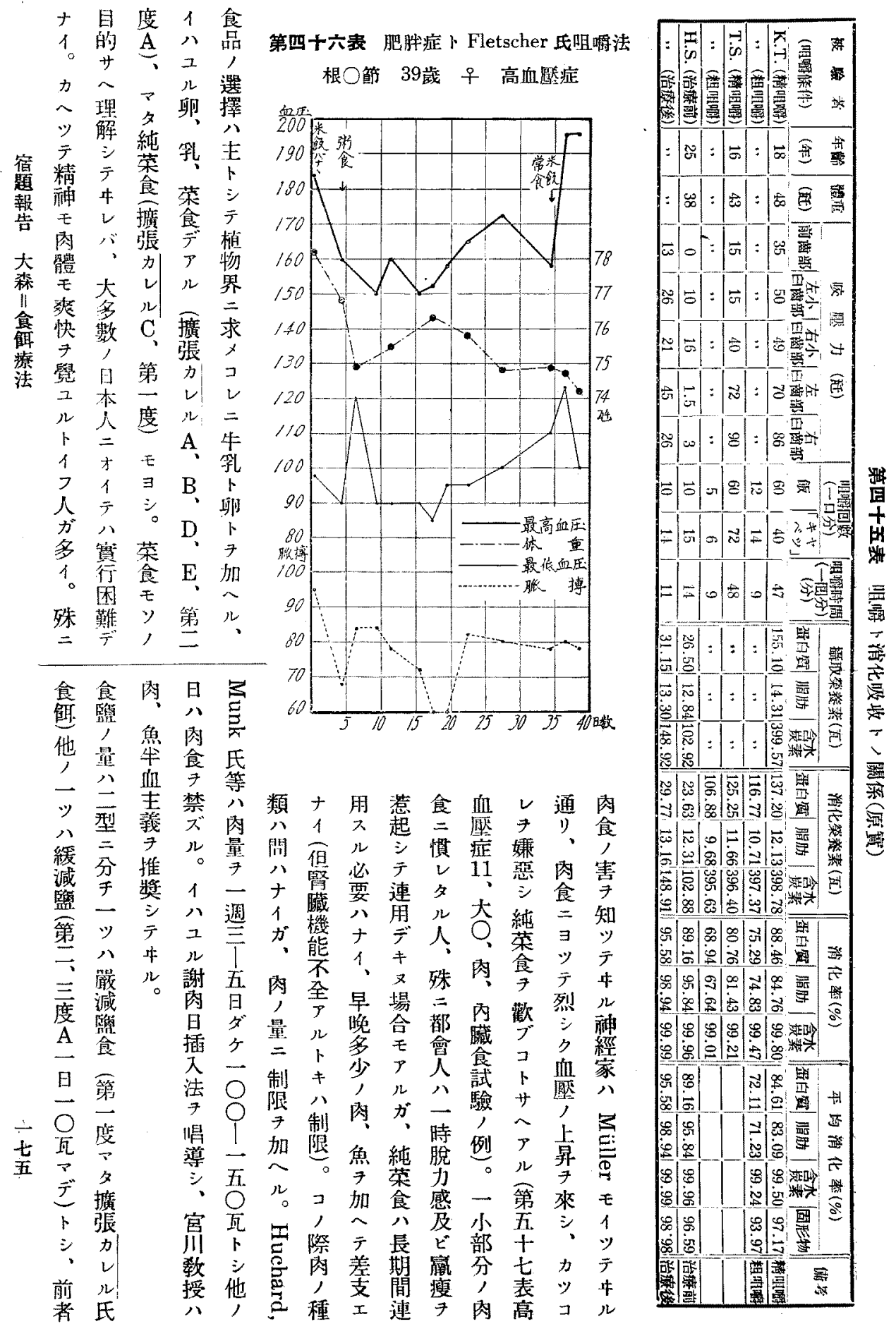


y係第三效

コ分多果

固り吾表桨

定 始 舞 固 標

ル篒定準

モ $\stackrel{1}{三}$ デ

ガ 百明至襐

多来力卧

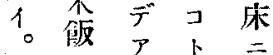

》多儿健

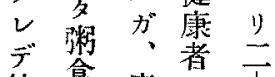

始食病者

メ $三$ 者實主

三 血 \begin{tabular}{llll} 
第 & $\vdots$ \\
\hline
\end{tabular}

百磿然宍テ

, 八モ表血

测下同兊厴

定降樣食分

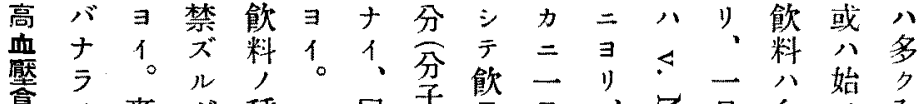

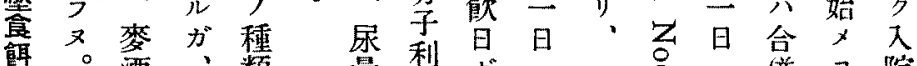

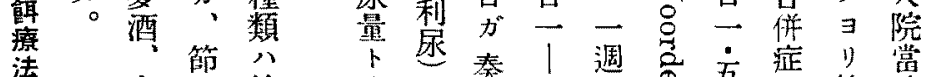

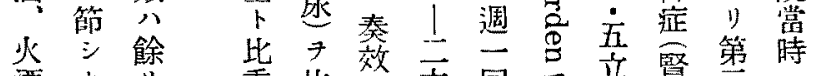

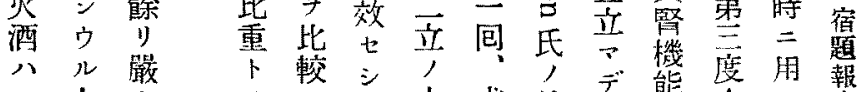
ヨ人シ,

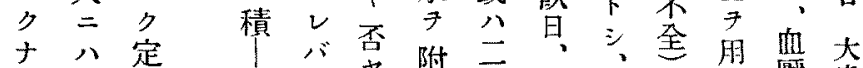

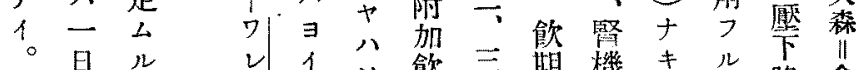

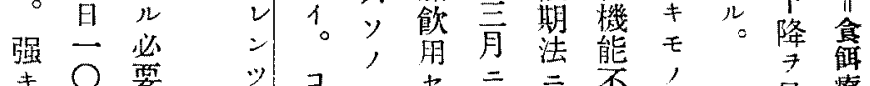

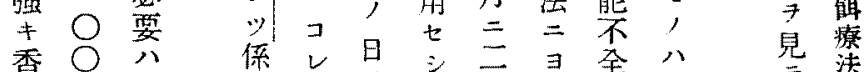
香○分係レ旦シテ寻全八見法

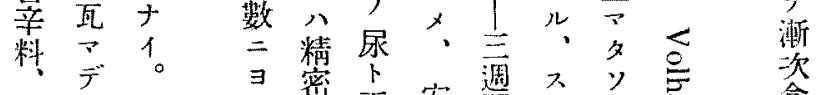

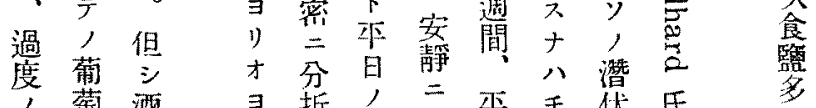

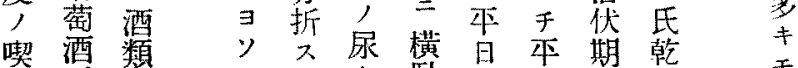

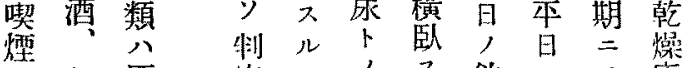

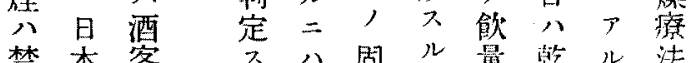

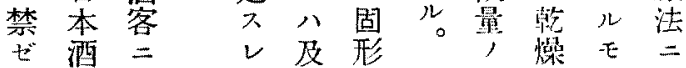
亦八ババ成果木法, 則年。

血次

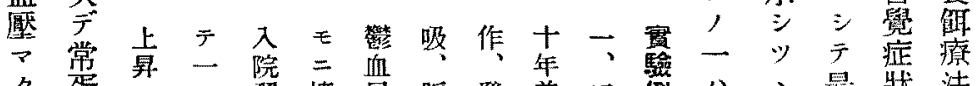
關 降

y示 = 自食

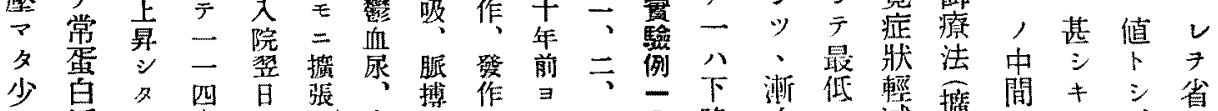

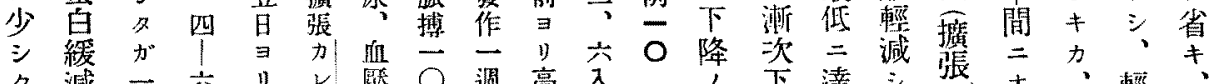

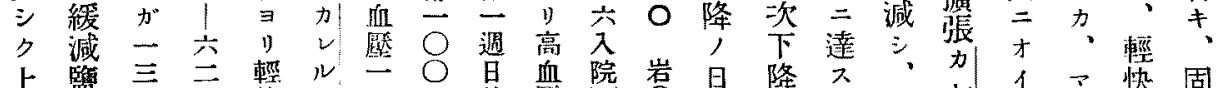

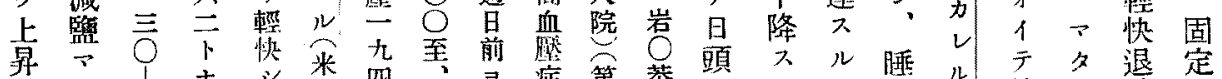

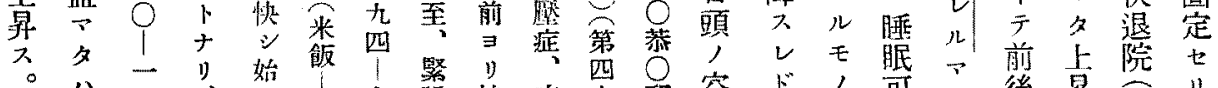

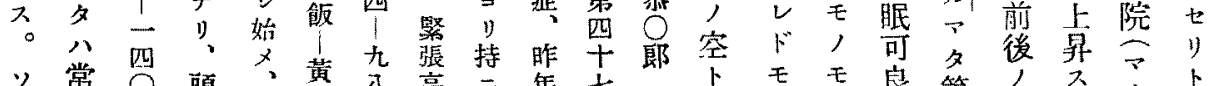

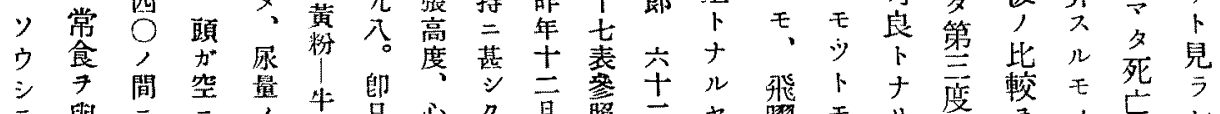

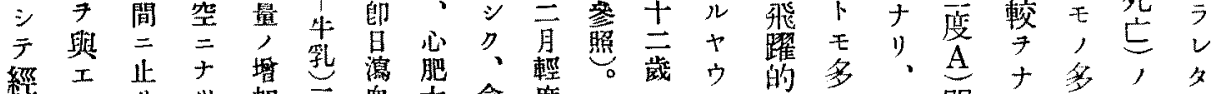

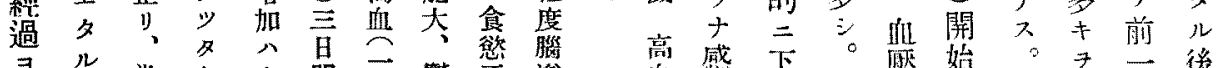

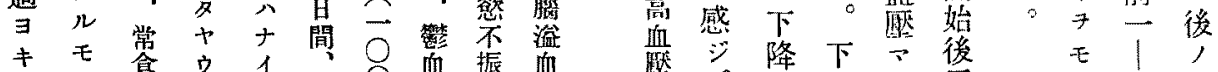

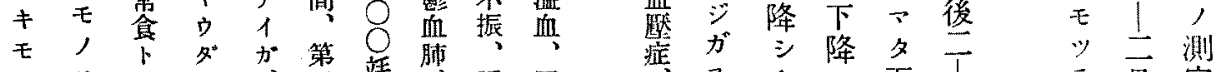

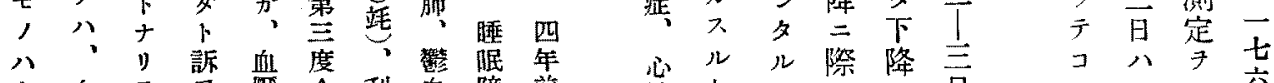

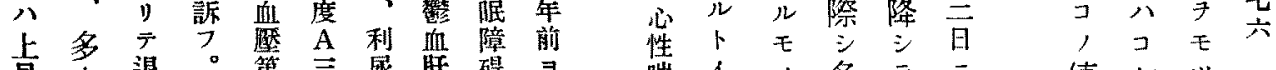

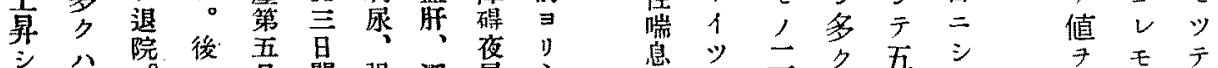

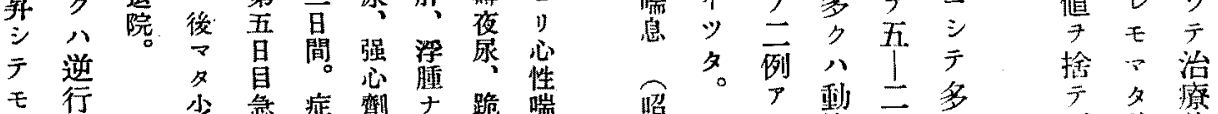

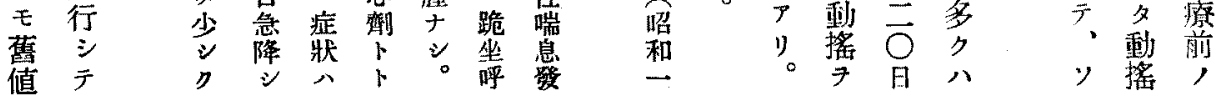




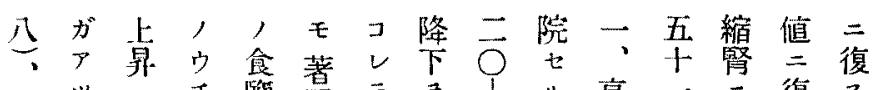

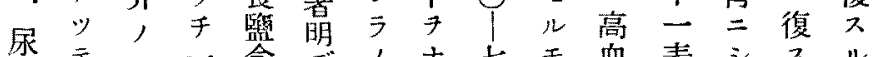
嚳层傾

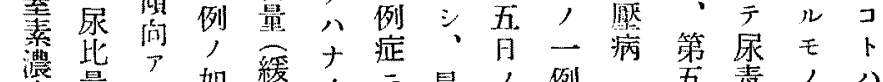

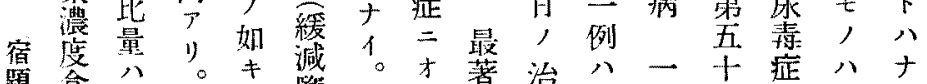

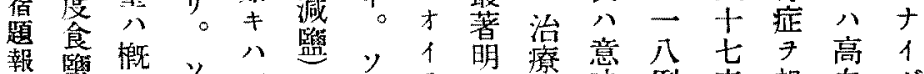
告裖香ウ再 $ォ$, テナ二味例表起血が

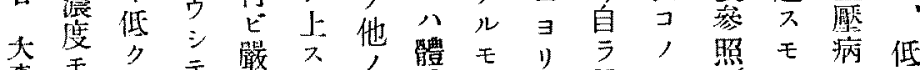

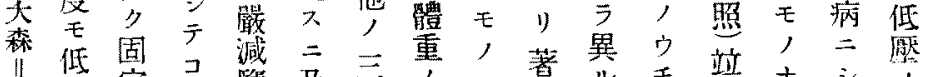

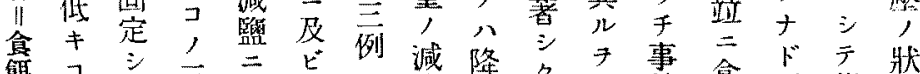

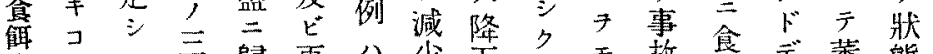
潦

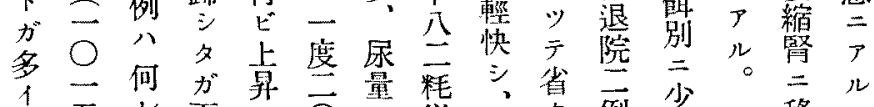

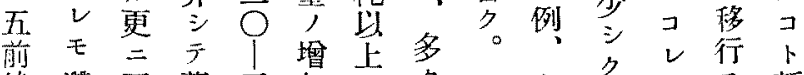
後穊下萑三加士ク一心詳

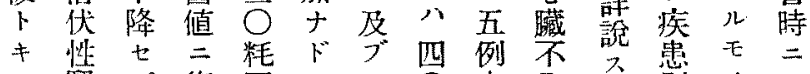

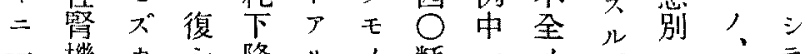

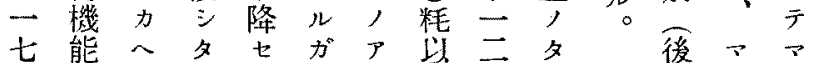
|不 $\%$ 、必》上例 メ項夕夕 一全テソモシ。方少入第萎舊

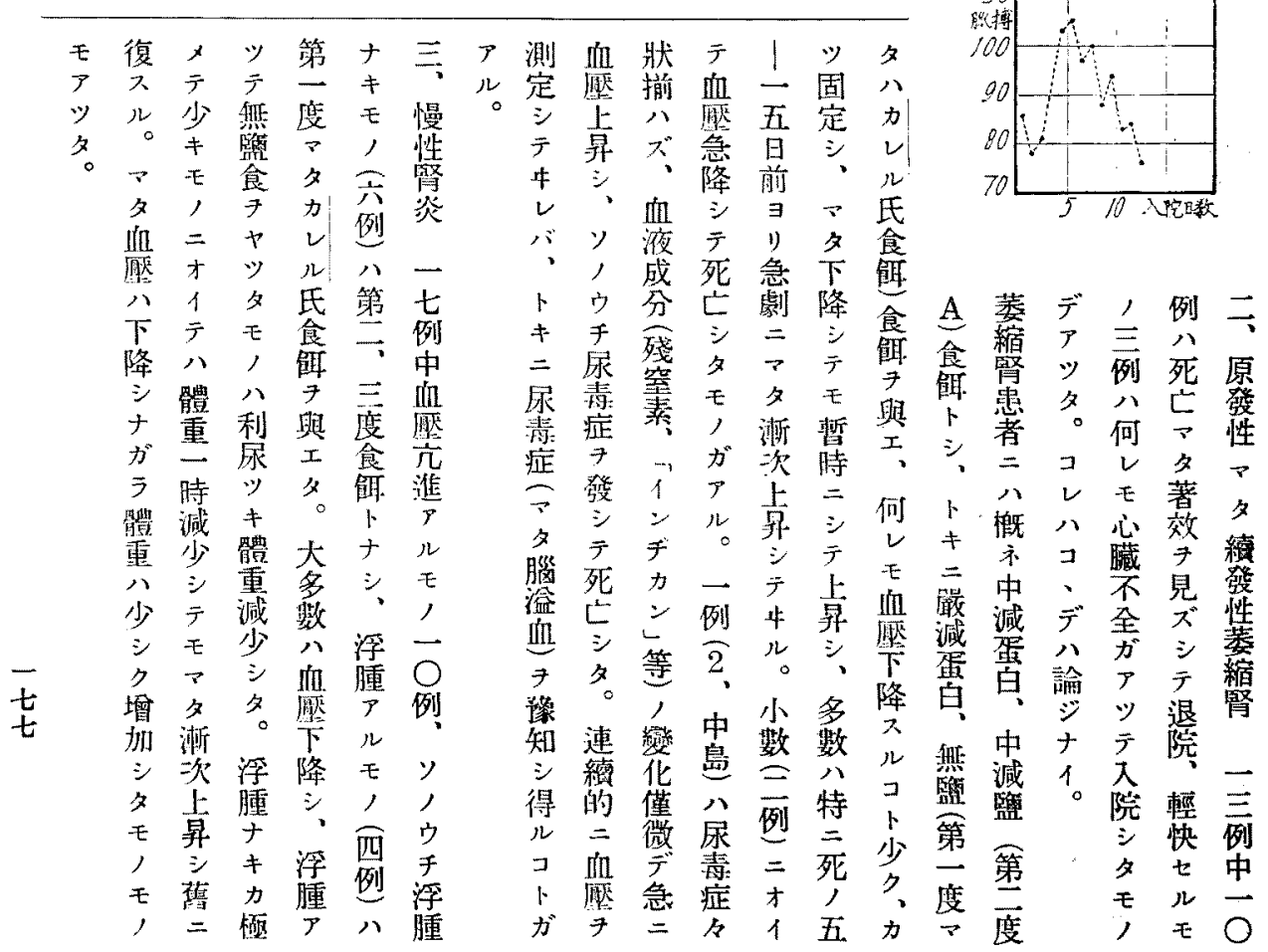

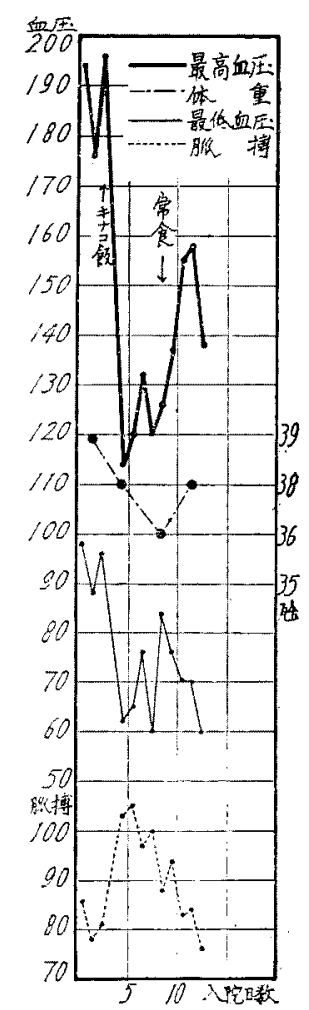


第四十八表 皆○信 $\bigcirc 75$ 歳 + 萎縮腎

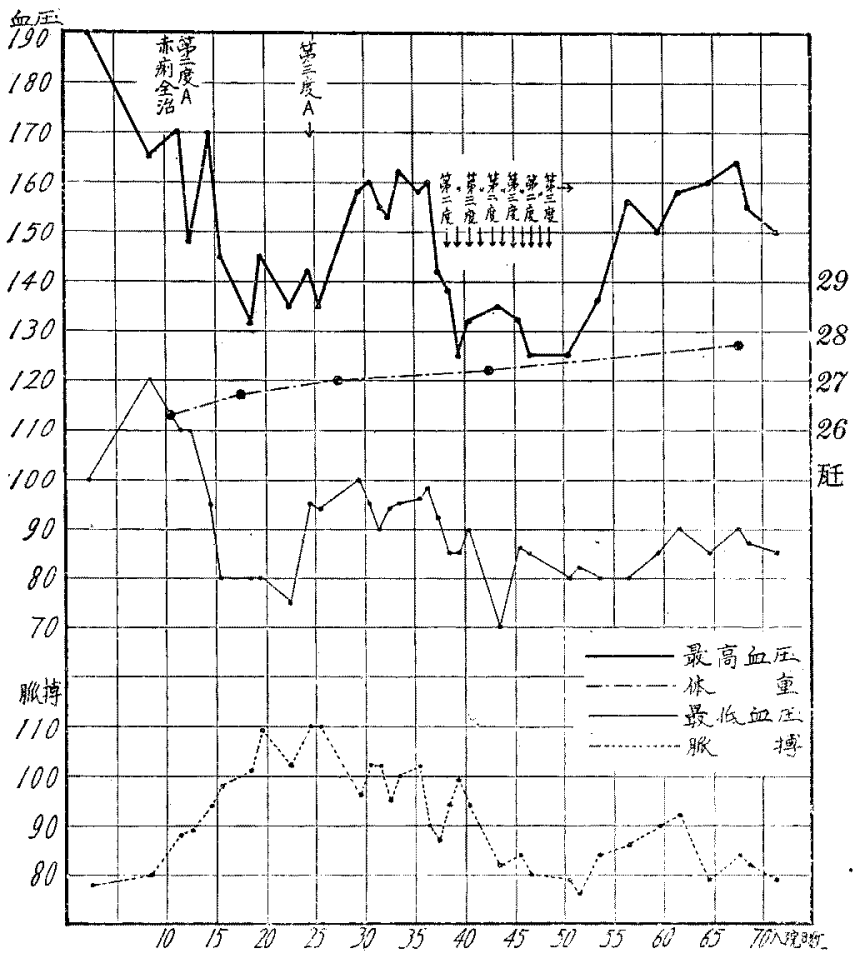

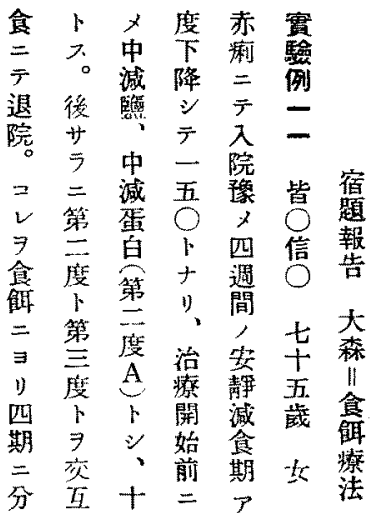

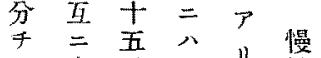

觀士日再 少。性

察 三シ九光九筷

ᄀ $\vec{日} \bar{\bigcirc}$ 院

$\checkmark$ 用䌅

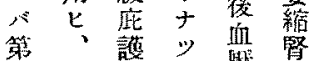

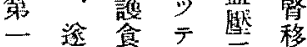

期三第

中第 第 タ。四 型

娍度度始二

第四十九表 高血瘘症，食聑别

度及ビ血壁，最モ低下スルニ要スル日数

\begin{tabular}{|c|c|c|c|c|c|c|c|c|}
\hline & \multirow{2}{*}{ 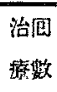 } & \multirow{2}{*}{ 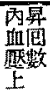 } & \multicolumn{3}{|c|}{ 血照隆下库 } & \multicolumn{3}{|c|}{ 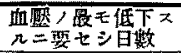 } \\
\hline & & & 鼠太 & 冣小 & 平均 & 鼠長 & 最短 & 平鸪 \\
\hline 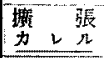 & 7 & 1 & 46 & $\begin{array}{c}(+) \\
15\end{array}$ & 32.2 & 15 & 4 & 10 \\
\hline 第 & 3 & 0 & 67 & 40 & 49.0 & 17 & 8 & 12.0 \\
\hline (频 悬) & 4 & 0 & 50 & 20 & 38.5 & 24 & 7 & 15.2 \\
\hline 第三度 & 4 & 0 & 90 & 0 & 41.5 & 17 & 5 & 12.0 \\
\hline
\end{tabular}

断降 ビルジ䈍

恝原 $又$ 及六 $=$

シ 因

十又六夕少、代血

入力八゙既シ再卜屏

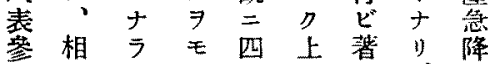

照卜 又

モ。テ閏

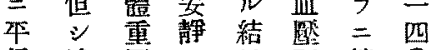

行減章, 果第 0

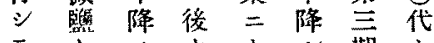

丁 $卜 丿 ナ+\%$ 期

戀減》レッ $レ コ+$

化蛋メ， テー， リ

皇二安中三中

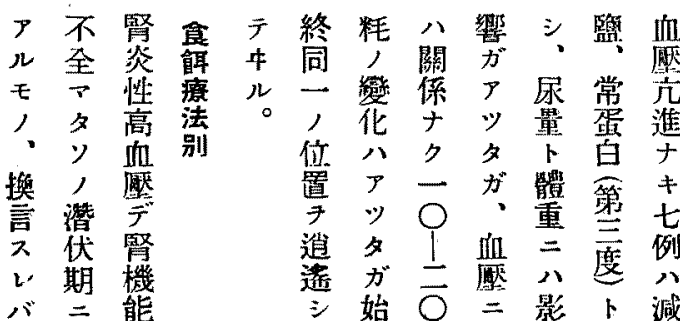

テ卡静ル。代減第

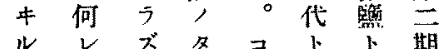

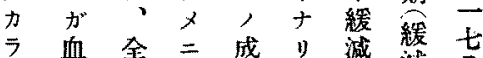

不孟全 $\bar{\gamma}$ 絰! 減娍入

明 三治 ラ 7 遂

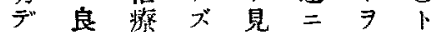

ア影，第交子

儿響 效 $\nabla=$ 四互

妿果 血期 $=$ 厂

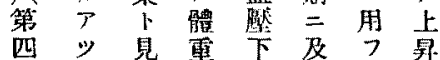


第五十表 楠 $\bigcirc$ 寺 $\bigcirc$ 郎 44 歲 高血塬症十筋肉性心藏不全

宿
題
告
大
森
㗏
療
注

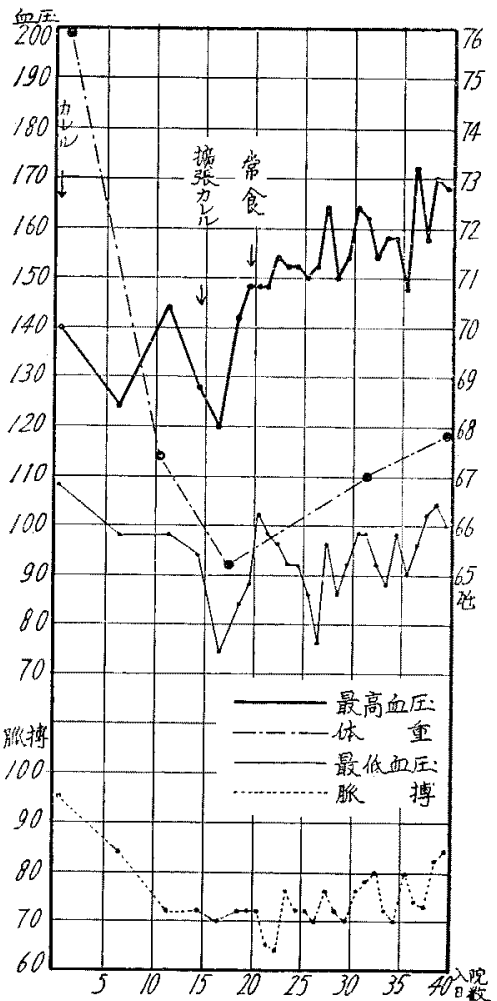

緩照ココナ非遷餌待白原

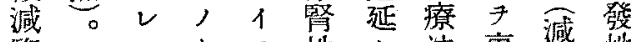
㽉二ウモ些七法裹筬性

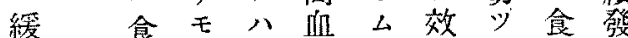

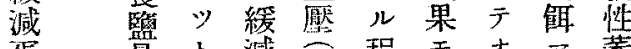
蛋量卜減高程モ才け萎

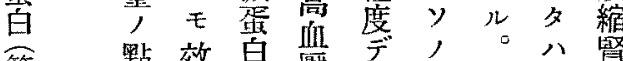

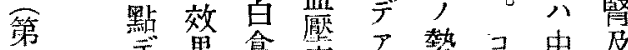

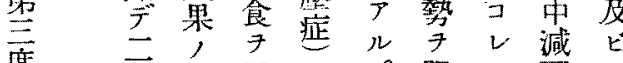
度種荖明垃。阻八嘼 , 奛 $上=$ 歨病白 第異デ、慢齐氮食近

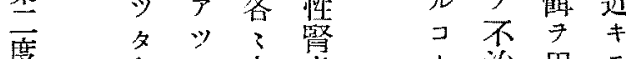
A 食夕良炎治用七

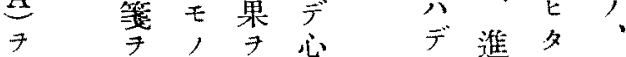

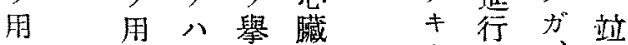
七 七高な゙禁ナ性、 夕夕血儿全付于り尿

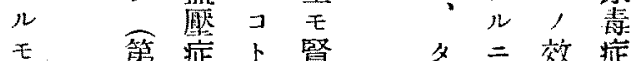
, 四 $\vec{\nabla}$ ガ機济果二

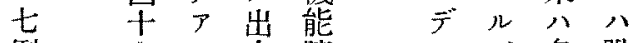
例 北儿来障年多嚴

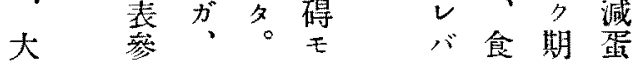

ナ柬二日血䉷見最八又部 シ易高デ厴減儿後正儿分 夕 1 di $>$ 降監コア，日， ○、椟儿下緩トデ食數卓 y從症。度減吕續監八效 ウッ, 但龺蛋殆行ガ二ア

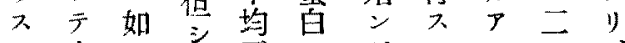

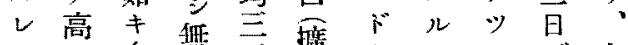

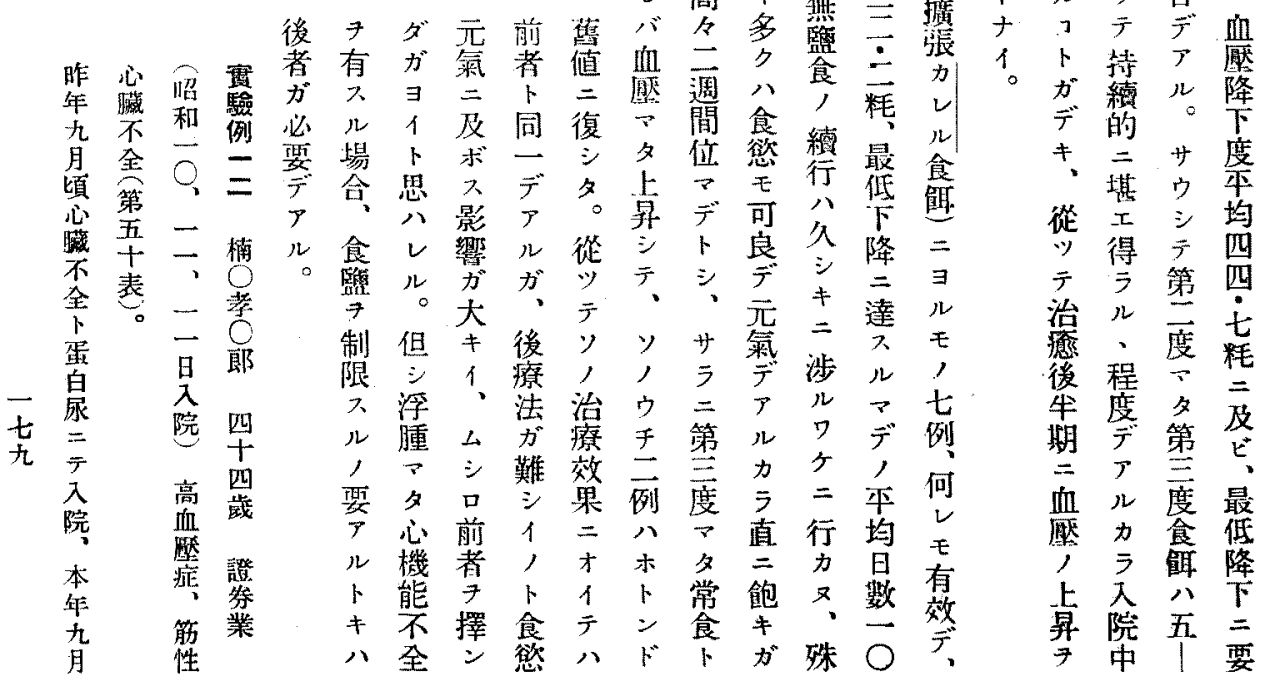


第五十一表 入院時(治潦前)卜退院時(治潦後)ト，血䵇ニッイテ

\begin{tabular}{|c|c|c|c|c|c|c|c|c|c|c|c|c|c|c|}
\hline 䣦 括 方 向 & 1 & & 昇 & & & & 下 & & P & & & & 動 & \\
\hline 病名 勲捙值 & $30-$ & $20-$ & $10-$ & 0 & -10 & -20 & -30 & -40 & -50 & -60 & 61 & 聂大 & 鼠小 & 平均 \\
\hline 高 血 唯症 & & & & & 1 & 1 & 2 & 4 & 3 & 0 & 4 & 82 & 10 & 42.8 \\
\hline 慢性腎炎 & & 2 & 4 & & 1 & $\overline{1}$ & 5 & 2 & 1 & 1 & & 56 & 5 & 24.5 \\
\hline 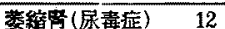 & 1 & 1 & 4 & & & 1 & 1 & 2 & 2 & & & 45 & 5 & 22.8 \\
\hline 急 性 堅 焱 & & 1 & 1 & 1 & & 4 & 2 & & & & 1 & 70 & 0 & 20.8 \\
\hline 「ネフロ-ぜ」 & & & 1 & 1 & 1 & 1 & & & & & & 12 & 0 & 5.2 \\
\hline
\end{tabular}

苐五十二表（A）各疾病血檿日時的動㨸，幅トソ，例數

\begin{tabular}{|c|c|c|c|c|c|c|c|c|c|c|}
\hline & 例 & [e] & \multicolumn{8}{|c|}{ 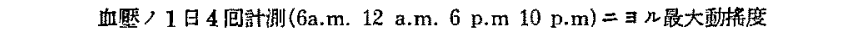 } \\
\hline 疾病㚙 & 数 & 數 & $\begin{array}{c}0-5 \\
\mathrm{mmHg}\end{array}$ & $6-10$ & $\begin{array}{c}11-20 \\
\cdots\end{array}$ & $\begin{array}{c}21-30 \\
. .\end{array}$ & $\begin{array}{c}31-40 \\
. \cdot\end{array}$ & $41-50$ & $51-60$ & 61 以上 \\
\hline 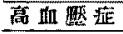 & 25 & 69 & & & 21 & 21 & 16 & 8 & 1 & 2 \\
\hline 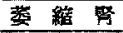 & 9 & 32 & & 3 & 9 & 6 & 12 & 1 & 1 & \\
\hline 性聚炎 & 11 & 40 & & 2 & 19 & 11 & 5 & 3 & & \\
\hline 急性罪贸 & 9 & 30 & 1 & 5 & 10 & 11 & 2 & 1 & & \\
\hline
\end{tabular}

第五十二表（B）各疾病血堐日時的動摇，幅卜最大最小動授，時刻

\begin{tabular}{|c|c|c|c|c|c|c|c|c|c|}
\hline & \multirow{2}{*}{ 竐 } & \multirow{2}{*}{ 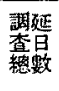 } & \multicolumn{3}{|c|}{1 日 4 回計測秘楼度 } & \multicolumn{4}{|c|}{ 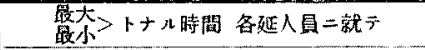 } \\
\hline 政 & & & 最大動播 & 最小㳟接 & 平 均 & 午前 6 時 & 正午前 & 午後 6 時 & 午後10時 \\
\hline \multirow{2}{*}{ 高血慜症 } & \multirow{2}{*}{25} & \multirow{2}{*}{69} & \multirow{2}{*}{77} & \multirow{2}{*}{12} & \multirow{2}{*}{29.9} & 12 & 23 & 28 & 6 \\
\hline & & & & & & 27 & 16 & 4 & 22 \\
\hline \multirow{2}{*}{ 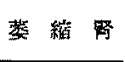 } & \multirow{2}{*}{9} & \multirow{2}{*}{32} & \multirow{2}{*}{55} & \multirow[b]{2}{*}{9} & \multirow{2}{*}{24.2} & 6 & 14 & 8 & 4 \\
\hline & & & & & & 12 & 8 & 0 & 12 \\
\hline \multirow{2}{*}{ 愠性姐炎 } & \multirow{2}{*}{11} & \multirow{2}{*}{40} & \multirow[b]{2}{*}{47} & & \multirow{2}{*}{23.6} & 7 & 17 & 15 & 1 \\
\hline & & & & & & 16 & 4 & 5 & 15 \\
\hline \multirow{2}{*}{ 急性盟炎 } & \multirow[b]{2}{*}{, } & \multirow{2}{*}{30} & \multirow[b]{2}{*}{40} & \multirow[b]{2}{*}{$b$} & \multirow{2}{*}{22.2} & 6 & 12 & 10 & 2 \\
\hline & & & & & & 12 & 0 & 4 & 14 \\
\hline
\end{tabular}

多テ均レ八度二ル列

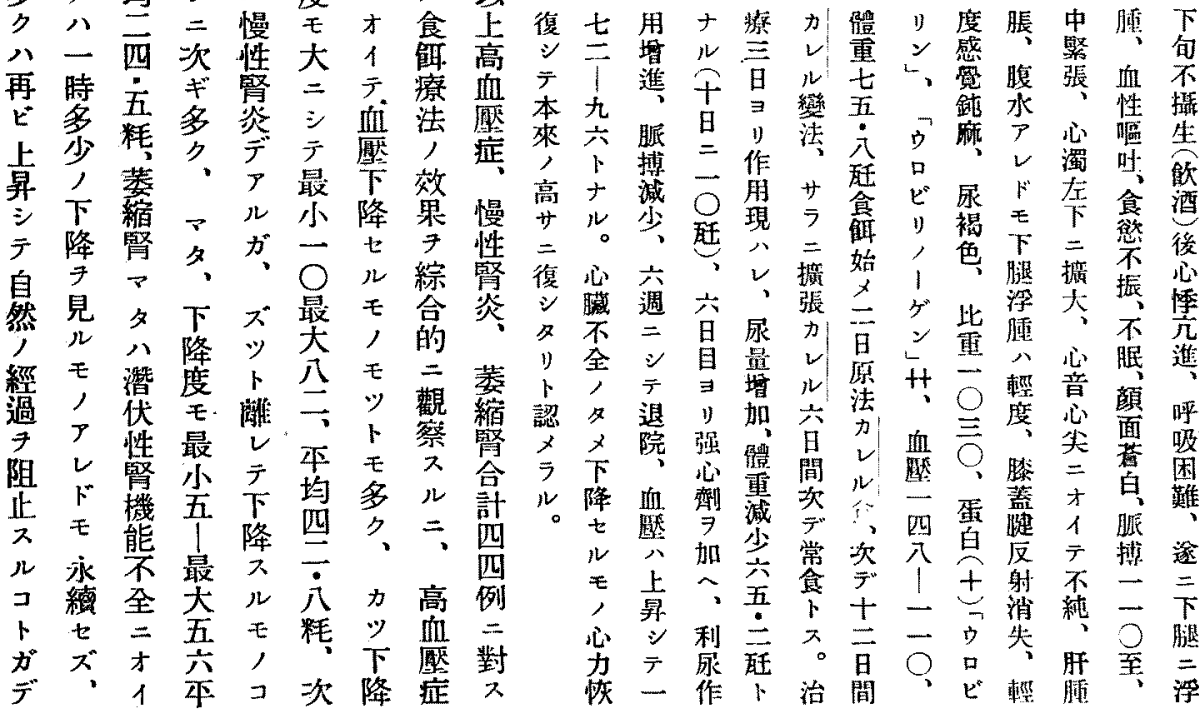



長院 短 カ 年間 日十血播 $\overline{\mathrm{O}}$ 下第

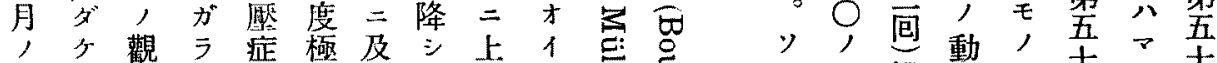

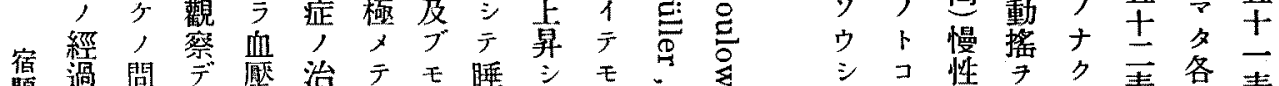

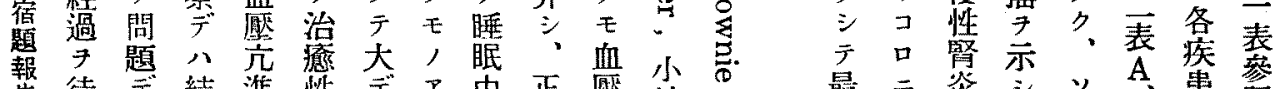

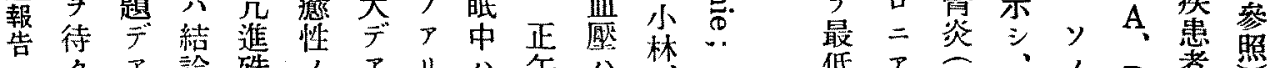

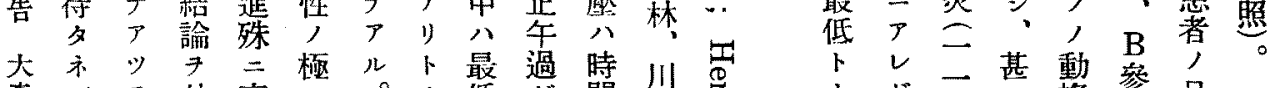

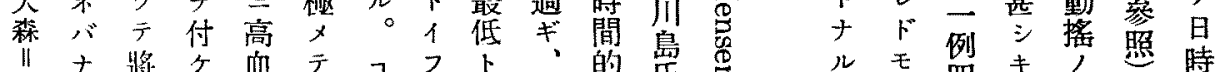

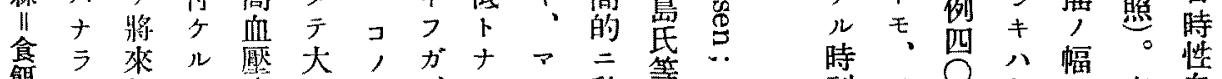

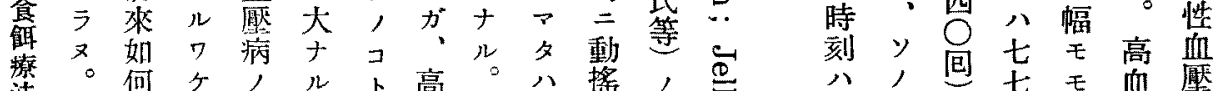

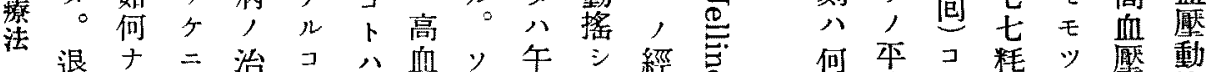

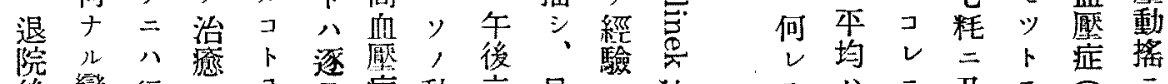

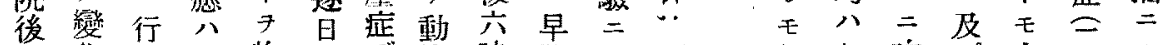

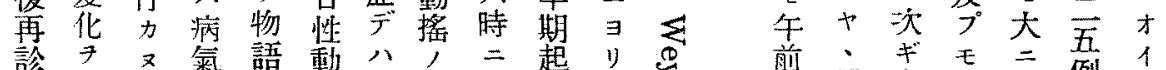

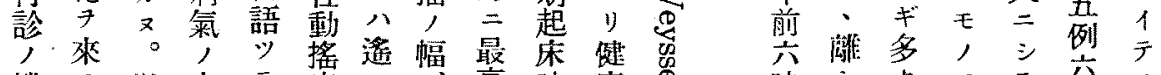

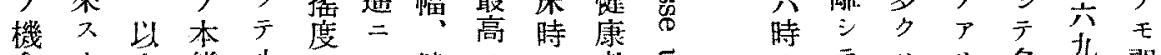

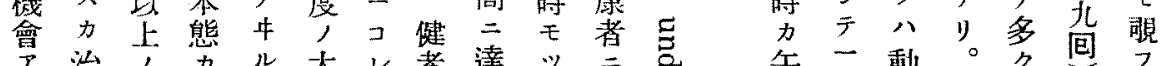

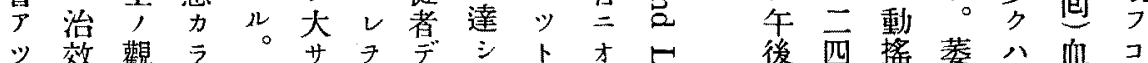

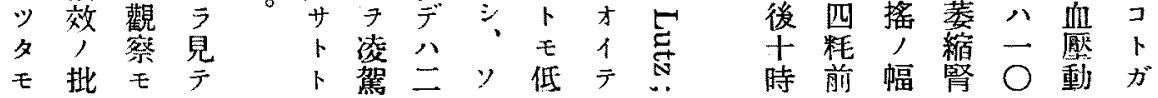

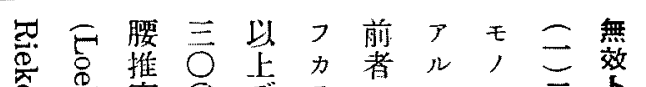

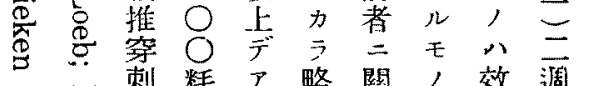

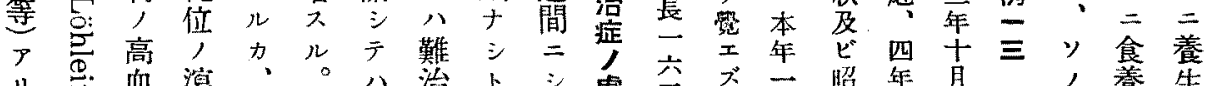

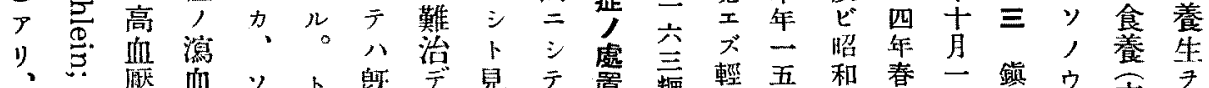

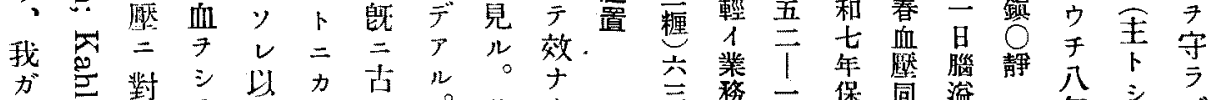

成勇童

方等儿 \#

オ

テリ

壬影關

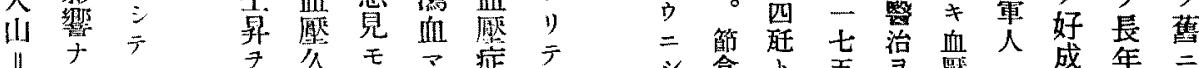

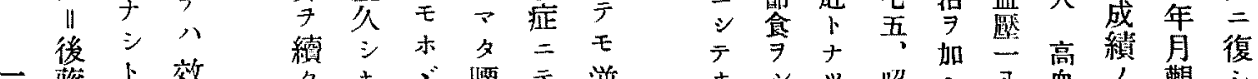

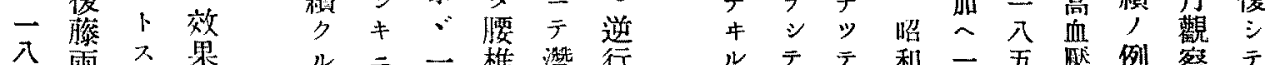

入兩入果 $ル=$ 一椎潛行

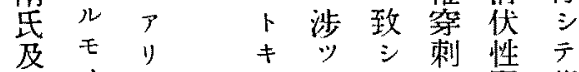

Eノト

田正+一三去行機

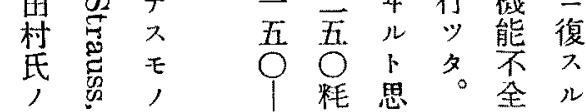

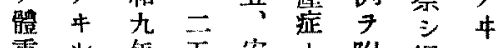

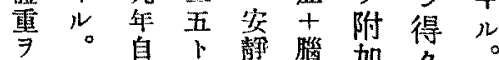

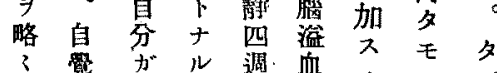

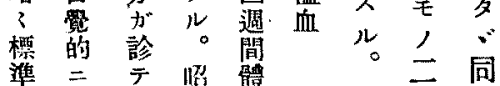

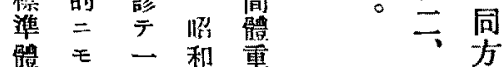


從庇 急蛋

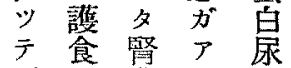

兩公臟

疾高炎テ夕

患蛋 7 糖 高

人白合尿 血

治常併病魔

療食七治,

方監儿療合

針 デ場, 併

二 合示吕

矛儿八力多

盾が食特向

撞腎療別

薯芘等法注,

另喰三意ウ

子食手省手

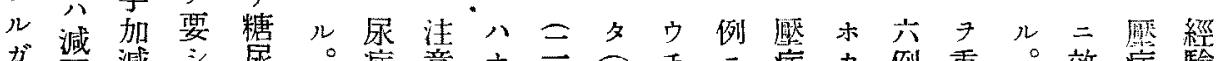

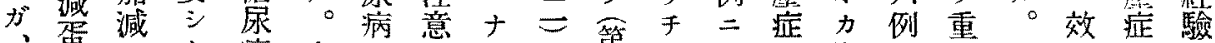

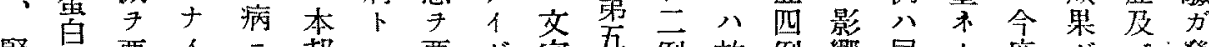

掔白要

炎減入力゙、基, 合入、通士八果、省毒が文認尿表

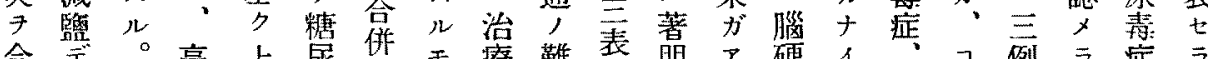

合

七ル尿 厴性

ル。病症疾八ア糖上 デ・ッ、三血,

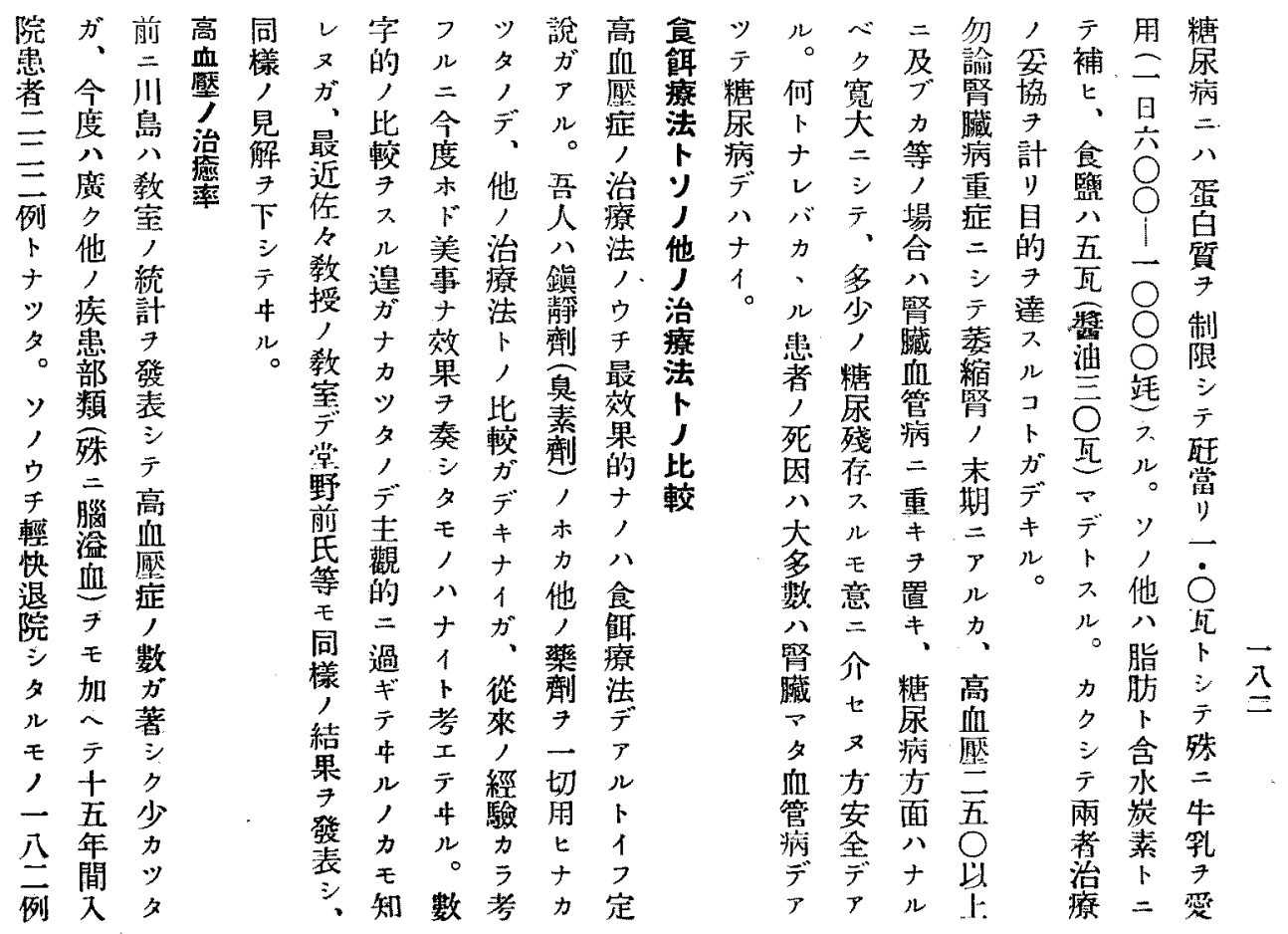




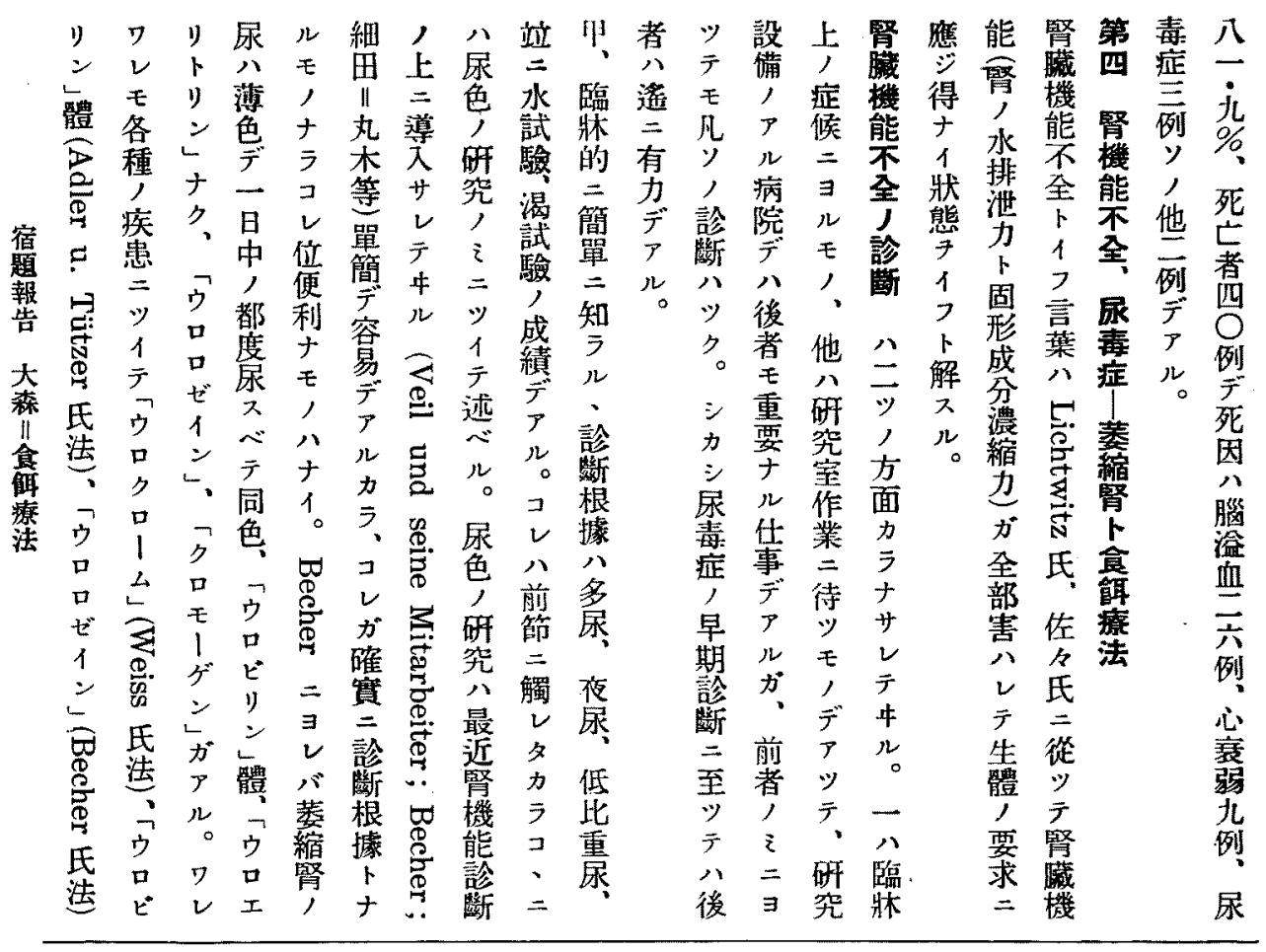

第五十四表 尿色素檢查(青木)

A 菱縮腎、尿毒症 ( 7 例)

\begin{tabular}{|c|c|c|c|c|c|c|c|c|c|c|c|c|c|}
\hline & \multirow{2}{*}{ 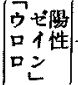 } & \multicolumn{4}{|c|}{ 「ウロクローム」(E.H.) } & \multicolumn{4}{|c|}{ 「ウロビリン」䯏(mg) } & \multicolumn{4}{|c|}{ 展 } \\
\hline & & 全 治 & 䣫 快 & & E & 全 治 & 輊 快 & 死 & L & 全 治 & 快 | & 死 & 亡 \\
\hline 网数 & 3 & 0 & 3 & 4 & & 0 & 3 & 4 & & 0 & 3 & 4 & \\
\hline 最小 & & & 1333 & 218 & & & 5 & 2 & & & 1500 & 80 & \\
\hline 最大 & & & 2428 & 2375 & & & 54 & 38 & & & 2050 & 2600 & \\
\hline 平均 & & & 1782 & 1408 & & & 26 & 11 & & & 1744 & 1427 & \\
\hline
\end{tabular}

B 心䁍 病 (13 例)

\begin{tabular}{|c|c|c|c|c|c|c|c|c|c|c|c|c|c|c|}
\hline & \multirow{2}{*}{ 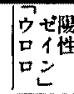 } & \multicolumn{4}{|c|}{ 「ウロクローム」(E.H.) } & \multicolumn{4}{|c|}{ 「ウロビリンJ體(mg) } & \multicolumn{5}{|c|}{ 层 } \\
\hline & & 全 治 & 提 快 & 死 & 亡 & 全 治 & 琶快 & & $\tau$ & 全 & & 锂 & 死 & 亡 \\
\hline 例數 & 3 & 0 & 13 & 0 & & 0 & 13 & 0 & & & 0 & 13 & 0 & \\
\hline 最小 & & & 660 & & & & 3 & & & & & 700 & & \\
\hline 最大 & & & 3750 & & & & 409 & & & & & 2500 & & \\
\hline 平均 & & & 2161 & & & & 115 & & & & & 1469 & & \\
\hline
\end{tabular}

忞

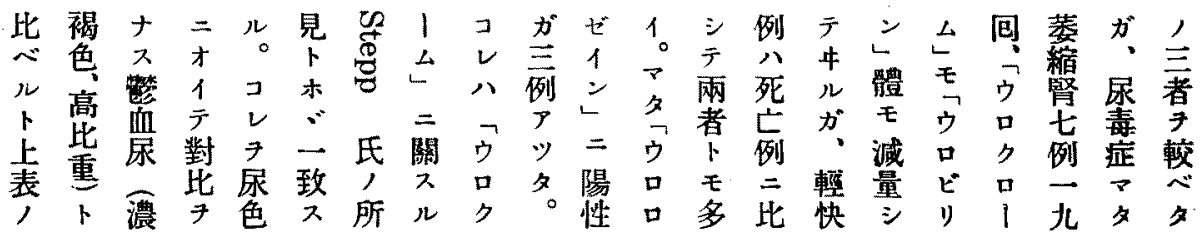




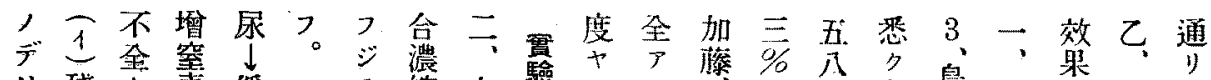

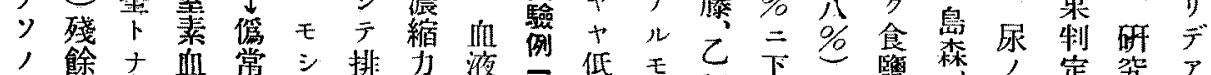

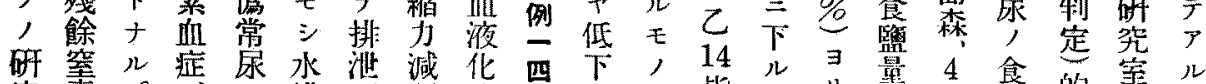

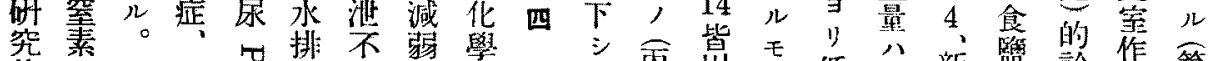

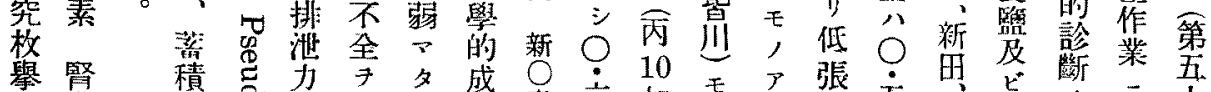

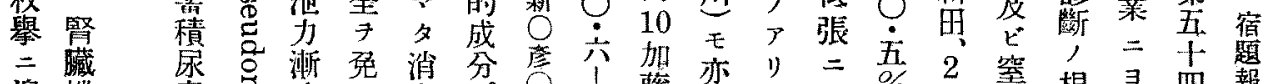

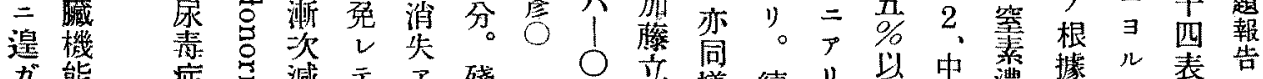

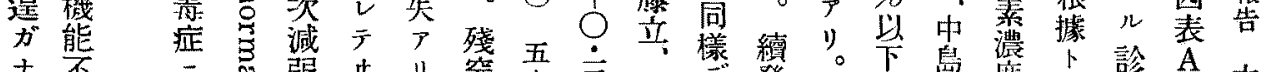

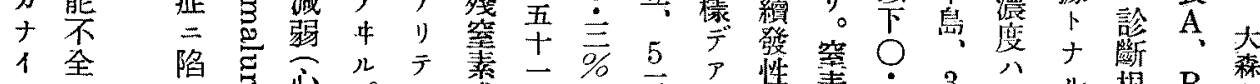

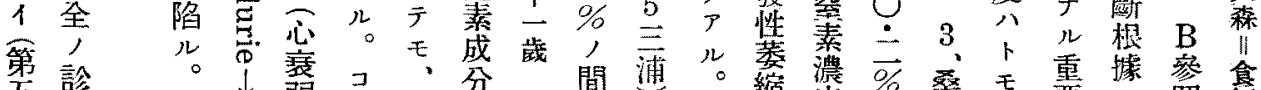

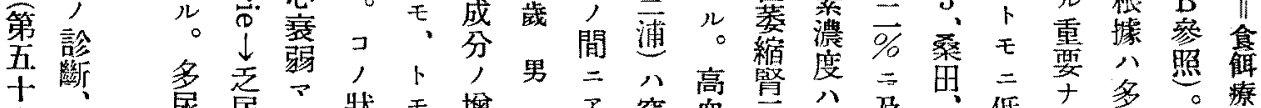

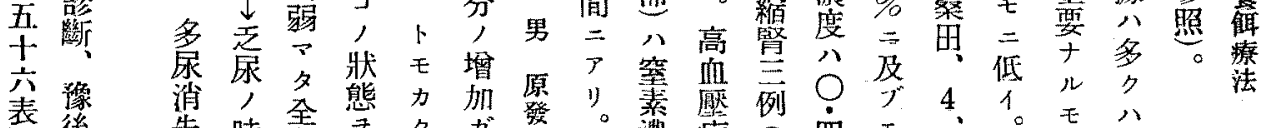

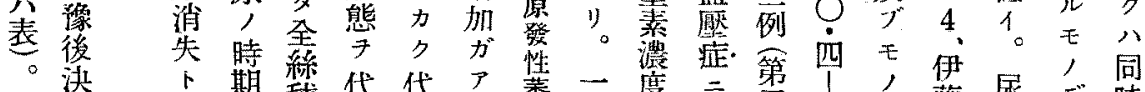

染 $\quad 卜$ 期趢代代 $>$ 萎

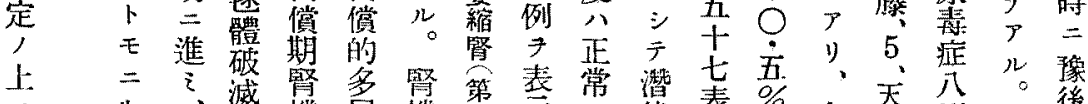

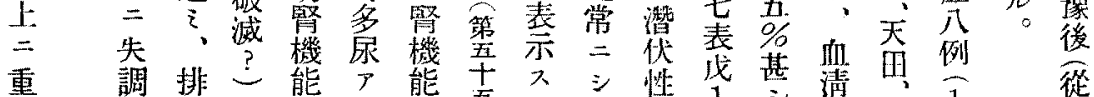

重調排こ熋

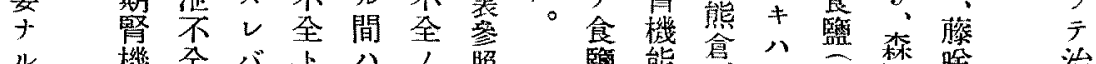

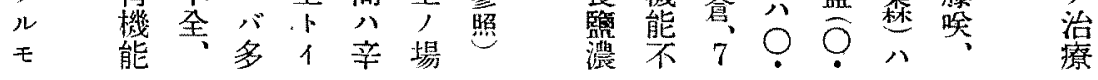

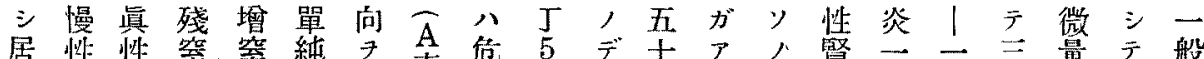

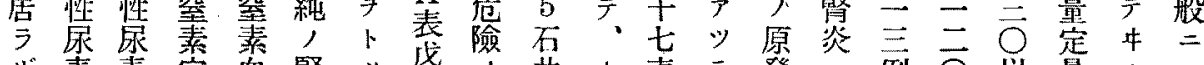
ザ表毒定血腎ッ战, 韭中表テ發三例 $\vec{\bigcirc}$ 以量儿八

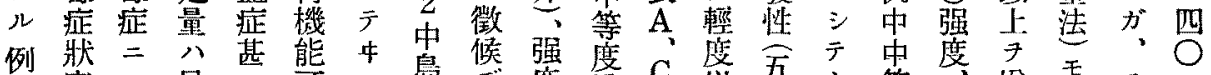

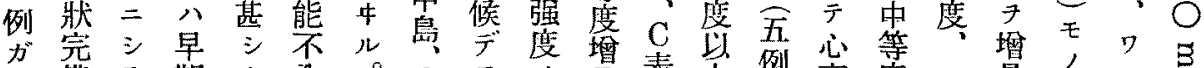

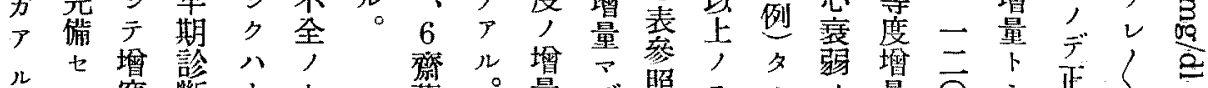

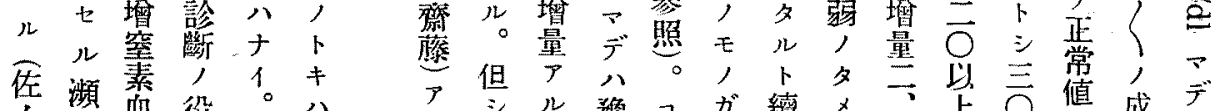

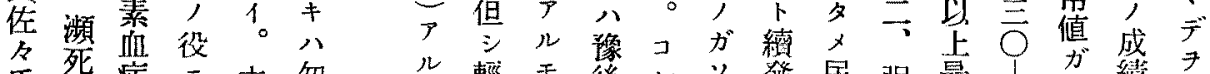

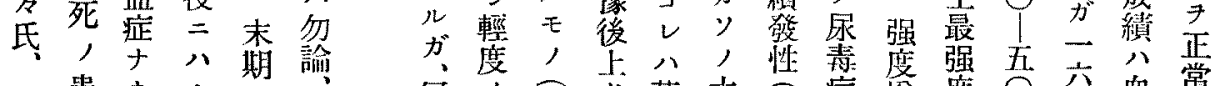

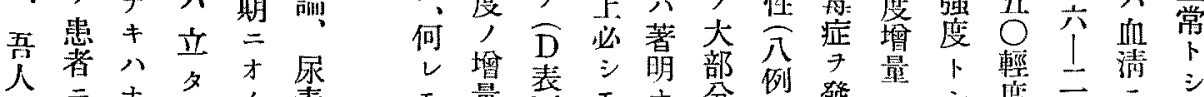

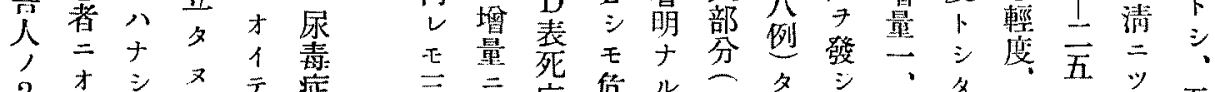

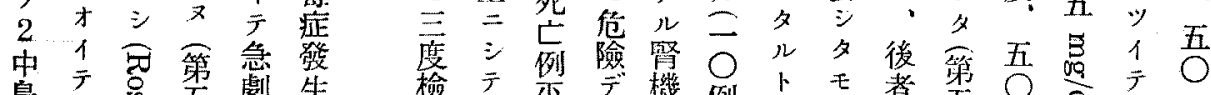
瞗

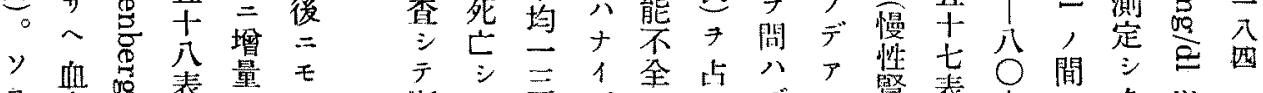

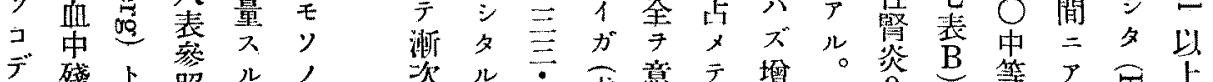

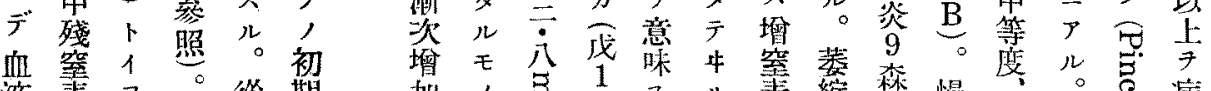

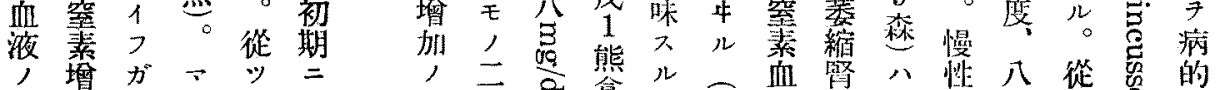

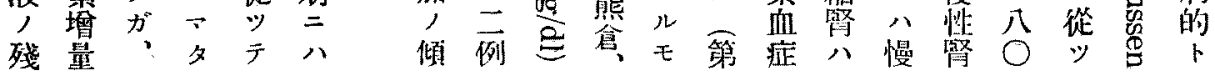




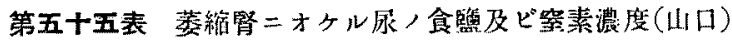

\begin{tabular}{|c|c|c|c|c|c|c|c|c|c|c|c|}
\hline \multirow{2}{*}{ 月日 } & \multirow{2}{*}{ 全镇 } & \multirow{2}{*}{ 饮 照 } & \multirow{2}{*}{ 效 尿量 } & \multirow{2}{*}{ 比正 } & \multirow{2}{*}{$\frac{\frac{72}{\dot{y}}}{\text { 係制 }}$} & \multirow{2}{*}{$\begin{array}{l}\text { 畓白 } \\
\%\end{array}$} & \multicolumn{2}{|l|}{ 露 } & \multicolumn{2}{|l|}{ 䇪 } & \multirow{2}{*}{ 捔 } \\
\hline & & & & & & & $\mathrm{g} / \mathrm{dl}$ & 一日量 & $\mathrm{g} / \mathrm{dl}$ & 一日量 & \\
\hline $26 / \mathrm{VI}$ & \multirow[t]{5}{*}{ I $[$ 「カレル] } & 800 & $\begin{array}{l}750 \\
350\end{array} 1100$ & $\begin{array}{l}10 \\
14 \\
\end{array}$ & $\begin{array}{r}75 \\
49 \\
\end{array}$ & 1.8 & 0.48 & 5.28 & 0.358 & 3.938 & ジーベック倈度 6 \\
\hline 27 & & 800 & $\begin{array}{ll}420 & 1120 \\
700 & \\
\end{array}$ & $\begin{array}{l}14 \\
10 \\
\end{array}$ & $\begin{array}{l}59 \\
70 \\
\end{array}$ & 2 & 0.365 & 4.08 & 0.329 & 3.684 & \\
\hline 28 & & 800 & $\begin{array}{l}400 \\
250\end{array} 650$ & $\begin{array}{l}10 \\
10 \\
\end{array}$ & $\begin{array}{l}40 \\
25 \\
\end{array}$ & 2 & 0.26 & 1.69 & 0.286 & 1.857 & \\
\hline 29 & & 800 & $\begin{array}{ll}630 & 1330 \\
700 & \\
\end{array}$ & $\begin{array}{l}11 \\
10 \\
\end{array}$ & $\begin{array}{l}69 \\
10 \\
\end{array}$ & 2.8 & 0.30 & 3.99 & 0.372 & 4.947 & \\
\hline 30 & & 800 & $\begin{array}{ll}600 & 950 \\
350 & 950 \\
\end{array}$ & $\begin{array}{l}8 \\
8\end{array}$ & $\begin{array}{l}48 \\
28\end{array}$ & 3.0 & 0.27 & 2.56 & & & . \\
\hline 31 & \multirow[t]{3}{*}{ 策二度 $\mathrm{A}$} & 1210 & $\begin{array}{l}520 \\
600\end{array} 1120$ & $\begin{array}{r}10 \\
6\end{array}$ & $\begin{array}{l}52 \\
36\end{array}$ & 4.2 & & & 0.398 & 4.457 & 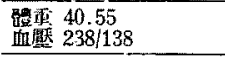 \\
\hline $1 / V \mathrm{~J}$ & & 1030 & $\begin{array}{ll}350 & 750 \\
400 & \\
\end{array}$ & $\begin{array}{l}10 \\
10 \\
\end{array}$ & $\begin{array}{r}35 \\
40 \\
\end{array}$ & 3.5 & 0.265 & 1.98 & 0.567 & 5.352 & \\
\hline 2 & & 400 & $\begin{array}{ll}430 & 780 \\
350 & 780 \\
\end{array}$ & $\begin{array}{l}13 \\
10 \\
\end{array}$ & $\begin{array}{l}56 \\
35\end{array}$ & 3 & 0.30 & 2.38 & 0.502 & 3.915 & \\
\hline 3 & \multirow[t]{2}{*}{ 第三度 $\mathrm{A}$} & 1400 & $\begin{array}{l}\text { 便和 } \\
500 \\
\end{array}$ & $\overline{10}$ & $\overline{50}$ & 4 & 0.22 & & 0.615 & . & \\
\hline 4 & & 750 & $\begin{array}{ll}750 & 1700 \\
950 & \end{array}$ & $\begin{array}{l}13 \\
12 \\
\end{array}$ & $\begin{array}{r}97 \\
114 \\
\end{array}$ & 3 & & & & & \\
\hline 5 & \multirow[t]{8}{*}{ 第一度 } & 950 & $\begin{array}{ll}400 & 900 \\
500\end{array}$ & $\begin{array}{l}12 \\
10 \\
\end{array}$ & $\begin{array}{l}48 \\
50 \\
\end{array}$ & 2 & 0.245 & 2.19 & 0.486 & 4.374 & \\
\hline 6 & & 1350 & $\begin{array}{ll}400 & 900 \\
500 & \end{array}$ & $\begin{array}{r}11 \\
6 \\
\end{array}$ & $\begin{array}{l}44 \\
30\end{array}$ & 3 & 0.225 & 2.02 & 0.516 & 4.644 & \\
\hline 7 & & 900 & $\begin{array}{l}500 \\
700\end{array} 1200$ & $\begin{array}{l}10 \\
10 \\
\end{array}$ & $\begin{array}{l}50 \\
70 \\
\end{array}$ & 3 & 0.14 & 2.68 & 0.456 & 5.472 & 血聇 $220 / 140$ \\
\hline 8 & & 1120 & $\begin{array}{ll}300 & 900 \\
600 & \end{array}$ & $\begin{array}{r}10 \\
8\end{array}$ & $\begin{array}{l}30 \\
48 \\
\end{array}$ & 3 & 0.12 & 1.08 & & & \\
\hline 9 & & 830 & $\begin{array}{ll}600 & 1100 \\
500 & \end{array}$ & $\begin{array}{l}8 \\
8 \\
\end{array}$ & $\begin{array}{l}48 \\
40 \\
\end{array}$ & 3 & 0.11 & 1.21 & & & \\
\hline 10 & & 710 & $\begin{array}{l}400 \\
500 \quad 900 \\
\end{array}$ & $\begin{array}{l}9 \\
8 \\
\end{array}$ & $\begin{array}{l}36 \\
40\end{array}$ & 3 & 0.20 & 1.8 & 0.529 & 4.761 & \\
\hline 11 & & 1200 & $\begin{array}{l}550 \\
900\end{array} 450$ & $\begin{array}{l}7 \\
8\end{array}$ & $\begin{array}{l}38 \\
72 \\
\end{array}$ & 2.5 & & & & & \\
\hline 12 & & 1310 & $\begin{array}{ll}300 \\
500\end{array} \quad 800$ & $\begin{array}{l}8 \\
6 \\
\end{array}$ & $\begin{array}{l}24 \\
30 \\
\end{array}$ & 2.5 & 0.24 & 1.92 & 0.487 & 3.896 & \\
\hline 13 & 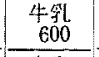 & 1050 & $\begin{array}{ll}400 & 900 \\
50\end{array}$ & $\begin{array}{r}8 \\
10 \\
\end{array}$ & $\begin{array}{l}32 \\
50 \\
\end{array}$ & 2.5 & 0.21 & 1.89 & 0.515 & 4.635 & \\
\hline 14 & \multirow[t]{6}{*}{$\begin{array}{l}494 \\
800\end{array}$} & 1600 & $\begin{array}{l}6501200 \\
550\end{array}$ & $\begin{array}{r}8 \\
10 \\
\end{array}$ & $\begin{array}{l}52 \\
55 \\
\end{array}$ & 3 & 0.13 & 2.16 & 0.515 & 6.18 & 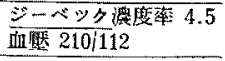 \\
\hline 15 & & 1450 & $\begin{array}{l}600 \\
600 \\
\end{array}$ & $\begin{array}{l}3 \\
8 \\
\end{array}$ & $\begin{array}{l}18 \\
48 \\
\end{array}$ & 3 & 0.18 & 2.16 & 0.520 & 6.24 & \\
\hline 16 & & 1070 & $\begin{array}{ll}500 & 950 \\
450\end{array}$ & $\begin{array}{l}10 \\
10\end{array}$ & $\begin{array}{l}50 \\
40\end{array}$ & 3.5 & & & 0.545 & 5.177 & \\
\hline 17 & & 850 & $\begin{array}{ll}370 & 670 \\
300 & \\
\end{array}$ & $\begin{array}{l}10 \\
10 \\
\end{array}$ & $\begin{array}{l}37 \\
30 \\
\end{array}$ & 4 & & & 0.547 & 3.664 & \\
\hline 18 & & & $\begin{array}{ll}550 \\
350\end{array} \quad 900$ & & & & & & 0.486 & 4.344 & 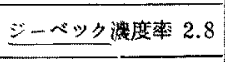 \\
\hline 19 & & & & & & & & & & & 死亡 \\
\hline
\end{tabular}


第五十六表 健康人血液殘餘䇺素正常量（大谷、青木）

\begin{tabular}{|c|c|c|c|c|c|}
\hline 㯕查晢 名 & 䊕 & 殘稌跮素 (mg/dl) & 检查苩名 & U & 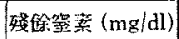 \\
\hline Hohlweg & 期清 & $41-65$ & T. S. Chasatzky & & $20-38$ \\
\hline Gettler & 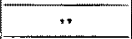 & $35-45$ & Pincussen & 血溥 & $20-40$ \\
\hline Strauss & $"$ & $20-40$ & Tileston u. Deni & $"$ & $22.9-25.0$ \\
\hline Philipp & $\ddot{\prime \prime}$ & 32 & Hank & $"$ & $25-30$ \\
\hline V. Monakow & 血清 空亚時 & $18-31$ & Cohn & 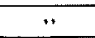 & $18-35$ \\
\hline " & 血清 食嵝6時 & $31-35$ & Farr u. Anetin & $"$ & $15-43$ \\
\hline Schenk & " & $25-28$ & Abderhalden & ." & $19-36$ \\
\hline Brun & $"$ & $24-35$ & 五斗，松山，大村 & 血清 & $18-35$ \\
\hline Schöndorf & 哲液 & 50 & 北 攸 & 血獎 & $33.6-22.98$ \\
\hline Siebeck & " & $35-40$ & " & 血液 & $37.52-24.64$ \\
\hline Rzentkowski & $"$ & $22.6-66.0$ & 林 & $"$ & 35 以下 \\
\hline Volhard & $"$ & $20-40$ & 岩城，金田 & $"$ & $24.17-41.3$ \\
\hline Folin u. Denis & $"$ & $22-37$ & 峦 \# & " & 32.4 \\
\hline Wolf & $\because$ & $25-28$ & 有 鵟 & $\because$ & $28.4-37.6$ \\
\hline Feigl & " & $20-35$ & 一松 & " & 20.16 \\
\hline Rosenberg & $"$ & 25 & 大西 & $"$ & $14.0-30.3$ \\
\hline Faylor & $"$ & $25-28$ & 加 用 & $"$ & $17.4-35.0$ \\
\hline Hulton & $\cdots$ & $25-28$ & 松用 & 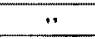 & $15.3-31.8$ \\
\hline Bang & $"$ & $19-36$ & 加 站 & ". & $15.4-36.4$ \\
\hline Michand & $"$ & 50 & 此 韭 & 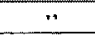 & $18.5-29.1$ \\
\hline Hefter & 血㵝 & $35-40$ & 站篮 & $\because$ & $17-30$ \\
\hline Ascoli & 血液 & 24.3 & 中尾，金，松椅 & $"=$ & $19.6-29.9$ \\
\hline Hammet & 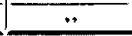 & 35.6 & 火谷䘚，橴本 & 血清 & $16-25$ \\
\hline
\end{tabular}

第五十七表 腎・血管疾患血液，化學的變化（A）

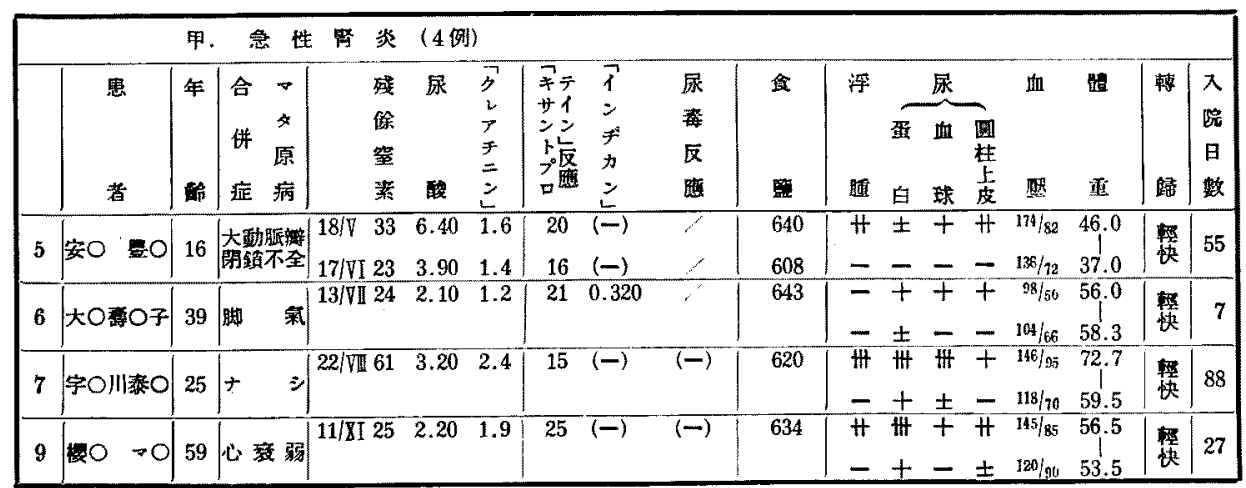


第五十七表 腎疾费血液，化學的變化 (A)

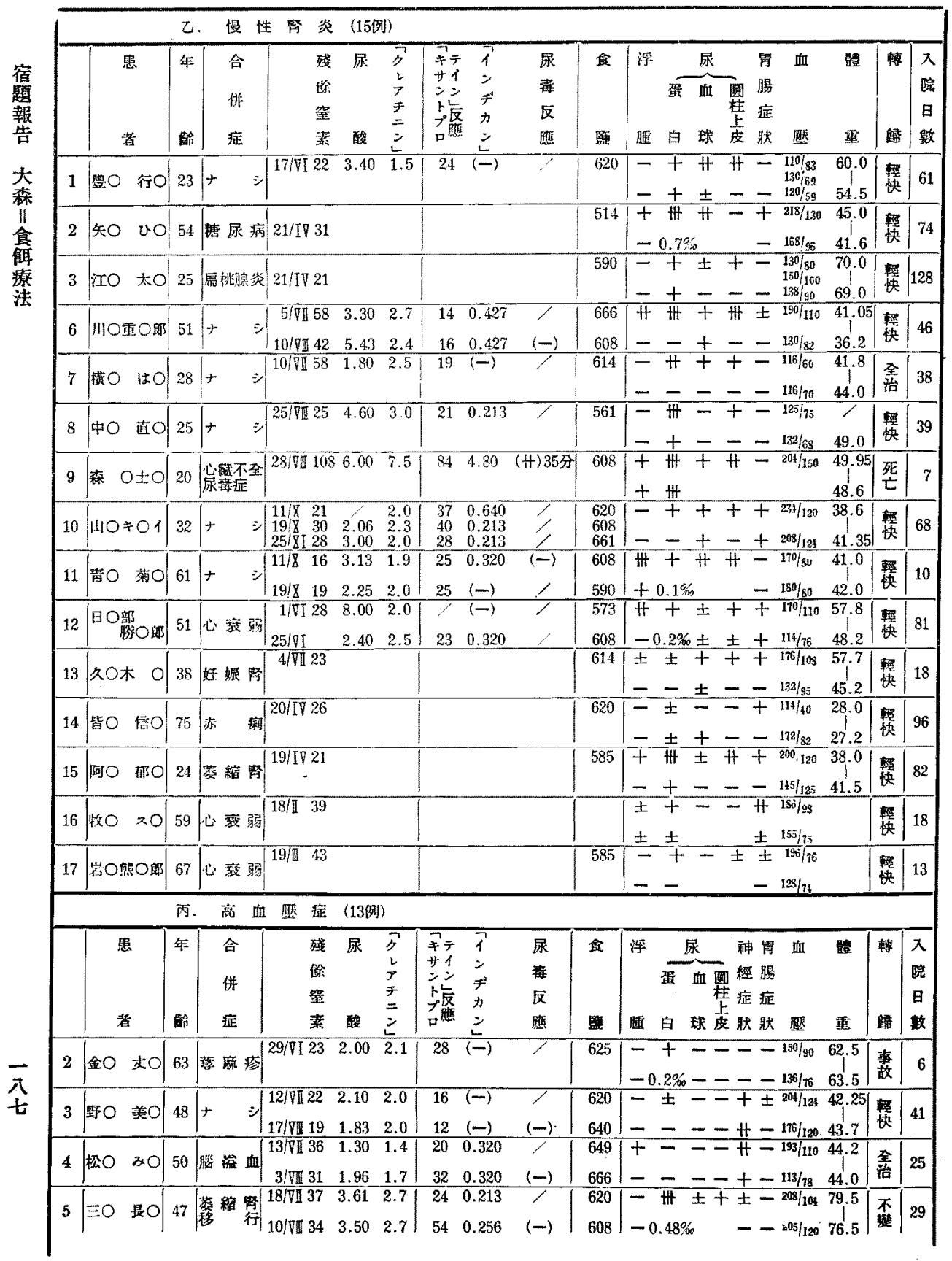









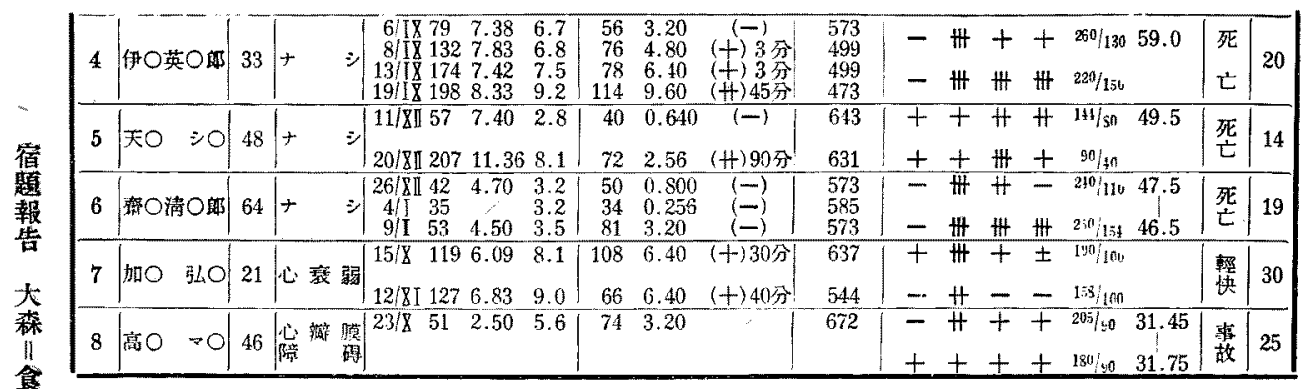

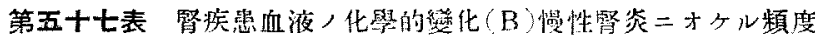

\begin{tabular}{|c|c|c|c|c|c|c|c|c|}
\hline & & & \multirow{2}{*}{\multicolumn{2}{|c|}{ 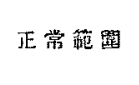 }} & \multicolumn{2}{|c|}{ 城 } & \multicolumn{2}{|c|}{ 量: } \\
\hline \multicolumn{2}{|c|}{ 慢 } & & & & 軽 & 中 等 底 & 度 & 最 强 庶 \\
\hline \multicolumn{2}{|c|}{ 性 } & 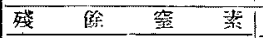 & $30 \mathrm{~m}$ & dl $\mathrm{LF}$ & $31-50$ & $51-80$ & $81-120$ & $121 \mathrm{WE}$ \\
\hline \multicolumn{2}{|c|}{ 醩 } & 厡 & $2.5 \mathrm{~m}$ & dI $\mathrm{MT}$ & $2.51-4.00$ & $4.01-6.00$ & $6.01-9.00$ & 9.01 以上 \\
\hline \multirow{2}{*}{\multicolumn{2}{|c|}{ 炎 }} & I夕 $27 \neq=21$ & $2.0 \mathrm{~m}$ & d $/ \mathrm{d} \mathrm{XF}$ & $2.1-3.0$ & $3.0-4.0$ & $4.1-10.0$ & 10.1以上 \\
\hline & & 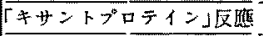 & 25 & 以下 & $26-40$ & $41-70$ & $71-100$ & $100.1 \mathrm{~L}$ 上 \\
\hline & & $\Gamma 1 \geqslant \neq$ * & $(-)$ & $\mathrm{ming} / \mathrm{d}$ & $0.213-0.427$ & $0.64-1.28$ & $2.13-4.8$ & 5.12 以上 \\
\hline \multirow{2}{*}{\multicolumn{2}{|c|}{ 入 }} & 残籍 倠 & & 4 & 1 & 2 & & \\
\hline & & 尿 酸 & & 1 & 3 & 1 & 1 & \\
\hline \multicolumn{2}{|c|}{ 院 } & $\begin{array}{lll}r y & 1 & 7\end{array}=21$ & & 4 & 3 & & & \\
\hline \multirow{2}{*}{\multicolumn{2}{|c|}{ 時 }} & 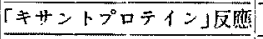 & & 5 & 1 & & & \\
\hline & & 「1 シ & & 3 & 3 & 1 & & \\
\hline \multirow{4}{*}{ 湿 } & \multirow{3}{*}{ 梙 } & 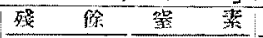 & & 2 & 1 & & & \\
\hline & & 尿 & & 2 & 1 & 1 & & \\
\hline & & Ib $27 \quad F=21$ & & 2 & 2 & & & \\
\hline & 森 & 「キサントプロテイシ」反隼 & & 3 & 1 & & & \\
\hline \multirow{3}{*}{ 完 } & & $r 12 y^{\prime}$ 力 & & 1 & 3 & & & \\
\hline & & 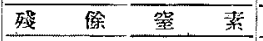 & & & & & 1 & \\
\hline & 死 & 尿 䣼 & & & & 1 & & \\
\hline \multirow[t]{3}{*}{ 钲 } & & $5327 \div=21$ & & & & & 1 & \\
\hline & 亡 & ケキサントプロテイン」反时 & & & & & 1 & \\
\hline & & $\Gamma 1 \geq x^{\prime}>21$ & & & & & 1 & \\
\hline
\end{tabular}

$\vec{\lambda}$
兄 


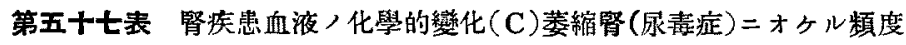

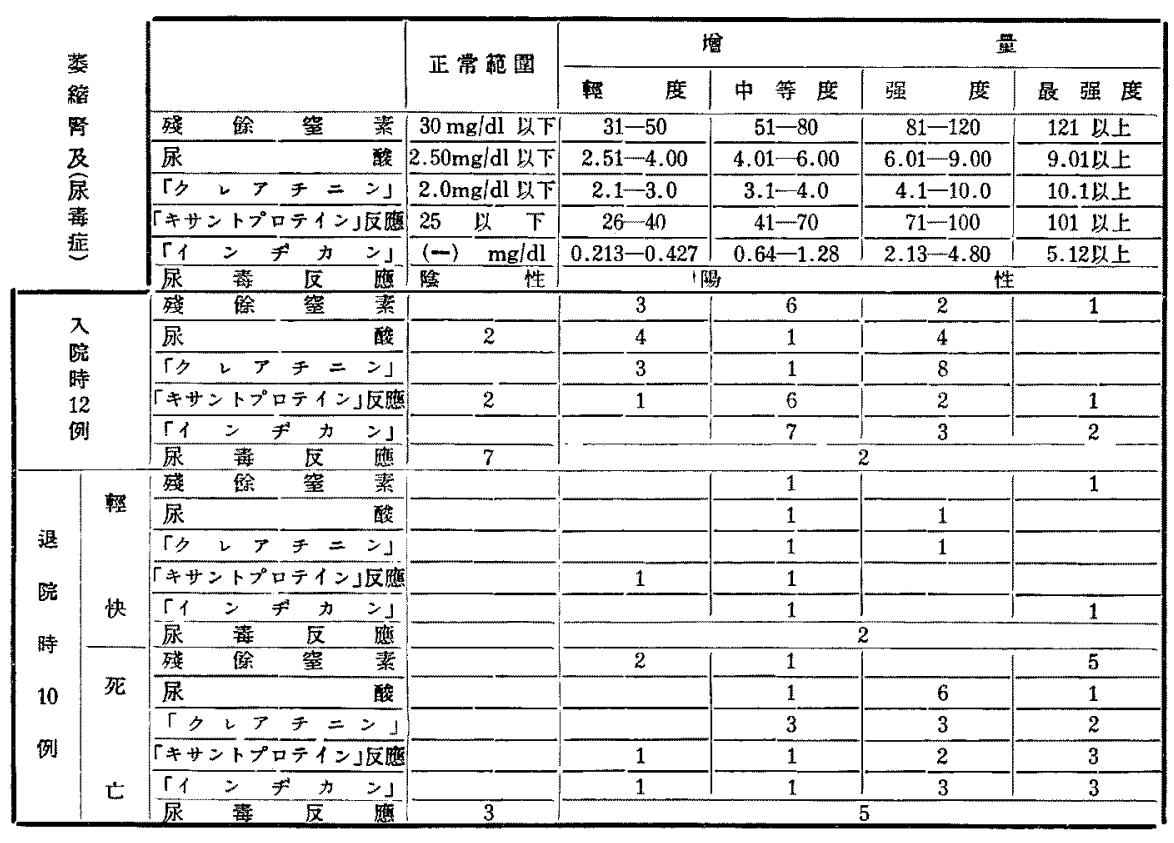

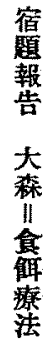

第五十七表 腎疾患血液，化學的變化 (D)平均值卜楙後

\begin{tabular}{|c|c|c|c|c|c|c|c|c|}
\hline & 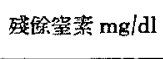 & 尿 $\mathrm{mg} / \mathrm{dl}$ & $\begin{array}{c}\text { 「クマテ=シ」 } \\
\mathrm{mg} / \mathrm{dl}\end{array}$ & 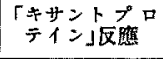 & 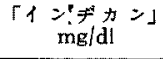 & 尿 毒 反睡 \\
\hline \multirow{3}{*}{ 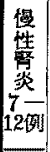 } & \multicolumn{2}{|c|}{ 入宽封 } & $\begin{array}{c}29.2 \\
(16-108)\end{array}$ & $\begin{array}{r}4.04 \\
(1.80-8.00) \\
\end{array}$ & $\begin{array}{r}2.2 \\
(1.5-2.7) \\
\end{array}$ & $\begin{array}{c}23.3 \\
(14-37) \\
\end{array}$ & $((-)-0.640)$ & (一) 1 例 \\
\hline & \multirow{2}{*}{ 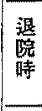 } & 慗 & $\begin{array}{c}29.7 \\
(19-42)\end{array}$ & $\begin{array}{r}3.27 \\
(2.25-5.43) \\
\end{array}$ & $\begin{array}{c}2.2 \\
(2.0-2.5)\end{array}$ & $\begin{array}{c}23.0 \\
(16-28)\end{array}$ & $((-)-240.427)$ & $(-) 2$ 例 \\
\hline & & 㤠 & 108 & 6.00 & 7.5 & 84 & 4.80 & (t) 1 例 \\
\hline \multirow{3}{*}{ 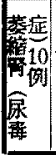 } & \multicolumn{2}{|c|}{ 入踪洔 } & $\begin{array}{c}73.9 \\
(42-143) \\
\end{array}$ & $\begin{array}{c}4.55 \\
(1.50-7.69)\end{array}$ & $\begin{array}{c}5.6 \\
(2.5-10.0) \\
\end{array}$ & $\begin{array}{c}56.6 \\
(15-108) \\
(5)\end{array}$ & $\begin{array}{c}2.495 \\
(0.640-6.40)\end{array}$ & 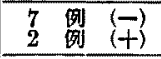 \\
\hline & 堲 & 枆 & $\begin{array}{c}91.0 \\
(55-127)\end{array}$ & $\begin{array}{c}6.32 \\
(5.81-6.83) \\
\end{array}$ & $\begin{array}{c}6.5 \\
(4.0-9.0)\end{array}$ & $\begin{array}{c}49.0 \\
(32-66) \\
\end{array}$ & $\begin{array}{c}3.60 \\
(0.80-6.40)\end{array}$ & 1 例 (+) \\
\hline & 等 & 死 & $\begin{array}{c}133.8 \\
(38-207) \\
\end{array}$ & $\begin{array}{c}7.36 \\
(6.13-11.36) \\
\end{array}$ & $\begin{array}{c}8.7 \\
(3.4-21.8) \\
\end{array}$ & $\begin{array}{c}84.3 \\
(22-176) \\
\end{array}$ & $\begin{array}{r}3.927 \\
(0.427-9.60) \\
\end{array}$ & $\begin{array}{lll}3 & \text { 例 } \\
5 & (-) \\
\end{array}$ \\
\hline
\end{tabular}

第五十八表 慢性尿毒症血中殘餘塋素量(小西) mg\%(Bang 氏法 $=\Xi ル .50 \mathrm{mg} \%$ 以上蹱量)

\begin{tabular}{|c|c|c|c|c|c|c|}
\hline & 50.0 以下 & $50-100$ & $100-150$ & $150-200$ & $200-250$ & $250-300$ \\
\hline 例敕 & 6 & 17 & 3 & 5 & 1 & 1 \\
\hline
\end{tabular}




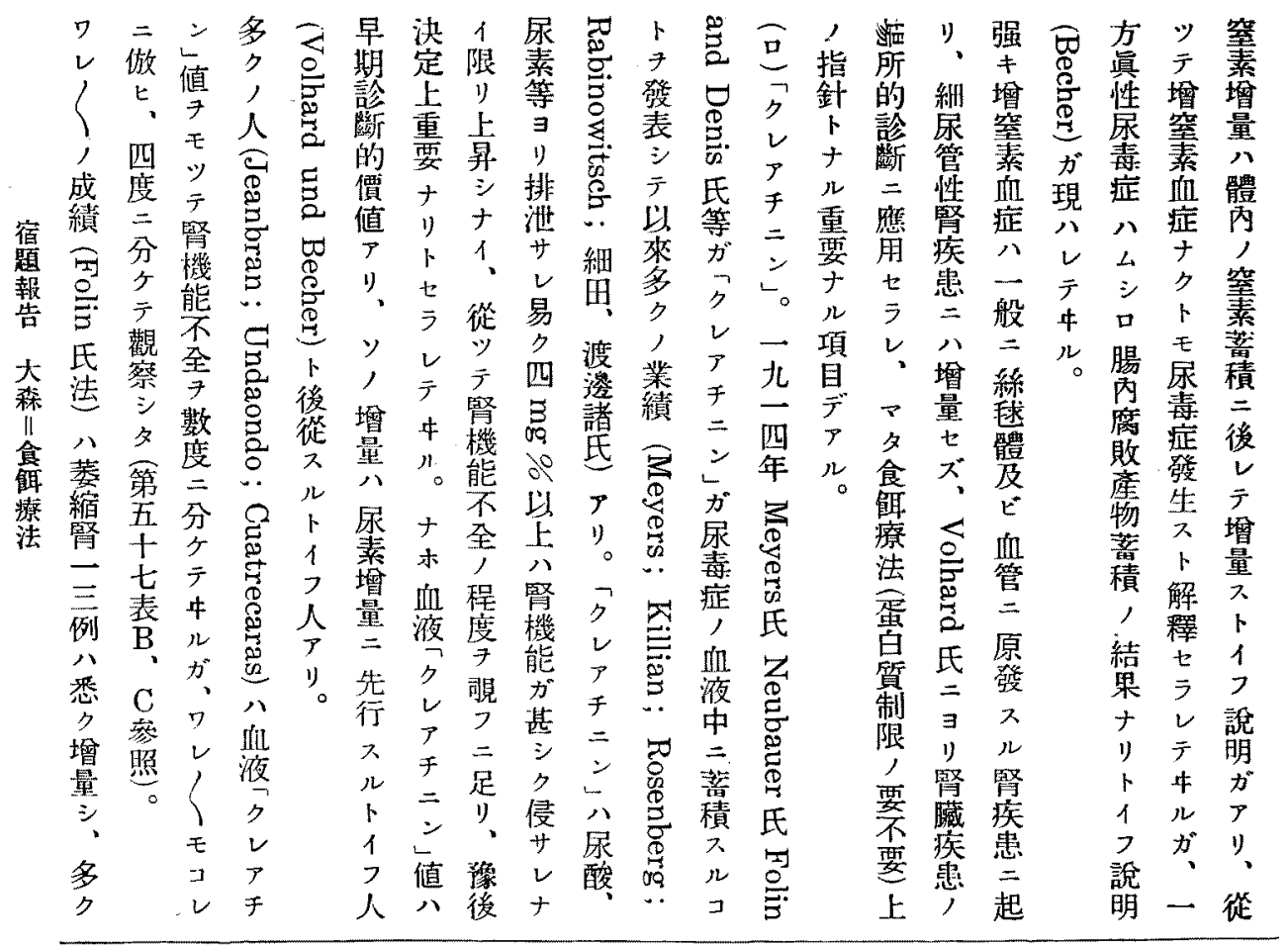

ワ夕從儿診二行へ伏血モ等慢デ

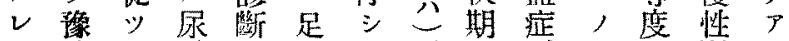

第五十九表 血清「クレナ

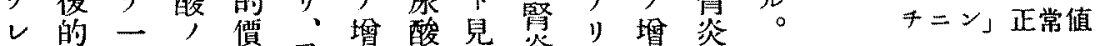

八價 $\bigcirc$ 量值

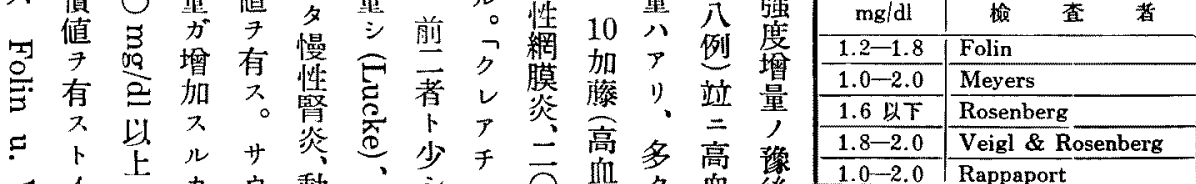

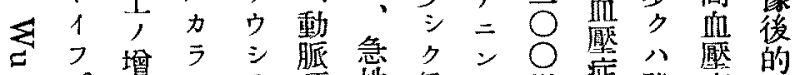

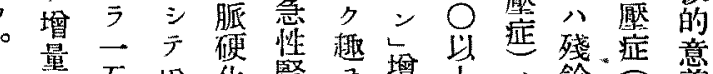

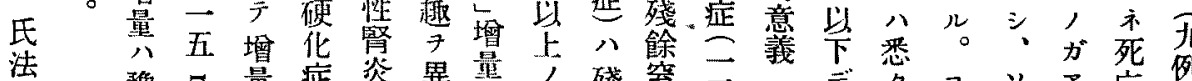

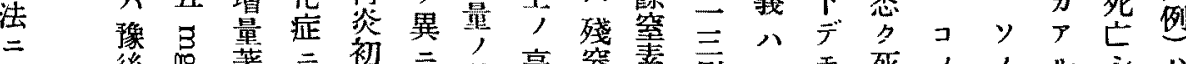

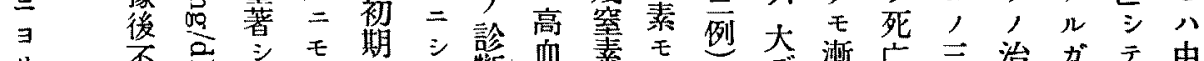

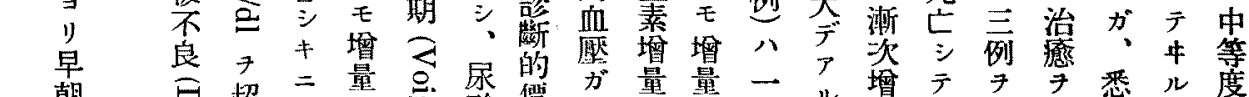

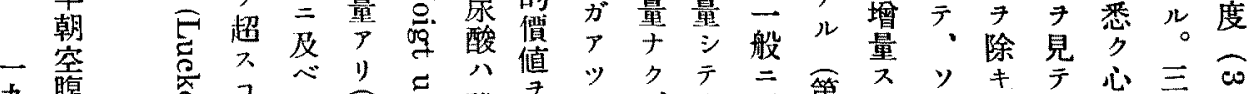

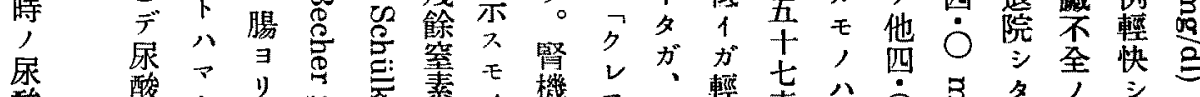

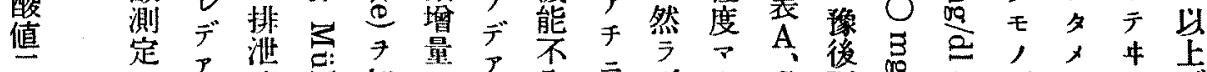

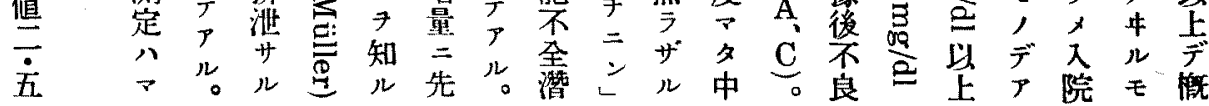




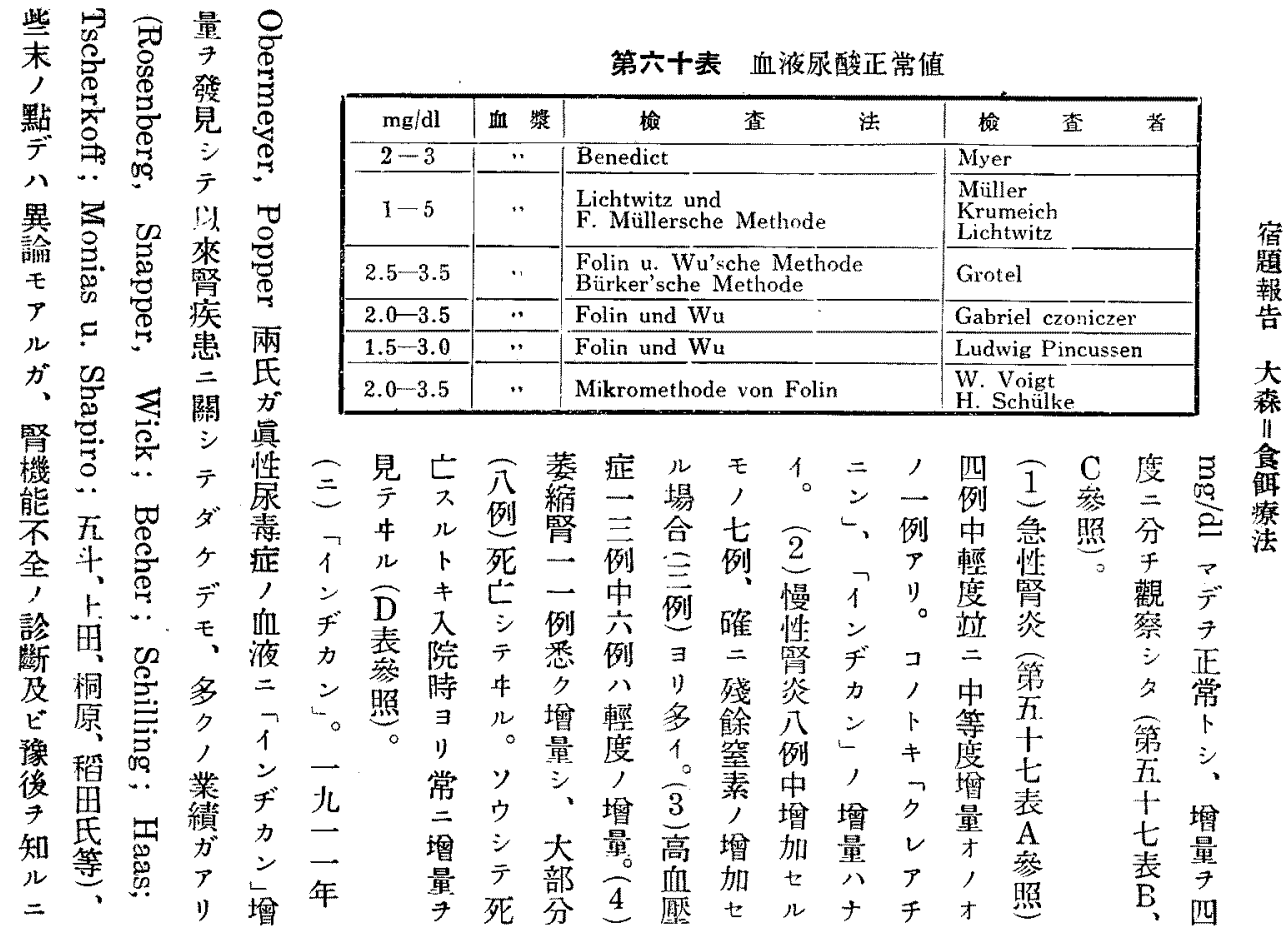

第六ナ一表 欰清「インヂカン 正常値

\begin{tabular}{|c|c|c|}
\hline $\mathrm{mg} / \mathrm{dl}$ & 萛 & 者 \\
\hline $0.026-0.082$ & \multicolumn{2}{|l|}{ Haas } \\
\hline $0.04-0.107$ & \multicolumn{2}{|l|}{ Rosenberg } \\
\hline $0.064-0.07$ & \multicolumn{2}{|l|}{ Schilling } \\
\hline $0.064-0.07$ & \multicolumn{2}{|l|}{ Eick } \\
\hline $0.04-0.13$ & \multicolumn{2}{|l|}{ Van Bommel } \\
\hline 0.16 以 $T$ & \multicolumn{2}{|c|}{ 上田佘治稳度营时直樹 } \\
\hline $0.1-0.16$ & 桐 原 三 & 的 \\
\hline $0.16 \mathrm{D} T$ & 茂上 & 人 \\
\hline
\end{tabular}

$\begin{array}{lll}モ & 1 & \\ \boldsymbol{P} & 1 & 8 \\ \sim & 7 & 0\end{array}$

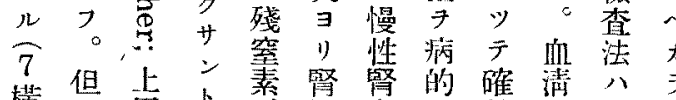

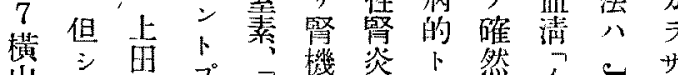

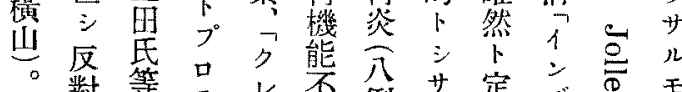

2 至

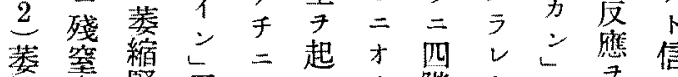

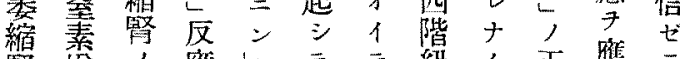

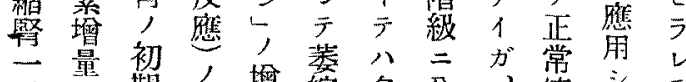

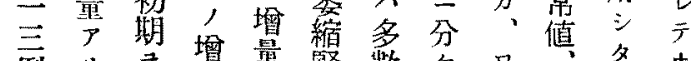

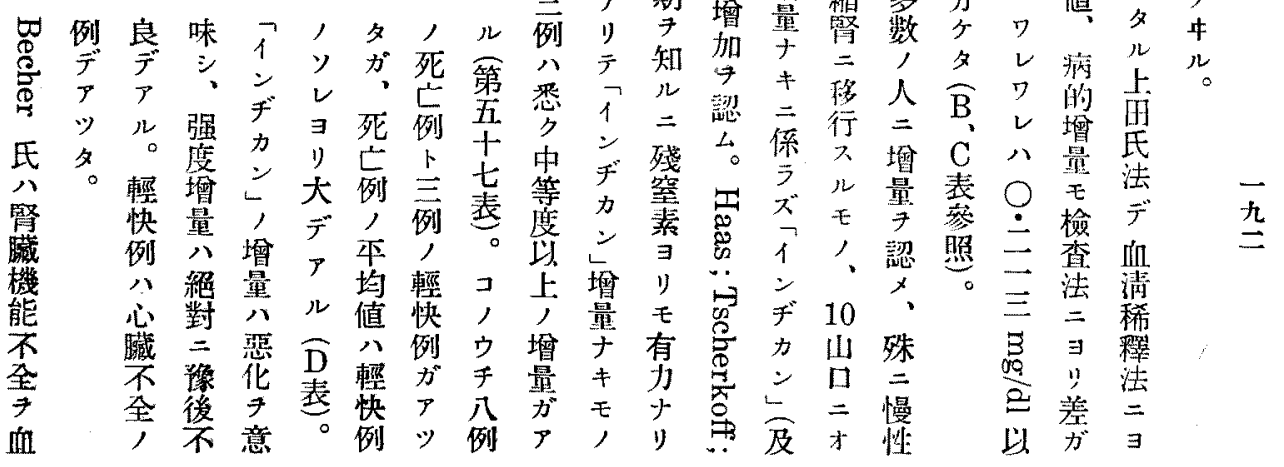




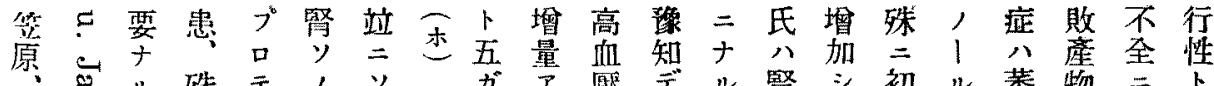

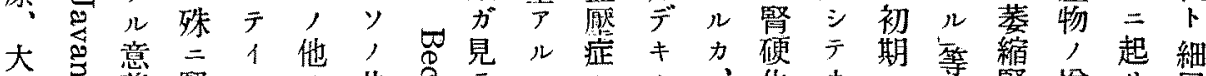

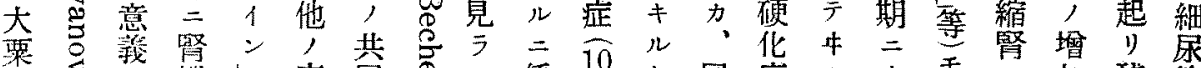

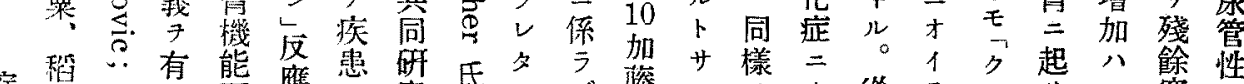
僆昌

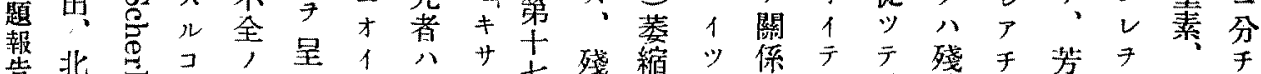

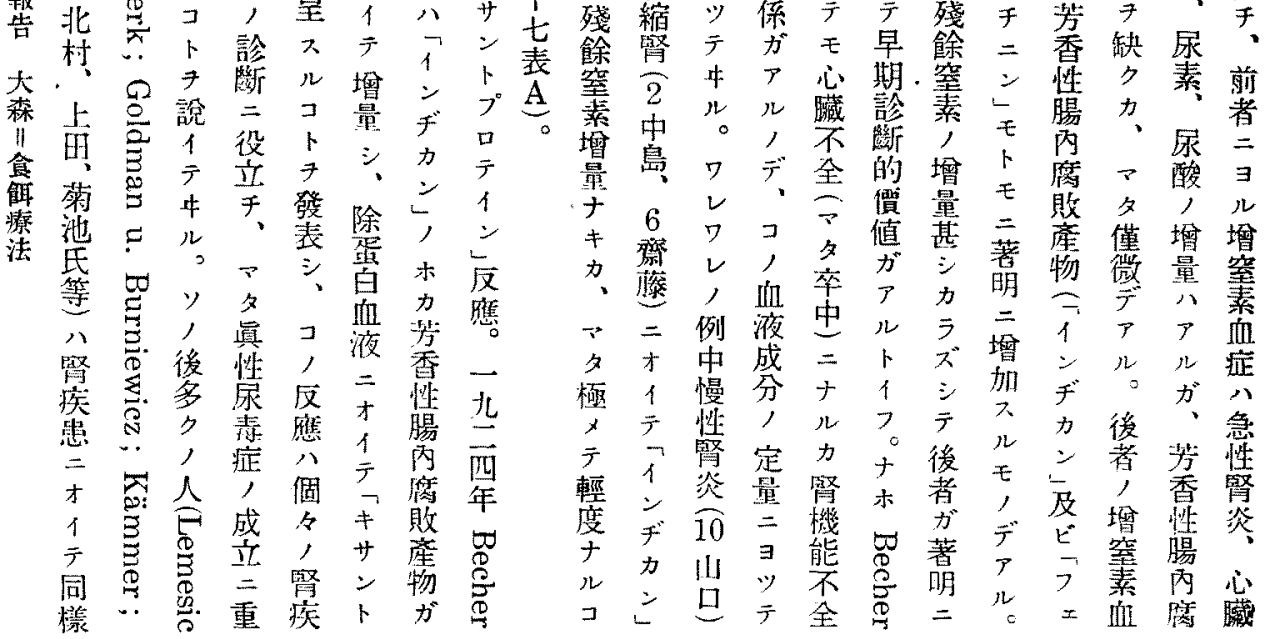

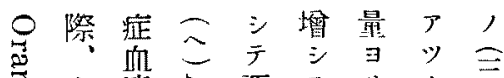

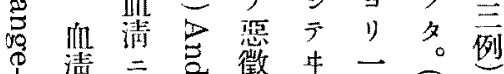
亭, 清

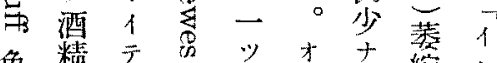

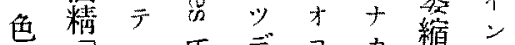
芫エ

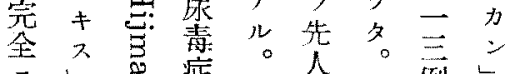

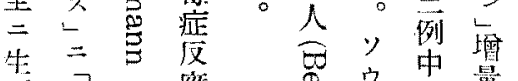

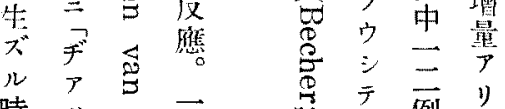
時 $y$ - 学 死例

第六十二表 血波「クサント疾嵌成

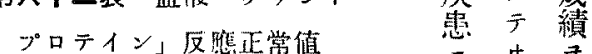

\begin{tabular}{|c|c|c|c|c|}
\hline 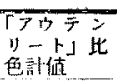 & 檢 & 查 & & \\
\hline $25-14$ & Becher & & & \\
\hline 23 以下 & Kämmer & & & \\
\hline $26-10$ & Goldman & & urni & wicz \\
\hline 25 以下 & Scherk & & & \\
\hline $20-13$ & 䇺 原 & 源 & 四 & 防 \\
\hline $25-14$ & 北 村 & 邦 & $太$ & 郎 \\
\hline $25-16$ & 菊波 & & 证 & $\equiv$ \\
\hline
\end{tabular}
$=$ \% モ 現 イ ゲ ハ元氏 ルガ, 第 1 說 六 デ贊 士 成 表 ナ シ 間方总北

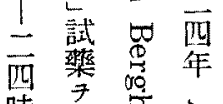

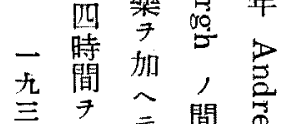

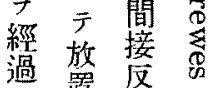

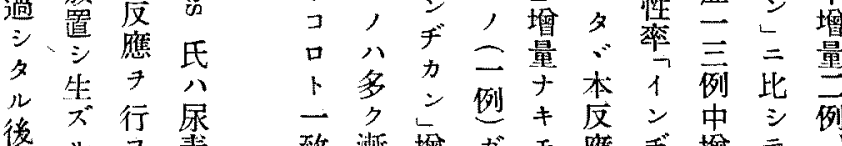

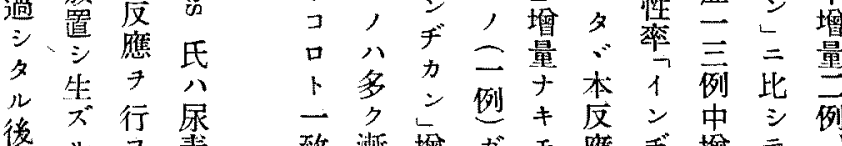
亡二テ陽力加少陽 1 區五方

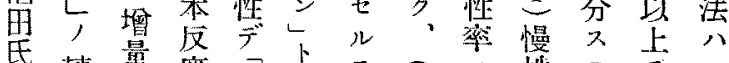
等轉量應

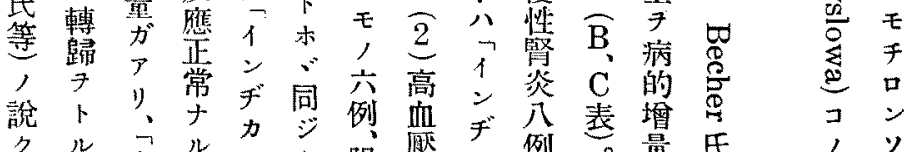

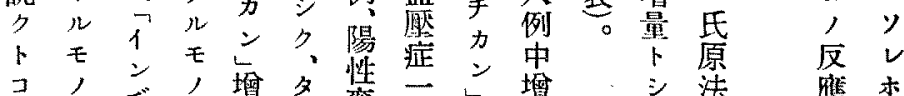

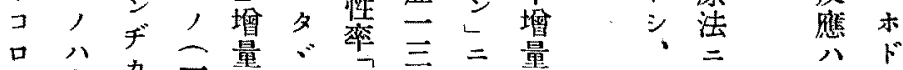
卜多力例ナ本1例比然四 致漱增がモ應 ゙堆デ、 


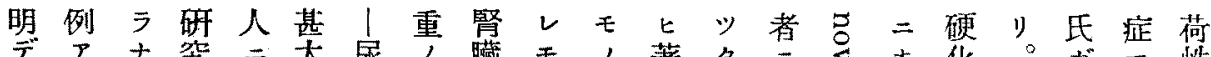

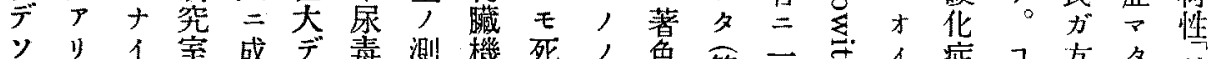
ソ

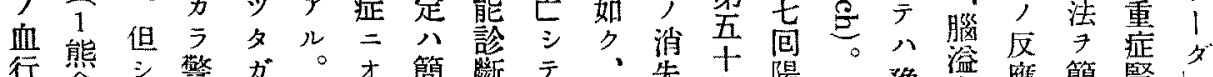

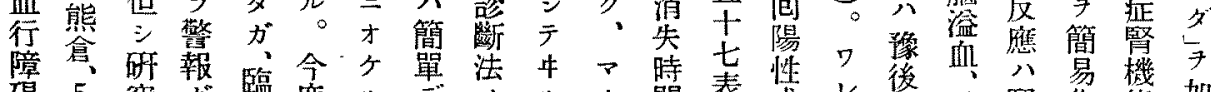

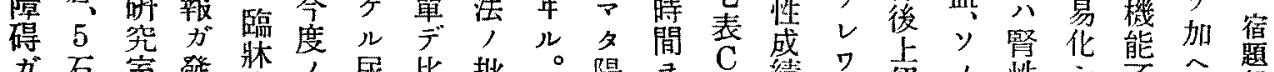

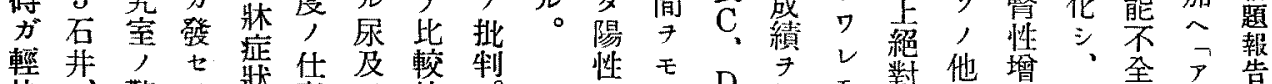
躌井, 警

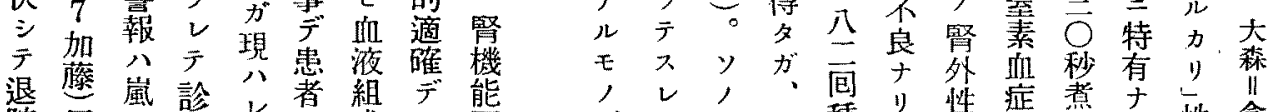

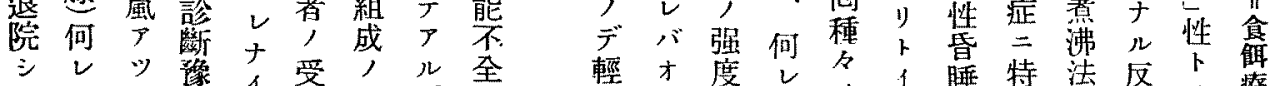

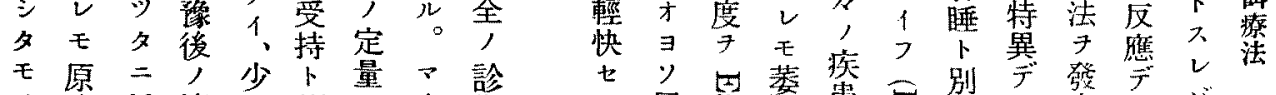

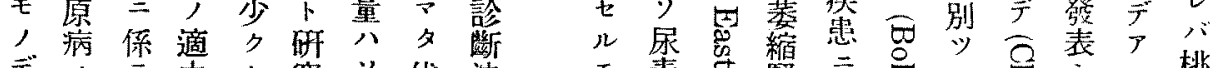

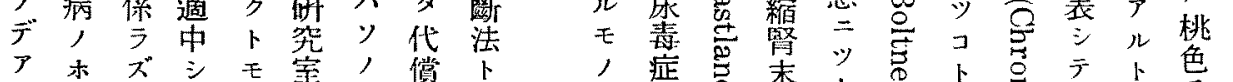
ア示

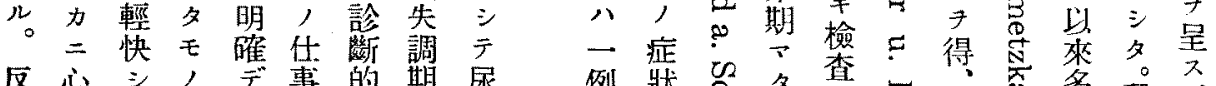

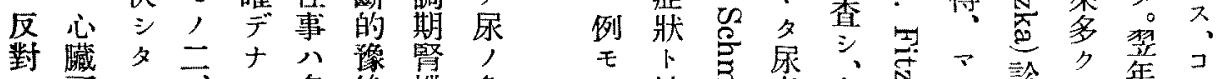

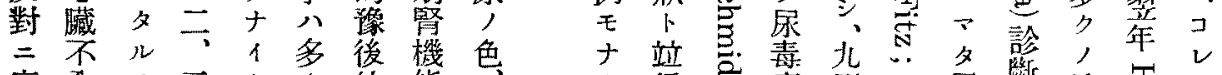

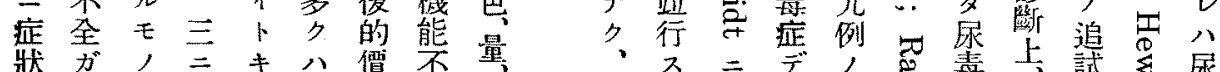

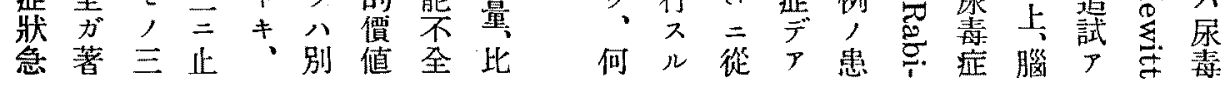

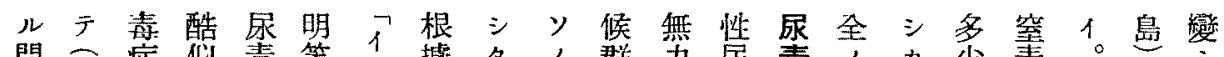

問员症似毒等

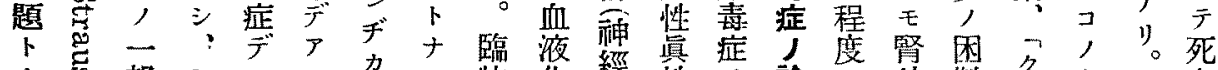

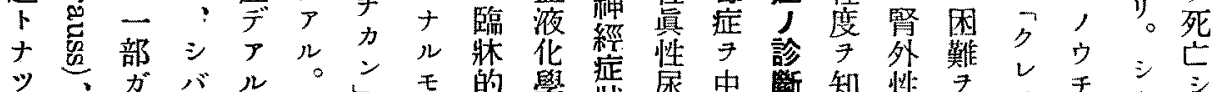

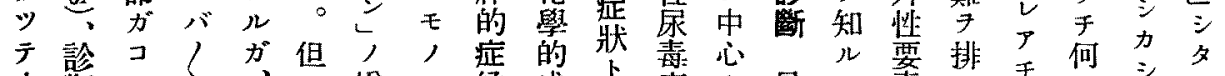

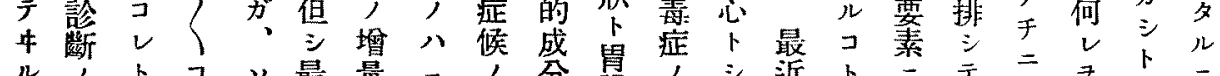

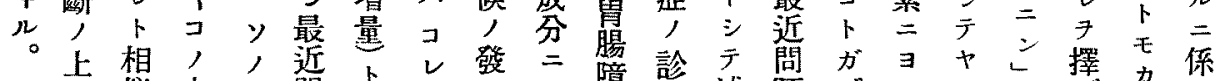

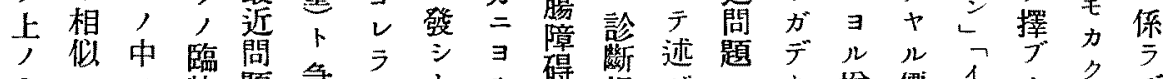

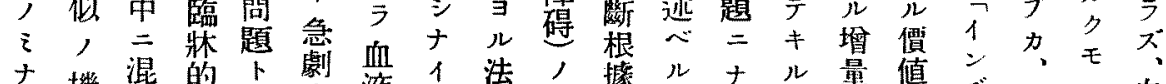

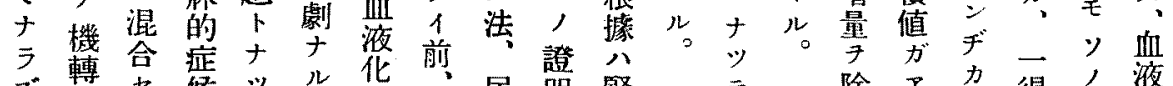

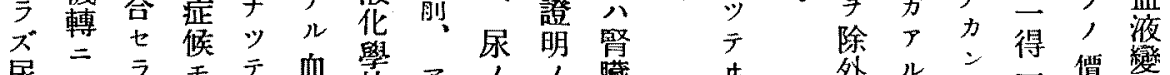

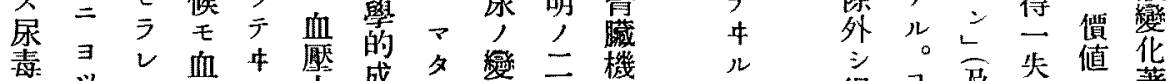
症テ $テ$ 血

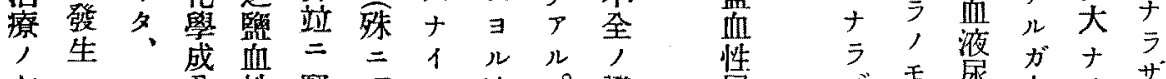
面儿夕モ原炎り

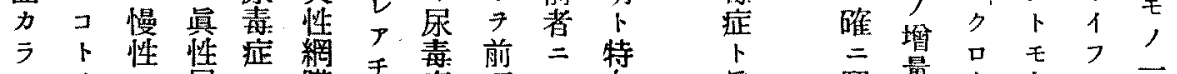

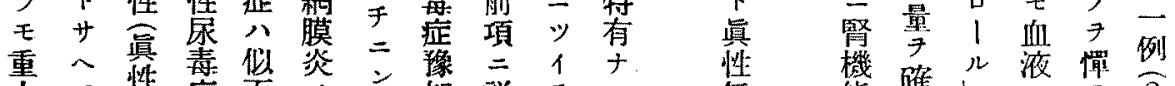

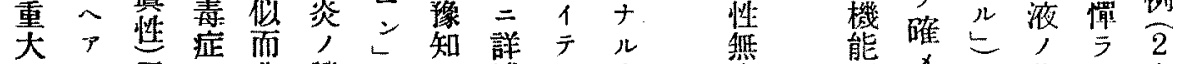
$ナ ッ$ 尿占韭證卜, 述八症妿势メ八殘ナ中 


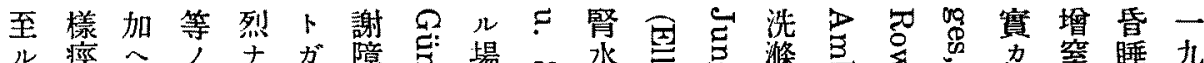

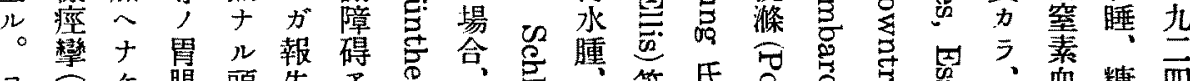

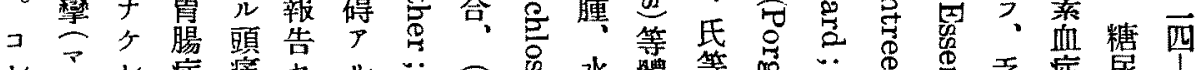

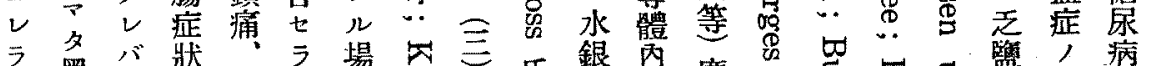

亏黑 溜 狀

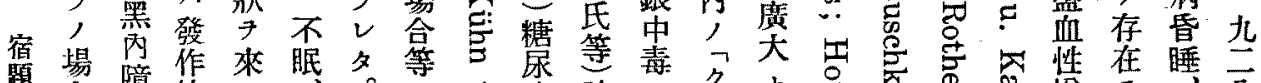

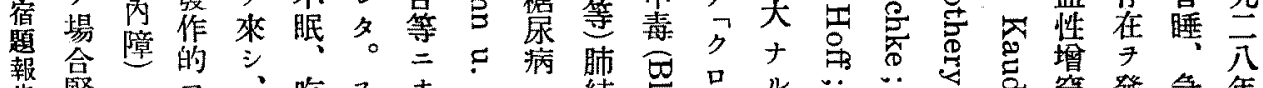

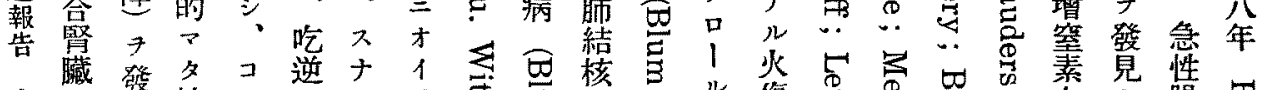
大八筑持,, 八

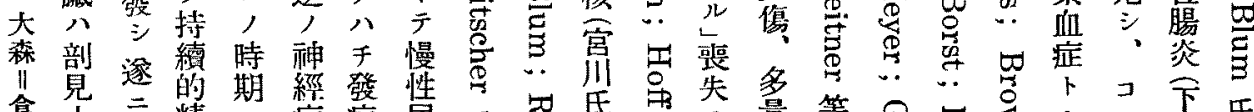

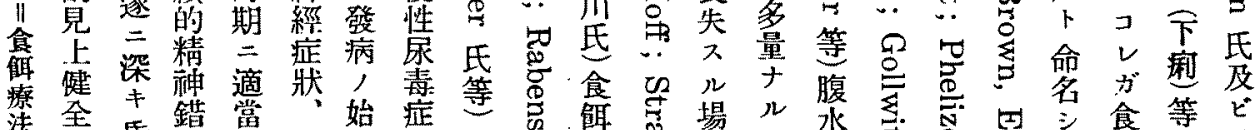

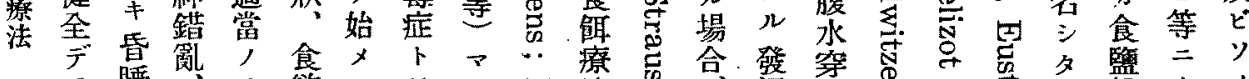

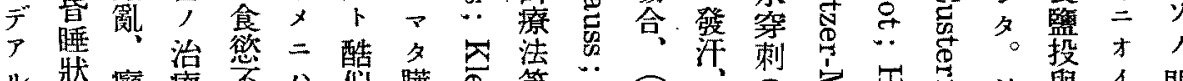

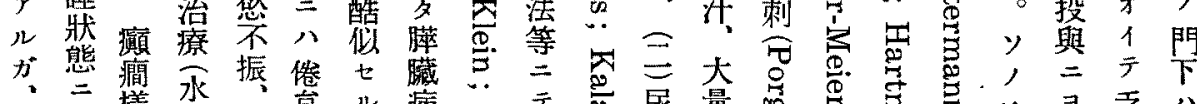

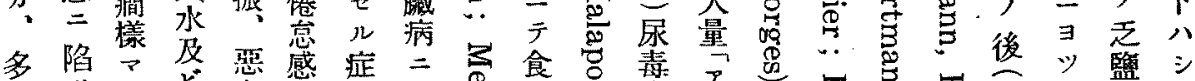

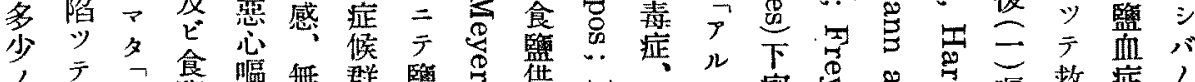
蛋死

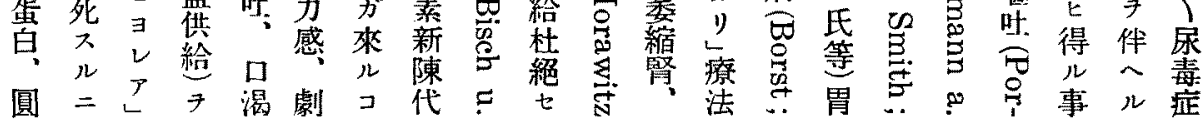

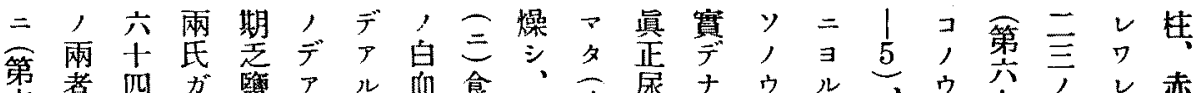

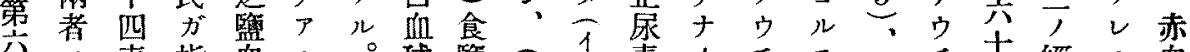

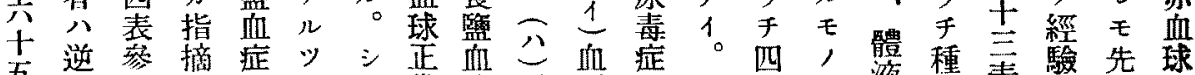

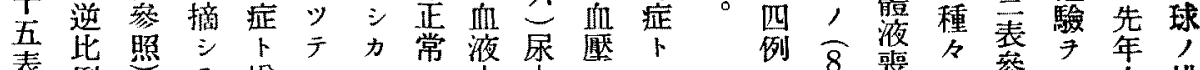

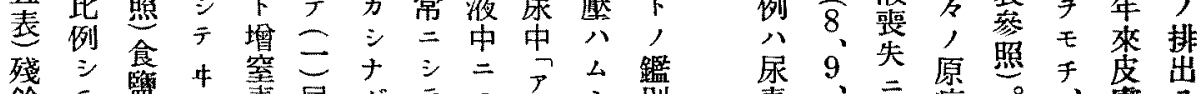

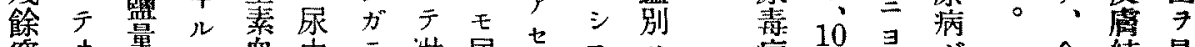

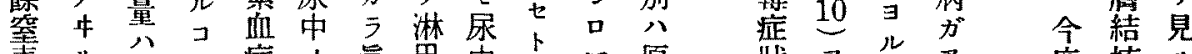

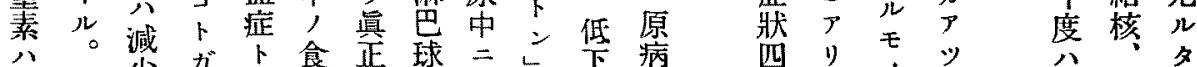
䂃ナ少ガ

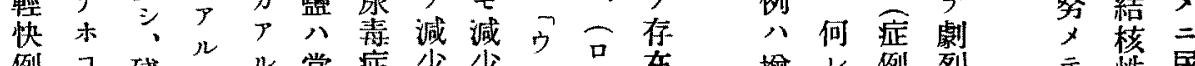
例了殘が。常症少少口品在增レ例烈厅性尿

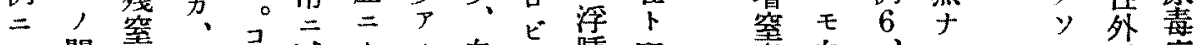

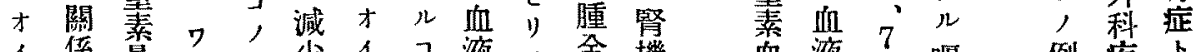
1 係韹 $レ コ$ 少 1 コ夜, 全機血液 7 嘔例疾

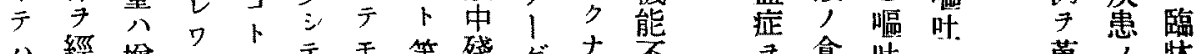

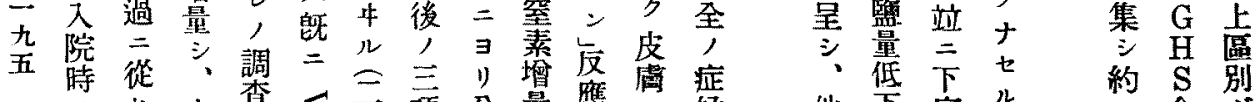

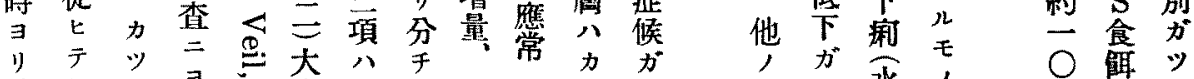

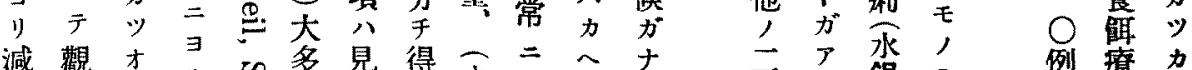
減觀 オ

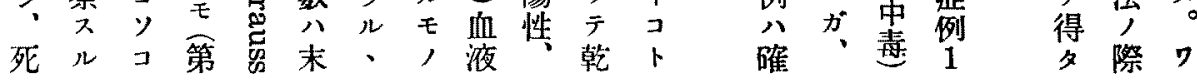




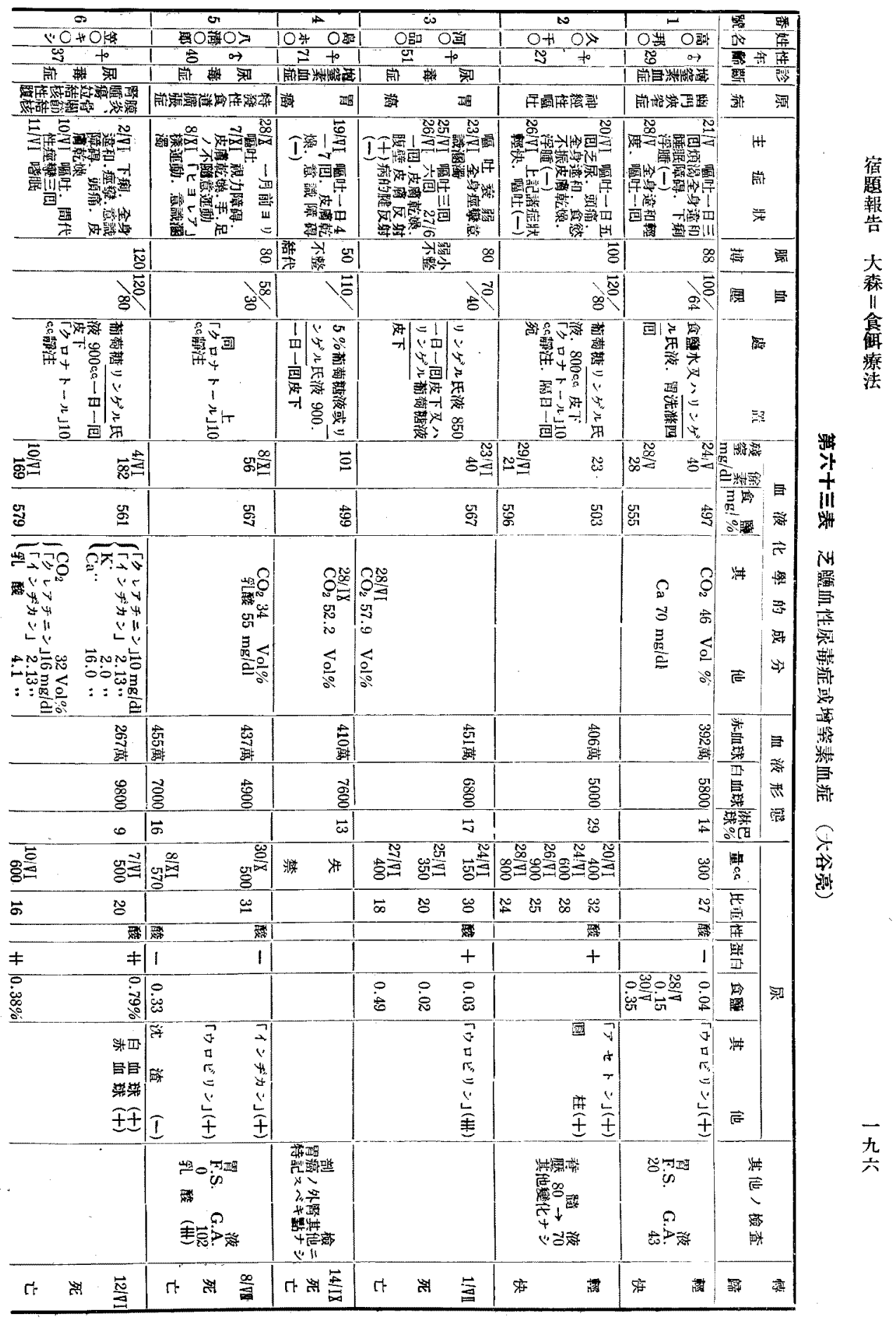



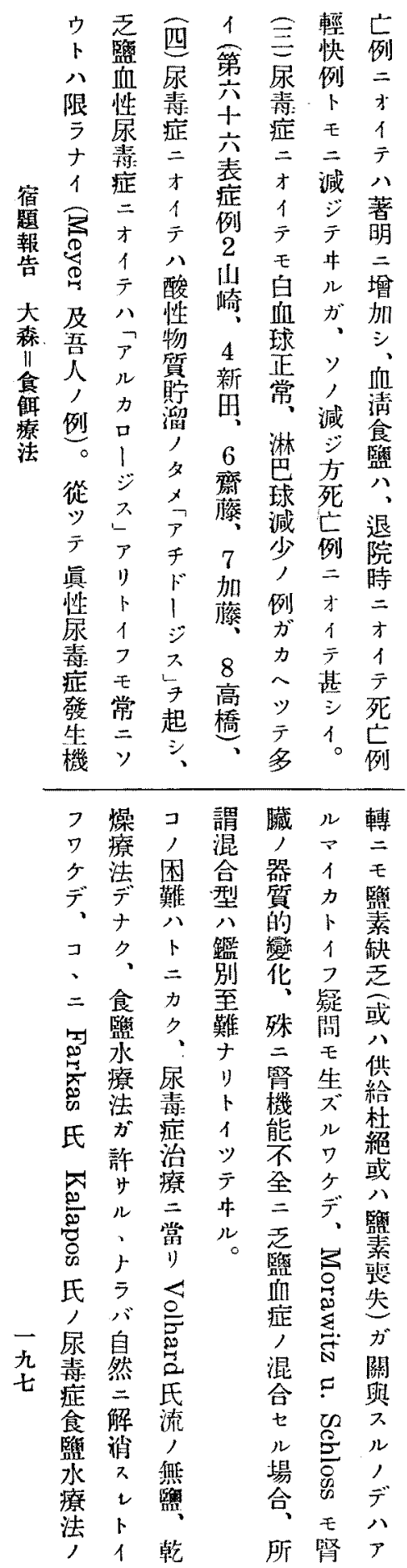

\begin{tabular}{|c|c|c|c|}
\hline$\frac{5}{6}$ & $\infty$ & $\frac{\infty}{4}$ & 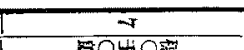 \\
\hline 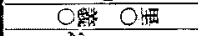 & Or ON & HONOE & DOHO蕰 \\
\hline & & $\vec{s} \quad$ to & 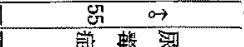 \\
\hline 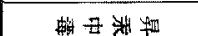 & 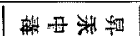 & 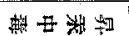 & 簿 \\
\hline$E_{x \rightarrow \infty}^{\infty}$ & & 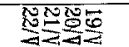 & 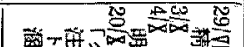 \\
\hline 的星星 & & 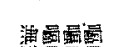 & 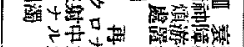 \\
\hline 简是 & 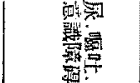 & 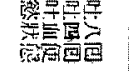 & 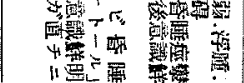 \\
\hline $\mathscr{8}$ & 호 & 8 & $\mathscr{8}$ \\
\hline & $\overline{3}$ & क्षे & ल) \\
\hline 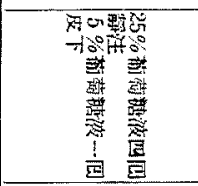 & 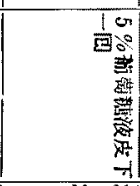 & 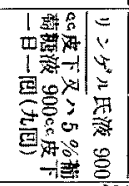 & 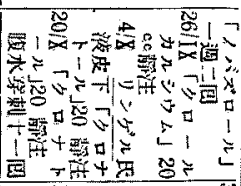 \\
\hline$\underset{\mathscr{\infty}}{\mathscr{\infty}}$ & 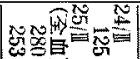 & ת?ํำ & 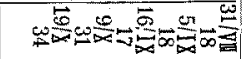 \\
\hline 趸 & 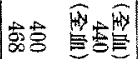 & 咨 & 㥕虫总念怘 \\
\hline 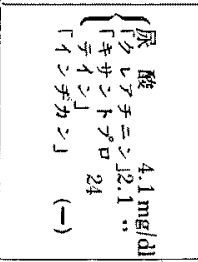 & 露 & 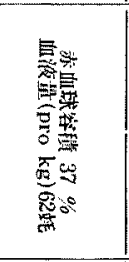 & 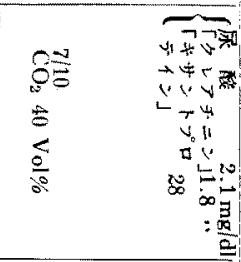 \\
\hline 罗 & 誌 & & 承 \\
\hline & 密| & & 蓉 \\
\hline S & $\omega$ & & $\Xi$ \\
\hline 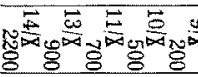 & & I: & 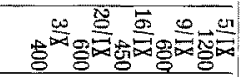 \\
\hline $\overrightarrow{0}$ & & 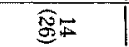 & 出 \& \& \\
\hline & & 彭 & 通 \\
\hline $\mathbb{E} \pm \pm$ & 三 & $\therefore \circ$ & 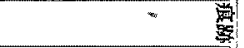 \\
\hline 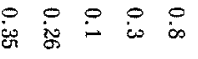 & & 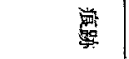 & 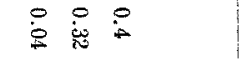 \\
\hline 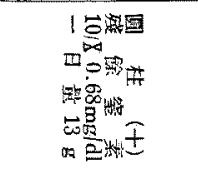 & 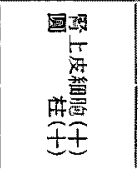 & & 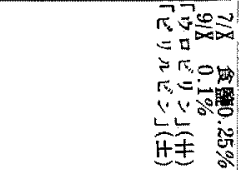 \\
\hline & 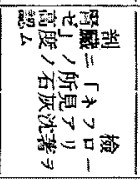 & 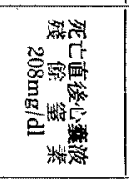 & 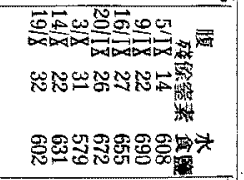 \\
\hline 正 & 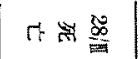 & rt 螎 & 가 䒿 \\
\hline
\end{tabular}




\begin{tabular}{|c|c|c|c|c|c|c|c|c|c|c|c|c|c|c|c|}
\hline $\begin{array}{l}\text { 考 } \\
\text { J } \\
\text { 島 }\end{array}$ & $\begin{array}{l}\text { シ } \\
\text { 力 } \\
\text { 三 } \\
\text { 重 }\end{array}$ & $\begin{array}{l}\text { 痤 } \\
\text { 攀 } \\
\text { 监 }\end{array}$ & $\begin{array}{l}\text { 像 } \\
\text { 防 } \\
\text { ス } \\
\text { U }\end{array}$ & $\begin{array}{l}\text { 㹂 } \\
\text { 機 } \\
\text { 能 } \\
\text { 丕 }\end{array}$ & $\begin{array}{l}\text { 婜 } \\
\text { 機 } \\
\text { 熊 } \\
\text { 奀 }\end{array}$ & $\begin{array}{c}\text { 皆 } \\
\text { 架 } \\
\text { 肧 } \\
\text { 胎 }\end{array}$ & & 六十 & 四表 & 血清 & $\begin{array}{l}\text { 会籃量 } \\
\text { (大谷亮， }\end{array}$ & 青木) & 證鮽窒素 & 点卜，閔 & \\
\hline $\begin{array}{l}\text { E⿱ } \\
\text { 氏 }\end{array}$ & $\begin{array}{l}\text { 要 } \\
\text { ナ } \\
\text { ル }\end{array}$ & $\begin{array}{l}\text { 素 } \\
\text { 症 } \\
\text { 种 }\end{array}$ & $\begin{array}{l}\vec{J} \\
r \\
j\end{array}$ & $\begin{array}{l}\text { 全 } \\
\text { 本 }\end{array}$ & $\begin{array}{l}\text { 主 } \\
\text { 㲾 } \\
\text { 素 }\end{array}$ & $\begin{array}{l}シ \\
\bar{F} \\
4\end{array}$ & 血筩筷思 & 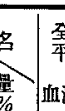 & 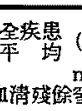 & 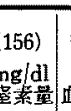 & 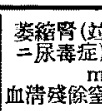 & 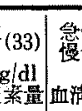 & 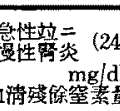 & & $\begin{array}{l}\text { 厔症 (20) } \\
\text { mg/dl } \\
\text { mg }\end{array}$ \\
\hline & 㓳 & 動 & 必 & 名 & & r & 510 以 & & 134.4 & (11) & 167.3 & & - & & $=$ \\
\hline & 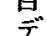 & 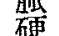 & 葵 & 氷 & 落 & & $511-54$ & & 85.7 & (10) & 133.0 & & $29.5 \quad$ (2) & & $.6(1)$ \\
\hline & 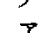 & 作 & 3 & 病 & 縮 & & $541-57$ & & 57.31 & (21) & 80.0 & & $25.0 \quad$ (1) & & $.0 \quad(2)$ \\
\hline & u & 症 & $n$ & $\frac{\pi}{7}$ & 6 & & $571-60$ & & 36.01 & (49) & 50.0 & & $22.0 \quad(4)$ & & $.0(5)$ \\
\hline & & $=$ & $\circ$ & 登 & 蓈 & & $601-63$ & & 35.51 & 35) & 78.3 & & $39.0(12)$ & & .0 (4) \\
\hline & $=$ & $\vec{\exists}$ & 层 & 5 & 苚 & & $630 \mathrm{D}$ & & 43.8 & 30) & 91.7 & 6) & $33.6 \quad(5)$ & & $4.4(8)$ \\
\hline & $y$ & $n$ & 蛋 & ザ & 被 & & & & & & 詿 & ) 內数与 & 字八例數 & & \\
\hline & & 变 & 㷥 & $ル$ & & & & & & & & & & & \\
\hline & هـ & 性 & 治 & ウ & & & & 六十三 & 五表 & 尿革戈 & 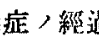 & 量卜血清 & 清，殘䤣 & 㝧素竝 & \\
\hline & 7 & 襪 & 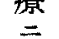 & $=$ & & & & & 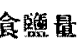 & （大往 & 谷亮， 表 & 木) & 慢性展毒 & 症 & \\
\hline & 远 & 症 & 期 & 冶 & & & & & 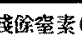 & 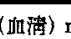 & $\mathrm{mg} / \mathrm{dl}$ & & 留（㥀 & 清) $\mathrm{m}$ & \\
\hline & & 除 & $\mu$ & 7 & & & & 整 & 快 & 死 & 亡 & 慗 & 快 & 死 & 亡 \\
\hline & 林 & 盖 & 韋 & 加 & & & & 入院時 & 持退院時 & 入院時 & 拫院時 & 入院時 & 退院時 & 入医時 & 退院時 \\
\hline & 最 & 弱 & 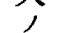 & - & & & 列 & 2 & $\overline{2}$ & 81 & 8 & $\overline{2}$ & 2 & 8 & 8 \\
\hline & 近 & $\tilde{\tau}$ & 力 & 原 & & & \begin{tabular}{c|} 
最大值 \\
\end{tabular} & 119 & 127 & $\overline{143}$ & 207 & 677 & 573 & 643 & 631 \\
\hline & 新 & 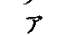 & 分 & 毒 & & & 晨小值 & 73 & 55 & 33 & 38 & 573 & 544 & 532 & 491 \\
\hline & シ & ル & 急 & 症 & & & 平均值 & 96 & $\overline{91}$ & 72 & 133.8 & 605 & 558.5 & 591.2 & 548.2 \\
\hline & キ & & 性 & 7 & & & & & & & & & & & \\
\hline
\end{tabular}

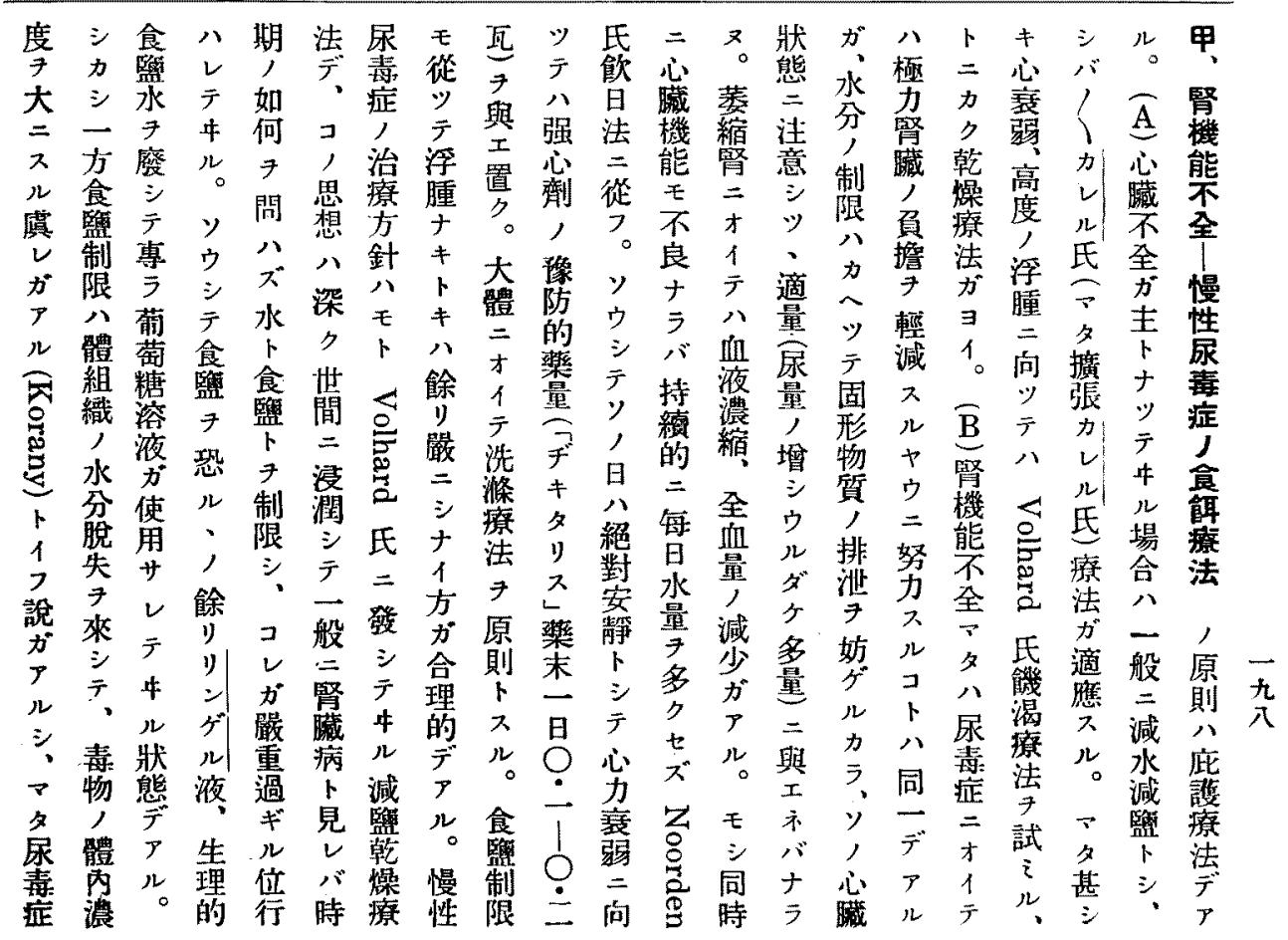




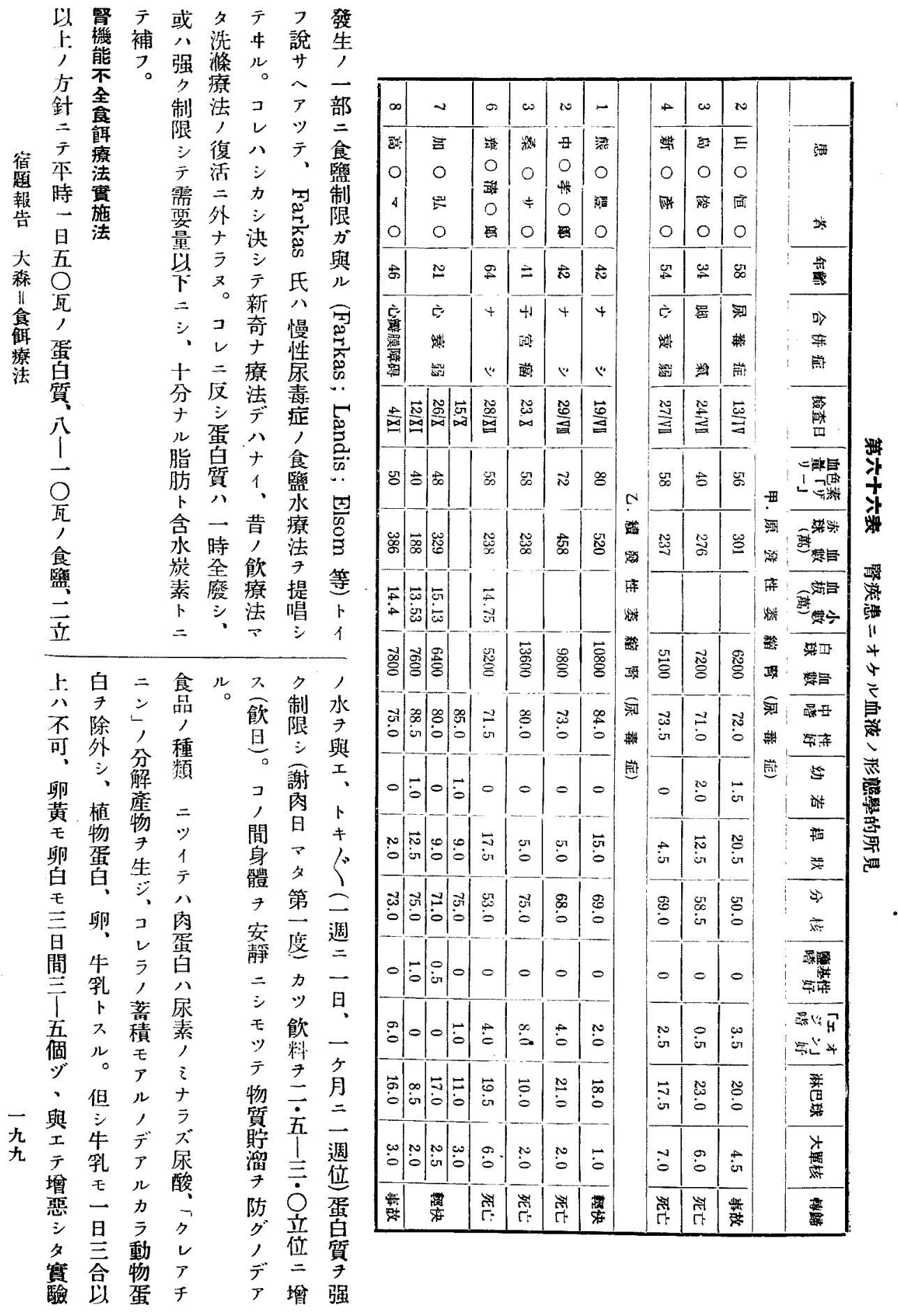




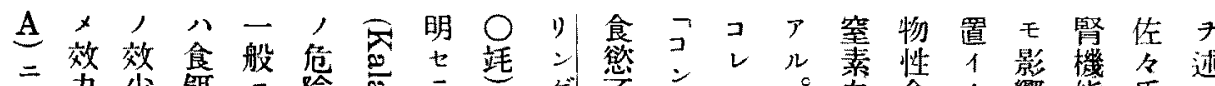

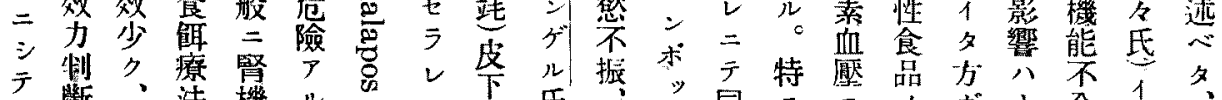

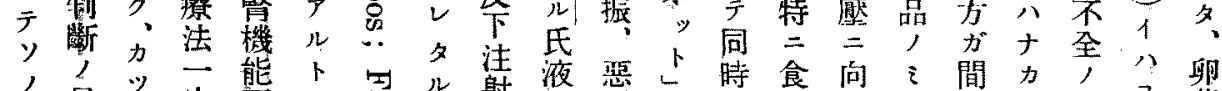

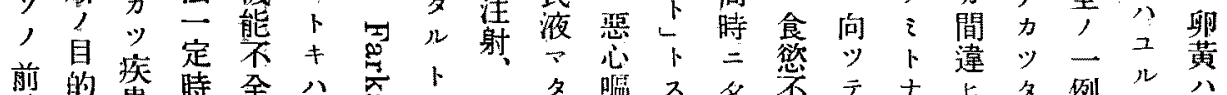

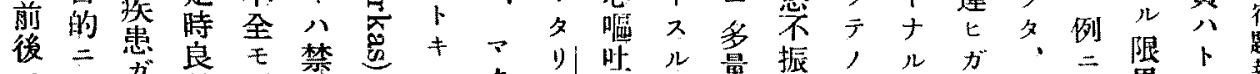

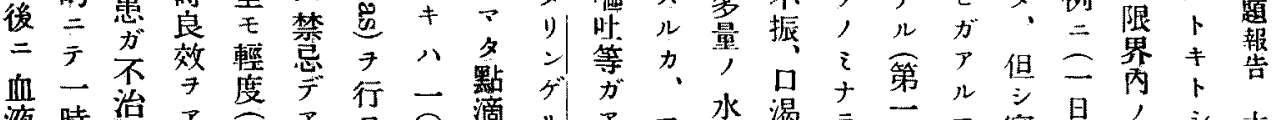

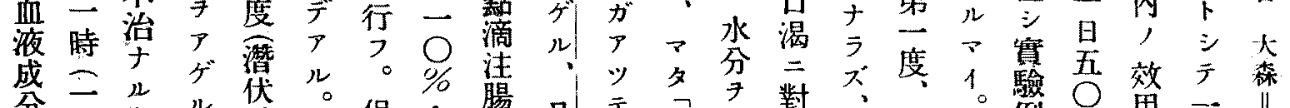

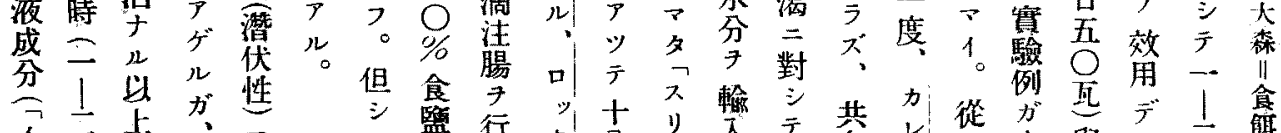

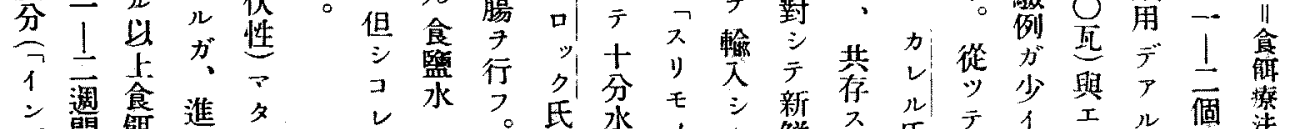

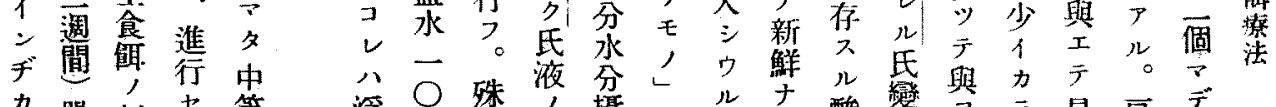

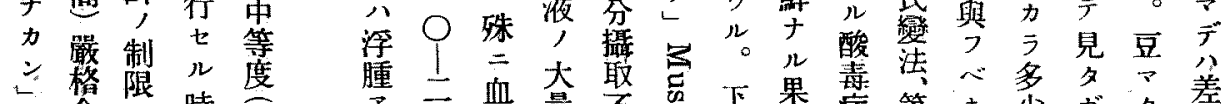

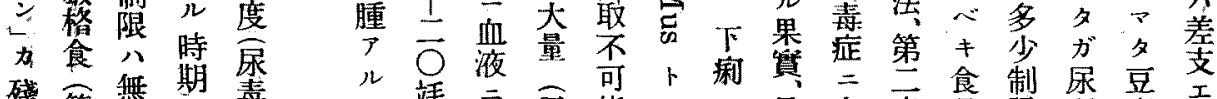

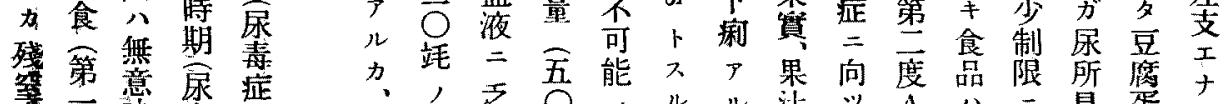

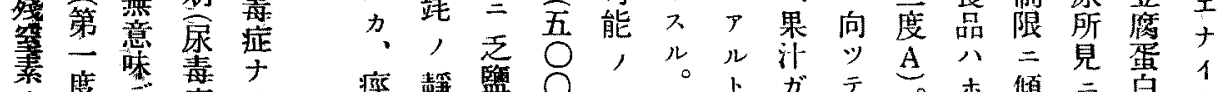

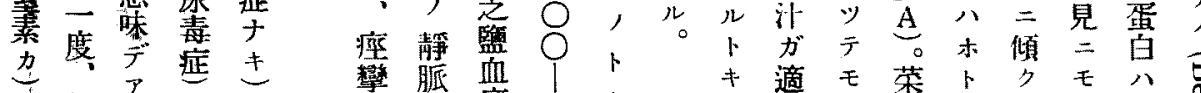

第古 定度妿 ソキ

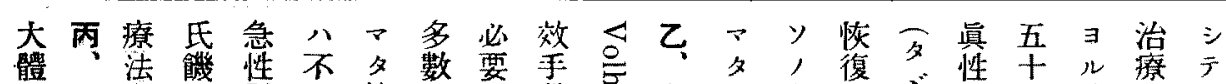

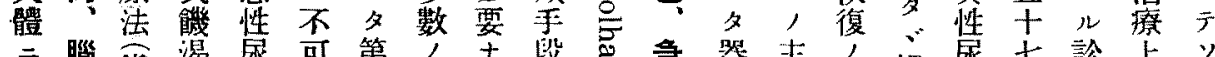

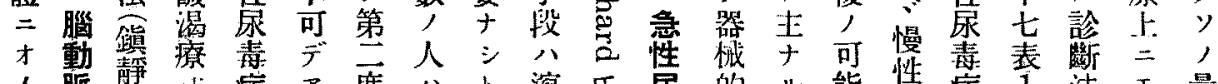

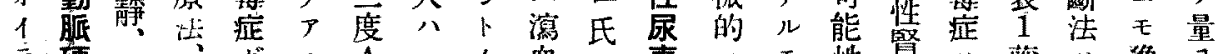

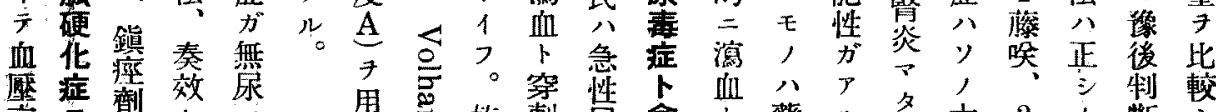

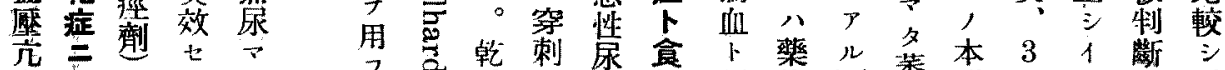

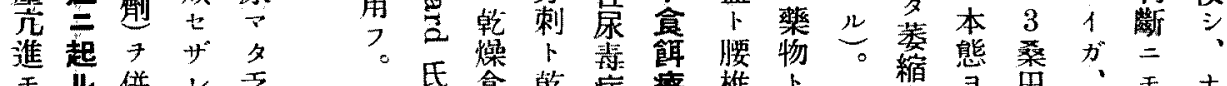

壬留併

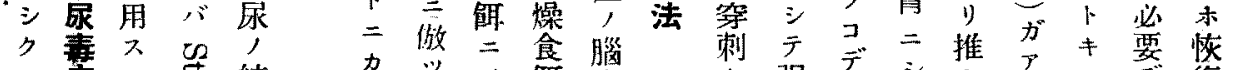

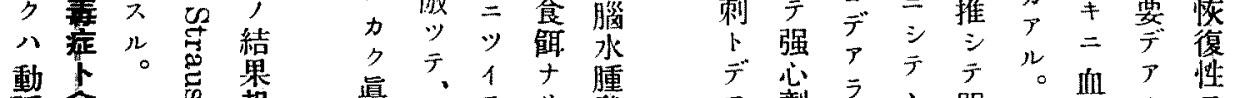

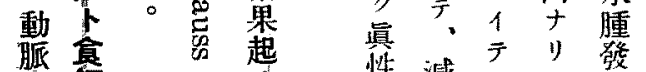

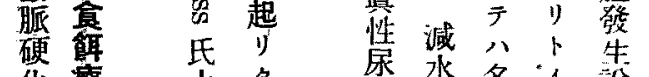

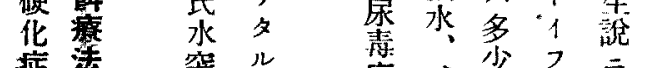

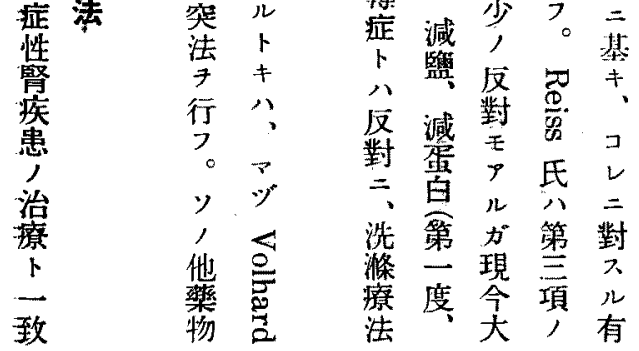

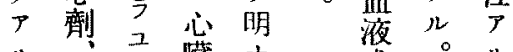

”。利儿贜ナ 威。

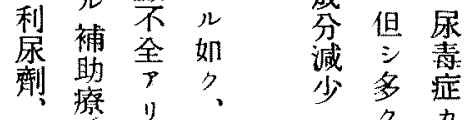

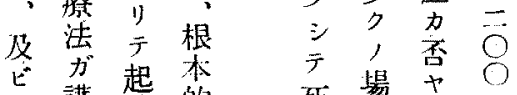

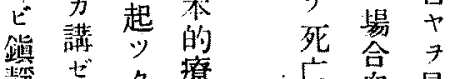

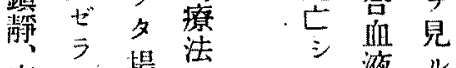

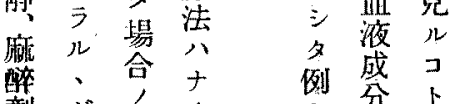

劑か， 


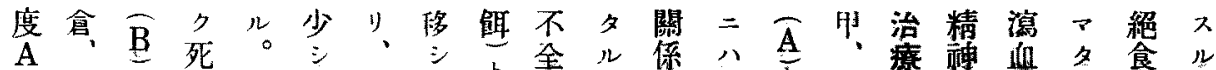

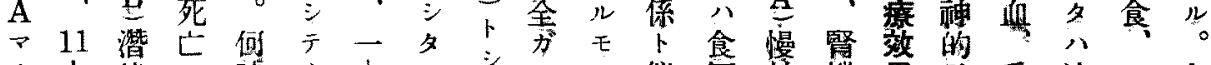

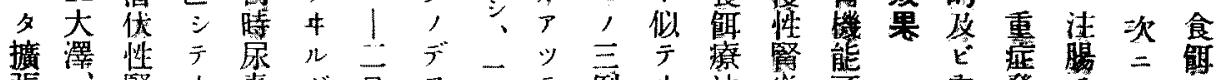

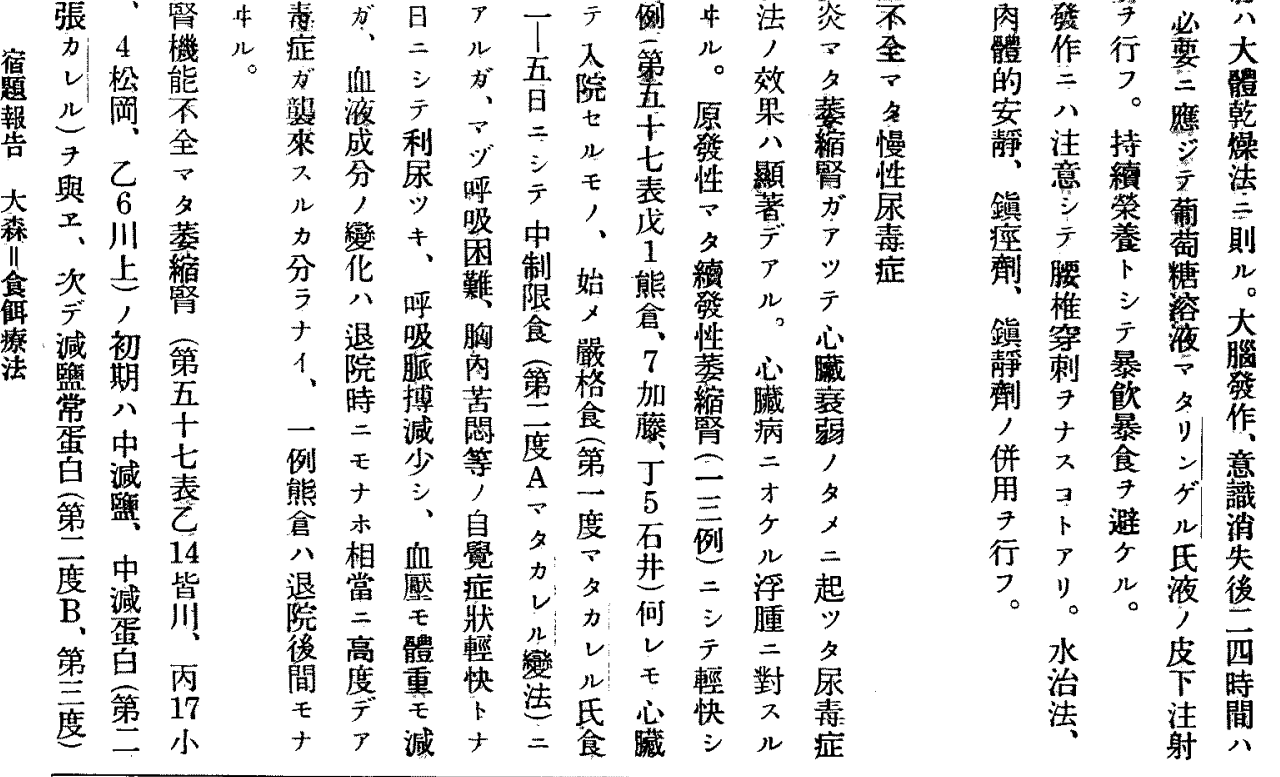

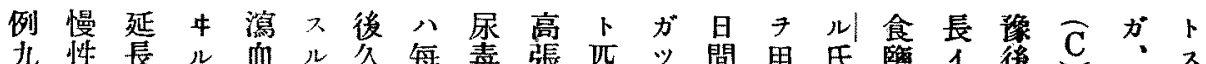

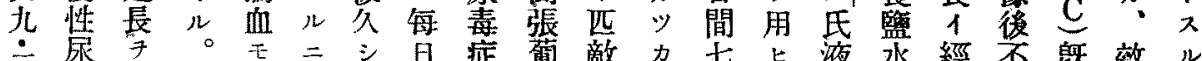

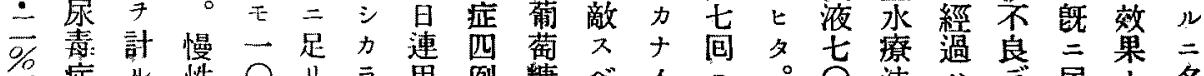

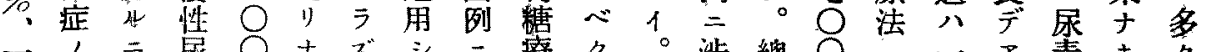

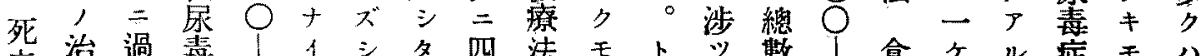

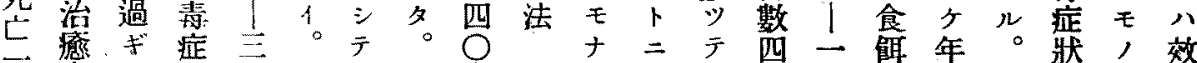
五萃 + 正言死三

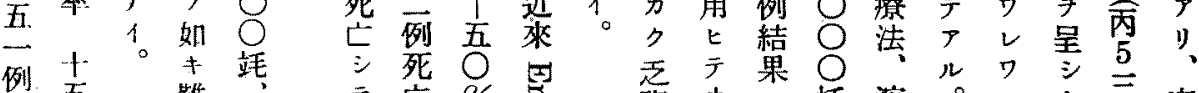

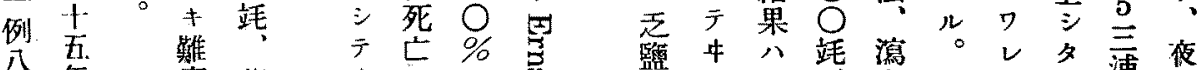

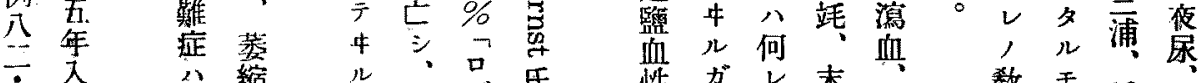

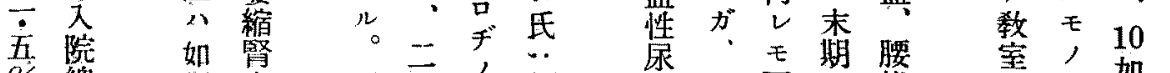

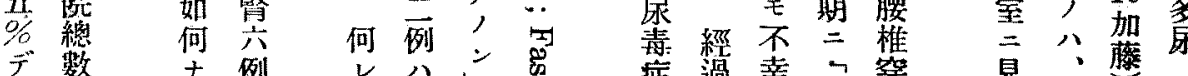

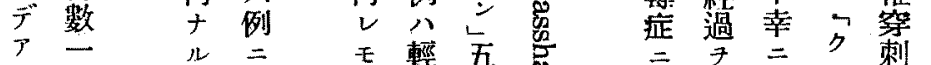

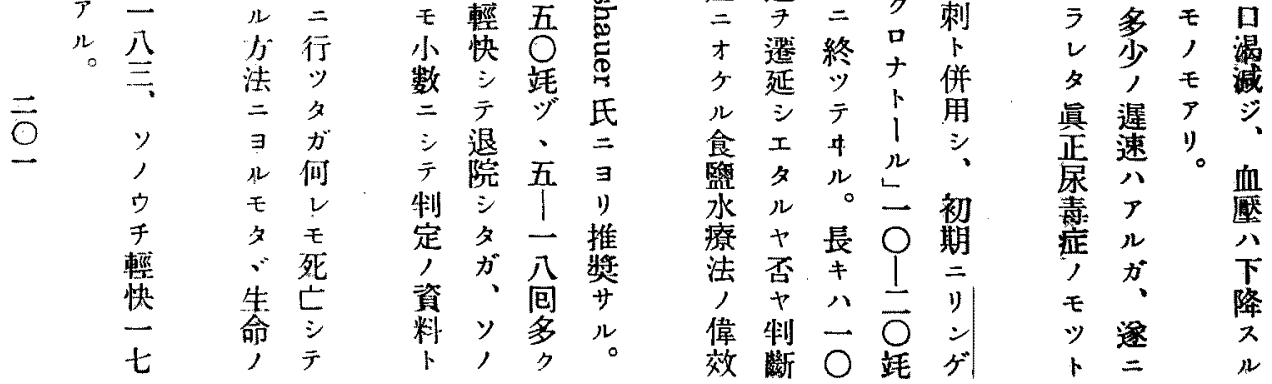




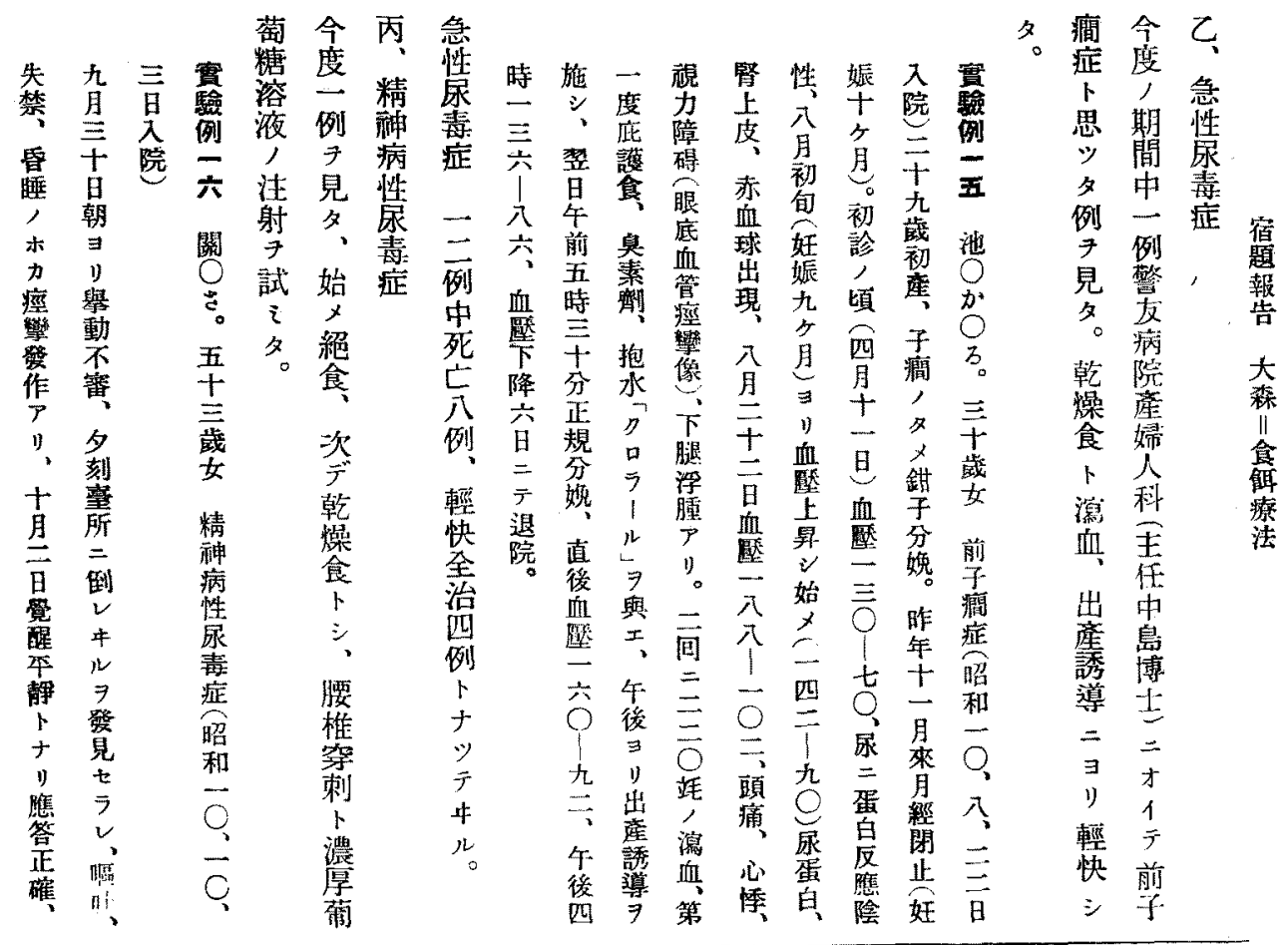

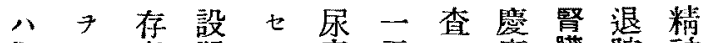

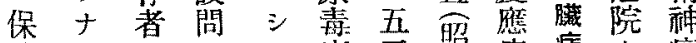

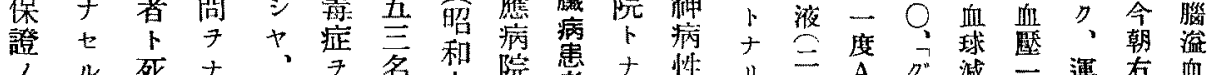

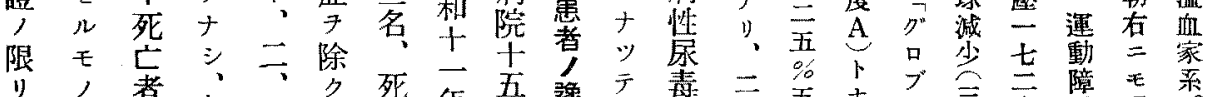

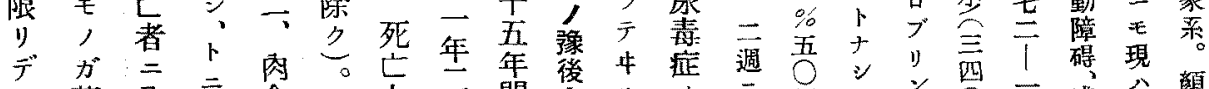
$ナ$ 著 分 イ

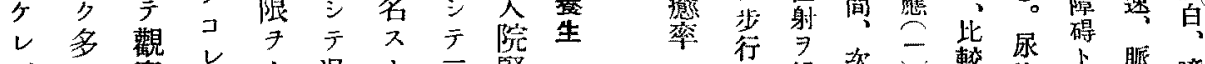

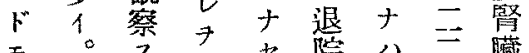

モ。公会七院八三藏

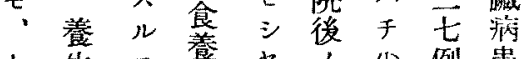

$卜$ 生二洁?, 牛例患

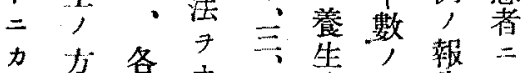

ク法種七雨法死告 シ

食が疾

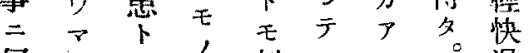

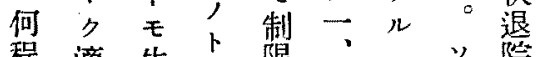

程適生存般食食, 院

‘七者般り監六ウル

注儿是中制十于

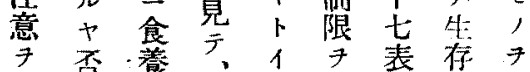

拂十生占 7 年者調

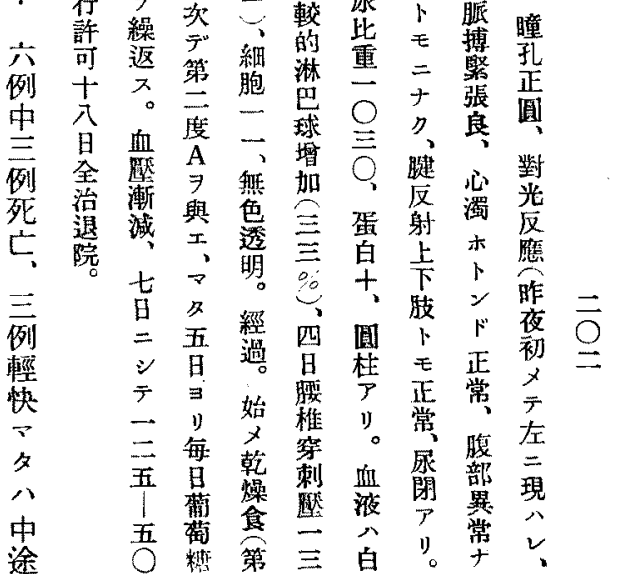




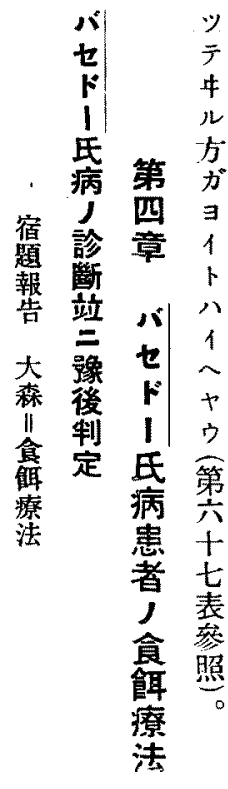

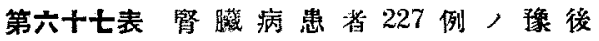

昭和十一年二月調查成績 (黑川)

\begin{tabular}{|c|c|c|c|c|c|c|c|c|c|}
\hline \multirow{2}{*}{ 病槑 } & \multirow{2}{*}{ 總數 } & 生存数 & \multirow{2}{*}{ 男 } & \multirow{2}{*}{ 女 } & \multirow{2}{*}{$\begin{array}{l}\text { 退院 徣 } \\
\text { 生存期間 }\end{array}$} & \multirow{2}{*}{ 平”均 } & \multirow{2}{*}{ 治痖期間 } & \multirow{2}{*}{ 平 均 } & \multirow{2}{*}{ 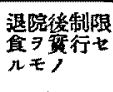 } \\
\hline & & 死亡数 & & & & & & & \\
\hline \multirow{2}{*}{ 急性野酮炎 } & \multirow{2}{*}{77} & 69 & 35 & 34 & 1一-15年 & 9.01年 & $2-88$ 日 & $30.1 \mathrm{~A}$ & $\begin{array}{r}32 \\
46.3 \% \\
\end{array}$ \\
\hline & & 8 & 3 & 5 & 12 日- 10 年 & 4.23年 & $20-76$ 日 & 46.0 日 & $\begin{array}{r}2 \\
25.0 \% \\
\end{array}$ \\
\hline \multirow{2}{*}{ 慢性腎睵炎 } & \multirow{2}{*}{93} & 54 & 27 & 27 & 2 月- 15 年 & 4.32年 & $3-246$ 日 & 40.6 日 & $\begin{array}{c}31 \\
57.4 \%\end{array}$ \\
\hline & & 39 & 18 & 21 & 1日一-11年 & 2.02年 & $17-71 日$ & 49.17日 & $10.2 \%$ \\
\hline \multirow{2}{*}{ 「ネフロービ」 } & \multirow{2}{*}{13} & 8 & 3 & 5 & 4 月一-11年 & 4.6 年 & 19-76日 & 48.3日 & $\begin{array}{c}5 \\
62.5 \% \\
\end{array}$ \\
\hline & & 5 & 3 & 2 & $9-240$ 日 & 81.8 日 & $35-116 日$ & 61.8 日 & $20.0 \%$ \\
\hline \multirow{2}{*}{ 原 登性 } & \multirow[t]{2}{*}{9} & 6 & 2 & 4 & 4月一6年 & 2.56 年 & $52-62$ 日 & $55.8 \boxminus$ & $\begin{array}{c}4 \\
66.6 \%\end{array}$ \\
\hline & & 3 & 3 & 0 & $7-38$ 日 & 21日 & 42 -62日 & 50.6日 & 0 \\
\hline \multirow{2}{*}{ 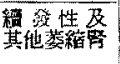 } & \multirow{2}{*}{11} & 1 & 0 & 1 & & 8 年 & & 49.0 日 & 1 \\
\hline & & 10 & 6 & 4 & $1-8.5$ 年 & 2.8 年 & $2-58$ 日 & 24.6 日 & 3 \\
\hline \multirow{2}{*}{ 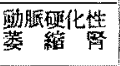 } & \multirow[t]{2}{*}{7} & 4 & 4 & 0 & 4-6年 & 4.9 年 & $60-77 日$ & 70.5日 & 0 \\
\hline & & 3 & 1 & 2 & 2遇一6年 & 2.1年 & $62-72$ 日 & 66.6 日 & 0 \\
\hline \multirow{2}{*}{ 杘 毒 证 } & \multirow{2}{*}{ 麦1 } & 5 & 2 & 3 & $2-6$ 作 & 4.4年 & $37-99 日$ & 66.2 日 & 2 \\
\hline & & 6 & 4 & 2 & $5-40 日$ & 15.6日 & $8-40 日$ & 21.3 日 & 0 \\
\hline \multirow[t]{2}{*}{ 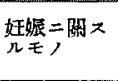 } & \multirow[t]{2}{*}{15} & 11 & & 11 & $1.5-15$ 年 & 7.5年 & 14-96日 & 35.0 日 & $\begin{array}{c}8 \\
72.7 \% \\
\end{array}$ \\
\hline & & 4 & & 4 & $1 月-5$ 和 & 1.66年 & $5-32$ 日 & $17.0 日$ & 0 \\
\hline
\end{tabular}

第六十八表 バセドー氏病，症候頻度（以下大谷周）

\begin{tabular}{|c|c|c|c|c|c|c|c|}
\hline 候 & 調查例 & 陟 性 & 售性雍 & 症 & 堛查例 & 陵 性 & 陆性率 \\
\hline 心僄公 猚 & 153 & 142 & $93 \%$ & 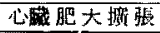 & 108 & 52 & $48 \%$ \\
\hline 甲 狀 縏 脸 & 151 & 134 & $89 \%$ & 赤㨁球減少 & 50 & 21 & $42 \%$ \\
\hline 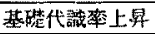 & 119 & 105 & $88 \%$ & 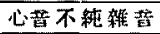 & 104 & 43 & $41 \%$ \\
\hline 淋巴球增绍 & 53 & 46 & $87 \%$ & 滕垶区射元進 & 92 & 35 & $38 \%$ \\
\hline 脈搏 80 以上 & 156 & 133 & $85 \%$ & 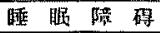 & 105 & 38 & $36 \%$ \\
\hline 朖毛不 全 & 62 & 53 & $85 \%$ & 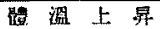 & 94 & 30 & $32 \%$ \\
\hline 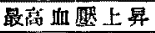 & 140 & 118 & $84 \%$ & 赤沈反礁促隻 & 25 & 8 & $32 \%$ \\
\hline 心星效䇣上罪 & 116 & 97 & $84 \%$ & 陵裇反射低下 & 92 & 26 & $28 \%$ \\
\hline 心藏勞作㐮上显 & 116 & 96 & $83 \%$ & & 87 & 21 & $24 \%$ \\
\hline 霞 & 152 & 126 & $83 \%$ & 思 不振 & 153 & 33 & $22 \%$ \\
\hline 月 絟 暴 常 & 82 & 63 & $77 \%$ & 浮 & 102 & 21 & $21 \%$ \\
\hline 皮消港知 & 91 & 68 & $75 \%$ & 白而球瑊少 & 54 & 11 & $20 \%$ \\
\hline 汗 & 141 & 98 & $70 \%$ & [スティワーダ] & 149 & 20 & $13 \%$ \\
\hline 哏球突 出 & 153 & 93 & $61 \%$ & 盆 白 展 & 89 & 10 & $11 \%$ \\
\hline 唭 & 136 & 82 & $60 \%$ & $\Gamma \not ゙ レ ー 7 エ 1$ & 148 & 14 & $9 \%$ \\
\hline 皮展色素沈素 & 73 & 40 & $60 \%$ & 「メ ビ & 149 & 12 & $8 \%$ \\
\hline 租液量埪大 & 14 & 8 & $57 \%$ & & & & \\
\hline
\end{tabular}

基六 院

整十工的

代八

謝 表 部

率參 桀 病

暴照

血悸 者 現

该一八

淮五ル

淋進六症

巴力名候

球 最

增高䋶

多率 就度

デ 的

頻 儿觀

脈光觀

腋 $\%$

毛

음

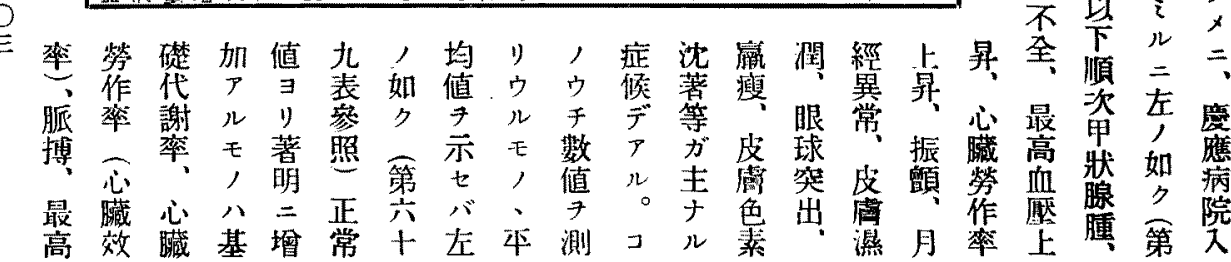




\begin{tabular}{|c|c|c|c|c|c|c|c|c|c|c|c|c|c|c|c|c|c|c|c|c|}
\hline $\begin{array}{l}\text { 父 } \\
\text { 明 }\end{array}$ & J & 照 & $\begin{array}{l}\text { 尹 } \\
\text { 計 }\end{array}$ & 崔 & 䀣业 & $\begin{array}{l}\text { テ } \\
\text { У }\end{array}$ & $\begin{array}{l}\text { Y } \\
1\end{array}$ & $\begin{array}{l}\text { テ } \\
\text { 次 }\end{array}$ & & & \multicolumn{3}{|c|}{ 第六十九贯 } & \multicolumn{7}{|c|}{ パセド二氏病鿊喉數值 } \\
\hline $\begin{array}{l}\not \\
=\end{array}$ & $\begin{array}{l}t \\
t\end{array}$ & & y & $\begin{array}{l}\text { 候 } \\
\text { ナ }\end{array}$ & $\begin{array}{l}\text { 嘔 } \\
\text { 㕸 }\end{array}$ & 占 & テ. & 如 & & & 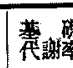 & & 㥕作箤 & 做 & 葴| 脈 & 脣搏 & 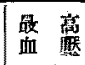 & 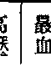 & 酦 集 & \\
\hline I & $\bar{*}$ & & ル & U & & 有 & Y & f & & 嘼查例 & 119 & & 116 & 116 & & 156 & 140 & & 138 & \\
\hline 昗 & 表 & & $x_{c}$ & ב & 下 & 厸 & 2 & 滒 & & 最大值 & +103 & $3 \%$ & $+146 \%$ & 0.824 & & 160 & 160 & & 100 跣 & \\
\hline シ. & 7 & & , & 1 & 角 & 7 & 5 & 阡 & & 最小值 & -22 & & $=30 \%$ & 0.637 & & 60 & 94精 & 拝 & 35耗 & \\
\hline & T & & , & オ & & 求 & 稕 & 时 & & 平均值 & +46 & $16 \%$ & $+42 \%$ & 0.752 & & 93 & 123精 & & 66朄 & \\
\hline 㟧 & , & & 平 & 知 & 食 & $x$ & 量 & 観 & & 正常值 & \pm 15 & $5 \%$ & $\pm 20 \%$ & 0.714 & & 67 & 110䊉 & & 66粍 & \\
\hline 梦 & 第 & & 均 & \% & 䆶 & 第 & 並 & 祭 & & & 赤血球 & & 白血球 & 淋巴球 & & 㿻球\% & $\begin{array}{l}\text { 血液意 } \\
\text { pro } \mathrm{kg}\end{array}$ & & 埊䧱 & \\
\hline 作 & 空 & & 相 & . & & $t$ & ' & 試 & & 翮租国 & 50 & 0 & 54 & 53 & & 14 & 14 & & 25 & \\
\hline 率 & + & & & \# & 等 & + & 占 & $i$ & & 最大值 & 784 & & 35200 & $57 \%$ & & $50 \%$ & 121蚝 & & 34 粍 & \\
\hline 八 & 旮 & & 永 & $\overline{7}$ & 等 & 表 & 有 & \& & & 最小值 & 259 & & 3000 & $21 \%$ & & $28 \%$ & 57 蚝 & & 2 粍 & \\
\hline サ & 表 & & ホ & $=$ & 界 & 參 & 數 & & & 本坞值 & 476 & & 8213 & $35 \%$ & & $42 \%$ & 88 䇅 & & 11 堹 & \\
\hline ラ & $\stackrel{r}{H}$ & & ス & 者 & 睗 & 照 & 全 & z & & 正常值 & & & & & & $45 \%$ & 85 䇎 & & & \\
\hline $\bar{H}$ & 較 & & $\therefore$ & 症 & 定 & 難 & 全 & 永 & ガ & $卜$ & 次 & U & 誹 & 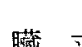 & & 千 & & & & \\
\hline 礎 & $\Xi$ & & 次 & 者 & 狀 & 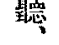 & 者 & $f$ & 夕 & 久 & & $\epsilon$ & シ & 效 & $x$ & , & & & + & 宸 \\
\hline 代 & $\bar{J}$ & & $\hat{j}$ & $=$ & 或 & & , & 重 & $x$ & ル & 治 & ' & 、 & 率 & 夕 & 7 & 基 & ル & 材 & 等 \\
\hline 謝 & 兒 & & 通 & $\%$ & 八 & 排 & 占 & 症 & $=$ & $=$ & 療 & デ & 體 & $=$ & 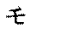 & $心$ & 礎 & & 料 & デ \\
\hline 率 & ப゙ & & i) & 1 & 中 & 求 & 有 & 者 & 重 & 足 & , & $\boldsymbol{P}$ & 表 & $\vec{\pi}$ & 1 & 贜 & 代 & 心 & ' & コ \\
\hline$\exists$ & 2 & & & 预 & 量 & 紧罢 & 數 & '́ & 症 & $\mu$ & 經 & 儿 & 面 & 分 & $\bar{F}$ & ' & 飽 & 藏荿 & $\rightarrow$ & v \\
\hline 7 & 其 & & 第 & 前 & 垷 & 政 & $r$ & 呈 & 者 & 症 & 過 & & 積 & 間 & & 營 & 率 & & デ & 5 \\
\hline 高 & 箖 & & $t$ & 同 & 爱 & 思 & F & र & 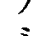 & 狀 & 或 & & $\overline{=}$ & ${ }^{\prime}$ & 世 & 作 & 屌 & 作 & $Y$ & 公 \\
\hline 度 & 䒫 & & - & 㧼 & 重 & 痛 & 比 & 症 & $\begin{array}{l}2 \\
=\end{array}$ & 知 & 㵀 & & 除 & 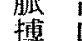 & 吕 & $\overline{\%}$ & 性 & 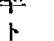 & ב & 㥖 \\
\hline$=$ & 謝 & & 表 & 數 & 篤 & & 較 & 候 & \% & 5 & 後 & & $\Xi$ & 數 & 氏 & 1 & 質 & 1 & $r$ & 上 \\
\hline 5 & 率 & & 參 & 値 & ナ & 便 & シ & $=$ & 1 & ン & $\Rightarrow$ & & タ & 7 & $心$ & テ & ; & 7 & $カ^{*}$ & 有 \\
\hline
\end{tabular}

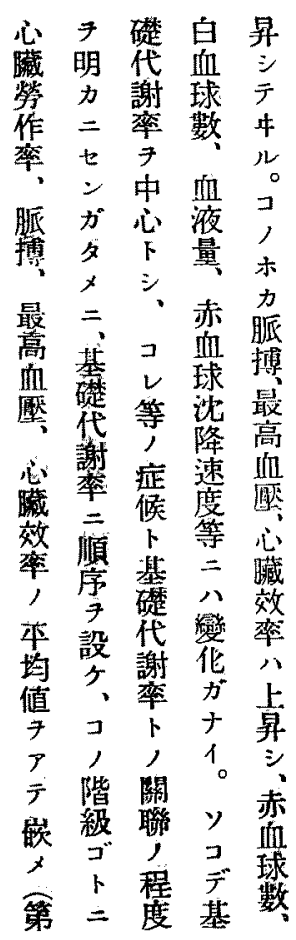

第七十表 バセド一氏病重症例症假頻度

\begin{tabular}{|c|c|c|c|c|c|c|c|}
\hline \multirow{2}{*}{$\begin{array}{cc}\text { 症 } & \text { 侯 } \\
\end{array}$} & \multicolumn{3}{|c|}{ 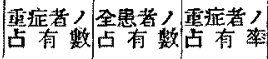 } & \multirow{2}{*}{ 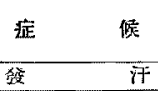 } & \multicolumn{3}{|c|}{ 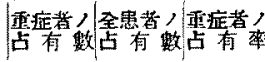 } \\
\hline & 2 & 2 & $100 \%$ & & 24 & 98 & $25 \%$ \\
\hline 排㽷頙 数 & 6 & 8 & $75 \%$ & $\begin{array}{ll} \\
\end{array}$ & 20 & 82 & $25 \%$ \\
\hline & 3 & 4 & $75 \%$ & 眼球笑出 & 22 & 93 & $24 \%$ \\
\hline 就 & 9 & 13 & $69 \%$ & 顽 痛 & 5 & 22 & $23 \%$ \\
\hline 吐 & 10 & 15 & $67 \%$ & 心缄肥大招張 & 12 & 52 & $23 \%$ \\
\hline & 13 & 23 & $57 \%$ & 心揫充 準 & 31 & 142 & $22 \%$ \\
\hline 盆思不振 & 18 & 33 & $55 \%$ & 月稴累常 & 14 & 63 & $22 \%$ \\
\hline & 7 & 15 & $47 \%$ & 葭 & 28 & $12 \hbar$ & $22 \%$ \\
\hline$[ク ゙ レ-フ \geq J$ & 6 & 14 & $43 \%$ & 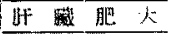 & 4 & 18 & $22 \%$ \\
\hline 「メビウ & 5 & 12 & $42 \%$ & 腋毛不全 & 11 & 53 & $21 \%$ \\
\hline 睡䁌障码 & 19 & 38 & $42 \%$ & 心昔不純轻琶 & 9 & 43 & $21 \%$ \\
\hline 伐 血 & 2 & 5 & $40 \%$ & 琶㦈 & 1 & 5 & $20 \%$ \\
\hline 籍力滑失 & 12 & 35 & $34 \%$ & 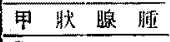 & 27 & 134 & $20 \%$ \\
\hline 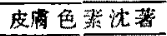 & 15 & 44 & $34 \%$ & 「ステルローダ」 & 4 & 20 & $20 \%$ \\
\hline 流 & 1 & 3 & $33 \%$ & 盆白尿 & 2 & 10 & $20 \%$ \\
\hline 原登反射低下 & 8 & 26 & $31 \%$ & 皮曹㵓洞 & 13 & 68 & $19 \%$ \\
\hline & 6 & 21 & $29 \%$ & 浮 & 4 & 21 & $19 \%$ \\
\hline 不 整 & 4 & 15 & $27 \%$ & 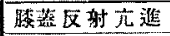 & 6 & 35 & $17 \%$ \\
\hline 躇㳑上暴 & 8 & 30 & $27 \%$ & 两症者 & 㣗全得 & 2200 & \\
\hline
\end{tabular}


第

バセド二氏病重症々候數值

\begin{tabular}{|c|c|c|c|c|c|c|}
\hline & 基壁碳 & 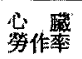 & 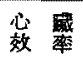 & 脈 搏 & 最篮 & 最 睢 \\
\hline 棓奝查洌 & 22 & 22 & 22 & 32 & 25 & 25 \\
\hline 最大值 & $+103 \%$ & $+146 \%$ & 0.815 & 160 & 150 粍 & 100 粍 \\
\hline 最小値 & $+15 \%$ & $+35 \%$ & 0.714 & 84 & 986 耗 & 58 粍 \\
\hline \multirow[t]{2}{*}{ 平垥值 } & $+65 \%$ & $\pm 69 \%$ & 0.764 & 109 & 130 粍 & 68 耗 \\
\hline & 赤血球 & 白㭰球 & 淋巴球 & 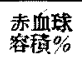 & $\begin{array}{l}\text { 血液量 } \\
\text { pro }\end{array}$ & 赤流 \\
\hline 誨盉例 & 8 & 8 & 6 & 4 & 4 & 4 \\
\hline 太值 & 645 & 10500 & $53 \%$ & $47 \%$ & 104 犝 & 11耗 \\
\hline 最小值 & 438 & 6920 & $22 \%$ & $36 \%$ & 80 钝 & 4钱 \\
\hline 平均值 & 486 & 8028 & $34 \%$ & $42 \%$ & 90 蹅 & 8 8粍 \\
\hline
\end{tabular}

第 $t+$ 二表

基礎代謝紊卜症侯，相關

\begin{tabular}{|c|c|c|c|c|c|c|c|c|}
\hline \multicolumn{2}{|c|}{ 基䃈代賭來 } & $\begin{array}{l}\text { 同上 } \\
\text { 列數 }\end{array}$ & 怘作婆 & \multirow{2}{*}{\multicolumn{2}{|c|}{$\frac{\mid \text { 压搏 }}{\mid 120}$}} & & $\begin{array}{l}\text { 心 } \\
\text { 效 }\end{array}$ & \\
\hline$+101-+$ & $110 \%$ & 1 & $+90^{\circ}$ & & & 146 & \multicolumn{2}{|l|}{0.815} \\
\hline$+91-7$ & $100 \%$ & 2 & $+79 \%$ & 11 & \multicolumn{2}{|r|}{134} & 0.758 & \\
\hline$+81=+$ & $90 \%$ & 8 & $+66 \%$ & 10 & \multicolumn{2}{|r|}{138} & 0.767 & \\
\hline$+71= \pm$ & $80 \%$ & 8 & $+65 \%$ & 10 & \multicolumn{2}{|r|}{135} & 0.777 & \\
\hline$+61+$ & $70 \%$ & 12 & $+48 \%$ & 9 & \multicolumn{2}{|r|}{129} & 0.761 & \\
\hline$+51=+$ & $60 \%$ & 23 & $+49 \%$ & 9 & \multicolumn{2}{|r|}{124} & 0.769 & \\
\hline$+41+$ & $50 \%$ & 15 & $+47 \%$ & 9 & \multicolumn{2}{|r|}{117} & 0.746 & \\
\hline$+31-\mp$ & $40 \%$ & 17 & $+22 \%$ & 81 & \multicolumn{2}{|r|}{117} & 0.736 & \\
\hline$+21-+$ & $30 \%$ & 16 & $+30 \%$ & 8. & \multicolumn{2}{|r|}{120} & 0.746 & \\
\hline$+11-t$ & $20 \%$ & 10 & $+25 \%$ & 8 & \multicolumn{2}{|r|}{112} & 0.732 & \\
\hline$+1-t$ & $10 \%$ & 3 & $+39 \%$ & 92 & \multicolumn{2}{|r|}{115} & 0.778 & \\
\hline$-11-$ & $0 \%$ & 2 & \multicolumn{2}{|c|}{$+28 \%$} & \multicolumn{2}{|r|}{110} & 0.728 & \\
\hline$-21=$ & $10 \%$ & 1 & +380 & 8 & & 106 & 0.728 & \\
\hline$-31-=$ & $20 \%$ & 1 & +360 & 9 & 3 & 108 & 0.728 & \\
\hline & & & 重伍 & & 分 & & & \\
\hline 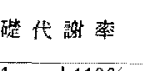 & 同点 & 淮垶 & 胃痽 & 拿思振 & 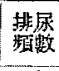 & 哂昍 & 便能 & 下㾥 \\
\hline$-+110 \%$ & 1 & 0 & 0 & 0 & 0 & 0 & 0 & 1 \\
\hline$=+100 \%$ & 2 & 0 & 0 & 1 & 0 & 0 & 0 & 0 \\
\hline$=+90 \%$ & 8 & 1 & 1 & 2 & 2 & 2 & 1 & 1 \\
\hline$=+80 \%$ & 8 & 0 & 1 & 3 & 2 & 2 & 2 & 3 \\
\hline$-+70 \%$ & 12 & 1 & 0 & 3 & 2 & 2 & 2 & 3 \\
\hline$-+60 \%$ & 23 & 0 & 0 & 5 & 0 & 2 & 0 & 4 \\
\hline$-+50 \%$ & 15 & 0 & 0 & 3 & 1 & 1 & 1 & 2 \\
\hline$-+40 \%$ & 17 & 0 & 0 & 2 & 0 & 0 & 1 & 1 \\
\hline$-+30 \%$ & 16 & 0 & 0 & 1 & 0 & 0 & 1 & 1 \\
\hline$-+20 \%$ & 10 & 0 & 0 & 3 & 1 & 1 & 1 & 2 \\
\hline$-+10 \%$ & 3 & 0 & 0 & 1 & 0 & 0 & 0 & 1 \\
\hline$=\quad 0 \%$ & 2 & 0 & 0 & 1 & 0 & 0 & 1 & 0 \\
\hline$--10 \%$ & 1 & 0 & 0 & 1 & 0 & 0 & 0 & 0 \\
\hline$=-20 \%$ & 1 & 0. & 0 & 0 & 0 & 0 & 0 & 0 \\
\hline
\end{tabular}


第 $t+$ 四表

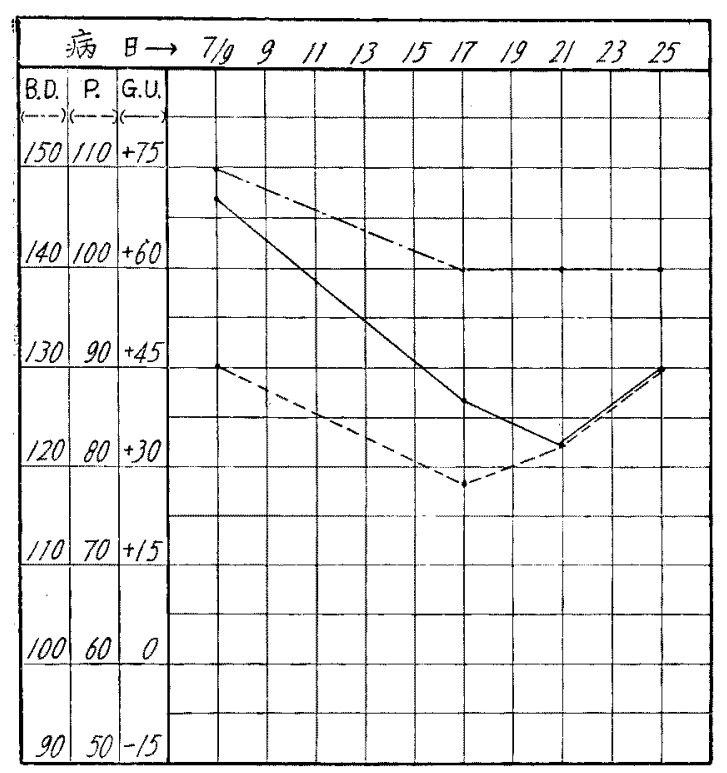

觀斷血察後經代， 祭八壓 $九$, 過謝上 二基 $=儿$ 診 7 受昇 基礎關必斷示艻 1 代入要上入低見 テ 謝 几窃基モ引ナ 次率函》礎，艼 1 如脈數儿。帒 キ數アソ率療心八郌 圖、儿占上踚經 標血力シ心早篇過

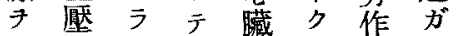

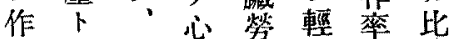
乙, 換藏作快, 較 バ關言管率入高的

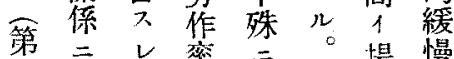

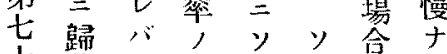
十著，基，コ谷ル 四竟七礎相 ゙゙多毛

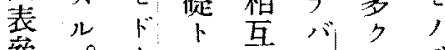
䕌。1 1 關七八 照y氏ル係代病了 基 礎デ, 臟精氏急が 代以潒效絧病劇 謝上後染 $=1+$ 基 率; 誩八觀潒儿礎

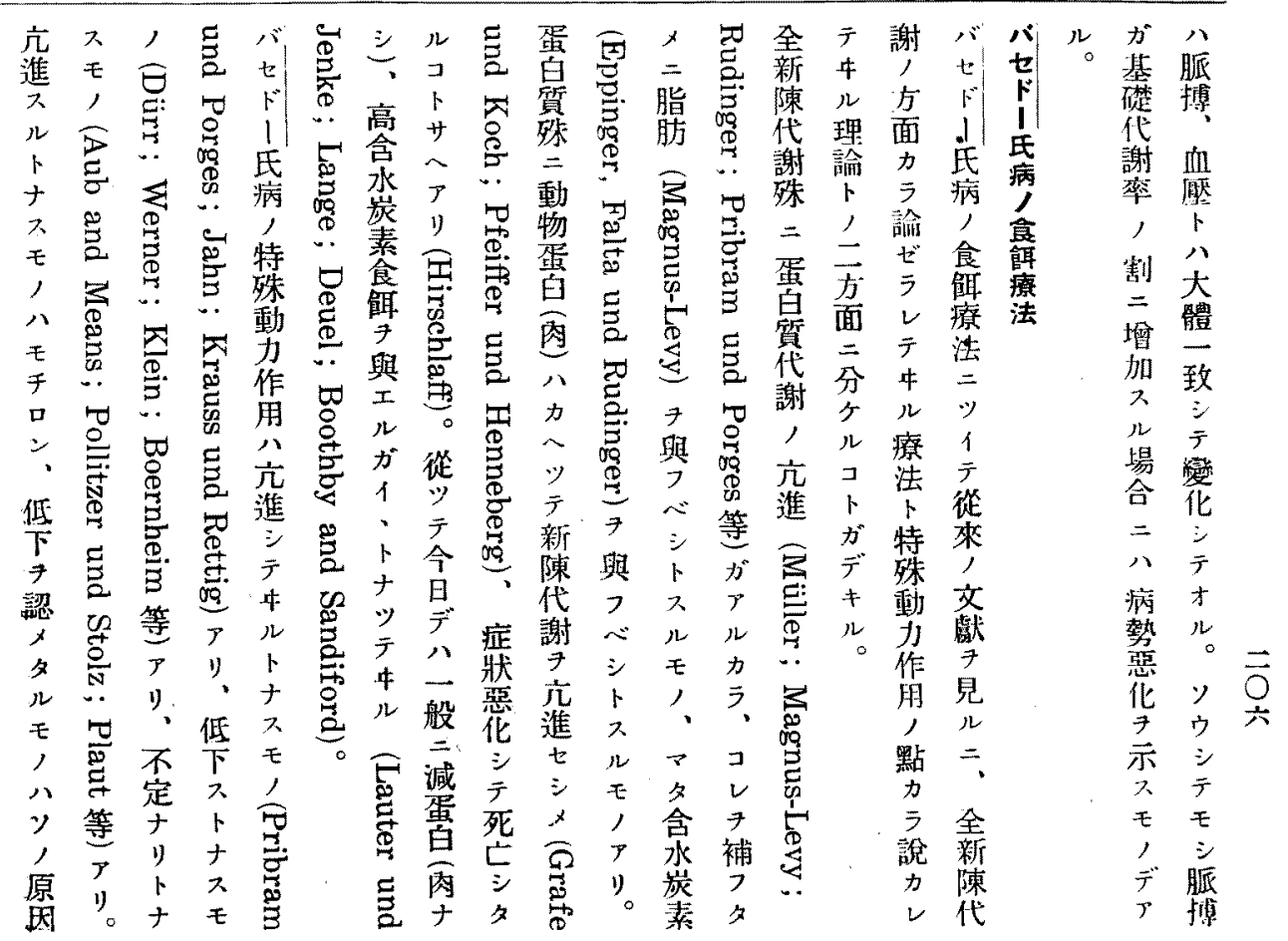


第七十五表 バセドー氏病庇護食食箋 (A)

\begin{tabular}{|c|c|c|c|}
\hline & Blum 氏食䇝 & König 氏食筙 & Kommerell 氏食辈 \\
\hline 铒 & 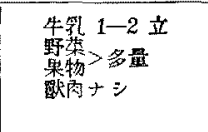 & 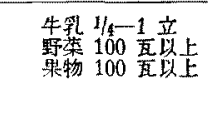 & 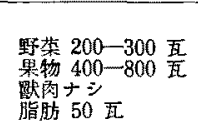 \\
\hline 特 & 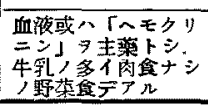 & 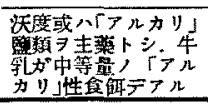 & 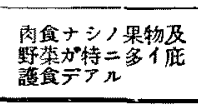 \\
\hline
\end{tabular}

菻

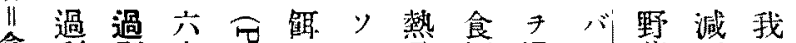

制剩表悬

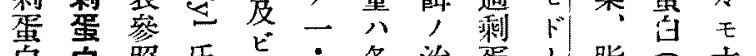

香皇照氏

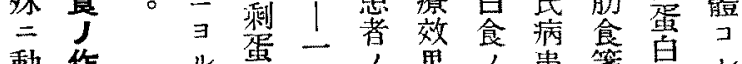

動作出蛋二, 果, 患籍白的

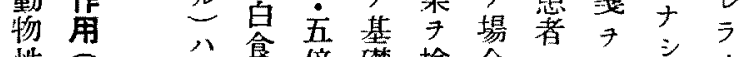

性第左, 食竞檢合奥作主,

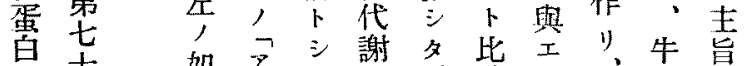

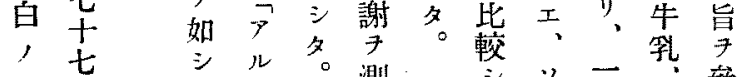

$\exists$ 表第力測主り西參

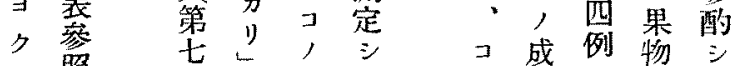

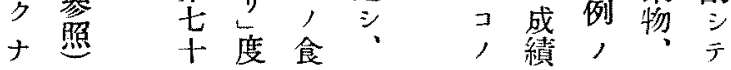

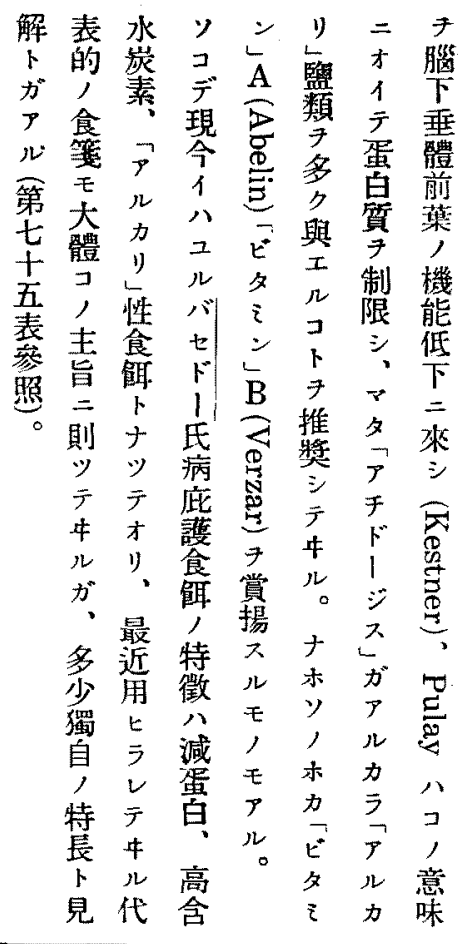

食加 $\bigcirc$ 示加較 7

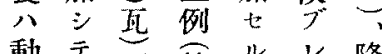

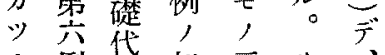

物症蛋第 ル く 降

性牀䅕 5 , 極七

两琵算 7 - メ

蛋言與。第僅

7 中 少方少, 例

使儿。占主第

シマ，第變

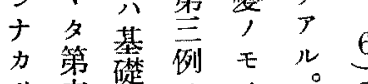

夕例謝如二

モ, 变夕例

,十卒非第二,

第七十六表「アルカリ」 度测定 (中野)

\begin{tabular}{|c|c|c|}
\hline 聕 & 笺 & 「アルカり」樶 \\
\hline 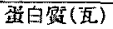 & 55 & \multirow{5}{*}{+18.92} \\
\hline 果 物 (西) & 800 & \\
\hline 生 乳(酉) & 400 & \\
\hline 米 濑(酶) & 700 & \\
\hline 脂 & 52 & \\
\hline 金 & 䔐 & 「アルカり」度 \\
\hline 蛋的钼 (瓦) & 133 & \multirow{5}{*}{-9.52} \\
\hline 果 物(酉) & - & \\
\hline 4 乳(玨) & - & \\
\hline 来 解(现) & 500 & \\
\hline 捾 肪 (互) & 37 & \\
\hline
\end{tabular}

第七十五表 バセド一氏病 食解食算 $(B)$

度怎病院

\begin{tabular}{|c|c|}
\hline 蛋白夏 & 體重一䣶二付キ一再 \\
\hline & $600-1000$ 五 \\
\hline 4 & 400 互 \\
\hline 黑乐 & $200-400$ 酉 \\
\hline 米 & $400-600$ 正 \\
\hline 脂 & 50 酉 \\
\hline 全祭器 & 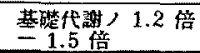 \\
\hline
\end{tabular}

八基 6 几 質 $儿 1$

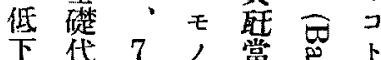

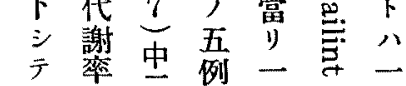

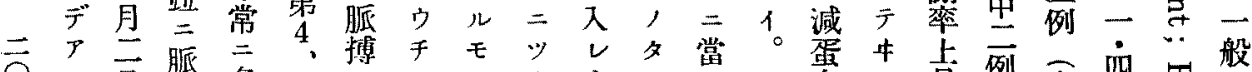

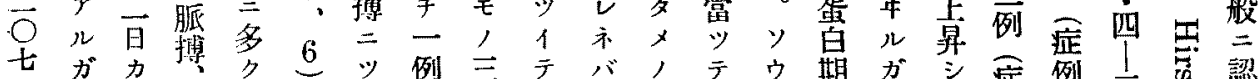

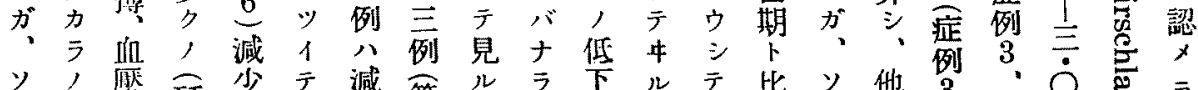

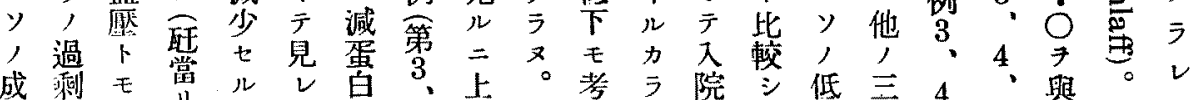

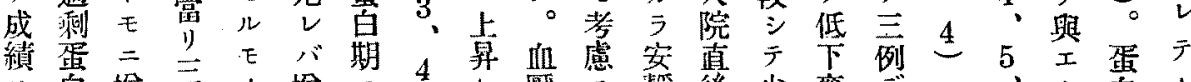

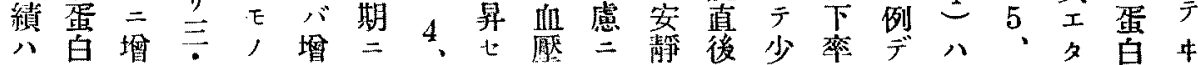




\section{第 $t+t$ 表 $(1)$ \\ 第二症例 松○清 38 歳 古 \\ 第一症例 宇 $\bigcirc$ 東 $\bigcirc$ 44歳}

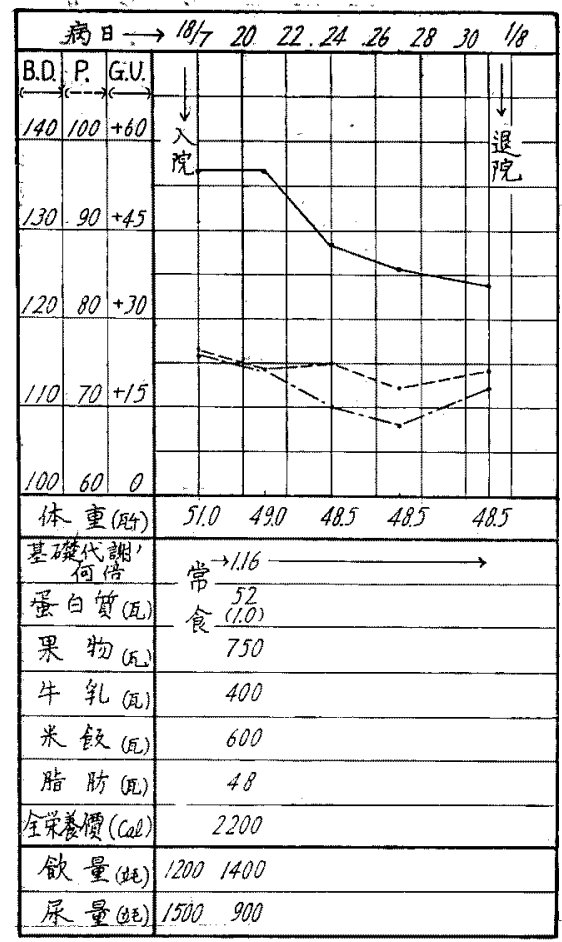

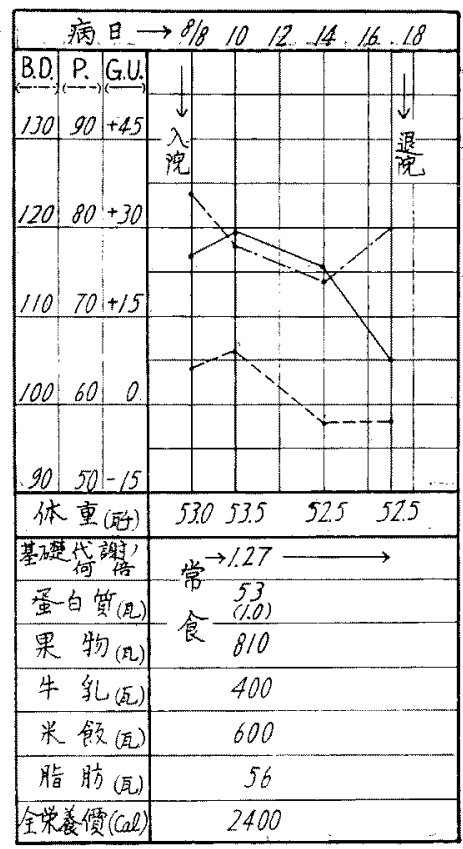

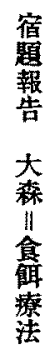

第三症例 荒

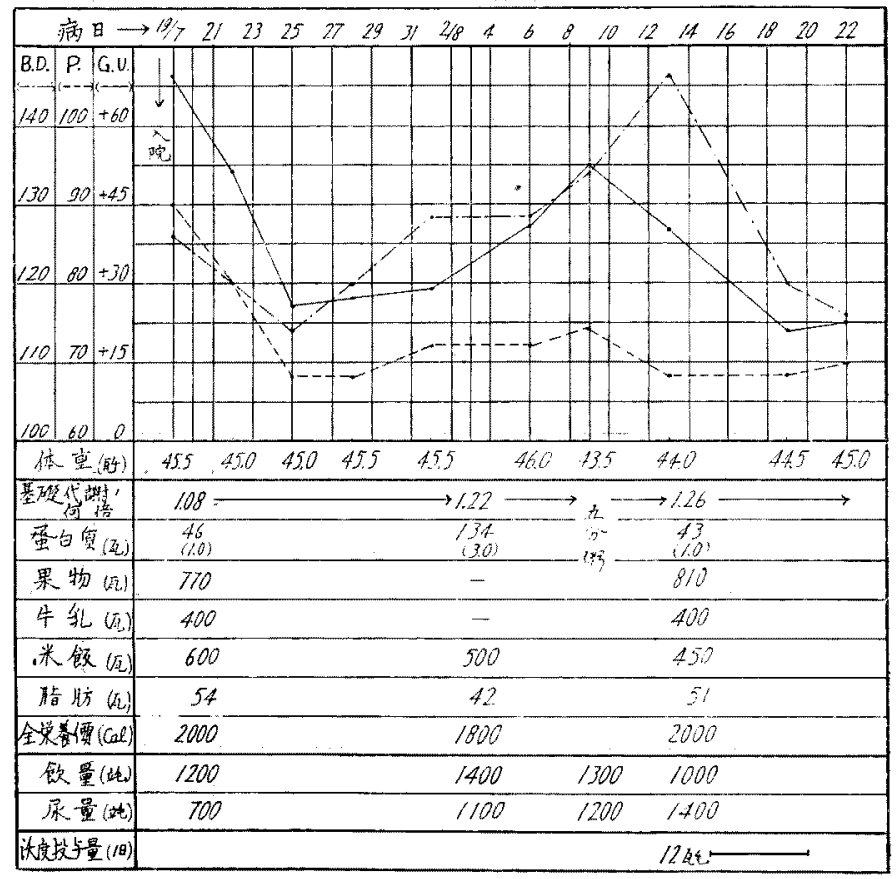

穴 


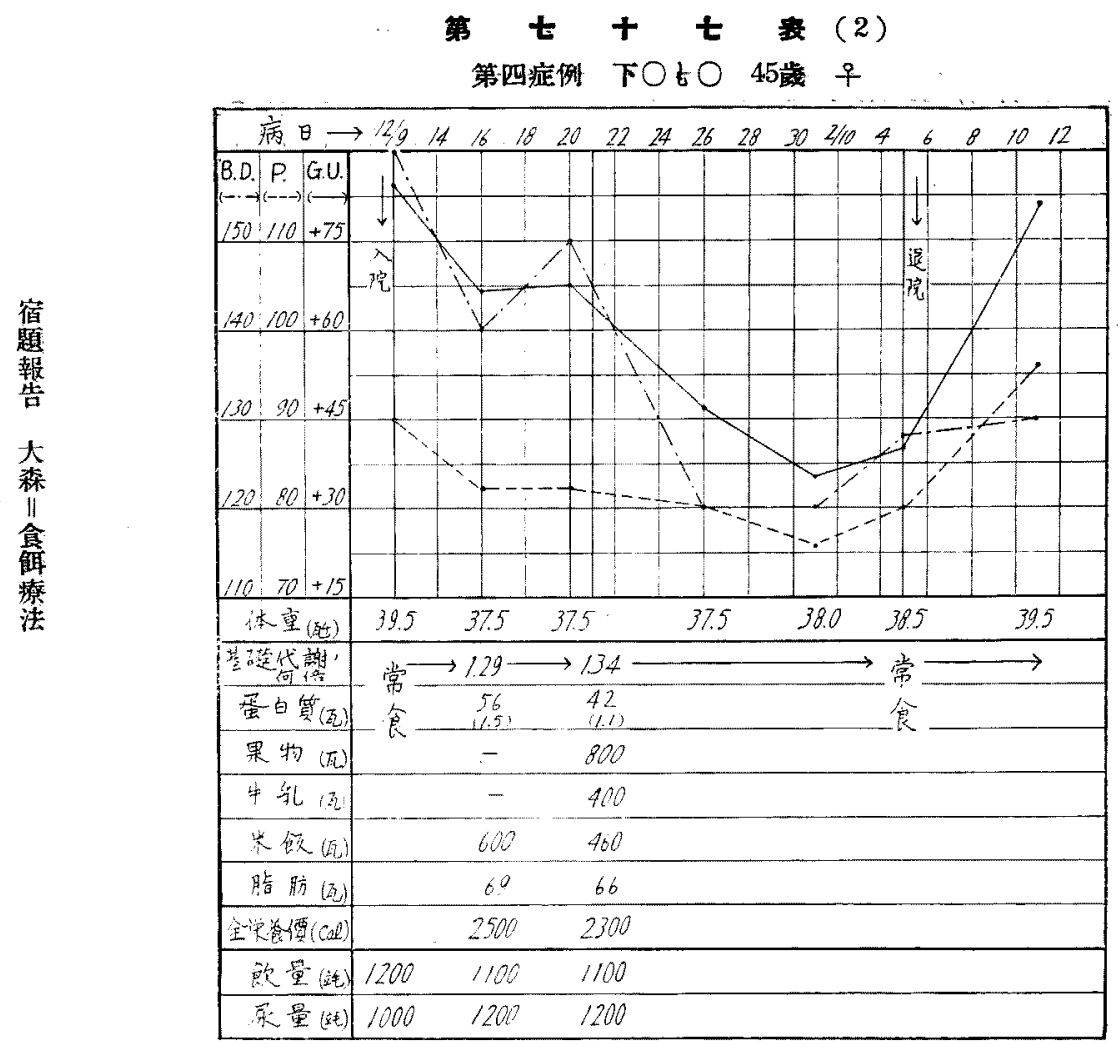

第五庭例 山○ス○ 35歳 +

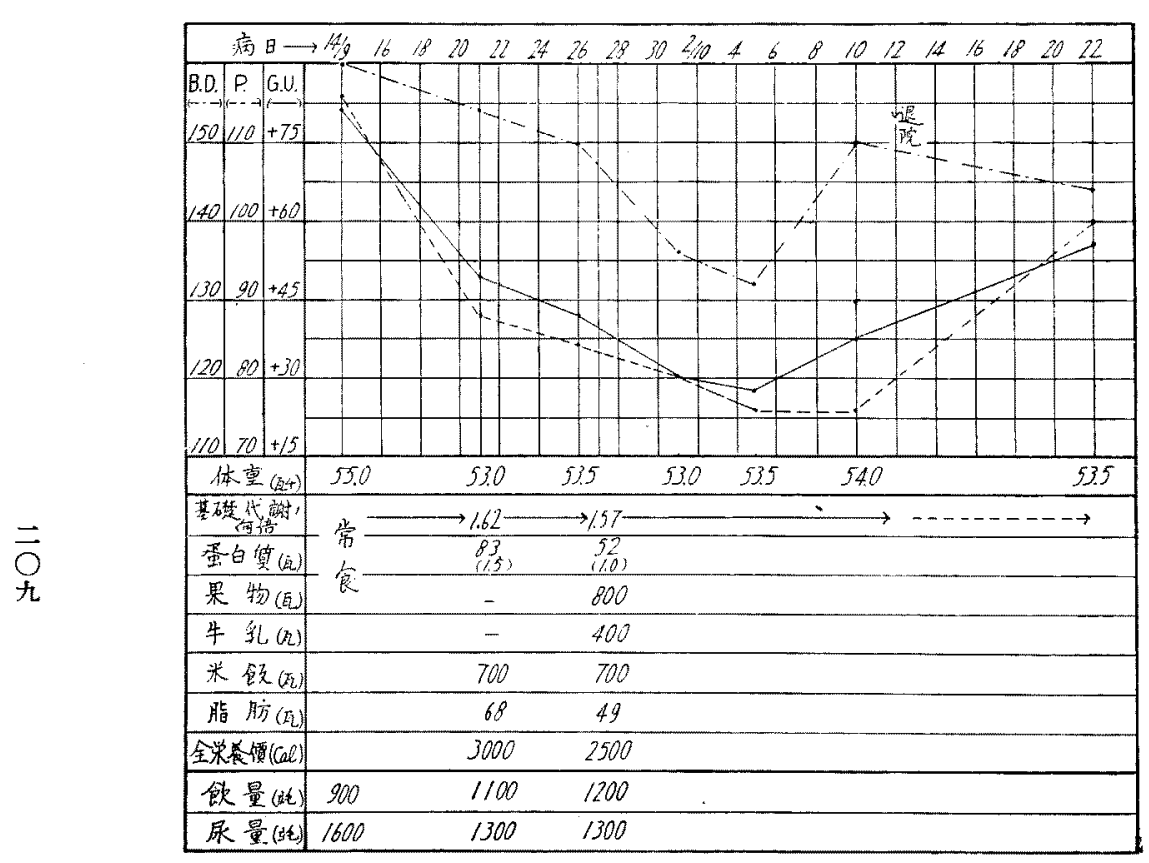




\section{第七症例 塙○ 38 歳 우 \\ 第六症例 柴○俊○ 25歳 令}

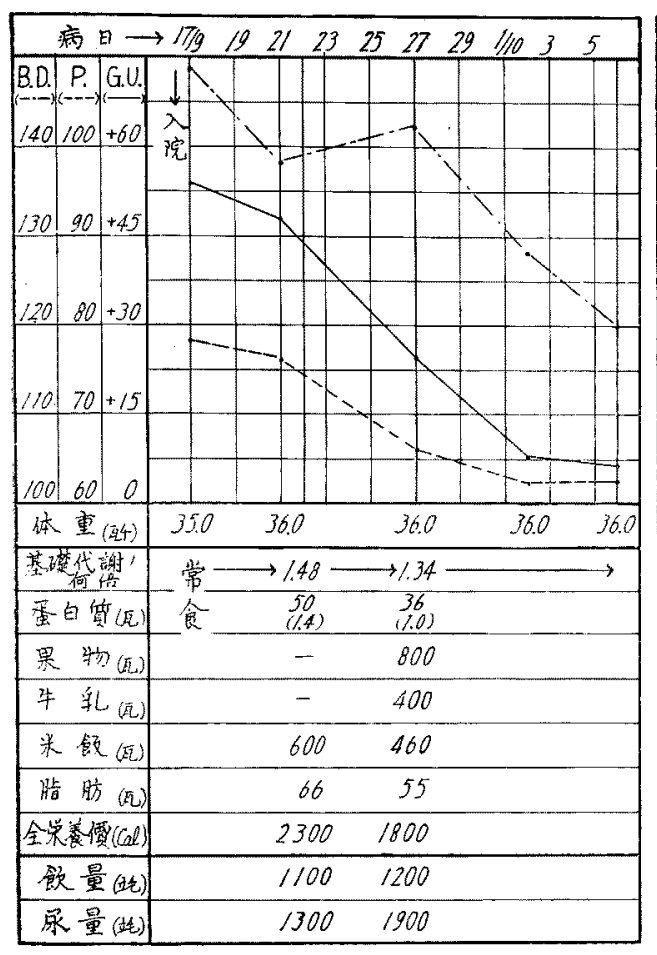

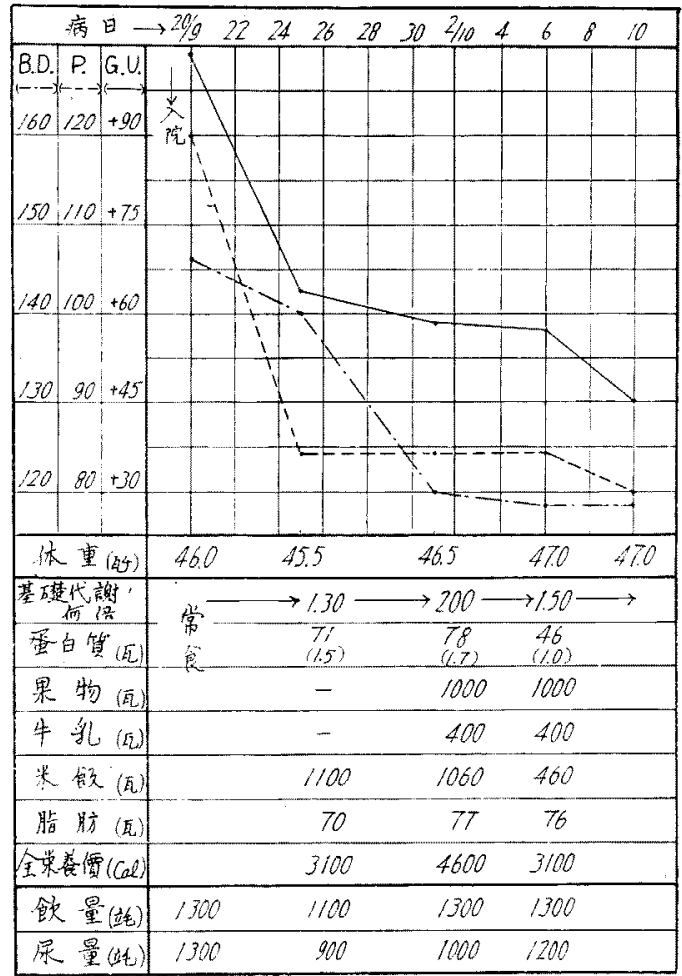

第入症例 務O織○ 52 歲 우

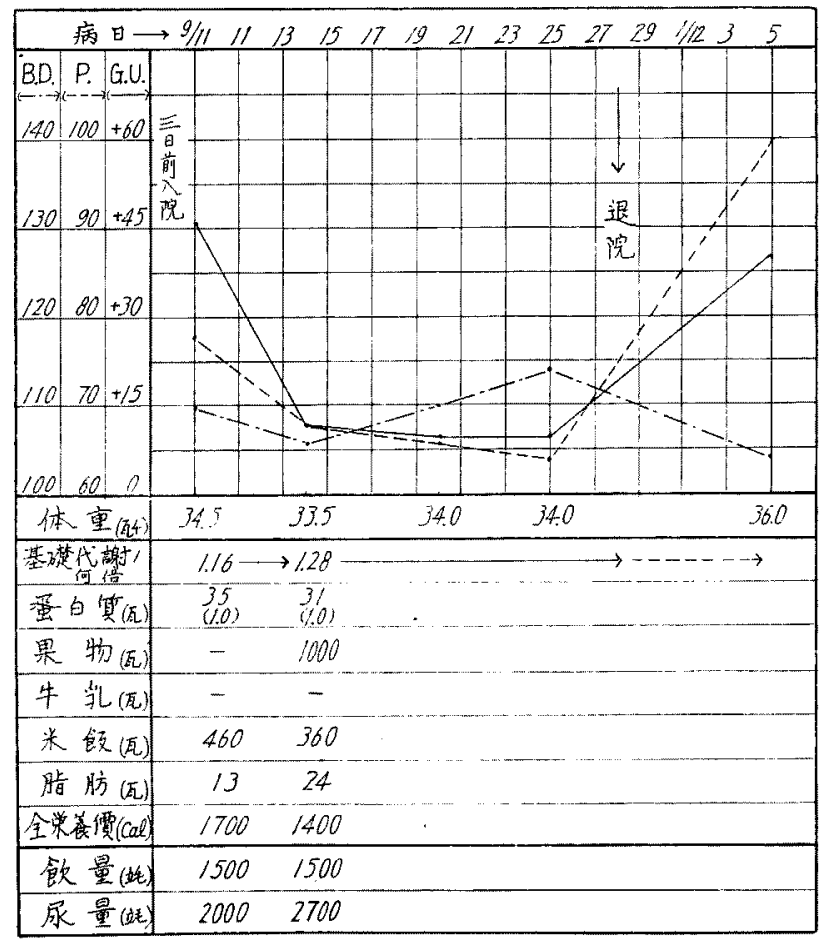




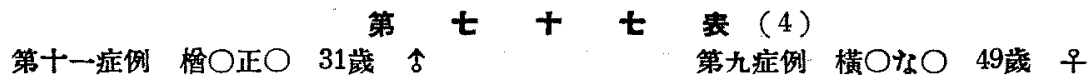

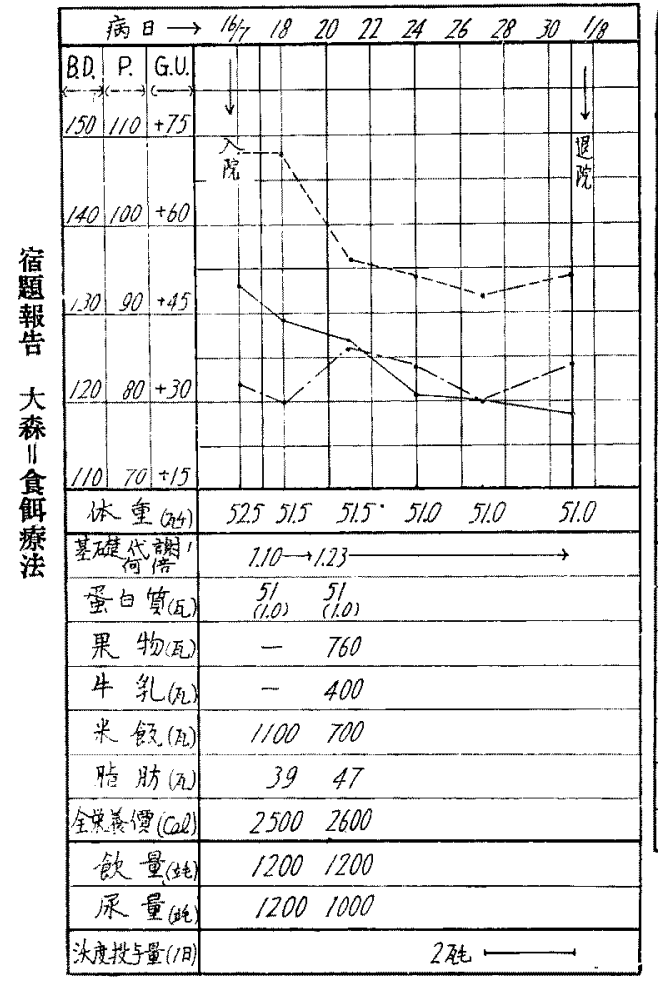

第十二症例 生○敏○ 23歳 우 -

第十症例 井○策○ 25歲 +

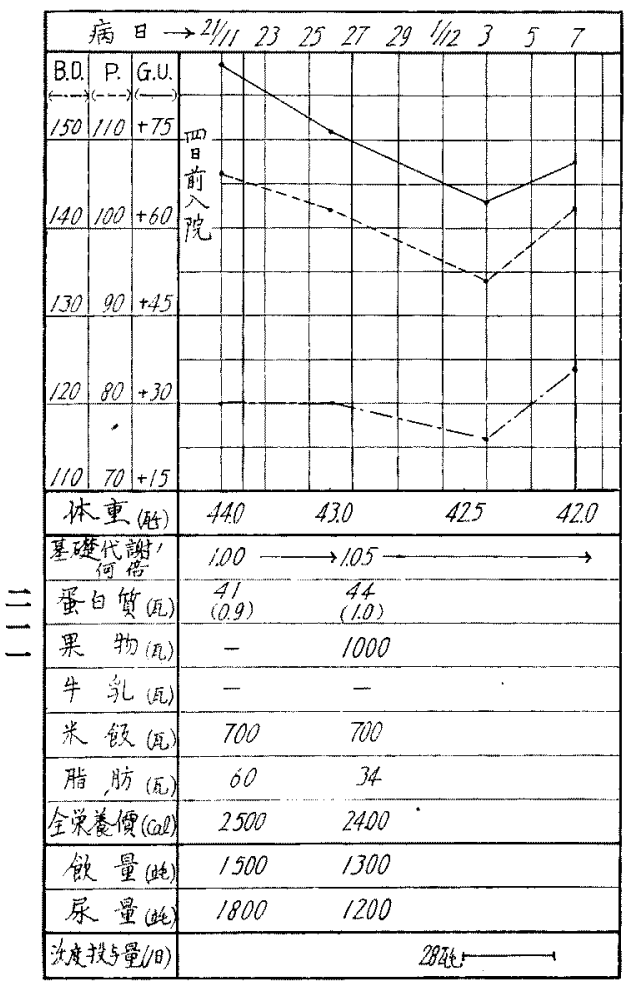

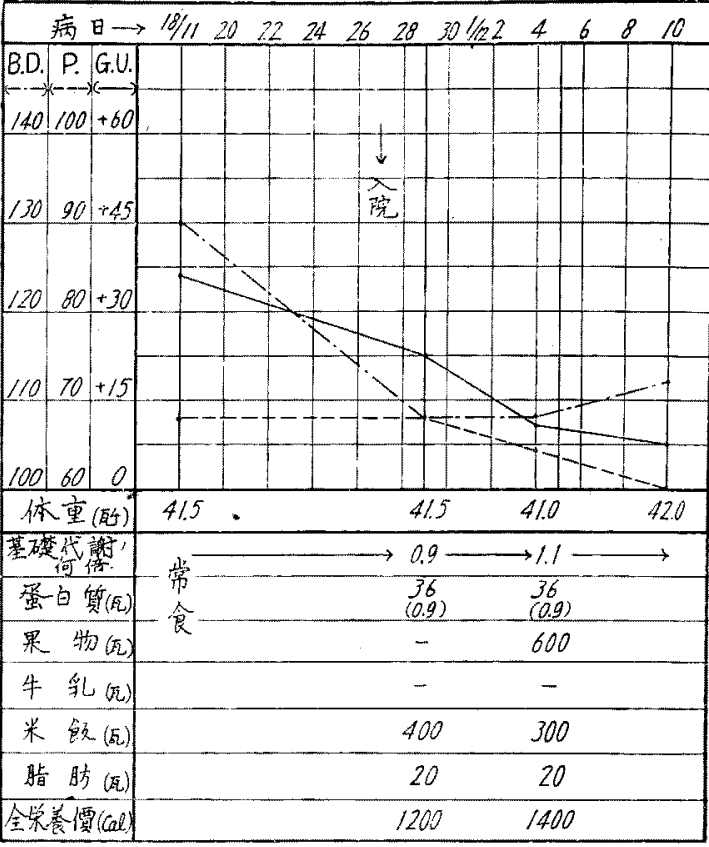

等十然的

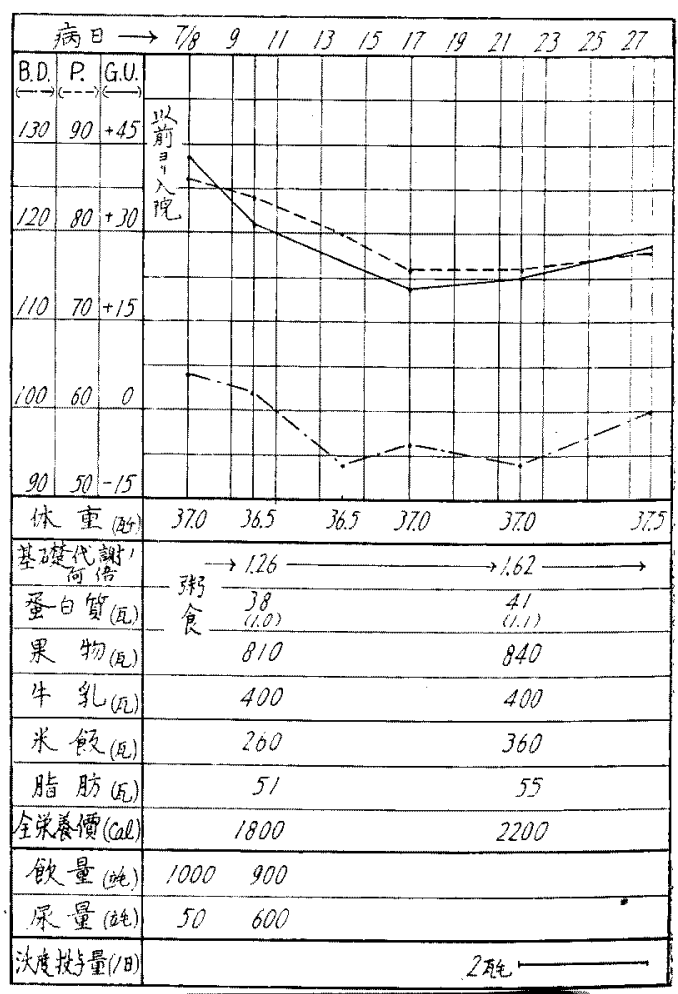


管 $t+t$ (5)

第十三症例 伊○と○ 38歳 +

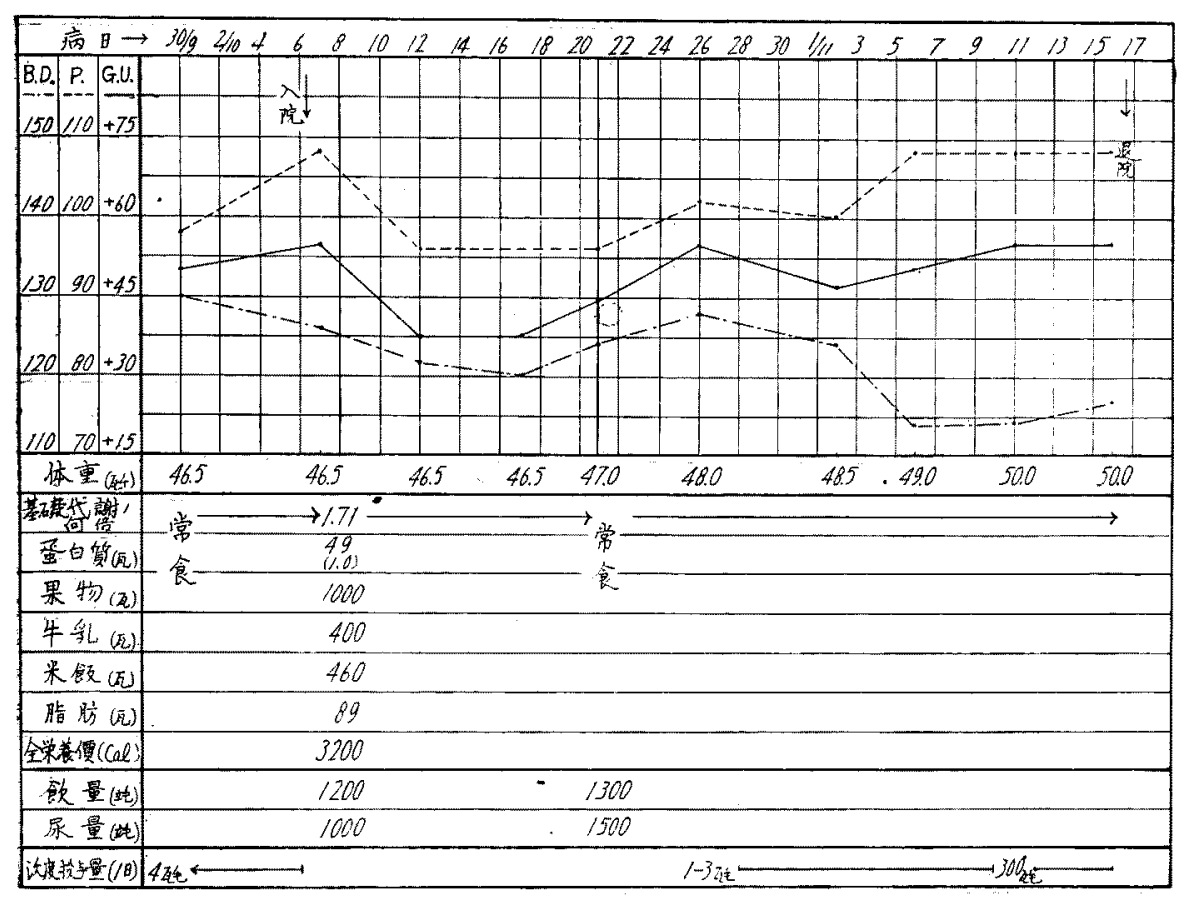

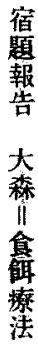

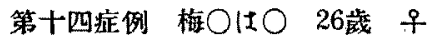

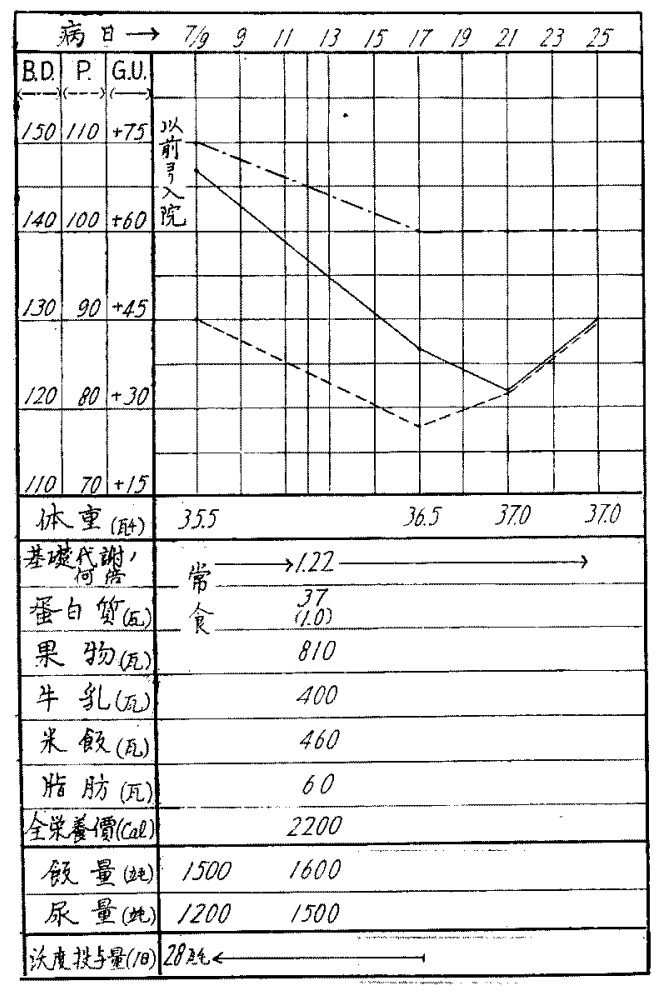




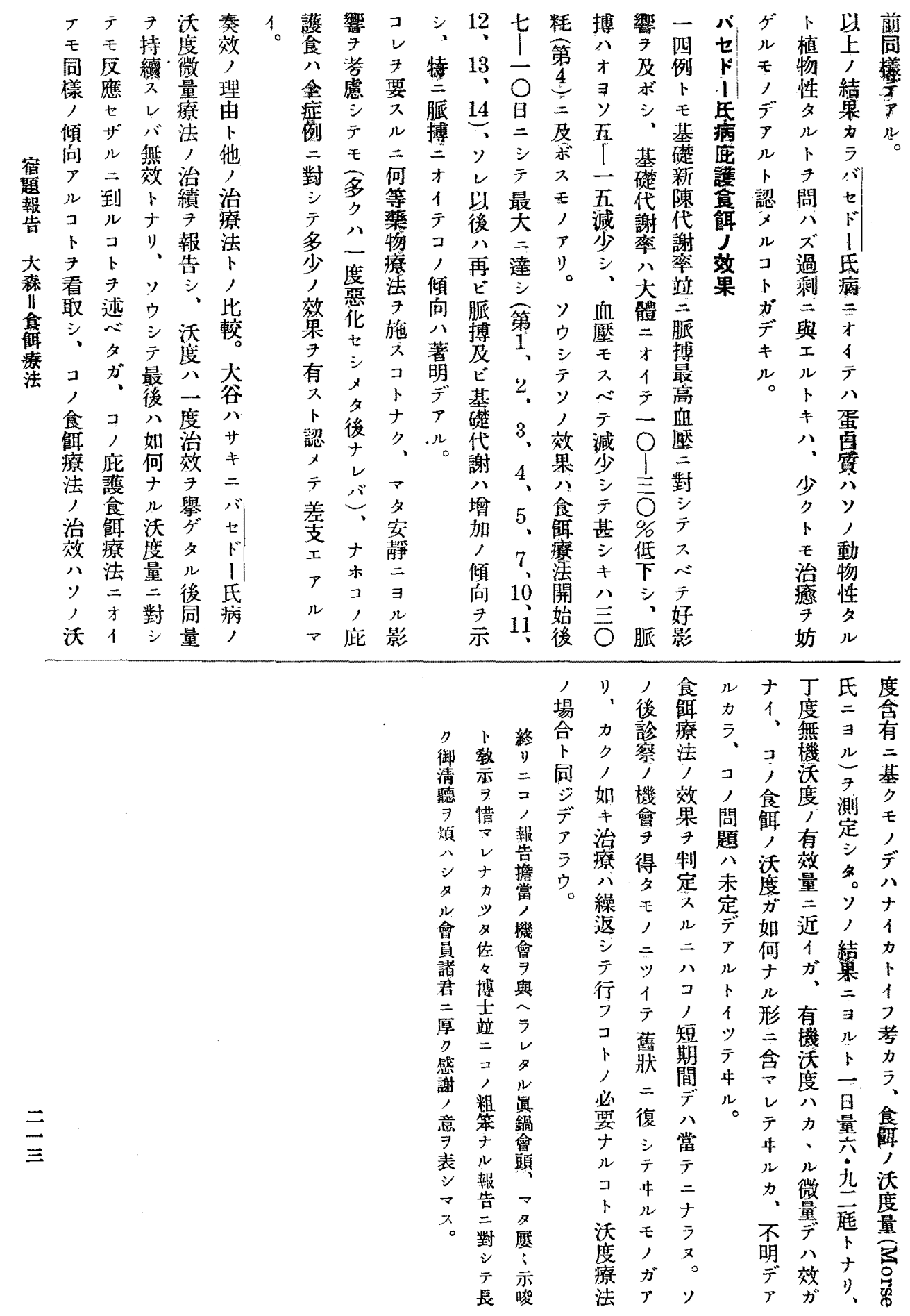




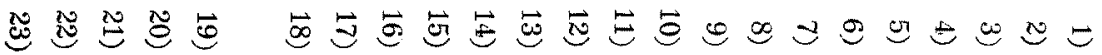

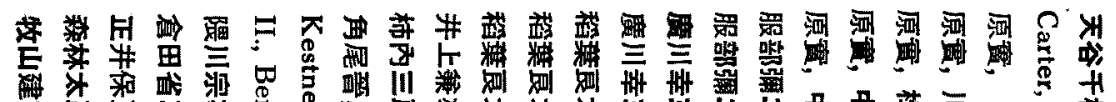

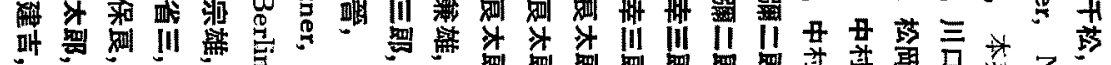

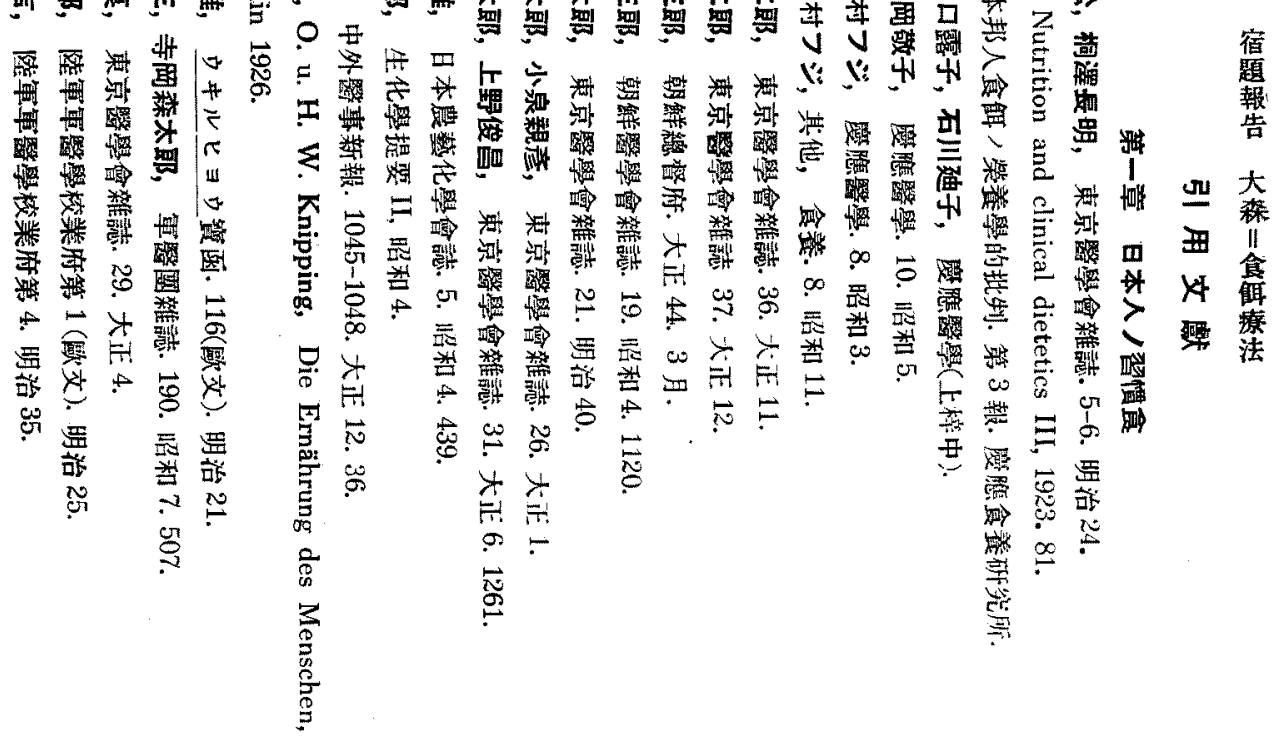

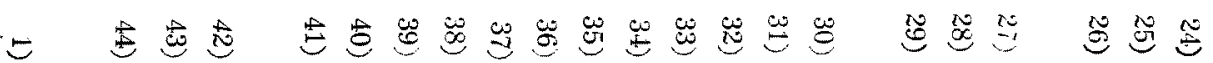

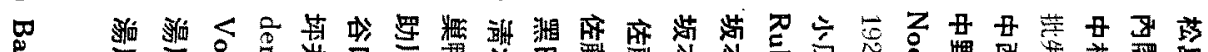

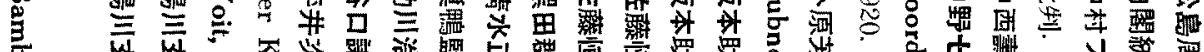

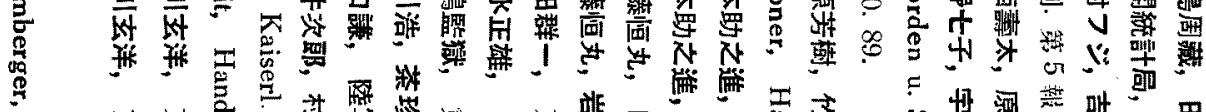

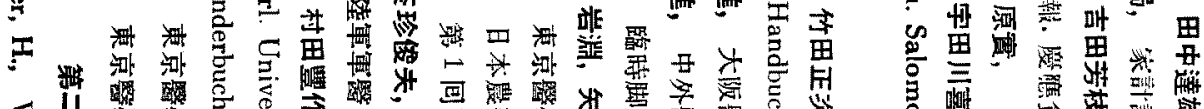

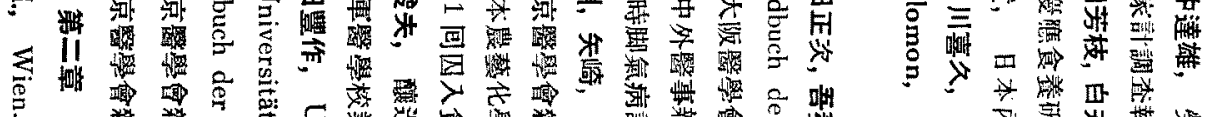

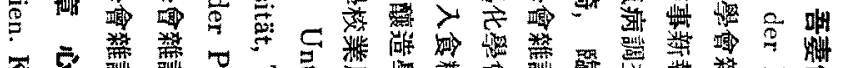

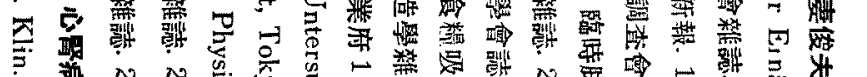

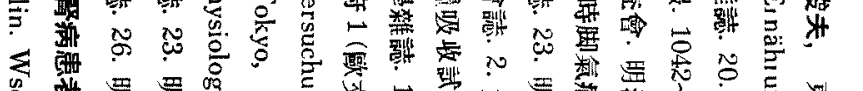

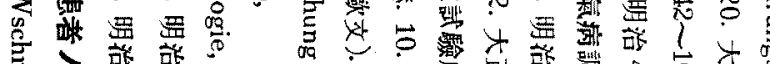

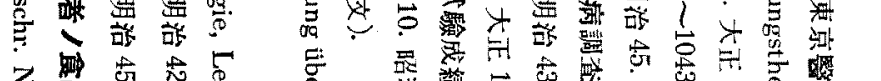

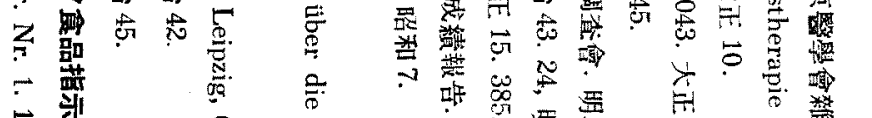

$\vec{\sim}$

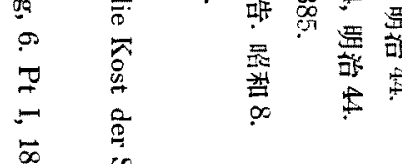

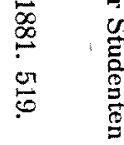

工雨

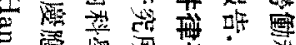

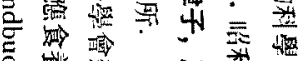

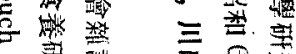

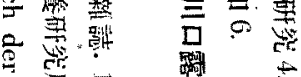

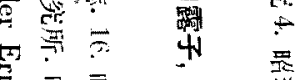

永变 


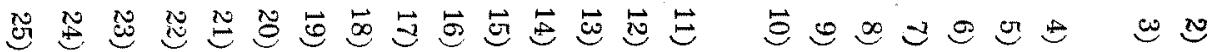

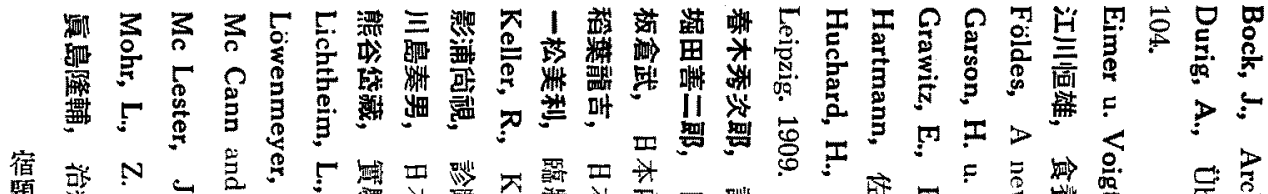

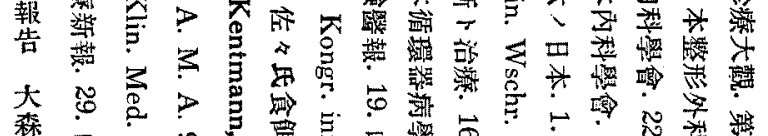

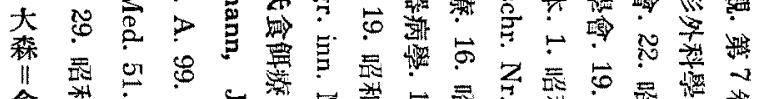

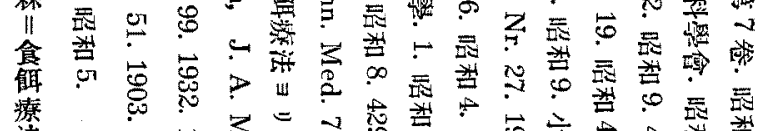
法

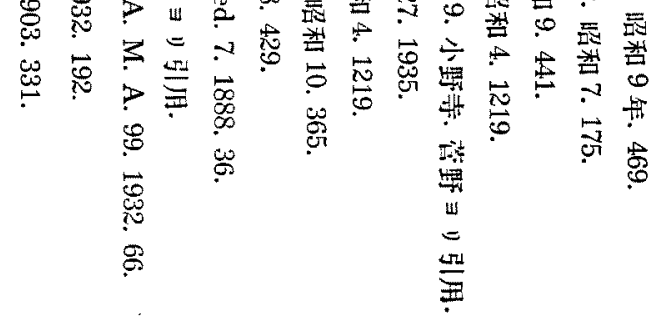
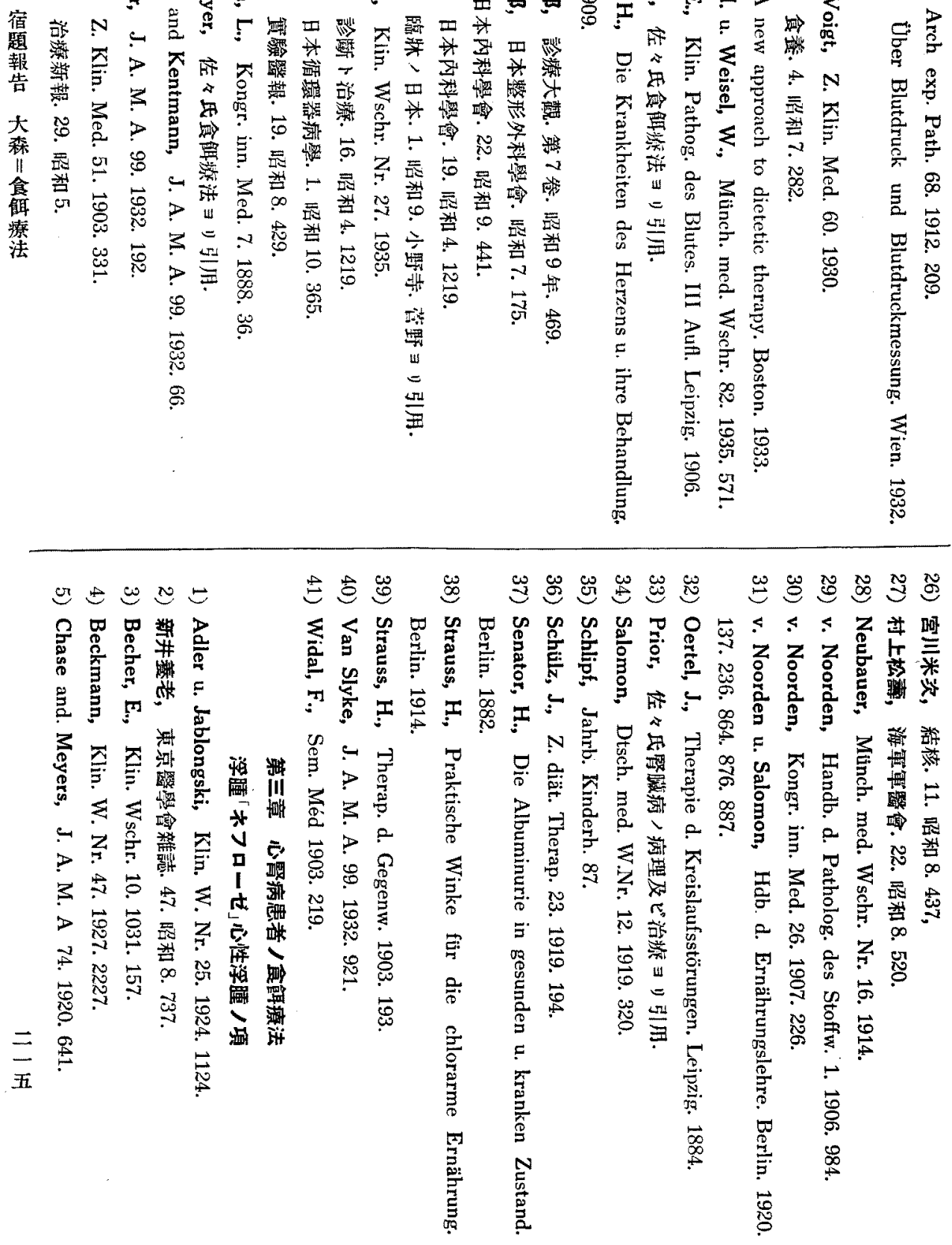


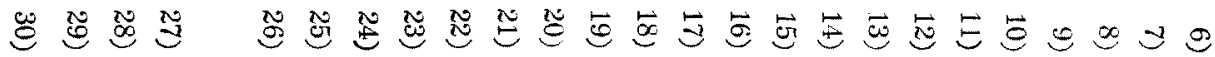

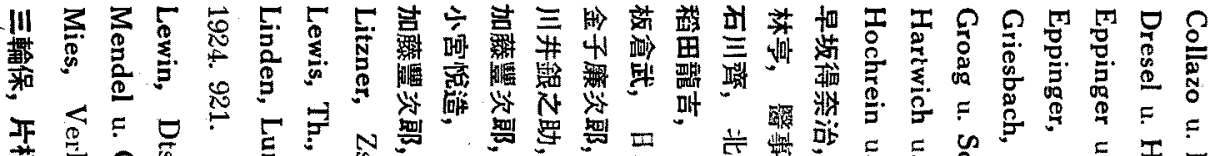

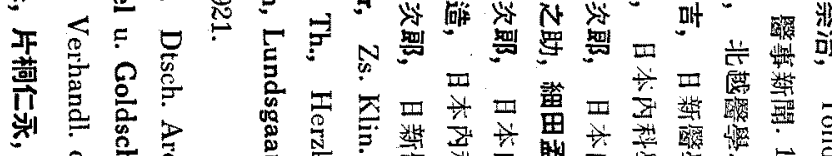

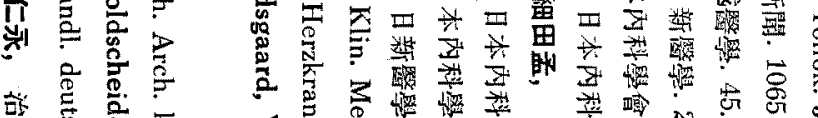

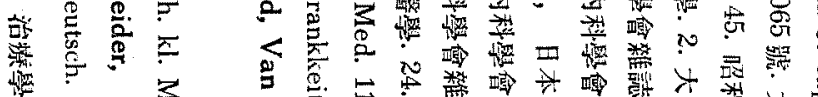

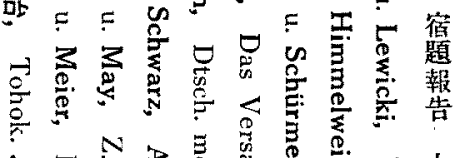

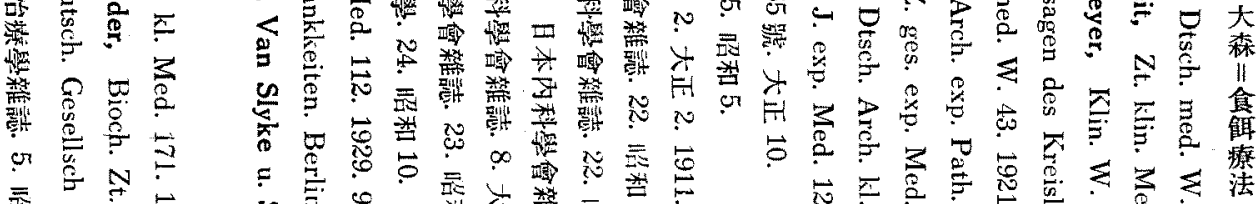

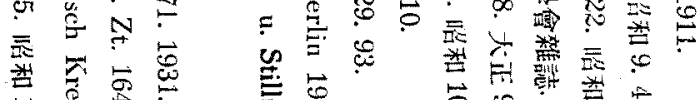

蓄

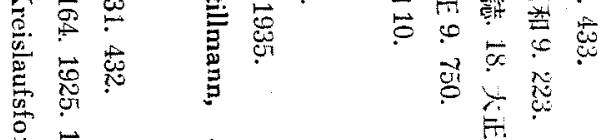

$$
\begin{aligned}
& \text { 委 } \\
& \text { 要 }
\end{aligned}
$$

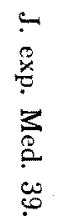

$$
\begin{aligned}
& \text { 悹 } \\
& \text {. }
\end{aligned}
$$

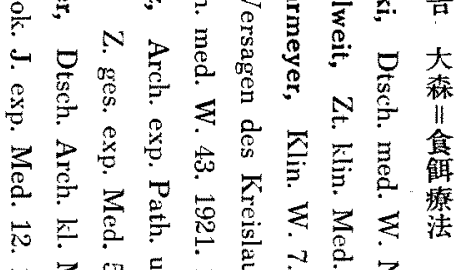

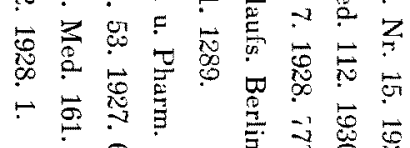

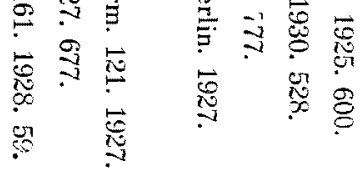

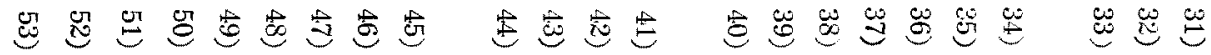

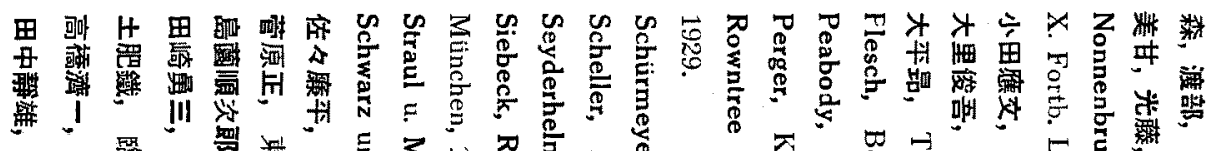

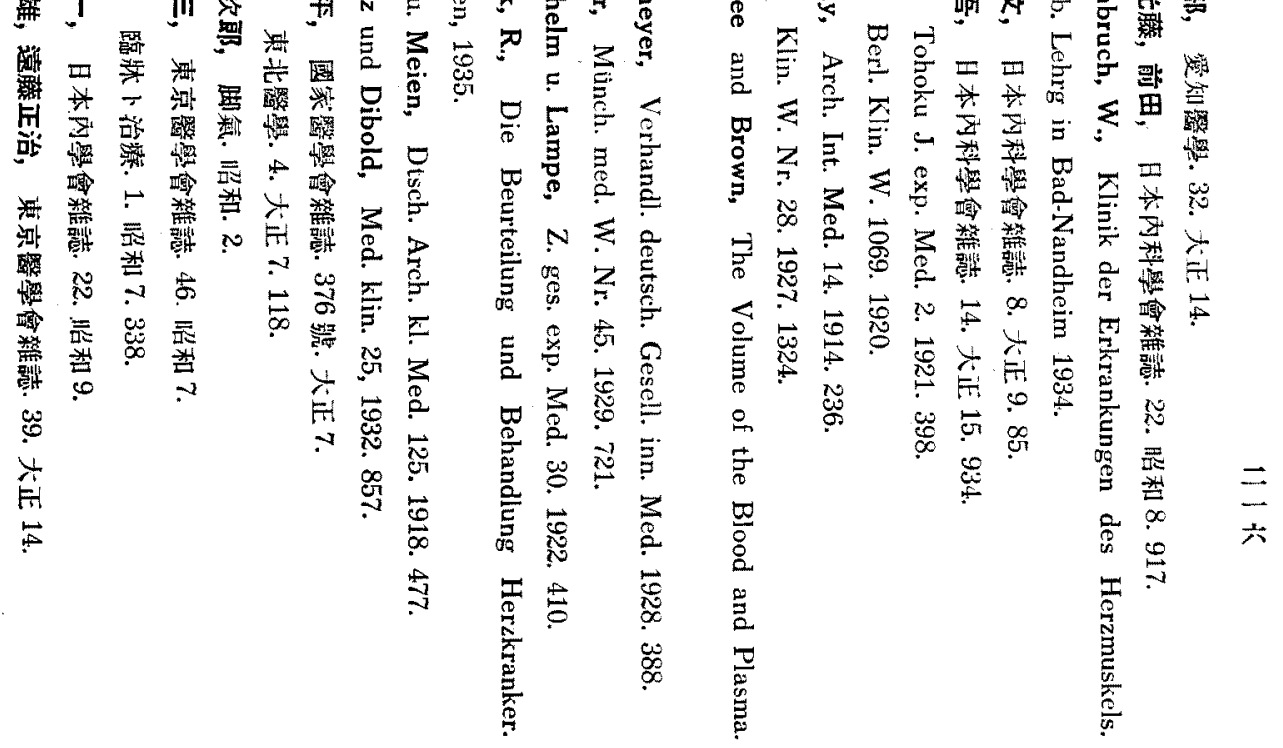




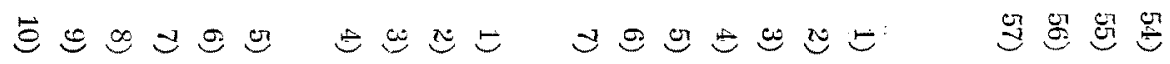

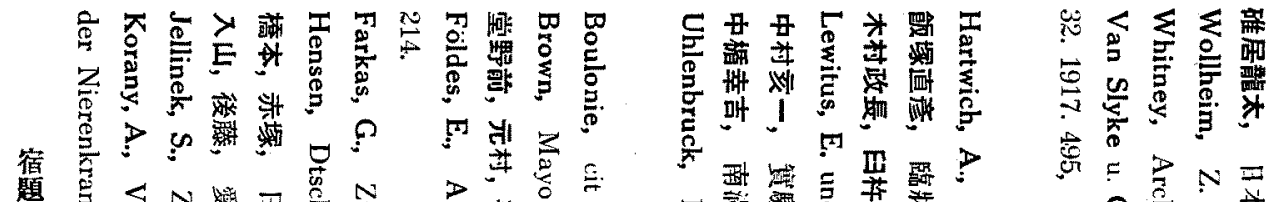

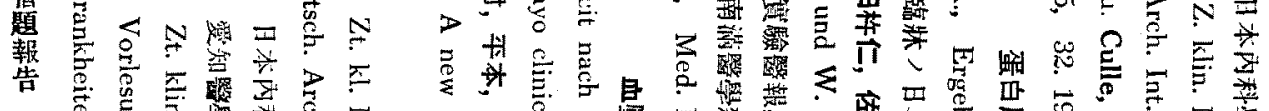

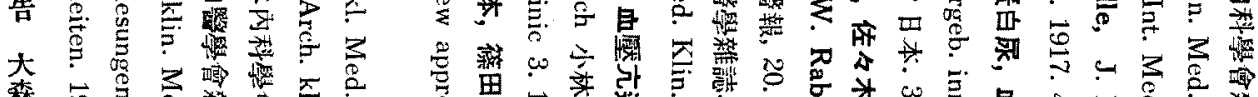

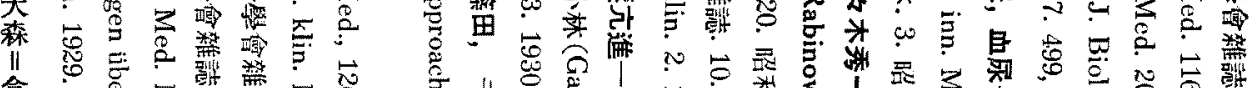

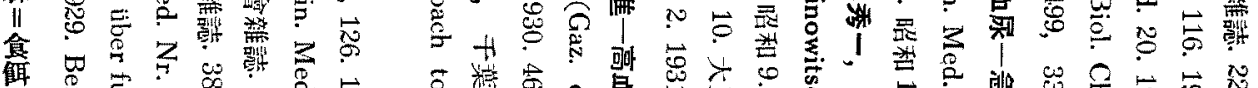

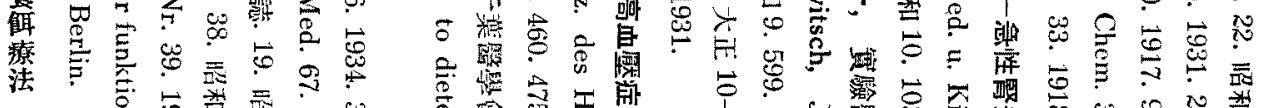

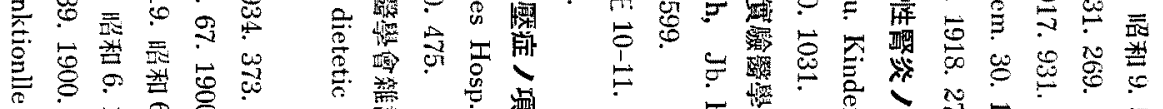

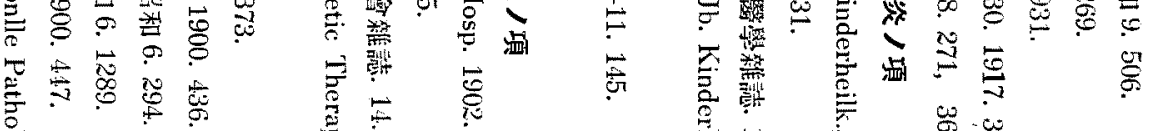

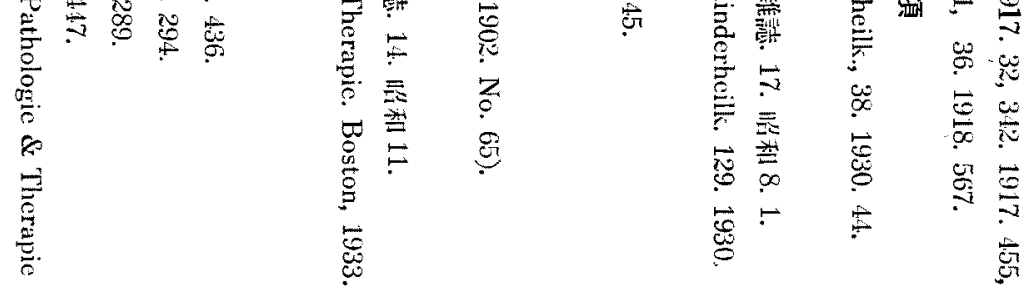

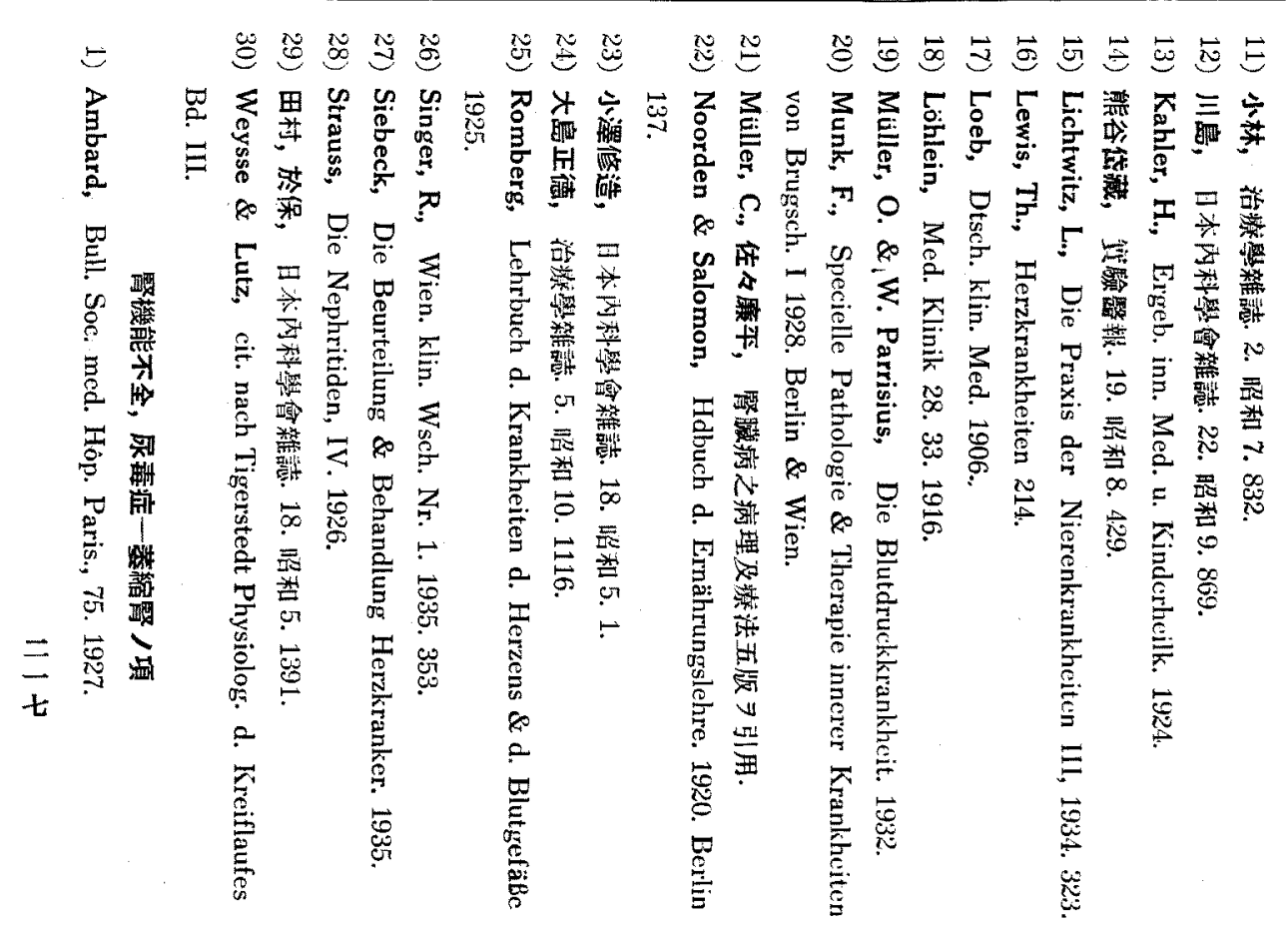




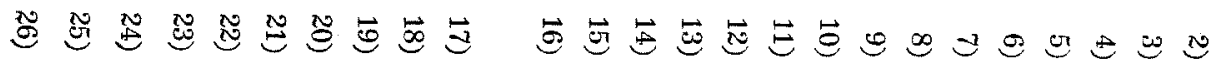

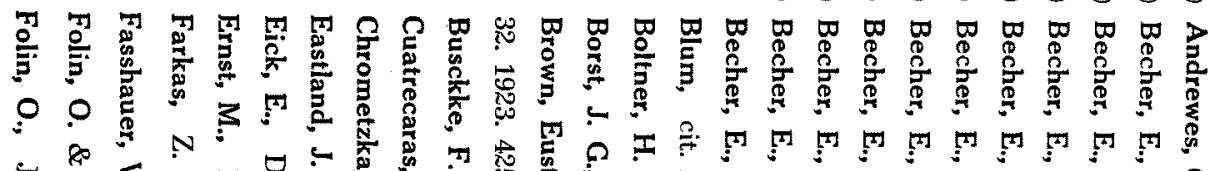

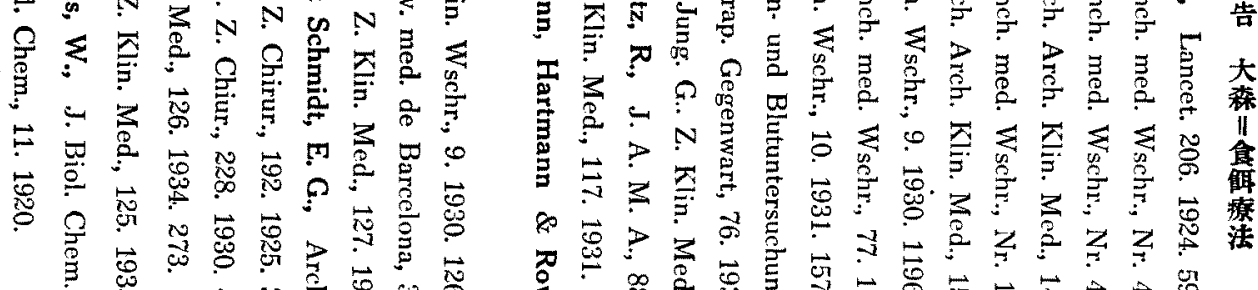

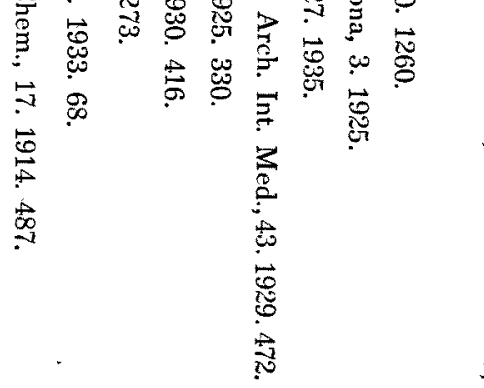

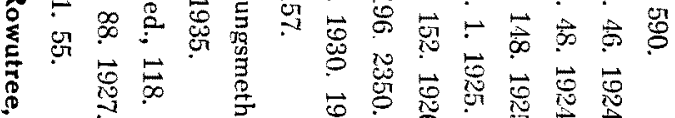

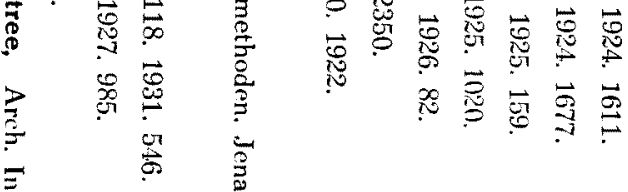

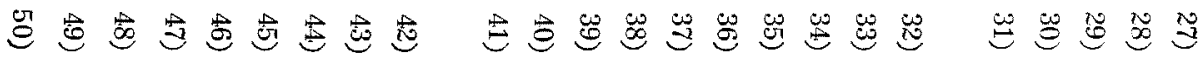

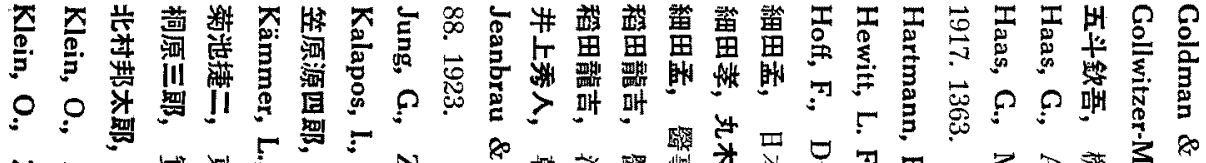

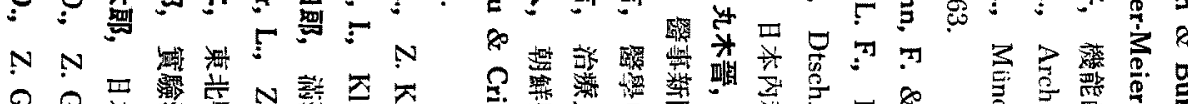

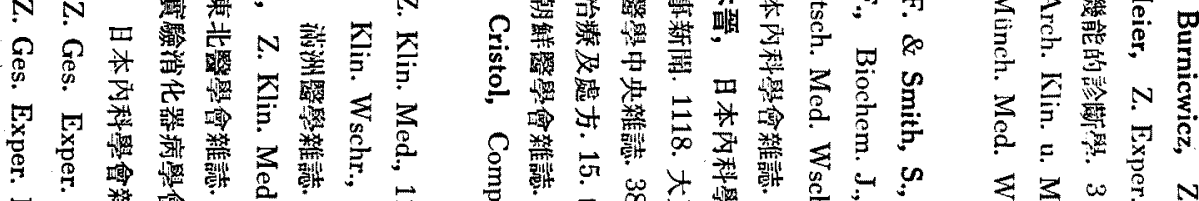

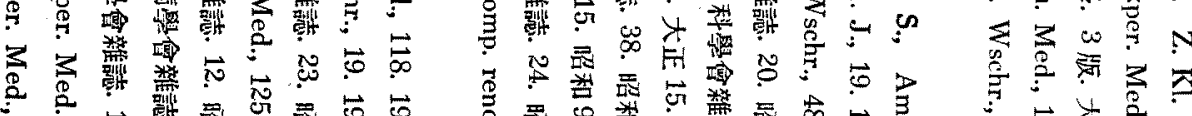

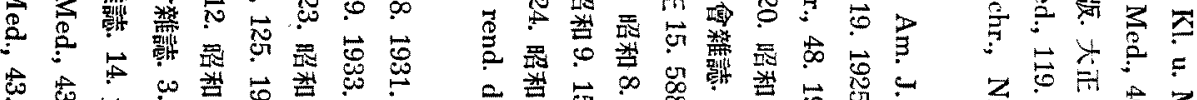

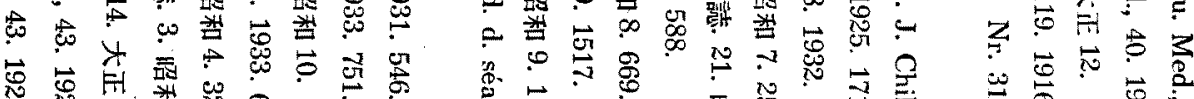

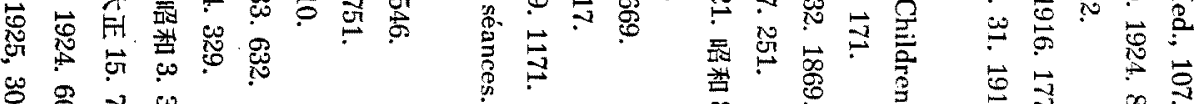

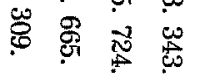

के

.

(1)

8

管

䆜




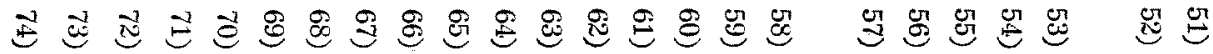

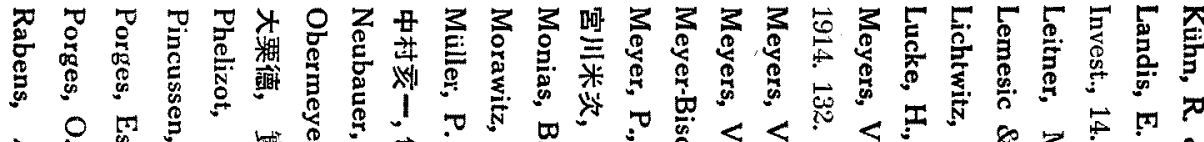

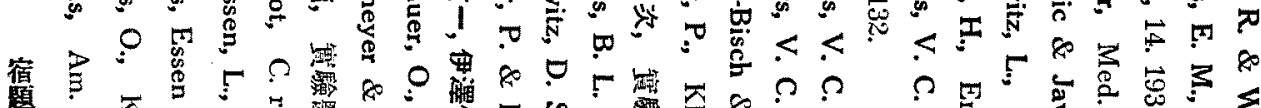

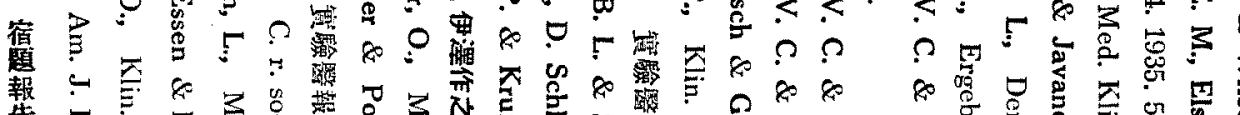

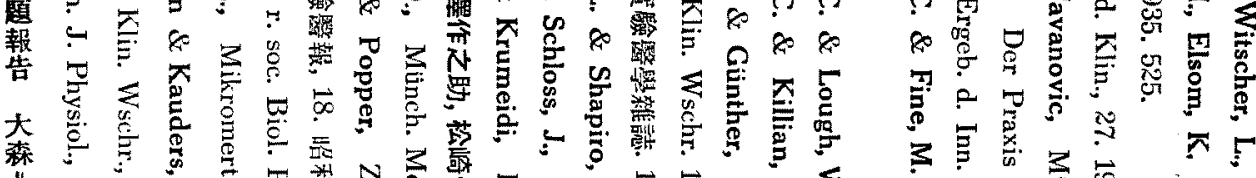

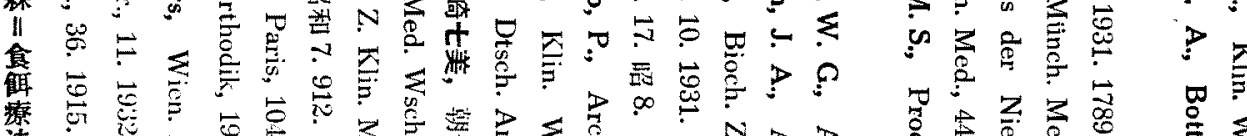

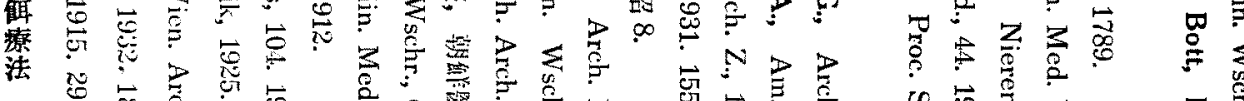

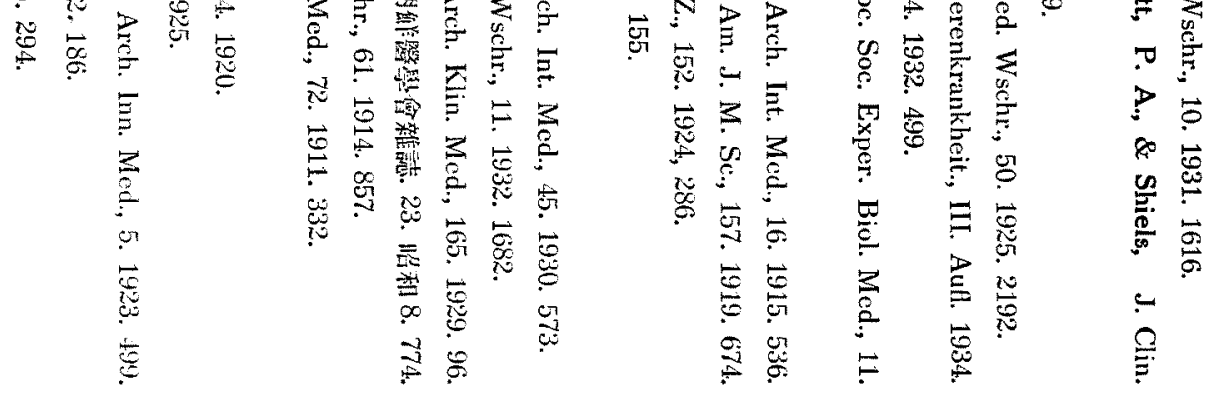

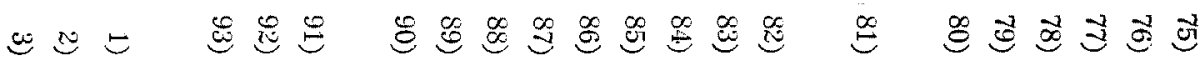

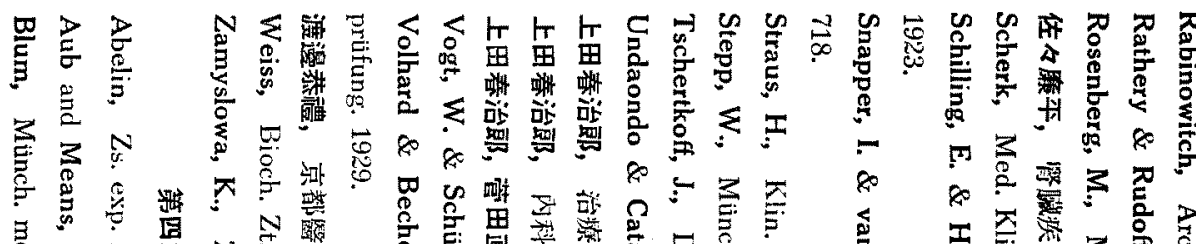

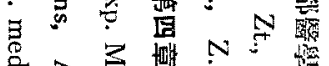

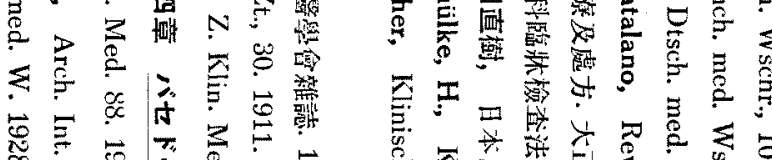

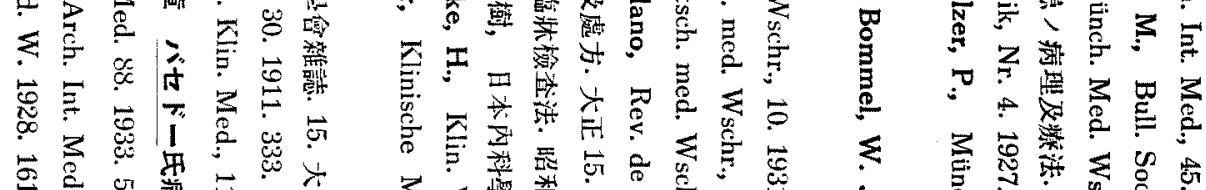

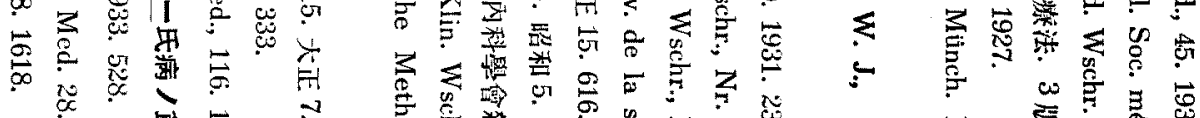

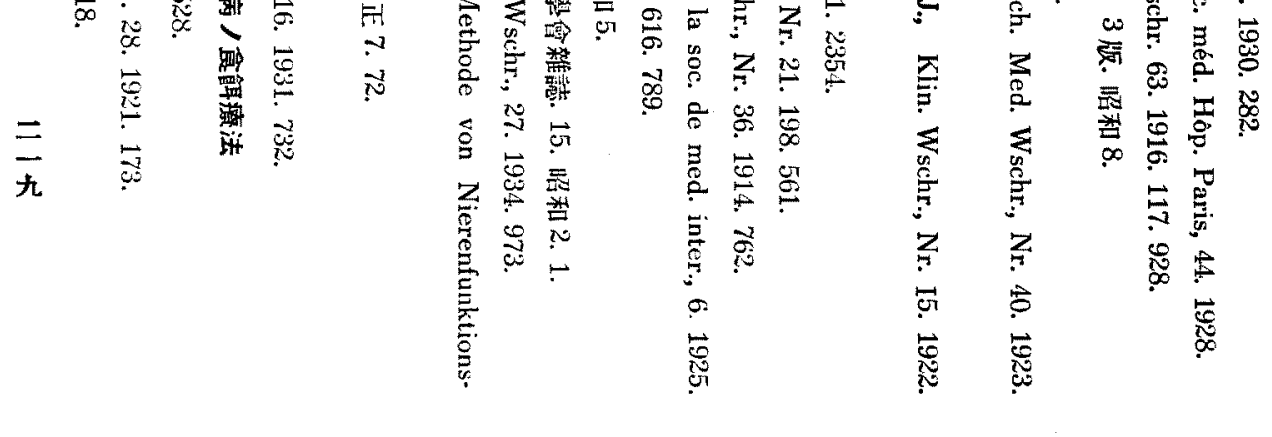




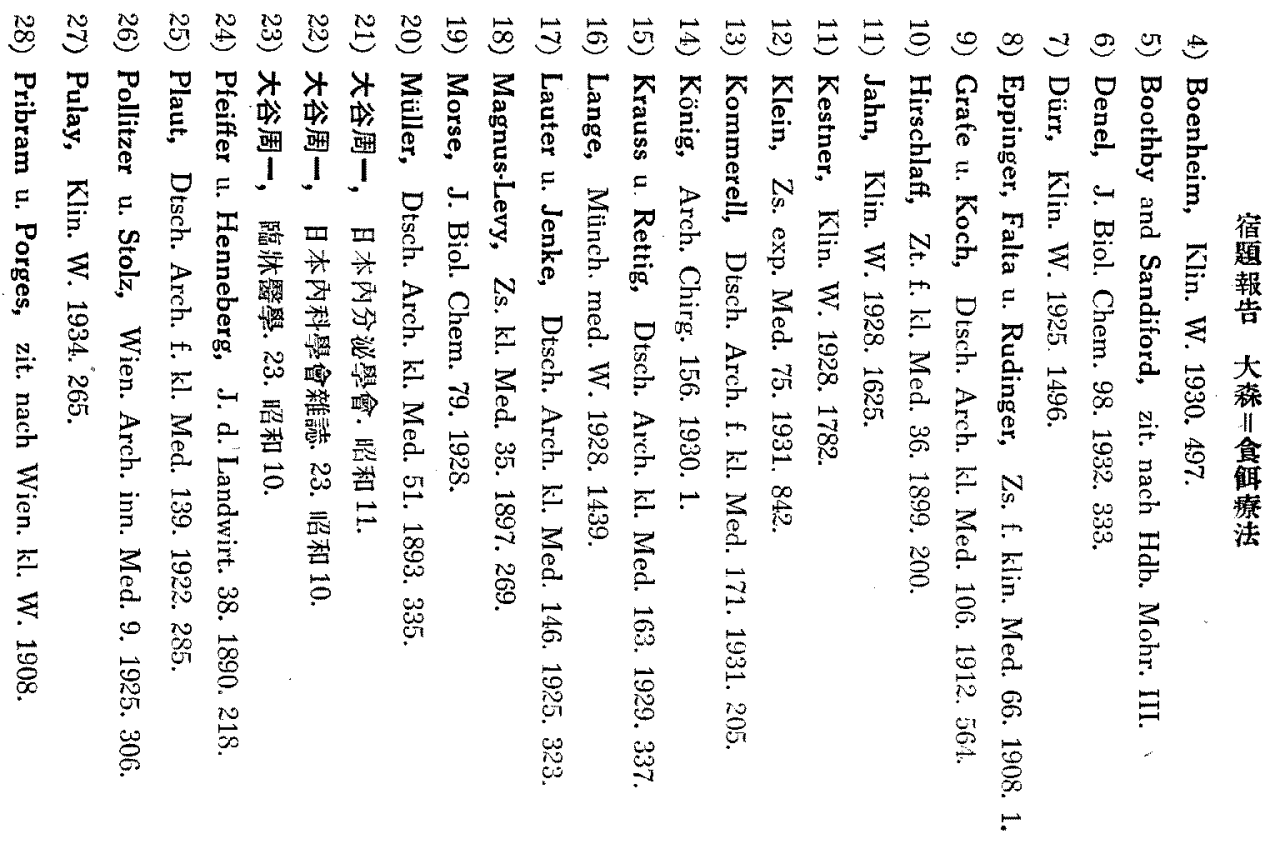

$\stackrel{\Theta}{8}$

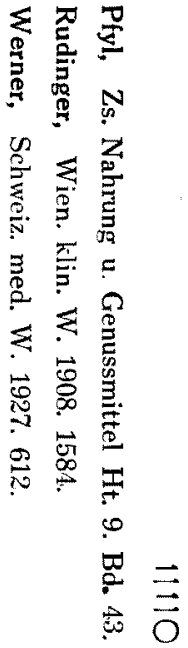




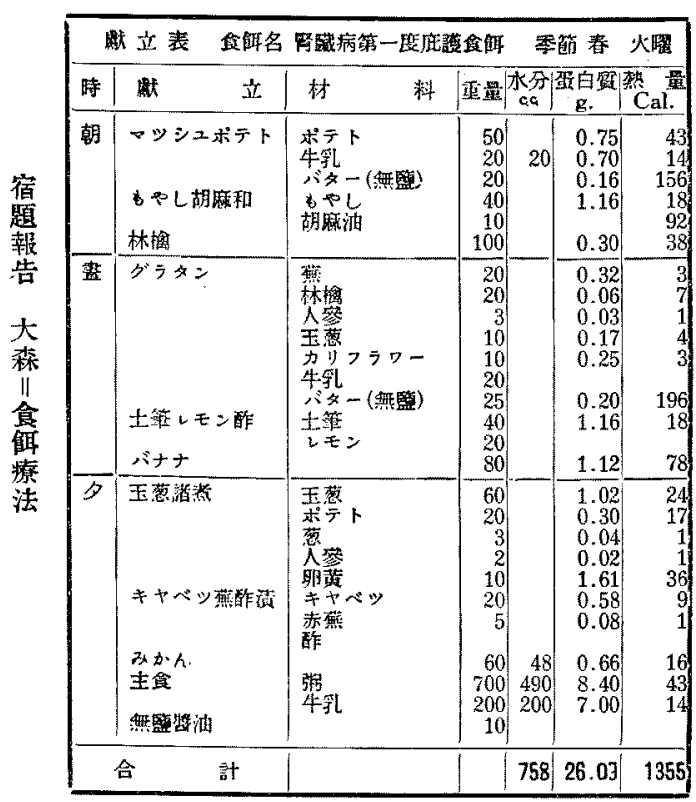

附淾（1）第一度庇讙会 4 種

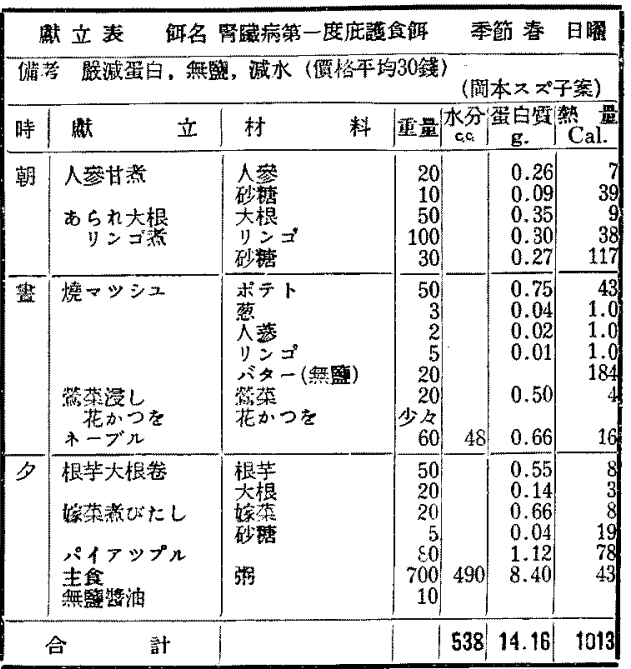

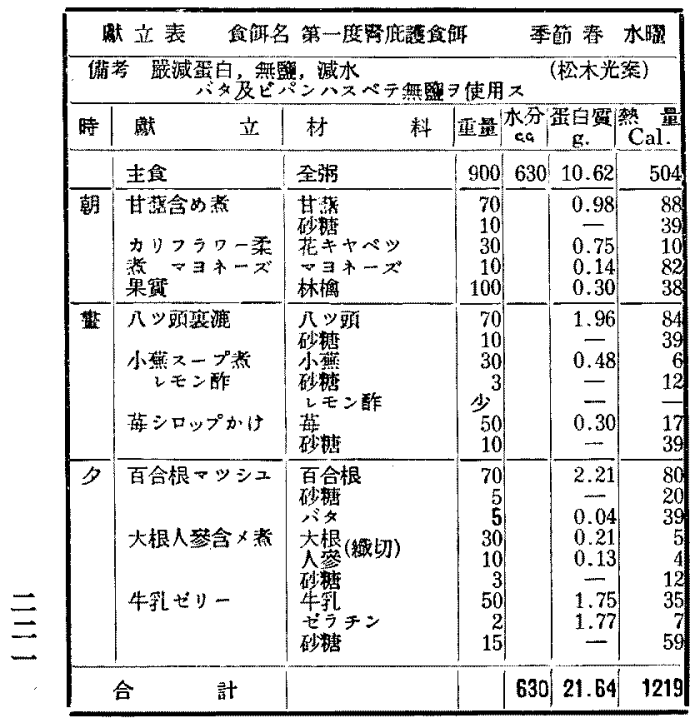

\begin{tabular}{|c|c|c|c|c|c|c|}
\hline \multicolumn{2}{|c|}{ 知立表 } & \multicolumn{2}{|c|}{ 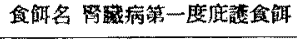 } & \multicolumn{3}{|c|}{ 季䇴春 月整 } \\
\hline 時 & 立 & 料 & 重: & 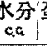 & $\begin{array}{c}\text { 蛋自贫 } \\
\mathrm{g} . \quad\end{array}$ & 第 \\
\hline 朝 & $\begin{array}{l}\text { さつまいも甘热 } \\
\text { キャペツスー } \\
\text { プ热 } \\
\text { みかん }\end{array}$ & 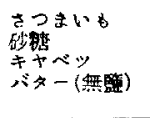 & $\begin{array}{l}70 \\
40 \\
30 \\
10 \\
60\end{array}$ & 48 & $\begin{array}{l}0.98 \\
0.38 \\
0.87 \\
0.08 \\
0.66\end{array}$ & $\begin{array}{r}88 \\
156 \\
14 \\
78 \\
16 \\
\end{array}$ \\
\hline 整 & 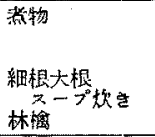 & 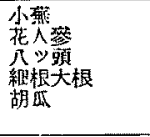 & $\begin{array}{r}40 \\
10 \\
50 \\
20 \\
5 \\
100 \\
\end{array}$ & & $\begin{array}{l}0.64 \\
0.13 \\
1.40 \\
0.14 \\
0.04 \\
0.30 \\
\end{array}$ & $\begin{array}{r}7 \\
3 \\
60 \\
3 \\
1 \\
38 \\
\end{array}$ \\
\hline 夕 & 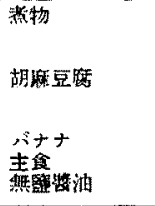 & 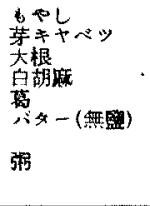 & \begin{tabular}{r|}
30 \\
10 \\
50 \\
3.5 \\
30 \\
20 \\
80 \\
700 \\
10
\end{tabular} & 490 & $\begin{array}{l}0.87 \\
0.29 \\
0.35 \\
0.70 \\
0.16 \\
1.12 \\
8.40\end{array}$ & $\begin{array}{r}14 \\
4 \\
9 \\
21 \\
90 \\
156 \\
78 \\
43\end{array}$ \\
\hline & 計 & & & 538 & 17.51 & 1276 \\
\hline
\end{tabular}




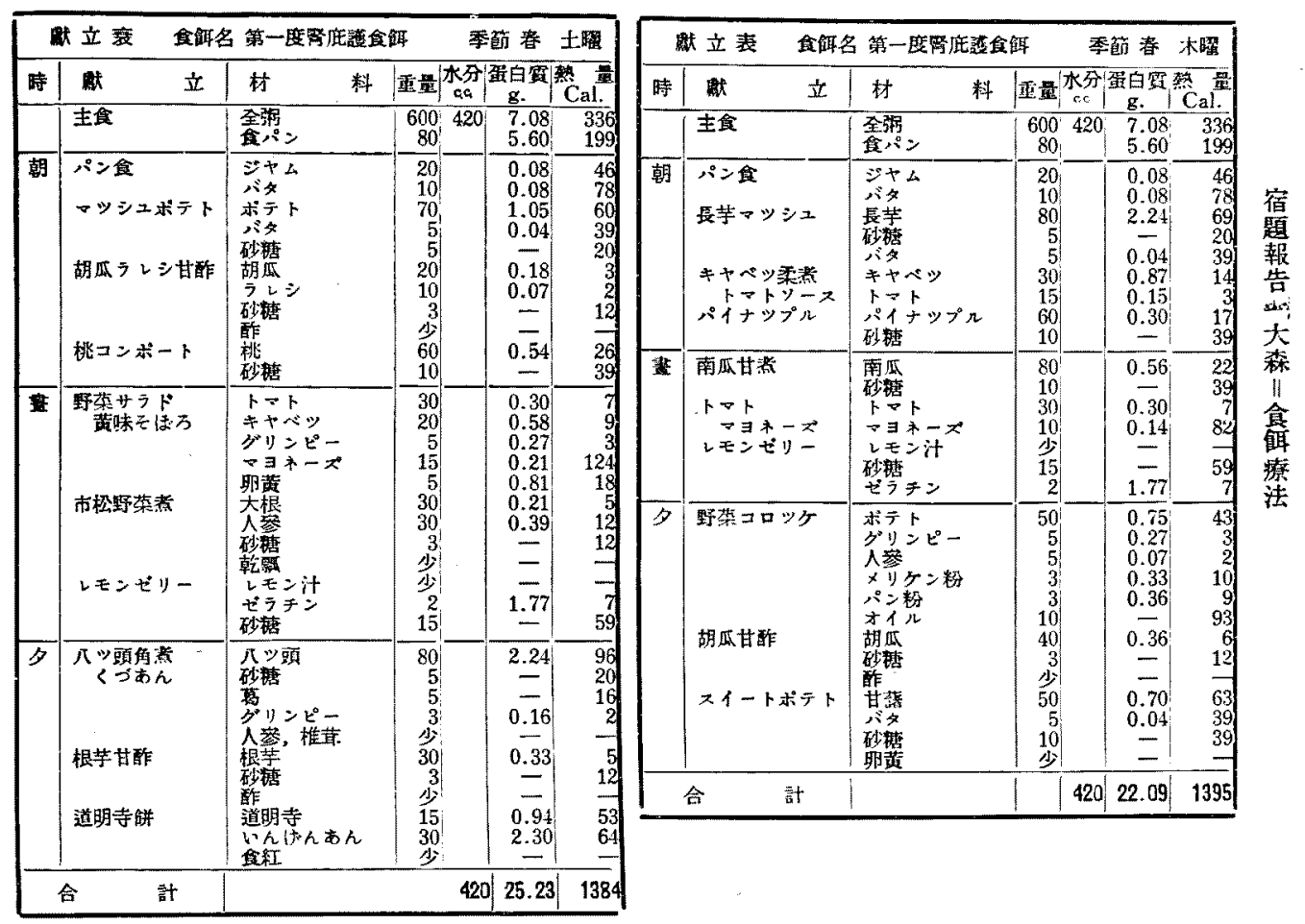

\begin{tabular}{|c|c|c|c|c|c|c|}
\hline \multicolumn{2}{|c|}{ 立表 } & \multicolumn{2}{|c|}{ 食领名 第一度腎底護食缺 } & \multicolumn{3}{|c|}{ 委節焉 月桓 } \\
\hline \multicolumn{7}{|c|}{ 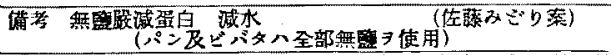 } \\
\hline \multirow[t]{2}{*}{ 時 } & 立 & 杍料 & 重量 & $\begin{array}{l}\text { 水份 } \\
\mathrm{ca}\end{array}$ & 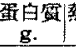 & 妿 致 \\
\hline & 主领 & 张 & 900 & 630 & 10.62 & 504 \\
\hline 朝 & $\begin{array}{l}\text { 南瓜マッシュ } \\
\text { 根茧甘胙 } \\
\text { パイナップル }\end{array}$ & 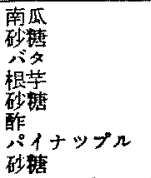 & $\begin{array}{r}60 \\
10 \\
5 \\
30 \\
3 \\
3 \\
60 \\
10\end{array}$ & & $\begin{array}{l}0.42 \\
0.04 \\
0.33 \\
\overline{-30} \\
-\end{array}$ & $\begin{array}{r}17 \\
39 \\
39 \\
5 \\
12 \\
17 \\
39\end{array}$ \\
\hline 害 & $\begin{array}{l}\text { 小繁甘酢 } \\
\text { 桃コンボート } \\
\text { カステラ }\end{array}$ & 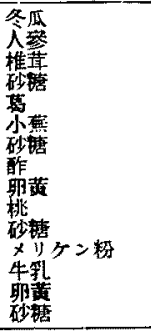 & \begin{tabular}{r|}
60 \\
少| \\
少| \\
5 \\
5 \\
40 \\
5 \\
5 \\
5 \\
5 \\
60 \\
10 \\
20 \\
10 \\
5 \\
15 \\
\end{tabular} & & $\begin{array}{c}0.18 \\
\bar{Z} \\
\bar{z} \\
0.64 \\
\overline{-} \\
0.81 \\
0.54 \\
2.18 \\
0.35 \\
0.81\end{array}$ & $\begin{array}{r}5 \\
\\
20 \\
8 \\
20 \\
18 \\
26 \\
39 \\
69 \\
7 \\
18 \\
59 \\
\end{array}$ \\
\hline & 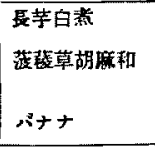 & 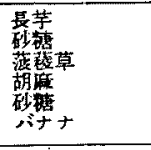 & $\begin{array}{r}60 \\
10 \\
30 \\
5 \\
5 \\
100\end{array}$ & & $\begin{array}{l}1.68 \\
0.69 \\
0.99 \\
1.40\end{array}$ & $\begin{array}{r}52 \\
39 \\
6 \\
29 \\
20 \\
98\end{array}$ \\
\hline & 故 & & & 630 & 21.98 & 1205 \\
\hline
\end{tabular}

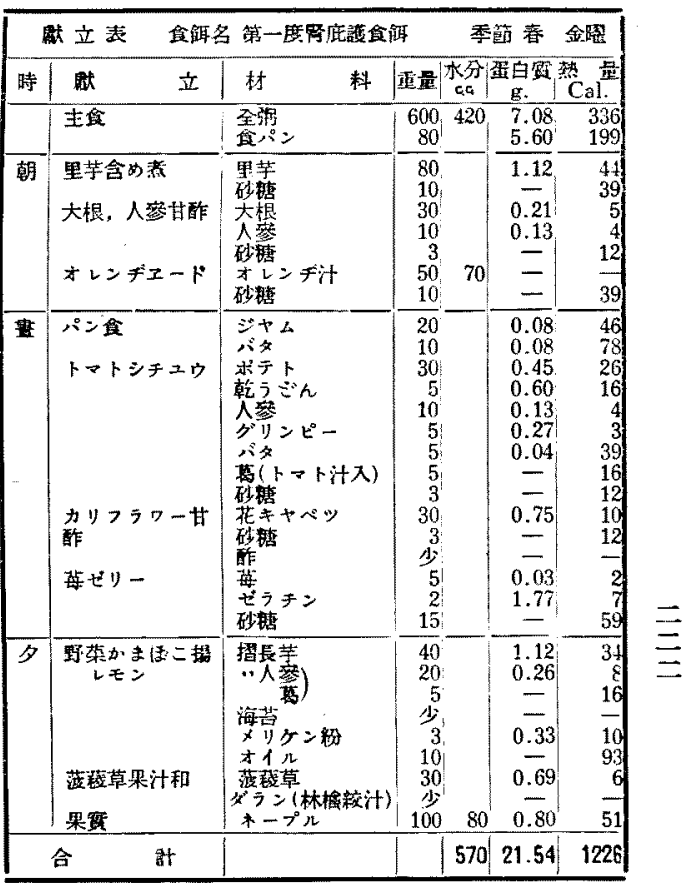




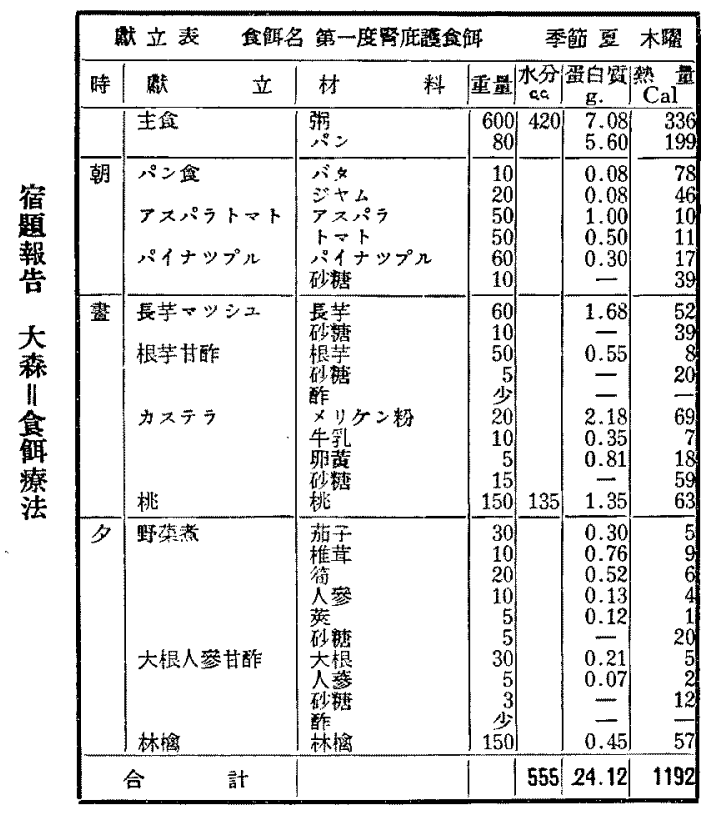

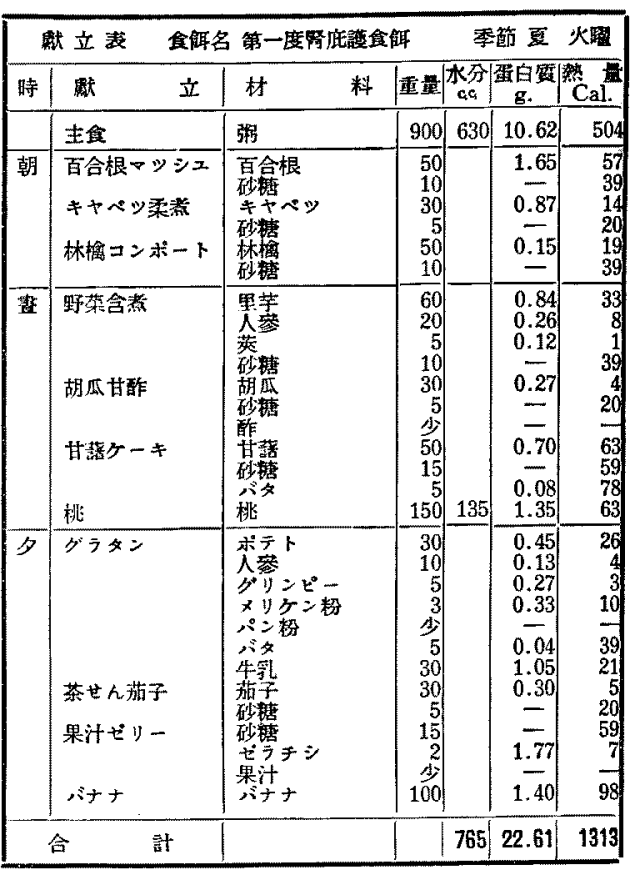

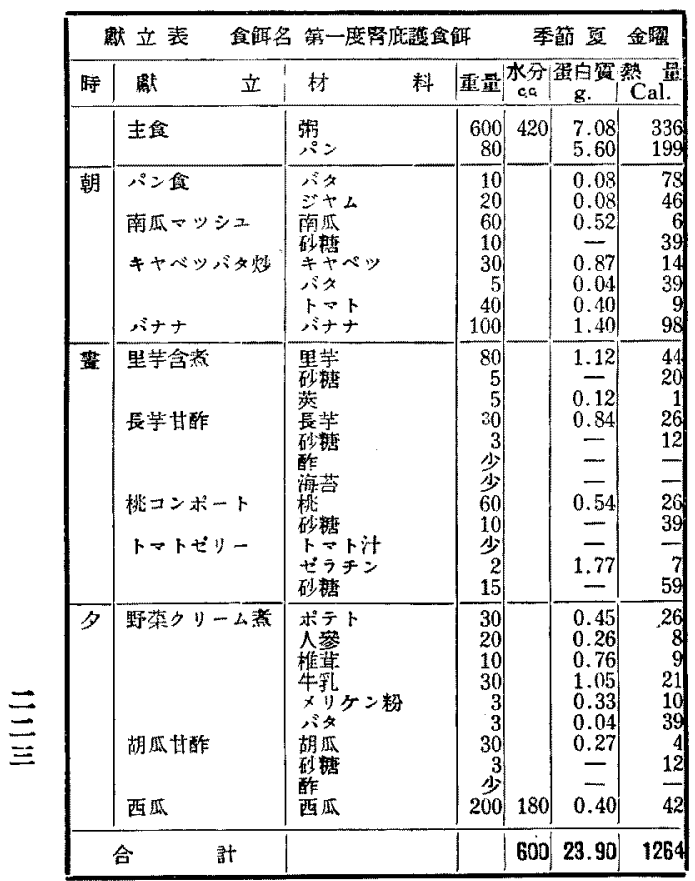

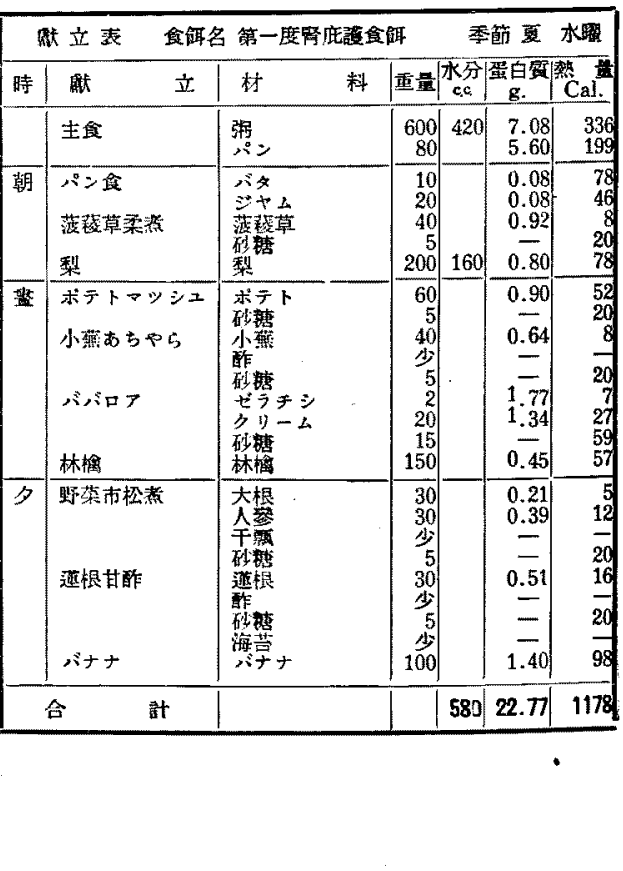




\begin{tabular}{|c|c|c|c|c|c|c|c|}
\hline \multicolumn{2}{|c|}{ 能立素 } & \multicolumn{3}{|c|}{ 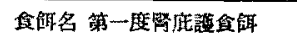 } & \multicolumn{3}{|c|}{ 季荊秋 日曜 } \\
\hline \multicolumn{4}{|c|}{ 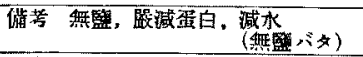 } & & \multicolumn{3}{|c|}{ (中野七于䇣) } \\
\hline \multirow[t]{2}{*}{ 時 } & 砳 立 & 材 & 料 & 重量 & 水分 & 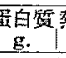 & 㷊 量 \\
\hline & 主目 & 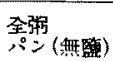 & & $\begin{array}{r}600 \\
80\end{array}$ & 480 & $\begin{array}{l}7.08 \\
5.60\end{array}$ & $\begin{array}{l}336 \\
199\end{array}$ \\
\hline 朝 & 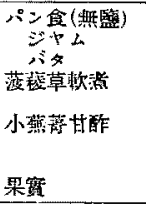 & 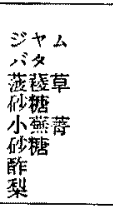 & & $\begin{array}{r}20 \\
10 \\
50 \\
5 \\
40 \\
3 \\
\text { 少 } \\
200\end{array}$ & 160 & $\begin{array}{l}0.08 \\
0.08 \\
1.15 \\
0.64 \\
- \\
0.80\end{array}$ & $\begin{array}{r}46 \\
78 \\
9 \\
20 \\
8 \\
12 \\
78 \\
\end{array}$ \\
\hline 整 & 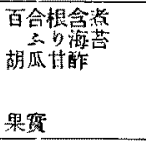 & 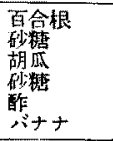 & & $\begin{array}{r}50 \\
10 \\
30 \\
3 \\
\text { 少 } \\
100\end{array}$ & 80 & $\begin{array}{c}1.65 \\
0.27 \\
- \\
1.40\end{array}$ & $\begin{array}{r}57 \\
39 \\
4 \\
12 \\
98 \\
\end{array}$ \\
\hline 夕 & $\begin{array}{l}\text { 市松大根者 } \\
\text { 栗含者 } \\
\text { 果泶 }\end{array}$ & 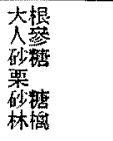 & & $\begin{array}{r}30 \\
30 \\
5 \\
60 \\
10 \\
150\end{array}$ & 120 & $\begin{array}{l}0.21 \\
0.39 \\
1.74 \\
0.45\end{array}$ & \begin{tabular}{r|}
5 \\
12 \\
20 \\
99 \\
39 \\
57
\end{tabular} \\
\hline & 滆 & & & & 840 & 21.54 & 1228 \\
\hline
\end{tabular}

\begin{tabular}{|c|c|c|c|c|c|c|}
\hline \multicolumn{2}{|c|}{ 閉立表 } & \multicolumn{2}{|c|}{ 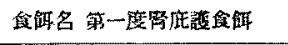 } & \multicolumn{3}{|c|}{ 悸简夏 土矅 } \\
\hline 時 & 献 & 材 & fitis & $\begin{array}{c}\text { 我分 } \\
0.4\end{array}$ & 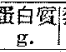 & 熱 \\
\hline & 主会 & 强ン & $\begin{array}{r}600 \\
80\end{array}$ & 420 & $\begin{array}{l}7.08 \\
5.60\end{array}$ & $\begin{array}{l}336 \\
199\end{array}$ \\
\hline 朝 & 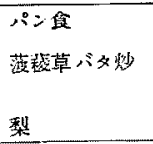 & 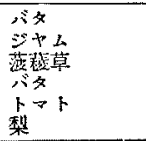 & \begin{tabular}{r|}
10 \\
20 \\
50 \\
5 \\
30 \\
200 \\
\end{tabular} & 160 & $\begin{array}{l}0.08 \\
0.08 \\
1.15 \\
0.04 \\
0.30 \\
0.80\end{array}$ & $\begin{array}{r}78 \\
46 \\
11 \\
39 \\
7 \\
78\end{array}$ \\
\hline 灆 & 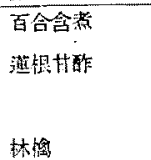 & 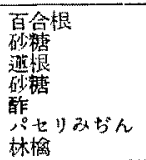 & \begin{tabular}{r|}
50 \\
10 \\
30 \\
5 \\
少 \\
150 \\
150
\end{tabular} & & $\begin{array}{l}1.65 \\
0.51 \\
- \\
\\
0.45\end{array}$ & $\begin{array}{l}57 \\
39 \\
16 \\
20 \\
7 \\
57\end{array}$ \\
\hline 3 & $\begin{array}{l}\text { ダラタン } \\
\text { 小篗苗知 } \\
\text { 西瓜 }\end{array}$ & 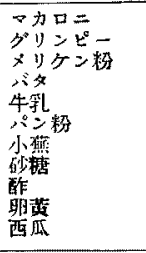 & \begin{tabular}{r|}
15 \\
5 \\
3 \\
5 \\
50 \\
少 \\
40 \\
5 \\
少 \\
200 \\
20
\end{tabular} & 180 & $\begin{array}{l}1.64 \\
0.27 \\
0.33 \\
0.04 \\
1.75 \\
0.64 \\
= \\
= \\
0.40\end{array}$ & $\begin{array}{r}54 \\
3 \\
10 \\
39 \\
35 \\
8 \\
20 \\
\\
42 \\
\end{array}$ \\
\hline & 計 & & & 760 & 22.81 & 1193 \\
\hline
\end{tabular}

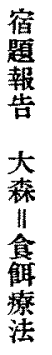

\begin{tabular}{|c|c|c|c|c|c|c|c|}
\hline \multicolumn{2}{|c|}{ 蹴立表 } & \multicolumn{3}{|c|}{ 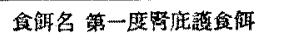 } & \multicolumn{3}{|c|}{ 委藍秋 月矅 } \\
\hline 眝 & 新 & 材 & 料 & I互焉 & $\begin{array}{l}\text { 交分 } \\
\text { ce. }\end{array}$ & 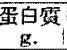 & Cal. \\
\hline & 圭食 & 全程 & & 900 & 720 & 10.62 & 504 \\
\hline 朝 & 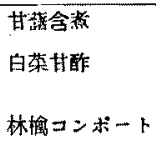 & 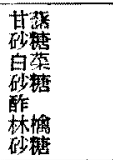 & & $\begin{array}{l}60 \\
10 \\
30 \\
3 \\
\text { 少 } \\
80 \\
15\end{array}$ & & $\begin{array}{c}0.84 \\
\overline{0.39} \\
\overline{-} \\
0.24 \\
\end{array}$ & $\begin{array}{l}77 \\
39 \\
12 \\
12 \\
30 \\
59\end{array}$ \\
\hline 竦 & 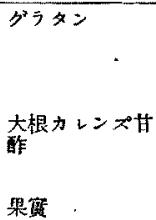 & 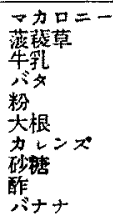 & & $\begin{array}{r}20 \\
30 \\
10 \\
5 \\
3 \\
30 \\
\text { 少 } \\
3 \\
\text { 少 } \\
100\end{array}$ & 80 & $\begin{array}{l}2.18 \\
0.69 \\
0.35 \\
0.04 \\
0.33 \\
0.21 \\
= \\
= \\
1.40\end{array}$ & $\begin{array}{r}72 \\
6 \\
7 \\
39 \\
10 \\
5 \\
12 \\
98\end{array}$ \\
\hline 8 & 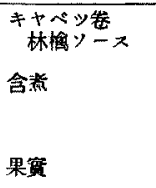 & 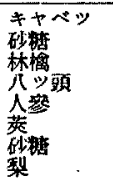 & & \begin{tabular}{r|}
100 \\
10 \\
30 \\
80 \\
30 \\
10 \\
10 \\
200
\end{tabular} & 160 & $\begin{array}{l}2.90 \\
0.09 \\
2.24 \\
0.39 \\
0.23 \\
0.80\end{array}$ & \begin{tabular}{l|}
47 \\
39 \\
11 \\
96 \\
12 \\
2 \\
39 \\
78
\end{tabular} \\
\hline & 辞 & & & & 960 & 23.32 & 1306 \\
\hline
\end{tabular}

\begin{tabular}{|c|c|c|c|c|c|c|c|}
\hline \multicolumn{2}{|c|}{ 嚾立茷 } & \multicolumn{3}{|c|}{ 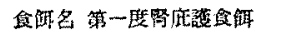 } & \multicolumn{3}{|c|}{ 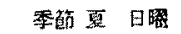 } \\
\hline 時 & 閔 & 村 & 料 & 垔器 & $\left|\begin{array}{c}\text { 水分 } \\
\mathrm{a}\end{array}\right|$ & $\begin{array}{l}\text { 蛋白宔 } \\
\mathrm{g} \text {. }\end{array}$ & $\begin{array}{l}\text { 高 } \\
\text { Cal. }\end{array}$ \\
\hline & 主食 & 楼 & & $\begin{array}{r}600 \\
80\end{array}$ & 420 & $\begin{array}{l}7.08 \\
5.60\end{array}$ & $\begin{array}{l}336 \\
195 \\
\end{array}$ \\
\hline 朝 & 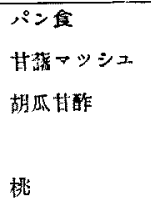 & 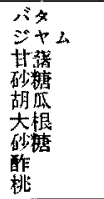 & & \begin{tabular}{r|}
10 \\
20 \\
60 \\
10 \\
20 \\
10 \\
5 \\
少 \\
150
\end{tabular} & 135 & $\begin{array}{l}0.08 \\
0.08 \\
0.84 \\
0.18 \\
0.07 \\
- \\
1.35\end{array}$ & $\begin{array}{r}78 \\
46 \\
76 \\
39 \\
3 \\
2 \\
20 \\
63\end{array}$ \\
\hline 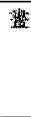 & 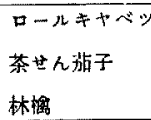 & 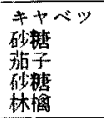 & & $\begin{array}{r}50 \\
5 \\
40 \\
5 \\
150 \\
\end{array}$ & & $\begin{array}{l}1.45 \\
0.40 \\
-.45 \\
\end{array}$ & $\begin{array}{r}24 \\
20 \\
7 \\
20 \\
57\end{array}$ \\
\hline タ & 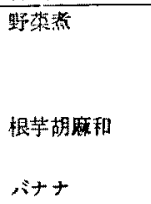 & 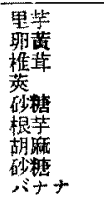 & & \begin{tabular}{r|}
80 \\
15 \\
10 \\
10 \\
10 \\
50 \\
5 \\
5 \\
100
\end{tabular} & & $\begin{array}{l}1.12 \\
2.42 \\
0.76 \\
0.12 \\
0.55 \\
0.99 \\
1.40\end{array}$ & $\begin{array}{r}44 \\
54 \\
9 \\
1 \\
39 \\
8 \\
29 \\
20 \\
98\end{array}$ \\
\hline & 部 & & & & 555 & 25.05 & 1293 \\
\hline
\end{tabular}




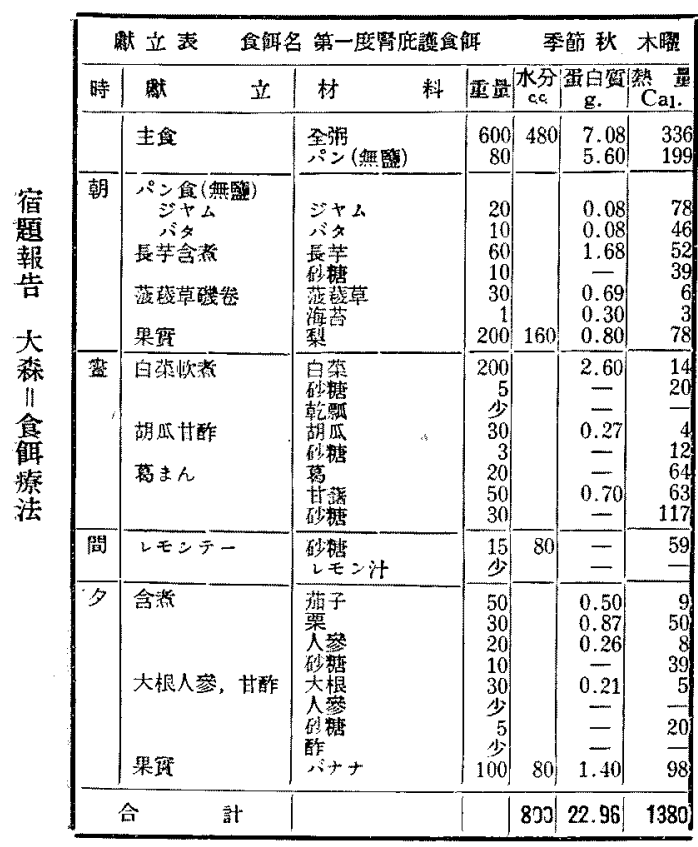

\begin{tabular}{|c|c|c|c|c|c|c|}
\hline \multicolumn{2}{|c|}{ 㩆立表 } & \multicolumn{2}{|c|}{ 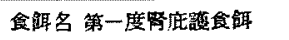 } & \multicolumn{3}{|c|}{ 季筧 秋 火晒 } \\
\hline 時 & 輌 & 料 & 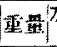 & 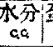 & 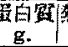 & Cal. \\
\hline & 圭食 & 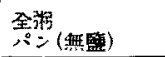 & $\begin{array}{r}600 \\
80 \\
\end{array}$ & 480 & $\begin{array}{l}7.08 \\
5.60\end{array}$ & $\begin{array}{l}336 \\
199\end{array}$ \\
\hline 朝 & 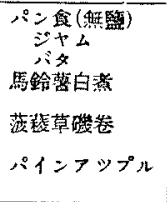 & 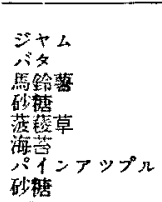 & \begin{tabular}{l|l}
20 & \\
10 \\
60 \\
10 \\
30 \\
1 \\
80 \\
15
\end{tabular} & & $\begin{array}{l}0.08 \\
0.08 \\
0.90 \\
0.69 \\
0.30 \\
0.40 \\
-\end{array}$ & $\begin{array}{r}46 \\
78 \\
52 \\
39 \\
6 \\
3 \\
23 \\
59\end{array}$ \\
\hline 㴔 & 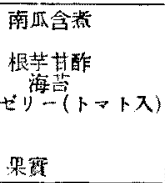 & 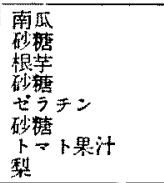 & \begin{tabular}{r|r}
60 \\
10 \\
30 \\
5 \\
2 \\
15 \\
少 \\
200 \\
\end{tabular} & 160 & $\begin{array}{l}0.42 \\
0.33 \\
\overline{1.17} \\
\overline{-} \\
0.80\end{array}$ & \begin{tabular}{r|}
12 \\
39 \\
5 \\
20 \\
79 \\
59 \\
78
\end{tabular} \\
\hline 夕 & 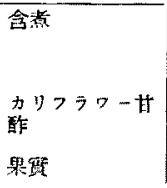 & 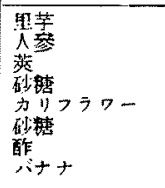 & \begin{tabular}{r|}
80 \\
20 \\
10 \\
10 \\
50 \\
5 \\
少 \\
100
\end{tabular} & 80 & $\begin{array}{l}1.12 \\
0.26 \\
0.25 \\
1.45 \\
\overline{1.40} \\
\end{array}$ & \begin{tabular}{r|}
44 \\
8 \\
2 \\
39 \\
16 \\
20 \\
98
\end{tabular} \\
\hline & 部 & & & 720 & 21.59 & 1318 \\
\hline
\end{tabular}

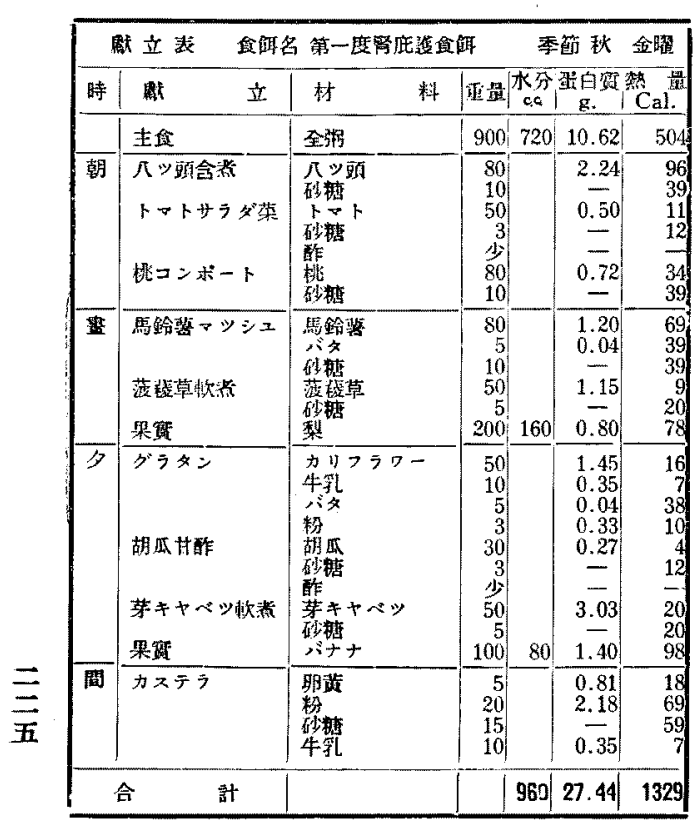

\begin{tabular}{|c|c|c|c|c|c|c|c|}
\hline \multicolumn{2}{|c|}{ 咅表 } & \multicolumn{3}{|c|}{ 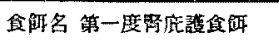 } & \multicolumn{3}{|c|}{ 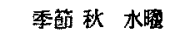 } \\
\hline 時 & 䙲 & 枯 & 料 & 垔量 & 水分 & $\begin{array}{c}\text { 蛋白得 } \\
\mathrm{g} .\end{array}$ & 䔳 \\
\hline & 声食 & 金弹 & & 900 & 720 & 10.62 & 504 \\
\hline 朝 & 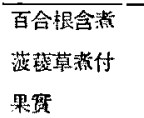 & 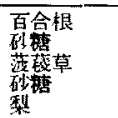 & & \begin{tabular}{r|}
50 \\
10 \\
50 \\
5 \\
200
\end{tabular} & 160 & $\begin{array}{c}1.65 \\
1.15 \\
0.80\end{array}$ & $\begin{array}{r}57 \\
39 \\
9 \\
20 \\
78\end{array}$ \\
\hline 整 & 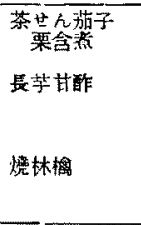 & 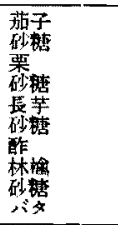 & & \begin{tabular}{r|}
50 \\
5 \\
30 \\
10 \\
30 \\
5 \\
15 \\
100 \\
20 \\
10
\end{tabular} & & $\begin{array}{c}0.50 \\
0.87 \\
-\overline{0.84} \\
\overline{-} \\
0.30 \\
-0.08\end{array}$ & $\begin{array}{l}9 \\
20 \\
50 \\
39 \\
26 \\
20 \\
38 \\
78 \\
78\end{array}$ \\
\hline 3 & 含䇣 & 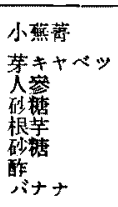 & & \begin{tabular}{r|}
40 \\
20 \\
20 \\
5 \\
30 \\
5 \\
少 \\
100
\end{tabular} & 80 & $\begin{array}{c}0.64 \\
1.20 \\
0.26 \\
\overline{0.33} \\
\overline{-} \\
1.40\end{array}$ & $\begin{array}{r}8 \\
8 \\
80 \\
5 \\
20\end{array}$ \\
\hline & 院 & & & & 960 & 20.64 & 1232 \\
\hline
\end{tabular}




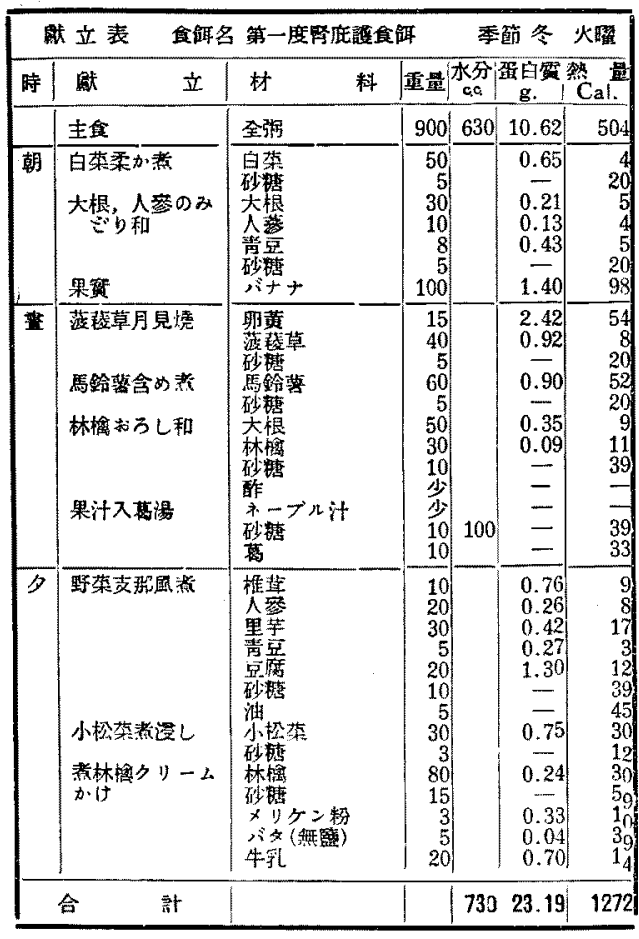

\begin{tabular}{|c|c|c|c|c|c|c|}
\hline \multicolumn{2}{|c|}{ 剧立表 } & \multicolumn{2}{|c|}{ 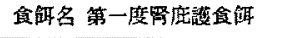 } & \multicolumn{3}{|c|}{ 季㽞 秋 土曜 } \\
\hline 時 & 散 & 材 & 重量 & 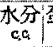 & 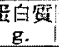 & 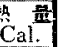 \\
\hline & 圭食 & 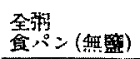 & $\begin{array}{r}600 \\
80\end{array}$ & 480 & $\begin{array}{l}7.08 \\
5.60\end{array}$ & $\begin{array}{l}336 \\
199\end{array}$ \\
\hline 朝 & 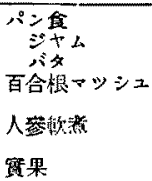 & 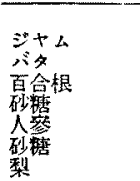 & $\begin{array}{r}20 \\
10 \\
50 \\
10 \\
50 \\
5 \\
200\end{array}$ & 160 & $\begin{array}{l}0.08 \\
0.08 \\
1.65 \\
0.65 \\
0.80\end{array}$ & $\begin{array}{l}50 \\
57 \\
39 \\
20 \\
20 \\
78\end{array}$ \\
\hline 藍 & 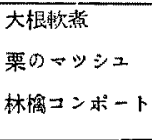 & 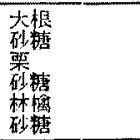 & $\begin{array}{r}80 \\
5 \\
30 \\
10 \\
80 \\
15 \\
\end{array}$ & & $\begin{array}{l}0.56 \\
0.87 \\
0.24\end{array}$ & $\begin{array}{l}14 \\
20 \\
50 \\
39 \\
30 \\
59\end{array}$ \\
\hline 夕 & 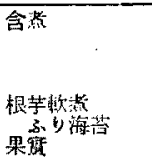 & 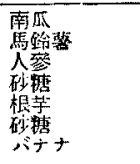 & $\begin{array}{r}50 \\
30 \\
10 \\
10 \\
30 \\
5 \\
100\end{array}$ & ${ }_{80}$ & \begin{tabular}{l|}
0.35 \\
0.45 \\
0.13 \\
0.33 \\
1.40
\end{tabular} & \begin{tabular}{r|r}
15 & \\
26 & \\
4 & \\
39 & \\
5 & \\
20 & \\
98 &
\end{tabular} \\
\hline & 計 & & & & 20.27 & 1292 \\
\hline
\end{tabular}

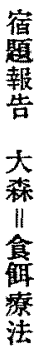

\begin{tabular}{|c|c|c|c|c|c|c|c|}
\hline \multicolumn{2}{|c|}{ 默立䔉 } & \multicolumn{3}{|c|}{ 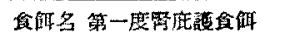 } & \multicolumn{3}{|c|}{ 季節 冬 水曜 } \\
\hline 眭 & 默 & 材 & 料 & 重量 & 永䓠同 & ${ }_{\mathrm{g}}$ 白䨢 & 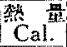 \\
\hline & 主食 & 全倨 & & 900 & 630 & 10.62 & 504 \\
\hline 朝 & 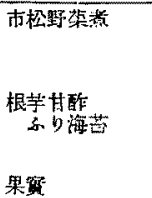 & 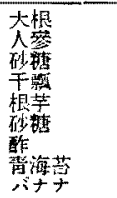 & & \begin{tabular}{r|}
30 \\
30 \\
5 \\
少 \\
10 \\
省 \\
100
\end{tabular} & & $\begin{array}{l}0.21 \\
0.39 \\
\overline{-} \\
0.55 \\
= \\
\bar{z} \\
1.40\end{array}$ & $\frac{39}{98}$ \\
\hline 書 & 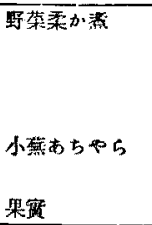 & 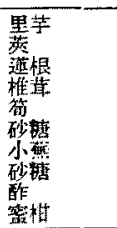 & & \begin{tabular}{r|}
50 \\
10 \\
30 \\
10 \\
20 \\
10 \\
40 \\
10 \\
少. \\
100
\end{tabular} & 80 & $\begin{array}{l}0.70 \\
0.37 \\
0.51 \\
0.76 \\
0.52 \\
0.64 \\
\overline{1.10} \\
1.10\end{array}$ & $\begin{array}{r}6 \\
39 \\
89 \\
27\end{array}$ \\
\hline タ & 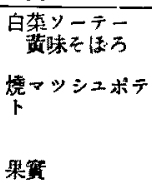 & 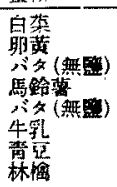 & & $\begin{array}{r}80 \\
10 \\
5 \\
80 \\
5 \\
10 \\
10 \\
150\end{array}$ & & $\begin{array}{l}1.04 \\
1.61 \\
0.04 \\
1.20 \\
0.04 \\
0.35 \\
0.54 \\
0.45\end{array}$ & $\begin{array}{r}6 \\
36 \\
39 \\
69 \\
39\end{array}$ \\
\hline & 部 & & & & & 23.04 & 1120 \\
\hline
\end{tabular}

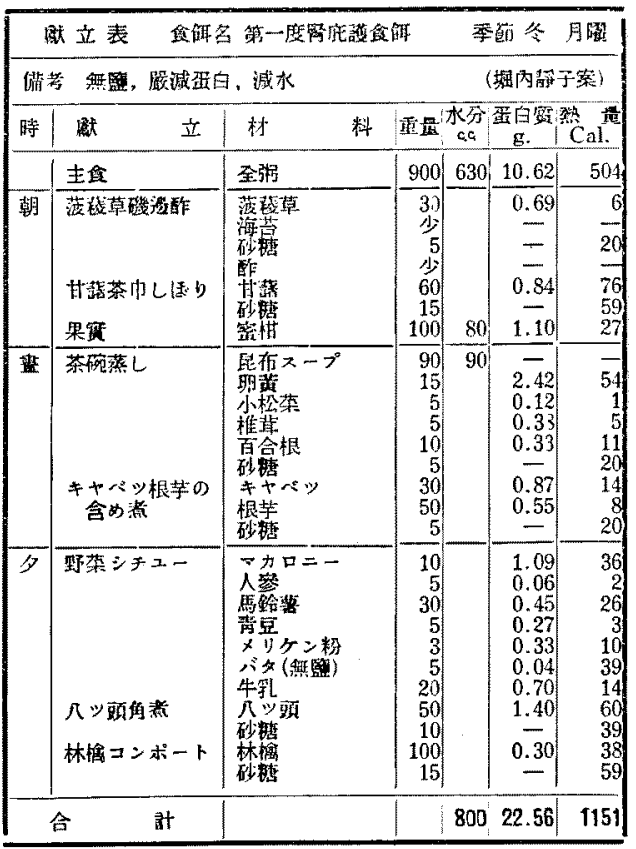

三 

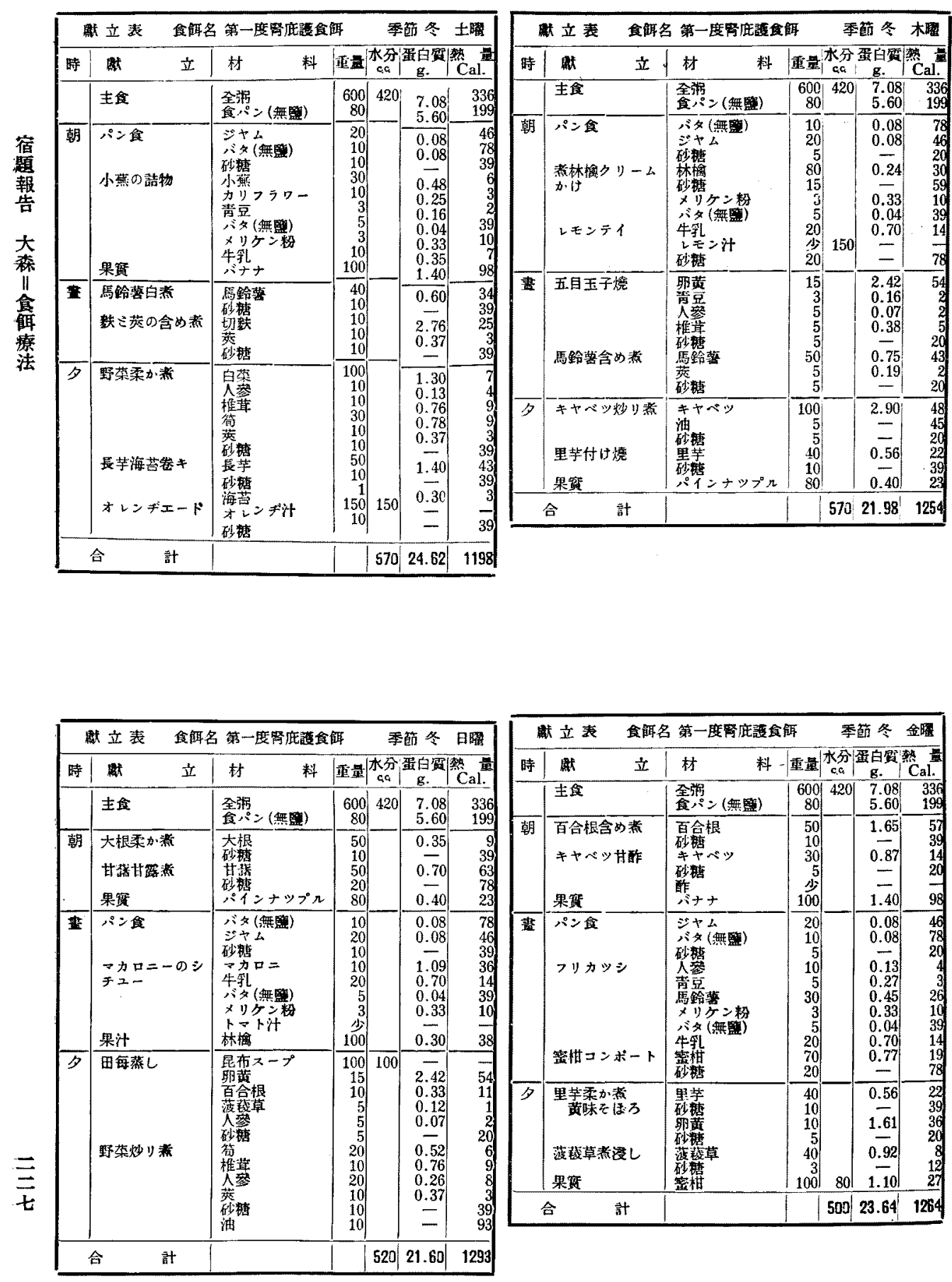

\begin{tabular}{|c|c|c|c|c|c|c|}
\hline \multicolumn{2}{|c|}{ 留主表 } & \multicolumn{2}{|c|}{ 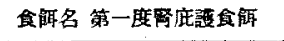 } & \multicolumn{3}{|c|}{ 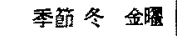 } \\
\hline 洔 & 鶌 & 材 & 料一重量 & & $\begin{array}{c}\text { 触白䇣 } \\
\mathrm{g} .\end{array}$ & $\begin{array}{l}\text { 曋 } \\
\text { Cal. }\end{array}$ \\
\hline & 主食 & 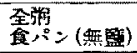 & $\begin{array}{r}600 \\
80 \\
\end{array}$ & b) 420 & $\begin{array}{l}7.08 \\
5.60\end{array}$ & $\begin{array}{l}336 \\
199 \\
\end{array}$ \\
\hline 朝 & 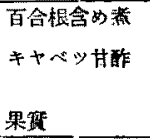 & 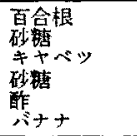 & $\begin{array}{r}50 \\
10 \\
30 \\
5 \\
\text { 少 } \\
100\end{array}$ & & $\begin{array}{c}\frac{1.65}{0.87} \\
\overline{-} \\
1.40\end{array}$ & $\begin{array}{l}57 \\
38 \\
14 \\
20 \\
98\end{array}$ \\
\hline 盗 & 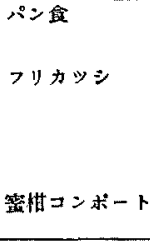 & 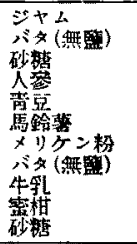 & $\begin{array}{r}20 \\
10 \\
5 \\
10 \\
5 \\
30 \\
3 \\
5 \\
20 \\
70 \\
20\end{array}$ & & $\begin{array}{l}0.08 \\
0.08 \\
0.13 \\
0.27 \\
0.45 \\
0.33 \\
0.04 \\
0.70 \\
0.77 \\
-\end{array}$ & $\begin{array}{l}4 \\
26 \\
10 \\
35 \\
14 \\
19 \\
78\end{array}$ \\
\hline 夕 & 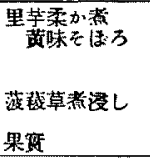 & 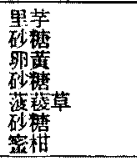 & $\begin{array}{r}40 \\
10 \\
10 \\
5 \\
40 \\
3 \\
100 \\
\end{array}$ & ) & $\begin{array}{l}\frac{0.56}{1.61} \\
\frac{0.92}{1.10}\end{array}$ & $\begin{array}{r}22 \\
39 \\
36 \\
20 \\
8 \\
12 \\
27 \\
\end{array}$ \\
\hline & 䚵 & & & 500 & 23.64 & 1264 \\
\hline
\end{tabular}




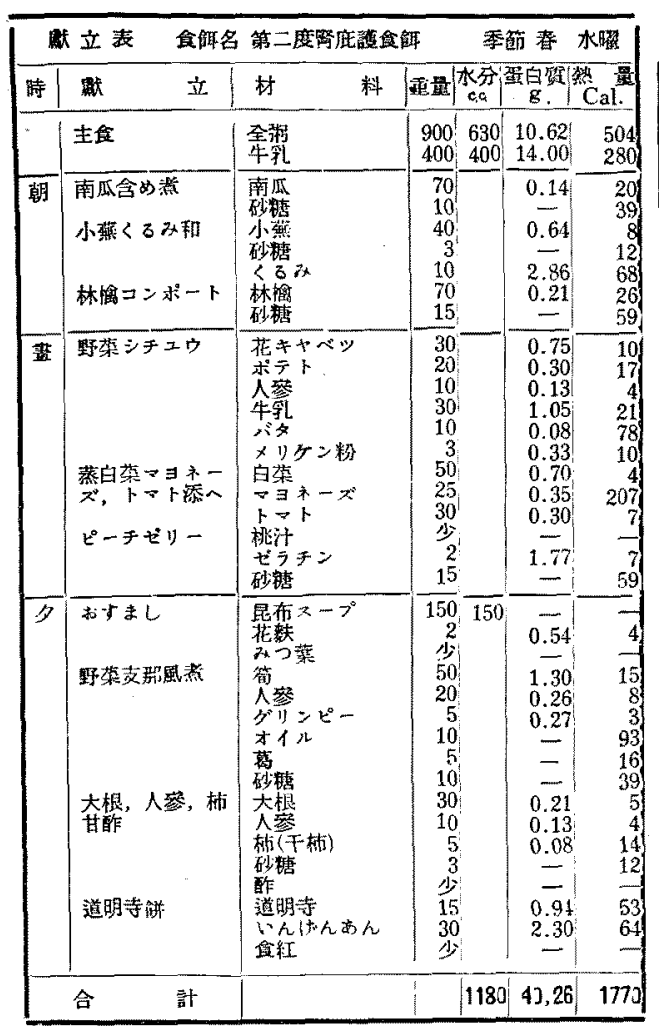

附錄 (2) 第二度 A 庇讙会 4 種

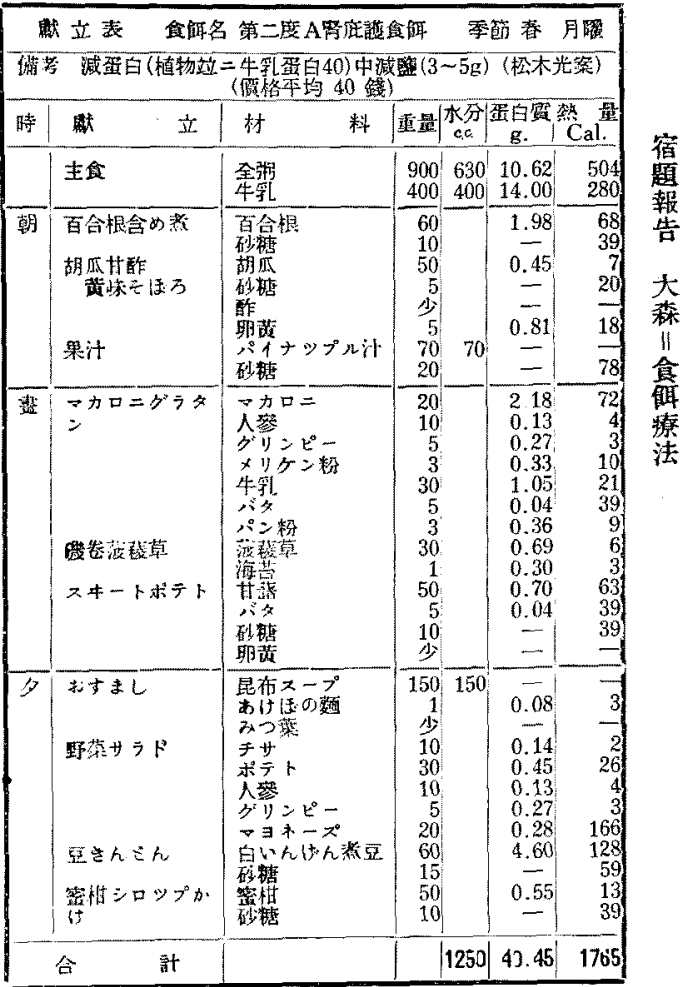

\begin{tabular}{|c|c|c|c|c|c|c|}
\hline \multicolumn{2}{|c|}{ 留立表 } & \multicolumn{2}{|c|}{ 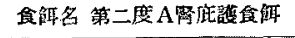 } & \multicolumn{3}{|c|}{ 㳵䈱 春 木嚁 } \\
\hline 時 & 韵 & 料 & Ite & $\begin{array}{l}k 30 \\
c . c .\end{array} \mid$ & 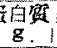 & 然 \\
\hline & 主祖 & 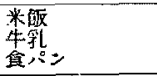 & $\begin{array}{l}400 \\
400 \\
100\end{array}$ & 400 & $\begin{array}{r}12.80 \\
14.00 \\
7.00\end{array}$ & $\begin{array}{l}584 \\
280 \\
249\end{array}$ \\
\hline 朝 & 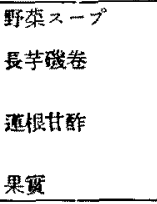 & 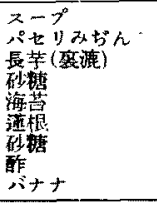 & \begin{tabular}{r|}
150 \\
少 \\
60 \\
10 \\
1 \\
30 \\
3 \\
少 \\
100
\end{tabular} & 150 & $\begin{array}{l}\overline{ } \\
\overline{1.68} \\
\overline{0.30} \\
0.51 \\
\overline{1.40}\end{array}$ & $\begin{array}{l}7 \\
52 \\
39\end{array}$ \\
\hline 童 & $\begin{array}{l}\text { サンドウキッチ } \\
\text { 萁シロップかけ } \\
\text { レモンテー }\end{array}$ & 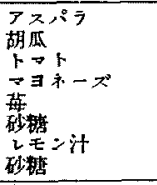 & $\begin{array}{l}20 \\
30 \\
30 \\
30 \\
50 \\
20 \\
\text { 少 } \\
15\end{array}$ & 150 & $\begin{array}{l}0.40 \\
0.27 \\
0.30 \\
0.42 \\
0.30 \\
= \\
=\end{array}$ & $\begin{array}{r}248 \\
17 \\
78 \\
59 \\
\end{array}$ \\
\hline 夕 & 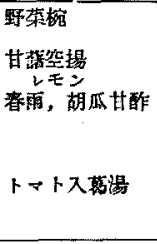 & 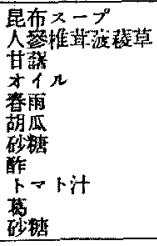 & \begin{tabular}{r|}
150 \\
少 \\
70 \\
5 \\
5 \\
40 \\
5 \\
少 \\
15 \\
15 \\
\end{tabular} & 150 & $\begin{array}{l}\overline{=} \\
0.93 \\
\overline{0.02} \\
0.36 \\
= \\
= \\
=\end{array}$ & $\begin{array}{l}- \\
88 \\
47 \\
17 \\
5 \\
20 \\
\\
48 \\
59\end{array}$ \\
\hline & 都 & & & 959 & 43.74 & 2034 \\
\hline
\end{tabular}

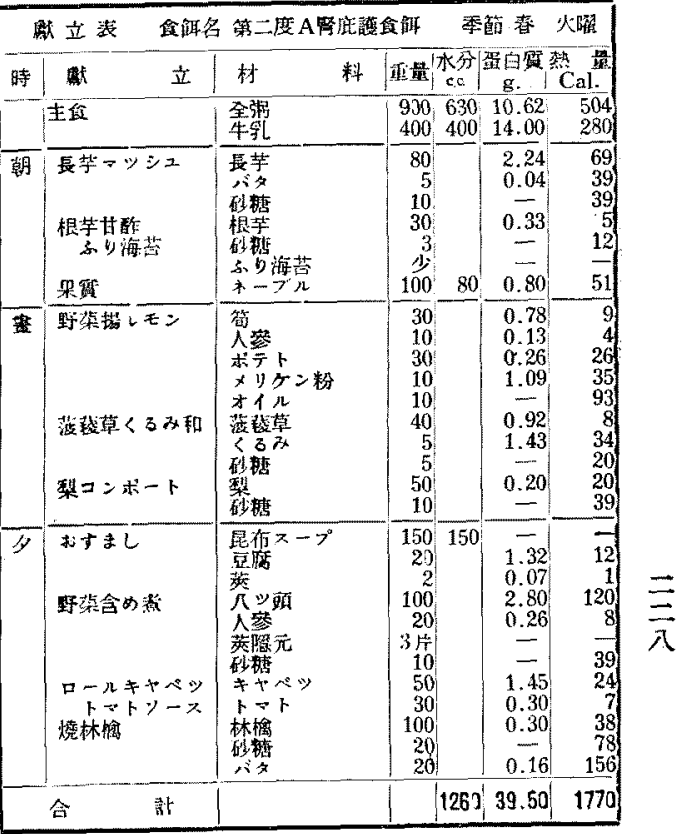



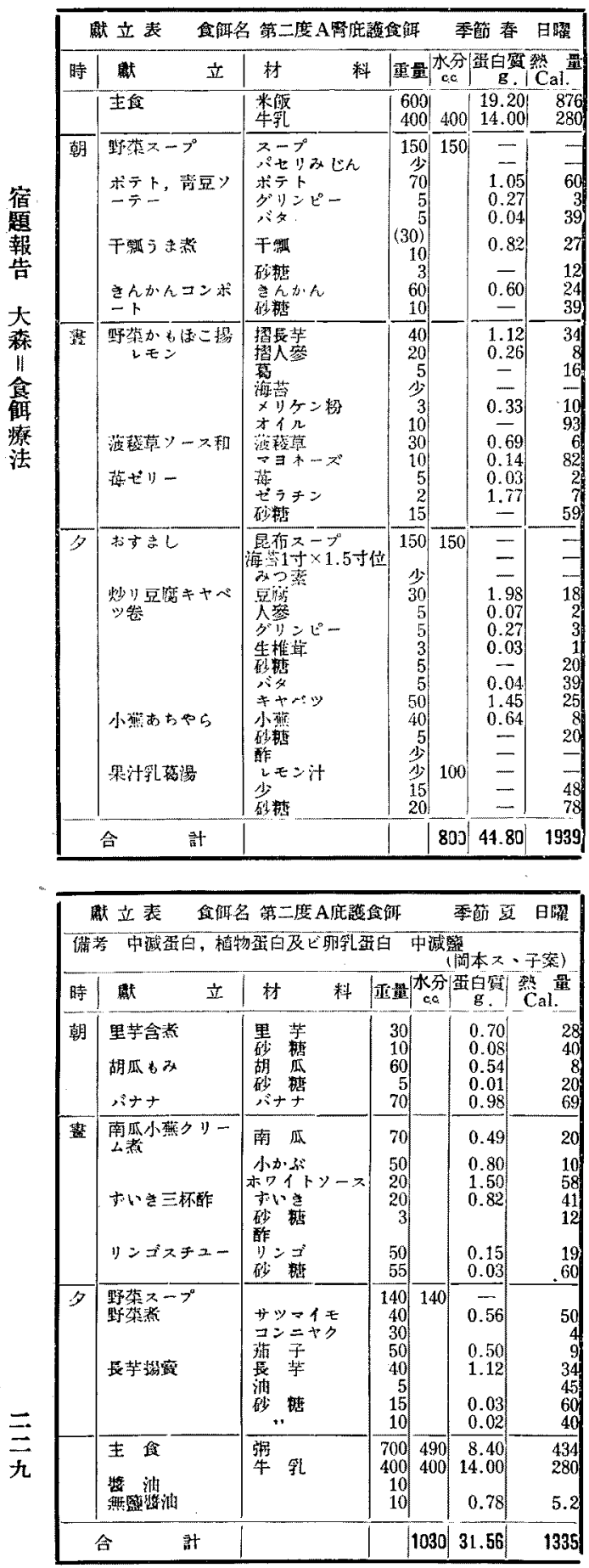

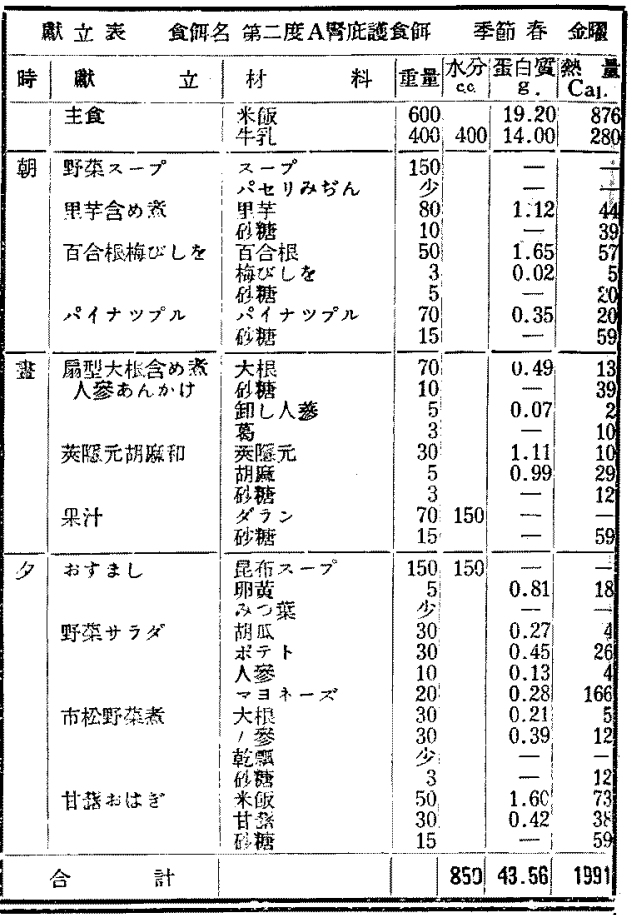

\begin{tabular}{|c|c|c|c|c|c|c|}
\hline \multicolumn{2}{|c|}{ 愿立表 } & \multicolumn{2}{|c|}{ 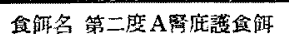 } & \multicolumn{3}{|c|}{ 李籍 春 士曜 } \\
\hline 時 & 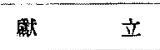 & 材 & 重量 & $\begin{array}{l}\text { 水分 } \\
\mathrm{c}, \mathrm{c}\end{array}$ & 埾白管 & $\mathrm{Cal}$ \\
\hline & 主食 & 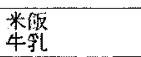 & $\begin{array}{l}600 \\
400\end{array}$ & 400 & $\begin{array}{l}19.20 \\
14.00\end{array}$ & \\
\hline 胡 & 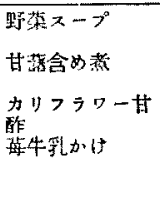 & 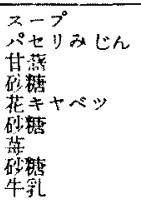 & \begin{tabular}{r|}
150 \\
少 \\
70 \\
10 \\
30 \\
3 \\
50 \\
10 \\
30
\end{tabular} & 150 & $\begin{array}{l}\overline{-} \\
0.98 \\
\overline{0.75} \\
0.30 \\
\overline{0} \\
1.05\end{array}$ & \\
\hline 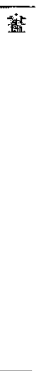 & 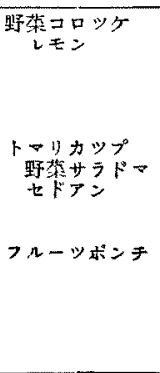 & 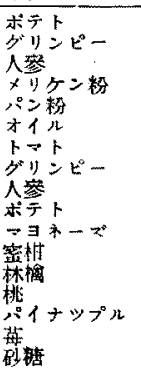 & \begin{tabular}{r|r}
50 & \\
5 & \\
5 & \\
3 & \\
3 & 10 \\
40 & \\
2 & \\
5 & 15 \\
20 & 15 \\
20 & 15 \\
10 & \\
10 & \\
15 &
\end{tabular} & 50 & \begin{tabular}{l|}
0.75 \\
0.27 \\
0.07 \\
0.33 \\
0.36 \\
0.40 \\
0.13 \\
0.07 \\
0.23 \\
0.28 \\
0.17 \\
0.06 \\
0.14 \\
0.05 \\
0.06
\end{tabular} & \\
\hline 3 & 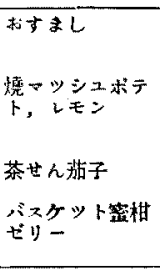 & 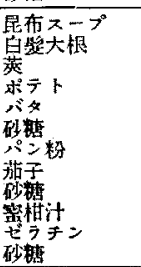 & \begin{tabular}{r|}
150 \\
5 \\
2 \\
100 \\
5 \\
5 \\
7 \\
50 \\
3 \\
70 \\
2 \\
15
\end{tabular} & $\overrightarrow{150}$ & $\begin{array}{l}\overline{\bar{Z}} \\
0.04 \\
1.07 \\
0.04 \\
\overline{-} \\
0.50 \\
\overline{-} \\
1 . \overline{7}\end{array}$ & \\
\hline & 計 & & & 780 & 43.57 & \\
\hline
\end{tabular}




\begin{tabular}{|c|c|c|c|c|c|c|}
\hline \multicolumn{2}{|c|}{ 立淢 } & \multicolumn{3}{|c|}{ 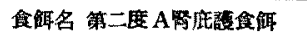 } & \multicolumn{2}{|c|}{ 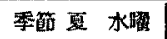 } \\
\hline 時 & 䝭 & 材 & 重量 & 水㞹 & 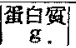 & $\begin{array}{l}\text { 知 } \\
\text { Cal. }\end{array}$ \\
\hline 朝 & 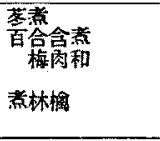 & 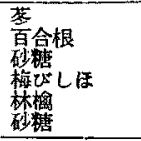 & $\begin{array}{r}40 \\
30 \\
2 \\
10 \\
100 \\
15 \\
\end{array}$ & & $\begin{array}{l}0.16 \\
0.90 \\
0.09 \\
0.30 \\
0.12 \\
\end{array}$ & $\begin{array}{r}52 \\
34 \\
8 \\
5 \\
38 \\
58 \\
\end{array}$ \\
\hline 害 & 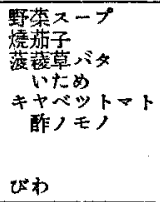 & 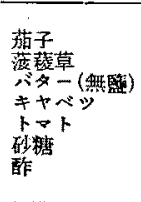 & \begin{tabular}{r|}
140 \\
80 \\
25 \\
40 \\
30 \\
20 \\
5 \\
100
\end{tabular} & 140 & $\begin{array}{l}\overline{0.80} \\
0.57 \\
0.32 \\
0.87 \\
0.20 \\
0.01\end{array}$ & $\begin{array}{r}14 \\
5 \\
314 \\
41 \\
4 \\
20\end{array}$ \\
\hline タ & 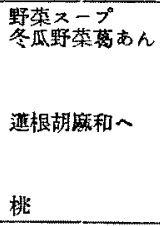 & 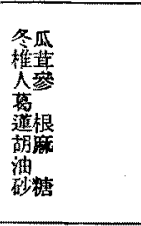 & $\begin{array}{r}140 \\
100 \\
1 \\
5 \\
5 \\
40 \\
5 \\
7 \\
20 \\
80 \\
\end{array}$ & 140 & $\begin{array}{l}-\overline{0.30} \\
0.11 \\
0.06 \\
\overline{0.68} \\
0.98 \\
\overline{0.04} \\
0.72\end{array}$ & $\begin{array}{r}8 \\
3 \\
16 \\
21 \\
29 \\
63 \\
80 \\
34\end{array}$ \\
\hline & 主食 & 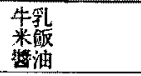 & $\begin{array}{r}400 \\
700 \\
15\end{array}$ & 400 & $\begin{array}{r}14.00 \\
22.40 \\
1.17\end{array}$ & $\begin{array}{r}280 \\
1022 \\
8\end{array}$ \\
\hline & 竐 & & & 680 & 44.80 & 2183 \\
\hline
\end{tabular}

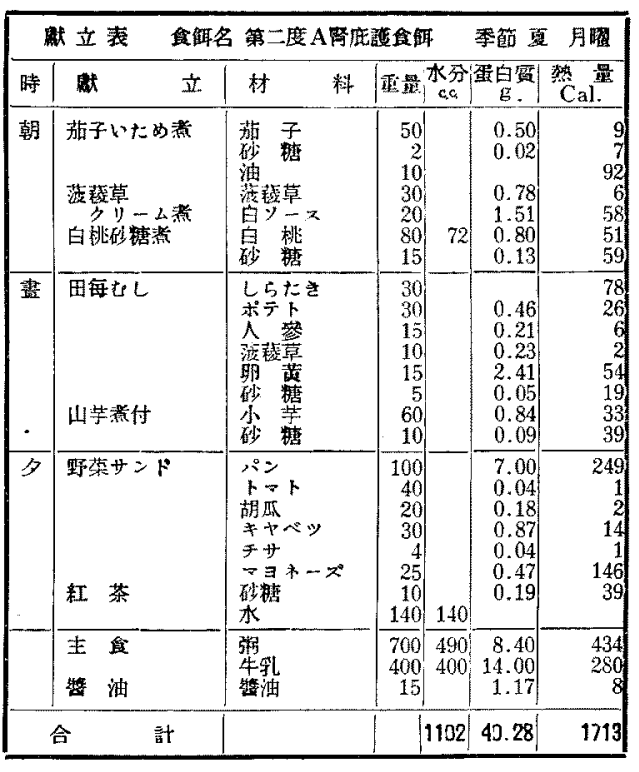

\begin{tabular}{|c|c|c|c|c|c|c|}
\hline \multicolumn{2}{|c|}{ 弲立表 } & \multicolumn{2}{|c|}{ 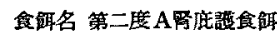 } & \multicolumn{3}{|c|}{ 等簛 夏 木虂 } \\
\hline 时 & 韵 & 料 & 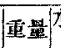 & $\begin{array}{c}\text { 水分 } \\
\mathrm{c}, 4\end{array}$ & $\mid$ & $\begin{array}{l}\text { 椥 } \\
\text { Cal. }\end{array}$ \\
\hline 胡 & 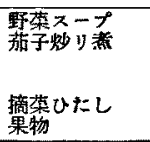 & 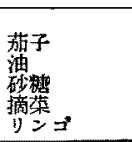 & $\begin{array}{r}140 \\
50 \\
10 \\
5 \\
20 \\
100 \\
\end{array}$ & 140 & $\begin{array}{l}- \\
0.50 \\
- \\
0.04 \\
0.80 \\
0.30\end{array}$ & $\begin{array}{r}- \\
9 \\
92 \\
19 \\
3 \\
38\end{array}$ \\
\hline 整 & $\begin{array}{l}\text { 野荣スープ } \\
\text { ラシチ }\end{array}$ & 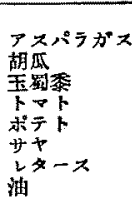 & \begin{tabular}{r|r}
140 \\
40 \\
20 \\
50 \\
少 \\
20 \\
5 \\
2 \\
10
\end{tabular} & 140 & $\begin{array}{l}-\overline{0.80} \\
0.18 \\
0.50 \\
0.30 \\
1.00 \\
0.02\end{array}$ & $\begin{array}{r}-8 \\
8 \\
11\end{array}$ \\
\hline b & 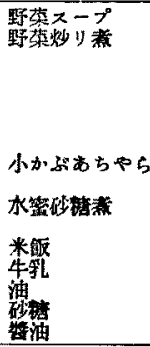 & 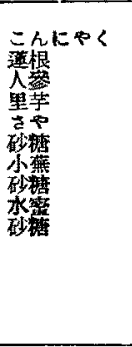 & \begin{tabular}{r|}
140 \\
10 \\
25 \\
10 \\
30 \\
少 \\
5 \\
60 \\
5 \\
60 \\
15 \\
700 \\
400 \\
10 \\
10 \\
15 \\
\end{tabular} & $\begin{array}{r}140 \\
54 \\
400 \\
\end{array}$ & \begin{tabular}{|r|}
- \\
0.42 \\
0.13 \\
0.42 \\
0.04 \\
0.96 \\
0.04 \\
0.05 \\
0.14 \\
22.40 \\
14.00 \\
0.09 \\
1.17 \\
\end{tabular} & $\begin{array}{r}1 \\
13 \\
4 \\
17 \\
20 \\
11 \\
17 \\
25 \\
59 \\
1022 \\
280 \\
92 \\
39 \\
8 \\
\end{array}$ \\
\hline & 棓 & & & 874 & 43.58 & 1914 \\
\hline
\end{tabular}

\begin{tabular}{|c|c|c|c|c|c|}
\hline \multicolumn{2}{|c|}{ 鹊立表 } & \multicolumn{2}{|c|}{ 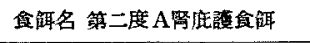 } & \multicolumn{2}{|c|}{ 栗筑 夏 火㨽 } \\
\hline 時 & 解 & 料 & 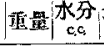 & 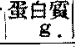 & $\begin{array}{c}\text { 䋣 } \\
\text { Cal. }\end{array}$ \\
\hline 朝 & 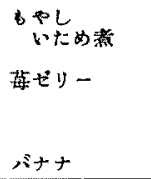 & 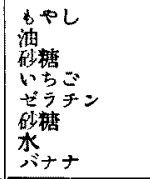 & \begin{tabular}{r|}
30 \\
5 \\
5 \\
15 \\
2 \\
10 \\
30 \\
60
\end{tabular} & $\begin{array}{c}0.87 \\
0.04 \\
0.09 \\
0.08 \\
0.84\end{array}$ & $\begin{array}{r}14 \\
46 \\
19 \\
5 \\
39 \\
58\end{array}$ \\
\hline 蕰 & 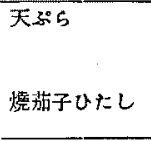 & 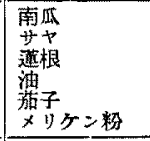 & $\begin{array}{r}40 \\
30 \\
30 \\
50 \\
3\end{array}$ & $\begin{array}{l}0.28 \\
0.51 \\
0.50 \\
0.32 \\
\end{array}$ & $\begin{array}{r}11 \\
16 \\
138 \\
9 \\
10 \\
\end{array}$ \\
\hline 夕 & 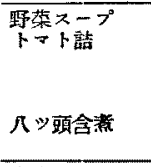 & 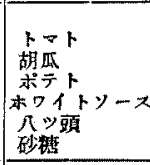 & \begin{tabular}{|r|}
140 \\
80 \\
15 \\
15 \\
10 \\
50 \\
10 \\
\end{tabular} & $\begin{array}{l}0.80 \\
0.13 \\
0.22 \\
0.75 \\
1.40 \\
0.09 \\
\end{array}$ & $\begin{array}{r}17 \\
2 \\
13 \\
29 \\
66 \\
39 \\
\end{array}$ \\
\hline & $\begin{array}{l}\text { 主食 } \\
\text { 非油 }\end{array}$ & 牛乳 & \begin{tabular}{|r|r|}
900 & 630 \\
400 & 400 \\
15 & \\
\end{tabular} & $\begin{array}{r}10.80 \\
14.00 \\
1.17 \\
\end{array}$ & $\begin{array}{r}558 \\
280 \\
8\end{array}$ \\
\hline & 計 & & 1170 & 32.89 & 1357 \\
\hline
\end{tabular}




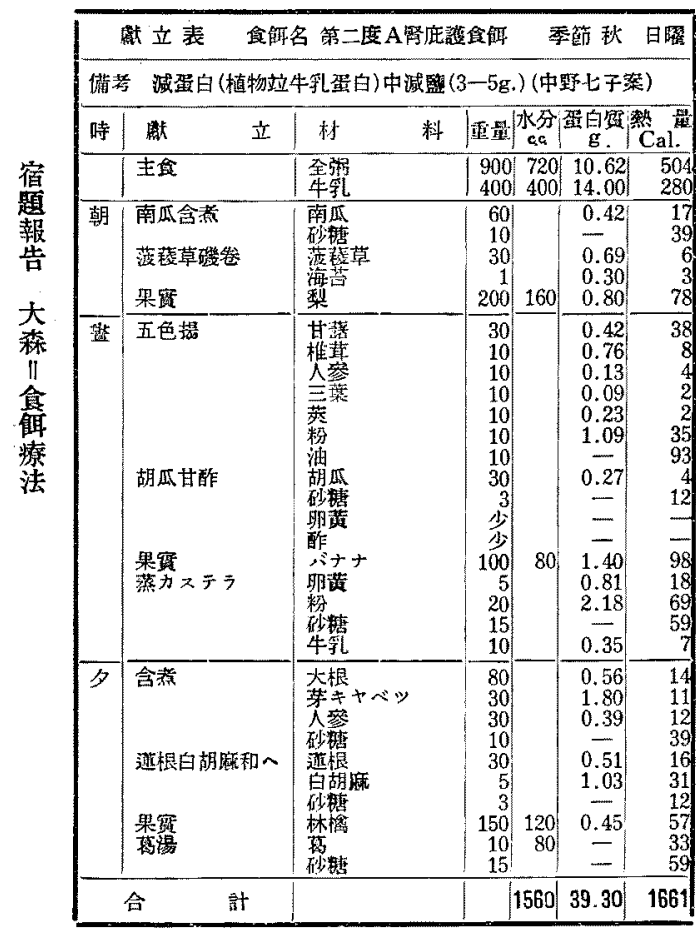

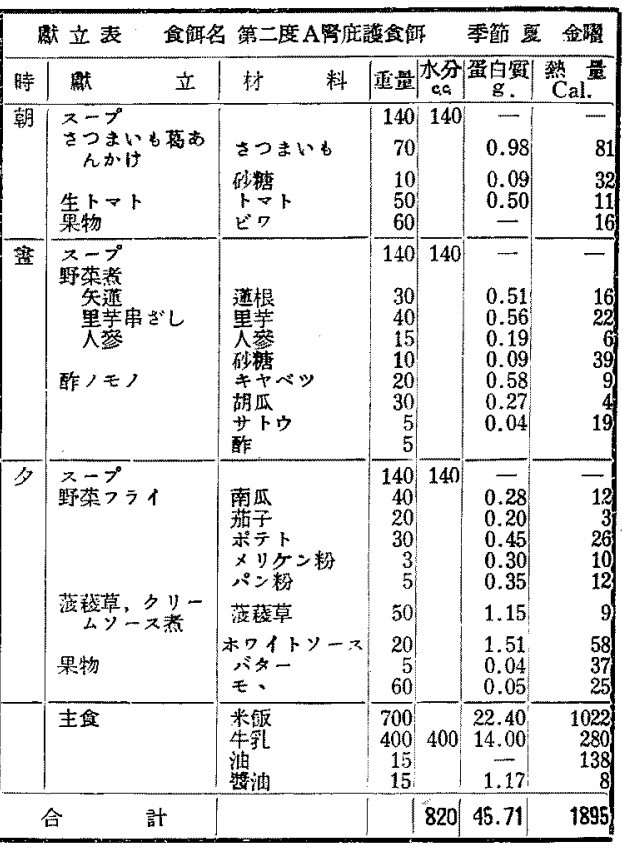

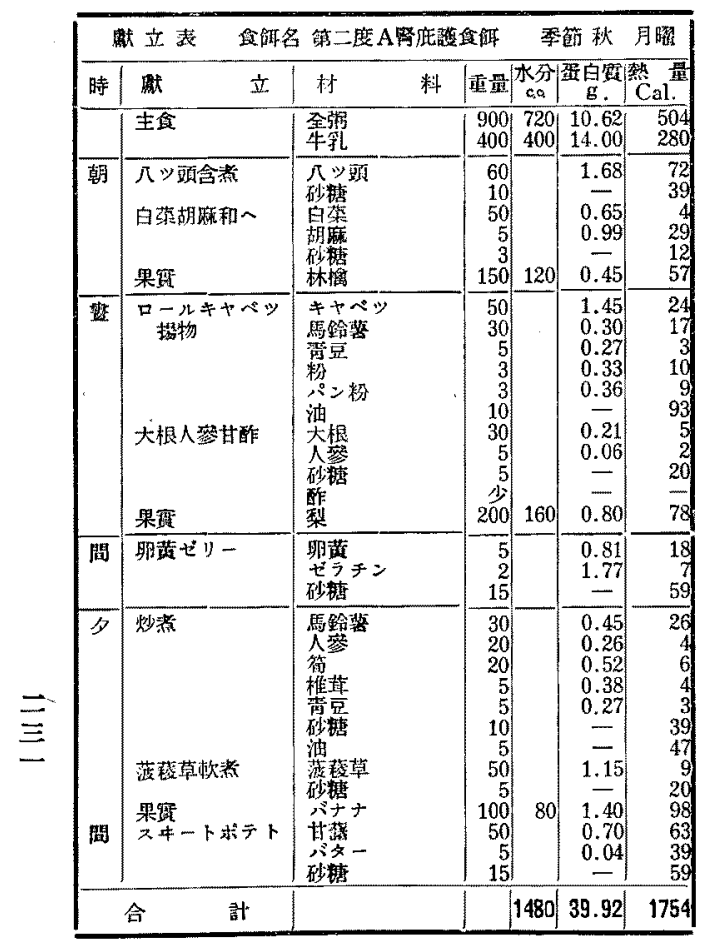

\begin{tabular}{|c|c|c|c|c|c|c|}
\hline \multicolumn{2}{|c|}{ 。隺立表 } & \multicolumn{2}{|c|}{ 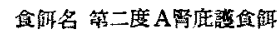 } & \multicolumn{3}{|c|}{ 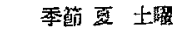 } \\
\hline 眭 & 器 & 料 & 重量 & $\left|\begin{array}{c}\text { 水分 } \\
a a\end{array}\right|$ & $\begin{array}{c}\text { 䍃白裳 } \\
\mathrm{g} .\end{array}$ & $\begin{array}{c}\text { 熱 } \\
\text { Cal. }\end{array}$ \\
\hline 朝 & 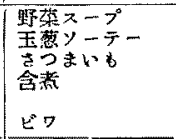 & 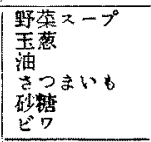 & $\begin{array}{r}140 \\
50 \\
50 \\
50 \\
15 \\
60\end{array}$ & 140 & $\begin{array}{l}-\overline{0} \\
\overline{0} \\
0.70 \\
\mathrm{C.14} \\
-\end{array}$ & $\begin{array}{l}2 \\
4 \\
6 \\
5 \\
1\end{array}$ \\
\hline 望 & 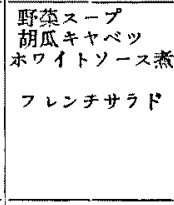 & 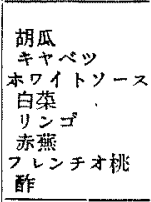 & $\begin{array}{r}140 \\
40 \\
20 \\
20 \\
20 \\
30 \\
10 \\
10\end{array}$ & 140 & $\begin{array}{l}-\overline{0.36} \\
0.52 \\
1.51 \\
0.26 \\
0 . \overline{16}\end{array}$ & $\begin{array}{r}- \\
5 \\
58 \\
11 \\
92\end{array}$ \\
\hline 3 & 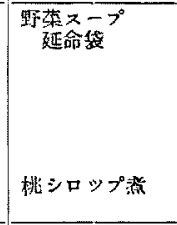 & 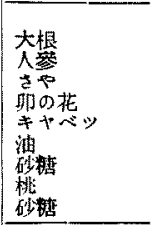 & $\begin{array}{r}140 \\
25 \\
10 \\
15 \\
10 \\
50 \\
10 \\
5 \\
60 \\
15 \\
\end{array}$ & 140 & \begin{tabular}{l|}
$-\overline{17}$ \\
0.12 \\
0.36 \\
1.45 \\
0.04 \\
0.54 \\
0.14 \\
\end{tabular} & $\begin{array}{r}- \\
- \\
5 \\
2 \\
9 \\
1 \\
2 \\
5\end{array}$ \\
\hline & 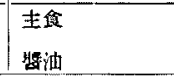 & $\begin{array}{l}\text { 类何 } \\
\text { 特 }\end{array}$ & $\begin{array}{r}700 \\
400 \\
15\end{array}$ & 403 & $\begin{array}{l}22.4 \\
14.0 \\
1.17 \\
\end{array}$ & $\begin{array}{r}1028 \\
280 \\
\end{array}$ \\
\hline & 都 & & & 874 & 44.89 & 187 \\
\hline
\end{tabular}




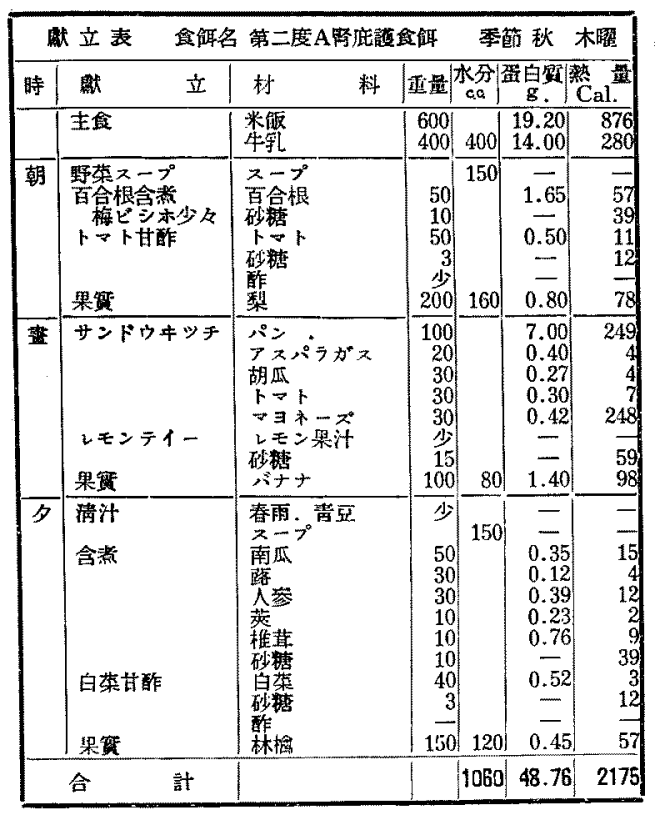

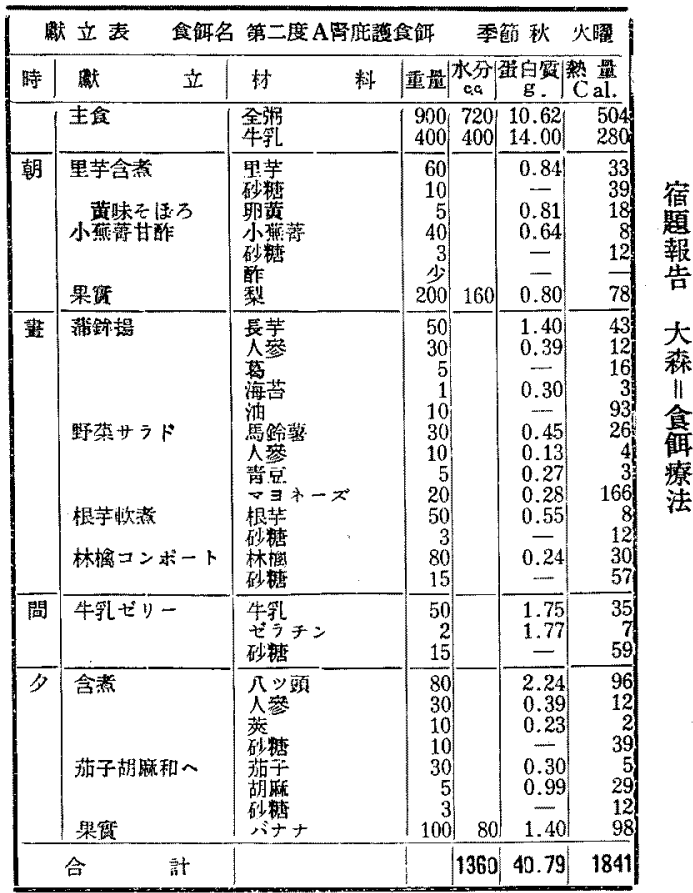

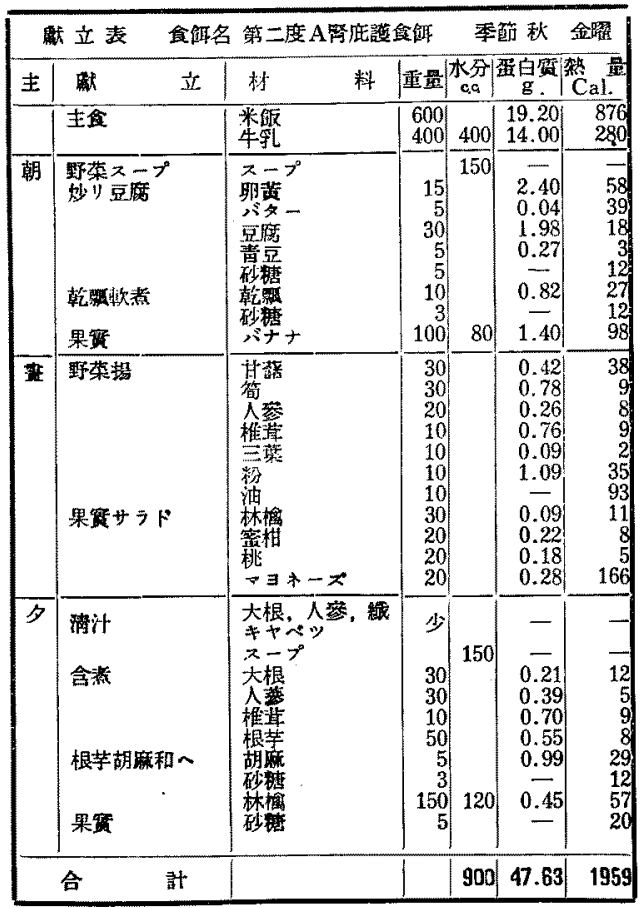

\begin{tabular}{|c|c|c|c|c|c|c|}
\hline \multicolumn{2}{|c|}{ 解立表 } & \multicolumn{2}{|c|}{ 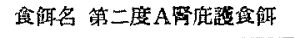 } & \multicolumn{3}{|c|}{ 季䈱 秋 水曜 } \\
\hline 時 & 搹 & 料 & 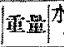 & & 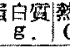 & Cal. \\
\hline & 王全 & 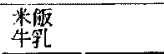 & $\begin{array}{l}600 \\
400 \\
\end{array}$ & 400 & $\begin{array}{l}19.20 \\
14.00\end{array}$ & $\begin{array}{l}887 \\
280 \\
\end{array}$ \\
\hline 朝 & 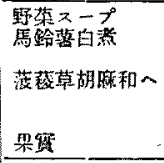 & 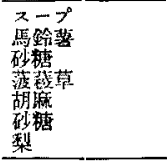 & $\begin{array}{r}60 \\
10 \\
30 \\
5 \\
3 \\
200 \\
\end{array}$ & 160 & $\begin{array}{l}\overline{0.90} \\
-\overline{0.69} \\
0.99 \\
0.80 \\
\end{array}$ & \begin{tabular}{r|}
52 \\
39 \\
6 \\
29 \\
12 \\
78 \\
\end{tabular} \\
\hline 察 & 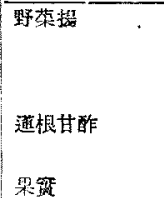 & 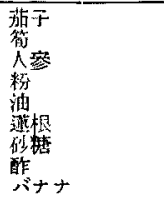 & $\begin{array}{r}30 \\
30 \\
30 \\
10 \\
10 \\
30 \\
3 \\
15 \\
100\end{array}$ & 80 & $\begin{array}{c}0.30 \\
0.78 \\
0.39 \\
1.09 \\
0.51 \\
= \\
1.40\end{array}$ & $\begin{array}{r}5 \\
9 \\
12 \\
35 \\
93 \\
16 \\
12 \\
98\end{array}$ \\
\hline 䦓 & 䚄林樆 & 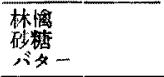 & $\begin{array}{r}100 \\
20 \\
10\end{array}$ & & $\frac{0.30}{0.08}$ & $\begin{array}{l}38 \\
78 \\
78\end{array}$ \\
\hline 夕 & 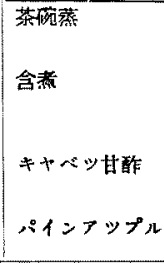 & 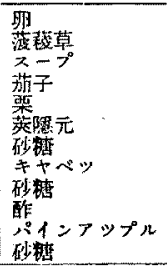 & $\begin{array}{l}50 \\
10 \\
50 \\
30 \\
10 \\
10 \\
30 \\
3 \\
30 \\
80 \\
15\end{array}$ & 150 & $\begin{array}{l}6.60 \\
0.27 \\
0.50 \\
0.87 \\
0.23 \\
0.87 \\
\overline{0} \\
0.40 \\
\end{array}$ & \begin{tabular}{r|}
81 \\
19 \\
9 \\
50 \\
2 \\
39 \\
14 \\
12 \\
23 \\
59 \\
\end{tabular} \\
\hline & 合 & & & 940 & 50.13 & 2156 \\
\hline
\end{tabular}



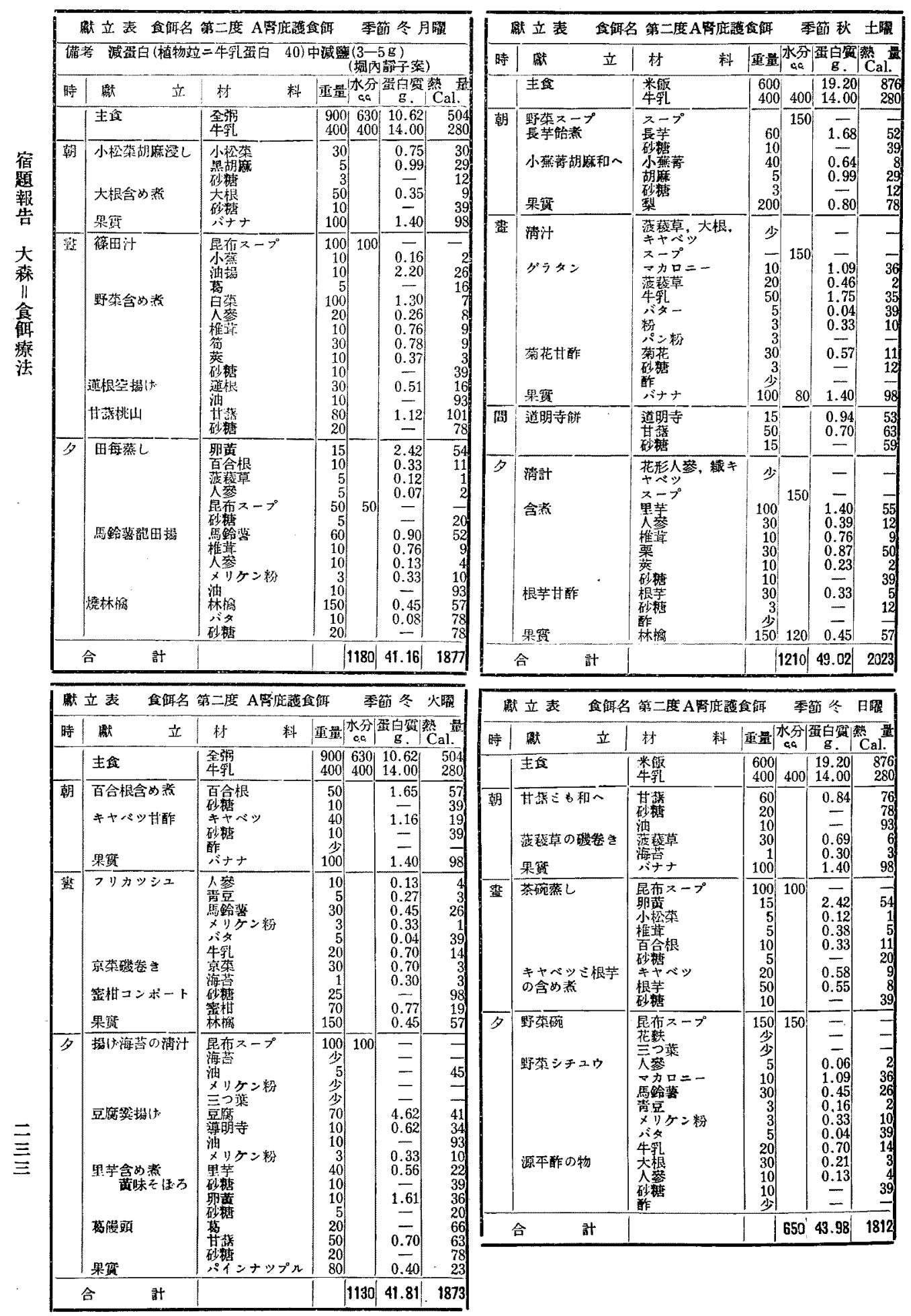


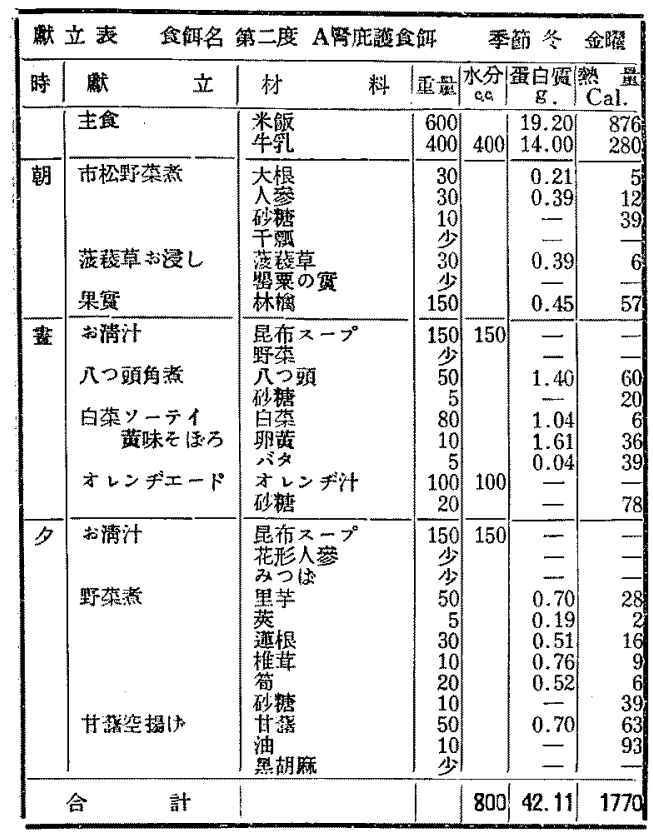

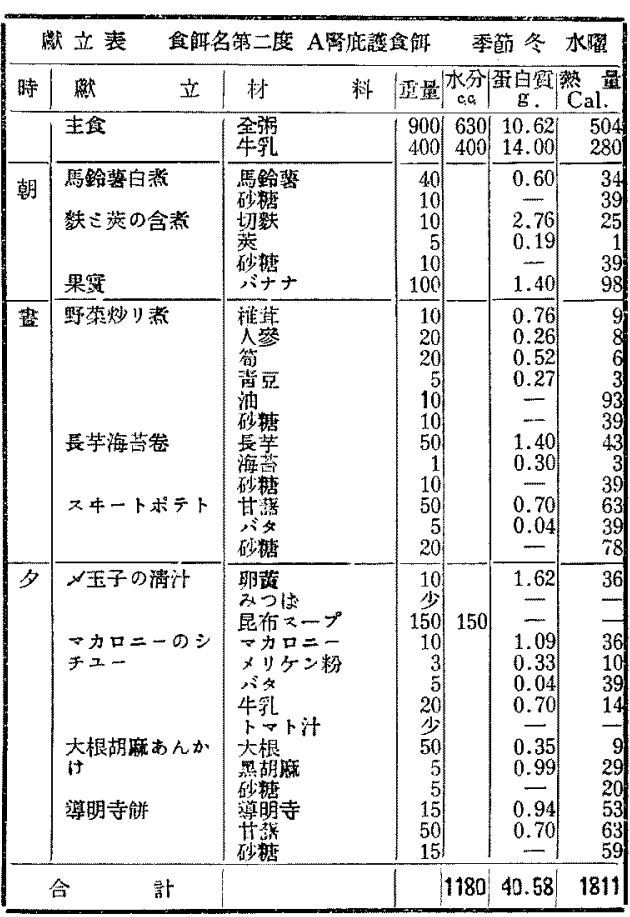

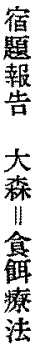

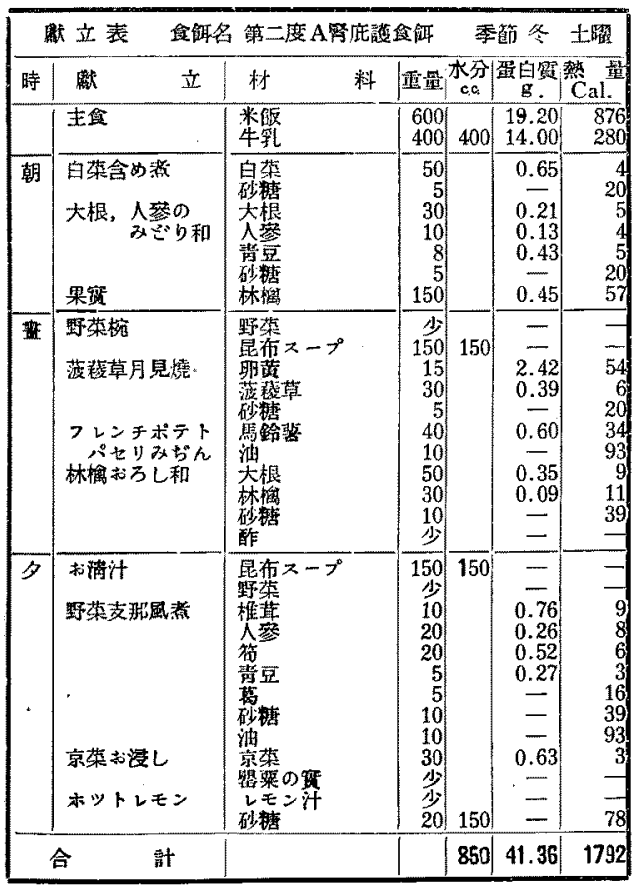

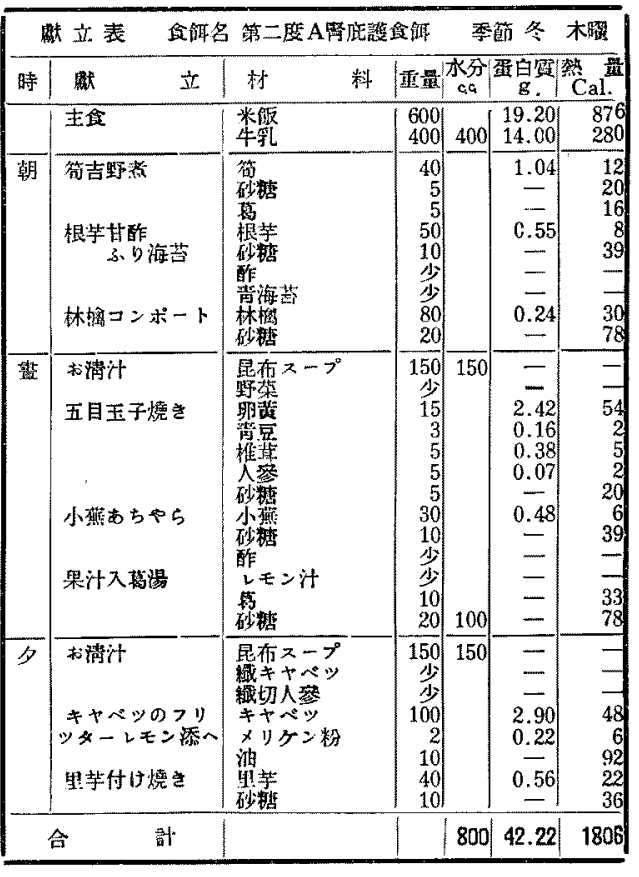


附錄 $(3)$ ）第二度 B 庇蓝食 4 種

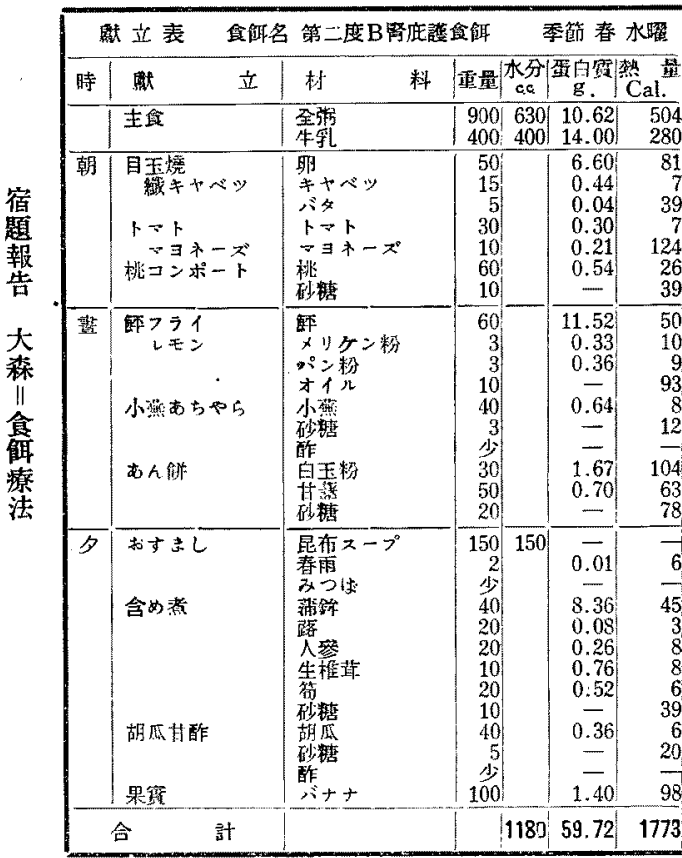

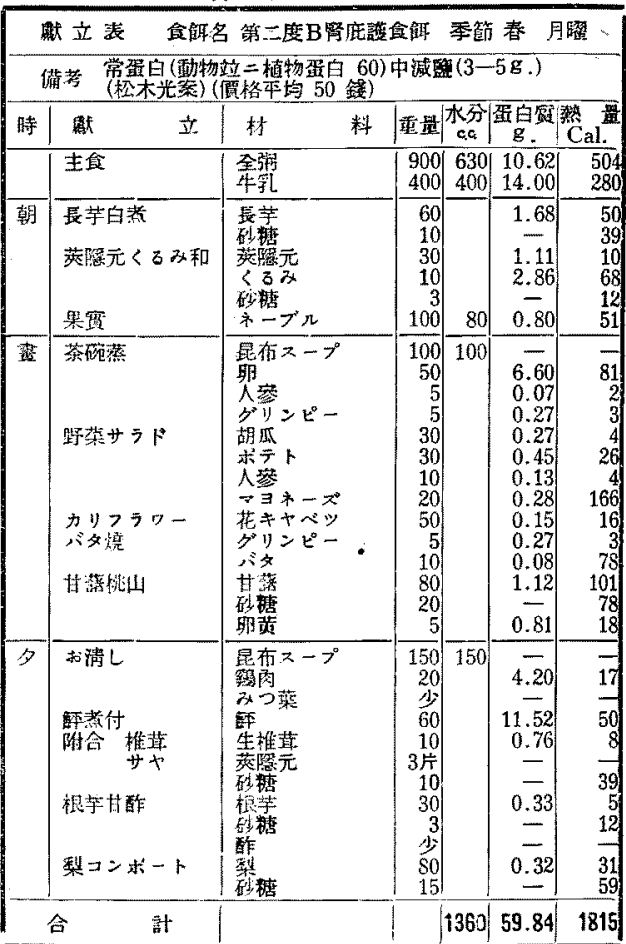

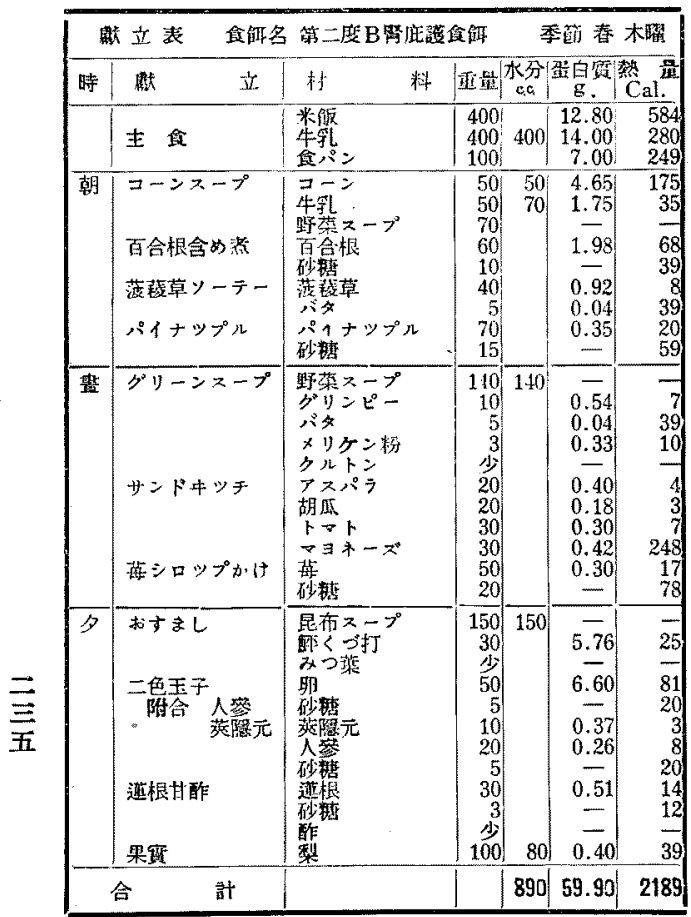

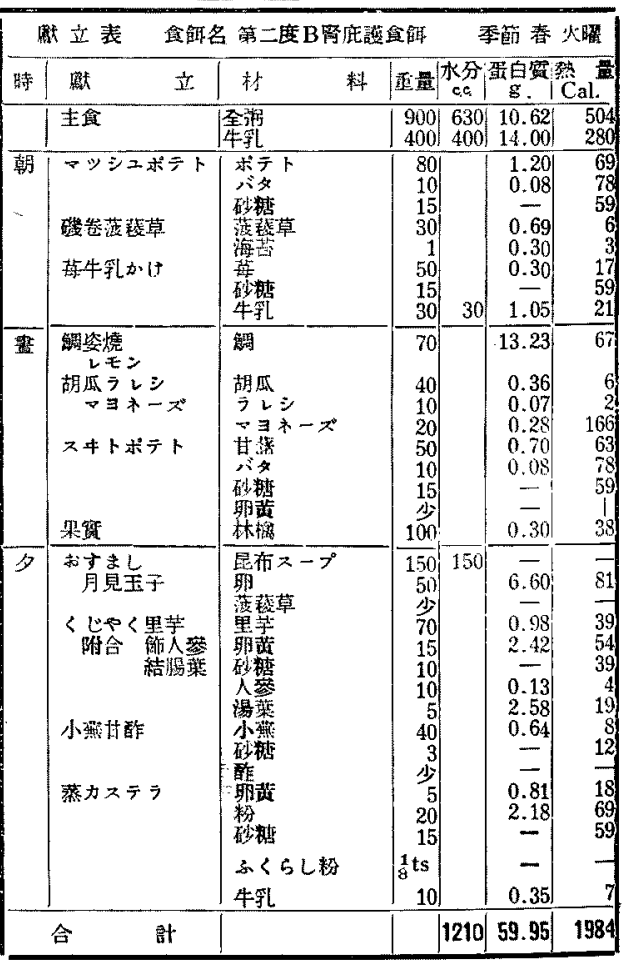




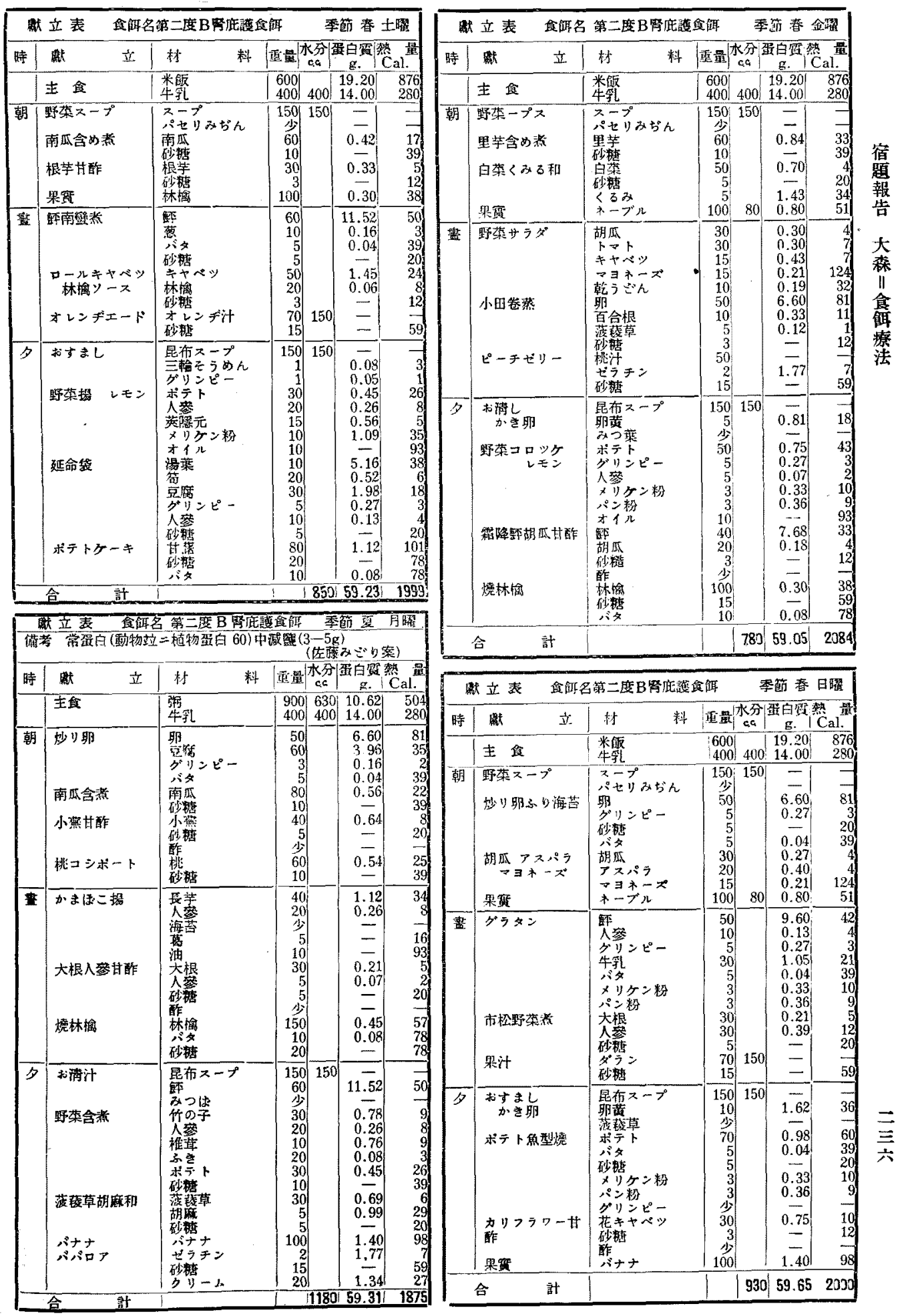



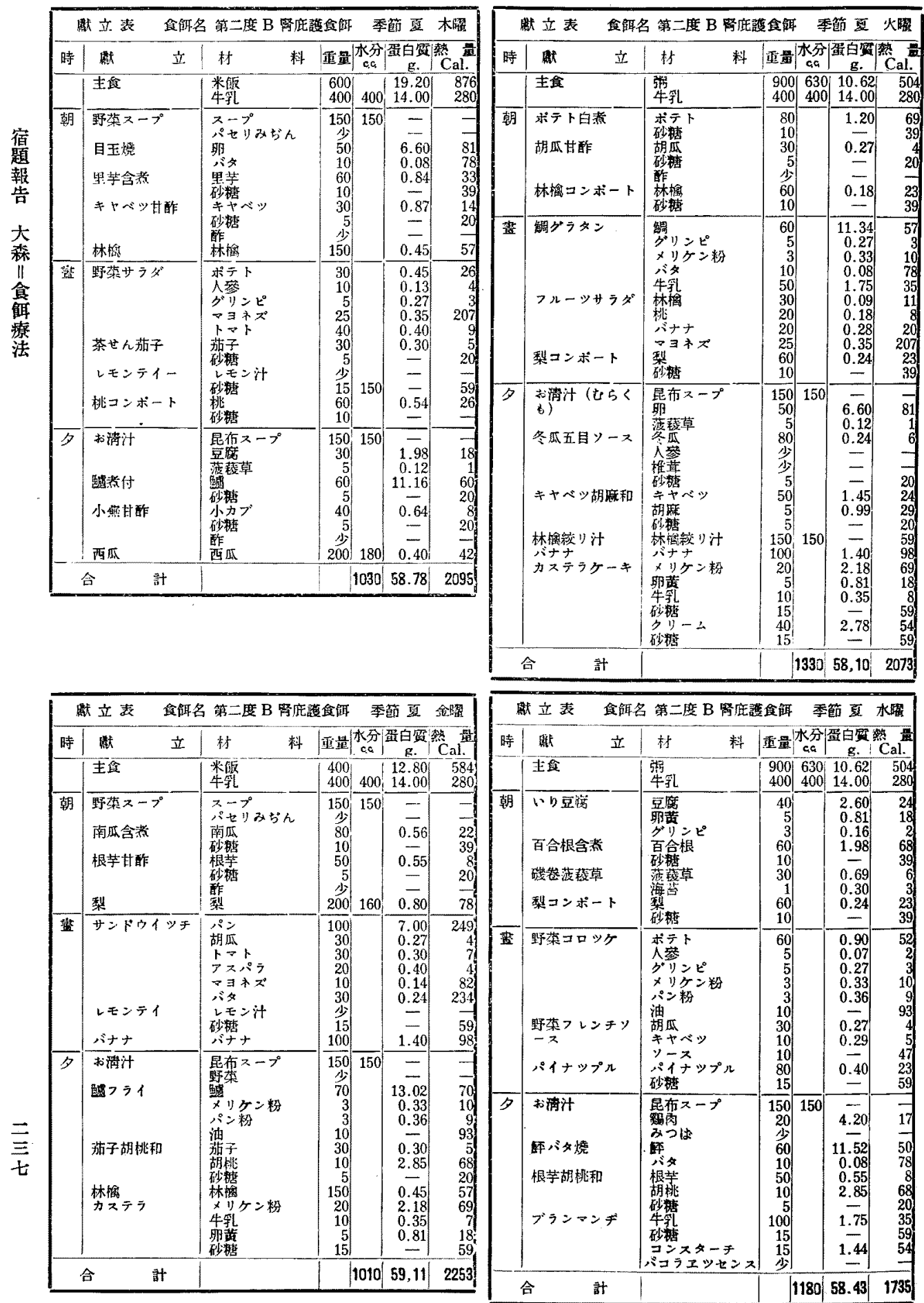

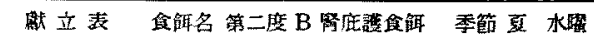

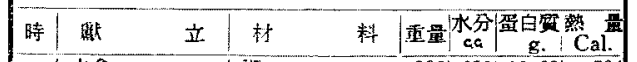

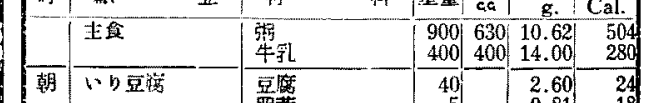

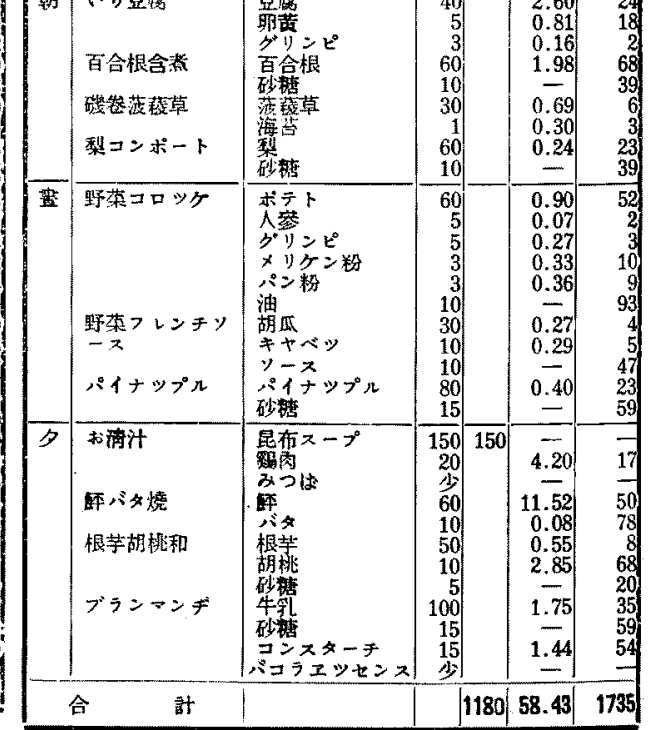




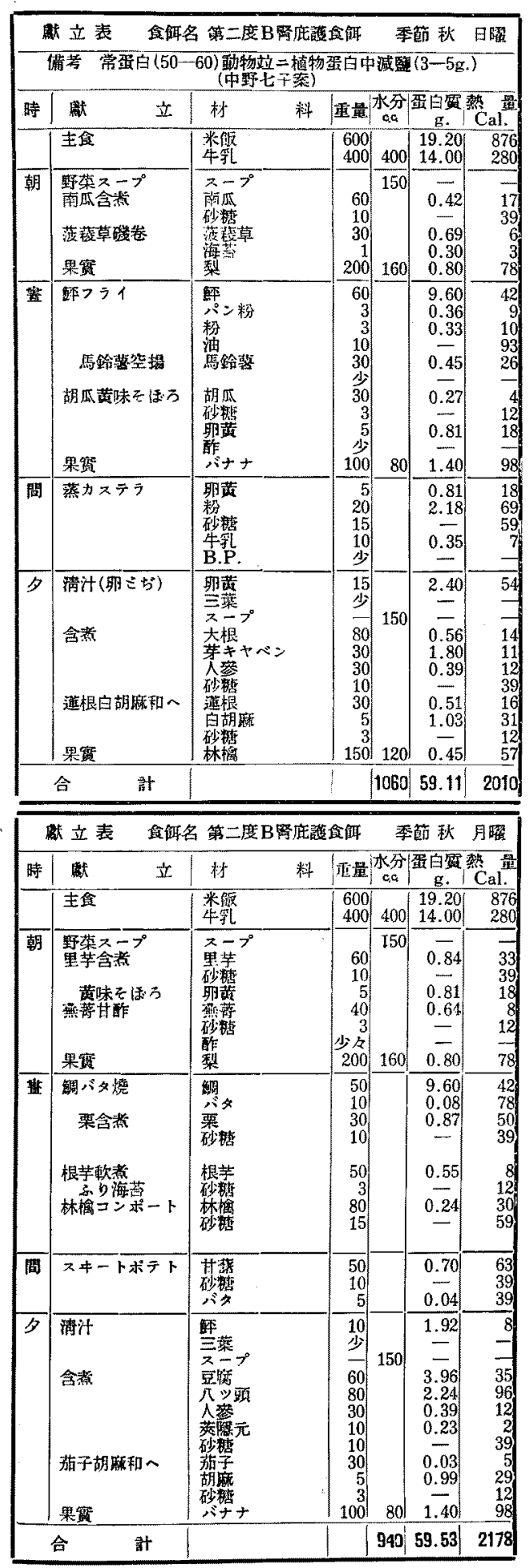

\begin{tabular}{|c|c|c|c|c|c|c|c|}
\hline \multicolumn{2}{|c|}{ 啸立表 } & \multicolumn{3}{|c|}{ 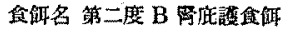 } & \multicolumn{3}{|c|}{ 籍 畐 土曜 } \\
\hline 時 & 概 & 立 & 村 & 重量 & $\begin{array}{l}\text { 水分 } \\
\text { ca }\end{array}$ & 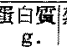 & 䓡 \\
\hline & 圭食 & & 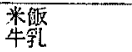 & $\begin{array}{l}600 \\
400\end{array}$ & 400 & $\begin{array}{l}19.20 \\
14.00\end{array}$ & $\begin{array}{l}876 \\
280\end{array}$ \\
\hline 翰 & 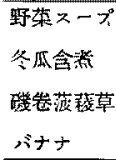 & & 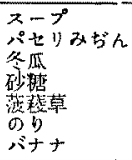 & $\begin{array}{r}150 \\
15 \\
80 \\
10 \\
30 \\
1 \\
100\end{array}$ & 150 & $\begin{array}{l}- \\
\overline{0} \\
0.24 \\
0.69 \\
0.30 \\
1.40\end{array}$ & $\begin{array}{r}- \\
39 \\
6\end{array}$ \\
\hline 暂 & 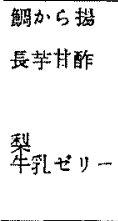 & & 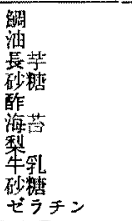 & \begin{tabular}{r|}
60 \\
10 \\
30 \\
5 \\
少 \\
200 \\
20 \\
15 \\
2
\end{tabular} & 160 & $\begin{array}{c}11.34 \\
0.84 \\
\bar{Z} \\
\overline{0.80} \\
1.75 \\
1.77\end{array}$ & $\begin{array}{l}57 \\
93 \\
26 \\
20 \\
\\
78 \\
35 \\
59 \\
7\end{array}$ \\
\hline ל & 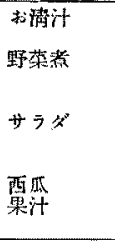 & & 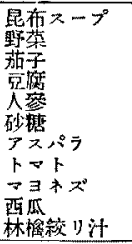 & \begin{tabular}{r|}
150 \\
少 \\
50 \\
60 \\
20 \\
10 \\
50 \\
40 \\
25 \\
200 \\
150 \\
\end{tabular} & $\begin{array}{l}180 \\
150 \\
\end{array}$ & $\begin{array}{l}\overline{-} \\
0.50 \\
3.96 \\
0.26 \\
1.00 \\
0.40 \\
0.35 \\
0.40 \\
\end{array}$ & $\begin{array}{r}207 \\
42 \\
59 \\
\end{array}$ \\
\hline & 計 & & & & 1030 & 59.20 & 2101 \\
\hline
\end{tabular}

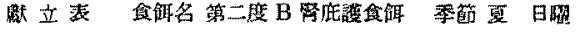

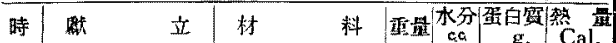

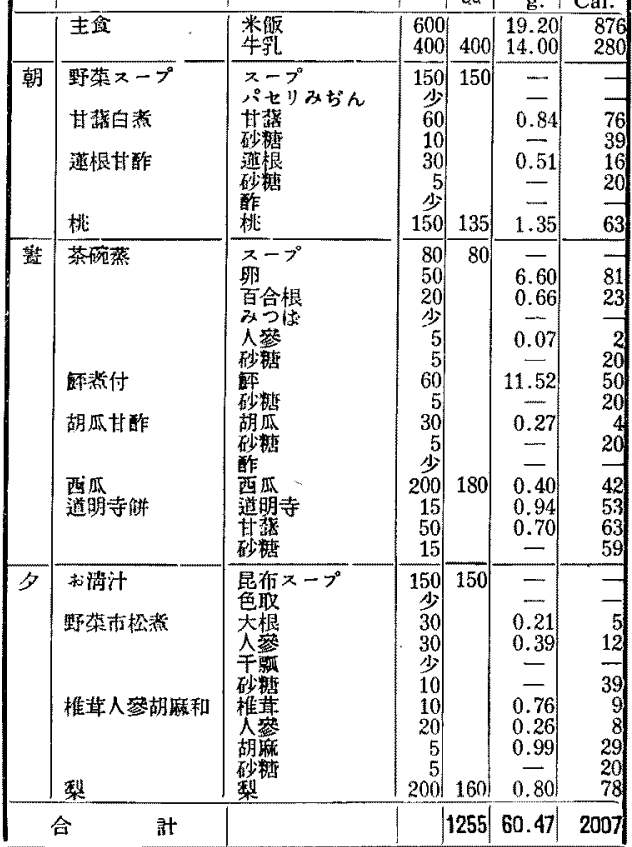




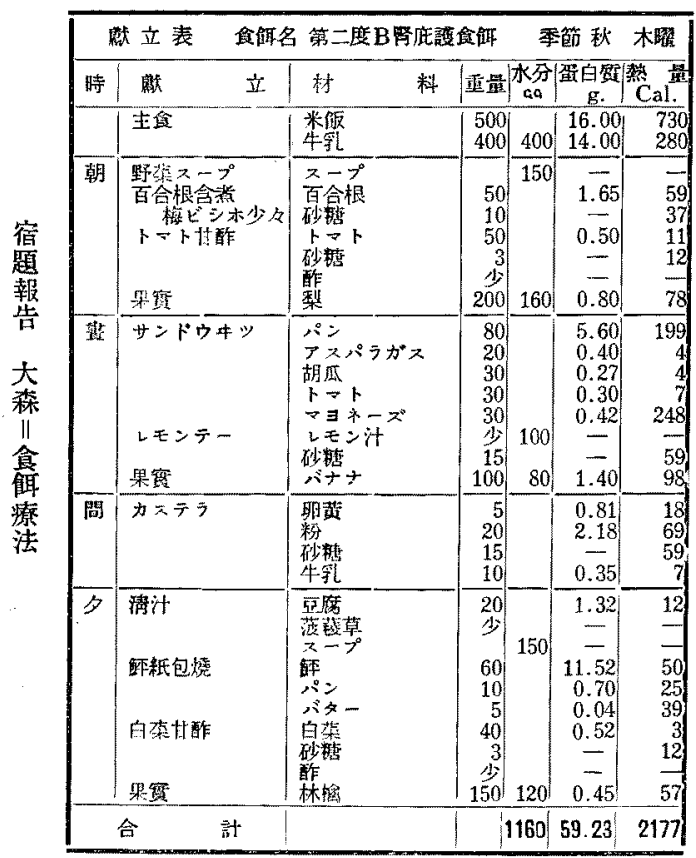

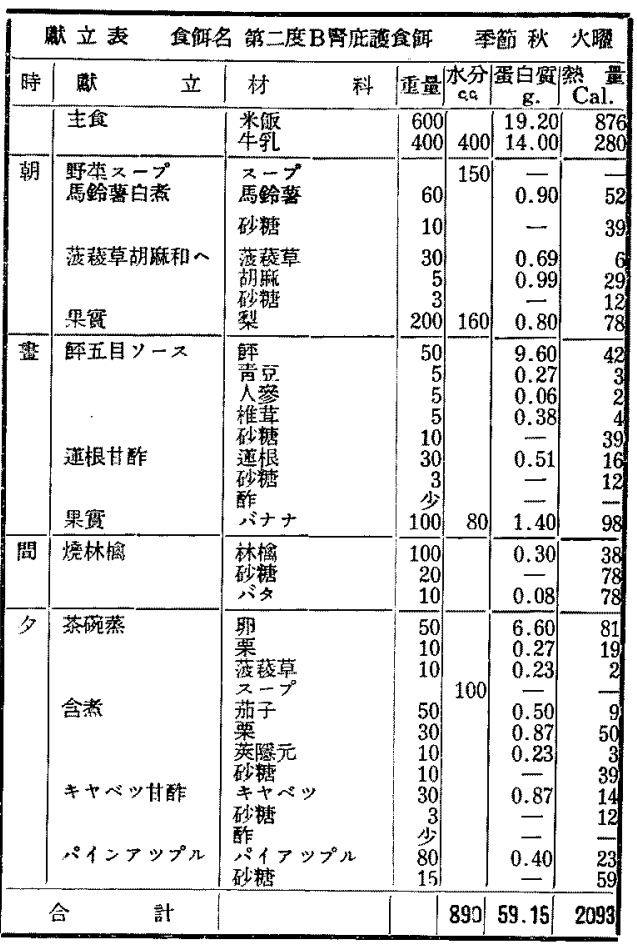

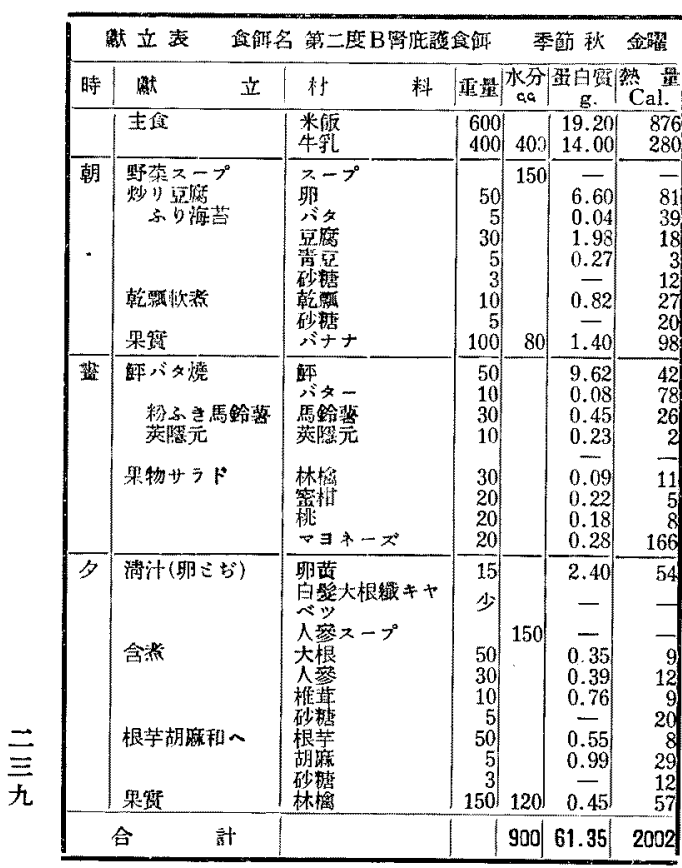

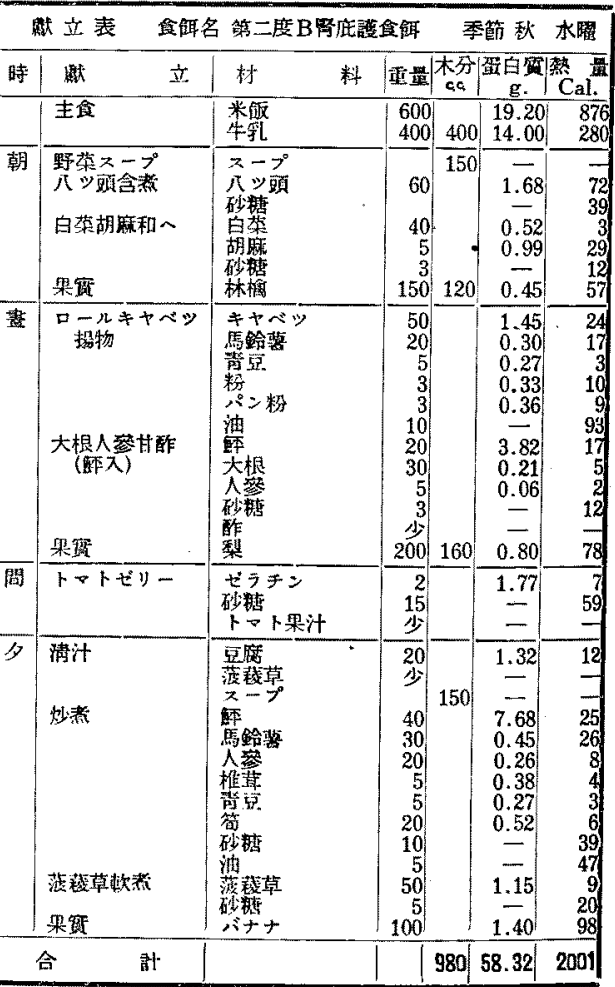



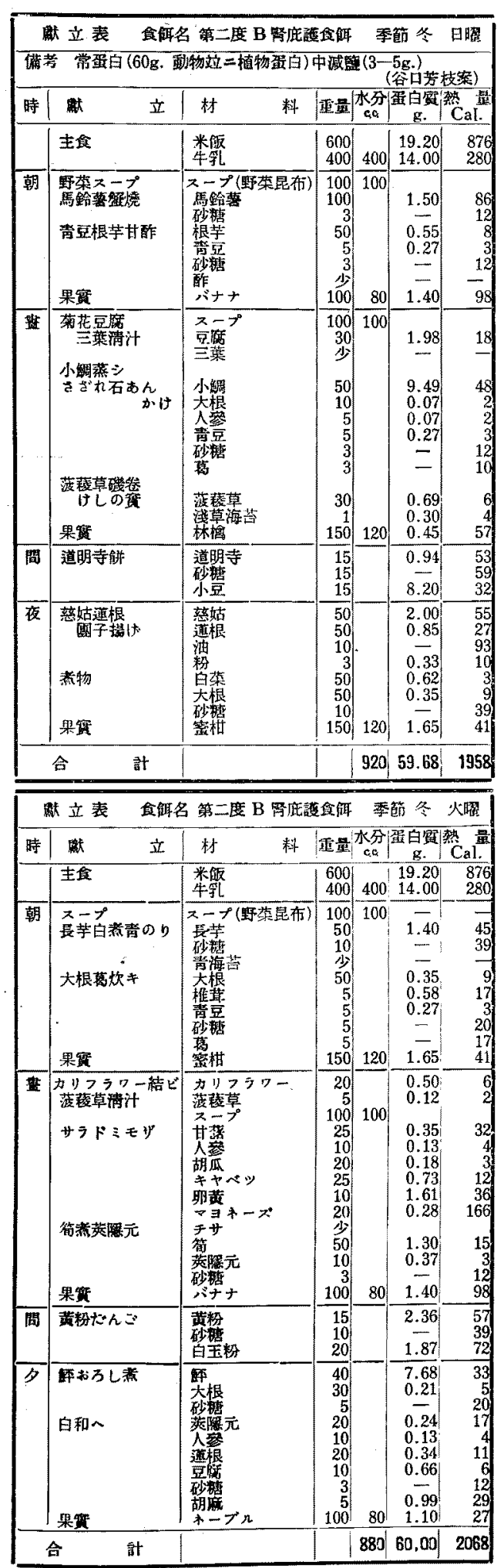

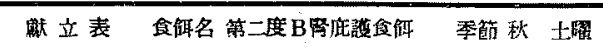

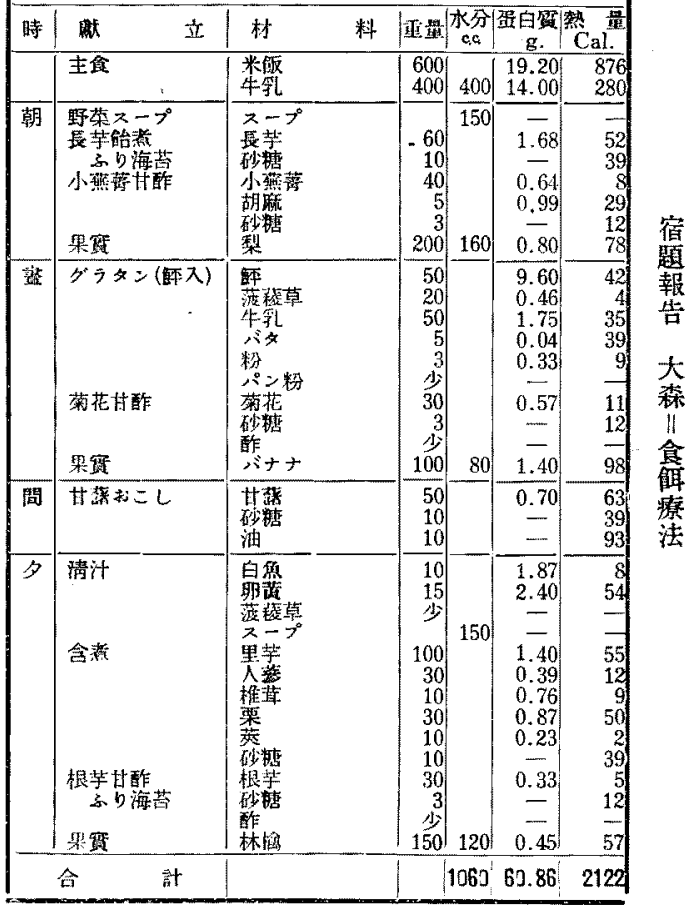

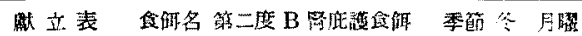

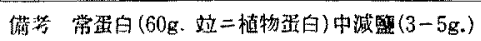

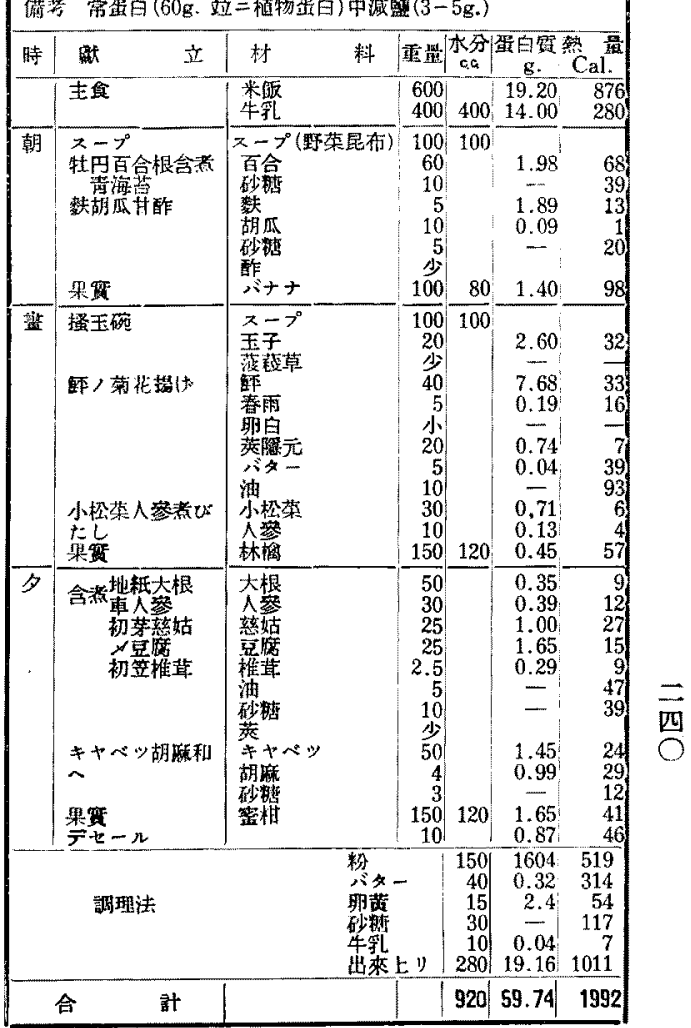




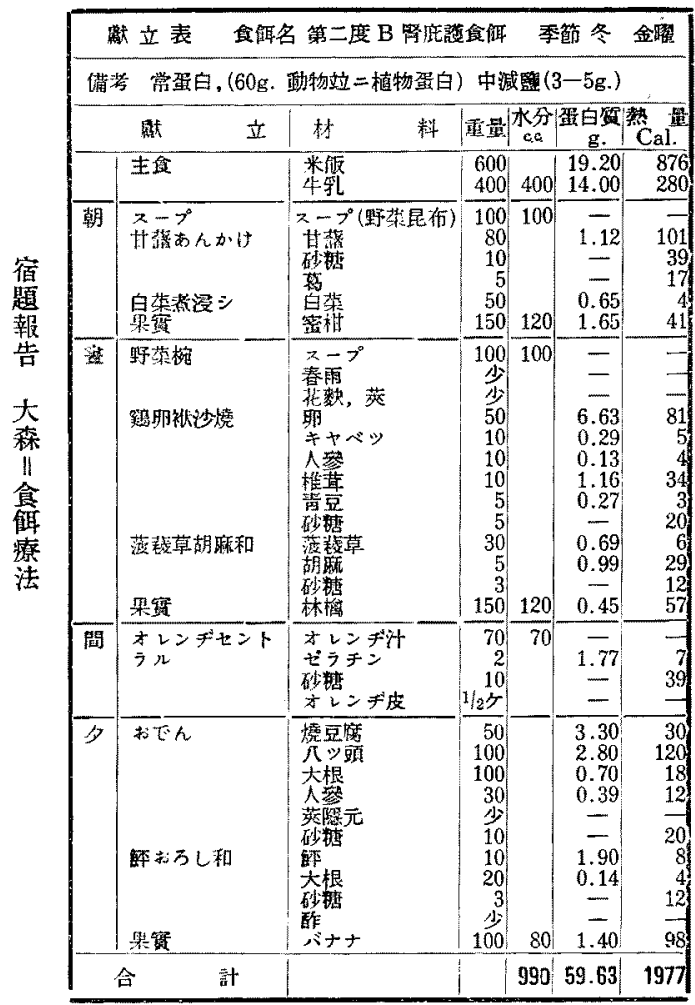

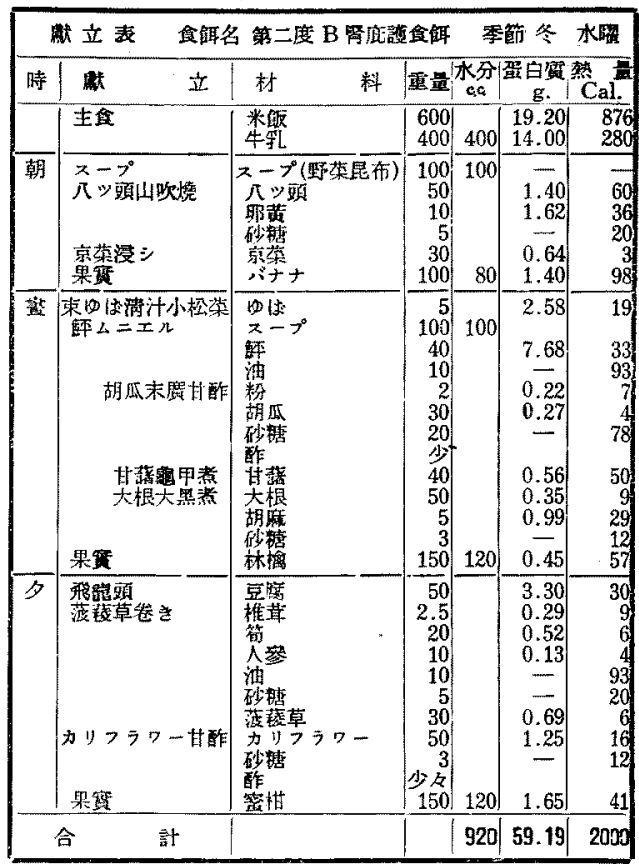

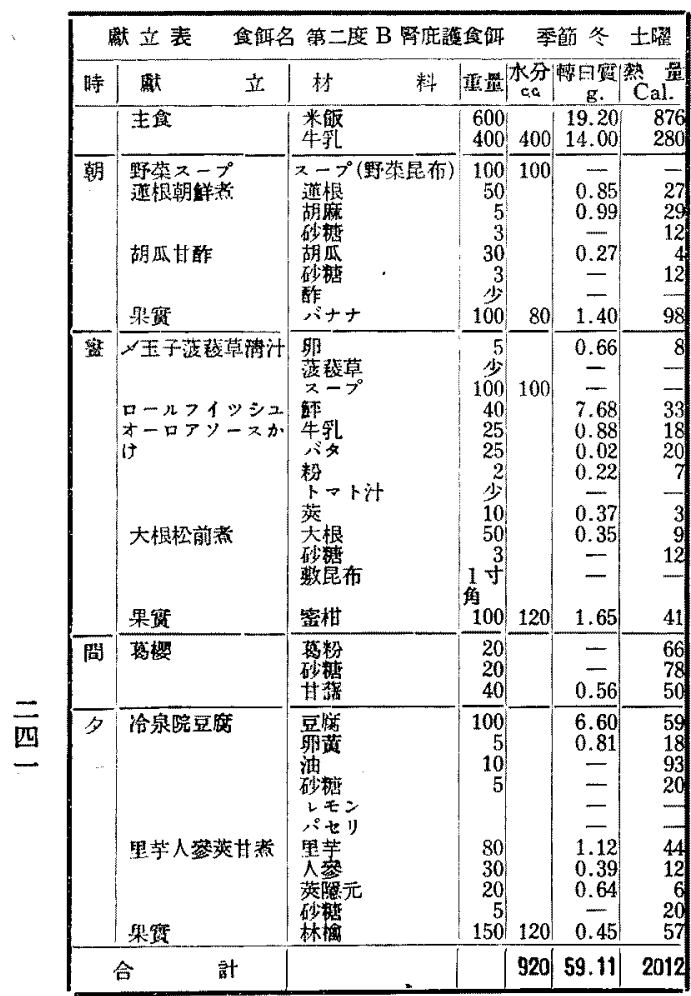

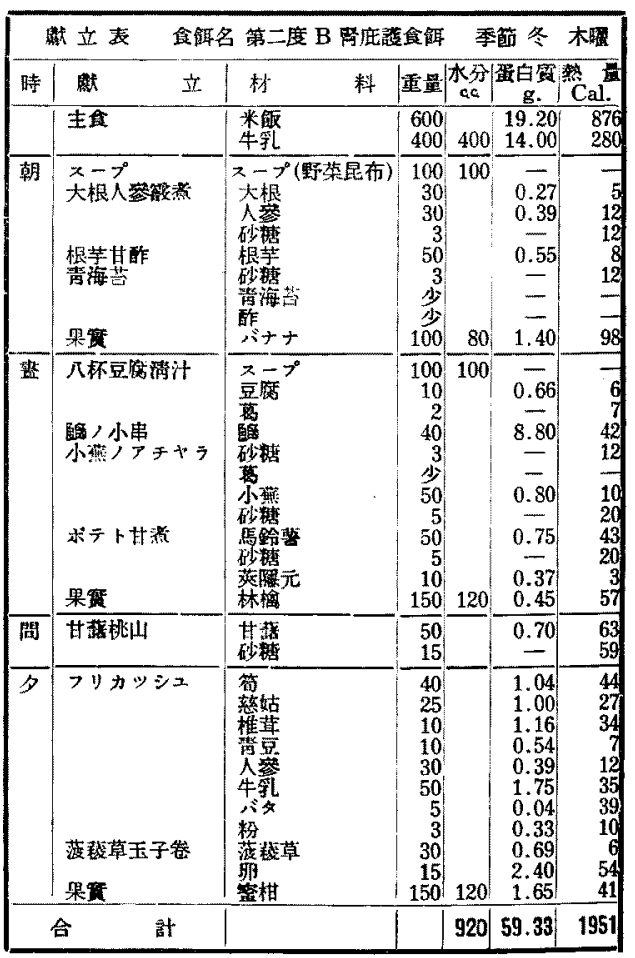




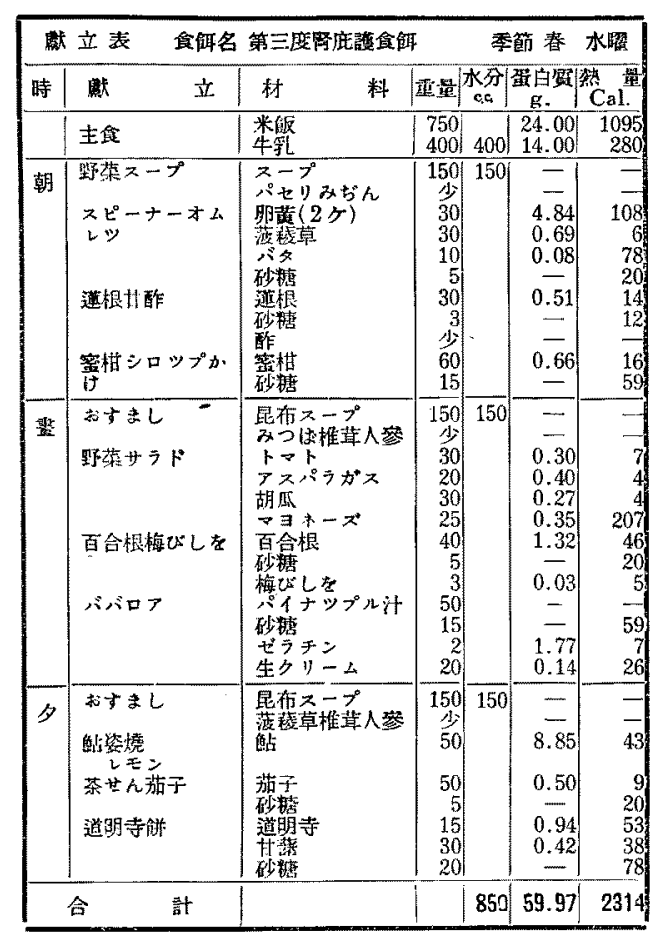

\begin{tabular}{|c|c|c|c|c|c|c|}
\hline \multicolumn{2}{|c|}{ 觔立表 } & \multicolumn{2}{|c|}{ 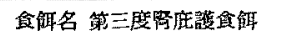 } & \multicolumn{3}{|c|}{ 季菂 奎 木躍 } \\
\hline 睳 & 洞 & 材 & 粼|画量| & $\mid$ & 尊百察 & 㙮 \\
\hline & 主食 & 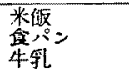 & $\left|\begin{array}{l}500 \\
100 \\
400\end{array}\right|$ & & $\begin{array}{r}16.00 \\
7.00 \\
14.00\end{array}$ & \\
\hline 朝 & 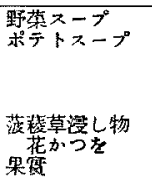 & 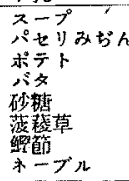 & $\begin{array}{r}150 \\
\text { 少 } \\
80 \\
5 \\
10 \\
30 \\
1 \\
100 \\
\end{array}$ & 150 & \begin{tabular}{r|}
$\overline{-}$ \\
1.20 \\
0.04 \\
0.69 \\
0.08 \\
0.80
\end{tabular} & \\
\hline 灌 & $\begin{array}{l}\text { 觐牛乳かけ } \\
\text { ホットレモネー }\end{array}$ & 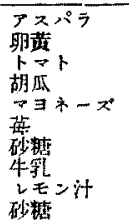 & \begin{tabular}{l|l|}
20 & \\
15 & 30 \\
20 & \\
30 & \\
50 & \\
15 & \\
30 & \\
15 &
\end{tabular} & 150 & $\begin{array}{l}0.40 \\
2.42 \\
0.30 \\
0.18 \\
0.42 \\
0.30 \\
-1.05 \\
=\end{array}$ & $\begin{array}{r}24 \\
17 \\
5 \\
21 \\
55\end{array}$ \\
\hline & 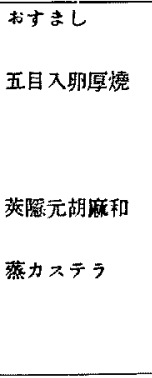 & 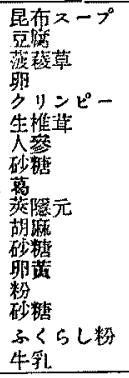 & \begin{tabular}{r|}
150 \\
30 \\
5 \\
50 \\
5 \\
3 \\
5 \\
5 \\
5 \\
30 \\
5 \\
3 \\
5 \\
20 \\
15 \\
1 ts \\
10 \\
\end{tabular} & $\begin{array}{l}50 \\
\\
\end{array}$ & $\begin{array}{l}1.98 \\
6.60 \\
0.27 \\
0.15 \\
0.07 \\
= \\
1.11 \\
0.99 \\
\overline{0.81} \\
2.18 \\
\overline{-} \\
0.35\end{array}$ & $\begin{array}{l}20 \\
10 \\
10 \\
20 \\
12 \\
18 \\
60 \\
5 \\
\end{array}$ \\
\hline & 計 & & & & 59.39 & 2286 \\
\hline
\end{tabular}

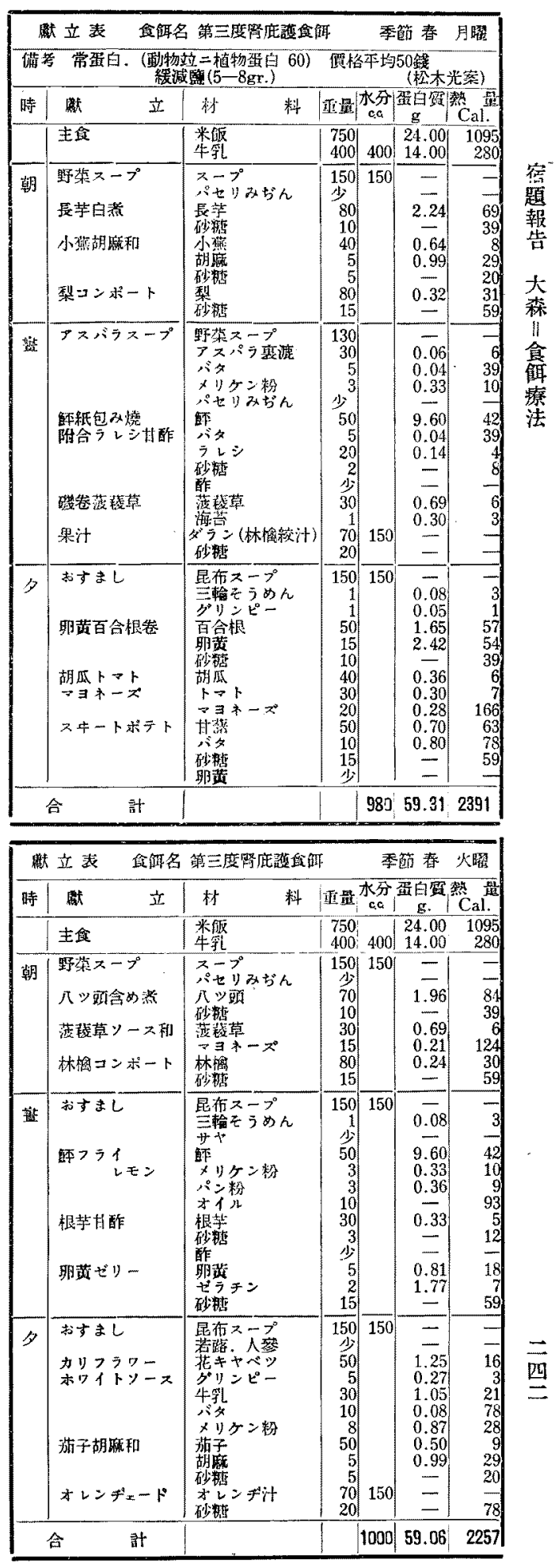



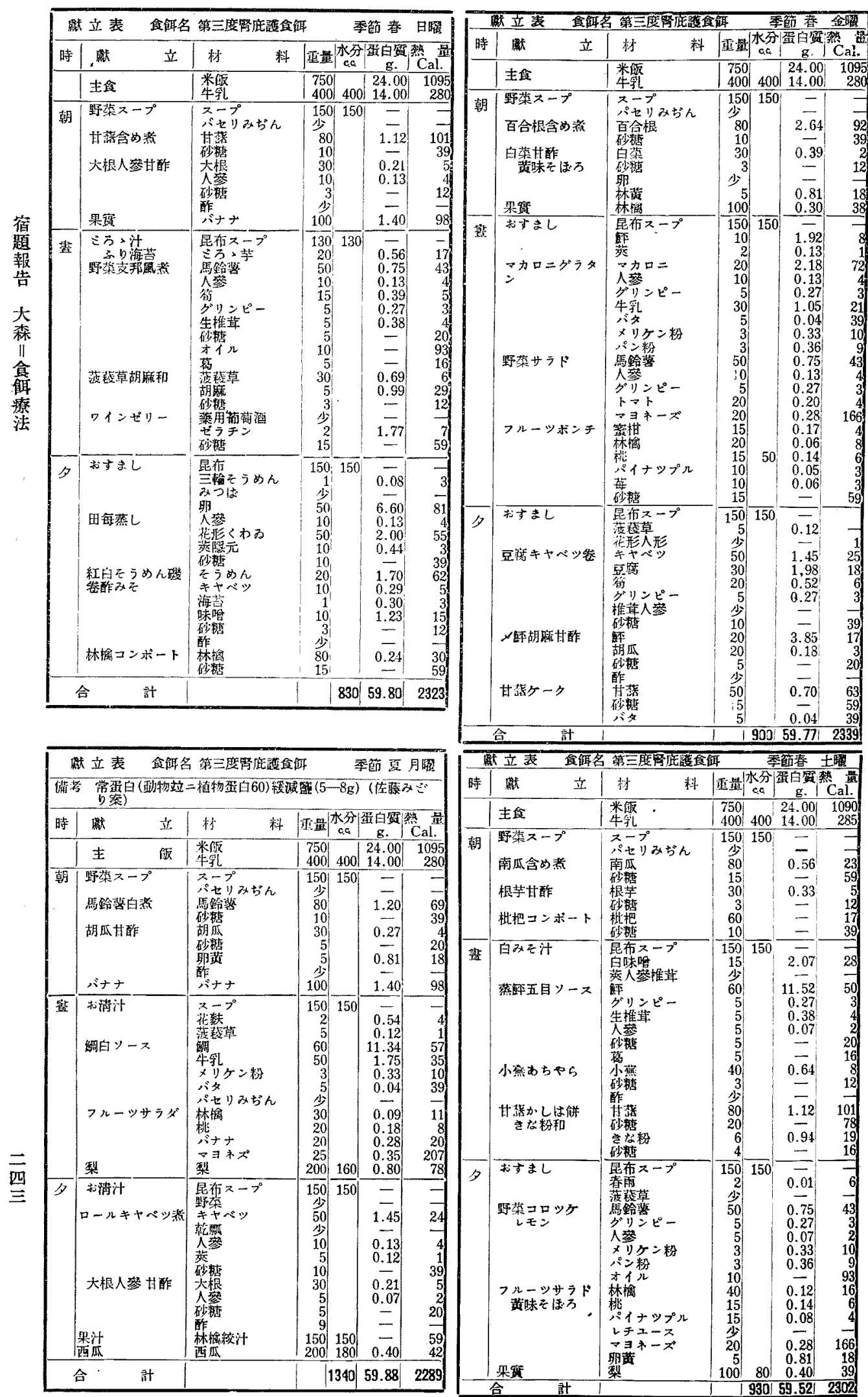

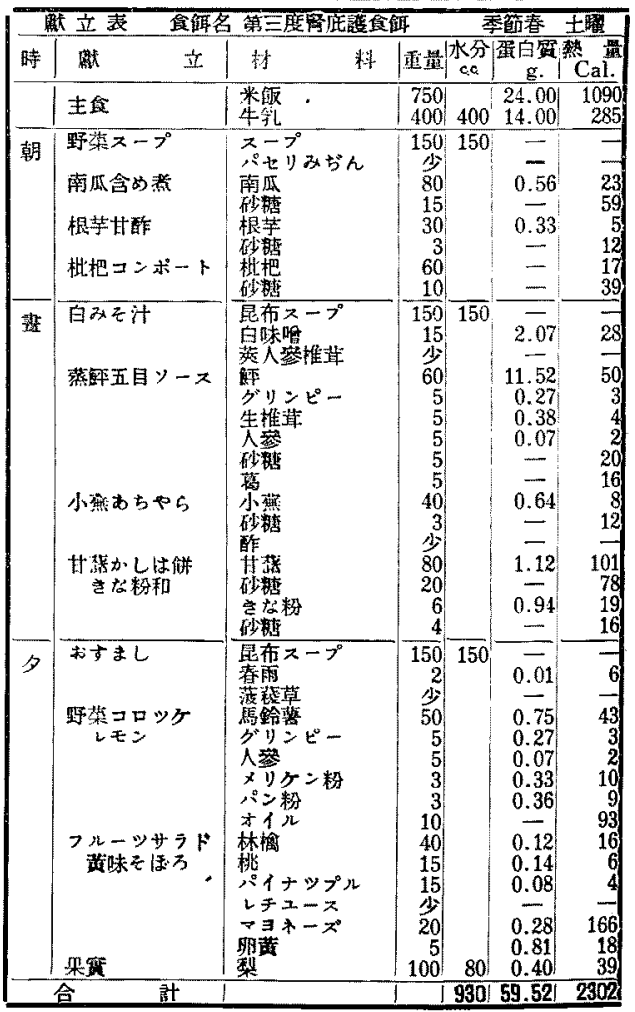




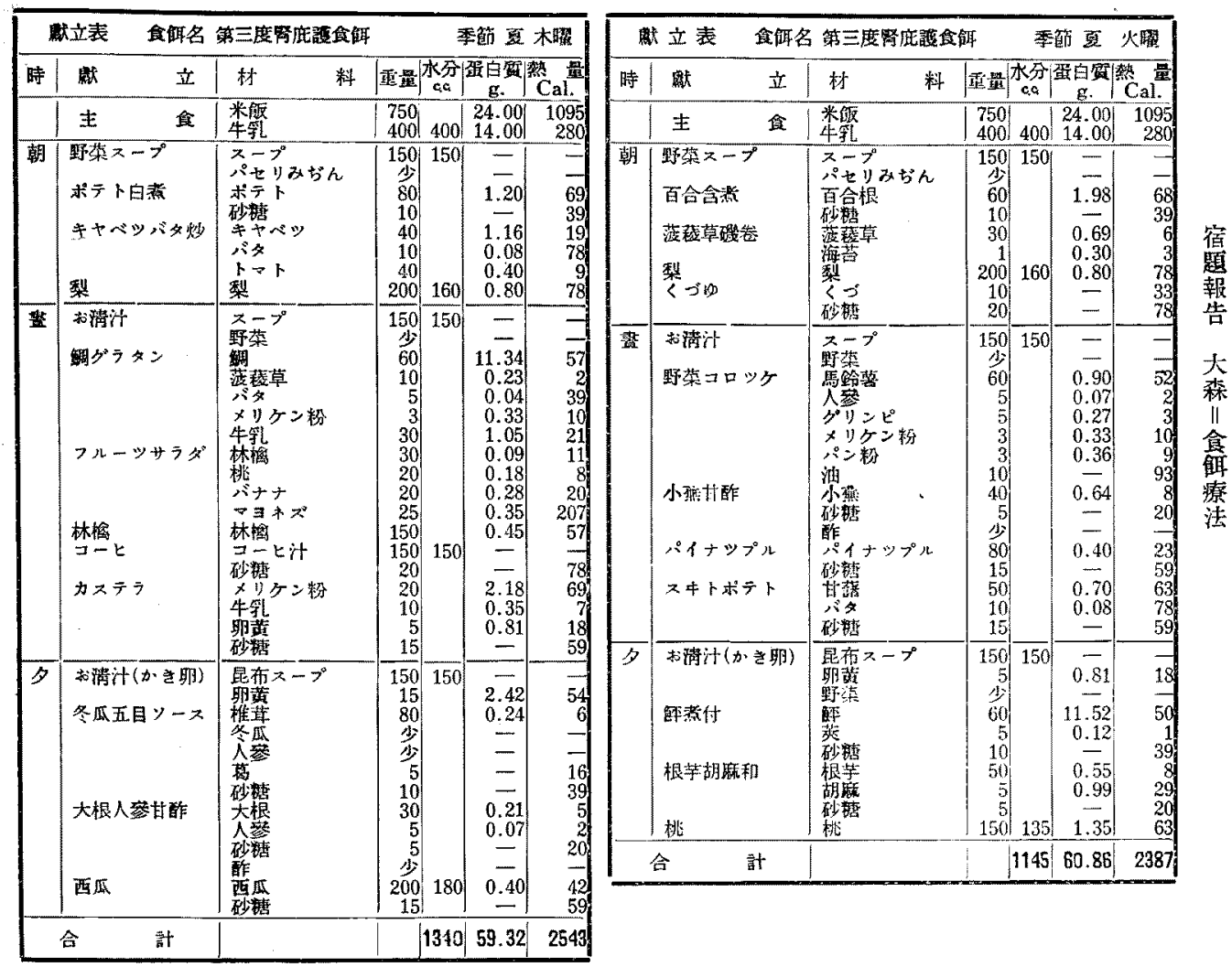

\begin{tabular}{|c|c|c|c|c|c|c|}
\hline \multicolumn{2}{|r|}{ 蹴立表 } & \multicolumn{2}{|c|}{ 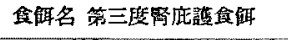 } & \multicolumn{3}{|c|}{ 季節 要 金㒛 } \\
\hline 時 & 立 & 。料 & 画照 & $\begin{array}{l}\text { 水分 } \\
\text { ca }\end{array}$ & 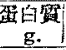 & $\mathrm{Cal}$ \\
\hline & 主 & $\begin{array}{l}\text { 娄触 } \\
\text { 午乱 }\end{array}$ & $\begin{array}{l}750 \\
480\end{array}$ & 400 & $\begin{array}{l}24.00 \\
14.00\end{array}$ & $\begin{array}{r}1095 \\
280\end{array}$ \\
\hline 朝 & 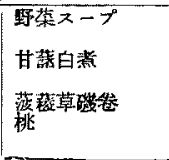 & 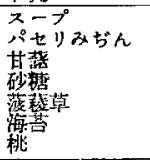 & $\begin{array}{r}150 \\
\text { 少 } \\
80 \\
10 \\
30 \\
1 \\
150\end{array}$ & 150 & $\begin{array}{l}\overrightarrow{-} \\
1.12 \\
0.69 \\
0.30 \\
1.35\end{array}$ & $\begin{array}{r}101 \\
39 \\
6 \\
3 \\
63 \\
\end{array}$ \\
\hline 曹 & 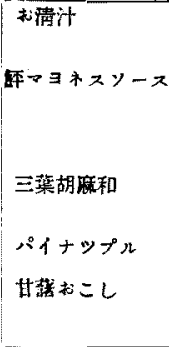 & 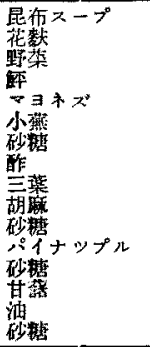 & $\begin{array}{r}150 \\
2 \\
\text { 多 } \\
60 \\
25 \\
40 \\
5 \\
3 \\
30 \\
5 \\
5 \\
80 \\
15 \\
80 \\
10 \\
20 \\
\end{array}$ & 150 & $\begin{array}{c}0.54 \\
11.52 \\
0.35 \\
0.64 \\
\overline{-} \\
0.27 \\
0.99 \\
\overline{0.40} \\
\overline{1.12} \\
\overline{-}\end{array}$ & $\begin{array}{r}7 \\
50 \\
207 \\
8 \\
20 \\
5 \\
29 \\
20 \\
23 \\
59 \\
101 \\
93 \\
78\end{array}$ \\
\hline 夕 & 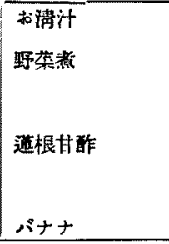 & 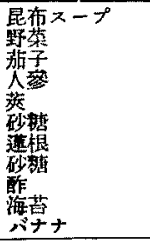 & $\begin{array}{r}150 \\
\text { 少 } \\
50 \\
20 \\
5 \\
10 \\
20 \\
5 \\
\text { 少 } \\
100 \\
\end{array}$ & 150 & $\begin{array}{l}\bar{E} \\
\overline{0.50} \\
0.26 \\
0.12 \\
\overline{0.51} \\
\overline{-} \\
\overline{1.40}\end{array}$ & $\begin{array}{r}- \\
9 \\
8 \\
1 \\
39 \\
16 \\
20 \\
98 \\
9\end{array}$ \\
\hline & 尌 & & & 985 & 60.08 & 2495 \\
\hline
\end{tabular}

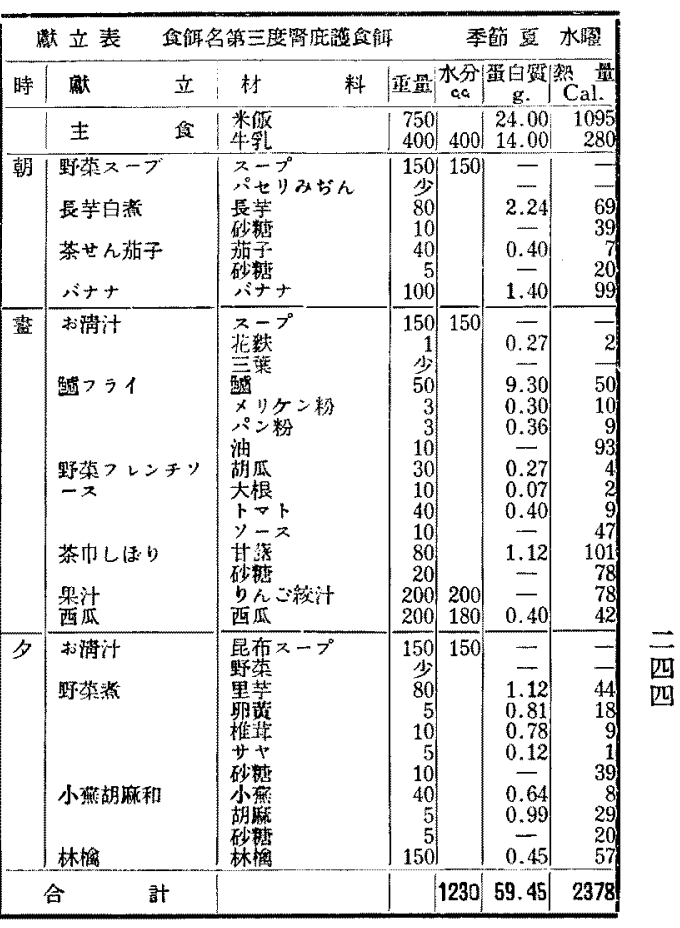



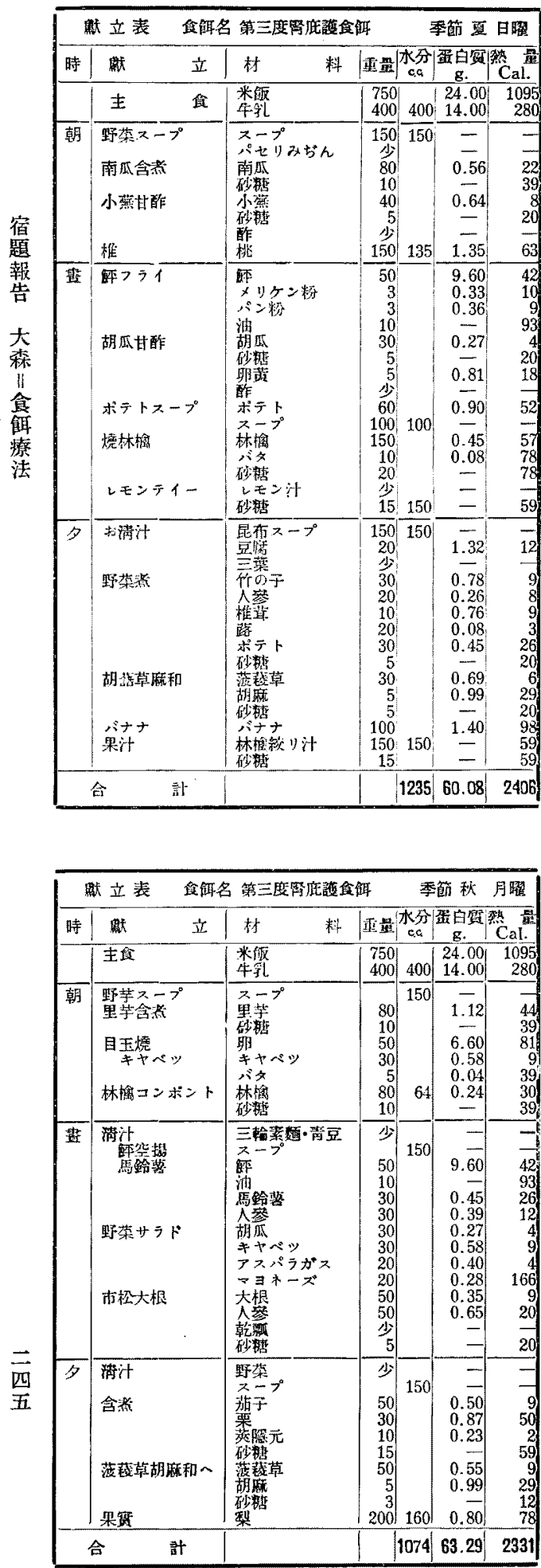

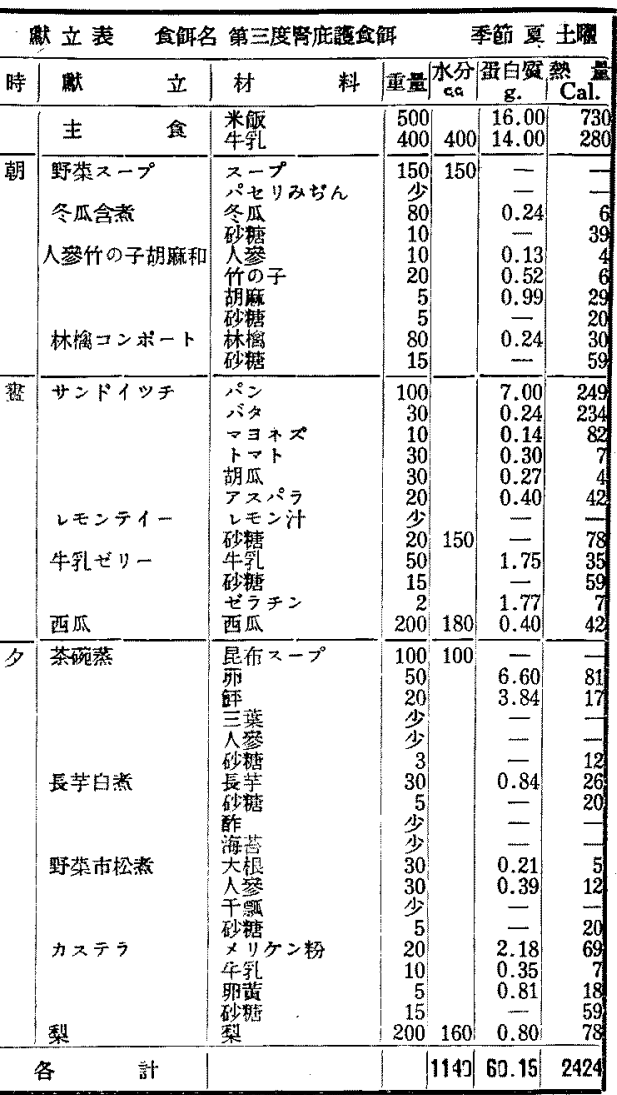

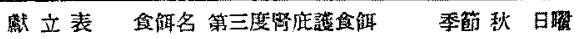

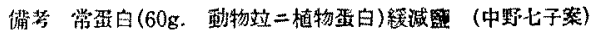

\begin{tabular}{|c|c|c|c|c|c|c|}
\hline 眰 & 嚾 & 料 & 重量: & 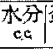 & 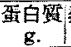 & 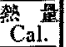 \\
\hline & 主苓 & 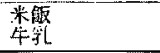 & $\begin{array}{l}750 \\
400 \\
\end{array}$ & 400 & $\begin{array}{l}24.00 \\
14.00\end{array}$ & $\begin{array}{r}1095 \\
280 \\
\end{array}$ \\
\hline 朝 & 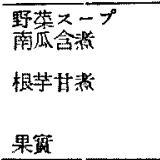 & 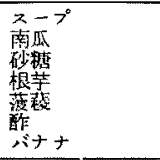 & $\begin{array}{r}80 \\
10 \\
50 \\
3 \\
\text { 少 } \\
100\end{array}$ & 150 & $\begin{array}{c}\overline{0.56} \\
\overline{0.55} \\
\overline{-} \\
1.40\end{array}$ & $\frac{12}{98}$ \\
\hline 需 & 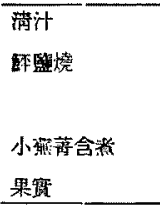 & 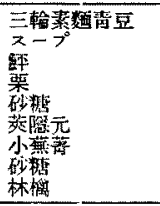 & \begin{tabular}{r|}
3 \\
50 \\
30 \\
10 \\
10 \\
50 \\
5 \\
150 \\
\end{tabular} & 120 & $\begin{array}{l}- \\
- \\
9.60 \\
0.87 \\
0.23 \\
0.80 \\
0.45\end{array}$ & $\begin{array}{l}10 \\
20 \\
57 \\
\end{array}$ \\
\hline 閶 & $\begin{array}{l}\text { 蔡カメララ } \\
\text { 紅茶(䔳ク) }\end{array}$ & 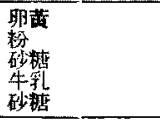 & \begin{tabular}{r|}
5 \\
20 \\
15 \\
10 \\
10 \\
\end{tabular} & & $\begin{array}{l}0.81 \\
2.18 \\
0.35 \\
- \\
\end{array}$ & $\begin{array}{l}18 \\
69 \\
59\end{array}$ \\
\hline 夜 & 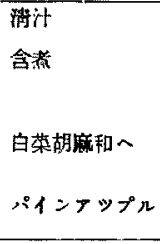 & 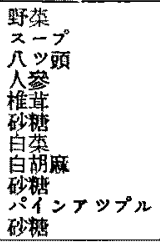 & \begin{tabular}{r|} 
少 \\
60 \\
30 \\
10 \\
10 \\
50 \\
5 \\
3 \\
80 \\
15 \\
\end{tabular} & 150 & $\begin{array}{l}\overline{-} \\
1.68 \\
0.39 \\
0.76 \\
0.65 \\
1.03 \\
0.40 \\
\end{array}$ & $\begin{array}{r}7 \\
72 \\
12 \\
9\end{array}$ \\
\hline & 䛌 & & & 1114 & 60.71 & 218 \\
\hline
\end{tabular}




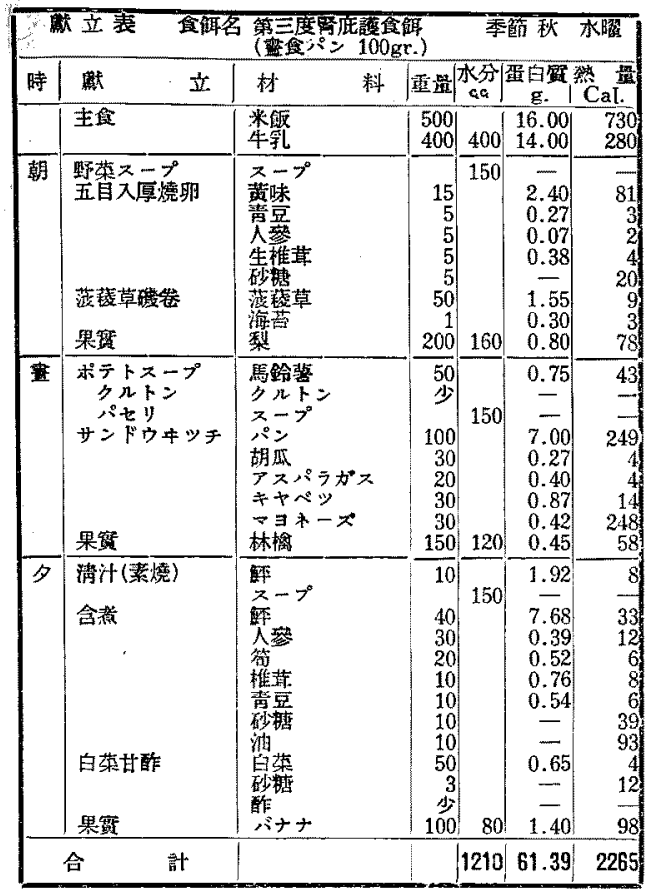

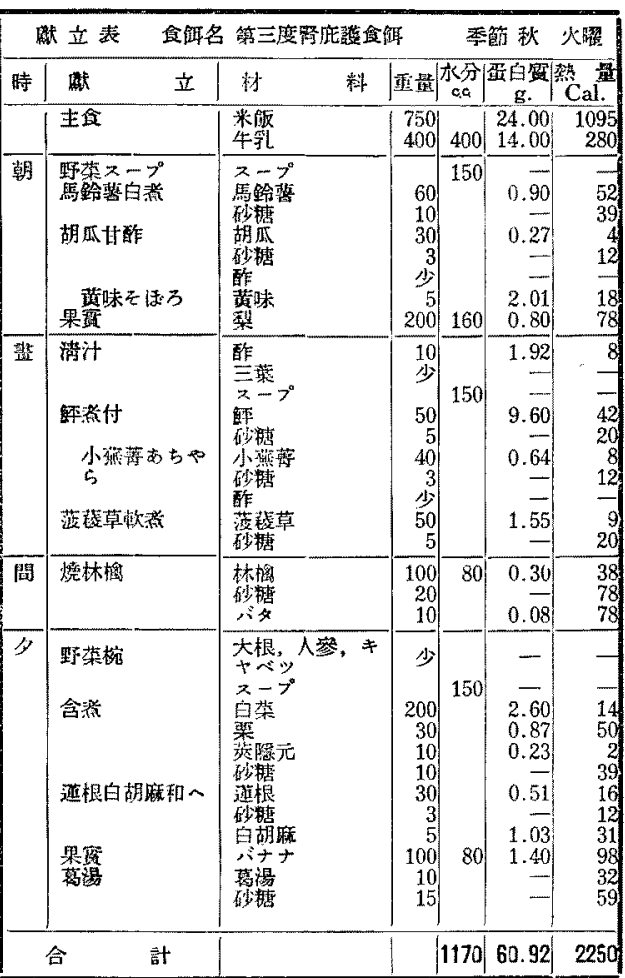

\begin{tabular}{|c|c|c|c|c|c|c|}
\hline \multicolumn{2}{|c|}{ 立表 } & \multicolumn{2}{|c|}{ 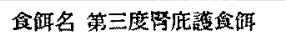 } & \multicolumn{3}{|c|}{ 䨋節 秋 金暗 } \\
\hline 時 & 畩 & 料 & 莁量| & 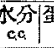 & 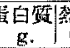 & 繁 \\
\hline & 主食 & 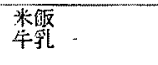 & $\begin{array}{l}750 \\
400\end{array}$ & 400 & $\begin{array}{l}24.00 \\
14.00\end{array}$ & $\begin{array}{r}1095 \\
280\end{array}$ \\
\hline 朝 & 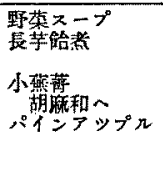 & 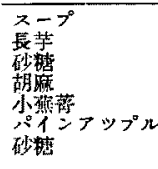 & $\begin{array}{r}70 \\
10 \\
5 \\
40 \\
80 \\
15\end{array}$ & 64 & $\begin{array}{r}1.68 \\
99 \\
0.64 \\
0.40 \\
-\end{array}$ & $\begin{array}{r}52 \\
39 \\
29 \\
8 \\
23 \\
59\end{array}$ \\
\hline 萋 & $\begin{array}{l}\text { 吕りフラロー甘 } \\
\text { 期 } \\
\text { 道明寺垪 }\end{array}$ & 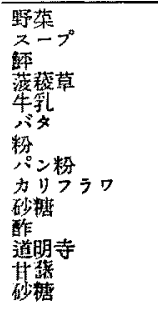 & 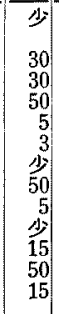 & 150 & $\begin{array}{c}\overline{7} \\
5.76 \\
0.69 \\
1.75 \\
0.04 \\
0.33 \\
\overrightarrow{1.25} \\
\overline{0} \\
0.94 \\
0.70\end{array}$ & $\begin{array}{l}- \\
25 \\
6 \\
35 \\
39 \\
10 \\
16 \\
20 \\
53 \\
63 \\
59\end{array}$ \\
\hline タ & $\begin{array}{l}\text { 清汁 } \\
\text { 含港 }\end{array}$ & 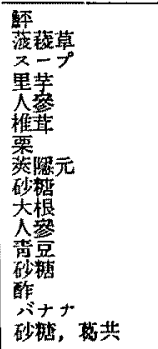 & \begin{tabular}{|r|}
20 \\
少 \\
100 \\
30 \\
10 \\
30 \\
10 \\
10 \\
50 \\
10 \\
少 \\
5 \\
100 \\
100 \\
25
\end{tabular} & ${ }_{80}^{150}$ & $\begin{array}{l}3.84 \\
\bar{Z} \\
1.40 \\
0.39 \\
0.76 \\
0.87 \\
0.23 \\
\overline{0.35} \\
0.13 \\
= \\
\bar{Z} \\
1.40\end{array}$ & $\begin{array}{l}\overline{20} \\
\overline{98} \\
91\end{array}$ \\
\hline & 㪟 & & & & 62.96 & 234 \\
\hline
\end{tabular}

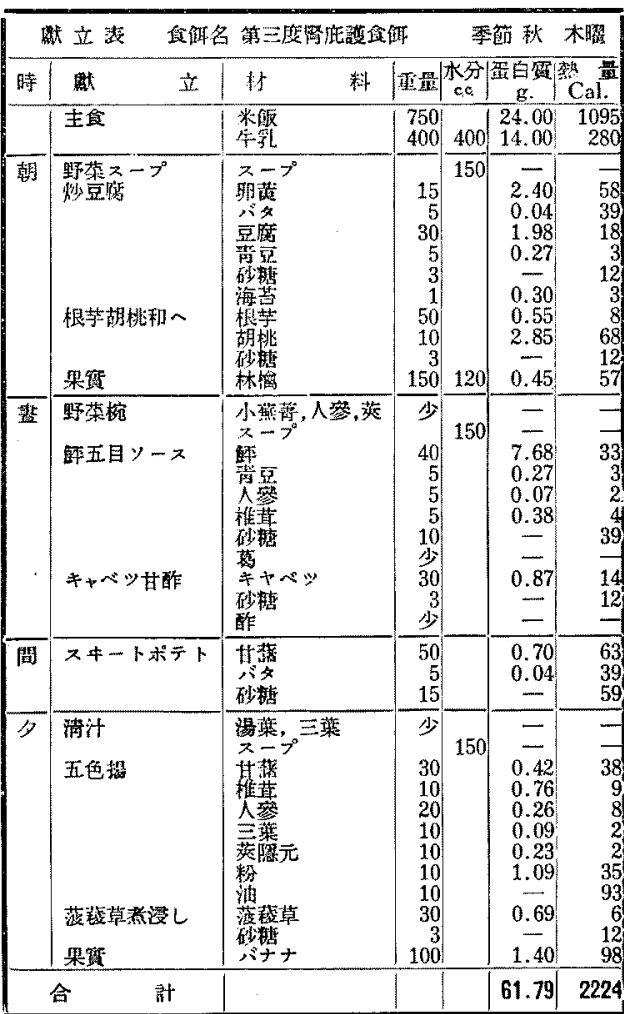



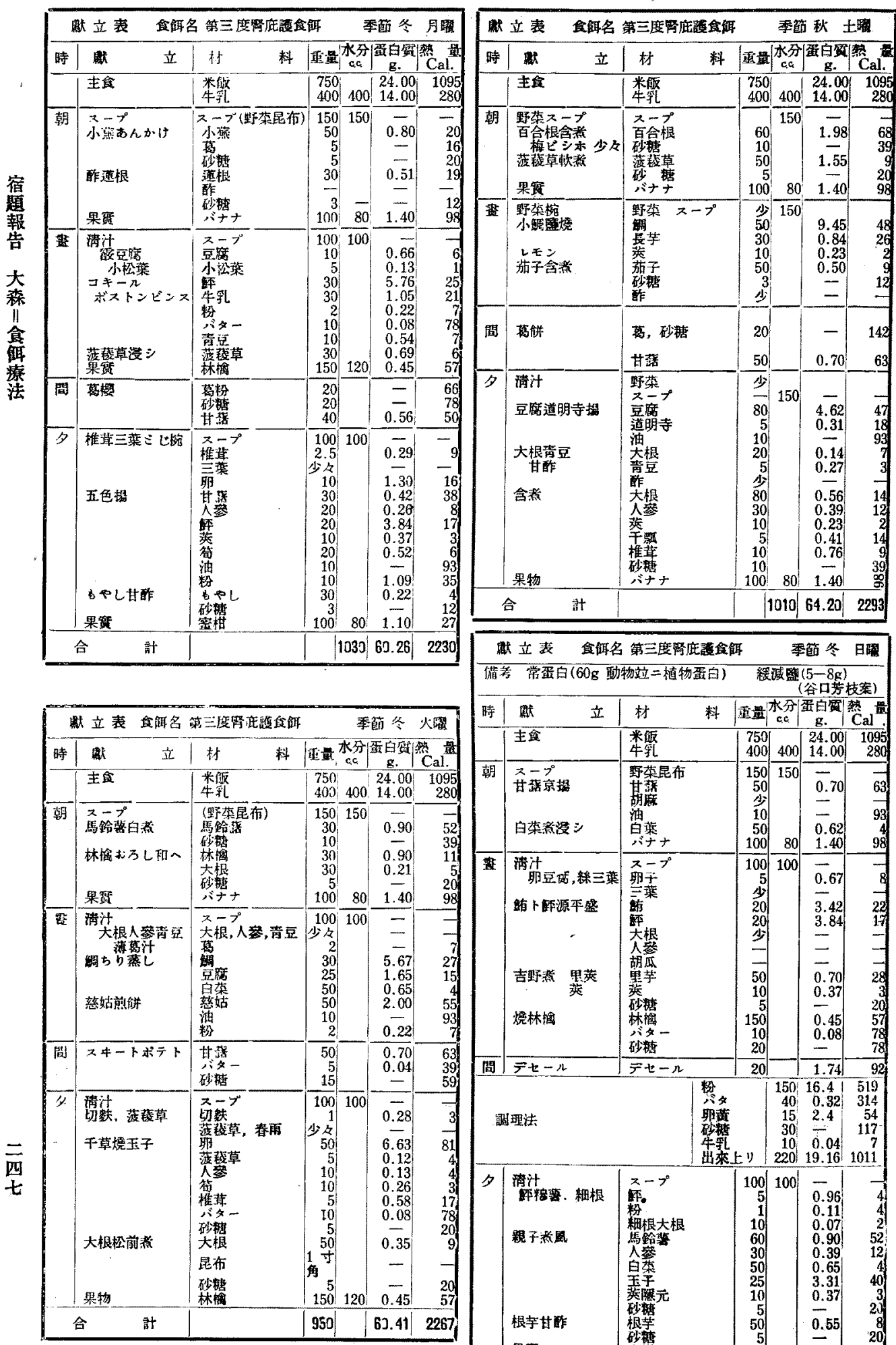

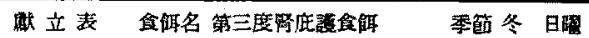

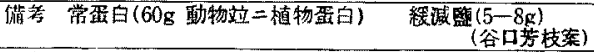

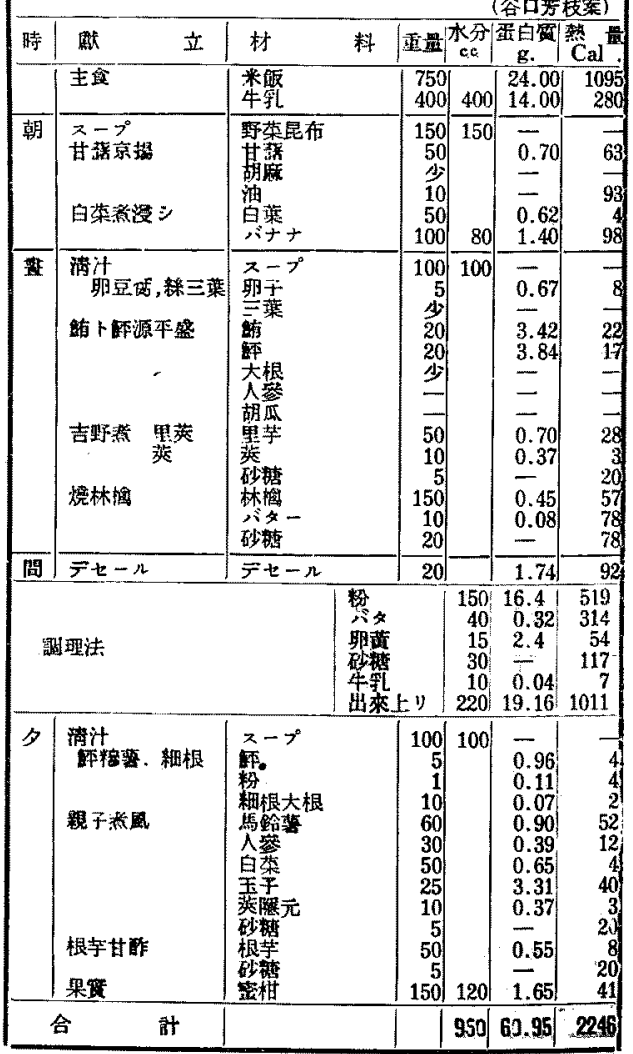




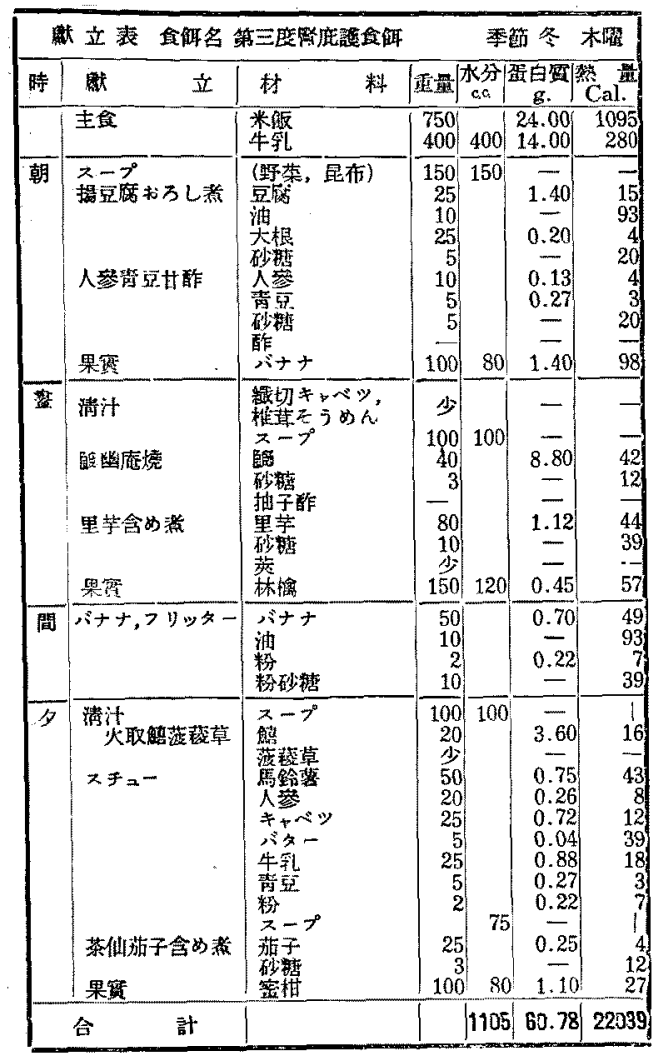

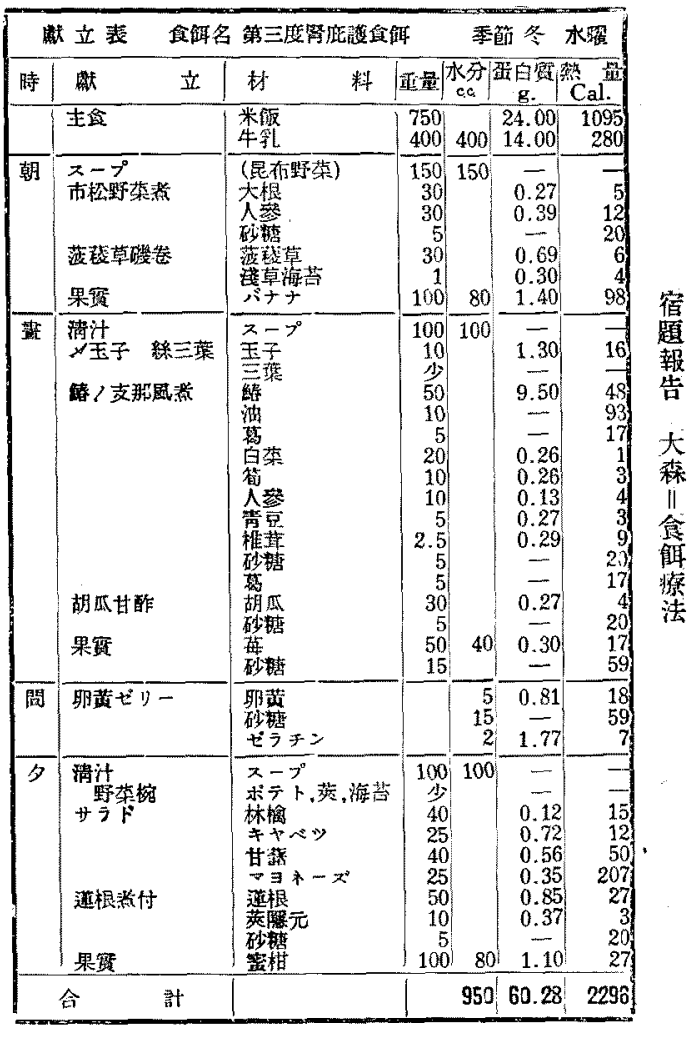

\begin{tabular}{|c|c|c|c|c|c|c|}
\hline \multicolumn{2}{|c|}{ 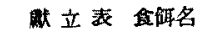 } & 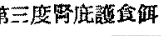 & \multicolumn{4}{|c|}{ 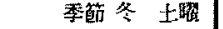 } \\
\hline 時 & 辟 & 料 & 垔量 & 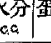 & 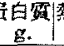 & 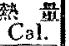 \\
\hline & 主食 & $\begin{array}{l}\text { 米幣 } \\
\text { 等 }\end{array}$ & $\begin{array}{l}750 \\
400 \\
\end{array}$ & 400 & $\begin{array}{l}24.00 \\
14.00\end{array}$ & $\begin{array}{r}1095 \\
280\end{array}$ \\
\hline 翰 & 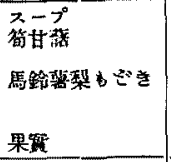 & 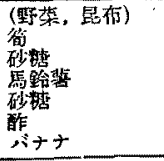 & $\begin{array}{r}150 \\
50 \\
10 \\
50 \\
5 \\
100 \\
\end{array}$ & 150 & $\begin{array}{l}\overline{1.30} \\
\overline{0.75} \\
\overline{1.40}\end{array}$ & $\begin{array}{l}7 \\
15 \\
39 \\
43 \\
20 \\
98\end{array}$ \\
\hline 軎 & 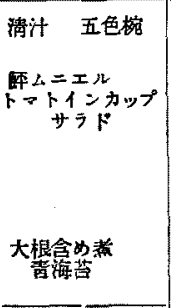 & 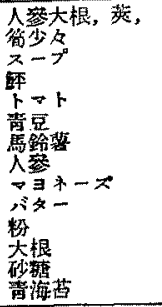 & \begin{tabular}{r|} 
少 \\
100 \\
40 \\
30 \\
1 \\
15 \\
5 \\
20 \\
10 \\
少 \\
50 \\
5 \\
-
\end{tabular} & 100 & $\begin{array}{l}- \\
-\overline{7.68} \\
0.30 \\
0.05 \\
0.23 \\
0.07 \\
0.28 \\
0.08 \\
\overline{0.35} \\
-\end{array}$ & $\begin{array}{r}- \\
33 \\
7 \\
1 \\
13 \\
2 \\
166 \\
78 \\
9 \\
20 \\
\end{array}$ \\
\hline 閣 & ホットクーキ & 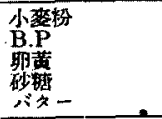 & $\begin{array}{r}20 \\
3 \\
5 \\
20 \\
5\end{array}$ & & $\begin{array}{l}\frac{2.18}{0.81} \\
\frac{0.04}{2}\end{array}$ & $\begin{array}{l}70 \\
18 \\
78 \\
39\end{array}$ \\
\hline 夜 & 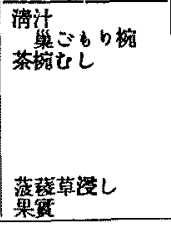 & 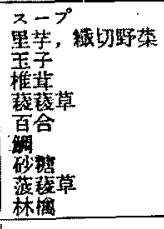 & $\begin{array}{r}100 \\
3 \\
25 \\
2.5 \\
10 \\
5 \\
10 \\
3 \\
30 \\
150 \\
\end{array}$ & 100 & $\begin{array}{l}\overline{ } \\
\overline{3} \\
3.31 \\
0.29 \\
0.23 \\
0.17 \\
1.90 \\
0.69 \\
0.45\end{array}$ & $\begin{array}{r}7 \\
40 \\
9 \\
2 \\
6 \\
10 \\
12 \\
6 \\
57 \\
\end{array}$ \\
\hline & 㖕 & & & & 60.56 & 2266 \\
\hline
\end{tabular}

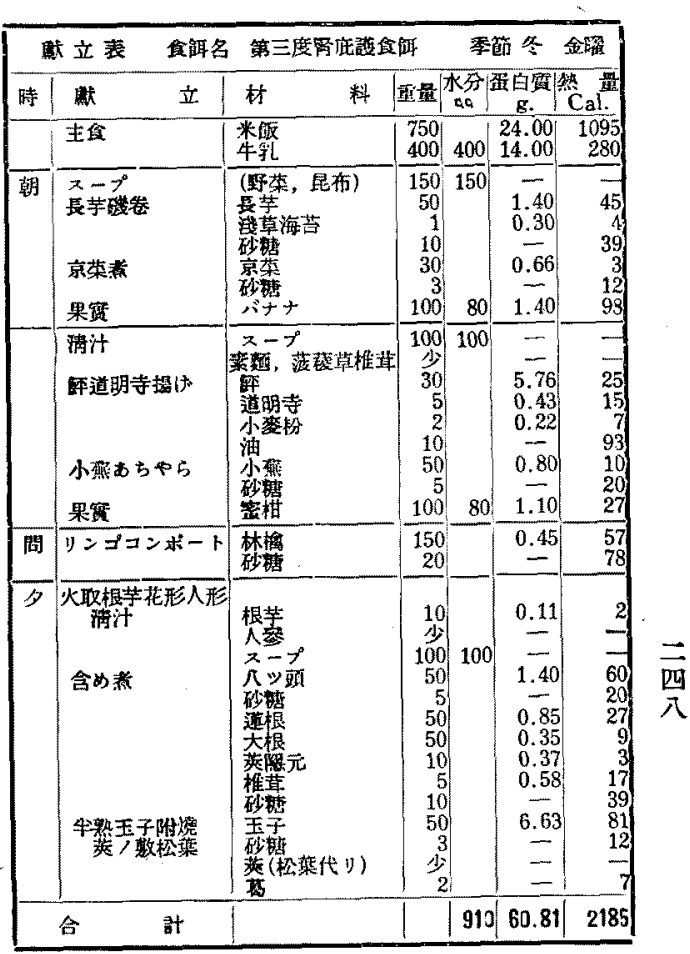




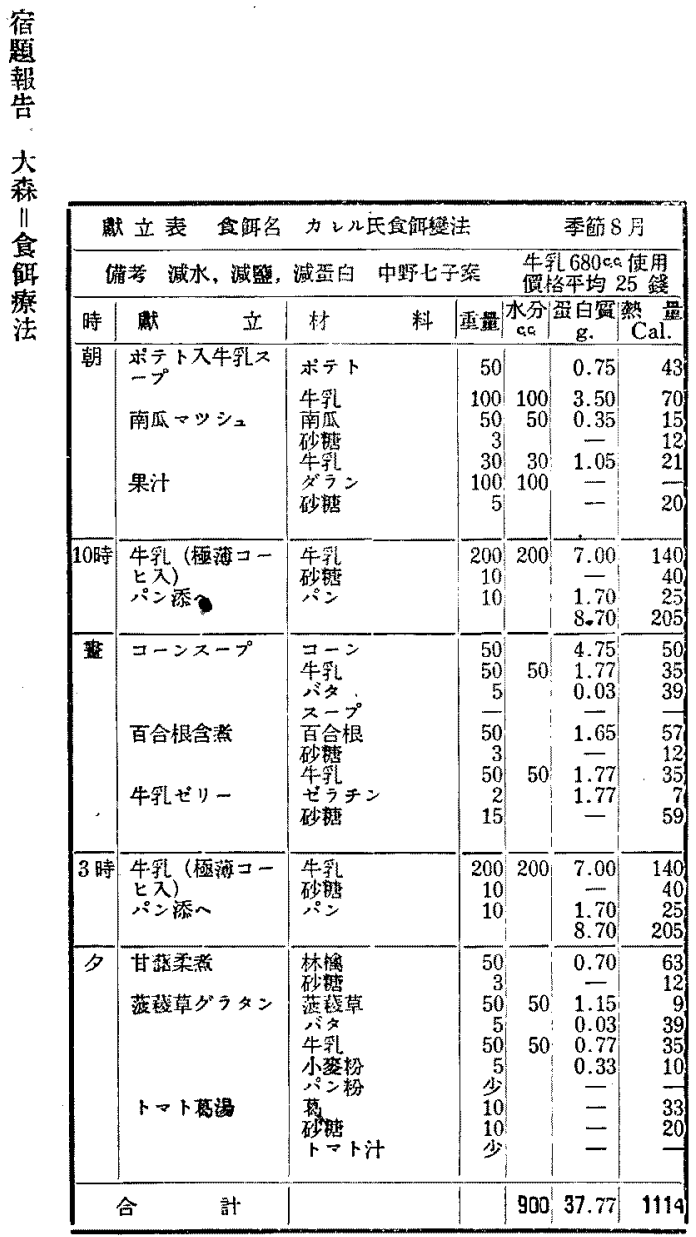

附錄 $(5)$ カレル食针篗法 6 種

\begin{tabular}{|c|c|c|c|c|c|c|}
\hline & 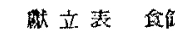 & & & 9 程 & 䨪 & \\
\hline & 青䓔 米䀠 450 之音 & & 络平均 20 & & & \\
\hline & 立 & 材 & 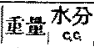 & 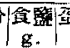 & 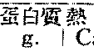 & Cal. \\
\hline & 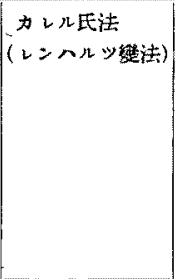 & 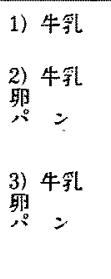 & \begin{tabular}{r|r}
800 & 800 \\
& 800 \\
800 & 800 \\
50 & \\
60 & 800 \\
800 & 800 \\
100 & \\
80 & \\
& 800
\end{tabular} & & 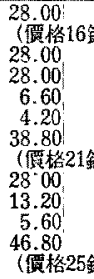 & 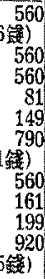 \\
\hline A) & 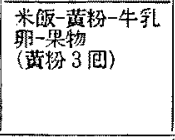 & 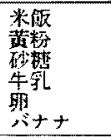 & \begin{tabular}{r|r}
450 & \\
30 & \\
30 & \\
400 & 400 \\
100 & \\
100 & \\
\end{tabular} & & $\begin{array}{r}14.40 \\
4.71 \\
14.00 \\
13.20 \\
1.40\end{array}$ & $\begin{array}{r}657 \\
96 \\
117 \\
280 \\
161 \\
98 \\
\end{array}$ \\
\hline & 計 & & & $|1.50|$ & 47.71 & 1409 \\
\hline B) & 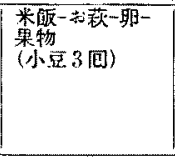 & 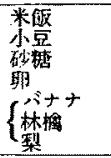 & \begin{tabular}{r|r}
450 & \\
60 & \\
450 & \\
100 & \\
150 & \\
200 & 160 \\
\end{tabular} & & \begin{tabular}{c|}
14.40 \\
13.20 \\
6.60 \\
1.40 \\
0.45 \\
0.80 \\
\end{tabular} & $\begin{array}{r}657 \\
193 \\
176 \\
81 \\
98 \\
57 \\
78\end{array}$ \\
\hline & 計 & & & 1.50 & 36.85 & 1340 \\
\hline C) & 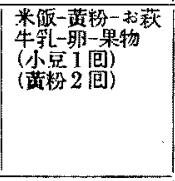 & 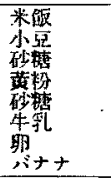 & \begin{tabular}{|r|r|}
450 & \\
20 & \\
15 & \\
20 & \\
20 & \\
400 & 400 \\
50 & \\
100 & \\
\end{tabular} & & \begin{tabular}{r|r|}
14.40 \\
4.40 \\
3.14 \\
14.00 \\
6.60 \\
1.40 \\
\end{tabular} & $\begin{array}{r}657 \\
64 \\
59 \\
64 \\
78 \\
280 \\
81 \\
98 \\
\end{array}$ \\
\hline & at & & & $|1.50|$ & 31.34 & 1681 \\
\hline & 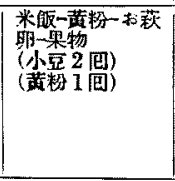 & 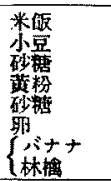 & $\begin{array}{r}450 \\
40 \\
30 \\
10 \\
10 \\
100 \\
100 \\
150\end{array}$ & & $\begin{array}{r}14.40 \\
8.80 \\
1.57 \\
13.20 \\
1.40 \\
0.45 \\
\end{array}$ & $\begin{array}{r}657 \\
128 \\
117 \\
32 \\
39 \\
161 \\
98 \\
57 \\
\end{array}$ \\
\hline & 部 & & & $|1.50|$ & $39.82 \quad 1$ & 1289 \\
\hline
\end{tabular}




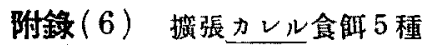

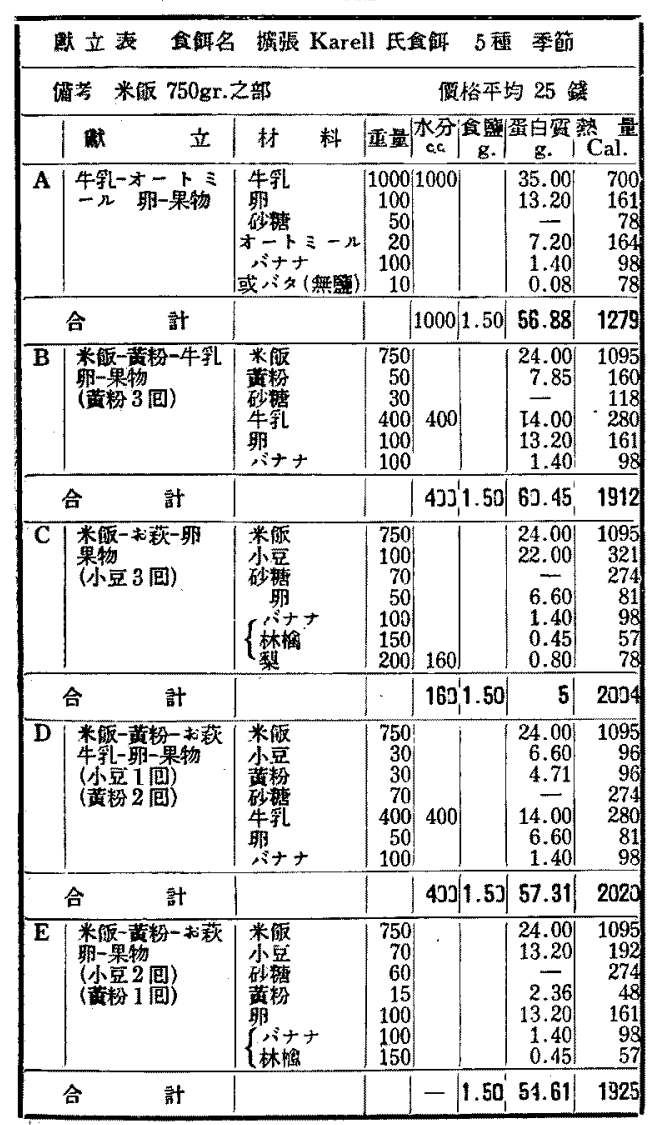

\begin{tabular}{|c|c|c|c|c|c|c|}
\hline \multirow{2}{*}{ 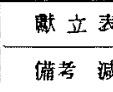 } & \multicolumn{3}{|c|}{ 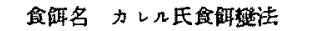 } & \multicolumn{3}{|c|}{ 李筥 8月 } \\
\hline & 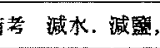 & 娍驾白 中野 & & & 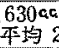 & 霓用 \\
\hline 時 & 立 & 材 & 重量 & 事分 & 白致 & 䇾 \\
\hline 朝 & $\begin{array}{l}\text { 人慈マッシュ } \\
\text { コンボート } \\
\text { 果汁 }\end{array}$ & 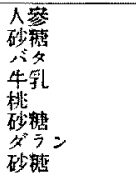 & $\begin{array}{r}50 \\
3 \\
5 \\
20 \\
50 \\
10 \\
100 \\
5\end{array}$ & $\begin{array}{r}50 \\
20 \\
50 \\
100\end{array}$ & $\begin{array}{l}0.75 \\
-\overline{0.04} \\
0.70 \\
0.45 \\
-\end{array}$ & $\begin{array}{l}20 \\
12 \\
39 \\
14 \\
21 \\
40 \\
20\end{array}$ \\
\hline . 0 時 & 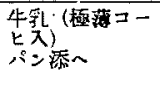 & 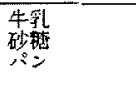 & $\begin{array}{r}200 \\
10 \\
10\end{array}$ & 200 & $\frac{7-}{1.70}$ & $\begin{array}{r}140 \\
40 \\
25\end{array}$ \\
\hline$\overline{\text { in }}$ & 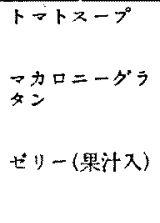 & 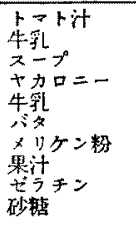 & \begin{tabular}{r|}
$\frac{5}{80}$ \\
10 \\
50 \\
5 \\
3 \\
$\frac{1}{2}$ \\
$\frac{15}{15}$
\end{tabular} & 50 & $\begin{array}{l}2.80 \\
1.10 \\
1.75 \\
0.04 \\
0.33 \\
1.77 \\
\end{array}$ & $\begin{array}{l}5 \\
3 \\
3 \\
35 \\
10\end{array}$ \\
\hline 3 時 & 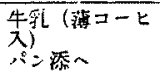 & 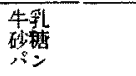 & $\begin{array}{r}200 \\
10 \\
10\end{array}$ & 200 & $\frac{7.00}{1.70}$ & $\begin{array}{r}140 \\
40 \\
25\end{array}$ \\
\hline צ & 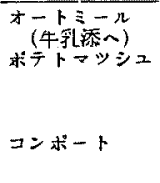 & 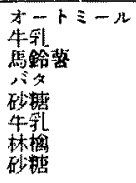 & $\begin{array}{r}30 \\
50 \\
50 \\
5 \\
3 \\
30 \\
50 \\
10\end{array}$ & $\begin{array}{l}50 \\
50 \\
30 \\
50\end{array}$ & $\begin{array}{l}5.16 \\
1.75 \\
0.75 \\
0.04 \\
-.05 \\
0.15\end{array}$ & $\begin{array}{r}116 \\
38 \\
43 \\
39 \\
12 \\
21 \\
19 \\
40\end{array}$ \\
\hline & 計 & & & 930 & 36.03 & 1102 \\
\hline
\end{tabular}

